Itämeren fysiikka, tila ja tulevaisuus 

Kai Myrberg, Matti Leppäranta ja Harri Kuosa

\section{Itämeren fysiikka, tila ja tulevaisuus}


Graafinen suunnittelu ja toteutus: Heikki Jantunen

PL 4 (Vuorikatu 3 A)

00014 Helsingin yliopisto

books@yliopistopaino.fi

Fax (09) 70102374

www.yliopistopaino.fi/kirjamyynti

www.palmenia.helsinki.fi

๑ 2006 Tekijät ja Yliopistopaino

Tämän teoksen kopiointi on tekijänoikeuslain mukaisesti kielletty.

Yliopistopaino Kustannus

Palmenia-sarja

ISSN 1795-8598;17

ISBN 951-570-654-8

ISBN 951-570-675-0 (PDF)

Yliopistopaino

Helsinki 2006 


\section{Esipuhe 7}

\section{Johdanto 9}

2. Itämeri ja sen tutkimus 15

2.1 Itämeren kehitys 15

2.2 Itämeren jako eri altaisiin 17

2.3 Itämeri numeroina 18

2.4 Tutkimustyön historiaa Suomessa ja muualla 19

3. Fysikaalisen tutkimuksen menetelmät 25

3.1 Tutkimusmatkat 25

3.2 Kiinteät asemat 33

3.3 Kaukohavainnointi 35

3.4 Mallit 38

4. Syvyyssuhteet ja hydrografia 44
4.1 Topografian pääpiirteet 44
4.2 Eri altaiden topografiset piirteet ja pohjan laatu 45
4.3 Hydrografian peruspiirteet 54
4.4 Itämeren vesirunko 63

5. Vesitase ja lämpötalous 80

5.1 Sää ja ilmasto 80

5.2 Meren ja ilmakehän välinen veden ja lämmön vaihto 89

5.3 Vesitase 92

5.4 Suolan säilymislaki 96

5.5 Lämpötase 98 


\section{Veden liikkeet 103}

6.1 Itämeren kiertoliike ja virtauskentän yleispiirteitä 103

6.2 Virtausdynamiikan perusteita - skaala-analyysi 107

6.3 Tärkeitä erikoistapauksia merten dynamiikassa 110

6.4 Itämeren virtausdynamiikan pääpiirteet ja vedenvaihto 111

6.5 Aaltoliike 122

7. Itämeren jääolot 138

7.1 Itämeren jäätyminen 138

7.2 Jään rakenne ja ominaisuudet 139

7.3 Jään kasvu ja sulaminen 145

7.4 Ajojäät 149

7.5 Jäämallit 158

7.6 Jääpeitteen vaikutukset Itämereen 159

8. Kriittiset prosessit ja ääritilanteet 162

8.1 Meri-ilmakehä vuorovaikutus 163

8.2 Kumpuaminen 166

8.3 Rintamat ja intruusiot 169

8.4 Suolapulssit 170

8.5 Poikkeukselliset vedenkorkeudet 177

9. Itämeren toiminta systeeminä 182

9.1 Taustaa 182

9.2 Havaitut muutokset 185

9.3 Ihmisen vaikutus Itämereen 188

9.4 Globaalimuutoksen vaikutus Itämereen 190

9.5 Tutkimuksen haasteita 194

\section{Lähdeluettelo 197}

Kirjoittajat 202 


\section{Esipuhe}

Itämeri on meidän meremme ja meitä asuu sen valuma-alueella 85 miljoonaa ihmistä. Itämeri on merenä nuori, sillä vasta noin 9.000 vuotta sitten sen pohjoisimmatkin osat vapautuivat jään alta. Itämeri on ollut asuttu lyhyen historiansa alusta asti ja se on tarjonnut asukkailleen sekä ravintoa että mahdollisuuden harjoittaa merenkulkua. Tänä päivänä sen monista kauniista alueista, kuten saaristoista ja rannikoista, nauttivat suuret ihmisjoukot joka kesä.

Itämeri on kuitenkin juuri ihmisen vaikutuksesta joutunut viimeisen sadan vuoden aikana suuren ulkoisen ravinnekuormituksen alaiseksi, ja lisäksi erilaisia ympäristömyrkkyjä on joutunut mereen huomattavia määriä. Näin Itämeren tila on selkeästi huonontunut. Vasta 1970-luvulta lähtien kiinnostus meremme suojeluun ja huoli sen tulevaisuudesta ovat kasvaneet huomattavasti. Meriympäristön tilan kehitys on herättänyt keskustelua paitsi tutkijoiden myös suuren yleisön keskuudessa.

Meriekosysteemin toiminnan sekä siinä ilmenevien syy-seuraussuhteiden ymmärtäminen on vaikeaa. Monet seikat, kuten rehevöitymiseen liittyvien leväkukintojen lisääntyminen ja vedenlaadun yleinen heikkeneminen, riippuvat merten fysikaalisia, kemiallisia ja biologisia prosesseja säätelevistä tekijöistä. Fysiikka määrää ne ulkoiset olosuhteet, joissa biologis-kemialliset prosessit tapahtuvat. Siten meren fysikaalisten ominaisuuksien ja prosessien tuntemus muodostaa perustan Itämerisysteemin toiminnan kokonaisvaltaisessa ymmärtämisessä.

Itämeren fysikaalisen oseanografian opetus on maassamme ollut varsin kapealla pohjalla keskittyen Helsingin yliopistoon ja sen Fysikaalisten tieteiden laitoksen geofysiikan osastoon. Professori Matti Leppäranta aloitti kurssin Itämeren oseanografia luennoinnin 1990-luvun puolivälissä. Kiinnostus kurssia kohtaan on hiljalleen kasvanut. Dosentti Kai Myrbergin luennoidessa vuodesta 2002 lähtien kurssilla on ollut 15-20 opiskelijaa useilta eri aloilta ja useista korkeakouluista.

Itämeren fysikaalisen oseanografian opetuksen pedagogisena ongelmana on ollut se, ettei minkään kielistä sopivaa oppikirjaa ole ollut saatavilla. Alalta on olemassa runsaasti eritasoista tietoa, mutta tämä tieto on melko hajallaan, eikä kokonaisvaltaista kirjallisuutta ole vielä paljon. Tieteelliset julkaisut ovat usein yliopistollista perusopetusta silmälläpitäen liian vaikeaselkoisia ja yksityiskohtiin meneviä, eikä niitä luonnollisesti ole kirjoitettu oppikirjamuotoon. Siksi syntyi ajatus kirjoittaa suomenkielinen oppikirja Itämeren fysikaalisesta oseanografiasta. Itämeren biologian opetuksen ongelmana on myös ollut fysikaalisten perusteiden oppimateriaalin puuttuminen. Nyt tehtyä suomenkielistä oppikirjaa tullaan käyttämään korvaamaan tätä puutetta.

Tässä kirjassa tarkastellaan Itämeren fysikaalisia ominaisuuksia ja prosesseja. Meren lämpötalous, liikkeet (virtaukset, vedenkorkeusmuutokset) sekä jäätyminen, niihin liittyvät kulkeutumis- ja sekoittumisprosessit, ja veden kerrostuneisuuden muutokset säätelevät niitä olosuhteita, joissa meren biologis-kemialliset prosessit tapahtuvat. Tämän vuoksi kirjassa kuvataan myös lyhyesti meren fysiikassa tapahtuvien muutosten ekologisia vasteita, pohditaan ihmisen vaikutusta Itämeren tilaan ja tarkastellaan Itämeren tulevaisuutta globaali ilmastonmuutos huomioiden. Kaiken kaikkiaan meren fysiikan ymmärtäminen laajassa perspektiivissä on tähdellistä tietoa kaikille merentutkijoille, meriensuojeluun liittyvään päätöksentekoon osallistuville tahoille ja yleensäkin kaikille Itämerestä kiinnostuneille kansalaisille.

Tämä oppikirja palvelee kotimaisen geotieteellisen yliopisto-opetuksen tarkoitusperiä. Moni- 
mutkaiset Itämeren fysiikan perusasiat puetaan suomen kielelle aineopintotasoiseksi oppimateriaaliksi, jolloin vieraaseen kieleen liittyvät ongelmat vältetään. Kirja muodostaa edellä mainitun kurssin Itämeren oseanografia sisällön. Sitä voidaan soveltaa myös lähialojen koulutuksessa. Esityksen tavoitteena on helppolukuisuus sekä perusasioiden ja pidemmälle menevien tarkasteluiden erottelu toisistaan, jolloin se soveltuu hyvin sekä pää- että sivuaineopiskelijoille. Lisäksi kirja sopii perusteokseksi myös tutkijanuralle siirtyneille henkilöille. Kirjaa voidaan myös käyttää annettaessa täydennyskoulutusta peruskoulun yläasteen sekä lukion fysiikan, maantieteen ja biologian opettajille.

Yliopisto-opiskelijan on hyvä hallita esitietona oseanografian perusteet, jotta kirjan sisällön voi täydellisesti omaksua. Tärkeimpänä taustatietona kurssin Itämeren oseanografia menestyksekkäälle suorittamiselle on geofysiikan osastolla luennoitava kurssi Meritieteen perusteet I. Lisätukea tarjoavat kurssit Meritieteen perusteet II sekä Virtausoppi. Vaihtoehtoisesti taustatietoa saa jostakin oseanografian perusteoksesta, esimerkiksi George L. Mellorin kirjasta Introduction to Physical Oceanography (Mellor 1996). Oppimisen tukena on lisäksi hyödyllistä seurata geofysiikan osaston ja Merentutkimuslaitoksen internet-sivustoja (www.geophysics.helsinki.fi ja www.fimr.fi).

Kirjan pääosan muodostavat Itämeren fysikaalisen oseanografian perusteet, jotka on kirjoitettu dosentti Kai Myrbergin ja professori Matti Leppärannan yhteistyönä. Osuudet Itämeren ekosysteemivasteista, ihmisen vaikutuksesta Itämereen ja pohdinnat Itämeren ekologian tulevaisuudennäkymistä on laatinut professori Harri Kuosa.

Tämän kirjan kirjoittamisen on mahdollistanut monien ihmisten ja organisaatioiden tuki. Tahdomme erityisesti kiittää seuraavia tahoja.

Itämeren oseanografian oppeja olemme saaneet vanhemmilta kollegoiltamme ja työtove- reiltamme. Tästä syystä tahdomme esittää kiitoksemme opettajillemme, professorit Pentti Mälkki, Åke Niemi, Erkki Palosuo ja Aarno Voipio sekä Dr.Sci. Rein Tamsalu. Edelleen kiitämme kollegoitamme FL Pekka Alenius, Ph.D. Oleg Andrejev, FM Riikka Hietala, professori Jouko Launiainen, Ph.D. Andreas Lehmann, professori Peter A. Lundberg, professori Alexei Nekrasov, professori Anders Omstedt, MMT Heikki Pitkänen, Dr.Sci. Vladimir Ryabchenko, professori Kunio Shirasawa ja professori Tarmo Soomere. Lisäksi kiitämme Itämeren oseanografia -kurssin osallistujien ja kurssiassistenttien kommentteja vuosien varrella.

Suuret kiitokset kuuluvat piirtäjä Pirkko Nummiselle, joka on tehnyt suuren työn kuvien laadinnassa ja viimeistelyssä. Kirjan tekstin ovat tarkastaneet DI Maria Gästgifvars, FM Riikka Hietala ja fil.yo. Ansku Leppäranta. Heille kuuluu erityinen kiitos raskaan urakan suorittamisesta.

Monet henkilöt ovat tämän lisäksi auttaneet meitä ja suhtautuneet myönteisesti kirjan syntyyn. Kiitokset siitä kuuluvat seuraaville henkilöille: FM Jan-Erik Bruun, B.Sc. Patrick B. Eriksson, Ph.D. Nils Gustafsson, dosentti Jari Haapala, kirjastosihteeri Helena Huttunen, FM Seija Hällfors, professori Kimmo Kahma, dosentti Seppo Kaitala, Ph.D. Toshiyuki Kawamura, merikapteeni Riitta Kyynäräinen, FM Ari O. Laine, FM Riku Lumiaro, dosentti Lasse Makkonen, tietotekniikka-asiantuntija Antti Nevalainen, FM Leena Parkkonen, FT Heidi Pettersson, FT Jouko Pokki, ylijohtaja Eeva-Liisa Poutanen, kenttämestari Henry Söderman, FM Laura Tuomi ja FM Jouni Vainio.

Kirja on saanut eri muodoissa taloudellista tukea. Kiitämme Suomen Tiedeseuran Sohlbergin Delegaatiota, Merentutkimuslaitosta, Helsingin yliopiston Fysikaalisten tieteiden laitosta ja Tvärminnen eläintieteellistä asemaa. 


\section{Johdanto}

Itämeri on monin tavoin ainutlaatuinen meri. Se on pieni ja matala allas, joka on yhteydessä valtameriin ahtaiden Tanskan salmien kautta (kuva 1.1). Itse asiassa se koostuu useista altaista ja jokaisella näistä on erilaiset fysikaaliset ja topografiset ominaisuutensa. Vedenvaihto Tanskan salmien läpi on rajoittunutta. Sen takia Itämeren vesi on murtovettä, jonka suolaisuus on vain viidesosa valtamerten suolaisuudesta. Vaihtelevat rannikon muodot ja saaristot antavat vahvan leiman Itämerelle. Tämä pitkänomainen alue sijoittuu lauhkean ilmaston ja subarktisen ilmaston väliin, ja talvisin Itämeri jäätyy, ankarina talvina jopa kauttaaltaan.

Itämeri on hyvin vanha painauma peruskalliossa. Viime jääkauden jälkeen se on muotoutunut maankohoamisen ja valtamerten pinnankorkeuden muutosten vaikutuksesta. Nykyisen kaltainen murtovesiallas Itämeri on ollut vain noin 2.000 vuotta. Maankohoaminen on vuosisatojen saatossa muuttanut itämerellistä maisemaa. Täällä on mahdollista seurata, miten maa nousee merestä ja miten maanpäällinen elämä vähitellen valtaa uuden maan. Ihminenkin on mukautunut Itämeren kehitykseen asutuksen levittäytyessä.

Veden suolaisuuskerrostuneisuus on Itämeren keskeisimpiä ominaisuuksia. Sen takia syvänteiden vesi vaihtuu huonosti, ja etenkin keskusaltaassa on happiongelmia. Hapettoman, kuolleen syvännealueen laajuus sykkii vedenvaihdon määräämässä tahdissa. Tämä piirre on luonnostaan

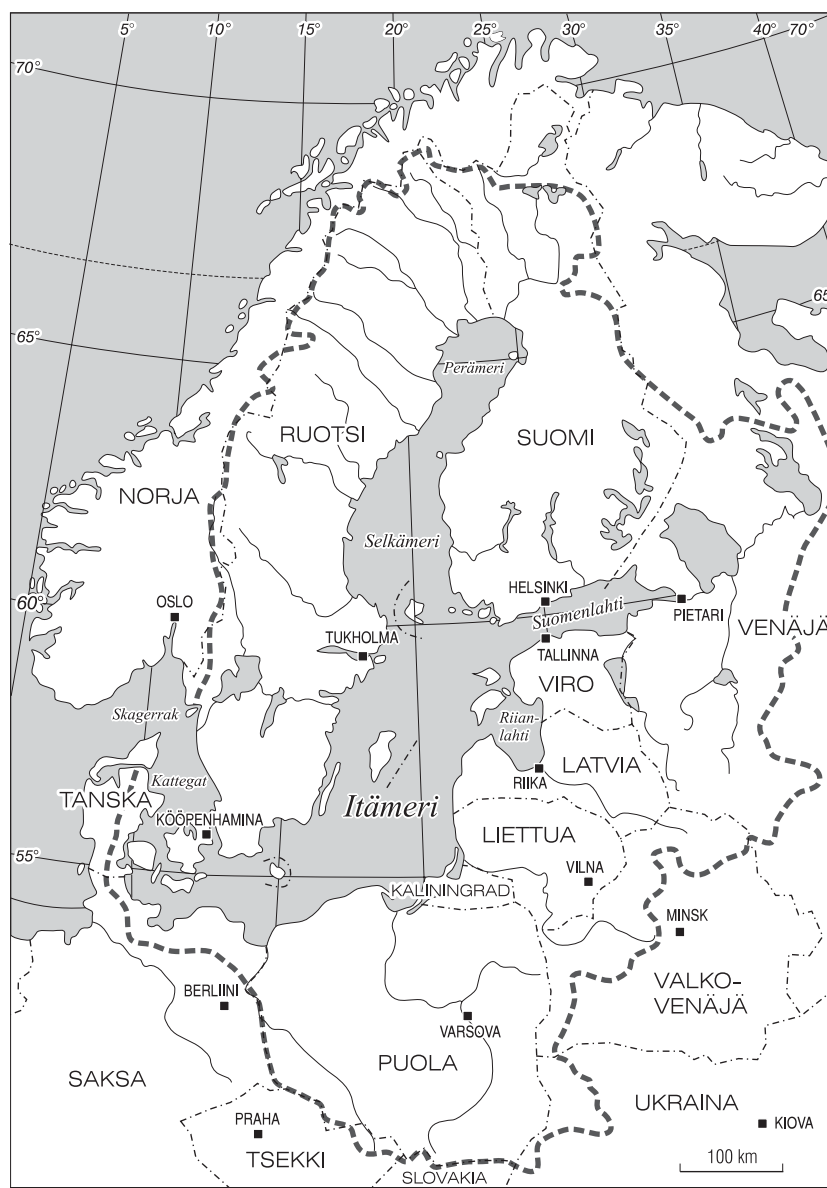

Kuva 1.1. Karttakuva Itämerestä ja sen valuma-alueesta.

Itämereen kuuluva. Ihmisen aiheuttama kuormitus on viime vuosikymmeninä lisännyt hapenkulutusta ja entisestään heikentänyt Itämeren tilaa ennen kaikkea rehevöitymisen kautta. Koko vesimassan vaihtumisaika on peräti noin viisikymmentä vuotta, mistä johtuen Itämeren vesien puhdistuminen on hidasta. Parantuminen kestäisi pitkään, vaikka nykyisiä päästörajoituksia tiukennettaisiin.

Itämeren ekologiaan vaikuttavat sen nuoruus, murtovesiluonne ja fysikaaliset ominaispiirteet. Itämeren suhteellinen nuoruus merkitsee sitä, että siihen on kulkeutunut vain harvalukuinen joukko lajeja. Jääkauden jälkeinen aika on ollut liian lyhyt omien murtovesilajien kehittymiseen 
ja vain harva makean veden tai valtameren laji on pystynyt sopeutumaan Itämereen. Lajistosta puuttuukin enin osa valtamerten suurista eläinja leväryhmistä. Koko ekosysteemi on siten hyvin herkkä häiriöille, sillä yhden lajin, erityisesti avainlajin, häviäminen saattaa muuttaa koko elinympäristön luonnetta. Näin on käynyt ainoalle monivuotiselle suurelle levällemmekin, rakkolevälle. Se hävisi vuosiksi eräiltä osilta rannikkoamme, mikä vaikutti muun muassa kalastoon. Samoin jonkin lajin äkillinen menestyminen vaikuttaa koko ekosysteemiin, kuten on käynyt rehevöitymisestä hyötyneen sinilevän, Nodularia spumigenan, kohdalla (kuva 1.2). Koska monet lajit esiintyvät levinneisyytensä äärirajoilla, suhteellisen pienetkin muutokset elinympäristössä näkyvät herkästi. Itämeren erityinen luonne näkyy myös sen kalastossa. Tärkein yksittäinen kalalajimme silakka, joka on Atlantin sillin pienempi muoto, on sopeutunut Itämeren murtoveteen. Elinympäristön muutokset näkyvät silakan hyvinvoinnissa ja siten kalastuksessa. Myös monet muut kalamme kuten lohi ja turska ovat herkkiä elinympäristön muutoksille.

Maailman valtamerissä on kolme merkittävää murtovesiallasta, suurimmasta pienimpään lueteltuina: Musta meri, Itämeri ja Chesapeaken lahti Amerikan Yhdysvaltojen itärannikolla. Näissä altaissa on suolaisuudessa voimakas pystysuuntainen kerrostuneisuus. Itämeri on näistä ainoa jääkauden kokenut allas, jossa maa kohoaa. Mustan meren koillinen allas, Asovan meri, jäätyy yleensä talvisin. Mustan meren vedenvaihto on hyvin hidasta ja vesi on 200 metrin syvyyden alapuolella hapeton (keskisyvyys on 1.100 metriä).

Itämeri - germaanisilla kielillä ja suomen kielellä Itämeri, viroksi länsimeri [Läänemeri] ja slaavilaisilla sekä balttilaisilla kielillä Baltian meri - on yksi maailman tutkituimpia meriä. Sitä reunustaa yhdeksän valtiota ja sen valuma-alueella asuu noin 85 miljoonaa ihmistä. Myös geopoliittisesti Itämeri on mielenkiintoinen alue. Sen ran-

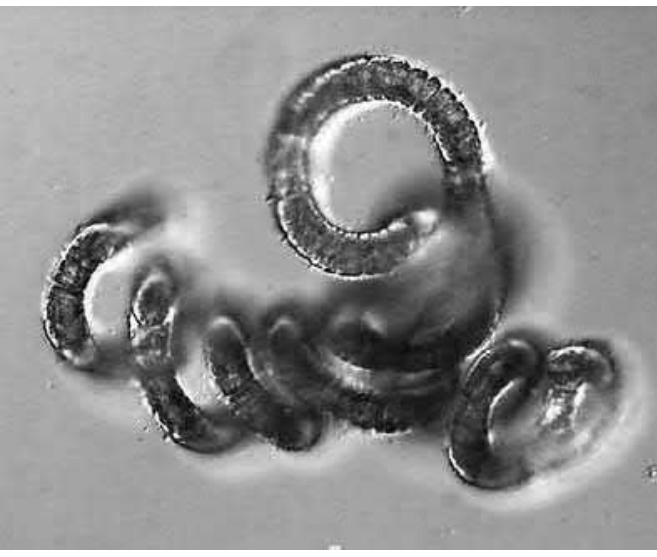

Kuva 1.2. Itämeren erityispiirteenä ovat sinileväkukinnat. Mikroskooppikuvassa (kuvan oikea leveys noin 0.1 $\mathrm{mm}$ ) on avomeren kukintoja muodostava Nodularia spumigena. Se pystyy sitomaan kaasumaista typpeä erilaissoluillaan (heterosyytit). Nodularia erittää maksamyrkkyä. (Merentutkimuslaitos/Seija Hällfors)

tavaltioista kaikki, paitsi Venäjä, ovat Euroopan Unionin jäsenvaltioita, ja kolme on Pohjoismaita. On ymmärrettävää, että raskaasta kuormituksesta kärsivä sekä vuosittain ainakin osin jäätyvä meri on laajan ja monipuolisen kansainvälisen tutkimuksen kohteena, mikä on ohjannut eritaustaiset maat tiiviiseen kanssakäymiseen.

Itämeren haavoittuvuus oli jo vuosikymmeniä sitten tiedossa ja sen tilan seurannan sekä suojelun edesauttamiseksi on tehty laajaa kansainvälistä yhteistyötä. Tästä syystä - ja Suomen aloitteesta - Itämerivaltiot solmivat vuonna 1974 Itämerisopimuksen, joka velvoittaa jäsenmaat huolehtimaan havainto-ohjelmasta ja luovuttamaan perusaineiston yhteiseen tietokantaan sekä suojelemaan Itämerta. Toimintaa hallinnoi Itämeren suojelukomissio HELCOM (Helsinki Commission). Tästä huolimatta Itämeren tila on vähitellen huonontunut, päästöt ja riskit ovat kasvaneet, ja suojelu on tullut yhä tähdellisemmäksi.

Tämä kirja on ensimmäinen yliopistollinen oppikirja Itämeren fysiikasta ja sen kytkennästä Itämeren tilaan sekä tulevaisuuteen. Sen kohderyhmänä ovat opintojen keskivaiheessa olevat 


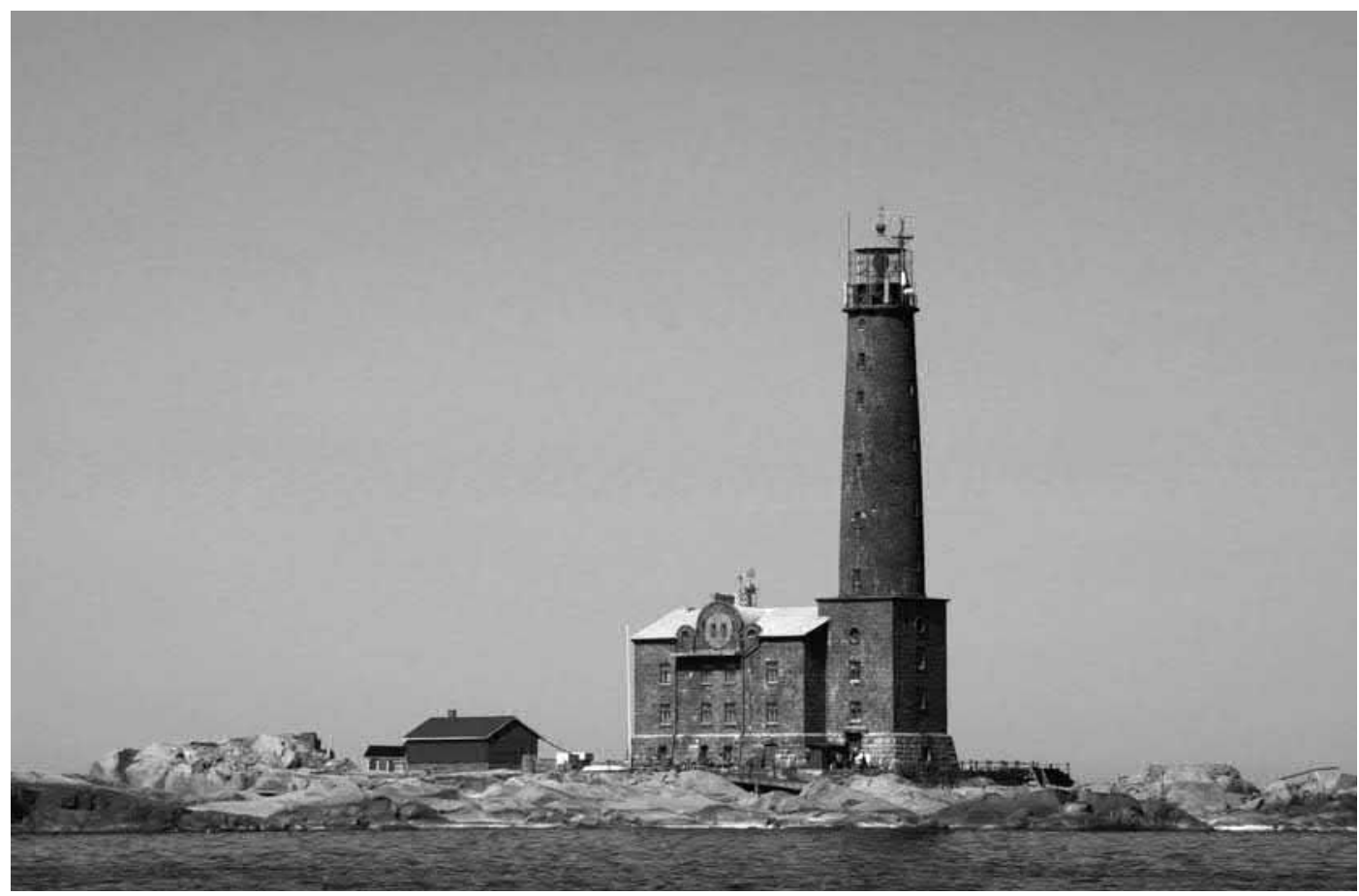

Kuva 1.3. Bengtskärin majakka (valmistunut 1906) sijaitsee 25 kilometriä Hangosta lounaaseen. Se on Pohjoismaiden suurin. Majakoiden henkilöstö osallistui meritieteelliseen havaintotoimintaan jo 1800-luvulta lähtien. (Merentutkimuslaitos/Riku Lumiaro)

geofysiikan, hydrobiologian ja limnologian opiskelijat, mutta teos on rakennettu niin, että lukion oppimäärä riittää esitiedoksi. Kirja soveltuu myös aikuiskoulutukseen, kuten lukion opettajien täydennyskoulutukseen ja palvelee yleensä alalla toimivien tutkijoiden ja viranomaisten käsikirjana.

Kirja koostuu yhdeksästä luvusta. Johdantoluku luo yleiskatsauksen Itämeren peruspiirteisiin sekä käy läpi kirjan sisällön ja käytetyn lähdekirjallisuuden. Toisessa luvussa tutustutaan Itämeren kehityksen eri vaiheisiin ja esitetään nykyisen Itämeren jako eri altaisiin. Itämeren tutkimuksen historiaan luodaan katsaus erityisesti Suomen osuutta tarkastellen. Tärkeitä tieteellisiä tuloksia mainitaan myös muiden maiden tutkimuksista. Luku 3 "Fysikaalisen tutkimuksen menetelmät" perehdyttää lukijan koko oseanografisen tutkimuksen kannalta hyvin oleelliseen asiaan eli mittaustoimintaan, joka käynnistyi aikoinaan majakoilta (kuva 1.3). Siinä esitellään ensin tutkimusaluksia, havaintoasemien toimintaa ja tavallisimpien mittalaitteiden toimintaperiaatteita. Lisäksi tarkastellaan kaukokartoitusmenetelmien hyödyntämistä oseanografisessa tutkimuksessa, ja lopuksi esitellään lyhyesti matemaattisen mallintamisen perusteita. Mallit antavat tärkeää tietoa fysiikan prosesseista, joita mittausten avulla ei pystytä tutkimaan riittävän kattavasti, ja ne soveltuvat fysikaalisten ilmiöiden ja tapahtumien ennustamiseen ja tutkimiseen.

Luku 4 "Syvyyssuhteet ja hydrografia" tarkastelee Itämeren eri altaiden pohjatopografiaa ja pohjan laatua. Keskeinen osuus on Itämeren hydrografian, lähinnä lämpötilan, suolaisuuden ja tiheyden, esittämisellä. Tämä kattaa Itämeren kerrostuneisuuden peruspiirteet vuodenaikaisvaihteluineen sekä lämpötilan ja suolaisuuden jakaumat horisontaali- ja vertikaalisuunnissa. 


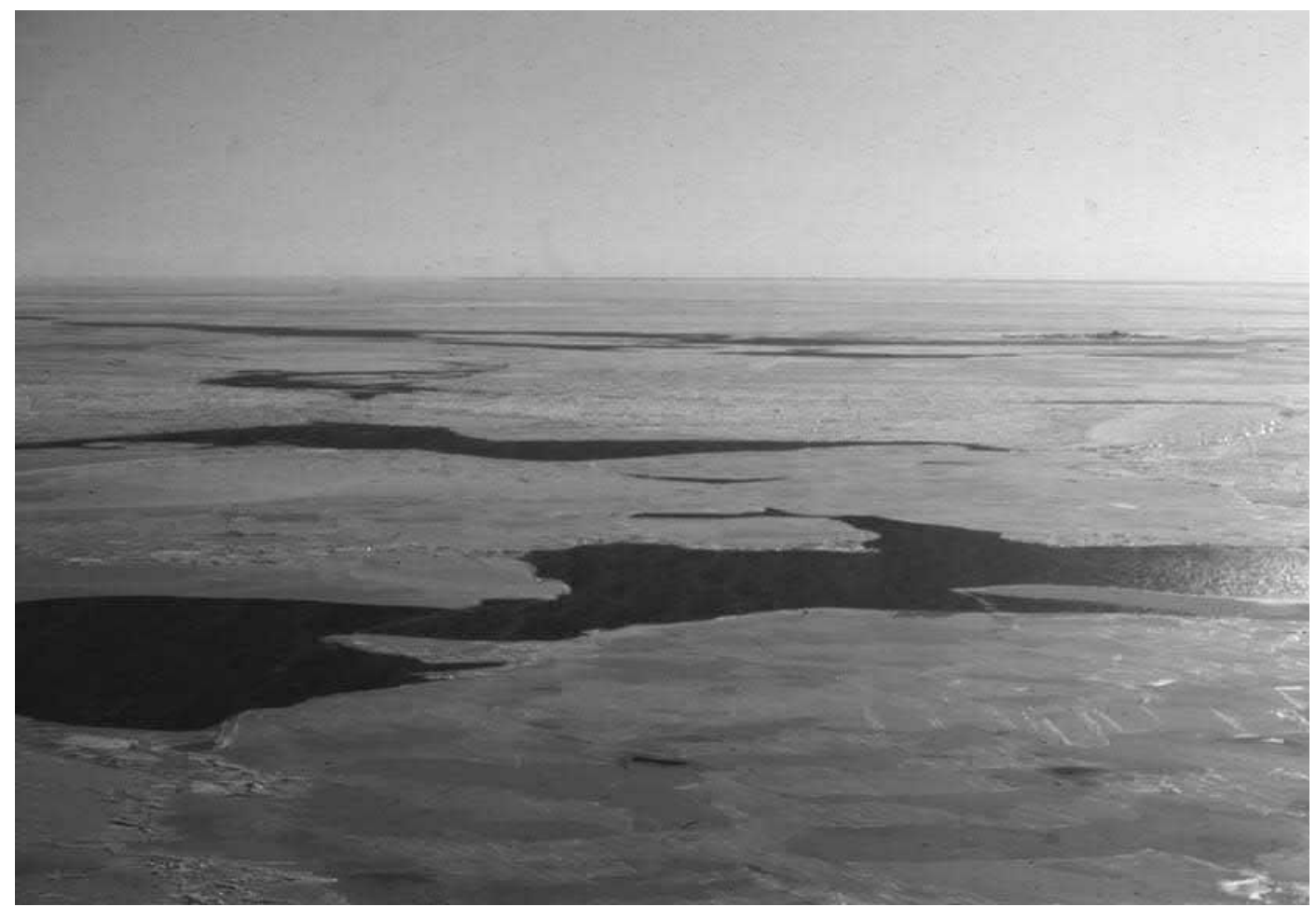

Kuva 1.4. Ajojäämaisema. Itämerellä on jäätä 5-7 kuukautta vuosittain. (Matti Leppäranta)

Seuraavassa luvussa "Vesitase ja lämpötalous" käsitellään aluksi Itämeren alueen ilmaston yleispiirteitä sekä meren ja ilmakehän vuorovaikutusta. Tämän jälkeen seuraa Itämeren alueen vesitase eli sadannan, haihdunnan, jokivirtaamien ja Pohjanmeren kanssa tapahtuvan vedenvaihdon keskinäiset suuruussuhteet. Itämeren pinnan energiatasetta tarkastellaan yksityiskohtaisesti ja esitetään laskenta-algortimit sen eri komponenteille. Lopuksi katsotaan, kuinka ilmakehän lämmittävä ja jäähdyttävä vaikutus etenee Itämeren vesirungossa.

Luvun 6 "Veden liikkeet" alussa luodaan katsaus Itämeren yleiseen kiertoliikkeeseen tilastollisten havaintoanalyysien avulla ja esitellään havaintoja erilaisista virtausdynamiikan ilmiöistä ja prosesseista. Virtausdynamiikan yhtälöihin tehdään suuruusluokka-analyysi ja selvitetään virtausten synnyn kannalta keskeiset tekijät. Lisäksi tutki- taan eräitä erikoistapauksia: inertialiike, geostrofinen virtaus ja Ekman-virtaus. Tämän jälkeen luodaan katsaus vedenkorkeuksiin vaikuttaviin tekijöihin ja tarkastellaan niiden dynamiikkaa. Luvussa tarkastellaan myös monipuolisesti aaltoliikettä, mukaan lukien matalan veden aallot kuten Seiche-aalto, sisäiset aallot sekä tuulen nostattama aallokko.

Luvun 7 aiheena ovat Itämeren jääolot (kuva 1.4). Itämeren jääpeite kattaa vuosittain 10-100 prosenttia sen pinta-alasta ja on merkittävä meren fysiikkaa ja ekologiaa ohjaava tekijä. Aluksi tarkastellaan Itämeren jään muodostumista, rakennetta ja ominaisuuksia - se on rakenteellisesti napamerten merijään kaltaista. Jään paksuuskasvu ja sulaminen käsitellään seuraavaksi, ja sen jälkeen aiheena ovat ajojäät, morfologia ja dynamiikka. Lopuksi esitellään jäätalven kehitystä kuvaavia matemaattisia malleja. 


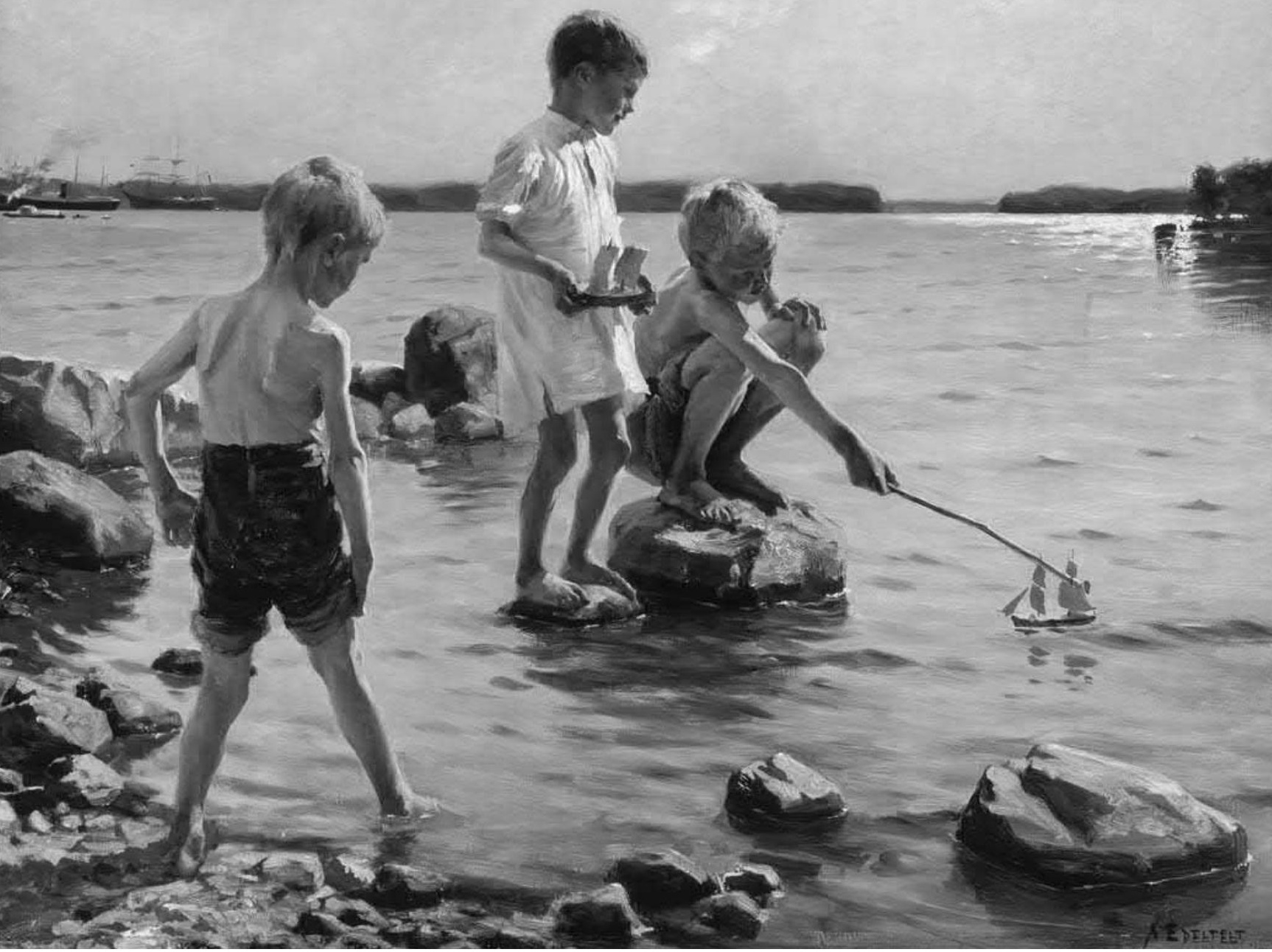

Kuva 1.5. Albert Edelfelt: Leikkiviä poikia rannalla (1884). (Ateneumin taidemuseo, kuvataiteen keskusarkisto/Hannu Aaltonen.)

Luku 8 "Kriittiset prosessit ja ääritilanteet” käsittelee Itämeren kannalta keskeisiä ja myös kriittisiä prosesseja. Se lähtee liikkeelle ilmastosta ja säästä, esitellen niitä kuvaavan Pohjois-Atlantin Oskillaation, NAO:n (North Atlantic Oscillation). Lisäksi tarkastellaan ilmakehän ja meren vuorovaikutusta eräissä ääritilanteissa. Seuraavaksi käsitellään kumpuamista eli dynamiikan pintaan syvemmistä vesikerroksista ajamaa, kesäoloissa kylmää ja usein ravinteikasta vettä. Tämän jälkeen tulevat erilaiset intruusiot ja rintamat, joissa vesimassan ominaisuudet hypähdyksenomaisesti muuttuvat. Seuraavaksi käsitellään suolapulssi eli Itämereen Tanskan salmien kautta epäsäännöllisin väliajoin tuleva suolaisen veden tavallista voimakkaampi sisäänvirtaus, joka tuulettaa syvänteiden vesimassat. Luvussa paneudutaan myös vedenkorkeuksien lyhyt- ja pitkäaikaisiin muutoksiin sekä poikkeuksellisiin vedenkorkeuksiin, joihin liittyy tulvatilanteita. Lopuksi tarkastellaan vielä jääpeitteen vaihteluita.

Viimeinen, 9. luku kokoaa Itämerestä saadun opin yhteen ja esittää arvioita Itämeren tulevaisuudesta. Itämeressä tapahtuneita fysikaalisen tilan muutoksia meritieteellisten mittaustoiminnan alusta nykypäivään asti tarkastellaan analysoimalla meriveden korkeuden, suolaisuuden, lämpötilan ja jääpeitteen aikasarjoja. Meren fysiikan luonnollisten vaihteluiden ekologisia 
vasteita havainnollistetaan esittämällä valaistusoloissa ja happitilanteessa tapahtunut kehitys. Luomme myös katsauksen ihmisen vaikutuksista Itämereen, kuten rehevöitymiseen, happitilanteeseen, meriliikenteeseen ja jokien säännöstelyyn. Pohditaan myös, mitä olisi tehtävä Itämeren tilan parantamiseksi eli parhaimmillaan sen palauttamiseksi ennen ihmisen vaikutusta olleeseen tilaan (kuva 1.5). Seuraavaksi analysoimme Pohjois-Euroopan ilmaston kehitysnäkymiä IPCC:n (Intergovernmental Panel on Climate Change) ilmastoskenaarioiden pohjalta. Keskilämpötilan, sademäärien ja tuulien muutosten vastetta Itämeren fysiikkaan arvioidaan. Ilmastonmuutokseen liittyvät ekologiset vasteet Itämeressä kuvaamme lyhyesti. Kirjan lopuksi pohditaan sitä, miten paljon me tällä hetkellä tiedämme Itämerestä, ja mitkä ovat suurimmat edessä olevat tutkimukselliset haasteet.

Itämerestä on runsaasti tieteellistä kirjallisuutta, jota on käytetty tätä teosta laadittaessa. Kirjan lopussa on lähdeluettelo, joskaan tässä yhteydessä ei ole tarkoitus esittää Itämeren tutkimuksen kirjallisuuskatsausta. Oheislukemiseksi voidaan mainita erityisesti seuraavat yleisesitykset, jotka sisältävät Itämeren fysiikan kuvauksia. On huomattava, että kyseiset kirjat ovat esityksen vaikeustasolta ja tyyliltään toisistaan poikkeavia.

Voipion ja Leinosen (1984) suomenkielinen kirja on yleistajuinen, havainnollinen ja poikkitieteellinen esitys, jota voi suositella lukemiseksi perustasolta lähdettäessä. Moderni esitys Itämeren oseanografiasta löytyy Fonseliukselta (1996), mikä on yksi tämän kirjan tärkeimmistä lähteistä. Stigebrandt (2001) ja Rodhe (1999) esittävät laajahkoja kokooma-artikkeleja Itämeren fysikaalisista prosesseista. Varhempia teoksia ovat Magaardin ja Rheinheimerin (1974) ja Voipion (1981) poikkitieteelliset Itämerikirjat sekä Mälkin ja Tamsalun (1985) Itämeren dynamiikkaa käsittelevä monografia. Itämeren tutkimustuloksia löytyy edelleen kokoussarjojen kokoomateoksista, tärkeimpiä ovat olleet sarja "Conference of Baltic Sea Oceanographers" sekä "BALTEX-Conference". Tieteellisiä artikkeleja on hajanaisesti eri julkaisusarjoissa, erityisesti Itämeren alueella julkaistavissa sarjoissa. 


\section{Itämeri ja sen tutkimus}

\subsection{Itämeren kehitys}

Itämeren allas on geologian näkökulmasta katsoen vanha painuma, joka jääkausina on ollut mannerjään peitossa. Itämerellä tarkoitetaan tätä allasta ja sen kehitystä viime jääkauden jälkeen. Se sai alkunsa, kun mannerjäätikkö oli perääntynyt sen etelärannikon tienoille noin 15.000 vuotta sitten (kuva 2.1). Noin 3.000 vuotta myöhemmin jään reuna oli linjalla Gotlanti Viron pohjoisrannikko - Neva. Suomen eteläosista jää vetäytyi 10.000-11.000 vuotta sitten, ja heti sen jälkeen myös asutus levisi sinne. Perämeren alueen mannerjäätikön reuna saavutti noin 9.000 vuotta sitten. Kaikki Itämeressä esiintyvät eläin- ja kasvilajit ovat luonnollisesti levinneet siihen vasta jääkauden jälkeen. Jäätikön suuri massa aiheutti kallioperään suuren painauman, jonka hidas palautuminen aiheuttaa maankohoamisilmiön.

Kun perääntyvän mannerjäätikön eteläreuna oli Salpausselän kohdalla noin 11.000 vuotta sitten, sulamisvesistä oli muodostunut sub-arktinen Baltian jääjärvi, jonka katsotaan olevan Itämeren varhaisin vaihe (kuva 2.2). Tällöin maankohoaminen oli jo voimakasta eikä valtameriyhteyttä ollut. Jään sulamisvedet liikkuivat länteen päin, mahdollisesti Tanskan salmien kautta. Noin 10.000 vuotta sitten, jään reunan edelleen vetäydyttyä pohjoiseen tapahtui suuri luonnonkatastrofi: Baltian jääjärveen avautui

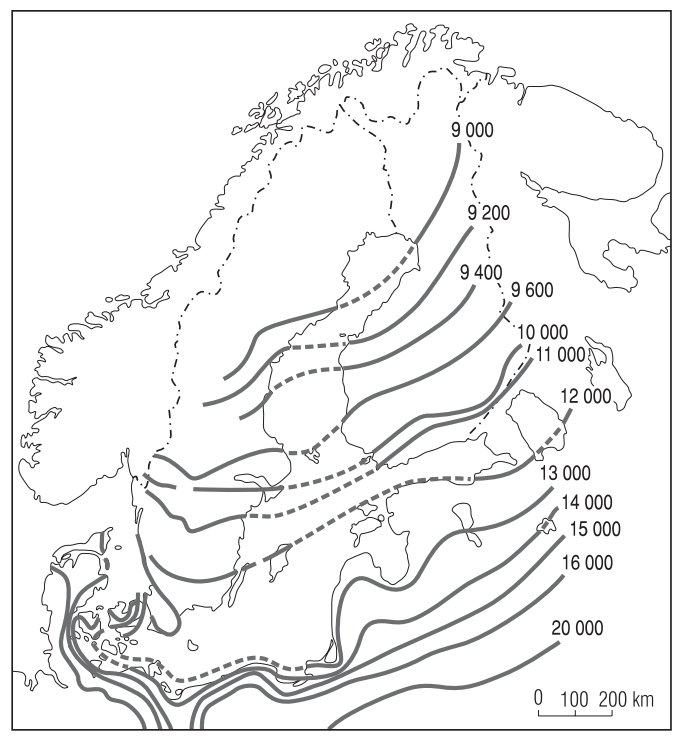

Kuva 2.1. Jään vetäytyminen Itämeren alueelta vuosina nykyhetkestä taaksepäin. (Piirretty Voipion ja Leinosen [1984] kuvasta.)

valtameriyhteys Keski-Ruotsin kautta jääjärven pinnan alentuessa samalla noin 26 metriä. Suolaista vettä pääsi sisään ja suolaisuus kasvoi nopeasti, sillä kanava Pohjanmereen leveni.

Itämeren suolainen Yoldiameri-vaihe alkoi (kuva 2.2). Mereen tuli eliöstöä Pohjanmereltä, muun muassa Yoldia arctica simpukka, jonka mukaan vaihe on nimetty. Vaiheen alkaessa Pohjanlahti oli vielä jäätikön peitossa, ja se päättyi noin 1.000 vuotta myöhemmin, kun valtameriyhteys katkesi. Tämä johtui siitä, että maan kohoaminen oli eustaattista merenpinnan nousua nopeampaa (eustaattinen merenpinnan vaihtelu johtuu valtamerten veden tilavuuden vaihtelusta). Alkoi taas jään sulamisvesistä ja joista laskevan makean veden hallitsema järvivaihe (Ancylusjärvi) mannerjäätikön ulottuessa yhä Perämerelle (kuva 2.2). Vaihe sai nimensä makean veden Ancylus fluviatilis -kotilosta. 

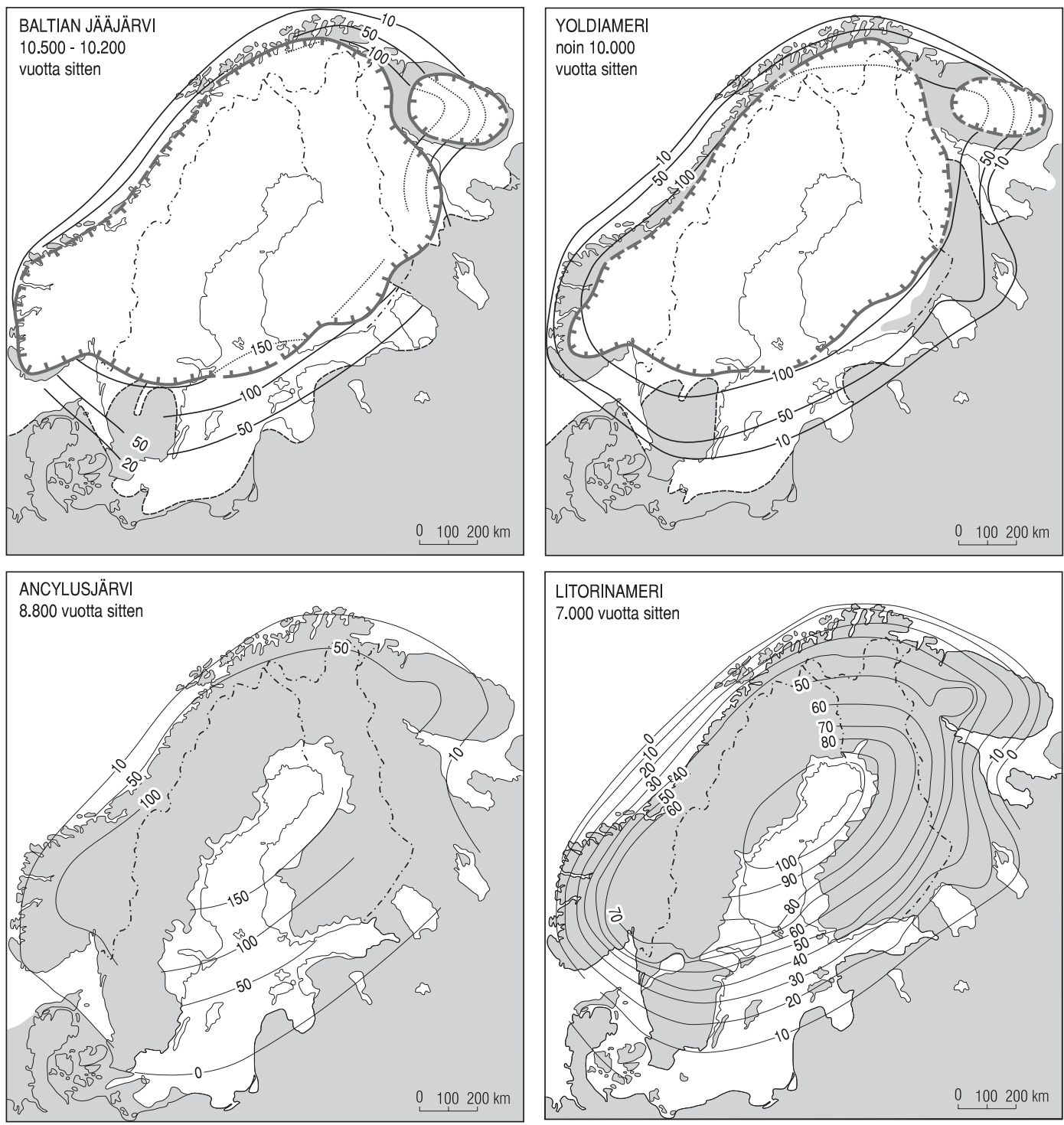

$\perp$ Iــ mannerjäätikön reuna

-50 — maan kohoaminen (cm/100 vuotta)

maa

Kuva 2.2. Itämeren vaiheet, jäätikön laajuus ja maankohoaminen: Baltian jääjärvi, Yoldiameri, Ancylusjärvi ja Litorinameri. (Piirretty Voipion ja Leinosen [1984] kuvasta.) Alhaalla piirrokset simpukasta ja kotiloista, joiden mukaan vaiheet on nimetty. Lymnea-kotilo viittaa Limneanmereen, joka seurasi Litorinamerta 4000 vuotta sitten. (Piirtänyt Harri Kuosa.)

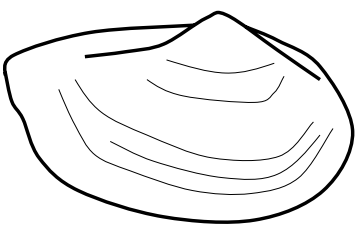

Yoldia arctica -simpukka

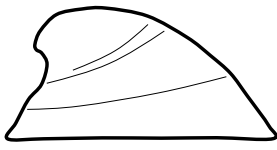

Ancylus fluviatilis -kotilo

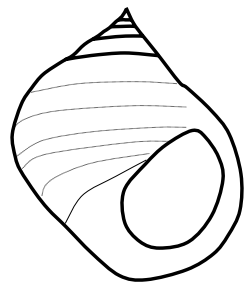

Littorina-kotilo

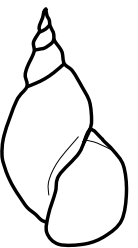

Lymnea-kotilo 


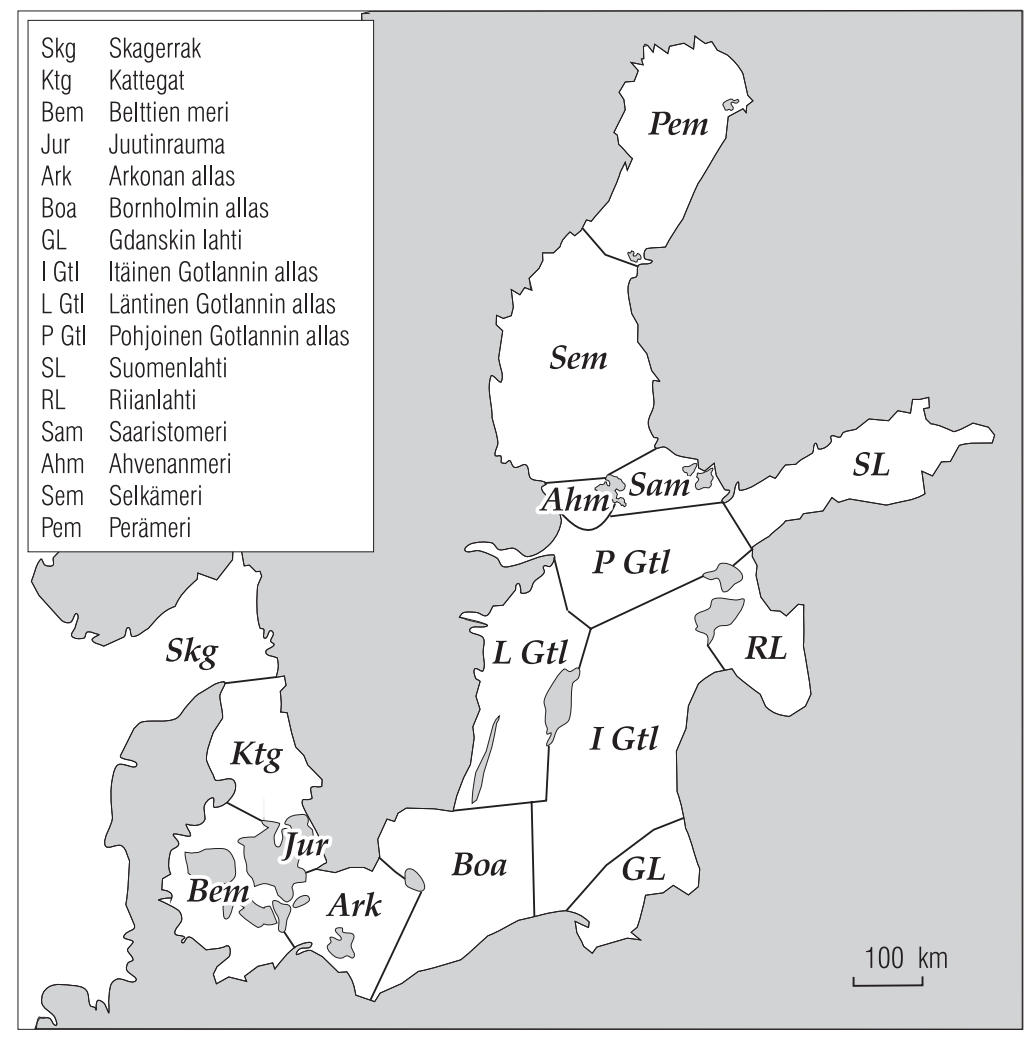

Kuva 2.3. Itämeren jako eri altaisiin. (Piirretty Fonseliuksen [1996] kartan pohjalta.)

\subsection{Itämeren jako eri altaisiin}

Noin 7.500 vuotta sitten maanpinnan kohoamisen ollessa pohjoisessa suurempaa kuin etelässä, vesimassat työntyivät etelään, ja valtameren pinnan samalla kohotessa Ancylusjärveen syntyi valtameriyhteys Tanskan salmien kautta. Tätä uutta vaihetta kutsutaan Litorina-mereksi (kuva 2.2). Suolapitoisuus oli hieman nykyistä suurempi, mistä on todisteena Littorina-kotilon esiintyminen. Tämän jälkeen suolaisuus alkoi hiljalleen alentua. Limneanmeren (Lymnea-kotilon mukaan) vaihe alkoi 4.000 vuotta sitten, ja nykyisen kaltainen Itämeri muodostui noin 2.000 vuotta sitten suolaisuuden edelleen hiukan alennettua. Itämeren eliöstöön on jäänyt niin sanottuja jäännös- eli reliktilajeja sekä suolaisen että makean veden kausista.
Itämeri on luokiteltu Atlantin valtameren pieneksi välimereksi (kuva 2.3). Siihen rajoittuu Pohjanmerestä uloimpana Skagerrak, josta etelään sijaitseva Kattegat on Pohjanmeren ja Itämeren välinen vaihettumisvyöhyke. Itämeren uloimmaksi osaksi luetaan Tanskan salmet, jotka toimivat yhdyssiteenä Pohjanmeren ja Itämeren sisäosien välillä. Salmet koostuvat Juutinraumasta sekä Belttien merestä, johon kuuluvat Mecklenburgin lahti, Kielin lahti, Vähä-Beltti ja Iso-Beltti.

Itämeren maantieteellinen jako eri merialtaisiin perustuu paljolti rannikon muotoihin, kynnyksiin sekä muihin luonnollisiin muodostumiin. Kynnyksellä tarkoitetaan kahden merialtaan välisen vesialueen minimisyvyyttä, eli 
Taulukko 2.1. Itämerta karakterisoivia lukuarvoja (Itämeren katsotaan rajoittuvan Kattegatiin).

\begin{tabular}{|c|c|}
\hline Suure & karakterisoiva lukuarvo \\
\hline Pinta-ala & $392.978 \mathrm{~km}^{2}$ \\
\hline Keskisyvyys/maksimisyvyys & $54 \mathrm{~m} / 459 \mathrm{~m}$ \\
\hline Valuma-alue & $1.649 .550 \mathrm{~km}^{2}$ \\
\hline Ikä & (104 vuotta), 2.000 vuotta nykyisessä muodossa \\
\hline Todellinen maannousu $^{1}$ & $-1-->9 \mathrm{~mm} /$ vuosi \\
\hline Veden vaihtumisaika & 50 vuotta \\
\hline Suolaisuus $\min / \max$ & $0 / 32 \%$ \\
\hline Keskisuolaisuus & 7,4 \%o (1/5 valtameren suolaisuudesta) \\
\hline Gotlannin altaan suolaisuus (pinta/pohja) & $6-7 \% / 11-13 \%$ \\
\hline Jäätyvä pinta-alaosuus vuosittain & $10-100 \%$ \\
\hline Perustuotanto ${ }^{2}$ & $30-250 \mathrm{~g} \mathrm{C} \mathrm{m}^{-2} \mathrm{a}^{-1}$ \\
\hline Ympäröivien valtioiden lukumäärä (2006) & 9 \\
\hline Valuma-alueen valtioiden lukumäärä (2006) & 14 \\
\hline Valuma-alueen asukasluku (2006) & 85 miljoonaa \\
\hline
\end{tabular}

'Näennäinen maannousu = todellinen maannousu-eustaattinen efekti

${ }^{2}{ }^{2}$ ksikkönä $\mathrm{g} \mathrm{C} \mathrm{m}^{-2} \mathrm{a}^{-1}=$ grammaa eloperäistä hiiltä neliömetrillä vuodessa.

syvyyttä, johon asti horisontaalinen vedenvaihto on mahdollista. Hydrografisen jaottelun pohjalta voidaan altaiden erilaisia vesimassoja tarkastella ja erotella ne toisistaan (luku 4).

Tutkittaessa Itämeren osia etelästä pohjoiseen ensimmäisenä Tanskan salmien jälkeen ovat Arkonan allas Ruotsin ja Saksan välissä sekä Bornholmin saaren itäpuolella oleva Bornholmin allas. Tämän jälkeen alkaa Gotlannin meri, joka koostuu itäisestä, läntisestä ja pohjoisesta Gotlannin altaasta sekä Gdanskin lahdesta. Arkonan allas, Bornholmin allas ja Gotlannin meri muodostavat niin sanotun Varsinaisen Itämeren. Läntisellä Gotlannin altaalla on myös Itämeren syvin kohta (Landsortin syvänne, 459 metriä). Varsinaisen Itämeren itäpuolella on kaksi merenlahtea, Suomenlahti ja Riianlahti. Edellinen on länsi-itäsuuntainen pitkänomainen lahti, joka jatkuu Varsinaisesta Itämerestä ilman kynnystä. Riianlahti sijaitsee Viron ja Latvian alueella ja on varsinaisesta Itämerestä jossain määrin eristyksissä. Maantieteellisesti pohjoisin allas on Pohjanlahti. Tämä pinta-alaltaan suuri pohjoiseteläsuunnassa pitkänomainen allas jakaantuu
Perämereen, Selkämereen, Ahvenanmereen ja Saaristomereen.

\subsection{Itämeri numeroina}

Itämeren pinta-ala on 392.978 neliökilometriä ja keskisyvyys 54 metriä (taulukko 2.1), kun uloimmaksi alueeksi lasketaan Tanskan salmet. Atlantin pinta-ala on 88 miljoonaa neliökilometriä ja keskisyvyys on 3.300 metriä. Itämeren pinta-ala on siis vain 0,5 prosenttia ja keskisyvyys vain 1,7 prosenttia Atlantin valtamerestä. Pohjoisen Itämeren alueella tapahtuu edelleen maankohoamista jääkauden jäljiltä. Itämeren veden vaihtumisaika, noin 50 vuotta, tekee sen ekosysteemistä herkän, ihmisen toiminnan vaikutuksille alttiin merialueen. Itämeri on murtovesiallas, jossa suolaisuus pienenee Tanskan salmista pohjoiseen ja itään päin mentäessä noin 30 promillesta nollaan. Meren alasta jätyy vuosittain 10-100 prosenttia.

Itämerta reunustaa nykyään 9 valtioita, joista 8 on Euroopan Unionin jäseniä. Valuma-alue, joka 


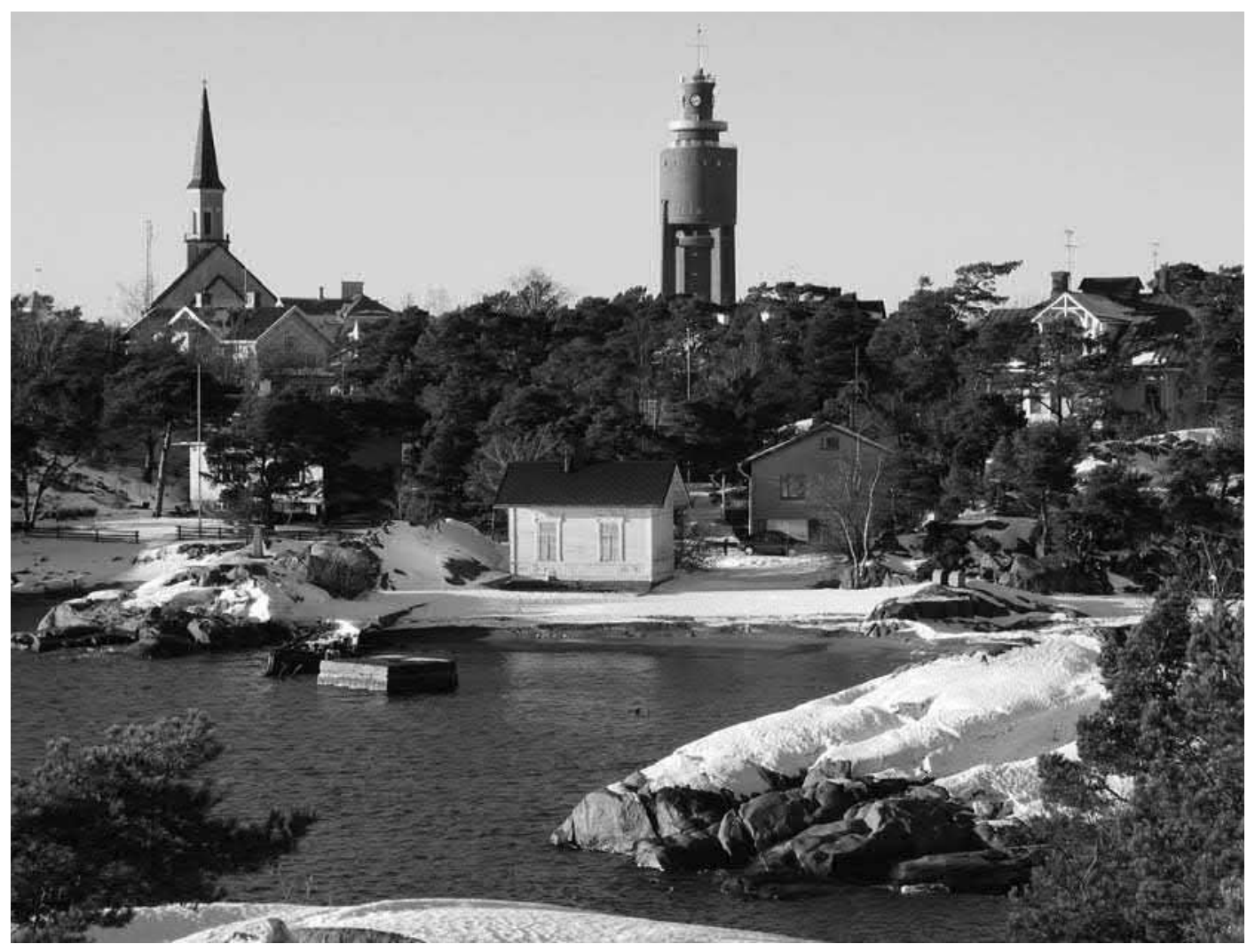

Kuva 2.4. Kuvan keskellä on Suomen vanhin mareografi, joka sijaitsee Hangossa. Mittaustoiminta alkoi siellä jo 1887. (Merentutkimuslaitos/Patrick B. Eriksson)

on pinta-alaltaan 4 kertaa Itämeren suuruinen, kattaa 14 valtiota ja 85 miljoonaa asukasta.

\subsection{Tutkimustyön historiaa Suomessa ja muualla}

Fysikaalisen oseanografian kehityksen eri vaiheista Suomessa on olemassa yksityiskohtaisia katsauksia (Simojoki 1978 ja Mälkki 2001). Tässä käsitellään suomalaisten tutkimusten lisäksi tärkeimpiä muissa Itämeren maissa tehtyjä tutkimuksia, jotka ovat tuoneet oleellista uutta tietoa Itämeren fysiikasta.

Kokeellisen merentutkimuksen ensi askeleet otettiin Itämerellä vuonna 1871, kun saksalaiselta Pommerania-alukselta käsin tehtiin ensimmäiset hydrografiset (suolaisuus ja lämpötila) mittaukset. Suomen merentutkimuksen varsinainen alku ajoittuu 1880-luvulle, mutta jo tätä aiemmin oli tehty joitain yksittäisiä tutkimuksia. Helsingin yliopiston fysiikan professori Gustaf Hällström tutki maankohoamisen ja Itämeren vedenkorkeusvaihteluiden syitä ja totesi tuulet merkittäväksi tekijäksi ilmanpainevaihteluiden lisäksi. Suomen Tiedeseuran järjestämät ensimmäiset vedenkorkeusmittaukset ajoittuvat jo 1840-luvulle. Vasta 1880-luvulla tapahtui geofysiikan tutkimuksen yleinen nousu Suomessa, ja vuonna 1887 perustettiin Suomen vanhin, edelleen toiminnassa oleva vedenkorkeusasema Hankoon (kuva 2.4) sekä 1904 myös edelleen toiminnassa oleva asema Helsinkiin. Samoihin aikoihin, 1880-luvulla, alkoivat säännölliset jää- ja hydrografiahavainnot, joista jälkimmäisten aloittamisessa oli keskeisenä henkilönä suomalainen 


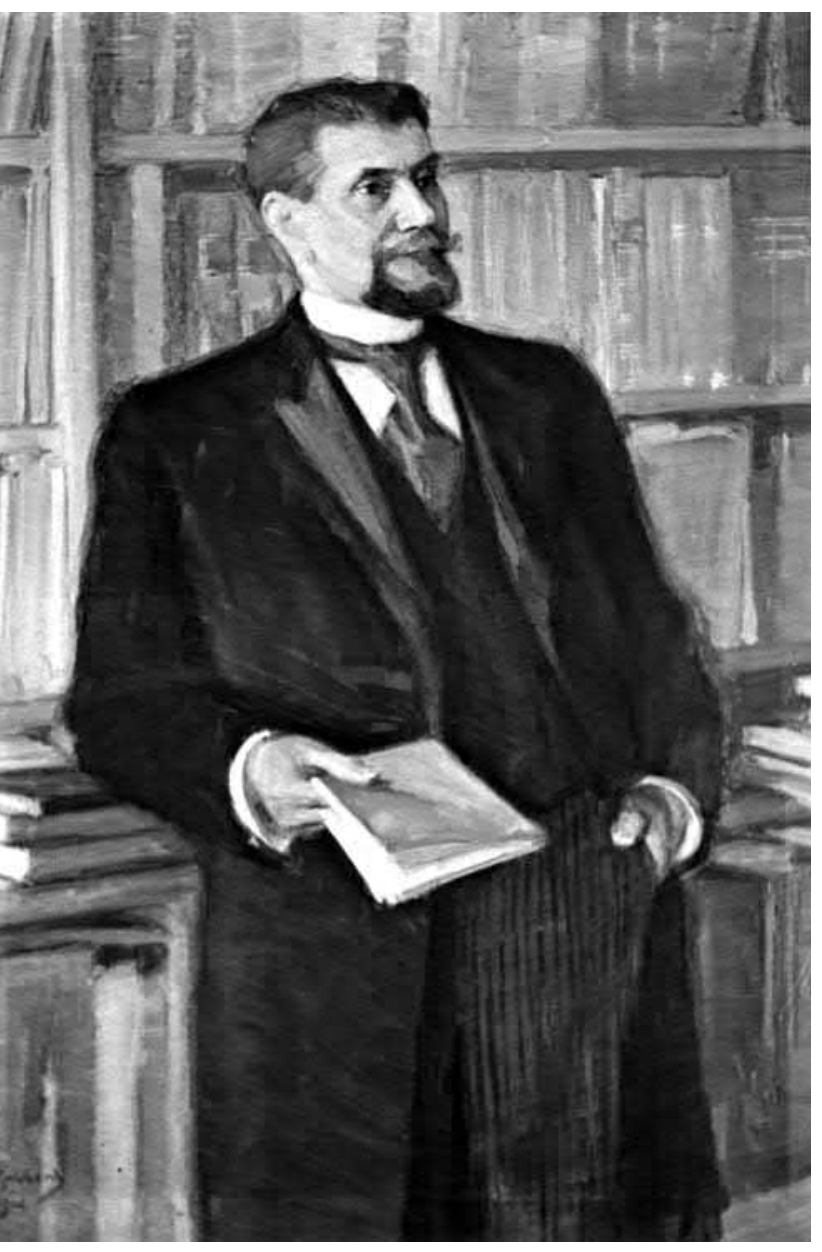

Kuva 2.5. Helsingin yliopiston fysiikan professori Theodor Homén (1858-1923, Helsingin yliopistomuseo Arppenaum). Homén oli keskeinen henkilö Suomen merentutkimuksen käynnistämisessä ja organisoinnissa.

Oskar Nordqvist. Tutkimus eteni myös muualla: vuonna 1894 venäläinen amiraali Stephan Makarov julkaisi tutkimuksen Suomenlahden veden liikkeistä ja kerrostuneisuudesta.

Vuosi 1898 oli merentutkimuksen kannalta Suomessa käänteentekevä, sillä silloin alkoi säännöllinen tutkimustoiminta. Samana vuonna oli pohjoismaisessa konferenssissa sovittu hydrogra-

Kuva 2.6. Vuosina 1903-1939 käytössä ollut tutkimusalus Nautilus. (Merentutkimuslaitoksen kuvaarkisto) fisten mittausten aloittamisesta Itämerellä. Aloitteen tekijöinä olivat Otto Pettersson Ruotsista, Martin Knudsen Tanskasta ja Helsingin yliopiston fysiikan professori Theodor Homén Suomesta (kuva 2.5). Hänen johdollaan ensimmäinen suomalainen tutkimusretki alkoi 30.8.1898 Suo$m i$-aluksella. Homén pyrki jo varhain kokonaisvaltaista merentutkimusta kohti muun muassa pitäen tärkeänä planktonmittausten kytkemistä hydrografisiin kenttätutkimuksiin. Tätä ajattelutapaa edusti myös Homénin työtoveri, professori J. A. Palmén, Tvärminnen eläintieteellisen aseman perustaja.

Merentutkimustyö lähti Pohjoismaissa laajalla rintamalla ripeästi käyntiin. Vuonna 1900 Martin Knudsen esitti kuuluisaksi tulleen teoriansa Itämeren ja Pohjanmeren vedenvaihdon laskemisesta. Hän teki myös merkittävän havainnon: Itämereen tulee Pohjanmereltä epäsäännöllisin väliajoin suolaista vettä pohjanläheisessä kerroksessa. Nykyisin ilmiö tunnetaan suolapulssina.

Vuonna 1902 Suomen Keisarillinen Senaatti päätti perustaa Suomen Tiedeseuran alaisuuteen hydrografis-biologisen komission, jonka tehtävänä oli merentutkimus. Toiminta keskittyi aluksi lähinnä majakkalaivoilta tehtäviin mittauksiin. Työ eteni ripeästi, sillä oma tutkimusalus, Nautilus, saatiin kesäksi 1903 (kuva 2.6).

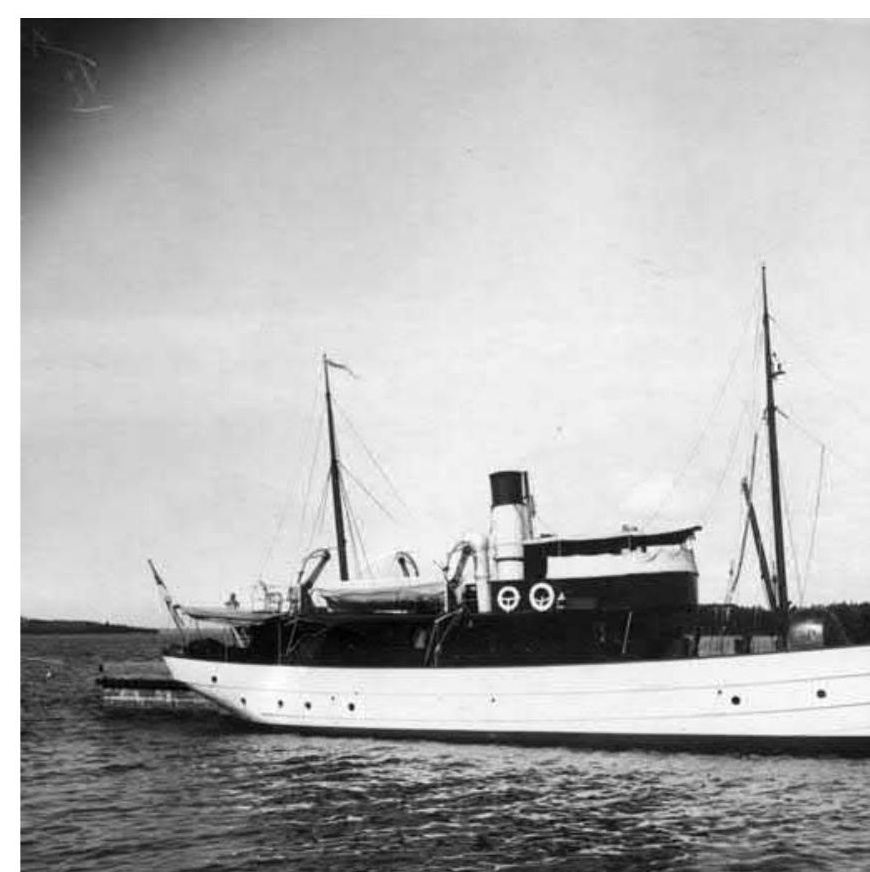


Wittingin ajatuksena oli suurten kokonaisuuksien aikaansaaminen. Hänen suunnitelmiinsa kuului muun muassa yhdistää Ilmatieteellisen Keskuslaitoksen meteorologiset tutkimukset hydrografis-biologisten tutkimusten kanssa ja saada aikaan monitahoinen tutkimuslaitos. Tämä ajatus ei ole vieras nykypäivänäkään. Kokonaisvaltaiseen ajatteluun kuului esimerkiksi se, että veden lämpötilahavaintoja voitaisiin käyttää hyödyksi seuraavien kuukausien ilman lämpötilan ennusteissa, kun taas meteorologisia havaintoja voitaisiin hyödyntää virtausennusteiden laadinnassa. Jääolojen kytkentä sääoloihin oli myös tärkeää jääpalvelun kehittämisessä.

Wittingin tutkimustyö oli monipuolista ja liittyi perushydrografian ja virtausolosuhteiden selvittämiseen (kuva 2.7) ja se ulottui hyvinkin pitkälle meneviin vedenkorkeus- ja vuorovesitutkimuksiin, joissa paneuduttiin ensi kertaa vedenpinnan nollatason määrittelyongelmiin. Jo näinkin aikaisin saatiin hämmästyttävän paljon aikaan, ja ilman minkäänlaisten tietokoneiden apua! Tiedon laajuudesta osoituksena Wittingin julkaisuissa kuvattiin jo 1910-luvulla Itämeren fysiikan peruspiirteet varsin hyvin (Witting 1912).

Suomalaisen fysikaalisen oseanografian tutkimuksen alkuvuosien tärkeistä henkilöistä on edellisten lisäksi mainittava seuraavat henkilöt tutkimuskohteineen: Erik Palmén (1898-1985, virtaukset ja meri-ilmakehä-vuorovaikutus), Eugénie Lisitzin (1905-1989, vedenkorkeus ja vuorovesi) ja Risto Jurva (1888-1953, jääolot).

1920-luvun oseanografisen tutkimuksen voidaan Suomessa katsoa koostuneen kolmesta pääasiallisesta alueesta: jää, vedenkorkeus sekä hydrografia. Nämä alkuvuosien usein hyvinkin kattavat mittaukset muodostivat tärkeän pohjan pitkille aikasarjoille, joiden avulla voidaan nykypäivänä tutkia muun muassa ilmastossa esiintyviä vaihteluita. Vedenkorkeuden mittaaminen, teknistä laitekehittelyä ja tarkkavaaituksia unohtamatta, oli mainittava kehityskohde, sillä aikavälillä 19211928 rakennettiin peräti 14 uutta vedenkorkeusasemaa Suomen rannikolle. Vedenkorkeus oli erityisen tähdellinen suure, koska virtauksien ja veden suolaisuus- ja lämpötilakerrostuneisuuden mittaaminen oli vielä vaikeaa. Vedenkorkeusmittausten avulla maankohoamisen arvioiminen tarkentui, ja saatiin lisätietoa Itämeren ja Pohjanmeren välisen vedenvaihdon yksityiskohdista.

Seuraavalla vuosikymmenellä tärkeitä tuloksia olivat Erik Palménin julkaisemat Pohjois-Itämeren virtauskartat (Palmén 1930) sekä tuulen ja virtausten välistä vuorovaikutusta käsittelevät tutkimukset. Gunnar Granqvist julkaisi ensimmäiset Suomen rannikon lämpötila- ja suolaisuustilastot (Granqvist 1938). Tutkimukset Itämeren ominaisheilahteluista eli Seiche-aalloista ja äärimmäisistä vedenkorkeuksista ovat myös maininnan arvoisia. Meren optiikan tutkimukset käynnistyivät mittauksilla näkösyvyydestä ja valon etenemisestä meressä. Myös tekninen kehitys otti askelia eteenpäin, sillä kehitetyn batytermograafin avulla voitiin mitata lämpötila syvyyden suhteen. Ruotsalaiset tutkijat (Gustafsson ja Kullenberg 1936) pystyivät virtamittausten avulla havaitsemaan Itämeressä niin sanotun inertialiikkeen, ensimmäistä kertaa maailmassa. Ensimmäisten vuosikymmenten aikana tutkimustöiden tuloksina syntyi monia huomattavia suomalaisia väitöskirjoja (Jurva 1937a, Granqvist 1938, Lisitzin 1938). Lisitzin oli ensimmäinen nainen, joka väitteli Suomessa fysiikan tohtoriksi. Yhdeksää kieltä taitanut Lisitzin valittiin myös ensimmäisenä naisena jäseneksi Suomen Tiedeseuran matemaattis-fysikaaliseen osastoon.

Tutkimuksen kehitystä 1940-luvulla häiritsi Toinen Maailmansota. Tutkimuksen saralla kuitenkin edistyttiin seuraavissa kysymyksissä: näkösyvyys, vuorovesi, jää, virtaukset sekä energiatase. Tuulten ja virtausten vuorovaikutusta sekä rannikon vaikutuksia virtauksiin pystyttiin kvantifioimaan. Ilmo Hela (1915-1976) julkaisi väitöskirjansa vedenkorkeustutkimuksista (Hela 1944). Kokeelliset veden sekoittumista koskevat tutkimukset aloitettiin ja ne jatkuivat seuraavina vuosikymmeninä. Hydrografian alalla edistyttiin ja edelleenkin käytössä olevaa perustietoa julkais- 
tiin ensi kertaa (Brogmus 1952). Dietrich ym. (1957) esittivät, että vesirungon painekenttiä voidaan käyttää virtausten arviointiin myös Itämerellä (geostrofinen menetelmä).

Suomessa tuli alalle uutta sukupolvea 1950luvulla. Ilmo Hela nimitettiin Merentutkimuslaitoksen johtoon 1955. Hänen tutkimuksensa, jotka ulottuivat 1970-luvulle asti, käsittelivät virtauksia ja veden sekoittumisprosesseja. Vuonna 1953 Erkki Palosuo julkaisi uraauurtavan väitöskirjansa Itämeren ajojääkenttien tutkimuksesta. Merentutkimus astui Suomessa suuren askeleen eteenpäin, kun 1953 saatiin tutkimusalus Aranda. Aina vuoteen 1976 asti Aranda toimi myös yhteysaluksena Saaristomeren kelirikkoliikenteessä. Huomattavia yleisesityksiä tehtiin muun muassa Itämeren vedenkorkeuksista samalla kun kyseistä instrumentaatiota modernisointiin (Lisitzin 1959). 1960-luvulle siirryttäessä teknisessä kehityksessä otettiin suuria askeleita eteenpäin, ja fysikaalisen oseanografian kuva muuttui kohti ekstaktimpaa suuntaa. Ensimmäiset numeeriset mallilaskennat suoritti Sulo Uusitalo (19201985). Myös kaukokartoitussatelliitit tulivat tutkimuksen avuksi.

Tutkimus edelleen syventyi ja alan kasvu ilmeni uusina työpaikkoina 1970-luvulla. Merentutkimuslaitoksen henkilökunta kasvoi usealla kymmenellä henkilöllä, ja Helsingin yliopistoon saatiin maapallon vesivaipan geofysiikan professuuri (1967) sekä apulaisprofessuuri (1971). Virtaus- ja lämpötaloustutkimukset sekä mallitus edistyivät. Kiinnostus meriympäristön tilaan oli virinnyt 1960-luvulla ja tämän seurauksena vuonna 1974 perustettiin Itämeren suojelukomissio eli HELCOM (Helsinki Commission). Komission perustamisessa oli Akateemikko Ilmo Helalla keskeinen merkitys.

Itämeren jääntutkimukset kasvoivat voimakkaasti. Vuodesta 1970 lähtien Suomen ja Ruotsin kaikki tärkeimmät satamat Perämeren pohjukkaa myöten otettiin ympärivuotiseen käyttöön ja perustettiin yhteinen suomalais-ruotsalainen talvimerenkulun tutkimussäätiö. Tämä säätiö tuki tutkimustyötä monipuolisesti: talvimerenkulun tekniikka, jääpeitteen kartoittaminen, jääolojen ennustaminen, sekä jään liikkeet ja ahtojäät olivat rahoitettavia tutkimuskohteita. Suomessa otettiin vuonna 1976 käyttöön ensimmäisten joukossa koko maailmassa numeeriseen malliin perustuvat operatiiviset jääennusteet. Nämä laadittiin Merentutkimuslaitoksessa ja lähetettiin faksimilenä jäänmurtajille. Ennen kaikkea jään liikenopeuden ennusteet olivat jäämurtajatoiminnassa tärkeitä. Jääolojen kartoittamisessa NOAA-satelliitit (National Oceanographic \& Atmospheric Administration) tulivat operatiiviseen käyttöön, ja Suomen päästessä ESA:n (European Space Agency) liitännäisjäseneksi vuonna 1987 kaukokartoitustutkimukset alkoivat laajentua. ESA:n täysjäseneksi Suomi tuli 1995.

Vedenkorkeuden mittausjärjestelmä automatisoitiin 1980-luvulla, ja tiedonsiirtojärjestelmästä tehtiin reaaliaikainen, mikä oli huomattava edistysaskel. Alettiin myös tehdä kasvavassa määrin tutkimusta Itämeren hydrografisten olojen pitkäaikaismuutoksesta, joissa vanhan mittausaineiston analyysillä oli keskeinen merkitys. Edellisellä vuosikymmenellä alkaneet meri-ilmakehä -vuorovaikutustutkimukset edistyivät, ja mittauksia analysoitiin modernien turbulenssiopillisten menetelmien avulla. 1970-luvulla alkaneet pinta-aallokon syntymekanismeihin liittyvät tutkimukset jatkuivat myös, ja meren ja ilman välisen kaasujenvaihdon tutkimukset alkoivat. Hydrodynaamisessa mallituksessa kehitys suuntautui virtaus- ja vedenkorkeusennusteiden laatimiseen. Myös Neuvosto-Virossa merentutkimuksen suunta oli kääntynyt Itämerelle. Virolaiset tutkijat tekivät huomattavia Itämeren hydrografian ja dynamiikan tutkimuksia 1980-luvulla.

Suomessa 1990-luvun huomattavat alan tapahtumat liittyivät edellisen vuosikymmenen lopussa uudistuneeseen aluskantaan. Uusi tutkimusalus Aranda valmistui 1989 tarjoten moderneja mahdollisuuksia tehdä laajamittaista kokeellista tutkimusta. Samana vuonna Särkkä muutettiin tutkimusalukseksi ja uudelleen nimettiin 


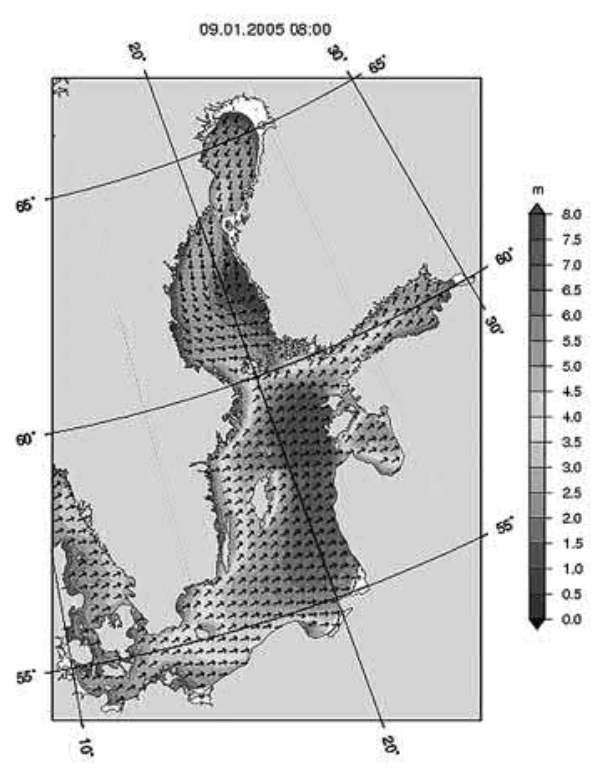

Kuva 2.8. Merentutkimuslaitoksen antama aaltoennuste ajalle 9. tammikuuta 2005 kello 08.00. Kyseisenä päivänä mitattiin lähes ennätyksellinen 7,2 metrin merkitsevä aallonkorkeus pohjoisella Itämerellä. Kartassa merkitsevä aallonkorkeus (metreinä) on kuvattu väreillä ja aallokon etenemissuunta nuolilla. Perämerellä olevat valkoiset alueet ovat jään peittämiä. (Merentutkimuslaitos/Laura Tuomi)

Muikuksi. Sillä on tehty Itämeren rannikkovyöhykkeen tutkimuksia. Tämän vuosikymmenen tutkimuksille oli lisäksi leimallista EU-rahoitteisten kansainvälisten projektien esiinmarssi. Erityisesti on mainittava BALTEX-ohjelma (Baltic Sea Experiment 1993-), jossa tutkitaan Itämeren energiatasetta ja veden kiertoa.

1990-luvulla suomalais-ruotsalainen Pohjanlahtivuosi 1991 sekä suomalais-virolais-venäläinen Suomenlahtivuosi 1996 olivat suuria projekteja. Itämeren voimistunut rehevöityminen johti meriympäristön tilaan liittyvän tutkimuksen lisääntymiseen ja sitä kautta sai aikaan operatiivisen leväseurannan (Alg@line) aloittamisen. Meriekosysteemiä tutkittiin muun muassa kolmidimensionaalisten, kytkettyjen hydrodynaamis-ekologisten mallien avulla. Vuonna 1994 tapahtuneen traagisen Estonian onnettomuuden jälkeen kehitettiin kytketty ilmakehä-aaltomalli, jolla alettiin nopeasti laatia operatiivisia aaltoennusteita (kuva 2.8). Lisäksi merelle perustettiin automaattiset sää- ja aaltopoijut, jolloin alettiin saada reaaliaikaisia havaintoja aallonkorkeudesta ja säästä merenkulun ja tutkimuksen tarpeisiin.

2000-luvulla operatiiviset sovellutukset ja teoreettiset tutkimukset ovat edelleen syventyneet ja mallitus on kehittynyt yhä nopeampien tietokoneiden avulla. Nyt ovat alkaneet myös koko Euroopan laajuiset EU-hankkeet, kuten GMES (Global Monitoring of Environment and Security of the European Area). Näissä hankkeissa Itämeri on myös mukana omalla tärkeällä panoksellaan. Leimallista nykyajan tutkimuksille ovat suuret hankkeet ja niiden mukanaan tuoma hallinnollistuminen. Kuitenkin yksittäisiä tutkimuskysymyksiä on paljon, ja vuodesta 2000 lähtien Suomessa on ilmestynyt yksi väitöskirja vuosittain fysikaalisen oseanografian alalta. $\mathrm{Ny}-$ kyisessä tutkimuksessa Itämeren tila ja sen tulevaisuus ovat keskeisessä osassa.

Kansainvälinen merentutkimusyhteistyö on toiminut ICES:in kautta. Lisäksi Itämeren tutkijoiden yhteistyö on jatkunut 1950-luvulta lähtien Conference of the Baltic Oceanographers (CBO) kokoussarjana, ja 1990-luvun puolivälistä asti on pidetty eri alojen oseanografien yhteiskokouksia (Baltic Sea Science Conference). Täten Itämeren eri alojen tutkijoiden välinen yhteistyö ja tiedonvaihto ovat kehittyneet ja laajentuneet.

Suomessa alan perustutkimusta tehdään Merentutkimuslaitoksessa, Helsingin yliopiston Fysikaalisten tieteiden laitoksen geofysiikan osastolla ja Suomen ympäristökeskuksessa (SYKE). Soveltavaa meriympäristön tutkimusta tehdään Suomen ympäristökeskuksessa, kun taas VTT: ssä ja Teknillisessä Korkeakoulussa tehdään alaan liittyviä teknillisiin sovellutuksiin painottuvia tutkimuksia. Itämeren ekologiaa tutkitaan Helsingin, Turun ja Oulun yliopistoissa sekä Åbo Akademissa. 


\section{Fysikaalisen tutkimuksen menetelmät}

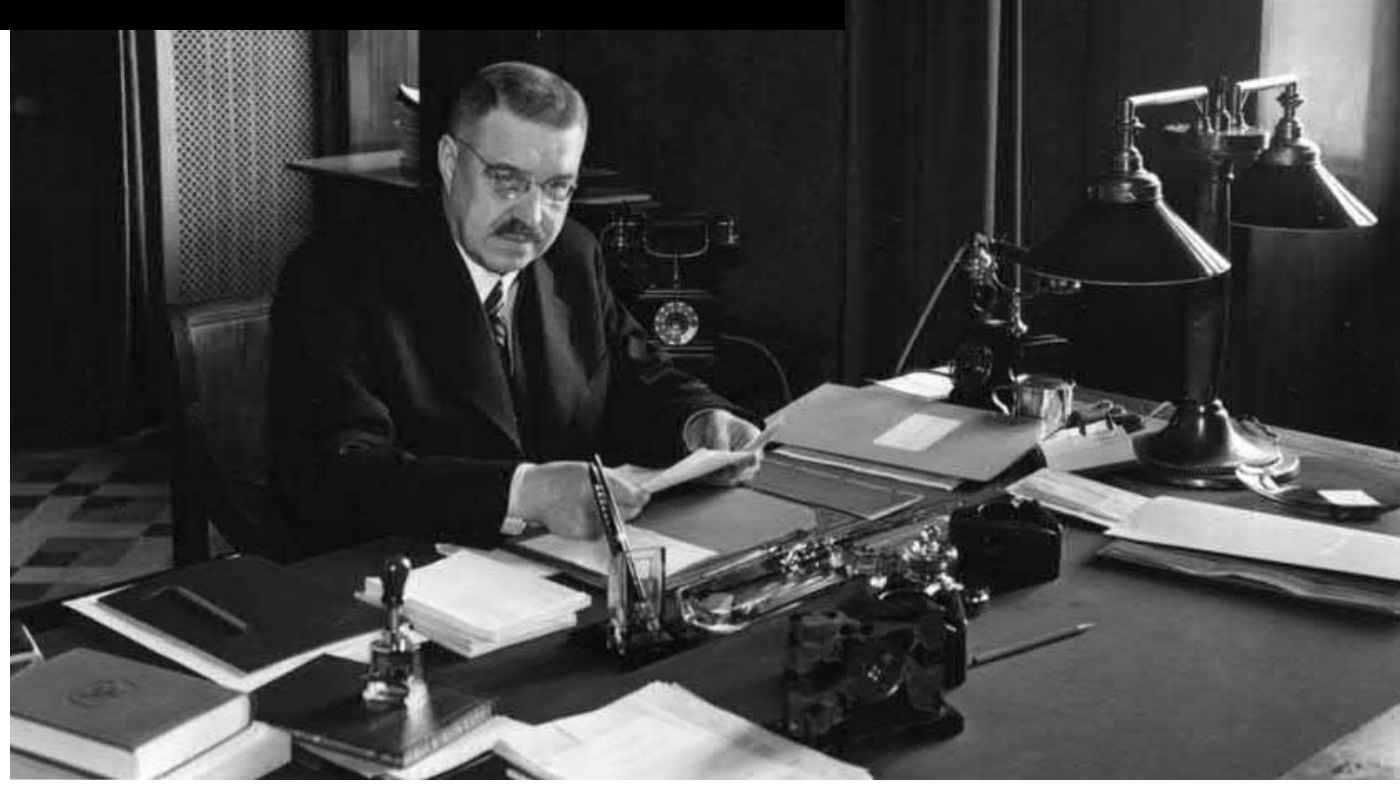

Kuva 3.0. Rolf Witting (1879-1944) on yksi suomalaisen merentutkimuksen historian merkittävimmistä henkilöistä. Hän toimi 1911-1918 Suomalaisen Tiedeseuran hydrografis-biologisen komission johtajana ja oli mukana suunnittelemassa Merentutkimuslaitosta, jonka ensimmäisenä johtajana hän toimi sen perustamisvuodesta 1918 aina vuoteen 1936. Wittingin laaja-alainen panos liittyi yhtälailla laite- ja mittaustoiminnan kehittämiseen, kuin myös teoreettisiin tutkimuksiin. Myöhemmin Witting teki merkittävän valtiomiesuran toimimalla muun muassa sodan aikana ulkoasiainministerinä. (Merentutkimuslaitoksen kuva-arkisto)

\subsection{Tutkimusmatkat}

\subsubsection{Tutkimusalukset}

Merentutkimuksen tärkein työalusta on tutkimusalus (käytetään lyhennettä T/A). Tietoa meren sisäisistä ominaisuuksista ja ilmiöistä ei saada muulla tavalla kuin menemällä tutkimusaluksella merelle ja laskemalla mittauslaitteet veteen valittuun syvyyteen asti. Itämeren rantavaltioilla on omat tutkimusaluksensa meren tilan seuran- taa ja tutkimuksia varten. Suomessa näitä aluksia on kolme: Merentutkimuslaitoksen T/A Aranda (kuva 3.1), Etelä-Savon ympäristökeskuksen T/A Muikku ja Geologisen tutkimuskeskuksen T/A Geola. T/A Muikku on Saimaan kanavan kautta operoinut sekä Saimaan vesistössä että Suomenlahdella. Lisäksi yliopistollisilla tutkimusasemilla ja alueellisilla ympäristökeskuksilla on pienempiä aluksia lähialueidensa tutkimuksiin.

Fysikaalisen oseanografian kenttätutkimuksissa tutkimusalukselta käsin tehdään havain- 


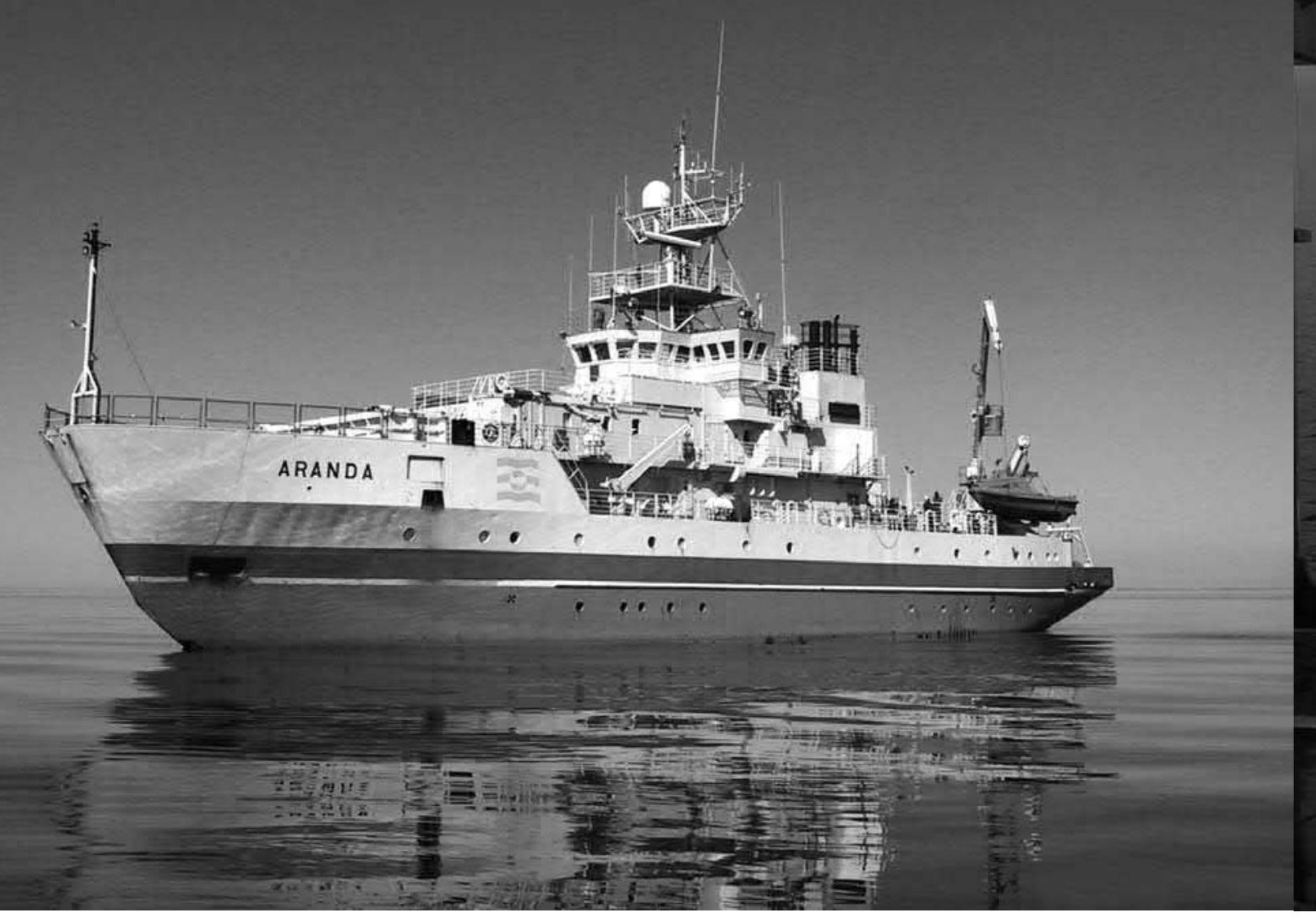

Kuva 3.1. T/A Aranda, valmistumisvuosi 1989. (Merentutkimuslaitos/Henry Söderman)

toja tutkimuspisteillä eli asemilla tai asennetaan ja nostetaan kiinteästi ankkuroituja, jatkuvatoimisia mittalaitteita. Lisäksi joitakin mittauksia tehdään laivan kulkiessa. Asemien havaintoja yhdistetään poikkileikkauksiksi ja näitä edelleen kolmiulotteisiksi kuviksi. Itämerellä on joitakin vakiintuneita asemia, joissa on tehty mittauksia jo yli sadan vuoden ajan. Nämä ovat yleensä altaiden syvimpiä kohtia. Fysikaalisen oseanografian erityistutkimukset ovat koeohjelmia, joissa kootaan intensiivijaksoilta ja -alueilta havaintoaineistoa käyttäen koordinoidusti useampaakin laivaa sekä hyödyntäen samanaikaisesti ankku- roiduista mittalaitteista saatavaa aineistoa. Tällaiset erityistutkimukset ovat kestoltaan yleensä 1-4 viikkoa. Fysikaalisen tutkimuksen "kokeet" ovat luonteeltaan erilaisia kuin esimerkiksi ekologisen merentutkimuksen koejärjestelyt. Ekologisissa kokeissa käsitellään yhtä muuttujaa kerrallaan siten, että käsittelyn tuottamia muutoksia verrataan käsittelemättömään yksikköön eli niin sanottuun kontrolliin. Ekologisten kokeiden avulla on selvitetty muun muassa ravinteiden vaikutuksia ekosysteemiin.

Aluksen paikantaminen tapahtuu nykyisin satelliitteihin perustuvaan GPS (Global Positio- 


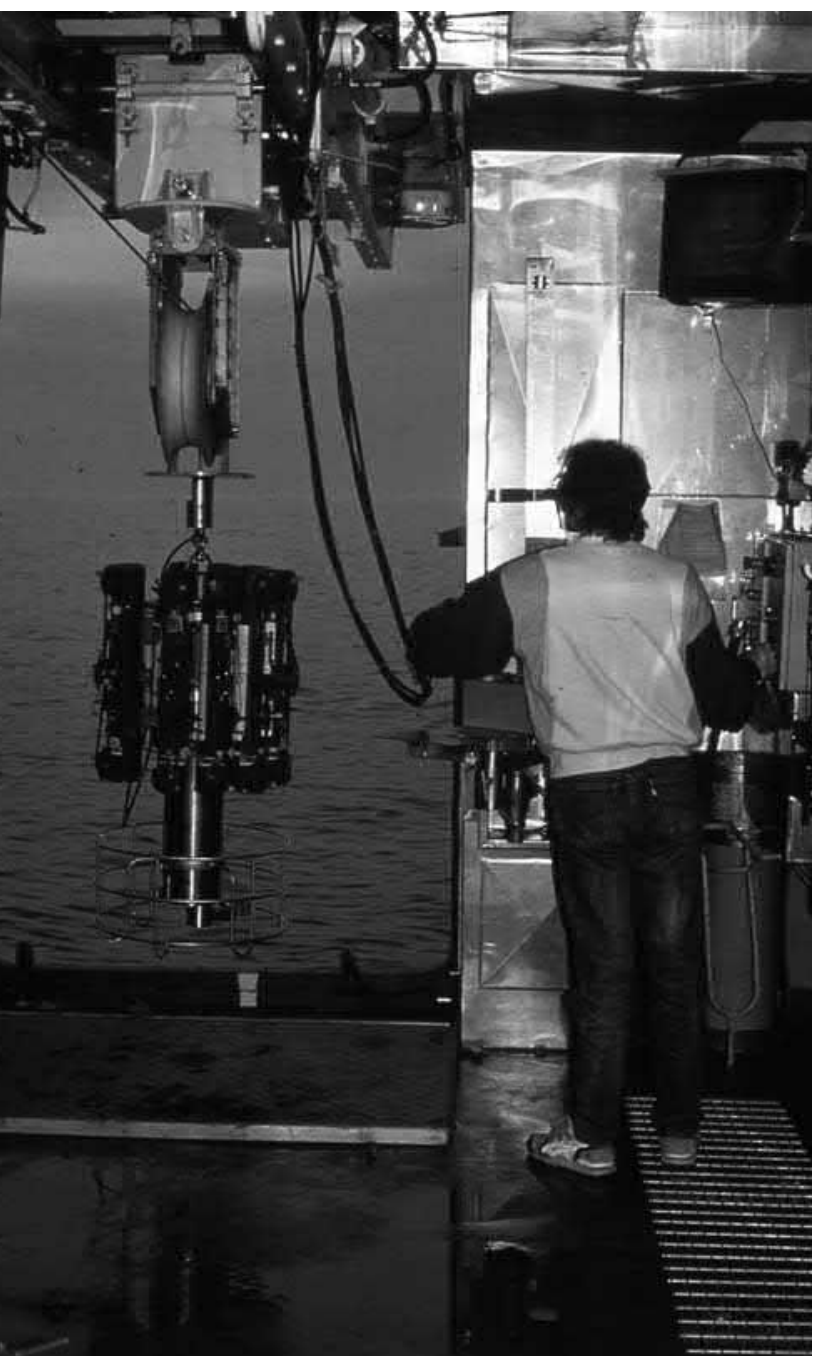

Kuva 3.2. CTD-luotaimen lasku alkamassa T/A Arandalla. (Merentutkimuslaitos/Ari 0. Laine)

ning System) järjestelmään. Differentiaali-GPSpaikantimella (DGPS) päästään noin 10 metrin tarkkuuteen. Meren syvyys $(H)$ määritetään tavallisella kaikuluotaimella: $H=1 / 2 c t$, missä $c$ on äänen keskimääräinen nopeus vertikaalisuunnassa ja $t$ on äänisignaalin käyttämä aika laivasta meren pohjaan ja takaisin. Äänen nopeus $c$ riippuu veden lämpötilasta $(T)$, suolaisuudesta $(S)$ ja paineesta $(p)$. Se on täsmällisesti ottaen $c=$ $\sqrt{K / \rho}$, missä $K$ on kokoonpuristuvuusmoduuli ja $\rho$ on tiheys. Hyvä likiarvo saadaan kaavasta
$c=c(T, S, h)=c_{\mathrm{o}}+c_{\mathrm{T}} T+c_{\mathrm{T} 2} T^{2}$

$+c_{\mathrm{S}}(S-35 \% 0)+c_{\mathrm{z}} h$

missä $h$ on syvyys, joka vastaa paineen vaikutusta, ja vakiot ovat $c_{\mathrm{o}}=1.449 \mathrm{~m} / \mathrm{s}, c_{\mathrm{T}}=4,6 \mathrm{~m} /(\mathrm{s}$ $\left.{ }^{\circ} \mathrm{C}\right), c_{\mathrm{T} 2}=-0,55 \mathrm{~m} /\left(\mathrm{s}^{\circ} \mathrm{C}^{2}\right), c_{\mathrm{s}}=1,4 \mathrm{~m} /(\mathrm{s} \%$ ) sekä $c_{\mathrm{z}}=0,017 \mathrm{~s}^{-1}$. Jos $T=0{ }^{\circ} \mathrm{C}, S=6 \%$, ja $h=$ 0 , on $c=1.408 \mathrm{~m} / \mathrm{s}$; edustava likiarvo on siis Itämerellä $\mathrm{c} \approx 1,4 \mathrm{~km} / \mathrm{s}$. Vain korkeissa lämpötiloissa $\left(T>15^{\circ} \mathrm{C}\right)$ päästään lähelle äänen nopeuden arvoa $c \approx 1,3 \mathrm{~km} / \mathrm{s}$. Äänen taajuutta säätämällä voidaan myös tarkastella pohjan laatua. Keilaavalla kaikuluotauksella voidaan tuottaa kaksiulotteisia kuvia pohjan topografiasta.

Havaintotoimintaa rajoittaa jossain määrin käytännön toimenpiteiden hitaus. Kun tutkimusaluksen kulkunopeus on vain 10-15 solmua ( 1 solmu $=1$ meripeninkulma tunnissa $=1.852$ $\mathrm{m} / \mathrm{h}$ ), asemien välisiin matkoihin menee paljon aikaa. Mittauslaitteet lasketaan mereen mekaanisilla vinsseillä noin $1 \mathrm{~m} / \mathrm{s}$ nopeudella, mutta matalilla merillä, kuten Itämerellä, tämä ei ole kovin aikaa vievää.

\subsubsection{Hydrografiset asemahavainnot}

Meritieteellisellä asemalla perinteinen fysikaalinen mittaussarja on hydrografinen luotaus eli veden lämpötilan ja suolaisuuden profiilien mittaus pinnasta pohjaan. Hydrografiseen luotaukseen otetaan toisinaan mukaan myös ekologisia ja kemiallisia suureita, kuten veden sameus, happipitoisuus ja fluoresenssi. Tarkoituksena on saada tietoa meriveden fysikaalisista ominaisuuksista sekä luotaustietoja yhdistämällä kartoittaa merivesien kiertoliikettä.

Hydrografia mitataan nykyisin CTD (Conductivity-Temperature-Depth) -luotaimella (kuva 3.2). Luotain lasketaan pinnalta miltei pohjaan asti, jolloin se samalla mittaa tasaisin väliajoin veden lämpötilan, sähkönjohtokyvyn ja paineen. Näistä saadaan laskennallisesti määrite- 
tyksi suolaisuus ja tiheys sekä mittausten syvyydet. Syvyydet $h$ saadaan hydrostaattisesta laista $p=\mathrm{p}_{0}+\mathrm{Q} g h$, missä $g=9,81 \mathrm{~m} / \mathrm{s}^{2}$ on painovoiman kiihtyvyys ja $\mathrm{p}_{0}$ on paine painnalla (ilmanpaine). Likimain (1\% tarkkuudella) paine-eroa $10 \mathrm{kPa}$ $=1 \mathrm{dbar}$ (desibaari) vastaa yhden metrin syvyysero, ja siksi "syvyys" ilmaistaan toisinaan suoraan desibaareina. Luotauksien pystysuuntainen erotuskyky on 1-100 cm, lämpötilan tarkkuus on $0,005^{\circ} \mathrm{C}$, ja suolaisuuden tarkkuus on $10^{-5}$ (0,01 \%o -yksikköä). CTD-luotaimissa voi olla myös muita sensoreita ja siihen voidaan liittää vesinäytteiden kerääjäjärjestelmä eli rosette.

Ennen 1970-lukua hydrografiset mittaukset tehtiin Nansen-pulloilla, joissa on elohopealämpömittari sekä näytteenottosäiliö. Pullosarja lasketaan vaijerissa mereen, jolloin mittaussyvyydet määräytyvät pullojen kiinnityskohdista vaijerissa. Lämpömittarissa ja pullossa on mekanismi, joka lukitsee elohopeapatsaan ja sulkee pullon mittaussyvyydellä. Vesinäytteestä määritetään suolaisuus laboratoriossa sähkönjohtavuuteen perustuvan salinometrin avulla.

Meriveden suolaisuus $S$ tarkoittaa vedessä olevien liuenneiden suolojen suhteellista massaa, ja se ilmaistaan yleensä promilleina (\%o). Se on tunnettava tarkasti, koska se vaikuttaa merkittävästi meriveden tiheyteen. Mittausteknisesti suolaisuus määritetään sähkönjohtokyvyn $R$ ja lämpötilan $T$ perusteella käyttäen empiiristä sovitusta $S=S(R, T)$. Aiemmin sähkönjohtavuus määritettiin suhteutettuna "standardimerivesi" -referenssiin. Vuonna 1981 otettiin käyttöön IOC:n (International Oceanographic Commission, UNESCO) standardi, jonka mukaan niin sanottu käytännöllinen suolaisuusasteikko PSS78 (Practical Salinity Scale 1978) tulee meriveden sähkönjohtavuudesta suhteutettuna väkevyydeltään 32,4356 \%o olevan kaliumkloridiliuoksen sähkönjohtavuuteen $15^{\circ} \mathrm{C}$ lämpötilassa ja normaalipaineessa. Nämä kaksi eri referenssiä antavat saman ja oikean tuloksen riittävällä tarkkuudella.
Itämeren veden sähkönjohtavuus on suuruusluokkaa $1 \mathrm{~S} / \mathrm{m}$. Meriveden suolojen suhteet ovat käytännössä samat kaikilla merillä, toisin sanoen merivesi on vain väkevyydeltään vaihteleva liuos, ja siksi tavallisia valtameriin säädettyjä algoritmeja voidaan käyttää suoraan Itämerellä. Suomen järvien tutkimuksissa käytetään yksinkertaisia laskentakaavoja suolaisuuden määrittämiseksi sähkönjohtavuudesta, sillä niissä pitoisuudet ovat pieniä eivätkä vaikuta merkittävästi veden tiheyteen. Yleensä riittää arvio $S \approx 0,6$. $R\left(25^{\circ} \mathrm{C}\right)$, kun $R$ :n yksikkö on $\mu \mathrm{S} / \mathrm{cm}$ ja se on lämpötilan suhteen kiinnitetty referenssiin $25^{\circ} \mathrm{C}$ (Huom. $S=$ Siemens $=$ ohmi $^{-1}=\Omega^{-1}$ ). Koska $1 \mathrm{~S} / \mathrm{m}=10^{4} \mu \mathrm{S} / \mathrm{cm}$, johtokyky $1 \mathrm{~S} / \mathrm{m}$ antaa suolaisuuden $S \approx 6 \%$.

Meriveden tiheyttä ei käytännössä mitata suoraan, vaan se lasketaan IOC:n standardoiman empiirisen tilayhtälön avulla lämpötilasta, suolaisuudesta ja paineesta, $\rho=\rho(T, S, p)$. Yhtälöstä kerrotaan tarkemmin seuraavassa luvussa. Tiheys on määritettävä tarkasti, sillä pienetkin tiheyserot voivat vaikuttaa veden kiertoliikkeeseen. Paineen vaikutus tiheyteen on Itämeren syvimmässä kohdassa (459 metriä) noin 0,2 prosenttia.

Auringonsäteilystä näkyvä valo ja osa ultraviolettisäteilyä tunkeutuu mereen ja siellä se absorboituu muuttuen lämmöksi ja kemialliseksi energiaksi sekä siroaa. Sisään pääsee siis yhteyttämiseen käyttökelpoista säteilyä eli PAR-spektrikaistaa (Photosynthetically Active Radiation) 400-700 nm. Absorptio ja sironta määräytyvät veden optisten ominaisuuksien perusteella ja ne vaikuttavat merkittävästi pintakerroksen fysiikkaan, kemiaan sekä biologiaan. Luonnonvesien optisesti aktivit aineet ovat vesi itse, kelta-aines, kiintoaines ja klorofylli. Kelta-aines sisältää erilaisia orgaanisia yhdisteitä ja se absorboi hyvin lyhytaaltoista valoa.

Vesi muuntaa etenevän säteilyn spektriä huomattavasti. Kirkkaammissa valtamerissä sininen valo tunkeutuu syvimmälle, aina 100 metriin asti, kun taas ultraviolettisäteily tunkeutuu vain vajaan metrin paksuiseen pintakerrokseen. Itä- 


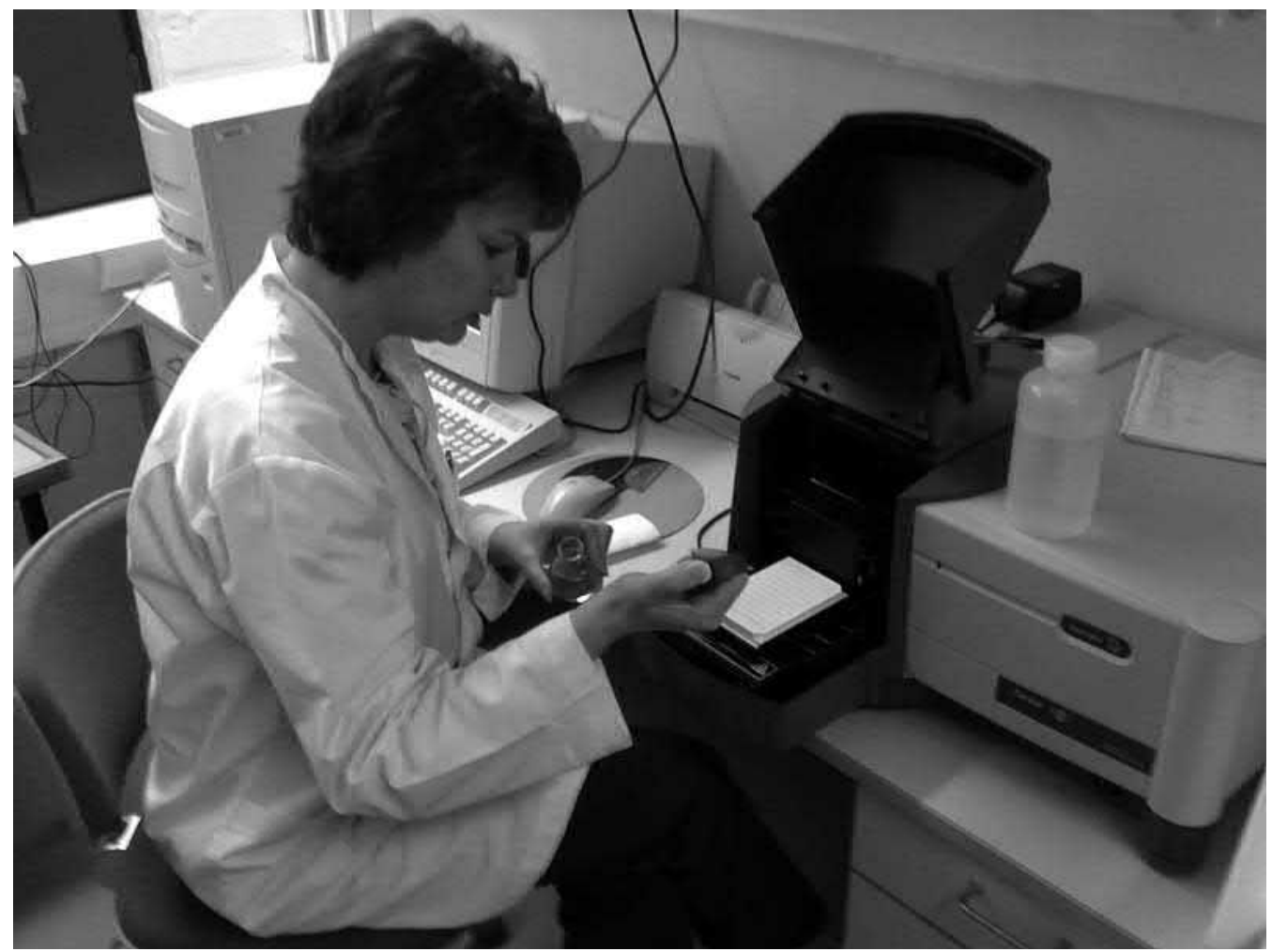

Kuva 3.3. Spektrofotometrillä mitataan vesinäytteestä valon spektristä vaimenemista. (Tvärminnen eläintieteellinen asema/Antti Nevalainen)

merellä valon tunkeutumissyvyys on parhaimmillaan noin 20 metriä; syvimmälle tunkeutuvat valon vihreät aallonpituudet, sillä kelta-aines siirtää Itämerellä spektrin huippua pidempiin aallonpituuksiin. Valon tunkeutumissyvyys määrää myös yhteyttävän kerroksen syvyyden, joka olennaisesti vaikuttaa meren ekologiaan. Lisäksi veden optiset ominaisuudet kertovat veden laadusta ja toimivat myös veden kiertoliikkeen jäljittiminä, kun niiden avulla voidaan seurata esimerkiksi samean jokiveden kulkeutumista ja sekoittumista mereen jokisuusta lähtien.

Veden optiikan perinteinen instrumentti on Secchi-levy. Tämä on $30 \mathrm{~cm}$ halkaisijaltaan oleva valkoinen, pyöreä levy, joka lasketaan veteen. Suurin syvyys, jossa levy voidaan paljain silmin nähdä, on määritelty näkösyvyydeksi. Menetelmän etu on sen yksinkertaisuus, ja lisäksi historiallista näkösyvyysaineistoa on Itämereltä olemassa noin 100 vuoden ajalta vertailuja varten.
Veden sameus määritetään valon vaimenemisnopeuden avulla; tavallisesti se tarkoittaa, kuinka monta prosenttia valo vaimenee yhden metrin matkalla. Kehittyneempiä mittalaitteita ovat in situ spektriset tai integroivat säteilymittarit, jotka laskettuina veteen eri syvyyksille kertovat säteilyn etenemisestä vedessä. Ne mittaavat säteilytasoa tai veden optisia ominaisuuksia. Optiikan tutkimuksissa otetaan myös vesinäytteitä, joista laboratoriossa määritetään valon kulkuun vaikuttavien optisesti aktiivisten aineiden pitoisuu$\operatorname{det}$ (kuva 3.3).

\subsubsection{Ankkuroinnit ja mittaukset liikkuvasta aluksesta}

Tutkimusaluksia ja muitakin laivoja käytetään myös automaattisten mittauslaitteistojen asennukseen ja purkuun. Mittarisarjat ankkuroi- 
daan pohjaan, ja ne rekisteröivät lyhyemmän tai pidemmän ajan kulloisenkin tutkimuksen tarkoituksen mukaisesti. Systeemiin kuuluvat tavallisesti lämpötilan, johtokyvyn ja virtauksen mittaukset eri syvyyksillä. Suolaisuus lasketaan lämpötilasta ja johtokyvystä, kuten CTD-luotaimen tapauksessa.

Virtausmittareita on erityyppisiä. Perinteisessä pistevirtausmittarissa on nopeuden itseisarvon integroiva roottori ja nopeuden hetkellisen suunnan ilmaiseva peräsin. Niillä tehdään yleensä pitkäaikaismittauksia, joissa rekisteröintiväli on 10-60 minuuttia. Seuraavassa luokassa ovat kaksiulotteiset vektorimittarit, jotka kertovat nopeuden horisontaaliset komponentit ja antavat siten perinteistä mallia tarkempaa tietoa veden ja liikemäärän kulkeutumisesta. Kolmiulotteista virtauskenttää mitataan profiloivilla, akustisilla Doppler-virtausmittareilla, jotka perustuvat vedessä olevien hiukkasten aiheuttamaan äänisignaalin takaisinsirontaan. Vektorimittarit ja profiloivat Doppler-mittarit ovat avainasemassa meren dynamiikan perustutkimuksessa ja kartoituksessa. Turbulenssimittarit mittaavat virtauskentän nopeita fluktuaatioita. Niitä käytetään erityisesti rajakerrostutkimuksissa, kun tarkastellaan liikemäärän vaihtoa merialtaiden pinnalla ja pohjassa. Jos lisäksi mitataan lämpötilan ja johtokyvyn fluktuaatioita, saadaan myös turbulenttinen lämmön ja suolan siirto määrätyksi.

Tutkimusaluksissa on automaattisia mittalaitteita, jotka keräävät tietoa merestä laivan kulkiessa. Näihin kuuluvat akustiset virtausmittarit, runkolämpömittarit, jotka mittaavat veden lämpötilan laivan rungon sisäpuolelta, sekä jatkuvatoimiset läpivirtauslaitteistot, joissa voidaan mitata merivesipumpun jatkuvasti pumppaamasta pintavedestä muun muassa lämpötila, johtokyky ja fluoresenssi. Laivoissa on lisäksi automaattinen sääasema ja tarkempia ilman rajakerrostutkimuksia varten keulasta ulos työnnettävä säänmittauspuomi. Sääasemissa on lähestulkoon tavanmukainen säähavaintolaitteisto, joka mittaa ilmanpainetta, ilman lämpötilaa, ilman kosteutta sekä tuulen nopeutta ja suuntaa. Lisäksi auringonsäteilyn mittareita on ollut käytössä. Aluksilla tehdyt säähavainnot ovat ensiarvoisen tärkeitä, sillä ulkomerellisiä sääasemia on hyvin vähän.

Varsinaisten tieteellisten tutkimusalusten lisäksi meritieteellistä tietoa on kerätty muiltakin laivoilta. Pintaveden lämpötilatietoa on kerätty useilta linjalaivoilta runkolämpömittarin avulla. Muutamilla Itämeren linjalaivoilla on myös läpivirtauslaitteisto, johon on liitetty automaattinen vesinäytteenotto. Fluoresenssia jatkuvasti mittaamalla ja analysoimalla vesinäytteet saadaan tietoa levistä. Tämä Alg@line-järjestelmä on toiminut Merentutkimuslaitoksessa vuodesta 1993 lähtien ja se on omalla allallaan ollut uraauurtavaa seurantatutkimusta.

\subsubsection{Jääntutkimukset}

Itämerellä on vuosittain jäätä 5-7 kuukauden ajan. Rannikolla ja saaristossa on kiintojäätä, joka on paikallaan aivan alku- ja lopputalvea lukuun ottamatta, kun taas ulkomerellä on ajojäätä, joka ajelehtii tuulten ja virtausten vaikutuksesta. Jääpeitteisillä alueilla tarvitaan tutkimustyössä erikoistoimenpiteitä. Tutkimusalukset voivat vielä liikkua jään reunan tuntumassa ja ohuessa jäässä, mutta eivät yleensä kykene kulkemaan Pohjanlahden, Suomenlahden ja Riianlahden normaaleissa jääoloissa. Suomen T/A Aranda on jääluokaltaan Super 1A jäävahvistettu alus, mutta riittämättömän konetehon takia sekin voi liikkua hyvin paksuissa Itämeren jäissä vain jäänmurtajan avustuksella.

Jääpeitteisillä merillä käytetään ajelehtivia jääasemia, jotka ovat jäähän kiinnitettyjä ja kulkeutuvat sen liikkeen mukana. Itämerellä on turvallisuussyistä käytetty jäähän ankkuroituja aluksia jääasemien tukikohtina. Ajelehtivien jääasemien lisäksi jääntutkimuksia on tehty myös 


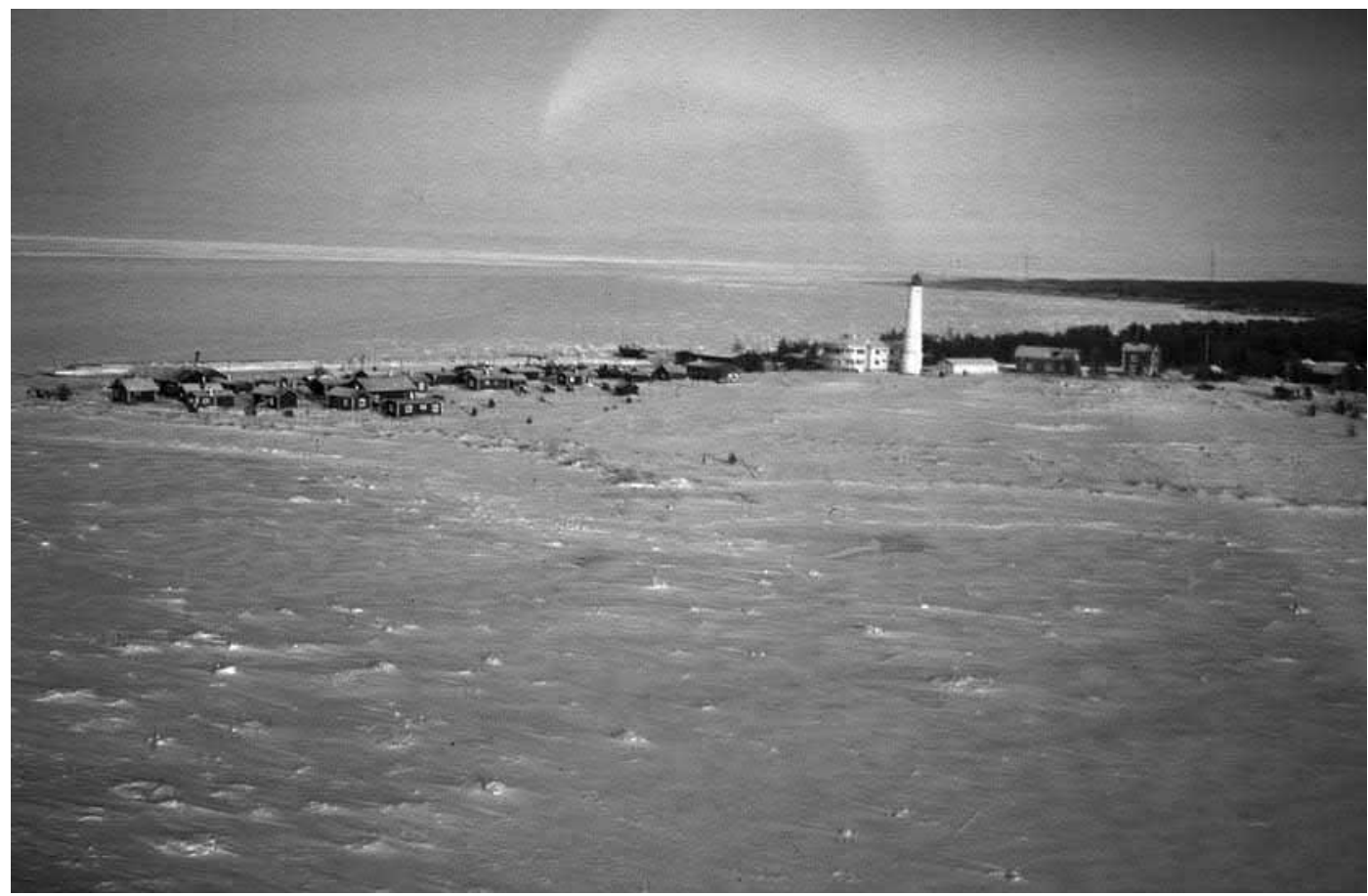

Kuva 3.4. Marjaniemi Hailuodossa on toiminut useiden jääntutkimusten tukikohtana. Paikka on kiinto- ja ajojään rajavyöhykkeellä. (Matti Leppäranta)

Itämeren majakoilta ja ulkosaarilta (kuva 3.4). Jääasemien havaintotoiminta kohdistuu jäähän, jäänalaiseen veteen ja sääoloihin. Vettä ja säätä tutkitaan talvella periaatteessa samaan tapaan kuten avovesikautena, joskin olosuhteet ovat talvella hankalammat. Toisaalta jääpeite kylläkin tarjoaa oivan alustan niin jäänalaisiin kuin jäänpäällisiin rajakerrostutkimuksiin. Jääntutkimusten kannalta jään ja veden vuorovaikutus on keskeinen tutkimuskohde, joka sisältää jään ja veden välisen kitkan, lämmönsiirron vedestä jäähän sekä suolan/makean veden vuon jäästä veteen.

Oseanografisten ja meteorologisten mittausten lisäksi jääpeitteestä tehdään monipuolisia tutkimuksia, sillä jäällä on oma tutkimuksellinen ja käytännöllinen mielenkiintonsa, ja lisäksi jääpeite on sangen keskeinen tekijä meren ja ilmakehän välisessä energian ja materian vaihdossa. Jääntutkimukset voidaan jakaa tutkimuskohteen koon puolesta kolmeen kategoriaan: mikrokoko- luokka $\left(10^{-4}-10^{-1} \mathrm{~m}\right)$, paikallinen kokoluokka $\left(10^{-1}-10^{2} \mathrm{~m}\right)$ ja makrokokoluokka $\left(10^{2}-10^{5} \mathrm{~m}\right)$. Jäälauttojen koko on paikallisen ja makrokokoluokan raja-alueella $\left(10^{2}-10^{3} \mathrm{~m}\right)$.

Mikrokokoluokan tutkimuksissa analysoidaan jään kiderakennetta ja epäpuhtauksia. Työ perustuu jäänäytteiden ottamiseen ja niiden analysointiin laboratoriossa. Jäänäytteistä höylätään kylmälaboratoriossa (lämpötila alle $-5^{\circ} \mathrm{C}$ ) ohuthieitä (noin $10 \mathrm{~cm} \times 10 \mathrm{~cm}$, paksuus alle $1 \mathrm{~mm}$ ), joista määritetään kiderakenne. Näytteen sulamisvedestä mitataan jään suolaisuus ja tarkastellaan jäässä olevia muita epäpuhtauksia. Tuloksena saadaan myös tietoa jään laadusta ja sen muodostumistavasta. Ehjää näytettä on myös mahdollista kartoittaa elektronimikroskooppien avulla, jolloin päästään tarkempaan tietoon epäpuhtauksien laadusta ja rakenteesta.

Jäässä elävien eliöiden tutkiminen luonnossa on erittäin hankalaa. Näytteenotto muuttaa aina tutkittavan kohteen luonnetta ja häiritsee 


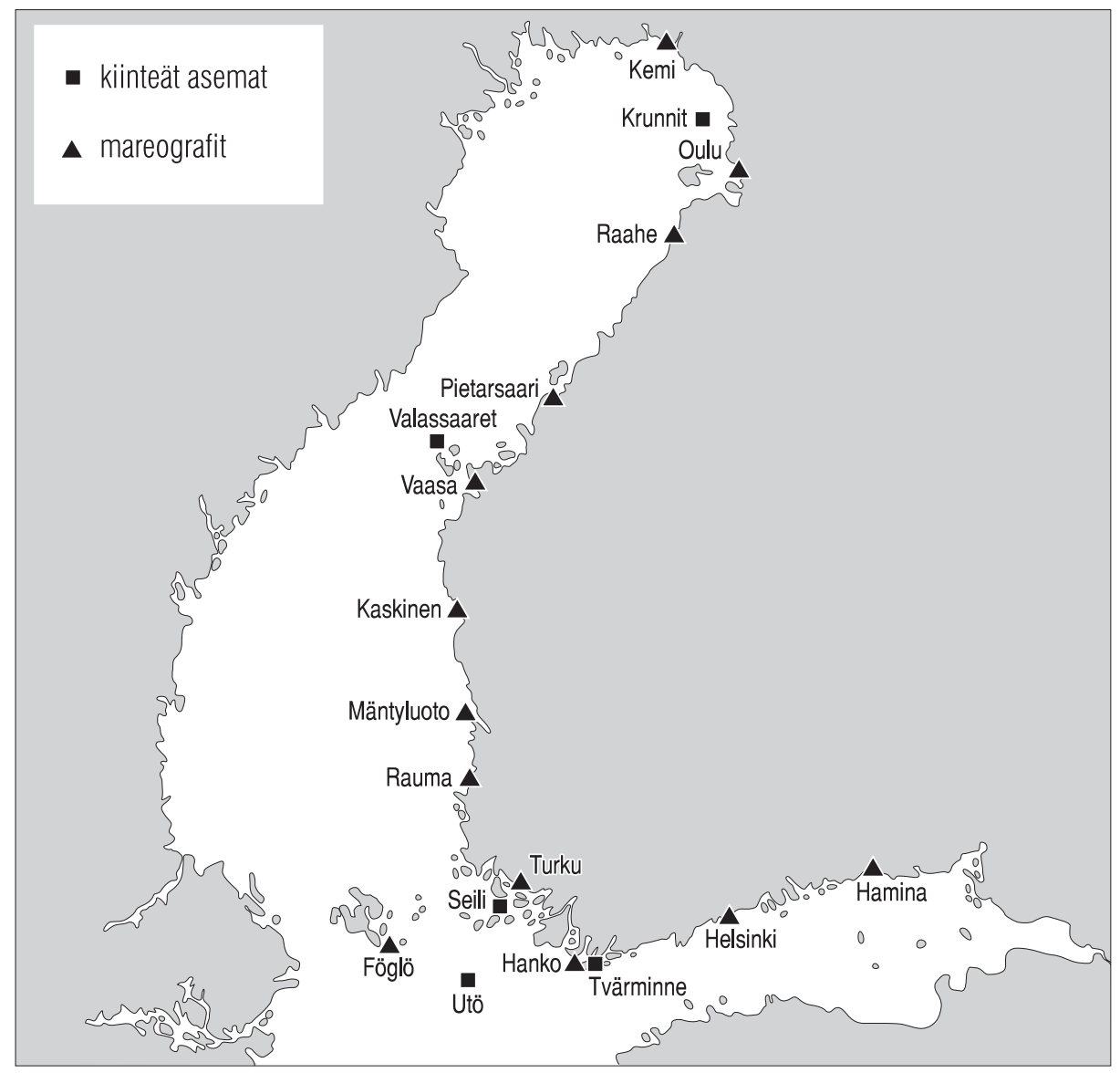

Kuva 3.5. Suomen kiinteiden meritieteellisten asemien ja mareografien verkosto.

prosesseja. Jään eliöiden aktiivisuutta ja lajistoa tutkitaan sekä kentällä tehtävin kokein että laboratorio-oloissa sulatetuista näytteistä. Näytteiden sulatus vaikuttaa kuitenkin haitallisesti tutkittaviin eliöihin. Jään biologinen tutkimus onkin vielä voimakkaassa kehitysvaiheessa erityisesti menetelmiensä suhteen.

Paikallisen kokoluokan tutkimuskohteina ovat jään ja lumen paksuus sekä jään morfologiset rakenteet. Ehyen, yhtenäisen jäälevyn paksuus on erittäin tärkeä suure, sillä se kertoo jäässä olevasta kylmävarastosta, jääpeitteen eristävyydestä sekä jään lujuudesta. Siitä voidaan tehdä pienellä alueella havaintoja kairausten avulla. Lumitutkimukset ovat myös keskeisessä asemassa ennen kaikkea koska lumi eristää lämpöä, heijastaa ja sirottaa auringonsäteilyä takaisin sekä vaimentaa sitä nopeasti lumen sisällä, ja muodostaa sohjouduttuaan kohvajäätä.

Lämmönsiirto ilma-lumi-jää-vesi -systeemissä ja siitä seuraava jään paksuuden kehitys on yksi paikallisen kokoluokan pääkysymyksistä. Jäähän ja lumeen asennetaan automaattisia mittalaitteita rekisteröimään jään lämpötilaa sekä jään yllä ja alla olevia meteorologisia ja oseanografisia olosuhteita. Ajojääkentillä muodostuu jään puristuessa morfologisia rakenteita kuten ahtojäävalleja, ja näiden geometriaa ja sisäistä rakennetta kartoitetaan kairausten ja kaikuluotausmenetelmien avulla. Myös sukeltajia on käytetty havaintotyössä, useinkin jään alaiseen biologiseen näytteenottoon. Sukeltaja pystyy keräämään näytteitä häiriten mahdollisimman vähän ympäristöä. 
Makrokokoluokan tutkimuskohteina ovat jääkenttien rakenne ja jään ajelehtiminen. Rakenteen tärkeimmät kysymykset ovat jään laatu, jäälautat ja jään paksuus. Jään paksuus vaihtelee paljon. Ohut uusi jää on muutaman senttimetrin paksuista, tyypillinen kiintojään ja ajojään tasaisten alueiden paksuus on $20-60 \mathrm{~cm}$, kun taas ahtojäät ovat usein 5-15 metriä paksuja. Rakenteen kartoitus perustuu pääasiassa kaukokartoitusmenetelmiin, joista on puhe enemmän kohdassa "kaukohavainnointi” myöhemmin tässä luvussa. Jään paksuus on suurin jään kartoitusongelma, sillä hyvää, käyttökelpoista menetelmää ei sitä varten ole. Käytännössä kaukohavainnoista on epäsuorasti arvioitu paksuutta joitakin pintareferenssejä hyväksi käyttäen, mutta tällainen arvio on tutkimustarkoituksiin sangen heikkoa.

Makrokokoluokan havaintotyötä tehdään myös operatiivisesti Itämeren jääpalveluissa ja tulokset julkaistaan joka päivä ilmestyvissä jääkartoissa. Näissä esitetään pintalämpötila, jääpeitteen laajuus sekä jään alueelliset tyypilliset paksuudet ja jään laatu.

Jääasemilla tehdään mittauksia jään ajelehtimisesta sekä itse aseman ajelehtimisesta että lähialueille asennettujen automaattiasemien avulla. Jään liikkeen mittauksissa on käytetty samanlaisia ajopoijuja kuin pintavirtausten tutkimuksissa. Jään ajelehtimisnopeus voi olla samaa luokkaa kuin pintavirtauksilla, mutta ankarina talvina jäät ovat paksuja ja liikkuvat sydäntalvella heikosti pohjoisella Itämeren alueella.

\subsection{Kiinteät asemat}

Kiinteitä havaintoasemia on perustettu Itämeren rannikoille ja saarien edustalle jo 1800-luvulla, ja jotkin niistä tarjoavat arvokkaita pitkiä aikasarjoja tutkimukseen. Näillä asemilla on joko kiinteitä rekisteröiviä mittalaitteita tai havaintopisteitä, joilla käydään säännöllisesti näytteenotossa. Seuraavassa kerrotaan Suomen asemista (kuva 3.5).

\subsubsection{Vedenkorkeus}

Vedenkorkeutta mitataan mareografiasemilla, joita Suomessa on 13: Kemi, Oulu, Raahe, Pietarsaari, Vaasa, Kaskinen, Mäntyluoto, Rauma, Turku, Föglö, Hanko, Helsinki ja Hamina. Vanhimmat on perustettu yli 100 vuotta sitten, ensimmäisenä (1887) Hanko (kuva 2.4). Asemalla on mereen yhteydessä oleva kaivo, jossa tapahtuvia vedenpinnan korkeuden muutoksia mareografi rekisteröi verrattuna kiinteään referenssiin. Korkeusreferenssi on geodeettisella tarkkavaaituksella määritetty kullekin mareografille.

Vedenpinnan kiinnittäminen tiettyyn nollatasoon nähden maapallon kaltaisella geoidilla on hankala ongelma, jonka yksityiskohtainen käsittely jätetään tämän kirjan ulkopuolelle. Aihetta on käsitellyt esimerkiksi Lisitzin (1966). Mareografin alla oleva maa saattaa liikkua, jolloin tämän pisteen korkeus muuttuu. Mareografin korkeuspiste vaaitetaankin vuosittain lähellä olevan peruskallioon sidotun kiintopisteen suhteen. Nämä kiintopisteet puolestaan ovat sidottuja geodeettiseen korkeusjärjestelmään N60. Geodeettisia korkeusjärjestelmiä on Suomessa tällä hetkellä käytössä kolme: NN, N43 ja N60 (www.fimr.fi).

Suomen ensimmäinen tarkkavaaitus tehtiin vuosina 1892-1910, minkä tuloksena saatiin korkeusjärjestelmä NN, ”normaalinolla”. Tämän järjestelmän nollakohdaksi otettiin Helsingin Katajanokan laiturissa sijainneen vedenkorkeusasteikon nollakohta, joka oli 30,465 metriä Suomen pääkiintopisteen alapuolella. Pääkiintopiste sijaitsee Helsingissä Tähtitieteellisen observatorion läheisyydessä. Suomen toinen tarkkavaaitus tehtiin vuosina 1935-1975. Sen tuloksista vuosilta 1935-1955 määriteltiin korkeusjärjestelmä N43. Tällöin ei käytetty koko vaaitusverkkoa eikä myöskään otettu huomioon maankohoamisen vaikutusta mittausajalta.

Korkeusjärjestelmä N60 laskettiin kahden ensimmäisen vaaituksen perusteella maanko- 
hoaminen huomioon otettuna. Sen katsotaan noudattavan geoidia paremmin kuin aiemmat järjestelmät. Käytännön tarpeita varten Merentutkimuslaitoksella on otettu käyttöön niin kutsuttu teoreettinen keskivesi (MW), joka on arvio vedenkorkeuden pitkäaikaisesta keskiarvosta. Siinä on otettu huomioon maan kohoaminen sekä valtameren vedenpinnan hidas nousu eli eustaattinen vedenkorkeuden muuttuminen. Näiden muutosten vuoksi teoreettinen keskivesi muuttuu vuosittain. Se vastaa arkikokemusta siitä onko vesi korkealla eli keskiveden yläpuolella ja päinvastoin. Esimerkiksi radiossa luettavat ja sanomalehdissä ilmoitettavat vedenkorkeudet annettaan teoreettisen keskiveden suhteen.

\subsubsection{Hydrografia, virtaukset, jää ja sää}

Hydrografisia asemia alettiin perustaa noin 100 vuotta sitten. Ne ovat yleensä merivartio- tai luotsiasemia. Kiinteitä havainto- ja näytteenottopisteitä oli aiemmin runsaammin, mutta nykyisin toimivia ovat enää Krunnit, Valassaaret, Seili, Utö ja Tvärminne. Asemilla tehdään kiinteissä pisteissä lämpötilaluotaus ja otetaan vesinäytteet suolaisuuden määrittämiseksi. Havaintoja on tehty vertikaalisuunnassa 5-10 metrin välein, kolmesti kuukaudessa (kuukausien 1., 11. ja 21. päivinä). Asemien tuottamat aikasarjat ovat tarjonneet ensiarvoisen tärkeätä tietoa Itämeren fysikaalisen tilan pitkäaikaiseen seurantaan ja ilmastonmuutoksen vaikutusten tutkimuksiin.

Säännöllisiä virtausmittauksia ei enää tehdä, mutta ennen niitä kerättiin majakkalaivoilla muun havaintotoiminnan ohessa (kuva 2.7), mihin perustuen jo 1900-luvun alussa julkaistiin karttoja Itämeren keskimääräisestä kiertoliikkeestä. Näiden havaintojen puuttuminen on pahin lovi Itämeren fysiikan kiinteässä havaintoverkossa.

Jääoloja seurataan kiinteillä paikoilla Suomen rannikolla ja saaristossa. Siihen kuuluu paikallisten jääkarttojen laadinta sekä jään laadun ja paksuuden havainnointi. Työ liittyy ennen kaikkea operatiivisen jääpalvelun toimintaan Itämeren jääoloja kartoitettaessa. Mutta havaintosarjoista on kasvanut myös tieteellisesti merkittäviä, pitkiä aikasarjoja, joista nähdään jäätymisen ja jäänlähdön ajankohtien sekä jään paksuuden ilmastollisia vaihteluita. Lisäksi niissä on runsaasti yksityiskohtaista tietoa rannikko- ja saaristoalueiden jäätilanteen kehityksestä erilaisina talvina. Vanhimmat havaintosarjat ovat jo 175 vuoden pituisia.

Merisäätä on havainnoitu aiemmin miehitetyillä majakoilla sekä rannikko- ja saaristoasemilla, mutta nykyisin tiedonkeruu perustuu automaattiasemien verkostoon. Näitä automaattiasemia on Suomella noin 40. Merellistä säätä hyvin edustavia asemia ovat Kemi 1, Marjaniemi, Nahkiainen, Ulkokalla, Tankar, Valassaaret, Kristiinankaupunki Majakka, Tahkoluoto, Isokari, Kumlinge, Märket, Nyhamn, Bogskär, Utö, Russarö, Harmaja, Kallbådagrund, Orrengrund ja Rankki. Ulkomerellisten sääasemien määrä Itämeren alueella on kuitenkin kokonaisuudessaan valitettavan pieni, millä on vaikutusta merisään ennustustarkkuuteen. Sääasemilla tehdään havaintoja säätilan perussuureista kuten ilmanpaineesta, sademäärästä, ilman lämpötilasta ja kosteudesta, sekä tuulen nopeudesta ja suunnasta. Miehitetyillä asemilla havaitaan myös pilvisyys. Synoptiseen havaintoverkostoon havainnot toimitetaan kolmen tunnin välein. Auringon säteilyä rekisteröiviä asemia Suomessa on vain neljä: Helsinki, Jokioinen, Luonetjärvi ja Sodankylä. 


\subsubsection{Mittauspoijut}

Pinnan sekä pinnanläheisiä mittauksia tehdään automaattisten mittauspoijujen avulla. Nämä voivat olla paikalleen ankkuroituja poijuja tai vapaasti ajelehtivia ajopoijuja.

Pintavirtauksia kartoitetaan ajopoijujen avulla. Näitä paikannetaan satelliittitekniikkaan perustuvien Argos- ja GPS-järjestelmien avulla. Argos-järjestelmä on perustettu 1970-luvulla, ja sen päämaja on Toulousessa, Ranskassa. Argospoijuihin on joskus lisätty myös ilmakehän tai meren pintakerroksen ominaisuuksia mittaavia antureita. Niitä on käytetty lähinnä pitkäaikaisen pintakuljetuksen seurantaan sekä veden ja ilman energianvaihdon tutkimuksiin. Poijujen avulla tehdyt ajelehtimiskokeet antavat tietoa ainesten kulkeutumisesta ja dispersiosta meren pinnalla, mikä on tähdellinen seikka esimerkiksi mereen joutuneen öljyn leviämisen arvioinnissa.

Tuulen nostattamaa pinta-aallokkoa mitataan kiinteästi ankkuroidulla aaltopoijulla. Tämä liikkuu vapaasti pystysuunnassa aallonkorkeuden vaihteluiden mukana ja mittaa samalla kiihtyvyyttään (a), jonka avulla voidaan integroida poijun vertikaalinen liikerata ja siis aallonkorkeuden $\xi$ kehitys mekaniikan peruslakien mukaan, $\mathrm{d}^{2} \xi / \mathrm{d} t^{2}=a$. Edelleen käytetään kiinteästi ankkuroituja sääpoijuja täydentämään sääasemaverkostoa.

\subsection{Kaukohavainnointi}

\subsubsection{IIma-alukset}

Lentokone ja helikopteri ovat ilmasta tehtävän kaukokartoituksen mittausalustat. Niitä on jo kauan käytetty visuaalisiin tiedustelulentoihin, ja 1960-luvulla niihin alettiin lisätä instrumentointia. Merentutkimuksessa näitä menetelmiä rajoittaa kuvauskaistan leveys, jonka on käytännössä oltava lentokorkeuden suuruusluokkaa.
Niinpä esimerkiksi Suomenlahden kartoitukseen tarvittaisiin useita ylilentoja, jolloin kuvaus veisi paljon aikaa ja sen kustannukset nousisivat suuriksi. Satelliittikaukokartoituksen teknologia oli jo 1990-luvun alkuun mennessä kehittynyt niin hyväksi, että se oli jo pitkälti syrjäyttänyt ilmasta tehtävän kartoituksen. Nykyisin ilma-alusten käyttö tulee kyseeseen erityisten meritieteellisten kokeiden tukiaineistojen hankinnassa sekä nopeassa operatiivisessa toiminnassa, kun toimintaan sopivia satelliittikuvia ei ole heti saatavilla.

Rannikkovesien tilan valvonnasta vastaavilla viranomaisilla (Suomessa SYKE) on monipuolinen järjestelmä operatiivista valvontaa varten. Rajavartiolaitoksen lentokaluston instrumentointiin kuuluu videokuvauslaitteita, lämpökamera sekä tutka, joita käytetään päästövalvonnassa sekä ympäristövahinkojen, kuten öljy- tai kemikaalionnettomuuksien, sattuessa. Jääpalvelut ovat käyttäneet lentokoneita ja helikoptereita jäätiedusteluun ja lämpötilakartoituksin 1930luvulta lähtien, mutta satelliittiteknologian kehittyessä niiden käyttö on miltei poistunut.

\subsubsection{Satelliitit}

Kaukokartoitussatelliitit ovat tuoneet paljon uutta merten tutkimukseen jo 1960-luvulta lähtien. Niiden vahvuutena ovat usein toistuvat laajaalaiset kartoitukset, kun taas heikkoutena on se, että informaatiota saadaan vain meren pinnasta. Optisilla kanavilla voidaan tutkia näkösyvyyden paksuista pintakerrosta, mutta muilla käytettävissä olevilla kanavilla havaitaan vain ohut meren pintafilmi.

Satelliitit kuvaavat maapallon pintaa ja pinnan ominaisuuksia sähkömagneettisten signaalien avulla. Signaaleilla on oma taajuus eli kanava, ja eri taajuus- tai aallonpituuskaistoja kutsutaan ikkunoiksi. Itämerellä satelliitteja hyödynnetään seuraavan kaavion mukaan: 


\begin{tabular}{|lll|}
\hline Aallonpituus & Nimi & Kartoituskohteet \\
& & \\
$380-760 \mathrm{~nm}$ & Optinen eli näkyvän valon ikkuna' & Jää, biologinen tuotanto, levät, päästöt \\
$760 \mathrm{~nm}-3 \mu \mathrm{m}$ & Lähi-infrapunaikkuna & Jää, levät, päästöt \\
$5-10 \mu \mathrm{m}$ & Terminen infrapunaikkuna & Jää, veden pintalämpötila \\
$0,1-100 \mathrm{~cm}$ & Mikroaaltoikkuna & Jää, aallokko, tuuli, pintalämpötila, pinnankorkeus \\
& & \\
& & \\
& &
\end{tabular}

Kaukokartoitusmenetelmät jaetaan passiivisiin ja aktiivisiin: edellinen mittaa kohteesta tulevaa luonnollista säteilyä ja jälkimmäinen mittaa satelliitin itse lähettämänsä signaalin takaisinsirontaa. Passiivisia menetelmiä ovat pintakerroksesta sironneen auringonsäteilyn ja pinnan emittoiman lämpösäteilyn mittaukset, aktiivisia puolestaan laser ja tutka. Auringonsäteilyn hyödyntämistä merenpinnan tai meren pintakerroksen havainnointiin rajoittaa vuorokaudenaika ja pilvisyys, kun taas lämpösäteilyn käyttöä rajoittaa vain pilvisyys. Ainoastaan mikroaaltoikkunasta löytyy aallonpituuksia, jotka läpäisevät ilmakehän kaikissa sääoloissa. Passiivista mikroaaltomenetelmää eli mikroaaltoradiometriä käytetään paljon valtamerten tutkimuksessa, mutta Itämerellä sen soveltuvuutta rajoittaa vakavasti pieni altaiden koko, sillä instrumentin erotuskyky on 20-30 kilometriä.

Merijää on tärkeä kaukokartoituksen sovellusalue. Näkyvän valon ikkunassa eli valokuvassa jää on vettä vaaleampaa, erityisesti lumipeitteinen jää, koska jää sirottaa paremmin valoa kuin vesi. Lisäksi valokuvissa näkyy erilaisia jään laatuja ja geometrisia muotoja, kuten kiintojään reuna ja erillisiä jälauttoja. Vastaavanlainen kontrasti on edelleen lähi-infrapunan alueella. Kun ilman lämpötila on nollan alapuolella, lämpökuvaukseen saadaan kontrasti jään ja avoveden pintalämpötiloista, ja lisäksi silloin paksumpi jää on pintalämpötilaltaan kylmempää. Mikroaaltokuvauksessa kontrasti löytyy sekä pintalämpötilasta että emissiokertoimesta passiivisen menetelmän tapauksessa ja sirontakertoimesta tutkaa käytettäessä (kuva 3.6). Myöhäiskevään jäillä, kun pinta on märkä ja jäällä on sulavesilammikoita, kaikki kontrastit ymmärrettävästi heikkenevät ja satelliittikartoituksen antama tieto tulee epävarmemmaksi. Satelliittikuvia yhdistämällä voidaan edelleen määrittää jääkentässä tapahtuneet siirtymät kuvaushetkien välillä. Jäissä on paljon piirteitä kuten jälauttoja ja ahtojäävalleja, jotka voidaan tunnistaa ja paikantaa perättäisistä kuvista.

Pintalämpötila saadaan parhaiten määritetyksi termisen infrapunaikkunan kautta. Menetelmän tarkkuus on noin $1{ }^{\circ} \mathrm{C}$, joten merkittävät lämpötilaerot saadaan hyvin selville. Altaiden rantojen ja keskialueiden välillä on useiden asteiden lämpötilaeroja. Erityisesti havaitaan veden kulkeutumisen aiheuttamia piirteitä lämpötilajakautumassa sekä kumpuamisen aiheuttamia kylmän veden vyöhykkeitä rannikoilla. Satelliitin mittaama lämpötila tulee ainoastaan ohuesta $(1 \mathrm{~mm})$ pintafilmistä, joten se ei aina edusta hyvin koko pintakerroksen lämpötilaa. Erityisesti tyyninä tai heikkotuulisina kesäpäivinä aurinko voi nostaa pintafilmin lämpötilan paljon pinnanalaista vettä lämpimämmäksi. Lämpötilatiedolla on jonkin verran käytännön tarvetta, ja niinpä ainakin Ruotsissa Itämeren lämpötilakarttoja julkaistaan läpi vuoden.

Leväkukintoja, jokivesien purkautumista mereen ja haitallisten aineiden päästöjä voidaan seurata optisen ja lähi-infrapunaikkunan kautta. Erityisesti leväkukintojen havaittavuutta on 


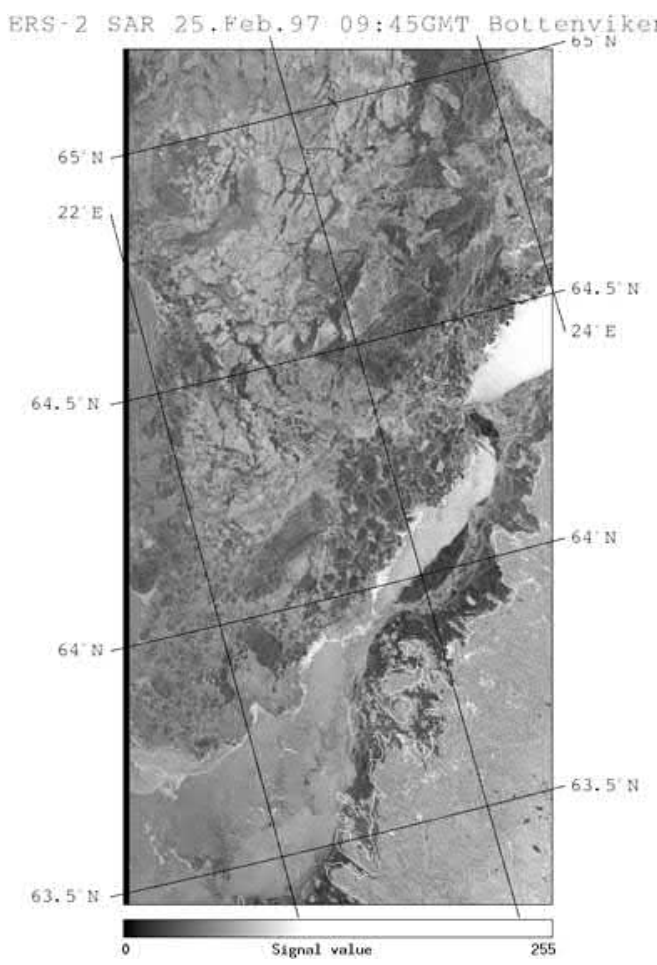

Kuva 3.6. Satelliitin ERS-2 ottama SAR-tutkakuva Perämereltä 25.2.1997. Oikeassa alareunassa on Pohjanmaan rannikkoa. Kiintojään edustalla on railo, jossa tapahtuu voimakas takaisinsironta aallokon takia. Ulompana merellä näkyy erikokoisia ajojäälauttoja.

viime vuosina tutkittu Itämerellä paljon (kuva 3.7). Satelliittimittaukset soveltuvat kuitenkin vain pinnalla esiintyvien kukintojen havaitsemiseen. Lisäksi Itämereen valuva kelta-aines aiheuttaa ongelmia kuvien tulkinnassa muun muassa siten, että maailman merten levämääriä kartoittavissa kuvissa Itämeri, erityisesti Pohjanlahti, on esiintynyt myös talvella hyvin runsastuottoisena ("punaisena") alueena. Itämerelle onkin kehitetty omat leväalgoritmit kuvatulkintaa varten. Pinnalla esiintyvien sinileväkukintojen kartoittamisen kehitystyössä on jo onnistuttu hyvin ja nykyisin voidaan seurata sinileväkukinnan kehitystä ja laajuutta päivittäin sään sen salliessa. Lisäksi uudet satelliitit tulevat edelleen edistämään levämäärien seurantaa. Satelliittikartoitus tuskin tulee kuitenkaan korvaamaan täysin me-

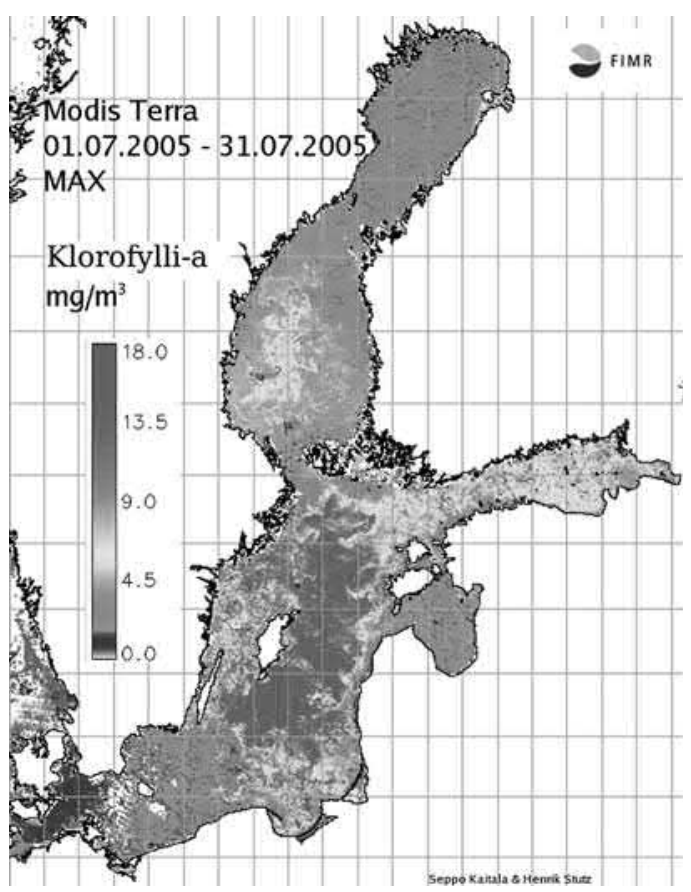

Kuva 3.7. Terra/Aqua -satelliitin MODIS-kuvista prosessoitu maksimi klorofylli- $a$-tilanne Itämerellä heinäkuussa 2005. (Merentutkimulaitos/Seppo Kaitala ja Henrik Stutz)

rellä tehtäviä havaintoja, sillä niillä ei saa selville esimerkiksi lajikoostumusta.

Itämeren dynamiikan tutkimuksissa voidaan satelliittitietoa käyttää suoraan ja epäsuorasti, mutta tämä sovellusalue ei ole ollut kovin laajasti tutkimuksissa mukana. Välillisesti kaikki pinnalla kelluvat kappaleet ja pinnan ominaisuudet toimivat pintavirtausten jäljittiminä, ja siten jotakin tietoa dynamiikasta saadaan kaikkien ikkunoiden kautta. Tutkan avulla saadaan vielä muunkinlaista tietoa. Tutkan havaitsema takaisinsironta riippuu pinnan karkeudesta, ja tämän riippuvuuden avulla saadaan tietoa aallokosta. Aallokko-algoritmeja on kehitetty myös operatiiviseen käyttöön. Meren sisäinen dynamiikka vaikuttaa epäsuorasti pinnan karkeuteen tuottamalla konvergenssi/divergenssi -vyöhyk- 
Taulukko 3.1. Itämerellä tavallisimmin hyödynnettävät kaukokartoitussatelliitit.

\begin{tabular}{|l|l|l|l|l|}
\hline Nimi & Ikkunat & Erotuskyky & Toistojakso & Haltija \\
\hline NOAA $^{1}$ & Optinen - infrapuna & $1,1 \mathrm{~km}$ & $<1 \mathrm{vrk}$ & USA \\
\hline Terra/Aqua & Optinen - infrapuna & $250 \mathrm{~m}$ & $1 \mathrm{vrk}$ & USA \\
\hline ERS $^{2}$ & Tutka & $30 \mathrm{~m}$ & $3 / 35 / 178 \mathrm{vrk}$ & ESA \\
\hline Radarsat & Tutka & $10-500 \mathrm{~m}$ & n. $5 \mathrm{vrk}$ & Kanada \\
\hline SSM $/$ I $^{3}$ & Mikroaaltoradiometri & $25 \mathrm{~km}$ & $1 \mathrm{vrk}$ & USA \\
\hline ENVISAT & $\begin{array}{l}\text { Optinen - infrapuna - } \\
\text { mikroaallot }\end{array}$ & Riippuu ikkunasta & Riippuu ikkunasta & ESA \\
\hline
\end{tabular}

${ }^{1}$ National Oceanographic and Atmospheric Administration; ${ }^{2}$ European Remote Sensing Satellite; ${ }^{3}$ Special Sensor Microwave/Imager

keitä, kuten usein sisäisten aaltojen tapauksessa on laita.

Satelliittien tutkasignaaleja käyttävät korkeusmittarit eli altimetrit piirtävät jo melko tarkasti valtamerten pinnan topografiaa, joka on suoraan kytköksissä geostrofiseen virtaukseen (katso luku 6). Altimetria on hyödynnetty Itämerellä kyllä geodeettisissa tutkimuksissa, mutta dynamiikan puolella Itämeren pieni koko on yhä rajoittava tekijä.

Itämerellä käytetään satelliittikuvia laajasti operatiiviseen toimintaan ja tutkimukseen (taulukko 3.1). Tärkeimmät operatiivisen toiminnan sovellusalueet ovat jäätilanteen ja pintalämpötilan kartoitus sekä haitallisten leväkukintojen ja haitallisten päästöjen havaitseminen. Jäätilanteen kartoituksen perustana ovat NOAA, Terra/Aqua ja RADARSAT -satelliittien tuottama monen kanavan kattama informaatio. Pintalämpötilan sekä leväkukintojen ja haitallisten päästöjen havaitsemiseen käytetään NOAA- ja MODIS-kuvia. Mikroaaltoradiometriä sekä RADARSATia edeltäviä tutkasatelliitteja kuten Euroopan avaruusjärjestön (ESA) ERS-satelliitteja on käytetty jääolojen tutkimustarkoituksiin, ja nykyisin ESAn monikanavaista uuden sukupolven ENVISAT-satelliittia (2002-) käytetään Itämerellä erilaisiin kaukokartoitustutkimuksiin.

\subsection{Mallit}

\subsection{Perusteet}

Meritieteessä käytetään paljon malleja ilmiöiden ymmärtämiseksi ja ennustamiseksi. Mallit voidaan ensi vaiheessa jaotella matemaattisiin ja fysikaalisiin malleihin.

Fysikaaliset mallit ovat laboratorioihin rakennettuja pienoismalleja, joilla voidaan tehdä kokeita hallituissa olosuhteissa. Esimerkiksi vedenalaisen kummun vaikutus veden virtaukseen on yksi tällainen ongelma, jota voidaan lähestyä fysikaalisen mallin avulla. Toisena esimerkkinä voidaan laivatekniikan alalta mainita laivan kulkuominaisuuksien tutkiminen laivasta rakennetun pienoismallin avulla. Tyypillistä fysikaalisille malleille on, että niillä voidaan tutkia jotain yksittäistä kysymystä mutta ei kokonaisvaltaisia ongelmia. Niinpä esimerkiksi Itämeren kiertoliikettä ei voida ratkaista Itämerestä rakennetun pienoismallin avulla. Siksi fysikaalisten mallien käyttö on meritieteessä jäänyt melko vähäiselle sijalle, eikä niitä käsitellä tässä kirjassa.

Matemaattiset mallit perustuvat tutkittavaa ilmiötä hallitsevien matemaattisten yhtälöiden ratkaisemiseen. Itämeren fysiikassa näitä matemaattisia yhtälöitä on pieni määrä, minkä ansiosta voidaan saavuttaa pitkälle meneviä tuloksia. Merten fysiikan perusyhtälöt ovat: 
(pohjoisella pallonpuoliskolla) oikealle tuulen suunnasta ja virtauksen nopeus pienenee eksponentiaalisesti syvemmälle edettäessä (katso kohta 6.3.2). Nykyisin nämä mallit ovat vähemmän keskeisessä asemassa mutta kylläkin edelleen tärkeitä, sillä niiden kautta on mahdollista "nähdä metsä puilta”.

Esimerkki. Beerin lain käyttö valon vaimenemiseen vedessä. Yksinkertainen valon kulkua kuvaava malli perustuu Beerin lakiin, jonka mukaan valon vaimeneminen on verrannollinen sen määrään. Jos valon irradianssi on $E=E(z, \lambda)$, missä $z$ on syvyys ja $\lambda$ on valon aallonpituus, on $\mathrm{d} E / \mathrm{d} z=\kappa E$, missä $\kappa$ on valon vaimenemiskerroin. Tämän ratkaisu on

$$
E(z, \lambda)=E(0, \lambda) \exp \left(-\int_{0}^{z} \kappa d z^{\prime}\right)
$$

Parametri $\kappa$ on vielä valittava; siihen voidaan käyttää mitattua tietoa tai sille voidaan olettaa jokin realistinen jakautuma. Erityisesti kun $\kappa=$ vakio, eksponenttifunktio integroituu suoraan muotoon $\exp (-\kappa z)$.

\subsubsection{Tilastolliset ja stokastiset mallit}

Tilastolliset mallit perustuvat tilastollisiin yhteyksiin syöttösuureiden ja ennustussuureiden välillä. Ne eivät välttämättä sisällä oletuksia ilmiön fysiikasta, vaan tilastomenetelmien avulla etsitään istuvia sovituksia havaintoaineistoihin. Tilastollisia malleja käytettiin erityisesti ennen numeeristen mallien aikakautta, mutta nykyisinkin ne ovat käyttökelpoisia yksinkertaisuutensa ansiosta. Varsin suosittu menetelmä on monilla aloilla ollut yksinkertainen lineaarinen regressio, jossa havaintoaineistoon sovitetaan suora minimoimalla sovitusvirheen varianssi. Muita menetelmiä ovat esimerkiksi empiiriset ortogonaaliset funktiot, autokovarianssianalyysi ja Markovin ketjut. Toisaalta tilastollisten mallien avulla voidaan myös kompressoida havaintoaineistoja fysikaalisten yhteyksien selvittämiseksi sekä käyttämiseksi muunlaisten mallien vertailuaineistona.

Esimerkki. Tilastollinen malli. Pinnalla kelluvan kappaleen ajelehtimisnopeutta $u$ mallitetaan usein lineaarisella mallilla

$\boldsymbol{u}=\underline{A} \underline{u}_{\mathrm{a}}+\boldsymbol{b}+\varepsilon$

missä $\boldsymbol{u}_{\mathrm{a}}$ on tuulen nopeus, $\underline{\boldsymbol{A}}$ on lineaarinen operaattori, joka kiertää ja lyhentää tuulivektoria, $\boldsymbol{b}$ on systemaattinen taustaliike (johtuu tuulesta riippumattomista merivirroista) ja $\varepsilon$ on virhetermi. Suureet $\boldsymbol{u}, \boldsymbol{u}_{\mathrm{a}}, \boldsymbol{b}$ ja $\varepsilon$ ovat vektoreita. Lineaarisen regression avulla voidaan havainnoista määrittää suureet $\underline{\boldsymbol{A}}$ ja $\boldsymbol{b}$ minimoimalla virheen varianssi. Vektori $\underline{\boldsymbol{A}} \boldsymbol{u}_{\mathrm{a}}$ edustaa puhdasta tuulen ajovirtaa, ja se on voimakkuudeltaan 2-5\% tuulen nopeudesta ja kulkee 10-40 astetta tuulen suunnasta oikealle. Suure $\underline{\boldsymbol{A}}$ riippuu kelluvan kappaleen muodosta ja uppoumasta, mutta suure $\boldsymbol{b}$ taas määräytyy puhtaasti taustalla vallitsevan virtaustilanteen mukaan. Optimoitua mallia sovellettaessa asetetaan $\varepsilon=0$ ja $\boldsymbol{b}$ pyritään arvioimaan muun tiedon perusteella; kun tuuli on voimakas, vallitsee Itämerellä relaatio $\left|\underline{\boldsymbol{A}} \boldsymbol{u}_{\mathrm{a}}\right|>|\boldsymbol{b}|$.

Stokastiset mallit ovat yleensä fysiikkaa sisältäviä differentiaaliyhtälöitä, joissa muuttujille ja mahdollisesti myös parametreille annetaan deterministinen ja stokastinen eli satunnainen komponentti. Ideana on ratkaista suoraan fysiikan lakien kautta satunnaistekijöiden merkitys tarkasteltavassa fysikaalisessa systeemissä. Stokastiset mallit voivat edelleen olla analyyttisia tai numeerisia.

Esimerkki. Veden lämpötilaa $T$ voidaan tarkastella stokastisella mallilla

$\frac{d T}{d t}=\mu\left(T_{a}-T\right)+\varepsilon$ 
missä $t$ on aika, $\propto$ on relaksaatiokerroin, $T_{\mathrm{a}}$ on ilman lämpötila, ja $\varepsilon$ on satunnaispakote, jonka keskiarvo on nolla. Yhtälön ratkaisu on

$$
T=\int_{-\infty}^{t} \exp [\mu(s-t)]\left(\mu T_{a}+\varepsilon\right) d s
$$

Vaikka lämpötilan muutoksia ajava stokastinen termi on, se integroitaessa kumuloi lämpötilan kehitykseen nollasta eroavan lisätermin. Systeemiin aiheutetut häiriöt vaimenevat pois relaksaatioajan $\propto^{-1}$ puitteissa, ja puhdas satunnaishäiriö syöttötiedoissa muuntuu muistin omaavaksi vaihteluksi veden lämpötilassa.

\subsubsection{Numeeriset mallit}

Fysikaalisen meritieteen perusyhtälöt ovat pääsääntöisesti tavallisia differentiaaliyhtälöitä tai osittaisdifferentiaaliyhtälöitä. Koska luonnonaltaissa reunat ovat monimutkaisia ja pakote ajallisesti ja paikallisesti vaihtelevaa, analyyttisilla malleilla ei päästä tutkimaan kovin realistisia tilanteita. Ongelmat voidaan tällöin ratkaista numeeristen menetelmien avulla likimääräisesti tietokoneita käyttäen. Meritieteellisissä numeerisissa malleissa käytetään lähestulkoon aina äärellisten differenssien menetelmiä ratkaisualgoritmien laatimisessa (katso alempana).

Ratkaisun konstruointi lähtee liikkeelle hilasta (kuva 3.8) tai 2-3 lomittaista hilaa sisältävästä hilaryhmästä. Hila on laskentasolukko, jossa kuhunkin hilan solmupisteeseen on tarkoitus hakea laskettavana olevien suureiden arvot. Hila kiinnitetään yleensä paikka-avaruuden $(x, y, z)$ kiinteisiin pisteisiin, ja ajassa $t$ se etenee tietyn aikaaskeleen verran kerrallaan. Koordinaatistoon $(x$, $y, z ; t)$ asetetaan siis diskreetit hilapisteet $\left(x_{\mathrm{i}}, y_{\mathrm{j}}\right.$, $\left.z_{\mathrm{k}} ; t_{\mathrm{p}}\right)$. Mallin perusyhtälöt kuvaavat ratkaistavia funktioita $f_{\ell}(x, y, z ; t)$, ja numeerisessa tehtävässä tuntemattomia ovat näiden funktioiden arvot $f_{\ell}\left(x_{\mathrm{i}}, y_{\mathrm{j}}, z_{\mathrm{k}} ; t_{\mathrm{p}}\right)$ kaikissa hilapisteissä.

Äärellisten differenssien menetelmässä derivaatat korvataan erotusosamäärillä. Funktion $f=$

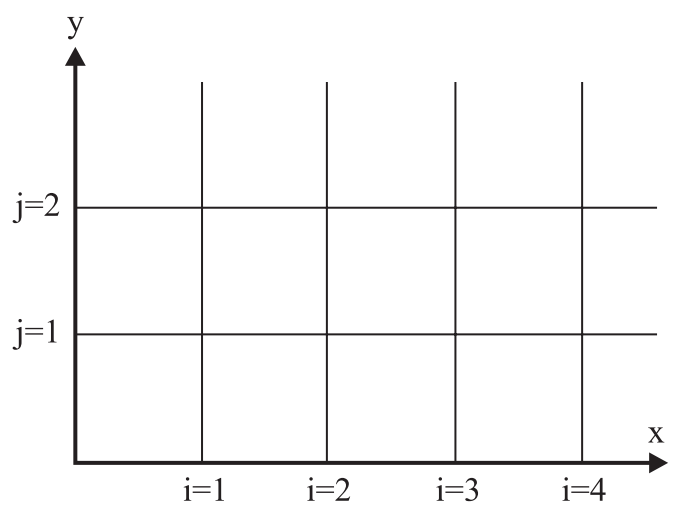

Kuva 3.8. Numeerisissa malleissa käytetään hiloja eli laskentasolukoita, joissa kuhunkin solmupisteeseen lasketaan ennustettavien suureiden arvot. Samassa mallissa voi olla useampi hila lomittain.

$f(x, y, z ; t)$ aikaderivaattaa approksimoidaan usein etuerotuksella ja paikkaderivaattoja keskeiserotuksilla; suoraan derivaatan määritelmästä saadaan

$$
\begin{aligned}
& \frac{\partial f}{\partial t} \approx \frac{f_{p+1}-f_{p}}{t_{p+1}-t_{p}}, \frac{\partial f}{\partial x} \approx \frac{f_{i+1}-f_{i-1}}{2 \Delta x}, \\
& \frac{\partial^{2} f}{\partial x^{2}} \approx \frac{f_{i+1}-2 f_{i}+f_{i-1}}{(\Delta x)^{2}}
\end{aligned}
$$

missä on oletettu, että paikkahila on tasavälinen, $\Delta x=x_{i+1}-x_{i}=$ vakio. Vastaavasti hoituvat muut paikkakoordinaatit $\partial f \partial y$ ja niin edelleen. Kun erotusosamäärät sijoitetaan mallin perusyhtälöihin derivaattojen paikoille, saadaan algebrallinen yhtälöryhmä tuntemattomien $f_{\ell}\left(x_{\mathrm{i}}, y_{\mathrm{j}}\right.$, $\left.z_{\mathrm{k}} ; t_{\mathrm{p}}\right)$ ratkaisemiseksi. Hilapisteiden lukumäärä on yleensä suuri, minkä takia tarvitaan suurta laskentakapasiteettia kaikkien tuntemattomien ratkaisemiseksi.

Esimerkki (jatkoa aiempaan vedenkorkeusmalliesimerkkiin). Itämeren vedenkorkeusmallissa ratkaistavia funktioita on kolme: horisontaaliset nopeuskomponentit $u$ ja $v$ sekä vedenkorkeus $\xi$. Jos hilan paikkaväli on 10 kilometriä, Itämeren alueelle mahtuu noin 4.000 hilapistettä, jolloin tuntemattomia $u\left(x_{\mathrm{i}}, y_{\mathrm{j}}\right), v\left(x_{\mathrm{i}}, y_{\mathrm{j}}\right), \xi\left(x_{\mathrm{i}}, y_{\mathrm{j}}\right)$ on kussakin aika-askeleessa yhteensä 12.000 kappaletta. Jos edelleen aika-askel on 10 minuuttia, vedenkorkeu- 


\begin{tabular}{|c|c|c|c|c|c|c|}
\hline$t_{0}$ & 0,0 & \multicolumn{4}{|c|}{ alkuehto = ... } & 5,00 \\
\hline$t_{\mathrm{p}}$ & 0,0 & 0,50 & 1,00 & 2,00 & 4,00 & 5,00 \\
\hline$t_{\mathrm{p}+1}$ & 0,0 & 0,50 & 1,05 & 2,10 & 3,90 & 5,00 \\
\hline$t_{\mathrm{p}+2}$ & 0,0 & 0,51 & 1,10 & 2,18 & 3,62 & 5,00 \\
\hline \multicolumn{7}{|l|}{$\cdots$} \\
\hline$t=\infty$ & 0,0 & 1,00 & 2,00 & 3,00 & 4,00 & 5,00 \\
\hline
\end{tabular}

Kuva 3.9. Esimerkki laskennan etenemisestä lämpötilamallissa hetkestä $t_{\mathrm{p}}$ hetkeen $t_{\mathrm{p}+2^{*}}$ Tässä $Q=0$ ja $D \Delta t$ / $(\Delta z)^{2}=0,1$. Reunaehdot ovat 0 ja $5{ }^{\circ} \mathrm{C}$ ja kun $t=\infty$, lämpötilajaukama on lineaarinen.

den vuorokauden mittaisen kehityksen ennustamiseksi on ratkaistava 1.728.000 tuntematonta.

Hilakoko paikkakoordinaateissa määrätään annetun ongelman perusteella, mutta sitä viime kädessä rajoittaa laskentakapasiteetti. Pienempi hilakoko antaa aina tarkemman ratkaisun, mutta vaatii yhä enemmän laskenta-aikaa. Merten fysiikassa vallitsee horisontaalisen ja vertikaalisen suunnan välillä voimakas anisotropia eli horisontaaliset mittasuhteet ovat monta kertaa suurempia kuin vertikaaliset. Siksi horisontaalinen hilaväli on aina suuri, 0,1-10 kilometriä sovelluksesta riippuen, kun taas vertikaalinen hilaväli on suuruusluokkaa 1-50 metriä. Kun paikkahila on kiinnitetty, aika-askeleen valinta riippuu käytetystä numeerisesta menetelmästä. Aika-askeleen täytyy pystyä kuvaamaan ulkoisen pakotteen vaikutuksia, jolloin sen pituus saa olla korkeintaan kymmenesosan pakotteen ajallisten vaihteluiden jaksonpituuksista. Toisaalta numeerisen ratkaisun stabiliteettivaatimus voi asettaa myös ylärajan aika-askeleen pituudelle.

Esimerkki. Vertikaalinen lämpötilamalli. Tarkastellaan yksinkertaista vertikaalista lämpötilamallia. Perusyhtälö on

$$
\frac{\partial T}{\partial t}=D \frac{\partial^{2} T}{\partial z^{2}}+\kappa \frac{Q}{\rho c} \exp (-\kappa z)
$$

missä $T$ on lämpötila, $D$ on lämmön diffuusiokerroin, $Q=Q(t)$ on auringonsäteily pinnassa, $c$ on veden omnaislämpö ja $\kappa$ on auringonsäteilyn vaimenemiskerroin. Eulerin menetelmän mukaan tätä yhtälöä approksimoidaan äärellisten differenssien avulla seuraavasti:

$$
\begin{aligned}
& \frac{T\left(t_{p+1}, z_{k}\right)-T\left(t_{p}, z_{k}\right)}{\Delta t}= \\
& D \frac{T\left(t_{p}, z_{k+1}\right)-2 T\left(t_{p}, z_{k}\right)+T\left(t_{p}, z_{k-1}\right)}{(\Delta z)^{2}} \\
& +\frac{Q\left(t_{p}\right)}{\rho c} \exp \left(-\kappa z_{k}\right)
\end{aligned}
$$

missä aika-askel $\Delta t=t_{\mathrm{p}+1}-t_{\mathrm{p}}$ ja hilaväli $\Delta z=z_{\mathrm{k}+1}-$ $z_{\mathrm{k}}$ ovat vakioita. Piste $z_{\mathrm{o}}$ on meren pinnassa ja piste $z_{\mathrm{N}}$ pohjassa. Kun lämpötila ajanhetkellä $t_{\mathrm{p}}$ tunnetaan, yhtälöstä voidaan suoraan laskea lämpötila ajanhetkillä $t_{\mathrm{p}+1}$ ja niin edelleen (kuva 3.9). Lämpötilan $T\left(t_{\mathrm{p}+1}, z_{\mathrm{k}}\right)$ laskeminen edellyttää, että lämpötila tunnetaan pisteissä $T\left(t_{\mathrm{p}}, z_{\mathrm{k}-1}\right), T\left(t_{\mathrm{p}}, z_{\mathrm{k}}\right)$ ja $T\left(t_{\mathrm{p}}, z_{\mathrm{k}+1}\right)$; reunapisteisiin $z_{\mathrm{o}}$ ja $z_{\mathrm{N}}$ lämpötila on tuotava reunaehtojen kautta.

Reunaehdoiksi voidaan asettaa kiinteät lämpötilat pinnalla ja pohjalla, $T\left(t_{\mathrm{p}}, z_{0}\right)=T_{\mathrm{o}}$ ja $T\left(t_{\mathrm{p}}, z_{\mathrm{N}}\right)$ $=T_{\mathrm{b}}$. Tällöin systeemiä ohjaavat auringonsäteilyn tuoma lämmitys ja lämmön diffuusio reunojen kautta ulos. Aika-askelten määrä riippuu sii- 
tä, miten pitkästä ajassa ulottuvasta laskennasta on kyse, kun puolestaan vertikaalikoordinaatin hilapisteiden määrä kiinnitetään etukäteen. Jos meren syvyys on 100 metriä, hilaväliksi voitaisiin ottaa 0,5 metriä, jolloin näiden hilapisteiden lukumääräksi tulisi 200. Eulerin menetelmän stabiliteettikriteeri antaa $D \Delta t<(\Delta z)^{2} / 2$; jos otetaan $D=0,01 \mathrm{~m}^{2} / \mathrm{s}$, on siis oltava $\Delta t<$ 12,5 sekuntia.

\subsubsection{Itämeren tärkeimmät mallit}

Itämeren fysiikassa tavanmukaiset mallit voidaan jakaa käyttötarkoituksen mukaan seuraaviin luokkiin:

(1) Vertikaalimallit. Lasketaan lämpötilan, suolaisuuden ja virtausnopeuden vertikaalisia profiileja. Vedenlaatusovelluksissa otetaan mukaan myös ainespitoisuuksia.

(2) Laatikkomallit eli box-mallit. Jaetaan Itämeri altaisiin ("laatikoihin"), ja laaditaan omat mallit altaille ja niiden vuorovaikutukselle.

(3) Vedenkorkeusmallit. Lasketaan meriveden kulkeutumista ja vedenpinnan korkeutta. Sovelluksissa tavoitteena on ensisijaisesti ennustaa vedenkorkeuden kehitystä rannikolla.

(4) Virtausmallit. Lasketaan meriveden virtauskentän horisontaalista ja vertikaalista osaa eli meren kiertoliikettä. Osana virtausmalleja ovat pinnalla kelluvien kappaleiden ja aineiden ajautumismallit.

(5) Aallokkomallit. Lasketaan tuulen nostattaman aallokon kehittymistä.

(6) Jäämallit. Lämpötalousmalleilla lasketaan jään paksuuntumista ja sulamista ja dynamiikkamalleilla ajojään liikettä.

(7) Merelliset ilmastomallit. Ratkaistaan Itämeren ilmastoprobleema eli lasketaan veden tila, kiertoliike ja jäätalven kehitys. Siten saadaan kokonaiskuva Itämerestä fysikaalisena systee- minä ja voidaan laatia itämerellisiä ilmastoskenaarioita.

Mallien tärkein reunaehto on meren pinnassa, ja se määräytyy meren ja ilmakehän välisestä vuorovaikutuksesta ja auringonsäteilystä. Meren ranta ja pohja ovat passiivisia eli ne vaikuttavat geometriansa ja kitkan kautta ohjaavasti veden liikkeeseen. Tanskan salmissa on meren vapaa reuna, jonka kautta Itämeri on vuorovaikutuksessa Pohjanmeren kanssa. Joissain tapauksissa tämä reuna voidaan keinotekoisesti sulkea, mutta muutoin on sen läpi tuleva vesi, lämpö ja suola määritettävä. Edelleen tarvitaan myös alkuarvot laskennan aloitushetkeltä. $\mathrm{Ne}$ voidaan konstruoida havainnoista tai sitten asettaa jokin yksinkertainen tilanteeseen sopiva alkutila. Jälkimmäisessä tapauksessa siirtämällä laskennallista nollahetkeä kauemmas yli systeemin muistiajan taakse, saadaan alkutilan epätarkkuus häivytetyksi.

Vedenkorkeusmalli, aallokkomalli, jäämalli sekä pintakuljetusmalli ovat nykyään myös operatiivisessa ennustuskäytössä Itämerellä. Ennustusajojen pakotteena on sääennuste, jonka ajallinen ulottuvuus asettaa ylärajan merellisten ennusteiden laatimiseen. Lisäksi tarvitaan vapaa reuna Tanskan salmiin, kun halutaan hyviä useamman vuorokauden ennusteita.

Matemaattisia malleja on nykyisin verrattain hyvin saatavilla. Jokaisen ei ole tarvetta itse konstruoida malleja, mutta sen sijaan on kyllä syytä tuntea mallimaailman ajatustapa ja mahdollisuudet. Vaikkei itse mallia konstruoisikaan, on hyvä tehdä mallilla monipuolisia testejä sen ominaisuuksien ymmärtämiseksi, aivan kuten tutkija tekee kokeita luonnossa sen ilmiöiden ymmärtämiseksi.

Tämä kirja ei käsittele mallien konstruointia - siihen on olemassa runsaasti kirjallisuutta - vaan Itämeren fysiikkaa. Siksi malleihin ei mennä syvemmälti, mutta fysiikan esittelyssä kyllä käytetään mallien tuloksia hyväksi. 


\section{Syvyyssuhteet ja hydrografia}

\subsection{Topografian pääpiirteet}

Itämeren tyypillinen piirre on sen mataluus: keskisyvyys on vain 54 metriä, ja syvin kohta, Landsortin syvänne Tukholman ja Gotlannin välissä, on 459 metriä. Itämeren pinta-alakin on pieni, $392.978 \mathrm{~km}^{2}$ ja sen tilavuus on $21.205 \mathrm{~km}^{3}$. Itämeri on jakautunut altaisiin, joiden geometria ja morfologia ovat erilaisia syvänteineen, matalikoineen ja painumineen. Rannikkoalueet ovat suurelta osin saaristoisia ja aallokon muovaamia. Kaikki tämä lisää omalta osaltaan Itämeren fysiikan monimuotoisuutta.

Itämeren katsotaan alkavan lounaassa Kattegatin eteläsuulta. Rannikko ja pohjatopografia vaihtelevat suuresti. Pääpiirteet ovat pre-glasiaalista alkuperää; ero nykyiseen pohjaan on muutamista metreistä kymmeniin metreihin. Topografian muutoksia ovat jääkauden jälkeen aiheuttaneet kulkeutumisprosessit ja sedimentaatio. Pohja on karkea siellä, missä sedimentaatio on ollut vähäistä.

Viime jääkauden jälkeisenä aikana on tapahtunut maankohoamista Itämeren alueella (kuva 4.1). Kun vähennetään havaitusta vedenkorkeudesta vesibalanssin osuus, jäljelle jäävät maankohoamisen ja valtameren eustaattisen pinnannousun vaikutukset. Ne voidaan yhdistää suhteelliseksi maankohoamisluvuksi, joka kuvaa maan kohoamista suhteessa keskimääräiseen vedenkorkeuteen. Suhteellinen maankohoaminen on

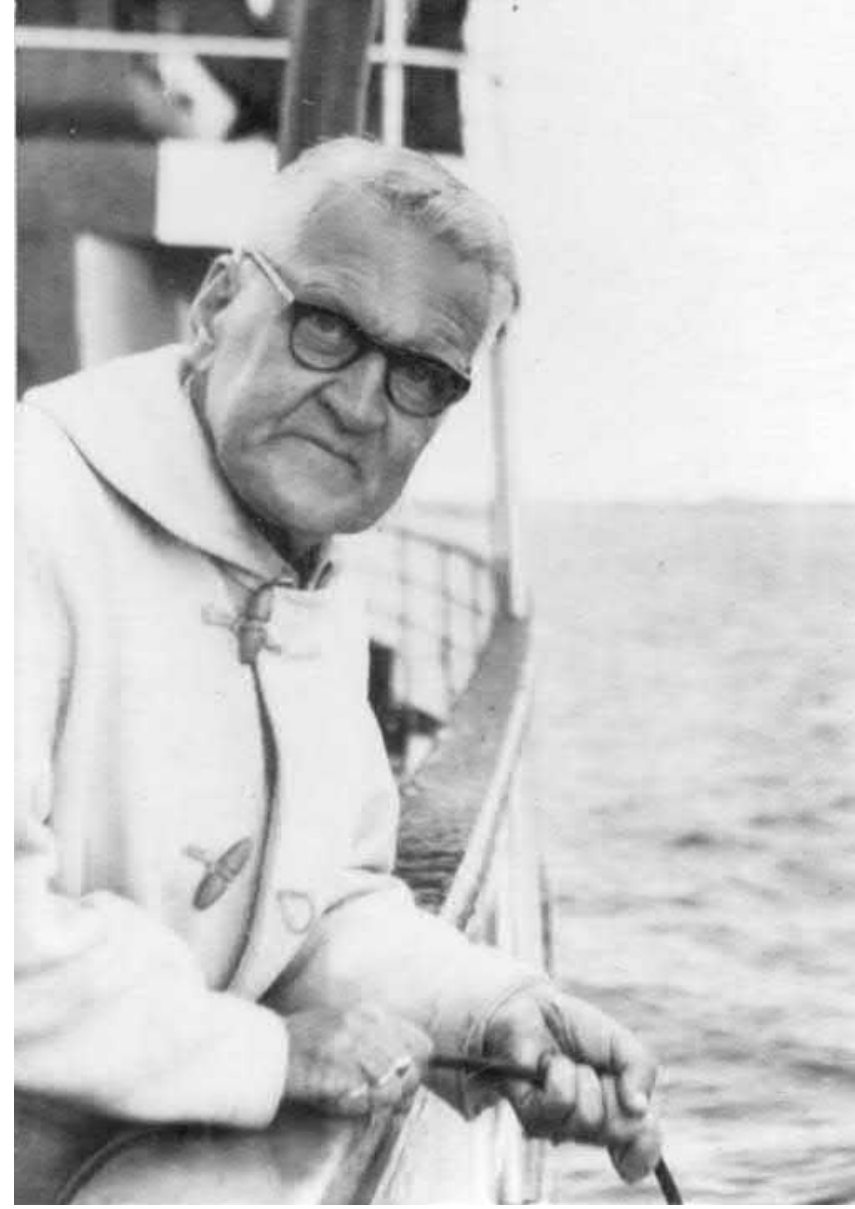

Kuva 4.0. Professori Gunnar Granqvist (1888-1965) vaikutti merkittävällä tavalla Merentutkimuslaitoksen mittaustoiminnan kehittämiseen. Hän oli Wittingin ja Jurvan aikana vt. johtajana useaan otteeseen. Granqvistillä oli pitkä ura takanaan ensin Suomen Tiedeseuran hydrografis-biologisissa tutkimuksissa ja sen jälkeen Merentutkimuslaitoksen palveluksessa. Granqvistin toimintakausi kesti kaikkiaan 36 vuotta aina vuoteen 1955. (Merentutkimuslaitoksen kuvaarkisto)

suurinta aivan pohjoisessa, Kemissä 7,20 $\pm 0,27$ $\mathrm{mm}$ /vuosi, kun Haminassa se on 1,62 \pm 0,26 $\mathrm{mm} /$ vuosi (eustaattinen vedenkorkeuden nousu on nyt muutamia millimetrejä vuodessa). Suhteellisen maankoamisen nollataso kulkee Viron eteläpuolella. Sen eteläpuolella maa laskee näennäisesti. Aivan uusimpien tulosten mukaan myös Suomenlahden tasalla suhteellinen maankohoaminen on vähitellen pysähtymässä. Tämä johtuu siitä, että valtamerten pinnan eustaattinen kohoaminen näyttää viime aikoina kiihtyneen. 


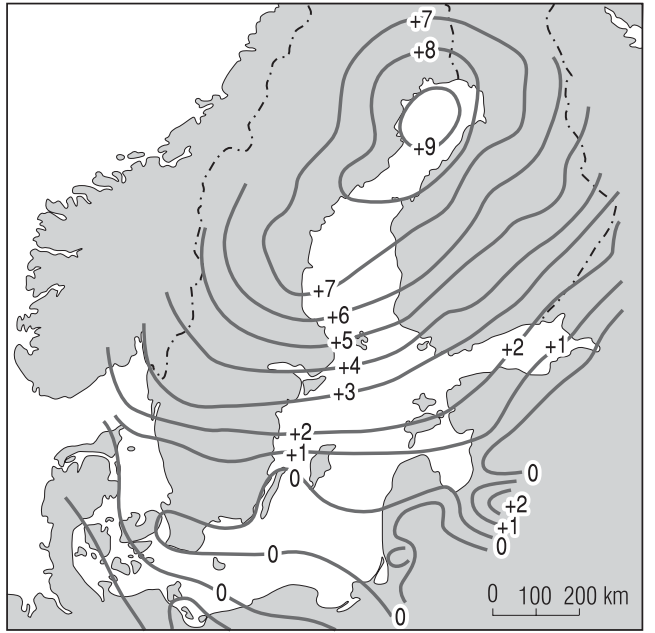

Kuva 4.1. Maankohoaminen Itämeren alueella millimetreinä vuodessa: + merkki tarkoittaa maankohoamista -merkki vajoamista. Kuvassa ei ole huomioitu merenpinnan eustaattista nousua. (Piirretty Voipion ja Leinosen [1984] kuvasta.)

Jääkauden jälkeen Itämerellä on tapahtunut pohjaan vajoavan aineksen kerrostumista eli sedimentaatiota (Voipio ja Leinonen 1984). Osassa Itämerta tämä on jatkunut jokseenkin ilman ulkoista häiriötä siten, että vanhimmat kerrostumasarjat löytyvät eteläiseltä Itämereltä, josta mannerjää ensiksi vetäytyi. Sedimentin paksuus vaihtelee eri alueiden välillä. Perämerellä se on yli 10 metriä, Selkämerellä 40-50 metriä ja Gotlannin altaalla noin 30 metriä. Lähellä jäätikön reunaa kerrostuminen oli nopeaa, vuosikertymä oli useita senttimetrejä. Jään edelleen vetäytyessä sedimentaationopeus pieneni ja nykyään se on noin $1 \mathrm{~mm}$ /vuosi syvimmissä altaissa. Sedimenteissä on selkeä jako karkean ja hienon aineksen välillä: kerrostuman alaosassa on karkeaa hiekkaa ja soraa, kun taas aineksen yläosassa on hienompaa hiesua ja savea. Syvien altaiden ulkopuolella sedimentaationopeus on huomattavasti pienempi, eikä 50 metriä matalammalla alueella tapahdu pysyvää sedimentoitumista, sillä aaltojen vaikutus ulottuu pohjaan saakka ja pohjasavi saattaa liettyä eli pohjalla tapahtuu eroosiota.

\subsection{Eri altaiden topografiset piirteet ja pohjan laatu}

Luvun 2 allasjaotuksen mukaan seuraavassa käydään läpi Itämeren altaiden topografiset piirteet (kuva 4.2). Yksityiskohtaisen pohjatopografian kuvauksen löytää Fonseliuksen (1996) julkaisusta, johon tässä oleva esitys pitkälti perustuu. Pohjan laatuun liittyvät tarkastelut perustuvat Voipion ja Leinosen (1984) esitykseen. Tarkasteluissa myös Kattegat on mukana, koska se on tärkeä Itämeren ja Pohjanmeren välissä oleva vyöhyke.

Altaiden välisessä vedenvaihdossa on tärkeää kiinnittää huomio Itämeren kynnyksiin. Kynnyssyvyys on suurin syvyys, jolla voidaan horisontaalisessa suunnassa kulkea altaasta toiseen. Kynnysyvyyteen asti altaiden välinen vedenvaihto on tehokasta. Kuvassa 4.3 on esitetty skemaattisesti veden eteneminen Itämeren sisäosiin erilaisten kynnysten yli.

Itämeren altaiden pinta-alat, tilavuudet sekä syvyyssuhteet antavat yleiskuvan topografiasta (taulukko 4.1). Selkeästi suurin allas on Gotlannin meri. Sen pinta-ala $151.920 \mathrm{~km}^{2}$ on 39 prosenttia koko Itämeren alasta ja sen tilavuus $10.824 \mathrm{~km}^{3}$ on 51 prosenttia koko Itämeren tilavuudesta, mikä selittyy altaan suurella keskisyvyydellä (71 metriä). Toinen suuri allas on Pohjanlahti, jonka pinta-ala on $115.516 \mathrm{~km}^{2}$. Sen tilavuus on kuitenkin vain $6.369 \mathrm{~km}^{3}$, koska keskisyvyys (55 metriä) on pienempi kuin Gotlannin altaan. Bornholmin allas, pinta-alaltaan $38.942 \mathrm{~km}^{2}$, on seuraavaksi suurin allas, keskisyvyys 46 metriä, jolloin tilavuudeksi saadaan $1.780 \mathrm{~km}^{3}$. Neljäntenä on Suomenlahti, pinta-ala $29.498 \mathrm{~km}^{2}$ (8 prosenttia Itämerestä) ja tilavuus $1.098 \mathrm{~km}^{3}$ (5 prosenttia Itämerestä). Keskisyvyys Suomenlahdella on noin 37 metriä, mikä on jo selvästi Itämeren keskiarvon alapuolella. Tanskan salmet, Arkonan allas, Gdanskin lahti ja Riianlahti ovat kaikki pinta-alaltaan ja tilavuudeltaan varsin pieniä, vaikkakin Tanskan 


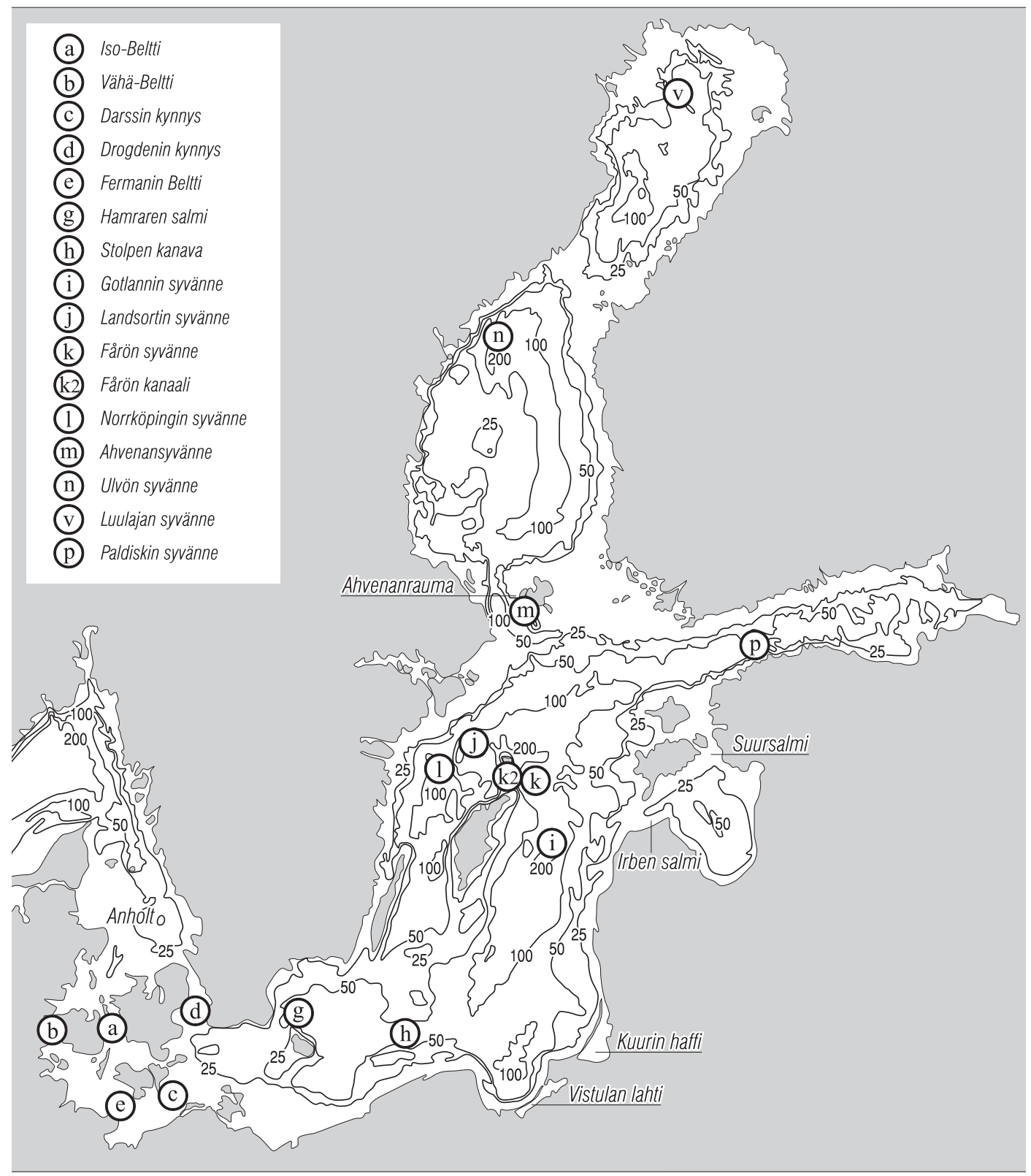

Kuva 4.2. Itämeren pohjatopografian pääpiirteet ja sen suhteen tärkeimpien paikkojen nimet. (Piirretty Fonseliuksen [1996] kuvasta.)

salmien rooli Itämeren ja Pohjanmeren välisessä vedenvaihdossa on keskeinen.

Varsinainen Itämeri on vakiintunut tarkoittamaan Itämeren keskusalueen altaita Tanskan salmista itäisiin ja pohjoisiin suuriin lahtiin asti. Se koostuu Arkonan ja Bornholmin altaista sekä Gotlannin merestä, joka voidaan jakaa itäiseen, läntiseen ja pohjoiseen altaaseen ja Gdanskin lahteen (taulukko 4.1).

Itämeren syvyysoloja voidaan tarkastella myös hypsografisten käyrien avulla. Nämä kuvaavat syvyyksien kumulatiivista syvyysjakaumaa (kuva 4.4). Itämeren mataluus tulee käyrissä hyvin esille: noin 12 prosenttia Itämeren alasta kattaa alueet, 


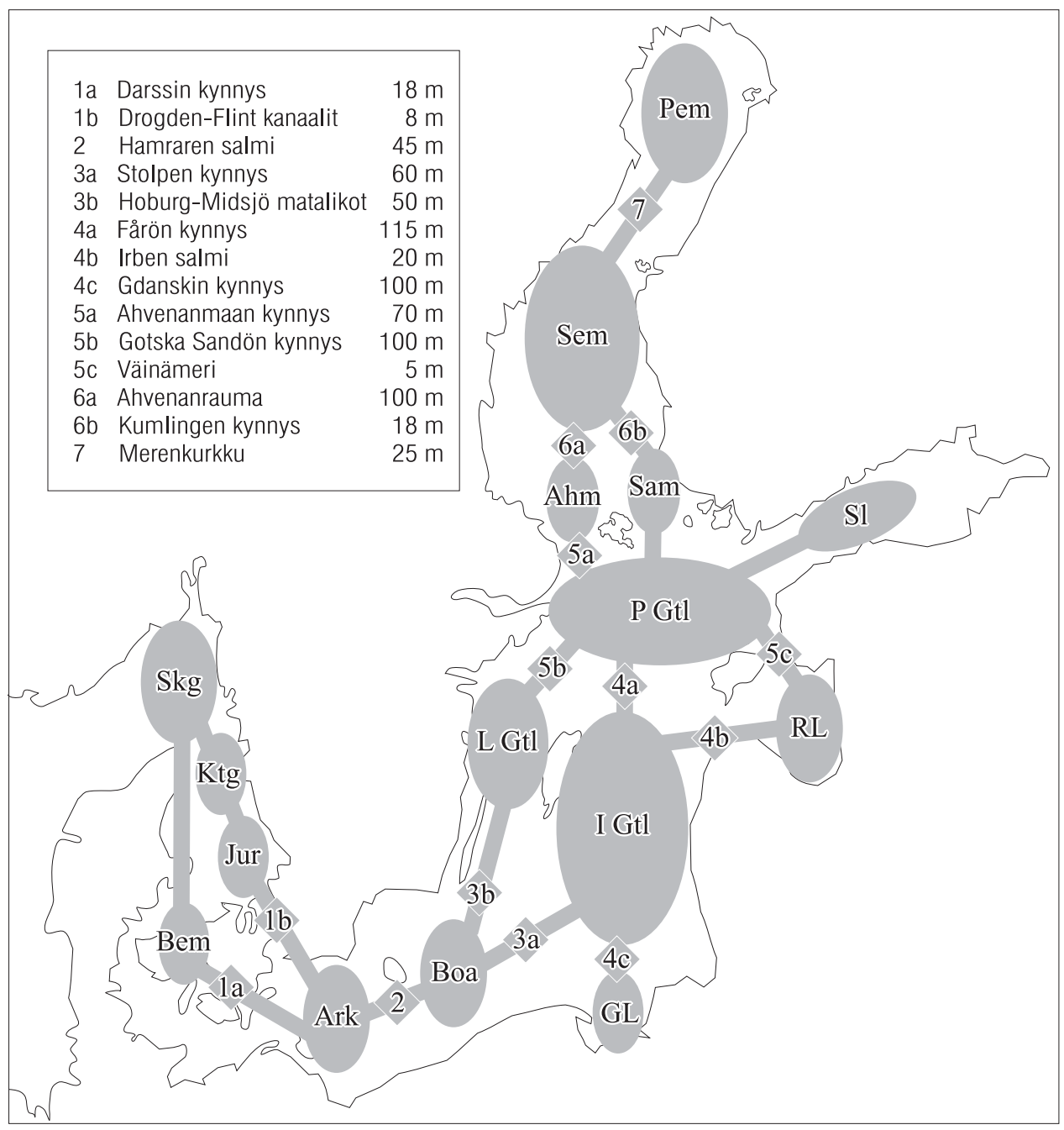

Kuva 4.3. Skemaattinen kuva kynnyksistä Itämeren altaiden välillä.

joilla syvyys on yli 100 metriä, ja vain 2,5 prosenttia alasta kattaa yli 150 metrin syvyiset alueet.

\subsubsection{Kattegat ja Lounainen Itämeri}

Kattegat on matala (keskisyvyys 23 metriä) Itämeren ja Pohjanmeren välinen allas, vesimassojen vaihettumisvyöhyke, jonka ei katsota kuuluvan kumpaankaan näistä meristä (kuva 4.5A). Siihen tulee Pohjanmereltä, Skagerrakista suolaista Atlantin vettä, joka laimentuu ja jatkaa matkaansa Itämereen. Itämeren vettä menee Kattegatista
Skagerrakiin pintavirtauksena ja jatkaa matkaansa länteen Norjan rannikkovirtana, jossa se voidaan jäljittää alhaisen suolaisuutensa ansiosta. Skagerrak on keskisyvyydeltään 230 metriä. Sen ja Kattegatin välillä ei ole kynnystä. Kattegatin ja Skagerrakin rajana on linja Skagen-Marstrand. Kattegatissa on paikallisia syvänteitä, kuten Anholtin lähellä (100 metriä). Ruotsin rannikkoa myötäilevän kanaalin syvyys on 75-100 metriä madaltuen etelään päin. Tanskan salmien ulkoreunalla, Itämeren portilla, Kattegatin syvyys on 20-40 metriä. 
Taulukko 4.1. Itämeren altaiden ja Kattegatin mitat (Fonselius 1996).

\begin{tabular}{|l|r|r|r|r|}
\hline & $\mathrm{A}$ & $\mathrm{H}_{\text {kesk }}$ & $\mathrm{H}_{\text {max }}$ & Tilavuus \\
\hline yksikkö & $\mathrm{km}^{2}$ & $\mathrm{~m}$ & $\mathrm{~m}$ & $\mathrm{~km}^{3}$ \\
\hline Merialue & & & 130 & 515 \\
\hline Kattegat & 22.287 & 23 & 459 & 21.205 \\
\hline $\begin{array}{l}\text { Itämeri (Tanskan salmien } \\
\text { kanssa) }\end{array}$ & 392.978 & 54 & 459 & 20.918 \\
\hline Itämeri (ilman Tanskan sal- & & & & \\
mia) & 372.857 & 56 & 81 & 287 \\
\hline Tanskan salmet & & & 81 & 260 \\
\hline Belttien meri & 20.121 & 14 & 53 & 27 \\
\hline Juutinrauma & 17.821 & 15 & 53 & 442 \\
\hline Arkonan allas & 2.300 & 12 & 105 & 1.780 \\
\hline Bornholmin allas & 19.068 & 23 & 459 & 10.824 \\
\hline Gotlanninmeri & 38.942 & 46 & 114 & 1.439 \\
\hline Gdanskin lahti & 151.920 & 71 & 249 & 4.911 \\
\hline Itäinen Gotlannin allas & 25.234 & 57 & 150 & 2.056 \\
\hline Pohjoinen Gotlannin allas & 63.478 & 77 & 459 & 2.418 \\
\hline Läntinen Gotlannin allas & 28.976 & 71 & 123 & 1.098 \\
\hline Suomenlahti & 34.232 & 71 & 51 & 405 \\
\hline Riianlahti & 29.498 & 37 & 293 & 6.369 \\
\hline Pohjanlahti & 17.913 & 23 & 301 & 411 \\
\hline Ahvenanmeri & 115.516 & 55 & 104 & 169 \\
\hline Saaristomeri & 5.477 & 75 & 293 & 4.308 \\
\hline Selkämeri & 8.893 & 19 & 146 & 1.481 \\
\hline Perämeri & 64.886 & 41 & & \\
\hline
\end{tabular}

Tanskan salmiin lasketaan kuuluviksi Belttien meri ja Juutinrauma [Öresund]. Rajalinjat Kattegatiin ovat Hasenør-Själlands Odde Jyllannista Själlantiin sekä Gilleleje-Kullen Själlanista Skåneen. Tämä alue onkin ratkaisevassa asemassa Itämeren ja Pohjanmeren välisessä vedenvaihdossa. Pirstaleinen Belttien meri koostuu seuraavista vesialueista Tanskan rannikon ja saarten välillä: Iso-Beltti Själlannin ja Fynin välissä, Smaalands farvandet, Mecklenburgin lahti, Fermanin Beltti, Kielin lahti sekä vesialueet Fynin eteläpuolella, Vähä-Beltti ja Fynin saaren pohjoispuoliset alueet sekä Århusin lahti. Belttien meressä syvyysolot ovat vaihtelevat. Syvimmissä kanaaleissa Iso-Beltin pohjoisosissa syvyys on jopa 60 metriä, mutta yleensä se on Iso-Beltissä 20 metriä, Vähä-Beltissä alle 15 metriä.
Tanskan salmet rajoittuvat etelässä Darsser Ortin ja Gedserin niemen kautta kulkevalle linjalle. Siinä on Pohjanmeren ja Itämeren vedenvaihdon kannalta todellinen topografinen kynnys, Darssin kynnys, jonka syvyys on 18 metriä. Iso-Beltin läpi ulottuu kapea kanaali aina Kattegatista Darssin kynnykselle asti, missä myös määräytyy enimmäissyväys Itämerelle tuleville aluksille.

Juutinrauma sijaitsee Tanskan ja Ruotsin välissä. Sitä rajoittaa etelässä linja Stevns Klint-Falsterbon niemi. Juutinrauman pohjoisosissa syvyys on yleensä 23-26 metriä, mutta Landskronan pienessä syvänteessä, Ven-saaren eteläpuolella, maksimisyvyys on peräti 53 metriä. Juutinrauman merkitys Itämeren ja Pohjanmeren välisessä vedenvaihdossa on suuri. Ruotsin puoleisessa Flintin kanaalissa kynnyssyvyys on 8,6 metriä ja 

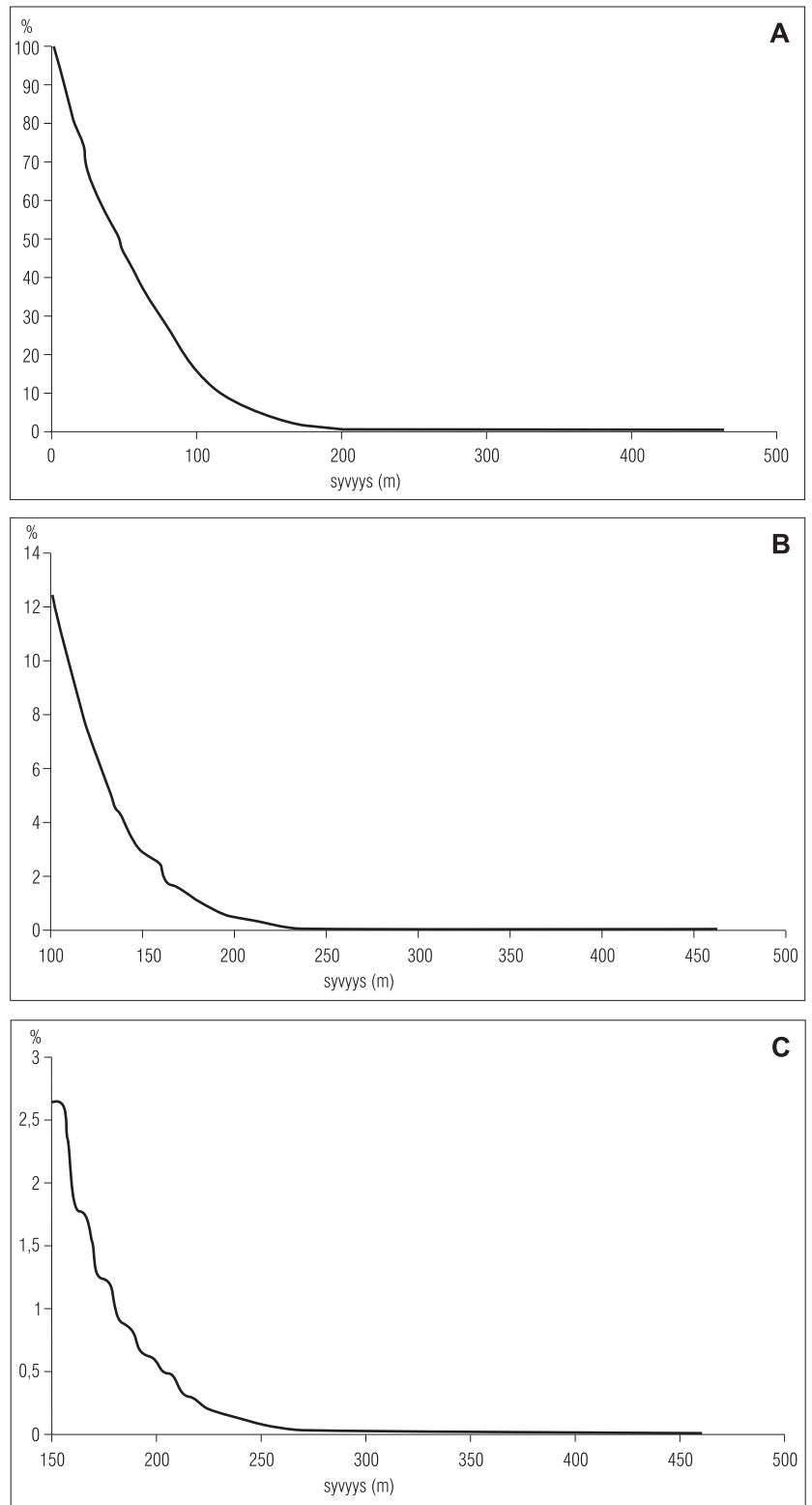

Kuva 4.4. Itämeren syvyyden hypsografiset käyrät eli syvyyksien kumulatiiviset jakautumat. A) Kaikille syvyyksille, B) Yli 100 metrin syvyyksille, C) Yli 150 metrin syvyyksille.

Tanskan puolella 8 metriä Drogdenin kanaalissa. Kynnyksestä etelään Itämeren puolella syvyys kasvaa noin 20 metriin.

Lounaisella Itämerellä (kuvat 4.5A-B) on kaksi pientä allasta: Tanskan salmiin rajoittuva Arkonan allas, jonka maksimisyvyys on 53 metriä

A

B

C 500 . 


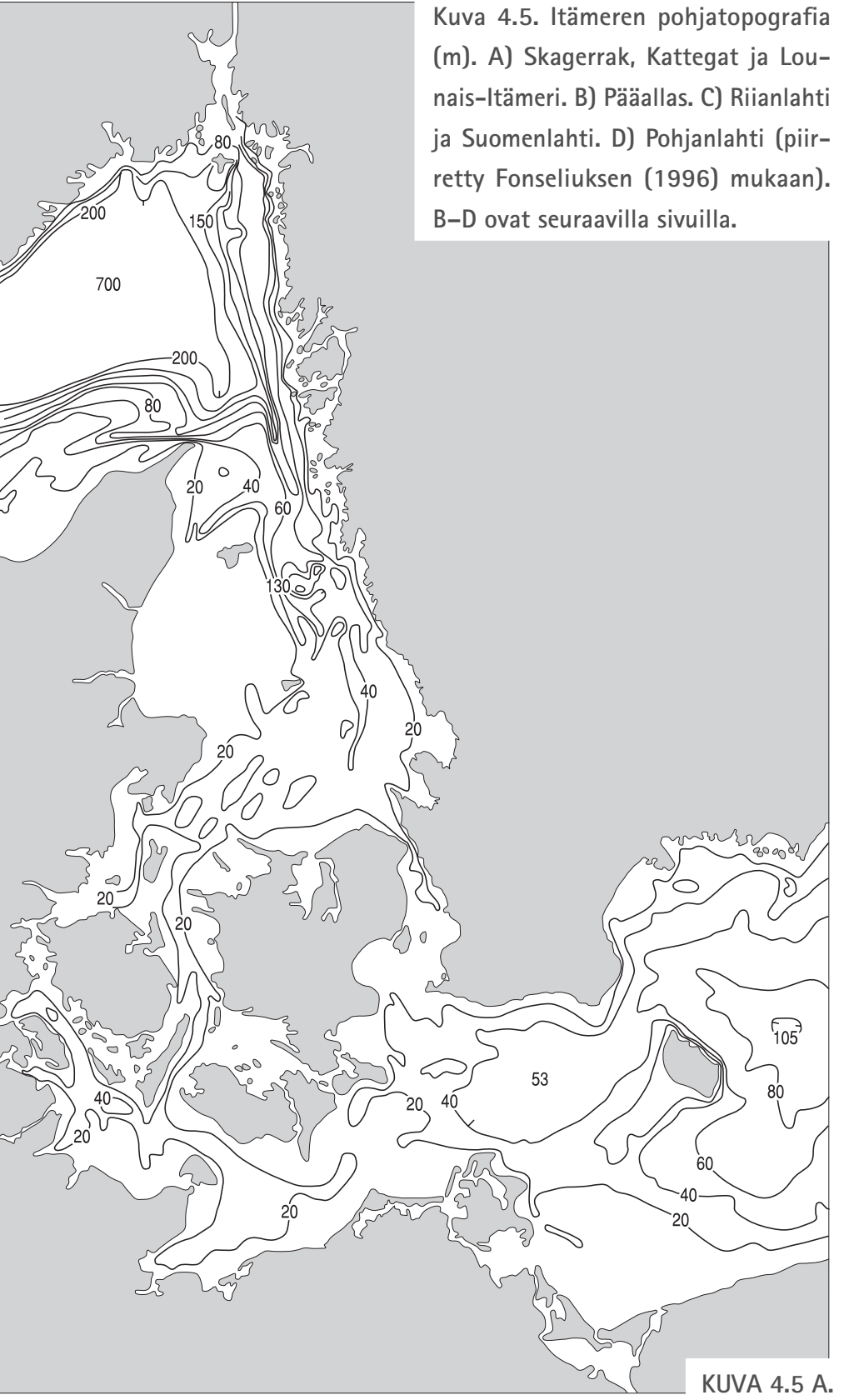

kun taas Bornholmin saaren lounaispuolella on varsin matalaa (20-25 metriä). Syvin väylä sisemmäs Itämereen, Itäiseen Gotlannin altaaseen, on Stolpen kanaali (kynnyssyvyys 60 metriä). Pohjoisessa Bornholmin allasta rajoittavat Ruotsin rannikko ja Midsjön matalikko.

\subsubsection{Gotlannin meri}

Gotlannin meri koostuu Gdanskin lahdesta ja Gotlannin altaasta ja kattaa lopun Varsinaisesta Itämerestä Arkonan ja Bornholmin altaiden jälkeen (kuva 4.5B). Gdanskin lahti rajoittuu linjalle Briusterort-Rozewie. Gotlannin allas on Itämeren keskusallas, joka jaetaan itäiseen, läntiseen ja pohjoiseen osaan. Leveä vedenalainen harjanne Gotlannista Puolan rannikolle erottaa läntisen ja itäisen altaan toisistaan. Siihen kuuluvat matalikot: Hoburg Bank (minimisyvyys 10 metriä)-Pohjoinen Midsjön matalikko (9 metriä)Eteläinen Midsjön matalikko (13 metriä)-Lawica Slupska (8 metriä). Ainoastaan Stolpen kanaali puhkaisee tämän harjanteen.

Itäiseen altaaseen kuuluvat Stolpen kanaali, Gotlannin syvänne saaren itäpuolella ja Fårön syvänne (205 metriä), joka sijaitsee Gotlannin koillispuolella. Stolpen kanaalin kautta kulkee syvin yhteys Bornholmin altaan ja Gotlannin meren välillä. Sen keskisyvyys on 90 metriä ja kynnyssyvyys 80 metriä Gotlannin altaan suuntaan. Itäinen Gotlannin allas on laaja-alainen, maljanmuotoinen syvännealue, jonka suurin syvyys on 249 metriä. Kynnyssyvyys Fårön syvänteeseen on 140 metriä. Fårön syvänteen, ja siten itäisen Gotlannin altaan, kynnyssyvyys Pohjoiseen Gotlannin altaaseen on 115 metriä. Fårön saaren ja Gotlannin välissä on Fårön kanaali. Itäisen Gotlannin altaan rajalinja Pohjoiseen altaaseen on hieman Gotlannin 
yläpuolella linjalla Fårö-Gotska Sandön-Ristna. Kynnyssyvyys Gotlannin syvänteestä Gdanskin lahteen on 100 metriä, ja Gdanskin lahdella suurin syvyys on 114 metriä (Gdanskin syvänne). Puolan, Kaliningradin alueen ja Liettuan edustalla on kaksi suurta laguunia, Vistulan lahti ja Kuurin haff, joista jälkimmäinen on tunnettu meripihkasta.

Pohjoinen Gotlannin allas ulottuu Suomenlahteen ja Pohjanlahteen asti. Hydrografisesti Suomenlahti on Gotlannin altaan jatke, koska välillä ei ole kynnystä. Pohjoisen altaan topografia on hyvin vaihtelevaista, ja siinä on laajoja yli 150 metriä syviä alueita. Pohjoisessa aluetta rajoittaa 45 metrin syvyinen Ahvenanmaan kynnys, kun taas lounaassa rajana Läntiseen Gotlannin altaaseen on linja Fårö-Kopparstenarna-Tukholman ulkosaaristo.

Läntiseen Gotlannin altaaseen kuuluu Landsortin syvänne (459 metriä), koko Itämeren syvin kohta. Se on puolikuun muotoinen halkeama, jonka seinämät ovat hyvin jyrkät. Lisäksi altaaseen kuuluu Norrköpingin syvänne (205 metriä). Västervikin (mantereen) ja Visbyn välillä on lisäksi alueita, joissa syvyys on 150 metriä. Etelään päin mennessä allas mataloituu siten, että Hoburgin ja Midsjön matalikoilla ja Bornholmin suunnalla syvyys on 20-40 metriä. Öölannin saari kuuluu tähän altaaseen. Öölannin ja Ruotsin mantereen välissä syvyys on alle 20 metriä.

Varsinaisen Itämeren syvänteissä pohjan pinnan laatu on Suomenlahden suulta Gdanskin lahteen asti hiesua, savea ja liejusavea. Keskussyvän-

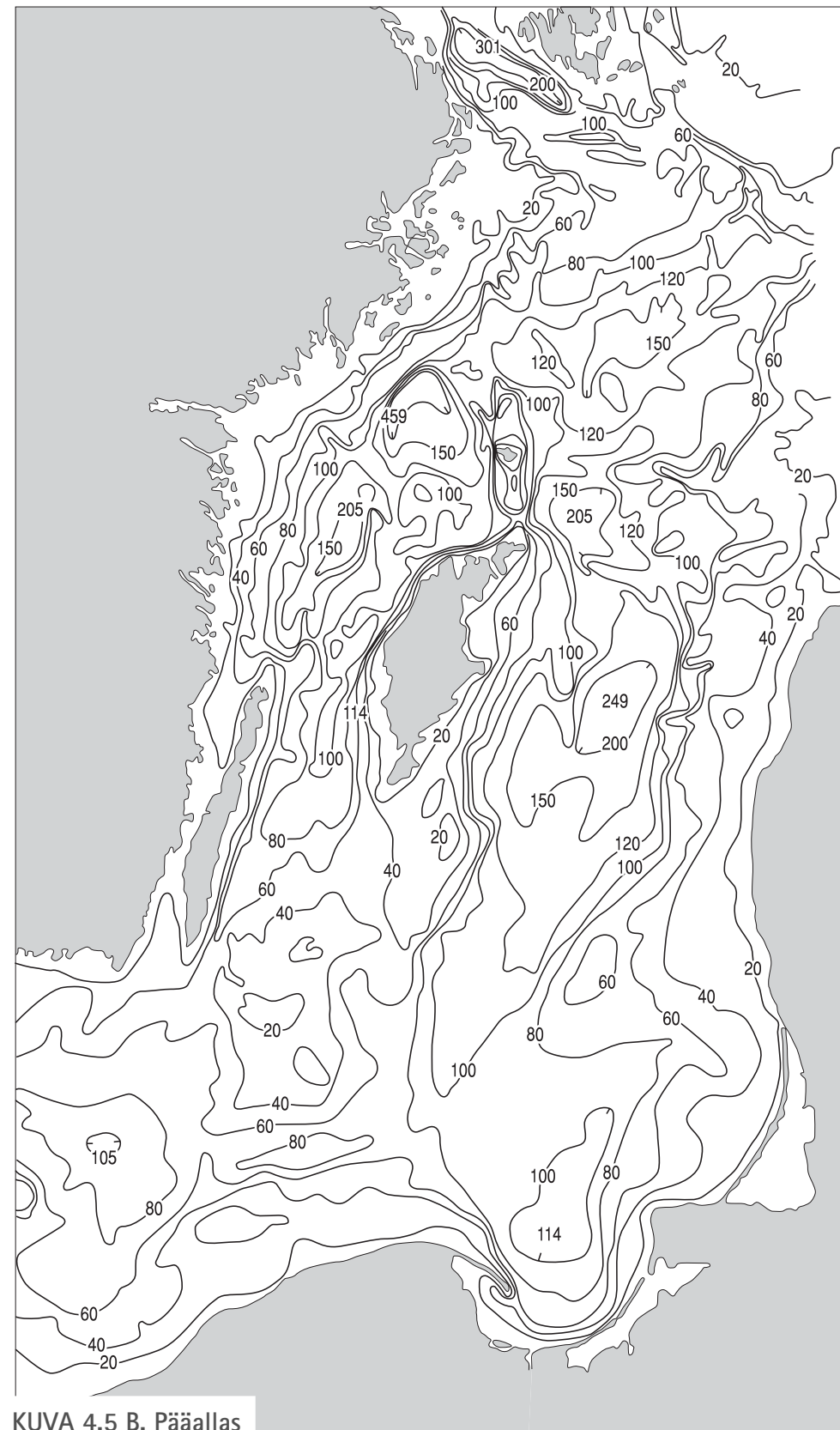

teiden pehmeiden pohjien ja rannikon välissä on laajoja sora- ja hiekka-alueita, jotka usein jatkuvat läheisillä rannikoilla. 


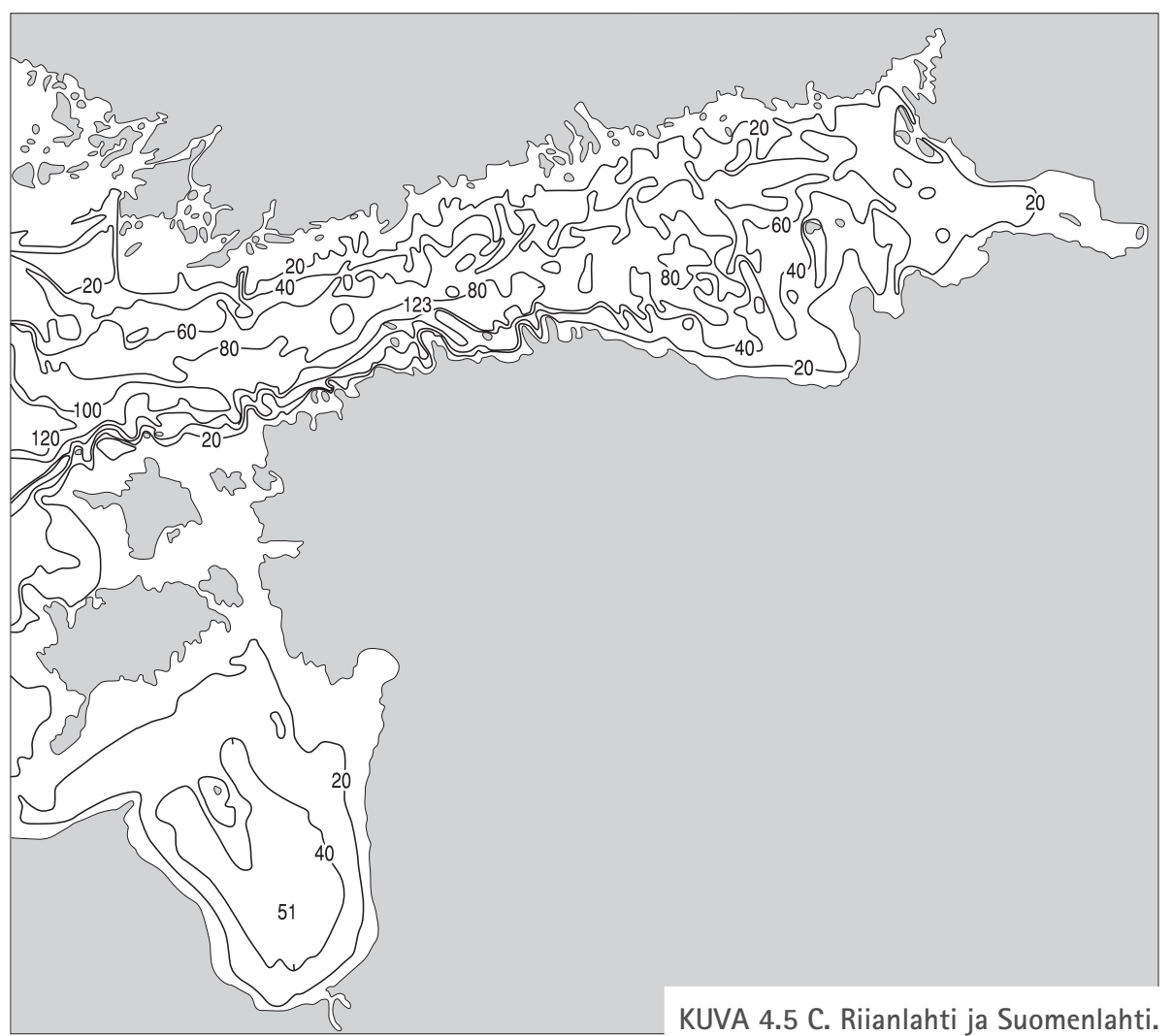

\subsubsection{Riianlahti}

Riianlahti sijaitsee Viron ja Latvian välissä (kuva 4.5C). Se on melko eristyksissä Gotlannin merestä, sillä välissä ovat Viron saaret Hiidenmaa ja Saarenmaa. Lännessä rajana on Irben salmessa linja Sórve-Ovisi. Pääasiallinen vedenvaihto tapahtuu kahden salmen kautta Saarenmaan reunoilla. Leveämpi näistä salmista on etelään avautuva Irben salmi, jonka leveys on 27 kilometriä, poikkipinta-ala $0,37 \mathrm{~km}^{2}$ ja kynnyssyvyys 21 metriä. Koillisessa on matala Väinämeri (keskisyvyys alle 10 metriä), joka on yhteydessä useiden salmien kautta Riianlahden pääaltaaseen (Suursalmi Muhun ja Viron mantereen välissä) sekä Pohjoiseen Gotlannin altaaseen. Riianlahden maksimisyvyys on 51 metriä ja keskisyvyys 29 metriä. Sen rannat ovat paljolti hiekkaisia dyynejä ja ulompana on vain kaksi saarta, Ruhnu ja Kihnu. Riianlahti on viroksi Liivilaht, joka tarkoittaa hiekkaista lahtea.

\subsubsection{Suomenlahti}

Suomenlahti on Itämeren itäisin allas, jota rajoittavat Suomi, Viro ja Venäjä (kuva 4.5C). Tällä kapealla ja pitkänomaisella altaalla ei ole kynnystä Gotlannin merelle, mutta länsireunana on pidetty Pöösapea-Osmussaari-Hankoniemi -linjaa. Suomenlahti mataloituu itään päin. Syvimmät alueet (80-100 metriä) sijaitsevat lahden länsi- ja eteläosissa; suurin syvyys (Paldiskin syvänne) on 123 metriä. Viron rannikko on selväpiirteinen ja Narvaan asti melko syvä (40-80 metriä), kun taas Suomen rannikko on matala (20-40 metriä) ja saaristoinen. Suomenlahden itäpäässä on matalaa, sillä Seiskarin itäpuolella syvyys on alle 40 metriä ja aivan Nevan suulla vettä on enää alle 5 metriä. Kerrostumat pohjassa ovat jakautuneet mosaiikkimaisesti siten, että syvänteissä on savikkoja ja rinteillä sekä matalimmilla alueilla hietikkoja, moreeni- ja sorapohjia 
tai jopa kallioita. Suomenlahden perukka Virolahdelta Pietariin on laakeaa hiekkaja sorapohjaa.

Hankoniemen itäpuolelta Tammisaaresta työntyy pohjoiseen Pohjanpitäjänlahti. Se on noin 10 kilometriä pitkä ja suurimmalta syvyydeltään 42 metriä (kynnyssyvyys 6 metriä). Se on Suomen ainoa varsinainen vuono. Pohjanpitäjänlahti on pysyvästi kerrostunut; Mustionjoen tuoma makea vesi virtaa suolaisemman syvän veden kerroksen päällä. Syvä vesi uudistuu lähinnä syksyisin, joten kesällä Pohjanpitäjänlahden pohjassa on selvää happikatoa.

\subsubsection{Pohjanlahti}

Pohjanlahti on hydrografisesti rajattu alue, jonka ominaisuudet ovat melko lailla erilaiset kuin muun Itämeren, sillä se on kynnysten ja saariston vuoksi pitkälti eristyksissä (kuva 4.5D). Siihen lasketaan kuuluvaksi Saaristomeri, Ahvenanmeri, Selkämeri ja Perämeri. Selkämeren erottaa Ahvenanmerestä Ahvenanrauma, Saaristomerestä saariston ulkoreuna ja Perämerestä Merenkurkku. Ahvenanraumaa ja Merenkurkkua ei tässä lasketa itsenäisiksi merialtaiksi, vaan edellinen kuuluu Ahvenan-

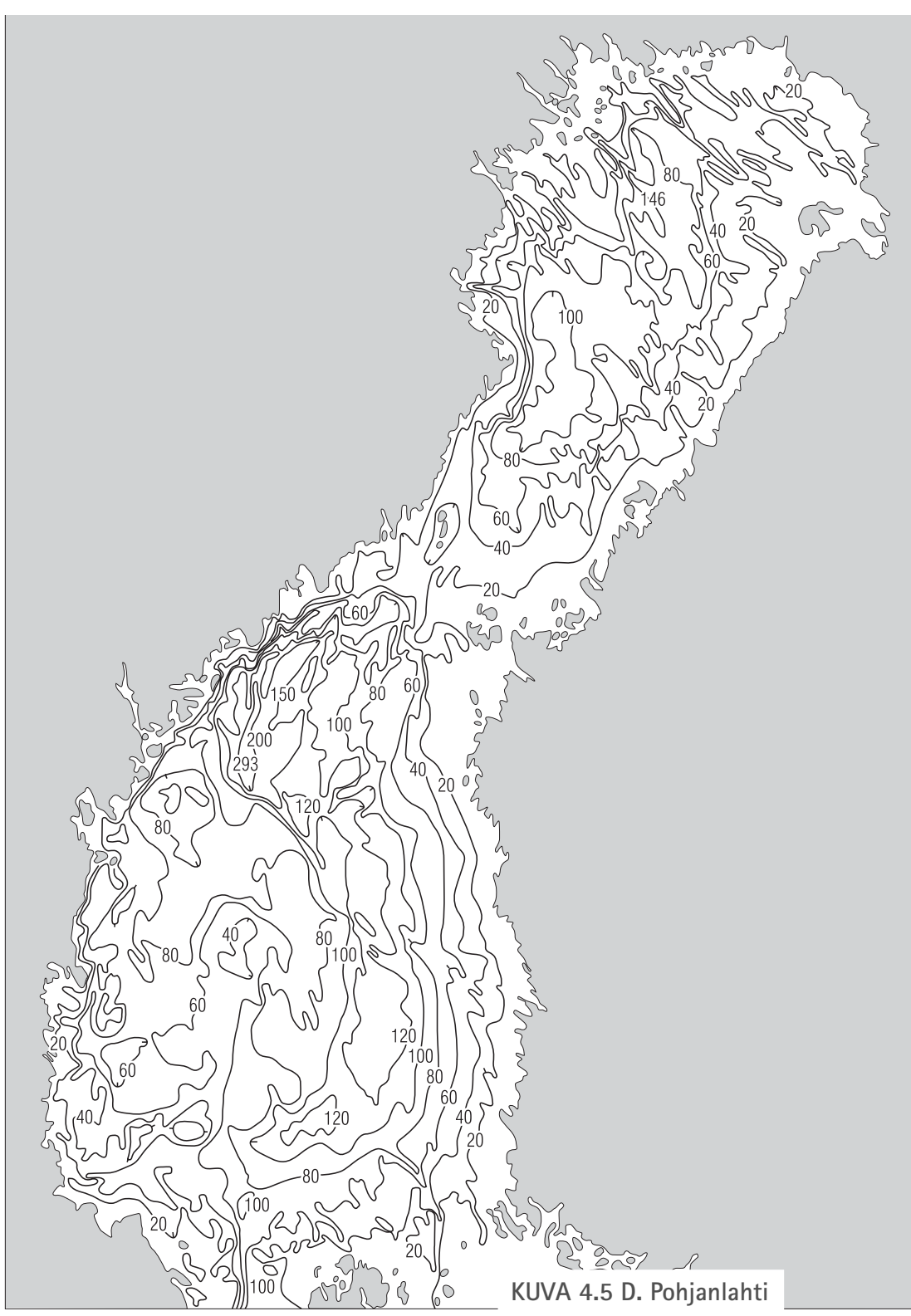

mereen ja Selkämereen ja jälkimmäinen Selkämereen ja Perämereen.

Ahvenanmeri koostuu kahdesta altaasta. Eteläisemmän maksimisyvvys on 220 metriä (Lågskärin syvänne), ja kynnyssyvyys Gotlannin merelle on 70 metriä hyvin kapeassa kanaalissa. Myös pohjoiseen altaaseen päin kynnyssyvyys on 70 metriä Söderarmin ja Lågskärin välistä. Ahvenanmeren ja samalla Suomen vesialueiden syvin kohta on 301 metriä, Eckerön ja Grisslehamnin välillä. Kyseistä syvännettä kutsutaan Ahvenansyvänteeksi [Ålandsdjup], josta useita noin 150 metriä syviä kanaaleja johtaa vettä Ahvenanrauman kautta Selkäme- 
relle, mutta etelässä oleva noin 70 metrin kynnys määrää tosiasiallisesti Selkämerelle pääsevän veden suolaisuuden. Eräissä lähteissä tälle kynnykselle annetaan myös 45 metrin syvyys, mutta 70 metriä on ilmeisesti oikea arvo. Ahvenanmeren ja Selkämeren rajalinjana on Söderön koillinen niemi-Ormö-Norrskär-Märkeskallan-MärketLångö-Eckerö.

Saaristomeri sijaitsee Ahvenanmeren ja Suomen mantereen välissä. Selkämerelle rajalinja on Saltvikin pohjoisin niemi-Landtö-Kauritsala-Lokalahti. Saaristomeri on matalikkoa. Siellä on tuhansia saaria ja sitä kutsutaankin "meren ja maan mosaiikiksi”. Kolme 30-40 metriä syvää kanaalia johtaa Saaristomeren läpi pohjoiseen ja vastaa osasta Selkämeren ja Gotlannin meren välistä vedenvaihtoa. Kynnyssyvyys Selkämeren suuntaan on 18 metriä. Pääkanava kulkee Kihdin selän kautta. Saaristomeren syvyys on alle 40 metriä, mikä rajoittaa Pohjoisen Gotlannin altaan syvän veden pääsyn Selkämerelle.

Selkämeren erottaa Perämerestä rajalinja: Iskmo-Raippaluoto-Björkö-Lappören-Valassaaret-Haddingin niemi. Se on itä-länsisuunnassa epäsymmetrinen siten, että Suomen puolella pohjan muoto on loiva, kun taasen Ruotsin puolella rannikko on jyrkkä ja pohjanmuoto epäsäännöllinen. Lisäksi Ruotsin rannikolla on pohjoisessa pienehköjä vuonoja. Tätä aluetta kutsutaan Korkearannikoksi [Höga Kusten]. Selkämeren eteläosa on matala ja topografia on vaihtelevaa. Laaja syvännealue ulotttuu eteläiseltä Selkämereltä aluksi itäkoilliseen Finngrundetin matalikon ohi, minkä jälkeen syvännealue jatkuu pohjoiseen, myöhemmin kääntyen länteen Ruotsin rannikkoa kohti. Syvin kohta, Ulvön syvänne (293 metriä), on lähellä Ruotsin rannikkoa. Keskellä Selkämerta on paleotsooisia kalkkikivialueita, jotka ovat muodostuneet noin 400 miljoonaa vuotta sitten. Näillä alueilla pohjan muoto on varsin tasainen.
Merenkurkku, joka yhdistää Selkämeren ja Perämeren, on melko matala (maksimisyvyys 65 metriä). Alueella on kaksi 25 metriä syvää kynnystä, Holmöarnin etelä- ja pohjoispuolella ja Suomen puolella on Vaasan laaja saaristoalue. Maantieteellisesti Merenkurkusta puhutaan usein omana alueenaan (eteläreuna: HörneforsVaasa, pohjoisreuna: Käringskär-Stubben). Meritieteessä Merenkurkku kuuluu sekä Selkämereen että Perämereen. Tämä on perusteltua, sillä kyseessä ei ole allas, jolla olisi omat hydrografiset olonsa, vaan salmi. Merenkurkun pohja-aines on soraa, hiekkaa ja kivikkoa. Karkeus johtuu siitä, että voimakkaat virtaukset huuhtovat hienomman aineksen pois.

Itämeren pohjoisin allas on Perämeri. Se on topografialtaan itä-länsisuunnassa epäsymmetrinen kuten Selkämeri. Alueella on kaksi painumaa, joista pohjoinen on pienempi. Pohjois-Perämerellä on laaja saaristoalue, jonka suurin saari on Hailuoto. Perämeri on suurelta osin melko matalaa ja sen keskisyvyys on vain 41 metriä. Suurin syvyys (146 metriä) on Luulajan kaakkoispuolella. Perämerellä rannikon läheisyydessä on hiekka- ja sorapohjaa. Molemmissa syvänteissä sen sijaan 40-60 metriä syvemmällä pohja on hiesua.

\subsection{Hydrografian peruspiirteet}

Hydrografia on varsin hankala käsite, koska sille ei ole olemassa täsmällistä määritelmää. Sillä tarkoitetaan yleisesti merten vesirungon fysikaalisten tilasuureiden ja kemiallisten ominaisuuksien kenttiä. Tässä kirjassa tutkitaan erityisesti fysikaalisia tilasuureita: suolaisuutta, lämpötilaa ja tiheyttä. Fysikaalisessa meritieteessä hydrografiaan sisällytetään myös eräitä kemiallisia ominaisuuksia lähinnä veden kiertokulun ja ekologisen yleistilanteen selittämisessä. Tällaisia ominaisuuksia ovat esimerkiksi happipitoisuus, sameus ja ravinteiden pitoisuudet. 


\subsubsection{Meriveden tilayhtälö}

Meriveden tiheys ( $\rho$ ) on fysikaalisen merentutkimuksen eräs keskeisimpiä suureita. Se on massan $(m)$ ja tilavuuden $(V)$ suhde

$\rho=\frac{m}{V}$

eli mitä pienemmässä tilavuudessa $V$ tietty vesimassa $m$ on, sitä suurempi on sen tiheys. Meriveden tilayhtälö antaa tiheyden muiden tilasuureiden funktiona ja se voidaan ilmaista yleisessä muodossa

$\rho=\rho(S, T, p)$

missä $S$ on suolaisuus, $T$ on lämpötila ja $p$ on paine. Nesteiden fysiikasta ei ole saatavissa teoreettisia menetelmiä tilayhtälön konstruoimiseksi. Toisin on kaasujen fysiikassa, jossa ideaalikaasun mallia voidaan soveltaa laajalti. Niinpä meriveden tilayhtälö on konstruoitu empiirisin menetelmin, ja siitä on laadittu kansainvälinen standardi (kaavaliite tämän luvun lopussa).

Merivesi on kemialliselta koostumukseltaan kaikkialla samanlaista, vain sen väkevyys vaihtelee. Tämä tarkoittaa sitä, että eri suolojen keskinäiset suhteet ovat vakiot. Sen takia tilayhtälössä riittää kokonaissuolaisuus. Tiheyden yksikkö on SI-järjestelmän mukaan $\mathrm{kg} / \mathrm{m}^{3}$. Suolaisuuden yksikkönä tässä käytetään promillea, ja lämpötilalle käytetään tavallisesti Celsius-asteita $\left({ }^{\circ} \mathrm{C}\right)$, joskus SI-yksiköiden mukaista Kelviniä (K).

Tilayhtälö kirjoitetaan muodossa

$\rho=\frac{\rho(S, T, 0)}{1-p / K(S, T, p)}$

missä $\rho(S, T, 0)$ on tiheys nollapaineessa ja $K(S, T, P)$ on kokoonpuristumiskerroin; molemmille on olemassa oma standardiyhtälönsä (UNESCO 1981). Meriveden kokoonpuristuminen on suuruusluokkaa $0,5 \cdot 10^{-4} \mathrm{bar}^{-1} ; 200$ metrin syvyydessä paine on noin 20 bar ja ko- koonpuristuminen on siis 0,1 prosenttia. Absoluuttisesti tämä on saman verran kuin yhden suolaisuuden promilleyksikön muutoksen vaikutus tiheyteen. Käytännön ongelmissa tiheyden paikalliset vertikaalimuutokset ovat ratkaisevia stabiliteetin kannalta ja Itämerellä paineen vaikutus ei vielä niissä tunnu. Sen sijaan (tilayhtälön epälineaarisuuden takia) valtamerten syvissä vesissä paineen paikallinen vaikutus on huomioitava.

Itämerellä kokoonpuristumista ei siis yleensä huomioida tiheyslaskuissa eli $K \rightarrow \infty$. Paineen vaikutus on suurimillaan Landsortin syvänteen 459 metrissä: tiheys kasvaa noin 0,2 prosenttia, kun vesipartikkeli viedän pinnasta pohjaan. Syvänteen vesipatsas on kokonaisuudessaan puristunut noin 0,5 metriä veden kokoonpuristuvuuden takia.

Meriveden tiheys on Itämeressä tyypillisesti $1.000-1.010 \mathrm{~kg} / \mathrm{m}^{3}$. Valtamerissä pintaveden tiheys on $1.025 \mathrm{~kg} / \mathrm{m}^{3}$, kun $T=0-10{ }^{\circ} \mathrm{C}, S=35$ promillea ja $p=p_{0}$ missä $p_{0}$ on ilmanpaine.

Meriveden tiheyden pystysuuntaisessa jakaumassa tulee esille toisenlainen paineen vaikutus: adiabaattinen muutos. Tällä tarkoitetaan tilannetta, jossa vesipartikkeli ei ole lämmön vaihdossa ympäristönsä kanssa, mutta sen lämpötila muuttuu ympäröivän paineen muuttuessa. Kun vesipartikkeli nousee ylöspäin meressä, ympäröivän veden hydrostaattinen paine pienenee, jolloin vastaavasti tiheys pienenee, ja vesipartikkelin laajenemiseen tarvittava työ kuluttaa sen sisäistä energiaa. Näin vesipartikkelin lämpötila laskee. Vastaavasti vesipartikkelin mennessä syvemmälle sen tiheys ja lämpötila kasvavat, kun ympäröivä vesi tekee siihen työtä. Tätä lämpötilan muutosta kutsutaan adiabaattiseksi muutokseksi ja sillä on merkitystä vesirungon stabiliteettia tarkasteltaessa.

Potentiaalilämpötila tarkoittaa lämpötilaa, joka vesipartikkelilla on, kun se tuodaan adiabaattisesti pintaan sen suolaisuutta muuttamatta. Potentiaalitiheys on potentiaalilämpötilan 


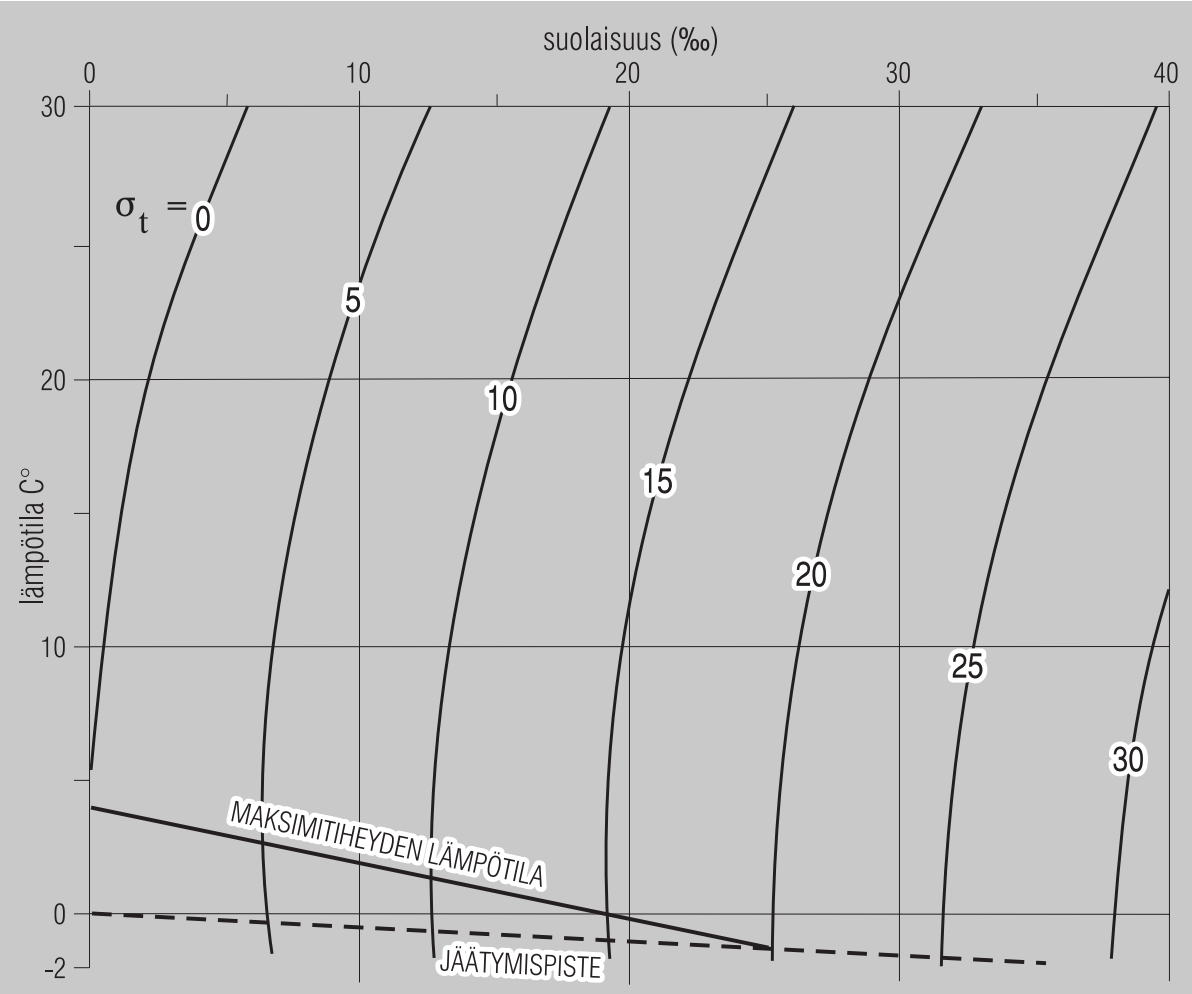

Kuva 4.6. Meriveden tiheys, jäätymispiste ja maksimitiheyden lämpötila (piirretty Pickardin ja Emeryn (1990) kuvasta). Tiheys $\left(\mathrm{kg} / \mathrm{m}^{3}\right)$ on $1000+\sigma_{\mathrm{T}^{*}}$

määräämä tiheys. Adiabaattisen lämpötilamuutoksen suuruus $\Gamma$ on noin $0,003{ }^{\circ} \mathrm{C} /$ bar $(\approx 0,03$ $\left.{ }^{\circ} \mathrm{C} / 100 \mathrm{~m}\right)$. Sen vaikutuksesta Itämerellä vesipartikkeli jäähtyy $0,03^{\circ} \mathrm{C}$, kun se tuodaan 100 metrin syvyydeltä pintaan.

Itämerellä vesi on kerrostunutta. Kerrostuneisuusolot voivat kuitenkin olla varsin erilaisia riippuen vesimassan stabiliteetista, joka riippuu veden tiheyden pystyjakaumasta. Käytännössä kerrostuneisuus on aina stabiili tai neutraali. Stabiilissa tilanteessa kevyempi vesi on raskaamman päällä, ja neutraalissa tilanteessa potentiaalitiheys on syvyyden suhteen vakio. Jos pintaveden tiheys kasvaa, se pyrkii vajoamaan ja kevyt vesi nousee ylöspäin. Näin estyy epästabiilin tiheysjakauman muodostuminen. Veden pystysuuntainen sekoittuminen jatkuu, kunnes kerrostuneisuus on muuttunut stabiiliksi tai neutraaliksi. Stabili- teetille $E$ voidaan esittää matemaattinen määritelmä muodossa

$E=-\frac{1}{\rho}\left[\frac{\partial \rho}{\partial S} \frac{\partial S}{\partial z}+\frac{\partial \rho}{\partial T}\left(\frac{\partial T}{\partial z}+\Gamma\right)\right]$

Tarkasteltava vesimassa on stabiili, jos $E>0$, neutraali, jos $E=0$, ja epästabiili, jos $E<0$. Jos suolaisuus on vakio, neutraalisti kerrostuneessa meressä lämpötila kasvaa syvemmälle mennessä adiabaattisen muutoksen verran.

\subsubsection{Meriveden maksimitiheys ja jäätymispiste}

Veden tiheys pienenee veden lämmetessä, kun lämpötila on suurempi kuin maksimitiheyden 


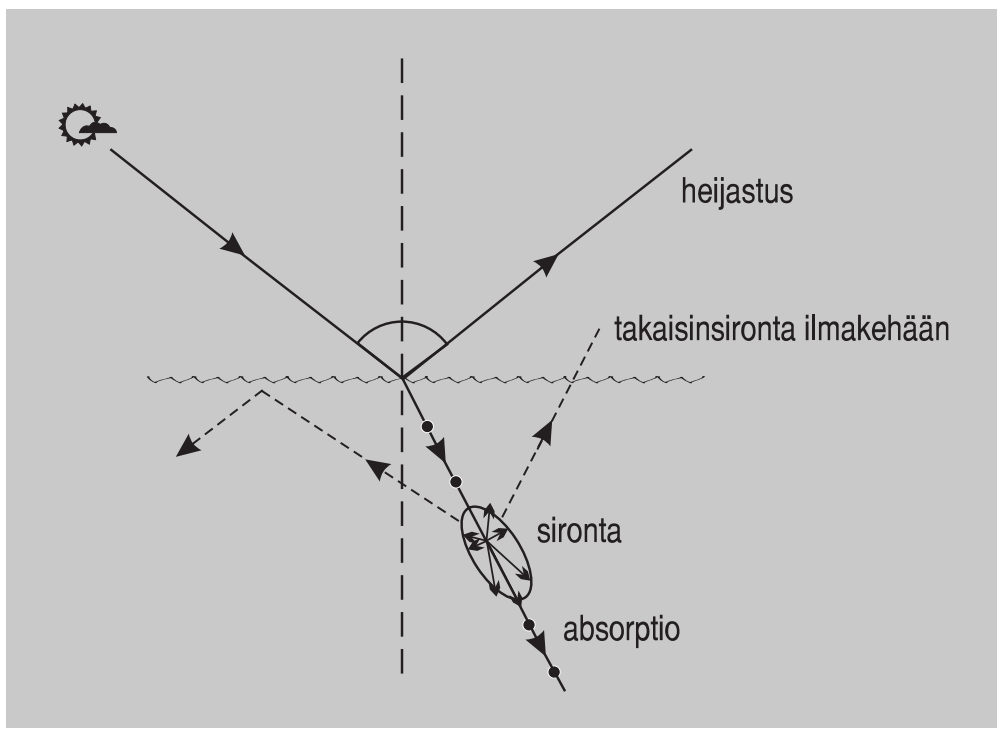

Kuva 4.7. Skemaattinen kuva auringon säteilyn heijastuksesta, absorptiosta ja sironnasta vesirungossa.

lämpötila $T_{m}$. Kun lämpötila laskee $T_{m}:$ n alapuolelle, tiheys pienenee veden edelleen jäähtyessä (kuva 4.6). Sen sijaan suolaisuuden ja paineen kasvaessa tiheys kasvaa aina. Pintaveden suolaisuutta pienentää mereen tuleva makea vesi, ja sitä puolestaan kasvattavat haihtuminen ja veden jäätyminen. Meriveden jäätyessä veden suolaisuus kasvaa, koska jään kasvu hylkii suolaa. Kun pintaveden tiheys kasvaa alla olevan veden tiheyttä suuremmaksi, seuraa veden vapaa pystysuuntainen sekoittuminen eli konvektio. Vesi vajoaa alaspäin, kunnes vallitseva tiheys vastaa sen omaa tiheyttä. Tällaista lämpötila- ja suolaisuusvaihteluista aiheutuvaa prosessia kutsutaan termohaliiniseksi konvektioksi.

Suolaisuus vaikuttaa meriveden jäätymispisteeseen $T_{\mathrm{f}}$ ja maksimitiheyden lämpötilaan $T_{\mathrm{m}}$ siten, että suolaisuuden kasvaessa nämä alenevat likimain lineaarisesti (kuva 4.6):

$$
\begin{aligned}
& T_{f}=-0,055 \cdot 10^{3} \mathrm{~S} \\
& T_{m}=3,98-0,216 \cdot 10^{3} \mathrm{~S}
\end{aligned}
$$

Itämerellä pintaveden suolaisuus vaihtelee laajasti (0-10 promillea), ja sen takia myös jäätymispiste vaihtelee suuresti $\left(-0,55-0{ }^{\circ} \mathrm{C}\right)$. Valtamerillä jäätymispiste on $-1,5$ ja $-2{ }^{\circ} \mathrm{C}$ välillä. Jäätymispisteeseen on olemassa myös tarkempi standardi kaava (tämän luvun kaavaliite), mutta Itämeren tutkimuksissa yllä oleva lineaarinen yhtälö tavallisesti riittää.

Makean veden maksimitiheyden lämpötila on 3,98 ${ }^{\circ} \mathrm{C}$. Suolaisuuden kasvaessa maksimitiheyden lämpötila alenee. Tämä aleneminen on nopeampaa kuin jäätymispisteen tapauksessa, ja ennen pitkää maksimitiheyden lämpötila painuu jäätymispisteen alapuolelle. Sellaista vesimassaa, jonka maksimitiheyden lämpötila on korkeampi kuin sen jäätymislämpötila, kutsutaan murtovedeksi. Suolaisuus on silloin pienempi kuin 24,7 promillea. Kun suolaisuus on riittävän alhainen $(S<0,1$ promillea), sillä ei ole käytännön merkitystä tiheyden kannalta ja vesi kelpaa talousvedeksi.

Itämerellä maksimitiheyden lämpötila on aina yli nolla astetta. Esimerkiksi 10 promillen suolaisuudessa maksimitiheyden lämpötila on noin 2 
${ }^{\circ} \mathrm{C}$. Syksyllä Itämeren vesi alkaa jäähtyä pinnalta käsin. Jäähtyvä vesi muuttuu raskaammaksi ja vajoaa alaspäin niin kauan, kunnes se kohtaa vettä, jolla on sen kanssa sama tiheys. Itämerellä suolaisuus on syvällä suurempi kuin pintakerroksessa, ja konvektiivinen sekoittuminen ei sen takia syksyllä ja talvella ulotu pohjaan asti. Jos suolaisuusero on suurempi kuin 0,5 promillea pintaveden ja syvemmällä olevan veden välillä (kuten Itämerellä miltei aina on), niin lämpötilamuutoksiin liittyvät tiheysmuutokset ovat suolaisuuden aiheuttamia pienempiä.

Kun pintavesi edelleen jäähtyy, niin vähitellen sen lämpötila alittaa maksimitiheyden lämpötilan. Tällöin vesi muuttuu aiempaa kevyemmäksi, eikä se enää sekoitu allaolevien vesimassojen kanssa. Siksi jäähtyminen tapahtuu ohuessa pintakerroksessa jäätymispistettä lähestyttäessä, ja vesi jäätyy vaikkei koko tasasuolaisen kerroksen lämpötila olisi saavuttanut jäätymispistettä. Prosessi on samankaltainen kuin järvillämme syksyisen täyskierron jälkeen, mutta Itämeressä kierto rajoittuu tasasuolaiseen kerrokseen.

Valtamerten veden maksimitiheyden lämpötila on huomattavasti jäätymispisteen alapuolella, eikä sitä koskaan käytännössä saavuteta, toisin sanoen vesi jäätyy sitä ennen. Tasasuolaisen kerroksen pystysuuntainen sekoittuminen jatkuu jäätymiseen asti, joten jään muodostus vaatii, että koko tämä vesipatsas on saavuttanut jäätymispisteen lämpötilan. Tämä tarkoittaa sitä, että tietyn tilavuuksisen valtamerivesimassan on luovutettava huomattavasti enemmän energiaa ilmakehään kuin vastaavan murtoveden, jotta jäätyminen alkaisi. Weddellin, Grönlannin ja Rossin merillä vesi on tasasuolaista, ja konvektio ulottuu talvella pohjaan asti.

Itämeren jäätymisessä suolaisuudella on vain sekundäärinen merkitys. Jäätymispiste on hieman nollan alapuolella, ja pintakerros sekoittuu maksimitiheyden lämpötilaan, joka on hieman alempi kuin järvissä. Pääasiallisena jäätymisen syynä on alueen kylmä ilmasto ja siihen nähden Itämeren lämpövaraston hidas uusiutuminen.

\subsubsection{Veden väri ja sameus}

Meriveden väristä ja sameudesta puhuttaessa tarkoitetaan perimmältään veden vuorovaikutusta auringonsäteilyn kanssa. Auringonsäteilyssä on mukana kaikkia aallonpituuksia, mutta vesi läpäisee käytännössä vain ultraviolettia säteilyä ja näkyvää valoa (380-760 nm). Säteilyn vapaata etenemistä estävät (i) absorptio eli säteilyn imeytyminen veteen ja muuttuminen lämmöksi sekä kemialliseksi energiaksi ja (ii) sironta eli säteilyn hajaantuminen eri suuntiin (kuva 4.7). Luonnonvesien optisiin ominaisuuksiin vaikuttavat vesi itse sekä vedessä olevat optisesti aktiiviset aineet, ja aine-säteily vuorovaikutus riippuu säteilyn aallonpituudesta. Näin ollen säteilyn absorptio- ja sirontaspektrit kertovat veden ominaisuuksista. Lisäksi auringonsäteilyn tunkeutumissyvyys kertoo, kuinka syvälle auringon tuoma lämpöenergia jakautuu ja kuinka syvälle biologinen perustuotanto voi ulottua.

Auringonsäteilyä kuvataan irradianssina, joka kertoo tason pinta-alayksikölle lankeavan säteilyn ylä- tai alapuolisesta puoliavaruudesta. Tuleva säteily ilmaistaan yläpuolelta tulevana irradianssina $E_{d}=E_{d}(z ; \lambda)$, missä $\lambda$ on aallonpituus, ja takaisinpalautuva osa on taas alapuolelta tuleva irradianssi $E_{u}=E_{u}(z ; \lambda)$. Näiden suhde

$r(z ; \lambda)=\frac{E_{u}(z, \lambda)}{E_{d}(z, \lambda)}$

on reflektanssi. Kun tuleva ja lähtevä irradianssi integroidaan aallonpituuden suhteen, saadaan tuleva ja lähtevä kokonaissäteily $Q_{s}(z)$ ja $Q_{\mathrm{r}}(z)$. Näiden suhde meren pinnassa on albedo, $\alpha=$ $Q_{\mathrm{r}}(z) / Q_{\mathrm{s}}(z)$.

Irradianssin yksikkönä on $\mathrm{W} /\left(\mathrm{m}^{2} \mathrm{~nm}\right)$, teho pinta-alayksikköä ja aallonpituusyksikköä kohti. Ekologisessa tutkimuksessa säteilyn määrä ilmaistaan valokvantteina, $\mu \mathrm{mol} /\left(\mathrm{m}^{2} \mathrm{~s}\right)$, jonka spektrijakautuma on 

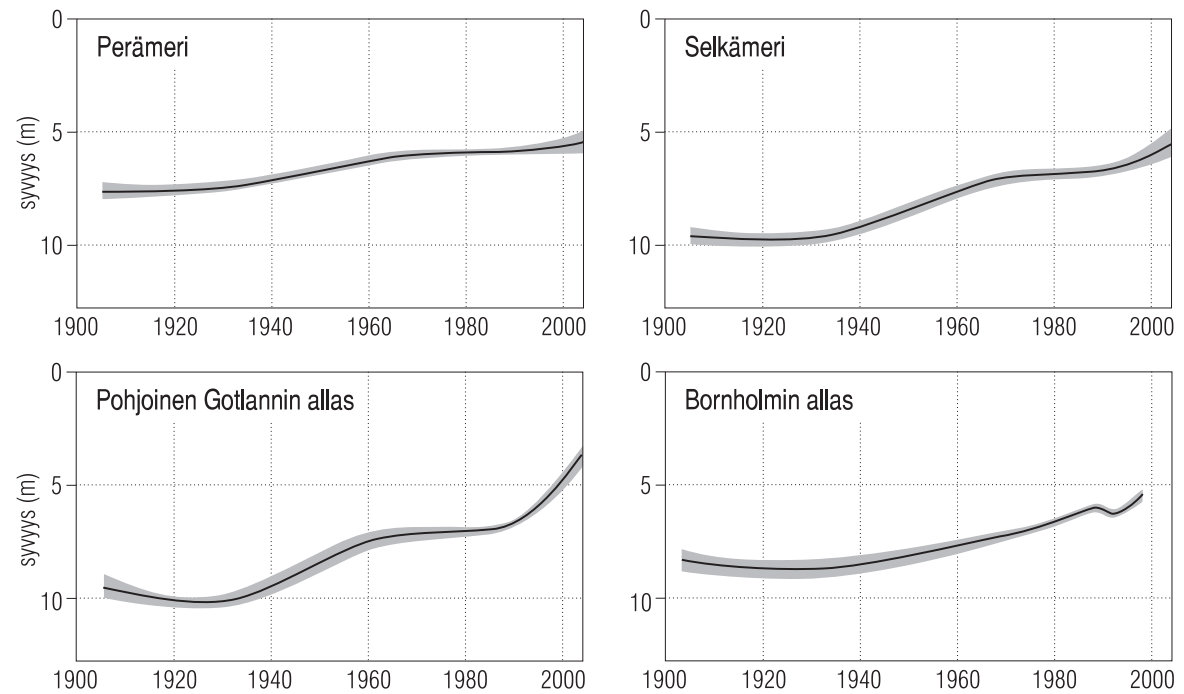

Kuva 4.8. Näkösyvyys Perämerellä, Selkämerellä, Pohjoisella Gotlannin altaalla ja Bornholmin altaalla 1900-2000. (Merentutkimuslaitos)

$q(z ; \lambda)=\frac{\lambda}{h c_{o}} E(z ; \lambda)$

missä $h=6,6255 \cdot 10^{-34} \mathrm{Js}$ on Planckin vakio ja $c_{\mathrm{o}}=2,9979 \cdot 10^{8} \mathrm{~m} / \mathrm{s}$ on valon nopeus tyhjiössä; 1 $\propto \mathrm{mol}=6,022 \cdot 10^{17}$ kvanttia.

Tyynestä pinnasta heijastuminen noudattaa Fresnelin peiliheijastuslakia, jonka mukaan säteilyn tulokulma ja lähtökulma ovat yhtä suuret. Peiliheijastuminen on riippumaton valon aallonpituudesta, mutta se riippuu säteilyn tulokulmasta. Kun auringon korkeuskulma on yli $20^{\circ}$, suoran säteilyn heijastuminen on aina alle $5 \%$. Matalilla korkeuskulmilla suoran säteilyn heijastavuus kasvaa nopeasti, mutta toisaalta silloin hajasäteilyn määrä kasvaa, ja kokonaisheijastuvuus jää tasolle 6,6 \%. Aaltoilevasta vesipinnasta tapahtuu eri suuntiin peiliheijastuksia, jotka summautuvat diffuusiksi heijastumiseksi.

Valonsäde taittuu rajapinnassa Snellin lain mukaisesti: $n \sin j=\sin i$,

missä $n$ on taitekerroin, $i$ on tulokulma, ja $j$ on taittuneen säteen lähtökulma. Ilma/vesi rajapinnan taitekerroin on noin 1,33. Takaisinsironta vesirungon sisältä kohtaa alhaaltapäin vesi/ilma rajapinnan, jossa tapahtuu taas heijastumista ja läpityöntymistä. Tämän rajapinnan taitekerroin on $1 / n$, ja tulokulman on oltava pienempi kuin $48,5^{\circ}$, jotta lähtökulman sini olisi korkeintaan yksi ja siten läpityöntymistä voisi päästä tapahtumaan. Jos tulokulma on suurempi, tapahtuu kokonaisheijastus. Vesi/ilma rajapinnan peiliheijastavuus on siksi alhaaltapäin noin $50 \%$. Takaisin vesirungosta lähtevän säteilyn spektri riippuu veden ja siinä olevien optisesti aktiivisten aineiden ominaisuuksista, minkä takia ylhäältä päin tarkasteleva ihmissilmä tai satelliitti näkee erilaisia värisävyjä. Sisältä tuleva säteily on suuruusluokkaa $10 \%$ pinnan peiliheijastuksesta ja tulee noin puolen näkösyvyyden paksuisesta kerroksesta. 

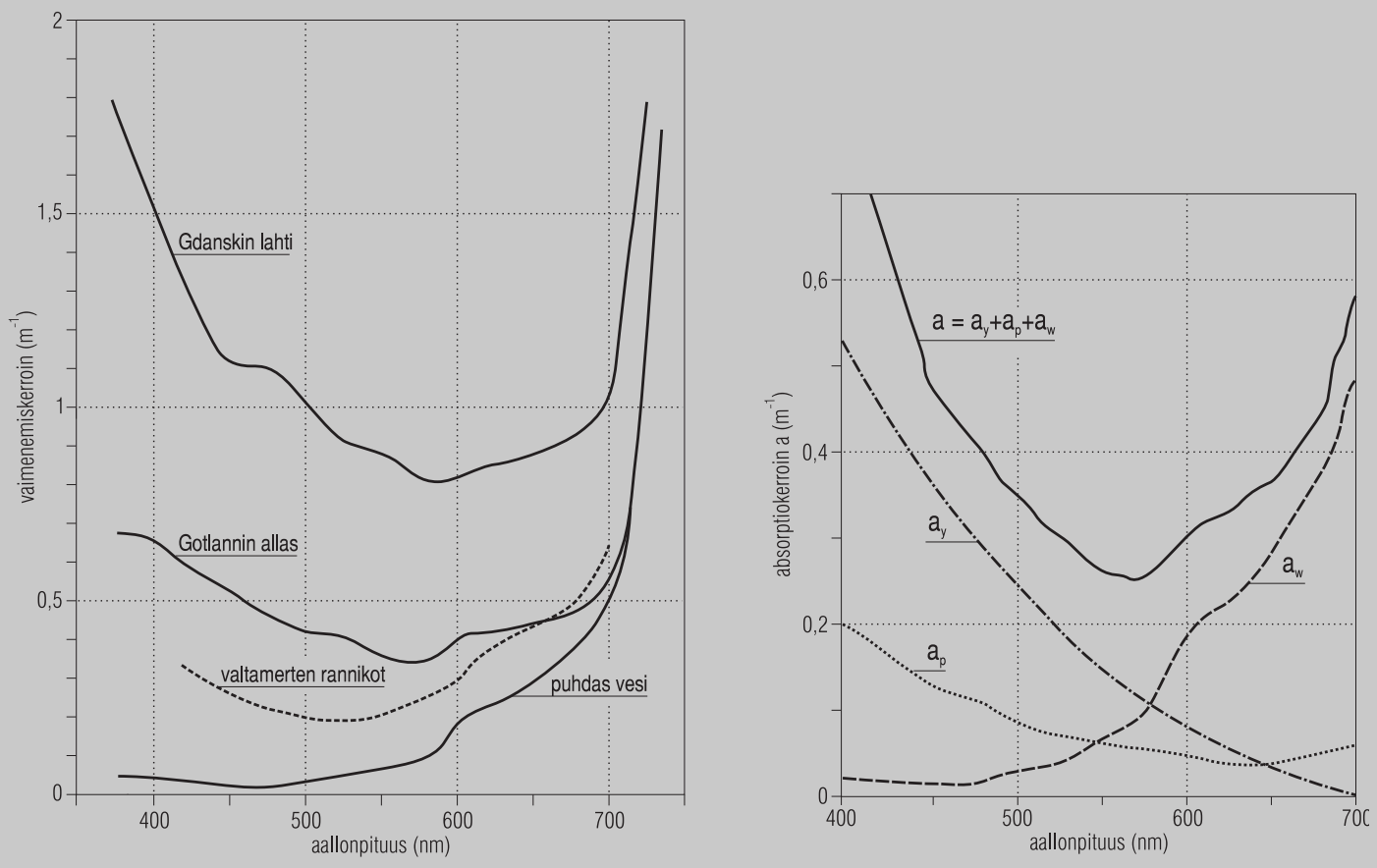

Kuva 4.9. Vasen kuva: Valon vaimenemisspektrit Gdanskin lahdella ja Gotlannin meressä sekä niiden vertailu normaalien rannikkomerien veden ja puhtaan veden vaimenemisspektriin. Oikea kuva: Valon absorption jakaantuminen puhtaan veden $\left(a_{w}\right)$, kelta-aineen $\left(a_{y}\right)$ ja kiintoaineen $\left(a_{p}\right)$ osuuksiin Itämeren rannikkovesissä. (Piirretty Deran [1992] mukaan.)

Luonnonvesien tärkeimmät absorboivat elementit ovat (i) vesi itse (tärkein, erityisesti punaisella ja infrapuna-alueella), (ii) kelta-aines (liuenneita orgaanisia aineita), (iii) klorofylli, ja (iv) kiintoaines. Kelta-aines on saanut nimensä optiikasta. Se sisältää erilaisia orgaanisia aineksia, jotka absorboivat erityisesti lyhyitä aaltoja. Tämän takia valon spektrin huippu siirtyy pidempiin aallonpituuksiin, eli veden väri kellertyy, kun kelta-aineksen määrä kasvaa. Myös kiintoaines absorboi yleensä enemmän lyhytaaltoisella alueella. Klorofyllin absorptio on aallonpituuden suhteen hyvin selektiivistä: maksimit ovat kaistoilla 430-440 nm ja 660-690 nm. Sironta aiheutuu veden tiheyden fluktuaatioista sekä kiintoainespartikkeleista, joiden aiheuttama sironta riippuu niiden koosta. Alle mikrometrin kokoiset partikkelit sirottavat voimakkaimmin lyhyitä aaltoja, kun taas suuremmilla partikkeleilla aallonpituusriippuvuus on heikompi.

Absorptio ja sironta aiheuttavat sen, että säteily vaimenee syvyyden mukana. Puhtaassa vedessä auringonsäteily pystyy tunkeutumaan noin 100 metrin syvyyteen, kun taas sameissa rannikkovesissä tunkeutumissyvyys on vain muutamia metrejä. Näkösyvyys määritellään syvyydeksi, johon asti Secchi-levy näkyy, ja eufoottinen syvyys määritellään syvyydeksi, jossa auringonsäteilyn taso on $1 \%$ pintaan tulevasta nettosäteilystä. Eufoottinen syvyys on noin 1,5 kertaa näkösyvyys. Itämerellä on tehty Secchi-levyhavaintoja jo noin sadan vuoden ajan, ja niistä on selvästi nähtävissä veden sameneminen 1900-luvun aikana (kuva 4.8). 
Asema BY15, 14.1.2003, 17.55 (UTC) suolaisuus $(\% 0), \sigma_{\mathrm{T}}\left(\mathrm{kg} / \mathrm{m}^{3}\right)$

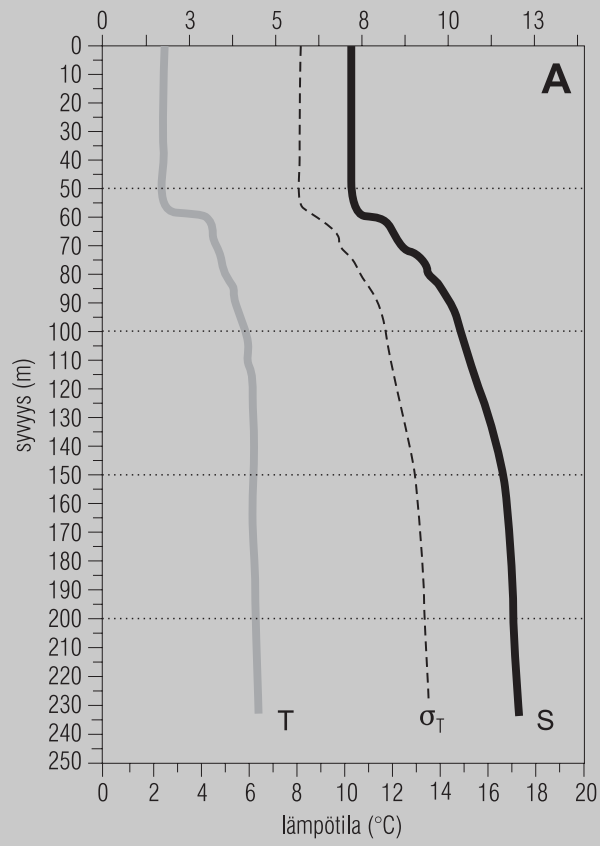

Asema BY15, 22.8.2003, 05.40 (UTC)

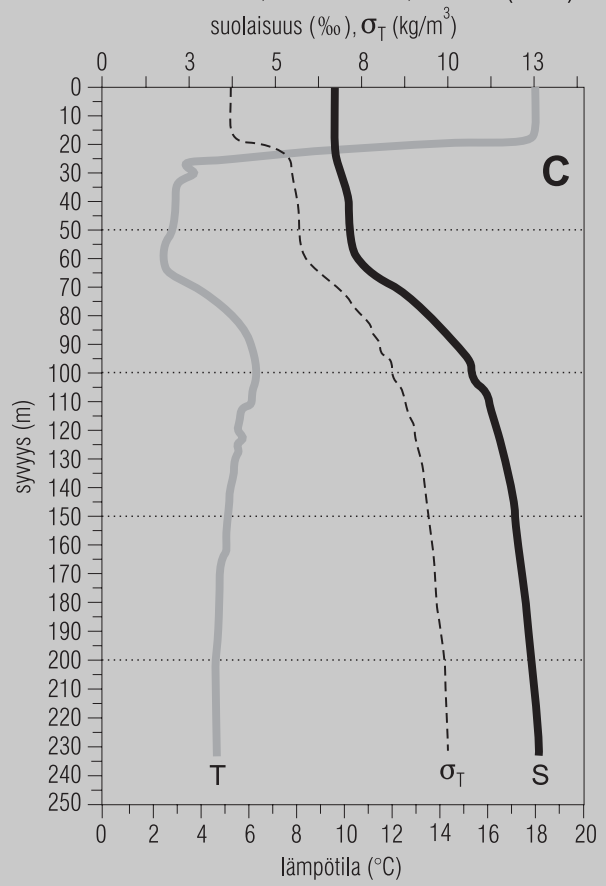

Asema BY15, 28.5.2003, 13.45 (UTC) suolaisuus $(\% 0), \sigma_{\top}\left(\mathrm{kg} / \mathrm{m}^{3}\right)$

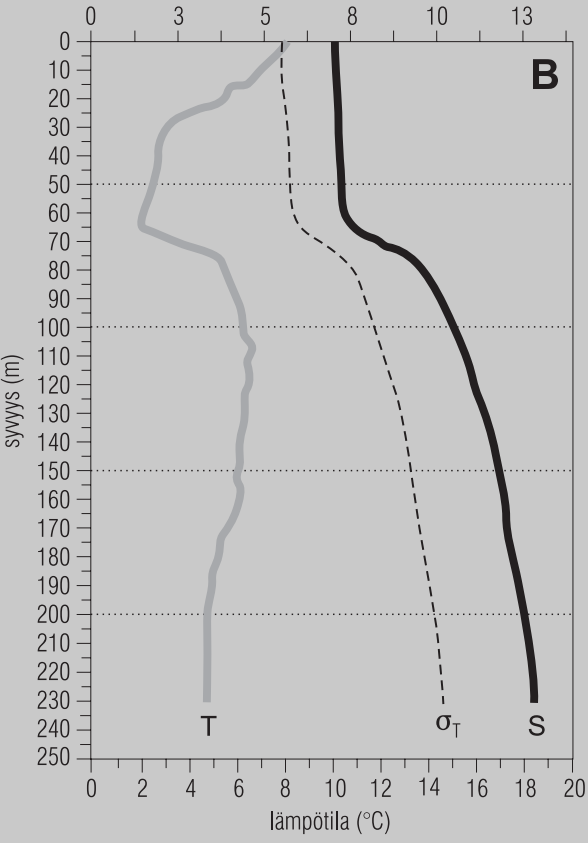

Asema BY15, 26.10.2003, 18.30 (UTC) suolaisuus $(\%), \sigma_{\mathrm{T}}\left(\mathrm{kg} / \mathrm{m}^{3}\right)$

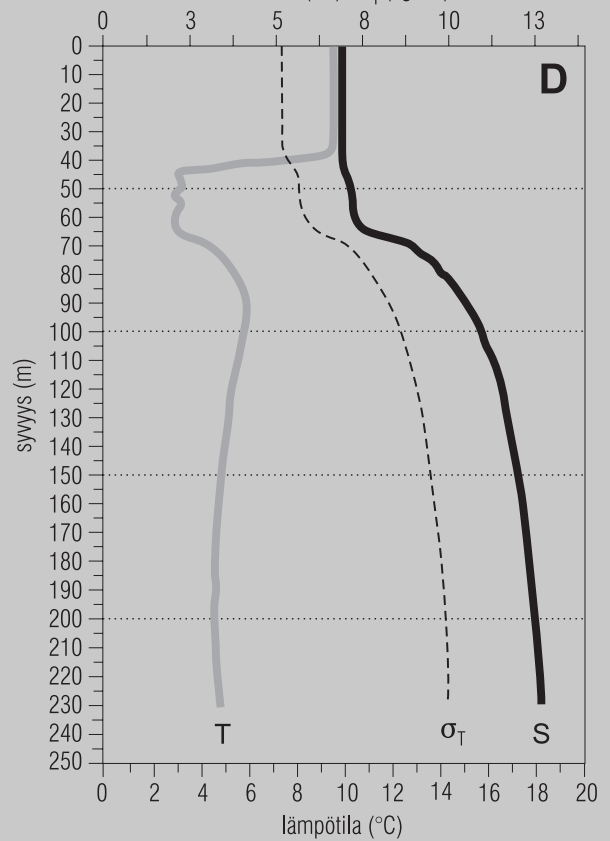

Kuva 4.10. Tyypilliset lämpötilan, suolaisuuden ja $\sigma_{T}:$ profiilit $\left(\sigma_{T}=\right.$ tiheys $\left.-1000 \mathrm{~kg} / \mathrm{m}^{3}\right)$ Gotlannin altaalla mittauspisteesä BY15 (lähde: Merentutkimuslaitos). A) Talvi. B) Kevät. C) Kesä. D) Syksy. 


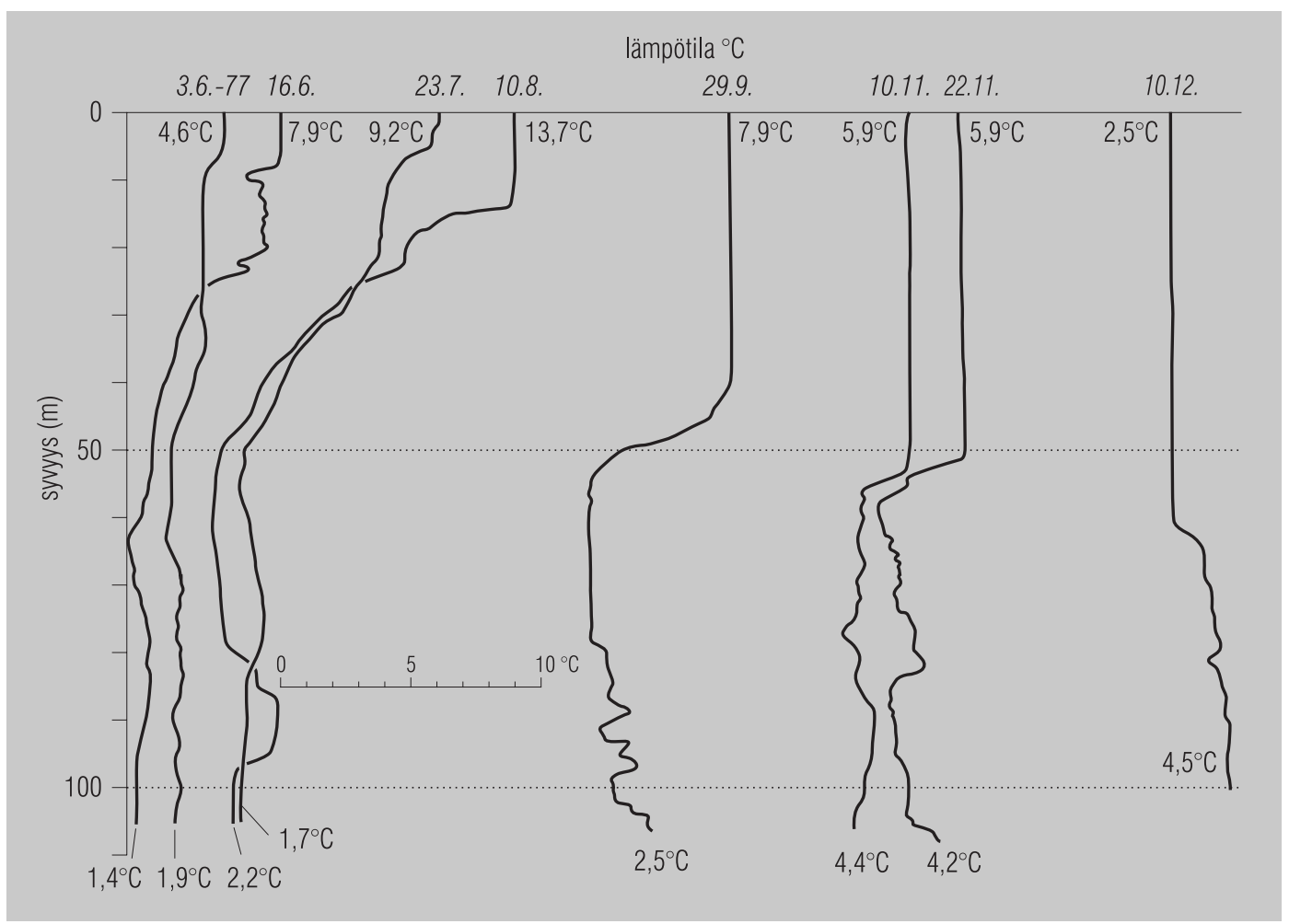

Kuva 4.11. Lämpötilan vertikaaliprofiilin vuodensisäinen kehitys Selkämerellä vuonna 1977. (Piirretty Aleniuksen [1978] mukaan.)

Säteilyn vaimenemista vedessä kuvataan Beerin lailla

$\frac{d E}{d z}=-c E$

missä $c=c(\lambda)$ vaimenemiskerroin. Jos $c$ ei riipu syvyydestä, ratkaisu antaa eksponentiaalisen vaimenemisen $E(z ; \lambda)=E(0 ; \lambda) \exp \{-c(\lambda) z\}$. Valaistuksen vaimenemista kuvataan myös valon kokonaismäärän $Q_{\mathrm{v}}=\int_{V} E(z ; \lambda) \mathrm{d} \lambda, V=(380 \mathrm{~nm}$, $760 \mathrm{~nm})$, avulla. Käytetään aallonpituudesta riippumatonta efektiivistä vaimenemiskerrointa $A$ siten, että $Q_{\mathrm{v}}(z)=Q_{\mathrm{v}}(0) \exp (-A z)$, jolloin siis syvyydellä $z=1 / A$ on valon kokonaisenergia vaimentunut osaan 1/e pinta-arvosta. Empiirisenä tuloksena on saatu, että näkösyvyys $\approx 2 / A$.

Merten optisessa luokittelussa Itämeri kuuluu Jerlovin tyyppiin III, sameat rannikkome- ret (kuva 4.9). Näiden optista tutkimusta vaikeuttaa runsas kelta-aineksen ja kiintoaineksen määrä, jolloin optisen takaisinsironnan inversio meriveden ominaisuuksiin ei aina ole yksikäsitteinen. Runsas kelta-aines absorboi valon lyhyitä aallonpituuksia, ja siksi veden väri - siitä takaisinsiroavan valon väri - on siirtynyt Itämeressä sinisestä keltaiseen suuntaan. Kiintoaineksen absoprtiospektri on sen sijaan melko tasainen aallonpituuden suhteen, mikä harmaannuttaa Itämeren väriä.

Voimakkaan perustuotannon aikana klorofylli absorboi valosta sinisen ja punaisen värin aallonpituuksia, jolloin merestä takaisinsiroavassa valossa alkaa vihreä dominoida. Muista pigmenteistä johtuen vesi voi olla ruskeaa tai jopa punaista ajoittain. 


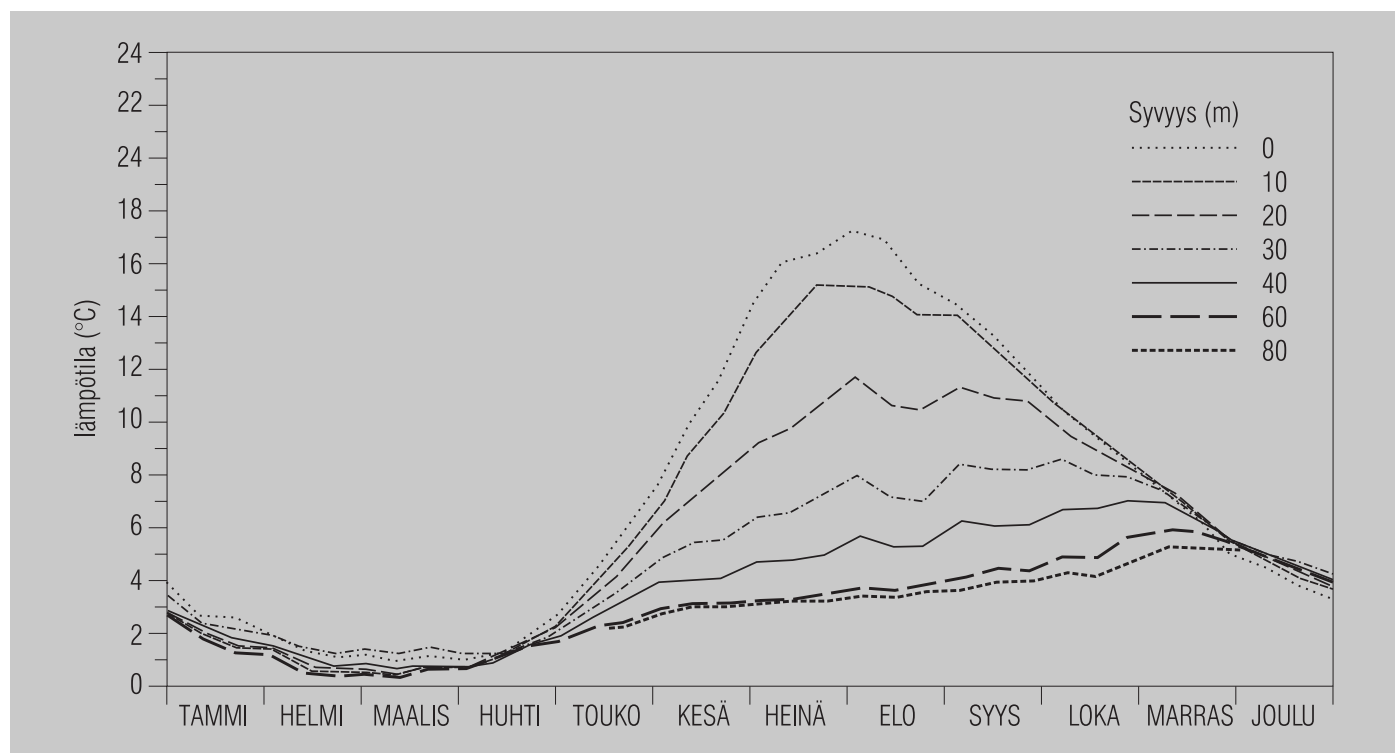

Kuva 4.12. Lämpötilan keskimääräinen vuosittainen kulku Utössä eri syvyyksillä. (Piirretty Launiaisen [1982] mukaan.)

\subsection{Itämeren vesirunko}

\subsection{Vesimassat ja veden kerrostuneisuus, halokliini ja termoklini}

Edellä on esitelty meriveden tilayhtälö ja siihen liittyviä peruskäsitteitä. Nyt siirrytään Itämeren hydrografian tarkasteluun. Keskeisin elementti on veden kerrostuneisuus ja siihen liittyvät hydrografian muutosvyöhykkeet.

Merten vesimassasta erotetaan vesityyppejä lämpötilan ja suolaisuuden perusteella. Esimerkiksi Pohjois-Atlantilla erottuu suolainen ja lämmin Välimeren vesi. Vesityypit karakterisoivat eri vesimassoja ja auttavat jäljittämään merten kiertoliikettä. Lämpötila ja suolaisuus ovat niin sanottuja konservatiivisia suureita. Niiden kokonaismäärä (tai keskiarvo) voi muuttua ainoastaan reunojen kautta, kun taas vesirungon sisällä tapahtuu vain lämpötilan ja suolaisuuden kuljetusta ja sekoittumista. Vesimassojen kulkeutuessa virtausten mukana ja kohdatessa toisensa, raskaampi vesimassa painuu kevyemmän alle. Itämerellä suolaisuus pitkälti määrittää vesityypit. Pohjanmereltä tulevat vesimassat Tanskan salmista yhä etääntyessään vajoavat syvempään ja muodostavat seuraavien altaiden syviä vesiä.

Konvektion ja tuulen aiheuttaman sekoittumisen vaikutuksesta vesirunkoon muodostuu homogeenisia vesimassoja, kerroksia, joissa tiheys on vakio. Kerrosten välissä on tiheyseroja. Mitä suurempi tiheysero rajapinnan eri puolilla on, sitä pienempää on sekoittuminen rajapinnan läpi. Itämeren vesirungossa erotetaan pintakerros, peitekerros ja alusvesi. Pintakerros on ylin tasalämpöinen kerros, ja peitekerros on ylin tasasuolainen kerros, johon pintakerros kuuluu. Alusvesi on peitekerroksen alapuolella oleva vesi. Näitä käsitellään tarkemmin kohdassa 4.4.3.

Rajakerrosta kahden eri vesimassan välillä kutsutaan harppauskerrokseksi eli kliiniksi. Termi kliini [cline] tarkoittaa "kaltevaa", sillä profiilikuvat ovat yleensä muuten suoria, mutta kliinien kohdilla kaltevia. Tälläisessa kerroksessa tiheys muuttuu voimakkaasti muutamien metrien matkalla eli muutos on luonteeltaan hypähdyksellistä. Lämpötilan harppauskerrosta kutsutaan termokliiniksi, suolaisuuden halokliiniksi ja tiheyden pyknokliiniksi. Nimi halokliini johtuu 

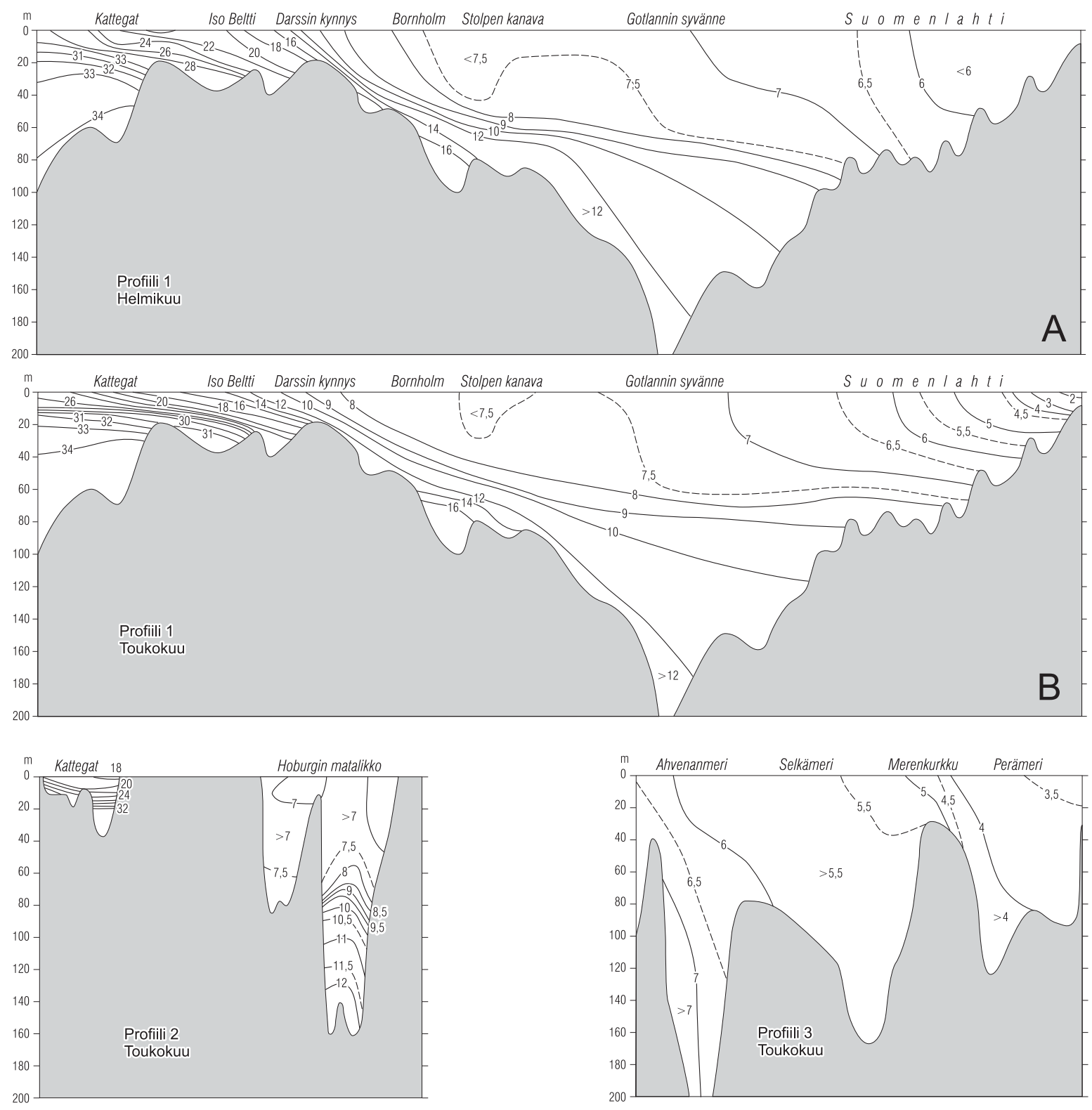

Kuva 4.13. Itämeren vesirungon suolaisuuden (\%) rakenne eri vuodenaikoina poikkileikkauksilla Kattegat-Suomenlahti keskilinjaa pitkin, Kattegat-Itäinen Gotlannin allas länsi-itä -suunnassa ja Pohjanlahti. A) Helmikuu, B) Toukokuu, C) Elokuu, D) Marraskuu. Helmikuussa on jääoloista johtuen ainoastaan Kattegat-Suomenlahti -poikkileikkaus. (Piirretty Bockin [1971] mukaan.)

siitä, että aiemmin veden suolaisuus määritettiin titraamalla kloriniteetti vedestä, josta tuloksena saatiin halogeenien summa vedessä. Voimakas, pysyvä halokliini esiintyy Itämerellä yleensä noin 40-80 metrin syvyydessä. Halokliinin esiintymissyvyydessä esiintyy ajallisia ja paikallisia vaih- teluita, joiden syitä tarkastellaan myöhemmin (kuva 4.10)

Tiettyä vesimassaa voivat rajoittaa rannikko, pohja tai toiset vesimassat, joilla on eri suolaisuus tai lämpötila. Pohjanmuodoista, kuten kynnyksistä ja kapeikoista johtuen vesimassan liike 

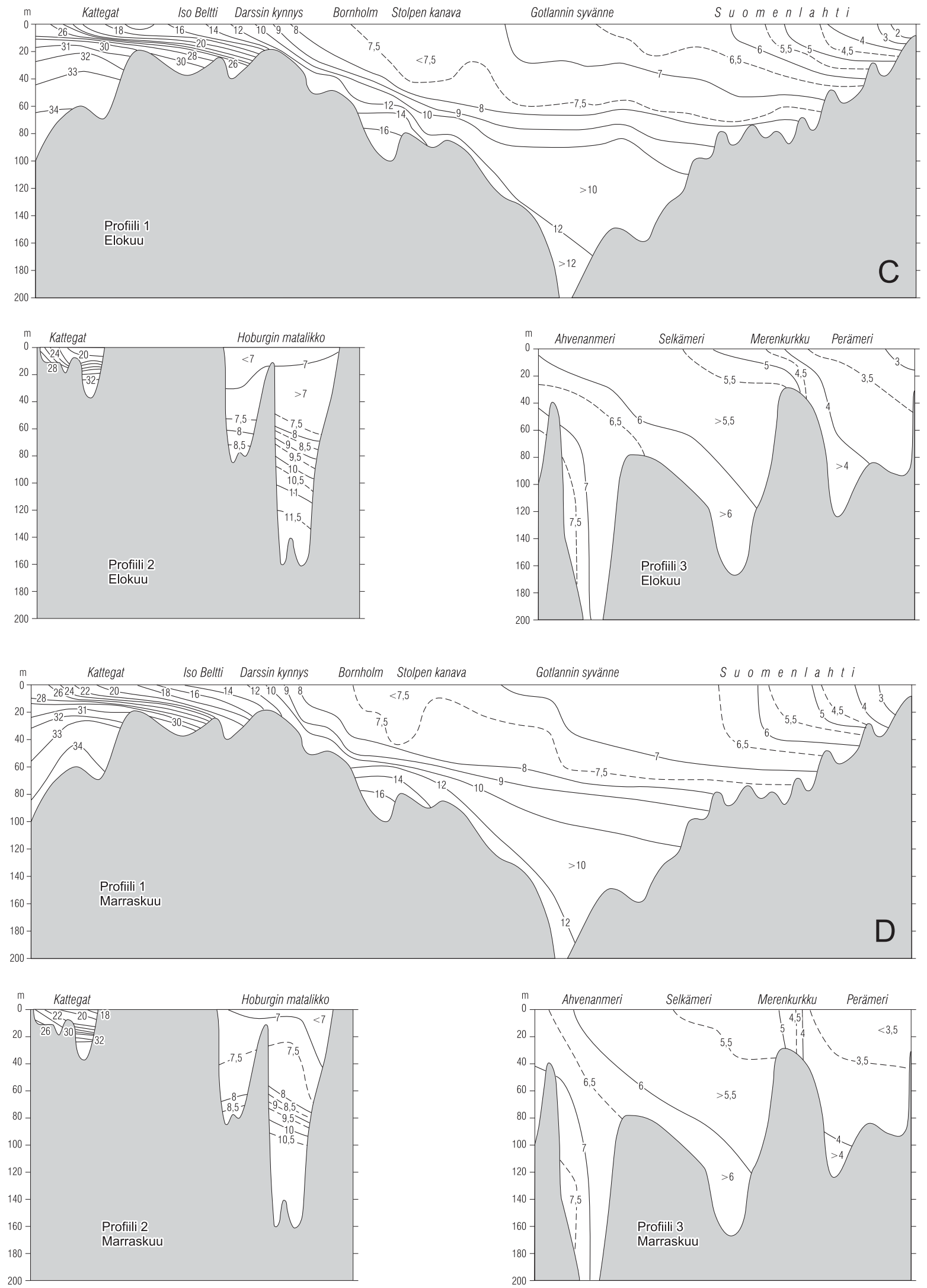

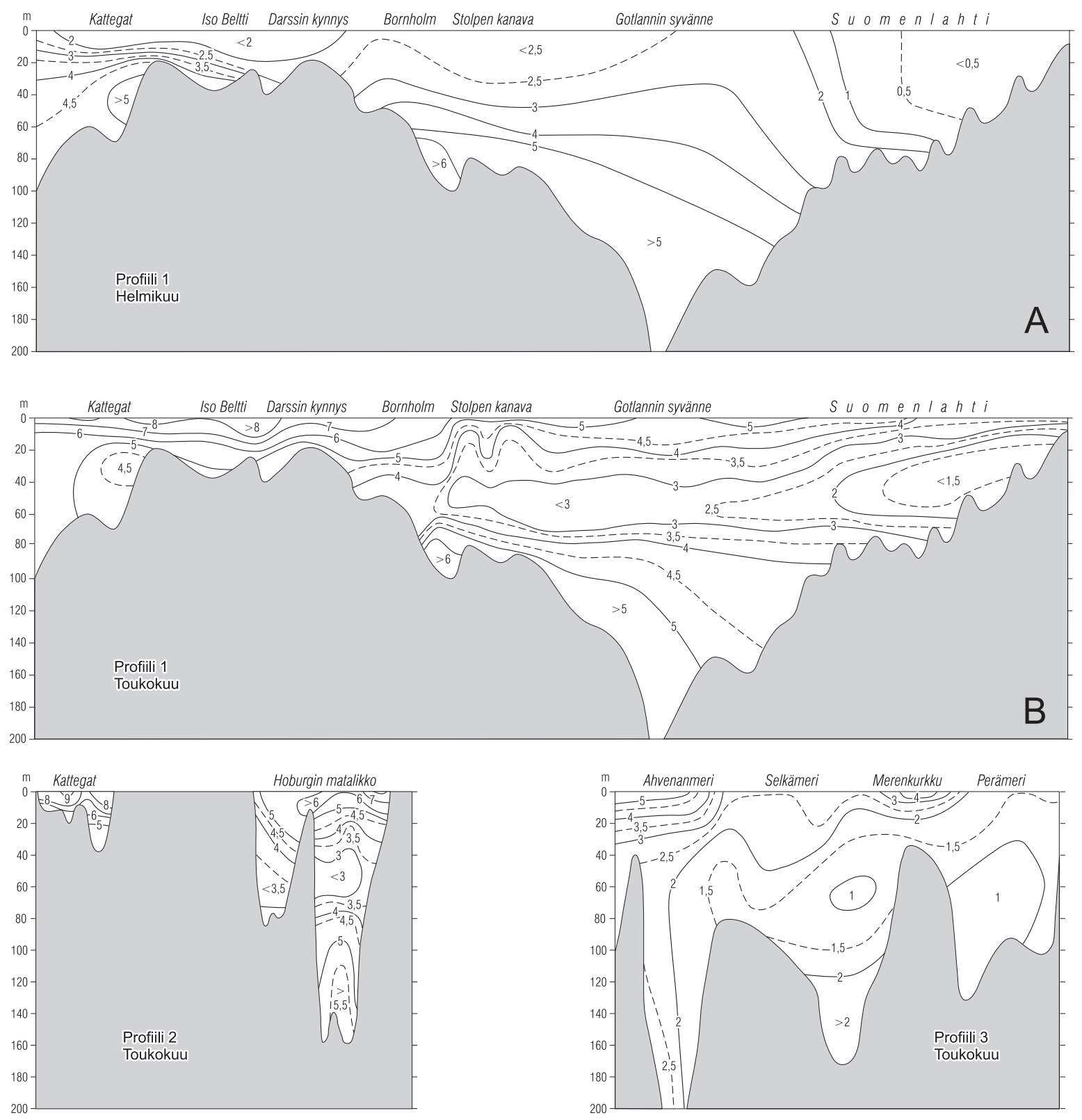

Kuva 4.14. Itämeren vesirungon lämpötilan $\left({ }^{\circ} \mathrm{C}\right)$ rakenne eri vuodenaikoina poikkileikkauksilla Kattegat-Suomenlahti keskilinjaa pitkin, Kattegat-Itäinen Gotlannin allas länsi-itä -suunnassa ja Pohjanlahti. A) Helmikuu, B) Toukokuu, C) Elokuu, D) Marraskuu. Helmikuussa on jääoloista johtuen ainoastaan Kattegat-Suomenlahti -poikkileikkaus. (Piirretty Lentzin [1971] mukaan.)

rajoittuu tietylle alueelle. Kahden vesimassan vaakasuuntaisella rajavyöhykeeellä veden hydrografiset ominaisuudet muuttuvat hypähdyksenomaisesti. Tätä vyöhykettä kutsutaan rintamaksi, jossa tiheämpi vesimassa vajoaa kevyemmän alle.
Tällainen horisontaalinen tiheysero voi johtua esimerkiksi klimatologisista syistä, jolloin konvektio on jatkuvaa. Tällöin muodostuu rintama ja siinä oleva paine-ero ajaa horisontaalivirtaukset rintaman suuntaisesti ja siis säilyttävästi. 
4. Syvyyssuhteet ja hydrografia 67
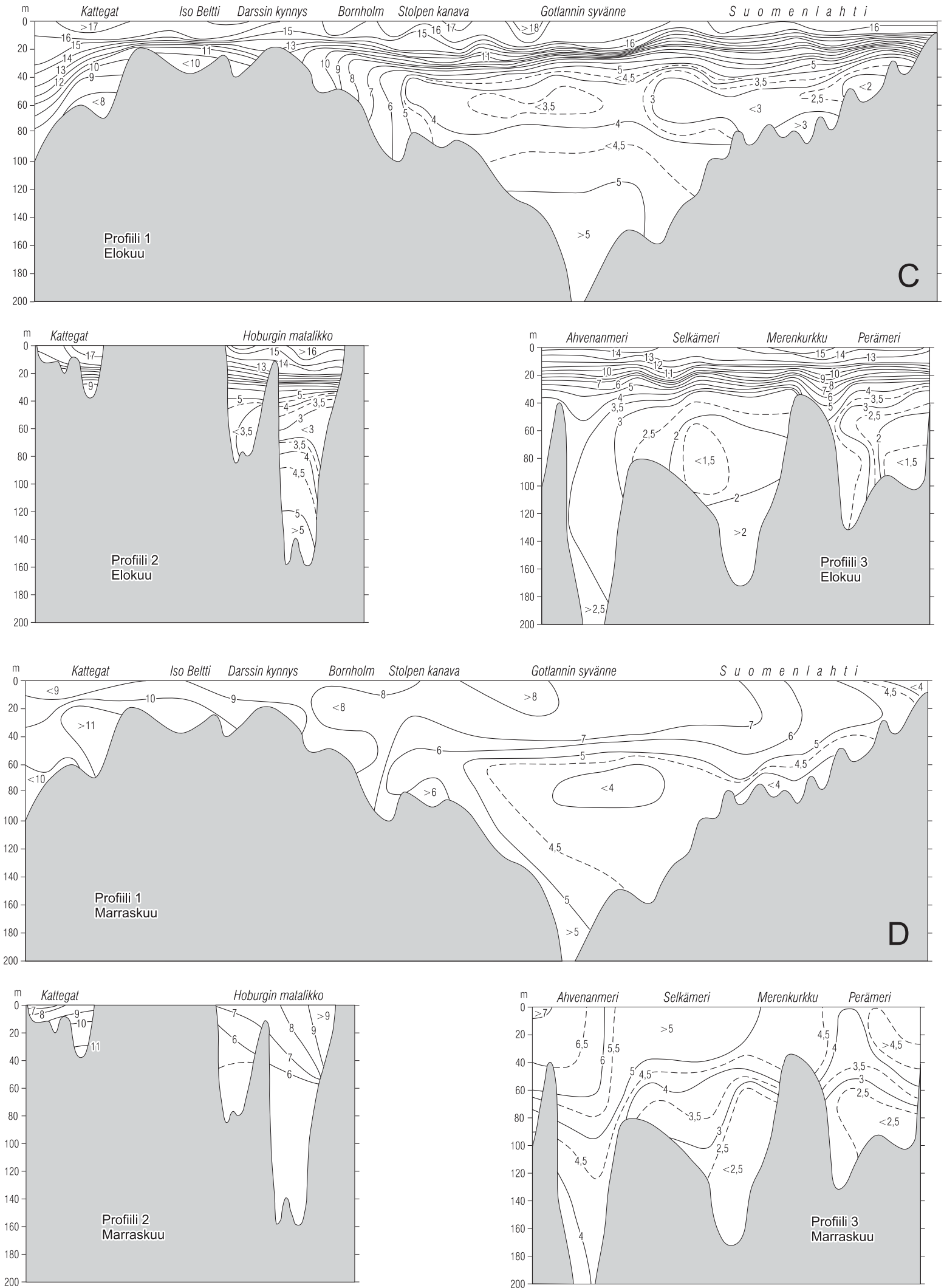


\subsubsection{Vuosisykli}

Varhain keväällä jään lähdön jälkeen aurinko lämmittää ohuen vesikerroksen (kuva 4.11). Tällöin meren pinnan energiatase on positiivinen, eli meri saa enemmän lämpöä kuin luovuttaa. Vesi saavuttaa tällöin nopeasti maksimitiheyden lämpötilan (eteläisellä Itämerellä veden lämpötila ei välttämättä alita maksimitiheyden lämpötilaa talven aikana), minkä jälkeen lämpenevä pintavesi muuttuu kevyemmäksi kuin sen alla oleva vesi. Konvektio lakkaa ja muodostuu lämpötilan harppauskerros eli termokliini ohuen, lämpimän pintakerroksen ja syvemmällä olevan kylmän veden välille. Auringonsäteily vaikuttaa lisäksi termokliinin syvenemiseen imeytyessään veteen suunnilleen näkösyvyyden verran. Termokliinin paksuus on tyypillisesti 5-10 metriä, ja sen täsmällinen muoto, toisin sanoen lämpötilan pystysuuntainen profili, vaihtelee melko paljon. Kesän edetessä lämmin pintakerros paksunee jossain määrin tuulen aiheuttaman mekaanisen sekoittumisen vaikutuksesta. Termokliini edesauttaa toisaalta myös jokien tuoman makean veden pysymistä pintakerroksessa, koska pystysuuntainen sekoittuminen on termokliinin läpi heikkoa. Tämä puolestaan vahvistaa tiheyseroa termokliinin ylä-ja alapuolen välillä, joten nämä kaksi prosessia vahvistavat toinen toisiaan.

Keväällä levien niin sanottu kevätkukinta alkaa jo heti jäiden lähdettyä. Mikroskooppiset levät liikkuvat pintakerroksessa, jossa keväällä valo riittää perustuotantoon. Tällöin jopa heikko termokliini estää ravinteiden täydentymistä alemmista vesikerroksista, mikä johtaa nopeasti ravinteiden ja sitä kautta kevätkukinnan loppumiseen. Kevätkukinnassa voi kuitenkin olla useita huippuja, mikäli tuulet rikkovat välillä syntyneen kerrostuneisuuden ja pinnalle tulee lisää ravinteita. Kevätkukinta päättyy levien nopeaan laskeutumiseen pohjalle eli niin sanottuun sedimentaatioon ravinteiden loputtua.
Termokliini muodostuu kesällä voimakkaaksi ja lämpötila voikin laskea siinä kymmenellä asteella muutaman metrin matkalla. Termokliini estää melko tehokkaasti tuulen ja aallokon sekoittavan vaikutuksen ulottumasta sen alapuoliseen vesimassaan. Se estää myös hyvin lämmön ja materian vaihdon pintakerroksen ja syvempien kerrosten välillä, millä seikalla on suuri vaikutus myös meren biologis-kemiallisiin prosesseihin (katso luku 8, kumpuaminen). Lämmin ja tyyni ilma kesällä saavat aikaan sen, että homogeenisen pintakerroksen paksuus ei kasva suuremmaksi kuin 10-15 metriä (kuva 4.11). Kesällä leviä esiintyy pääasiassa vain termokliinin yläpuolella. Termokliinin alapuolella on liian vähän valoa yhteyttämiseen. Pinnassa ravinteita on vähän tarjolla, sillä kaikki vapaat ravinteet on käytetty biomassan muodostamiseen. Eräät liikkumiskykyiset levät kuitenkin voivat vaeltaa termokliinin läpi hakemaan ravinteita syvemmältä. Siksi leviä voidaan löytää pysyvän halokliinin rajaltakin 80 metrin syvyydestä.

Itämerellä, kuten useilla jäätyvillä merillä, muodostuu kesällä niin sanottu dikoterminen kerros peitekerroksen pohjalle. Kun talven jälkeen peitekerros alkaa lämmetä pinnasta ja alusvesi on läpi vuoden $3-6^{\circ} \mathrm{C}$ lämpöistä, peitekerroksen pohjalle jää vesimassa, jossa lämpötila on minimissään (kuvat 4.10, 4.11). Pohjakerroksen korkeisiin lämpötiloihin on syynä lämpimän veden advektio etelämpää. Dikoterminen kerros säilyy läpi kesän ja katoaa vasta syksyn konvektiossa. Sitä on muodostumismekanisminsa takia kutsuttu myös (vanhaksi) talvivedeksi. Näin lämpötilalla onkin kesäaikaan kolmikerrosrakenne.

Elokuun lopussa merenpinnan energiatase kääntyy negatiiviseksi, pintavesi jäähtyy, tulee raskaammaksi ja vajoaa. Tällöin homogeenisen pintakerroksen paksuus alkaa kasvaa ja samalla termokliini heikkenee (kuva 4.11). Prosessi jatkuu syksyn edetessä, jolloin lämpöä siirtyy alaspäin konvektion vaikutuksesta. Esimerkiksi 30 


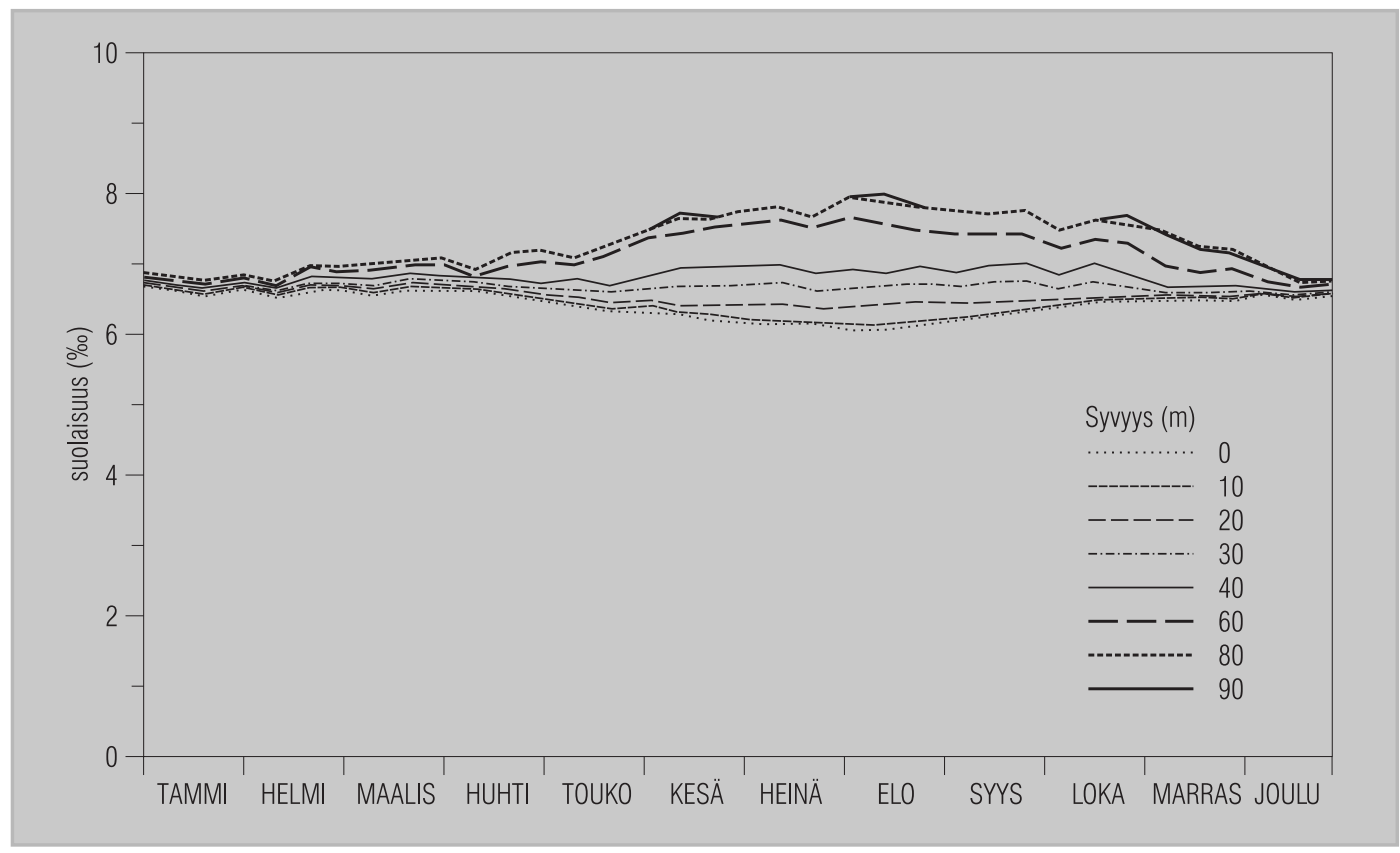

Kuva 4.15. Suolaisuuden keskimääräinen vuosittainen kulku Utössä eri syvyyksillä. (Piirretty Launiaisen [1982] mukaan.)

metrin syvyydellä lämpötilamaksimi saavutetaan vasta lokakuun alussa, kun se on pinnalla heinäelokuun vaihteessa (kuva 4.12). Samalla levätuotanto hiipuu, sillä syksyn valomäärä ei riitä kompensoimaan leväsolujen kiertoa syvälle. Syksyllä ja alkutalvella peitekerroksen vesi muuttuu isotermiseksi (lämpötila on syvyyden suhteen vakio) termohaliinisen konvektion ja mekaanisesti pakotetun (tuulen ajaman) sekoittumisen seurauksena. Vaikka Itämeren veden maksimitiheyden lämpötila on tyypillisesti noin $2-3{ }^{\circ} \mathrm{C}$, koko peitekerroksen lämpötila jäähtyy yleensä tätä alemmaksi, usein lähelle lämpötilaa $0{ }^{\circ} \mathrm{C}$ tehokkaan mekaanisesti pakotetun sekoittumisen ansiosta. Halokliinia ei kuitenkaan kumpikaan sekoitusmekanismi kykene läpäisemään.

Talvitermokliini on ohut kerros, jossa lämpötila kasvaa suunnilleen jäätymispisteestä maksimitiheyden lämpötilaan, ja se muodostuu näin ollen halokliinin kohdalle. Joissakin olosuhteissa talvitermokliini voi jäädä halokliinin yläpuolelle. Tällöin talvitermokliinin ja halokliinin välinen vesikerros pysyy koko talven isotermisenä. Horisontaalisen advektion vaikutuksesta alusveden lämpötila voi kuitenkin paikoin olla korkeampi kuin maksimitiheyden lämpötila. Jään laajuus on maksimissaan 15.2.-15.3. välisenä aikana, jonka jälkeen säteilytase kääntyy positiiviseksi ja kevätsulanta käynnistyy.

\subsubsection{Vesirungon rakenne}

Itämeren kerrostuneisuuden tärkein piirre on suolaisuuden kaksikerroksinen, voimakas ja pysyvä rakenne (kuva 4.13). Syynä tähän ovat jokien tuoma makea vesi lähinnä idästä ja pohjoisesta sekä Pohjanmereltä Tanskan salmien kautta Itämereen virtaava suolainen vesi. Halokliinin syvyyteen vaikuttavat veden sekoitusmekanismien (tuuli, konvektio) tehokkuus sekä kynnysten syvyydet. Halokliinin paikka vaihtelee ajan suhteen melko vähän Tanskan salmia lukuunottamatta. Tyypillisesti halokliinin syvyys on 40-80 

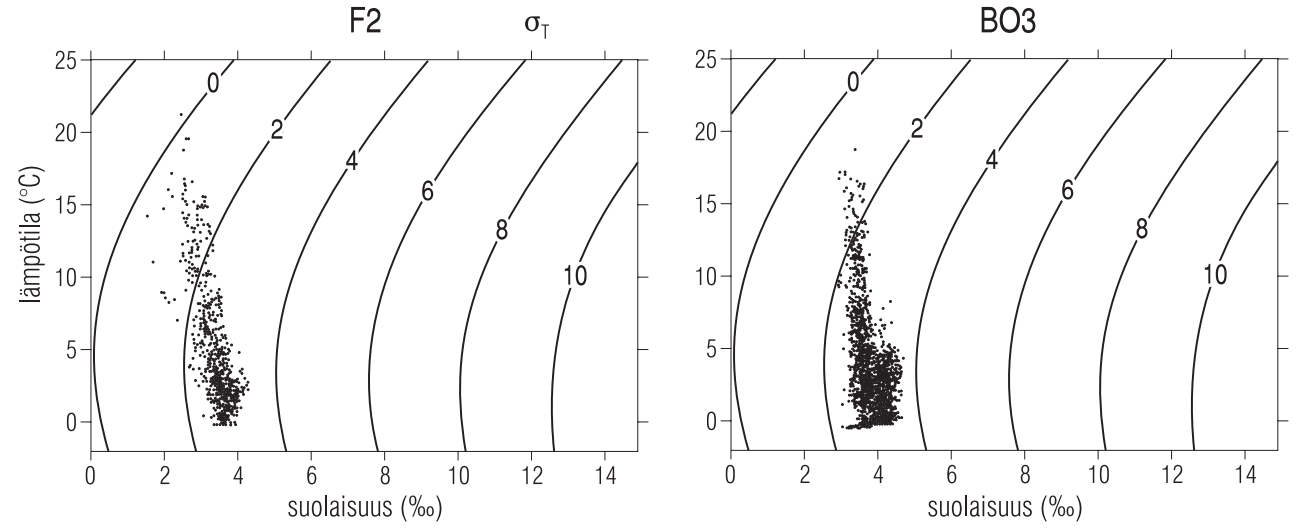

US5B
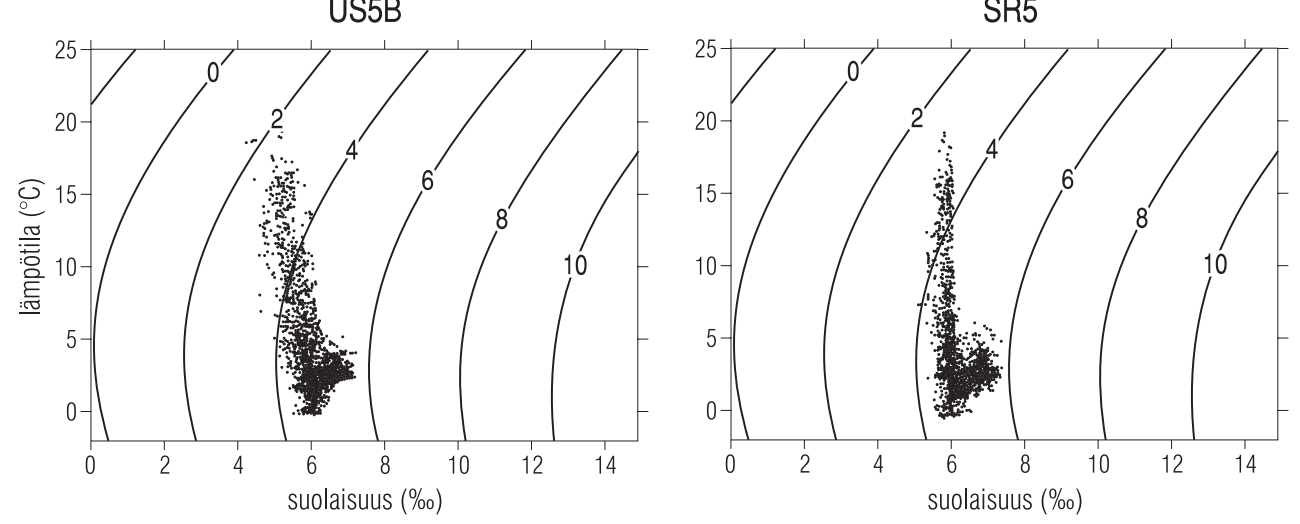

F64
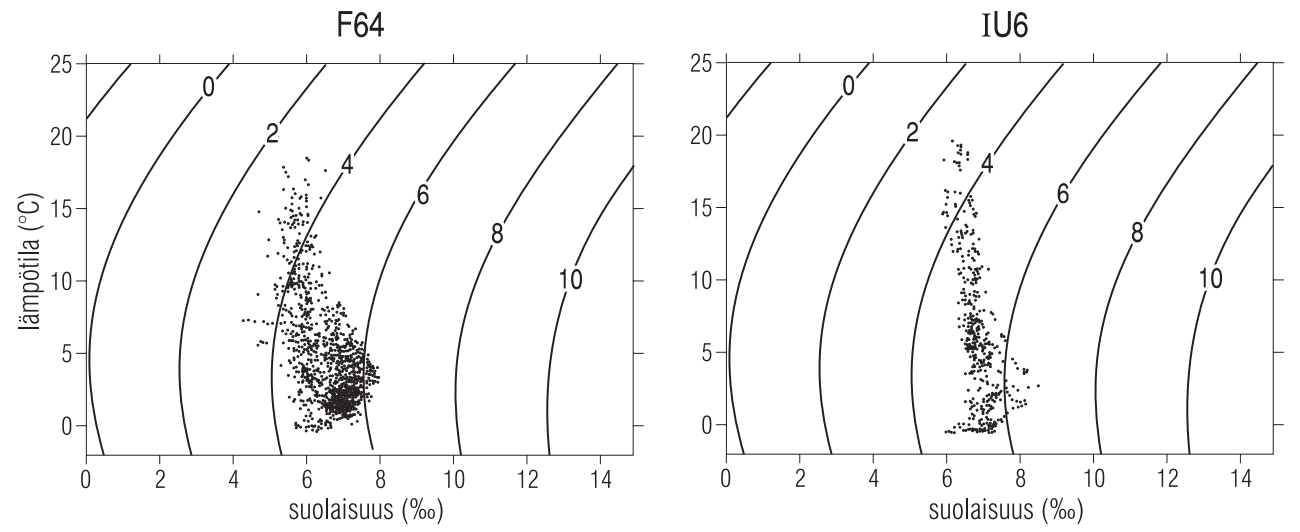

Kuva 4.16 TS -diagrammit eräille Pohjois-Itämeren asemille: F2 (Perämeri), B03 (Perämeri), US5B (Selkämeri), SR5 (Selkämeri), F64 (Ahvenanmeri) ja IU6 (Saaristomeri). Diagrammien tasa-arvonkäyrät antavat $\sigma_{\mathrm{T}}$ :n. (Piirretty Haapalan ja Aleniuksen [1994] mukaan.) 
Taulukko 4.2. Itämeren kerrostuneisuuden pääpiirteet.

\begin{tabular}{|l|l|l|l|}
\hline Kerros & Paksuus & Ylläpito & Esiintyminen \\
\hline Peitekerros & $40-80 \mathrm{~m}$ & Tuuli, konvektio & Koko vuosi \\
\hline $\begin{array}{l}\text { Kesäajan } \\
\text { pintakerros }\end{array}$ & $10-20 \mathrm{~m}$ & Lämmönsyöttö & Kesä \\
\hline $\begin{array}{l}\text { Kesäajan } \\
\text { termokliini }\end{array}$ & $5-10 \mathrm{~m}$ & Tuuli, aurinko & Kesä \\
\hline $\begin{array}{l}\text { Dikoterminen } \\
\text { kerros }\end{array}$ & Peitekerroksen pohjalla & Talviolot & Kesä \\
\hline Pysyvä halokliini & $10-20 \mathrm{~m}$ & Vesitase & Koko vuosi \\
\hline Alusvesi & Halokliini-pohja & Advektio & Koko vuosi \\
\hline Sekundäärinen halokliini & noin 125 m-pohja & Advektio & Ajoittaisesti \\
\hline
\end{tabular}

metriä, mutta Lounais-Itämeren matalilla alueilla se on pienempi. Alueilla, joissa kerrostuneisuus on heikko (pystysuuntaiset suolaisuuserot ovat pieniä), halokliini voi syys- ja talvimyrskyjen yhteydessä kadota. Näin voi tapahtua esimerkiksi läntisellä Suomenlahdella. Idässä Nevan tuoman makean veden vaikutus on suuri, ja suolaisuus kasvaa lineaarisesti syvyyden mukana. Pohjanlahdella halokliini on heikohko, sillä suolaisuuden pystymuutokset ovat melko pieniä. Etelä- ja Keski-Itämeren syvillä alueilla tilanne on erilainen, sillä halokiini on siellä varsin pysyvä ja voimakas.

Peitekerros ulottuu halokliinin, jonka paksuus on 10-20 metriä. Halokiinin alapuolinen vesikerros ei ole suorassa vuorovaikutuksessa tuulen ja konvektion aiheuttaman sekoittumisen kanssa, vaan sitä ylläpitää suolaisen veden advektio pohjoiseen. Tällöin suolaisuus pohjan lähellä pienenee etäännyttäessä Tanskan salmista. Alusvedessä suolaisuus kasvaa lineaarisesti syvyyden suhteen. Vanhan alusveden ja uuden Tanskan salmien kautta tulleen suolaisen veden välille voi muodostua myös sekundäärinen halokliini noin 125 metrin syvyydelle. Tämä ei kuitenkaan ole pysyvä ilmiö.

Suolaisuuden vaihtelu vaikuttaa ratkaisevasti Itämeren eliölajien levinneisyyteen. Suurin osa aidoista merilajeista ei pysty sopeutumaan Itä- meren murtoveteen, joten niitä esiintyy lähinnä vain Itämeren eteläosassa. Vähäsuolaisemmissa osissa esiintyy puolestaan myös makean veden lajeja. Itämeren lajisto onkin köyhää juuri eliöille vaikean murtovesiluonteen vuoksi.

Suolaisuuden jakaumissa on vuodenaikaisvaihteluita, mutta ne ovat selkeästi heikompia kuin vastaavat lämpötilan vaihtelut. Suolaisuuden minimi havaitaan alkukesällä, kun kevätvalunta on joista levinnyt meren pintakerrokseen. Termokliinin muodostuminen (kuva 4.14) ja siitä seuraava pystysuuntaisen sekoittumisen heikkous vahvistavat makean veden pysymistä pintakerroksessa ja siten suolaisuuden minimiä. Minimissään suolaisuus on normaalisti noin 0,5 promillea talvisia maksimiarvoja pienempi. Suolaisuuden minimi havaitaan jonkin aikaa jokivirtaamien kevätmaksimin jälkeen: esimerkiksi Utössä viive on noin 2,5 kuukautta (kuva 4.15), mikä merkitsee keskimääräistä virtausnopeutta muutamia senttimetrejä sekunnissa. Suolaisen veden sisäänvirtaus ja heikko pystysuora sekoittuminen kesällä aikaansaavat alusveden suolaisuuden maksimin. Talvitilanteessa taas veden pystysekoittuminen on voimakasta, jolloin suolaisuuserot pinnan ja pohjan välillä jossain määrin pienenevät. Näin tapahtuu eniten lähellä rannikkoa, jossa halokliinia ei ole. Tällöin havaitaan pintakerroksessa suolaisuuden vuosimaksimi ja pohjassa sen vuosiminimi. 


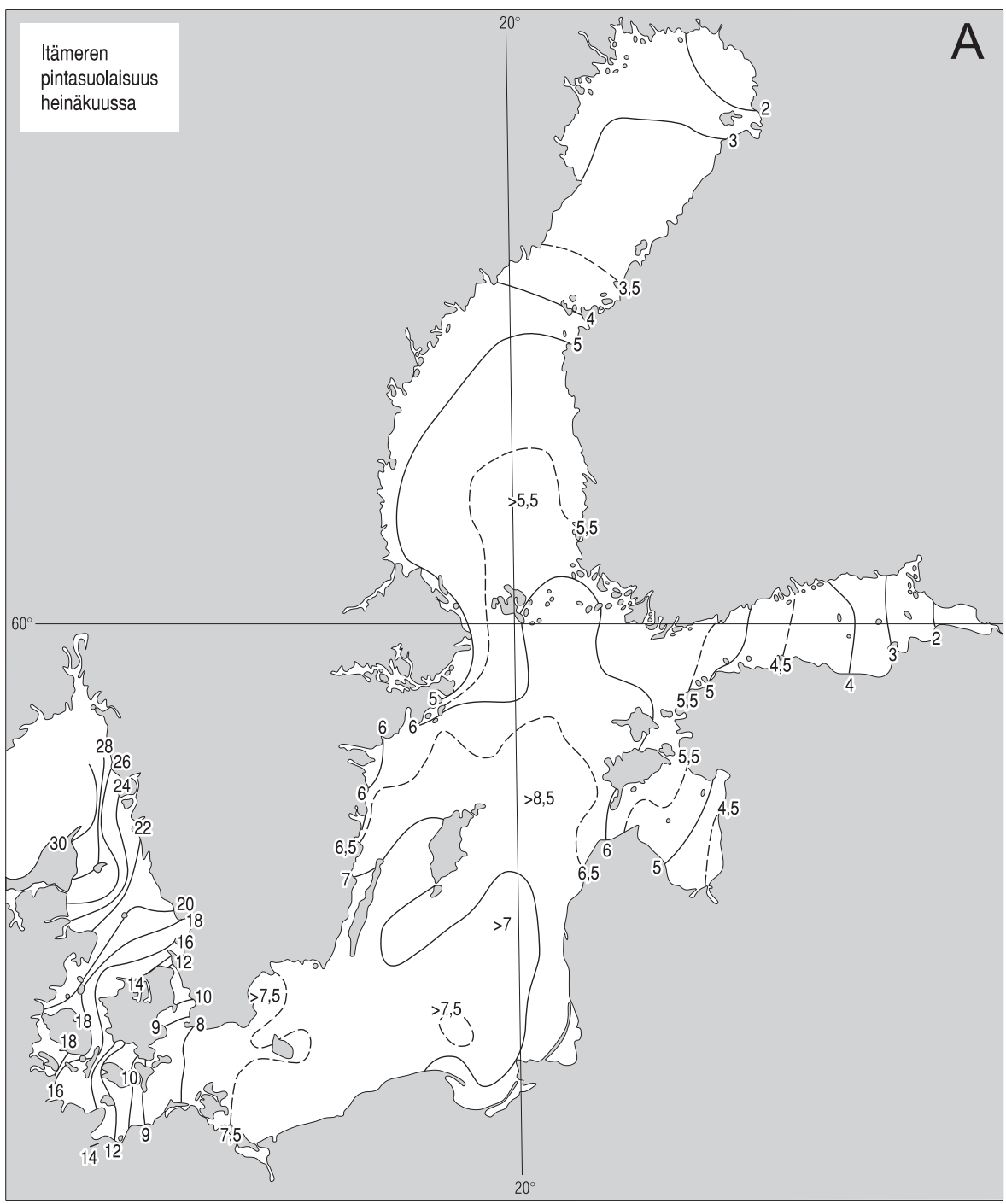

Kuva 4.17. Keskimääräisen suolaisuuden (\%) horisontaalijakauma Itämerellä heinäkuussa.

A) Pinnalla, B) Pohjassa (Piirretty Bockin [1971] mukaan.)

Suolaisuuden ja lämpötilan välistä yhteyttä voidaan tarkastella graafisesti TS (temperature-salinity) -diagrammin avulla (kuva 4.16). Esitystavan otti käyttöön norjalainen merentutkija Helland-Hansen vuonna 1916. Diagrammin avulla voidaan erottaa erilaisia vesimassoja ja arvioida niiden alkuperää ja sekoittumista. Näin TS- diagrammista tulee hyvin "venynyt" pistejoukko. Itämeren TS-käyrät ovat koukunmuotoisia ja ilmentävät jatkuvaa kerrostuneisuutta mieluummin kuin puhtaita vesimassoja. $\mathrm{Ne}$ osoittavat advektion vaikutuksia ja pystysuoran sekoittumisen rajoittumista halokliiniin. Pystyviiva liittyy pintakerrokseen ja lämpötilakerrostuneisuuteen, kun taas vaakaviiva alusveteen ja suolaisuuskerrostuneisuuteen. Vaakaviiva nousee pystyviivasta koukkumaisesti hieman oikealle, sillä alusveden lämpötila kasvaa syvempään mennessä. Koukkujen sijainti liukuu S-akselilla Tanskan salmista etäännyttäessä.

Kesällä peitekerroksen yläosaan muodostuu pintakerros ja termokliini. Tämä pintakerros ei ole 


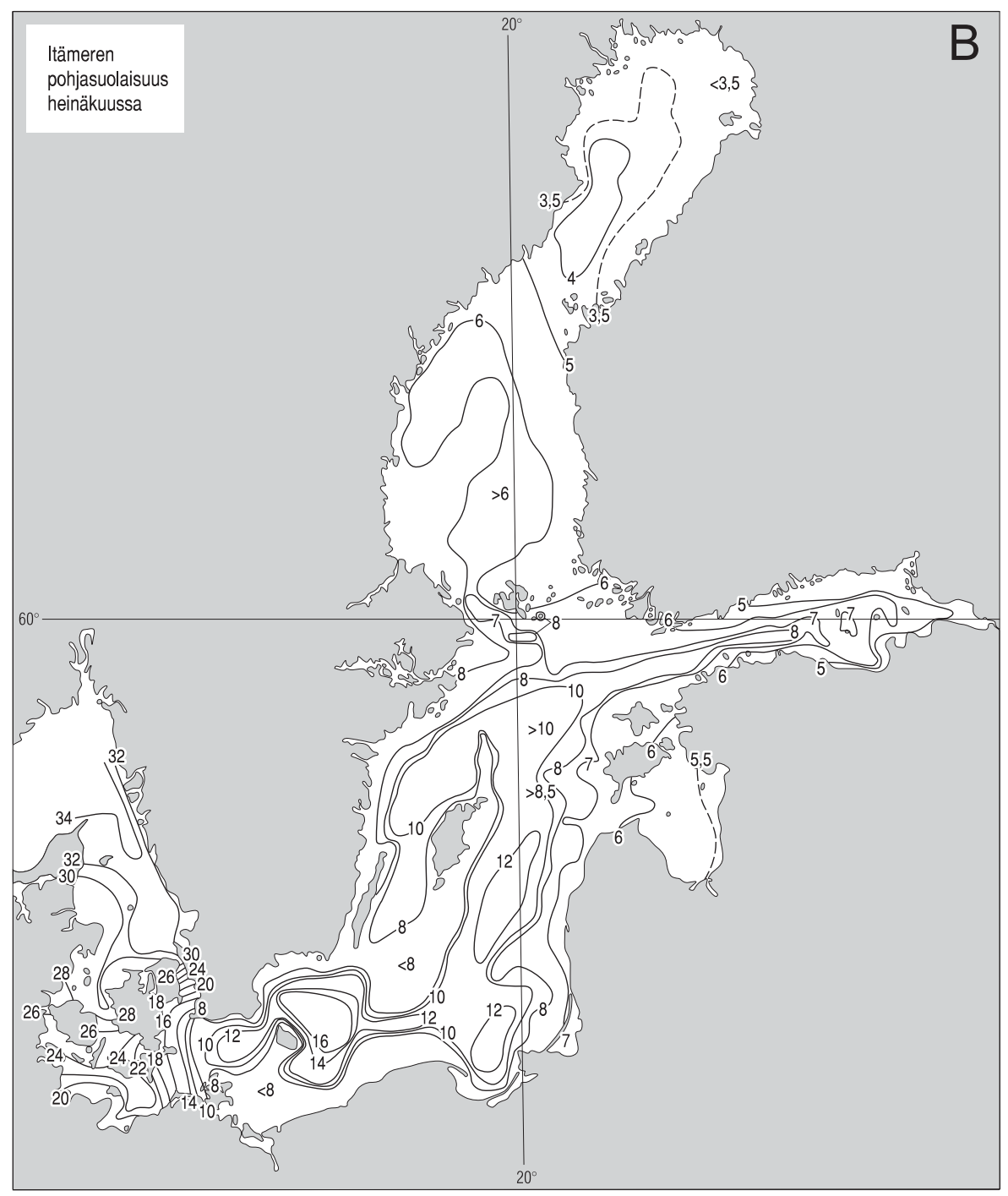

\subsubsection{Suolaisuuden ja lämpötilan vaihtelu eri altaissa}

aina homogeeninen, vaan siinä voi olla myös useita porrasmaisia pieniä lyhytkestoisia termokliinejä. Sekoittuneella pintakerroksella tarkoitetaan homogeenistä kerrosta, jossa lämpötilan vertikaalimuutos ei ylitä tiettyä, sovittua arvoa (esim $0,1^{\circ} \mathrm{C} / \mathrm{m}$, taulukko 4.2). Yksittäisestä lämpötilaprofiilista termokliinin voi määrittää yleensä helposti, mutta myös hankalasti tulkittavia tilanteita esiintyy. Useista havainnoista on mahdollista tilastollisesti analysoida termokliinin syvyyden vaihteluita.
Itämeren suolaisuus laskee yleisesti ottaen etäännyttäessä Tanskan salmista (taulukko 4.3). Keskimäärin virtaukset kiertävät altaissa vastapäivään, minkä vuoksi suolaisuus ja lämpötila ovat korkeampia altaiden itäosissa (kuvat 4.17 ja 4.18).

Kattegatissa suolaisuudessa on voimakas kaksikerrosrakenne (kuva 4.13), sillä pinnassa virtaa ulos Itämeren murtovettä ja syvemmällä virtaa kohti Itämerta Skagerrakista peräisin oleva suolainen valtamerivesi. Näiden vesikerrosten välil- 


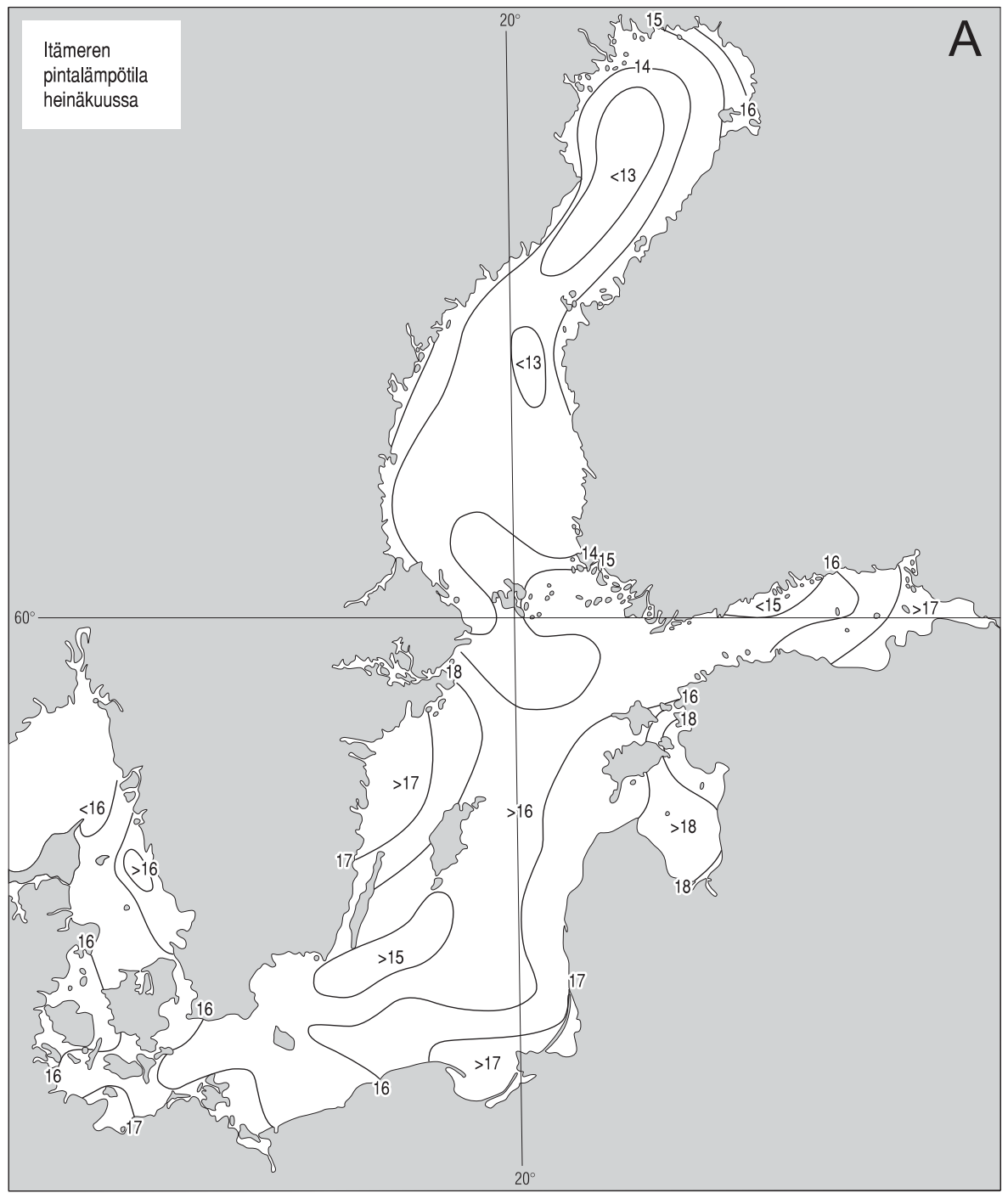

Kuva 4.18. Keskimääräisen lämpötilan $\left({ }^{\circ} \mathrm{C}\right)$ horisontaalijakauma Itämerellä heinäkuussa.

A) Pinnalla, B) Pohjassa (Piirretty Lentzin [1971] mukaan.)

lä on yleensä pysyvä, varsin voimakas halokliini noin 15 metrin syvyydellä. Pintasuolaisuus on 18-26 promillea ja pohjasuolaisuus 32-34 promillea. Belttien meressä on myös normaalisti kaksikerrosrakenne siten, että pinnassa on Itämeren vettä (8-10 promillea) ja pohjalla Kattegatin alusvettä, jonka suolaisuus voi olla jopa 32-33 promillea. Belttien meren pitkänomaisuudesta ja mataluudesta johtuen suolaisuusolot vaihtelevat paljon tuulten suunnan, voimakkuuden ja keston mukaan. Iso-Beltissä vesi voi olla homogee- nistä silloin kun sekoittuminen on voimakasta. Juutinraumassa on kolmea eri vesityyppiä. Pintavesi on peräisin Itämerestä (suolaisuus 8-10 promillea) sekä Kattegatista (suolaisuus 18-24 promillea) ja alusvesi on Kattegatista (suolaisuus 30-34 promillea).

Eteläisellä Itämerellä merialtaat ovat matalia ja halokliini on voimakas, koska suolaisen veden sisääntuloalue on lähellä ja alueen läpi virtaa pintakerroksessa ulos Itämeren pintavettä. Arkonan altaassa halokliini on keskimäärin 40-45 metrin 


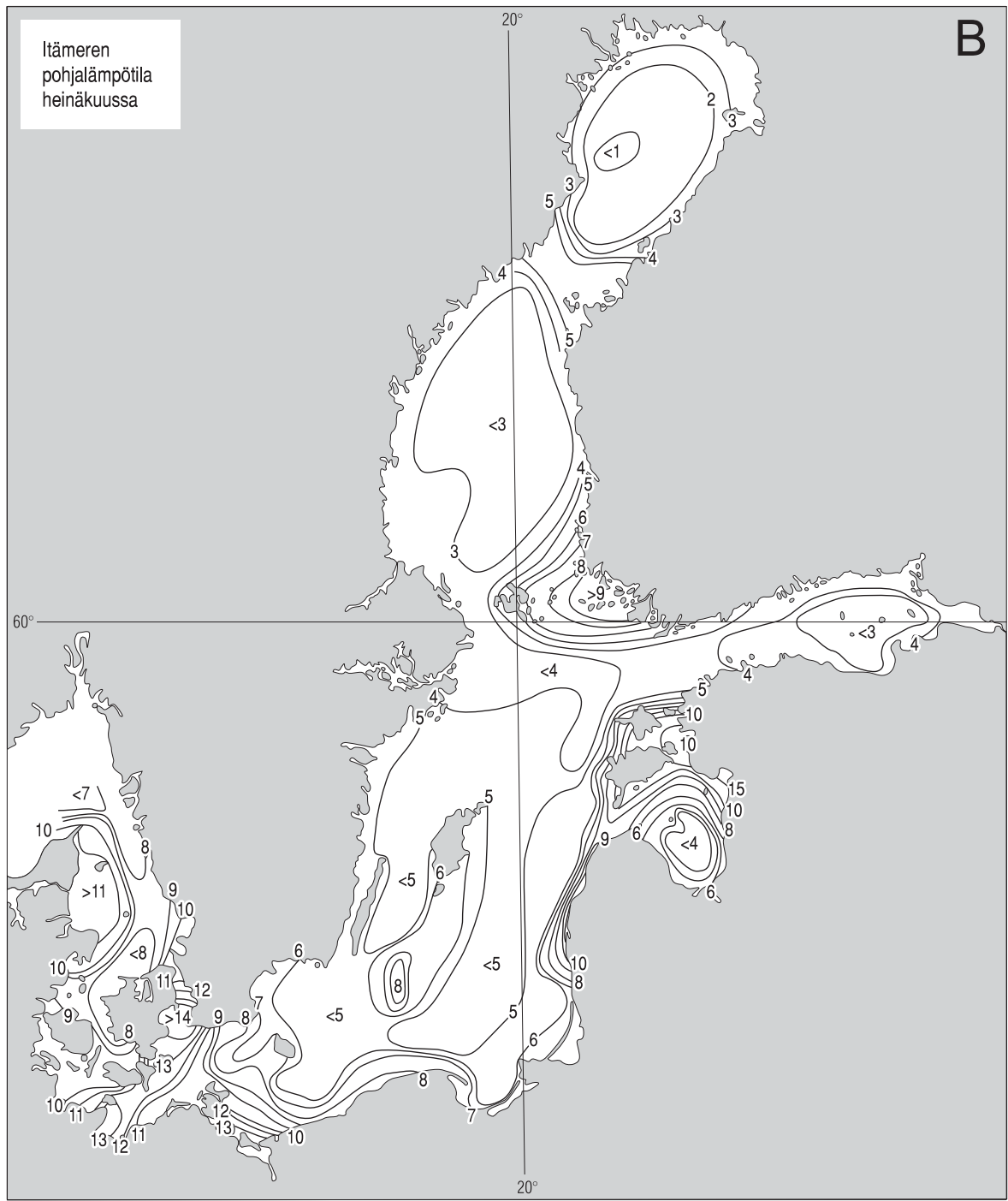

Taulukko 4.3. Suolaisuuden tyypilliset arvot Itämeren eri altaissa (Bock 1971). On huomioitava, että varsinkin Lounais-Itämerellä ja Suomenlahdella vaihtelut ovat varsin suuria.

\begin{tabular}{|l|l|l|l|}
\hline Allas & Suolaisuus (\%) & Halokliini \\
\hline & Pinta & Pohja & Syvyys (m) \\
\hline Perämeri & $2-4$ & $4-4,5$ & $50-60$ \\
\hline Selkämeri & $5-6$ & $6-7$ & $60-80$ \\
\hline Suomenlahti & $0-6$ & $(0) 3-9$ & $60-80$ \\
\hline Riianlahti & $4,5-6$ & $6-7$ & $20-30$ \\
\hline Gotlanti & $6,5-8$ & $9-13$ & $60-80$ \\
\hline Bornholm & $13-17$ & $50-55$ \\
\hline Arkona & $7,3-8,5$ & $10-15$ & $40-45$ \\
\hline Beltit & $7,5-8,5$ & $10-30$ & \\
\hline Kattegat & $8-24$ & $32-34$ & $15-20$ \\
\hline
\end{tabular}


syvvydellä. Pintaveden suolaisuus on tyypillisesti 7,5-8,5 promillea, voimakkaan sisäänvirtauksen yhteydessä altaan keskiosissa jopa 11 promillea. Darsserin ja Drogdenin kynnysten luona voi suolaisuus nousta 17 promilleen. Alusveden suolaisuus vaihtelee tyypillisesti 9 ja 15 promillen välillä, vaikkakin hetkellisesti voidaan havaita tätäkin suurempia arvoja. Peitekerros Bornholmin altaassa on 50-55 metriä paksu ja sen suolaisuus on 7,3-8,5 promillea. Alusveden suolaisuus on 13-17 promillea, eikä siinä esiinny niinkään vuodenaikaisvaihtelua, vaan suolaisen veden epäsäännöllisestä sisäänvirtauksesta johtuvaa vaihtelua (kuva 4.17, taulukko 4.3).

Itäisessä Gotlannin altaassa pysyvä halokliini on 60-70 metrin syvyydellä. Peitekerroksen suolaisuus vaihtelee 7 ja 8 promillen välillä. Halokliinin alapuolella suolaisuus on 100 metrin syvyydellä 9-12 promillea, 200 metrin syvyydellä 11,5-13 promillea. Baltian rannikoiden matalilla alueilla suolaisuus on huomattavasti näitä arvoja pienempi, varsinkin jokisuiden läheisyydessä. Pohjoisessa Gotlannin altaassa pintaveden suolaisuus on alempi kuin itäisessä johtuen veden vastapäiväisestä kiertoliikkeestä, jossa itäisen Gotlannin altaan vesi sekoittuu Suomenlahden ja Pohjanlahden makeampiin vesiin. Pintasuolaisuus on pohjoisessa altaassa 6-7,3 promillea, kun halokliinin alla se on 9,8-11,5 promillea ja pohjan lähellä Landsortin syvänteessä 10-11,5 promillea. Läntisessä altaassa pintasuolaisuus on 6,3-7,7 promillea, kun taasen halokliinin alapuolella 100 metrin syvyydessä suolaisuus on 8,7-10,3 promillea. Gotlannin altaan voimakas kerrostuneisuus ja suuri syvyys aiheuttavat happiongelmia pohjavesissä. Nämä tuulettuvat vain voimakkaiden suolaisten ja hapekkaiden Pohjanmereltä tulevien niin sanottujen suolapulssien yhteydessä keskimäärin kerran 10 vuodessa (katso luku 8).

Riianlahdella on suolaisuudessa myös kaksikerroksinen rakenne: siellä on ohut pintakerros ja halokliini 20-30 metrin syvyydellä. Pintavesi on varsinaista Riianlahden vettä, kun Itäisestä Gotlannin altaasta peräisin oleva lämmin ja suolainen alusvesi pääsee sisään Irben salmesta. Pintakerroksen suolaisuus on 4,5-6 promillea, alusveden enimmillään 7 promillea.

Suomenlahdella vallitsee myös osin kaksikerroksinen rakenne. Suomenlahtihan on Gotlannin altaan uloke, jonka itäpäässä laskee Neva mereen. Tästä johtuen suolaisuudessa on voimakas itä-länsisuuntainen vaihtelu. Pintasuolaisuus kasvaa itäpohjukan nollasta länsiosan 66,5 promilleen. Halokliini löytyy lähinnä vain Suomenlahden länsi- ja keskiosissa ja sen syvyys on 60-80 metriä. Pohjan lähellä suolaisuus on länsiosissa 7-9 promillea, keskiosissa 5-8 promillea ja idässä 0-5 promillea. Suomenlahden pohjanläheisissä vesikerroksissa esiintyy myös usein happiongelmia. Tämä liittyy kesäkerrostuneisuuteen ja alueelle tulevaan suureen ravinnekuormitukseen.

Pohjanlahden kerrostuneisuus poikkeaa huomattavasti Itämeren keskusaltaan oloista. Se on paljon heikompi ja pohjavedet vaihtuvat hyvin, joten happiongelmia ei ole. Kerrostuneisuus on kuitenkin riittävän voimakas estämään vesirungon pystysuuntaisen sekoittumisen pohjaan asti syksyisen jäähtymisen aikana, ja pohjavedet uudistuvat vain alusveden virtausten ansiosta. Heikko halokliini voidaan Selkämerellä erottaa 60-80 metrin syvyydeltä, Perämerellä 50-60 metristä. Kerrostuneisuus riippuu jokivirtaamista sekä sisään- ja ulosvirtauksesta Pohjanlahden ja Gotlannin meren välillä.

Ahvenanmeressä pintaveden suolaisuus on 5,25-6,25 promillea, kun taas suolaisuus noin 200 metrin syvyydessä on 7-7,75 promillea. Ahvenanmeren vesi, kuten Selkämerenkin, on lähinnä Gotlannin altaan peitekerroksen vettä, vaikka jonkin verran suolaisempaa vettä pääsee kynnysten yli. Toisinaan pääsee Ahvenanmeren kautta virtaamaan pohjanläheisessä kerroksessa suolaista vettä Selkämerelle asti, jolloin pinnassa poistuu vastaava määrä makeaa vettä Itäme- 
Taulukko 4.4. Pinta- ja pohjalämpötilan $\left({ }^{\circ} \mathrm{C}\right)$ keskimääräiset arvot Itämeressä eri vuodenaikoina (Lentz 1971). Lämpötilat taulukossa ovat keskimääräiset pinta/pohjalämpötilat tammi-, huhti-, heinä- ja lokakuussa.

\begin{tabular}{|l|l|l|l|l|}
\hline Allas & Lämpötila $\left({ }^{\circ} \mathrm{C}\right)$ : pinta/pohja \\
\hline & Tammikuu & Huhtikuu & Heinäkuu & Lokakuu \\
\hline Perämeri & jää & jää & $13-15 / 1-4$ & $4-6 / 3-5$ \\
\hline Selkämeri & osin jäässä & osin jäässä & $13-15 / 3-7$ & $5-8 / 3-8$ \\
\hline Suomenlahti & $0-2$ (itä jäässä) & $0-2$ (itä jäässä) & $15-17 / 2-5$ & $9-11 / 3-5$ \\
\hline Riianlahti & $0-1$ & $0-1$ & $17-18 / 7-15$ & $9-11 / 5-9$ \\
\hline Gotlanti & $2-3,5 / 3-6$ & $1-2 / 2-5$ & $15-17 / 5-10$ & $10-12 / 4-9$ \\
\hline Bornholm & $4 / 5-8$ & $2-3 / 3-5$ & $16 / 5-6$ & $11-12 / 7-9$ \\
\hline Arkona & $3-4 / 4-5$ & $3-5 / 2-4$ & $16 / 7-13$ & $12 / 9-12$ \\
\hline Beltit & $2-3,5 / 3-5$ & $5 / 4-5$ & $16 / 8-14$ & $12 / 12$ \\
\hline Kattegat & $3 / 5-6$ & $5 / 5$ & $16-17 / 8-11$ & $10-11 / 10-12$ \\
\hline
\end{tabular}

ren pääaltaalle ja tämän seurauksena Selkämeren kerrostuneisuus vahvistuu.

Selkämerellä pintasuolaisuus on 4,8-6,0 promillea ja alusveden suolaisuus 150 metrin syvyydellä 6,4-7,2 promillea. Perämerellä pintaveden suolaisuus on 2-3,8 promillea ja pohjan lähellä 100 metrin syvvyydessä 4-4,5 promillea. Pohjanlahteen laskee useita suuria jokia, joiden suistossa suolaisuus painuu nollaan (kuva 4.17).

Itämeren lämpötilan kehitys on varsin erilaista pinta- ja pohjakerroksissa. Pinnan energiataseen voimakkaan vuodenaikaisvaihtelun seurauksena pintaveden lämpötila saavuttaa kesällä maksiminsa ja talvella miniminsä, jolloin ainakin osa merestä myös jäätyy. Pohjanläheisen, halokliinin alapuolisen vesikerroksen, lämpötilan vuosivaihtelu on pientä ja riippuu varsinkin etelässä enemmänkin Tanskan salmien suunnasta tulevasta advektiosta. Kulkeutuessaan pohjoiseen lämmin vesi suolaisuutensa takia painuu alaspäin. Tämän takia pohjavedet ovat lämpimiä, esimerkiksi Gotlannin altaan keskussyvänteessä 4-6 ${ }^{\circ} \mathrm{C}$, pohjoisempana tyypillisesti $2-4^{\circ} \mathrm{C}$. Pintakerrokseen syntyy kesällä termokliini, jonka syvyys on keskikesällä 15-30 metriä koko Itämeren alueella. Termokliinin muodostuminen alkaa Etelä-Itämerellä toukokuun alkupuolella, kun taas Perämerellä se tapahtuu vasta kesäkuussa. Vastaavasti termokliinin syveneminen alkaa pohjoisessa jo elokuun lopus- sa, kun etelässä tämä tapahtuu vasta kuukautta myöhemmin (kuva 4.14). Vain suhteellisen harva eliölaji on pystynyt sopeutumaan Itämeren vaihtelevaan lämpötilaan, erityisesti kylmään talveen. Monet lajit ovatkin kehittäneet erilaisia talvehtimisstrategioita, joihin kuuluvat muun muassa erityiset kestosolut tai kasvun pysähtyminen talvella. Kevään kasviplanktonkukinnan muodostavat kylmän veden levät, jotka puolestaan viettävät kesän pohjasedimentissä lepomuotoina.

Meren pintalämpötila (taulukko 4.4, kuva 4.18a) seuraa ilman lämpötilaa viiveellä, koska meren lämpökapasiteetti on suuri. Vesi reagoi hitaasti ylhäältä tulevaan lämmön syöttöön, eli sen terminen inertia on suuri. Seuraavat lämpötilalukemat ovat pitkän aikavälin keskiarvoja, joten ne eivät kuvaa yksitttäisiä vuosia. Tammikuussa Perämeri ja Suomenlahden itäosat ovat keskimäärin jäätyneet, kuten myös Riianlahti ja Ruotsin rannikkovedet. Gotlannin altaalla pintalämpötila on $2-3{ }^{\circ} \mathrm{C}$, Lounais-Itämerellä $2-5^{\circ} \mathrm{C}$. Pohjaveden lämpötila on jäätyneilla alueilla hiukan nollan yläpuolella kasvaen etelän arvoihin $3-5^{\circ} \mathrm{C}$, Bornholmin altaalla jopa $8{ }^{\circ} \mathrm{C}$ :n lukemiin.

Huhtikuun puolivälissä jäätä on vielä Perämerellä, Selkämerellä ja itäisellä Suomenlahdella. Gotlannin altaalla pintaveden lämpötila on $1-2{ }^{\circ} \mathrm{C}$. Sen sijaan Lounais-Itämerellä keväinen lämpeneminen on jo alkanut, ja pintave- 
den lämpötila on $3-5^{\circ} \mathrm{C}$. Pohjanläheisen veden lämpötila on jäätyneillä alueilla hiukan nollan yläpuolella, kun Keski- ja Lounais-Itämerellä se on $2-5^{\circ} \mathrm{C}$.

Heinä-elokuun vaihteessa meriveden pintalämpötila on yleensä korkeimmillaan ja kerrostuneisuus voimakkaimmillan. Lämpötila on Pohjanlahdella $13-15^{\circ} \mathrm{C}$, Suomenlahdella $15-17^{\circ} \mathrm{C}$, ja muissa altaissa $15-18^{\circ} \mathrm{C}$. Pohjan läheinen lämpötila riippuu paljolti siitä, onko kysessä avomeri, jossa on termokliini vai matala rannikkoalue, jossa vesimassa on sekoittunut pohjaan asti. Täten pohjan läheinen lämpötila vaihtelee suurissa rajoissa. Perämerellä se on $1-4^{\circ} \mathrm{C}$, Selkämerellä $3-7^{\circ} \mathrm{C}$, Suomenlahdella $2-5^{\circ} \mathrm{C}$, kun matalalla Riianlahdella vaihtelu on edellämainituista syistä johtuen $7-15^{\circ} \mathrm{C}$ välil- lä. Gotlannin altaalla lämpötila on $5-10^{\circ} \mathrm{C}$ ja Lounais-Itämerellä $7-14^{\circ} \mathrm{C}$ asteen välillä (kuva 4.18, taulukko 4.4).

Lokakuussa pintaveden jäähtyminen on jo alkanut kaikkialla. Perämerellä pintaveden lämpötila on enää $4-6{ }^{\circ} \mathrm{C}$, Selkämerellä $5-8{ }^{\circ} \mathrm{C}$. Suomenlahdella ja Riianlahdella ollaan $9-11^{\circ} \mathrm{C}$ vaiheilla, kun Keski- ja Lounais-Itämerellä vesi on vielä $10-12{ }^{\circ} \mathrm{C}$ lämmintä. Pohja- ja pintaveden lämpötilaero on lokakuussa mekaanisen ja termisen konvektion vuoksi paljon pienempi kuin heinä-elokuussa. Perämerellä pohjanläheinen lämpötila on $3-5^{\circ} \mathrm{C}$, Selkämerellä $3-8{ }^{\circ} \mathrm{C}$ ja Suomenlahdella $3-5^{\circ} \mathrm{C}$. Riianlahdella lämpötila on $5-9{ }^{\circ} \mathrm{C}$, Gotlannin merellä $4-9^{\circ} \mathrm{C}$. Lounais-Itämerellä pohjanläheinen lämpötila on noin $10-12{ }^{\circ} \mathrm{C}$. 


\section{Kaavaliite: Meriveden tilanyhtälö (UNESCO 1981, Gill 1982)}

Meriveden tiheyden yhtälö havainnollistetaan tässä vaiheittain. Ensiksi makean veden tiheys $\rho_{w}(S=0)$ voidaan kirjoittaa muodossa

$\rho_{w^{\prime}}=999,842594+6,793952 \cdot 10^{-2} T-1,120083 \cdot 10^{-6} T^{4}+6,536332 \cdot 10^{-9} T^{5}-$

$9,095290 \cdot 10^{-3} T^{2}+1,001685 \cdot 10^{-4} T^{3}-1,120083 \cdot 10^{-6} T^{4}+6,536332 \cdot 10^{-9} T^{5}$

Seuraavaksi saadaan meriveden tiheys $\rho$, kun paine $p=0$

$\rho(S, T, 0)=\rho_{w}+S\left(0,824493-4,0899 \cdot 10^{-3} T+7,6438 \cdot 10^{-5} T^{2}+5,3875 \cdot 10^{-9} T^{4}\right)$

$+S^{3 / 2}\left(-5,72466 \cdot 10^{-3}+1,0227 \cdot 10^{-4} T-1,6546 \cdot 10^{-6} T^{2}\right)+4,8314 \cdot 10^{-4} S^{2}$

Lopulta, tiheys $\rho$ voidaan kirjoittaa paineessa $p$

$\rho(S, T, p)=\frac{\rho(S, T, 0)}{1-p / K(S, T, p)}$

missä $K$ on sekanttinen tilavuusmoduuli. Makean veden $(S=0)$ tapauksessa saadaan $K$ :Ile $K=K_{\mathrm{w}}$,

$K_{w}=19.652,21+148,4206 T-2,327105 T^{2}+1,360477 \cdot 10^{-2} T^{3}-5,155288 \cdot 10^{-5} T^{4}$

Seuraavaksi saadaan $K: \mathrm{n}$ arvo, kun paine $p=0$

$K(S, T, 0)=K_{w}+S\left(54,6746-0,603459 T+1,09987 \cdot 10^{-2} T^{2}-6,1670 \cdot 10^{-5} T^{3}\right)+$

$S^{3 / 2}\left(7,944 \cdot 10^{-2}+1,6483 \cdot 10^{-2} T-5,3009 \cdot 10^{-4} T^{2}\right)$

Lopulta, $\mathrm{K}$ voidaan kirjoittaa paineessa $\mathrm{p}$

$K(S, T, p)=K(S, T, 0)+p\left(3,239908+1,43713 \cdot 10^{-3} T+1,16092 \cdot 10^{-4} T^{-2}-5,77905 \cdot 10^{-7} T^{3}\right)$

$+p S\left(2,2838 \cdot 10^{-3}-1,0981 \cdot 10^{-5} T-1,6078 \cdot 10^{-6} T^{2}\right)+1,91075 \cdot 10^{-4} p S^{3 / 2}$

$+p^{2}\left(8,50935 \cdot 10^{-5}-6,12293 \cdot 10^{-6} T+5,2787 \cdot 10^{-8} T^{2}\right)+p^{2} S\left(-9,9348 \cdot 10^{-7}\right.$

$\left.+2,0816 \cdot 10^{-8} T+9,1697 \cdot 10^{-10} T^{2}\right)$

Arvoja, joilla yhtälöä voi testata:

$\rho(0,5,0)=999,96675, \rho(35,5,0)=1027,67547$ ja $\rho(35,25,1000)=1062,53817$

Meriveden jäätymispiste $T_{j}$

$T_{\mathrm{f}}=-0,0575 S+1,710523 \cdot 10^{-3} S^{1.5}-2,154996 \cdot 10^{-4} S^{2}-7,53 \cdot 10^{-3} p$ 


\section{Vesitase ja lämpötalous}

\subsection{Sää ja ilmasto}

\subsubsection{Yleinen ilmastotyyppi}

Itämeri sijaitsee länsituulivyöhykkeen subarktisella reunalla, jossa ilmastoa hallitsevat merellinen Pohjois-Atlantilta tuleva länsivirtaus, mantereinen Venäjän ilmasto, ja polaarinen vyöhyke pohjoisessa. Vuodenaikaisvaihtelu ja vuosien välinen vaihtelu ovat suuria. Kesällä Itämeren pintaveden lämpötila on $20^{\circ} \mathrm{C}$ tuntumassa, mutta talvella ainakin pohjoisilta ja itäisiltä osiltaan meri jäätyy. Länsivirtaus on voimakkaimmillaan lokakuusta helmikuulle ja heikoimmillaan huhtikuusta kesäkuulle. Polaaririntama on kesällä Itämeren pohjoispuolella, mutta talvella se yleensä ulottuu Itämerelle asti. Lämpiminä kesinä ja kylminä talvina ilmanpainekenttä on keskimäärin normaalia tasaisempi ja tuulet heikompia, ja yleisesti esiintyy lukkiutuneita korkeapainetilanteita [blocking high], joissa säätila pysyy vakaana useitakin viikkoja.

Länsivirtauksen voimakkuutta kuvataan $N A O-$ indeksillä (North Atlantic Oscillation). Sillä tarkoitetaan Azorien (Ponta Delgada) ja Islannin (Stykkisholmur) välistä ilmapaine-eroa. NAO-indeksi on positiivinen, kun etelässä on korkeapaine ja pohjoisessa matalapaine. Tällöin Itämeren alueella vallitsevat lauhat länsituulet. Matalapaineita eli sykloneita esiintyy merkittävästi ja ne kuljetta-

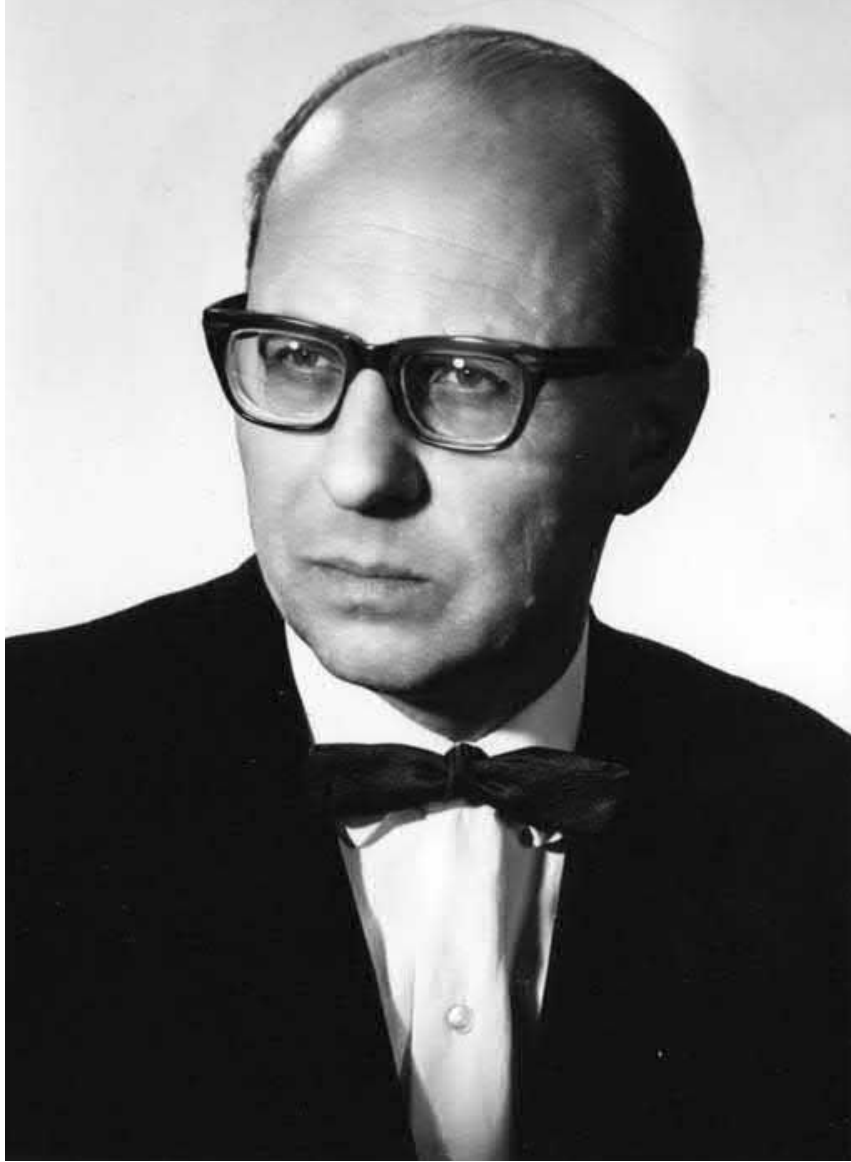

Kuva 5.0. Ilmo Helan (1915-1976) tieteellinen työ keskittyi virtausten, vedenkorkeuden ja meri-ilmakehä -vuorovaikutusten tutkimuksiin. Helan johtajakauden (1955-1975) alussa aloitettiin Merentutkimuslaitoksessa biologiset tutkimukset. Uutena kohteena otettiin mukaan ympäristötutkimukset. Hela oli kansainvälisestä yhteistyöstä ja tutkimuspolitiikasta kiinnostunut. Hän toimi Kansainvälisen Atomienergiajärjestön (IAEA) merentutkimuslaboratorion johtajana Monacossa sekä Suomen UNESCO-toimikunnan puheenjohtajana ja UNESCO:n hallitusneuvoston jäsenenä. (Merentutkimuslaitoksen kuva-arkisto)

vat mukanaan suuria lämpömääriä, jotka tasoittavat etelän ja pohjoisen lämpötilaeroja. Myös Pohjois-Atlantin virran (Golf-virran) vaikutus pääsee korostumaan, kun tuulet kuljettavat Pohjois-Atlantilta lämpöä itään päin. NAO-indeksin ollessa negatiivinen pohjoisessa on korkeapaine ja etelässä matalapaine. Tällöin meillä vallitsevat idän ja pohjoisen väliset tuulet, ja talvikuukausien keskilämpötilat ovat sangen alhaisia. 
Itämeren alueen ilmastossa on varsin huomattavia paikallisia eroja. Pohjoisosat ovat polaaririntaman tuntumassa, ja ilmasto on tyypiltään lähellä mannerilmastoa, jossa kesän ja talven välillä vallitsevat suuret lämpötilaerot. Pohjoisesta purkautuu arktista ilmaa, jolloin talvet ovat kylmiä ja melko kuivia. Itämeren etelä- ja lounaisosat kuuluvat ilmastollisesti Keski-Euroopan lauhkeaan vyöhykkeeseen, jossa vuoden sisäiset lämpötilaerot ovat paljon pienempiä kuin pohjoisessa ja jossa lauhat lounaistuulet ovat vallitsevia. Itämeren keskiosissa esiintyy tilanteesta riippuen kumpaakin edellä mainittua ilmastotyyppiä. Voidaankin sanoa klassisen meteorologian sanoin, että Itämeren ilmasto vaihtelee polaaririntaman täsmällisen sijainnin mukaan.

Korkeille leveysasteille on ominaista myös voimakas lämmönluovutus talvella merestä ilmakehään ja vastaavasti lämmönsiirto eteläisiltä leveyksiltä pohjoiseen. Itämereenkin kertyy kesällä merkittävästi lämpöä, joka vapautuu talvella. Lämmönsiirto etelästä tapahtuu ilmakehässä polaaririntamaan syntyneiden matalapaineiden välityksellä. Itämeren alueen matalapaineet syntyvät juuri tämän polaaririntaman yhteyteen ilman lämpötilajakaumaan liittyvän barokliinisen instabiliteetin seurauksena (katso Holton 1979). Meressä taas Golf-virta tuo lämmintä vettä pohjoiseen pitkin Norjan rannikkoa, mutta suoraan Itämereen tämä kuljetus ei pääse matalan Pohjanmeren kattavan mannerjalustan ja ahtaiden Tanskan salmien läpi. Sen sijaan lämpöä pääsee kulkemaan Atlantilta Itämerelle ilmakehän kautta matalapainetoiminnan ansiosta. Tuloksena on sangen leuto pohjoinen ilmastoalue - itse asiassa missään muualla maapallolla ei näin pohjoisessa ilmasto sovi maanviljelykseen.

Taulukossa 5.1 on perustietoa Itämeren alueen keskimääräisistä kuukausittaisista ilmasto-oloista. Itämeri ja alueellinen ilmasto ovat jatkuvassa vuorovaikutuksessa. Syksyllä ja talvella meri on ilmaa lämpimämpi. Ilmakehän rajakerroksen kerrostuneisuus on epästabiili ja tuulet ovat voimakkaita, minkä ansiosta turbulenttiset lämpövuot ovat suuria ja meri jäähtyy nopeasti. Keväällä ja alkukesällä ilma on merta lämpimämpi ja tilanne on päinvastainen. Pilvisyydellä on säteilytaseen kautta huomattava vaikutus lämpötilaan. Talven korkeapainejaksoina pilvettömällä ilmalla lämpötilat laskevat huomattavan alas pohjoisosissa. Keskimääräinen tuulen suunta on Kemissä kaakko-lounas -sektorissa ja Utössä etelä-länsi -sektorissa.

\subsubsection{IIman lämpötila}

Talvella ilman keskilämpötila vaihtelee paljon Itämeren alueella meren jäätymisen takia (taulukko 5.1; kuva 5.1). Pohjoisessa se on -10 ja $-12{ }^{\circ} \mathrm{C}$ välillä, kun taas avoveden tuntumassa lämpötila on vain muutaman asteen pakkasen puolella. Gotlannin altaalla, missä meri on normaalitalvina jäätön, ilman keskilämpötila on $0-2{ }^{\circ} \mathrm{C}$. Yleisesti avoveden ja ohuen jääpeitteen reunustamilla rannikoilla lämpötila on meren lämmittävän vaikutuksen takia useita asteita korkeampi kuin sisämaassa. Huhtikuussa lämpötilat ovat jo nousseet auringonsäteilyn vuoksi huomattavasti, ja lisäksi ero pohjoisen ja etelän välillä on pienentynyt. Pohjoisessa ilman keskilämpötila on $0^{\circ} \mathrm{C}$ tuntumassa, kun meressä on vielä jäätä, keskiosissa se on noin $2^{\circ} \mathrm{C}$ ja aivan etelässä jo $5-6^{\circ} \mathrm{C}$. Suomea etelämpänä ilma on maa-alueilla muutaman asteen meren yläpuolista ilmaa lämpimämpää, koska auringonsäteily lämmittää lumetonta maanpintaa tehokkaasti. Sen sijaan pohjoisessa tätä eroa ei vielä ole, koska maa on sulamistilassa olevan lumen peitossa.

Kesällä ilman lämpötila on Itämeren alueella tasaisempi kuin talvella; heinäkuussa keskilämpötila on $12-17^{\circ} \mathrm{C}$. Pohjoisessa vuoden sisäinen lämpötila-amplitudi on paljon etelää suurempi. Kesällä on kylmintä avomerellä ja lämpimintä sisämaassa; silloin lämmin ilma luovuttaa lämpöä kylmempään mereen. Syyskuussa tilanne on 
Taulukko 5.1. Normaalikauden 1961-1990 ilmastotietoa kolmelta Itämeren alueen sääasemalta: Kemi lentokenttä ( $\left.65^{\circ} 47^{\prime} \mathrm{N} 24^{\circ} 35^{\prime} \mathrm{E}\right)$, Utö $\left(59^{\circ} 47^{\prime} \mathrm{N} 21^{\circ} 23^{\prime} \mathrm{E}\right)$ ja Swinoujscie $\left(53^{\circ} 52^{\prime} \mathrm{N} 14^{\circ} 10^{\prime} \mathrm{E}\right)$. Suomen asemien tiedot ovat IImatieteen laitoksen (1991) mukaan. Swinoujscien lähteet ovat seuraavat: Mietus ja Owczarek (1994) - ilman lämpötila, sademäärä ja tuulen nopeus, Kwiecien (1987) - pilvisyys (1951-1970) ja ilman kosteus (1956-1980).

\begin{tabular}{|l|l|l|l|l|l|l|}
\hline Kemi & Lämpötila & Sademäärä & Pilvisyys & Ilman kosteus & Tuuli & \multicolumn{1}{l|}{} \\
\hline & $\left({ }^{\circ} \mathrm{C}\right)$ & $\mathrm{mm}$ & $1 / 8$ & $\%$ & $\mathrm{~m} / \mathrm{s}$ & suunta \\
\hline Tammikuu & $-12,4$ & 32,3 & 5,6 & 86 & 3,7 & 165 \\
\hline Helmikuu & $-11,5$ & 25,8 & 5,7 & 86 & 3,7 & 171 \\
\hline Maaliskuu & $-6,9$ & 28,7 & 5,5 & 84 & 3,8 & 168 \\
\hline Huhtikuu & $-0,5$ & 26,1 & 5,3 & 77 & 3,9 & 153 \\
\hline Toukokuu & 6,1 & 30,3 & 5,1 & 70 & 3,8 & 163 \\
\hline Kesäkuu & 12,5 & 39,2 & 5,0 & 68 & 3,8 & 235 \\
\hline Heinäkuu & 15,2 & 52,2 & 5,0 & 72 & 3,7 & 201 \\
\hline Elokuu & 13,0 & 63,4 & 5,4 & 79 & 3,7 & 150 \\
\hline Syyskuu & 7,9 & 58,1 & 5,8 & 84 & 3,9 & 194 \\
\hline Lokakuu & 2,3 & 59,9 & 5,9 & 86 & 4,2 & 194 \\
\hline Marraskuu & $-4,5$ & 44,8 & 5,9 & 89 & 3,9 & 164 \\
\hline Joulukuu & $-9,9$ & 33,0 & 5,5 & 88 & 3,8 & 173 \\
\hline
\end{tabular}

\begin{tabular}{|l|l|l|l|l|l|l|}
\hline Utö & Lämpötila & Sademäärä & Pilvisyys & Ilman kosteus & Tuuli \\
\hline & $\left({ }^{\circ} \mathrm{C}\right)$ & $\mathrm{mm}$ & $1 / 8$ & $\%$ & $\mathrm{~m} / \mathrm{s}$ & suunta \\
\hline Tammikuu & $-2,1$ & 33,1 & 6,3 & 85 & 7,9 & 244 \\
\hline Helmikuu & $-3,5$ & 21,5 & 6,0 & 87 & 6,9 & 198 \\
\hline Maaaliskuu & 1,7 & 23,5 & 5,4 & 86 & 6,5 & 193 \\
\hline Huhtikuu & 1,9 & 28,9 & 5,2 & 85 & 5,8 & 237 \\
\hline Toukokuu & 6,7 & 28,3 & 4,3 & 81 & 5,3 & 205 \\
\hline Kesäkuu & 12,6 & 30,1 & 4,1 & 81 & 5,3 & 258 \\
\hline Heinäkuu & 15,9 & 46,7 & 4,6 & 82 & 5,3 & 254 \\
\hline Elokuu & 15,7 & 63,8 & 5,0 & 81 & 5,7 & 266 \\
\hline Syyskuu & 11,9 & 60,1 & 5,6 & 82 & 6,7 & 257 \\
\hline Lokakuu & 7,9 & 59,9 & 5,9 & 83 & 7,6 & 242 \\
\hline Marraskuu & 3,8 & 62,8 & 6,4 & 83 & 8,1 & 245 \\
\hline Joulukuu & 0,4 & 47,9 & 6,4 & 83 & 8,3 & 252 \\
\hline
\end{tabular}

\begin{tabular}{|l|l|l|l|l|l|l|}
\hline Swinoujscie & Lämpötila & Sademäärä & Pilvisyys & Ilman kosteus & Tuuli \\
\hline & $\left({ }^{\circ} \mathrm{C}\right)$ & $\mathrm{mm}$ & $1 / 8$ & $\%$ & $\mathrm{~m} / \mathrm{s}$ & suunta \\
\hline Tammikuu & $-0,6$ & 39 & 5,8 & 87 & 4,2 & - \\
\hline Helmikuu & 0,0 & 27 & 5,6 & 86 & 4,1 & - \\
\hline Maaliskuu & 2,7 & 37 & 4,8 & 82 & 4,3 & - \\
\hline Huhtikuu & 6,2 & 39 & 4,8 & 81 & 4,3 & - \\
\hline Toukokuu & 11,3 & 45 & 4,6 & 79 & 4,2 & - \\
\hline Kesäkuu & 15,1 & 53 & 4,3 & 79 & 3,9 & - \\
\hline Heinäkuu & 16,9 & 52 & 4,6 & 80 & 3,6 & - \\
\hline Elokuu & 16,9 & 55 & 4,6 & 80 & 3,7 & - \\
\hline Syyskuu & 13,8 & 52 & 4,1 & 82 & 3,6 & - \\
\hline Lokakuu & 9,6 & 45 & 5,0 & 86 & 3,7 & - \\
\hline Marraskuu & 4,7 & 51 & 5,9 & 88 & 4,2 & - \\
\hline Joulukuu & 1,1 & 48 & 6,0 & 88 & 4,1 & - \\
\hline
\end{tabular}


taas kääntynyt päinvastaiseksi. Ilman keskilämpötila meren yläpuolella vaihtelee tällöin etelän $13^{\circ} \mathrm{C}$ ja pohjoisen $8{ }^{\circ} \mathrm{C}$ välillä ja on korkeampi kuin mantereilla, sillä nyt meri luovuttaa lämpöä ilmaan. Keväinen hidas lämpeneminen ja syksyinen hidas jäähtyminen näkyvät merellisessä ympäristössä myös kasvukauden käynnistymisen ja päättymisen myöhentymisessä mantereisiin olosuhteisiin verrattuna.

Itämeren alueen sadannasta suurin osa liittyy matalapainetoimintaan eli kyse on rintamasateista. Osa sateista on kuurotyyppisiä. Varsinkin keväällä ja alkukesällä kylmä Itämeri estää tehokkaasti kuuropilvien synnyn, mutta syksyllä ja alkutalvella tilanne on päinvastainen. Itämeren alueen sadannan määrittäminen on pysynyt ongelmallisena tähän päivään asti. Säähavaintoasemat sijaitsevat yleensä rannikoilla, eikä edustavia merellisiä havaintoja ole kuin joiltakin saarilta ja laivoilta. Säätutkaverkoston kattavuuden laajeneminen on kuitenkin jossain määrin parantamassa tilannetta, sillä tutkamittaukset ulottuvat avomerelle ja antavat kvalitatiivista tietoa sateiden esiintymisestä.

Itämeren etelärannikolla vuotuiset sademäärät ovat Puolan alueella yli $700 \mathrm{~mm}$ pienentyen länttä kohti (noin $500 \mathrm{~mm}$ ). Sademäärät ovat yleisesti Itämeren itärannikoilla suurimmillaan (kuva 5.2). Tämä johtuu länsi- ja lounaistuulien vallitsevuudesta sekä rannikoiden aiheuttamasta kitkasta, orografian aiheuttamasta ilman pakotetun noston vaikutuksesta sekä maanpinnan lämpenemisen aiheuttamasta termisestä konvektiosta rannikon lähellä. On huomattava myös, että Itämeren länsiosissa, varsinkin pohjoisessa, Köli-vuoriston yli tulleet matalapaineet ovat "kuivuneet" saapuessaan Itämerelle. Suomessa suurimmat vuosisademäärät saadaan maan lounaisosissa (noin $700 \mathrm{~mm}$ ). Pohjoista kohti luvut pienenevät ja ovat Selkämerellä 500-600 mm ja Perämerellä jopa alle $500 \mathrm{~mm}$. Ulkomerellä sademäärät ovat yleensä noin 400-500 mm/vuosi eli jonkin verran rannikoita pienempiä johtuen ilmeisesti konvektiivisten sateiden pienestä määrästä ja orografian vaihteluiden puuttumisesta.

Kuukausittaiset sademäärät vaihtelevat välillä 20-60 mm (taulukko 5.1). Ne ovat yleisesti ottaen matalimmillaan talvella ja keväällä sekä korkeimmillaan kesällä ja syksyllä (kuva 5.3). Talvisaikaan jää peittää osaa Itämerestä. Jäätyminen siirtää pintaveden kiinteään olomuotoon, ja sen jälkeen sadanta kumuloituu jään pinnalle vapautuakseen veteen vasta sulamiskautena.

\subsubsection{Tuuli}

Tuulten suunnat ja voimakkuudet johtuvat matalapaine- eli syklonitoiminnasta Itämeren alueella ja siihen liittyvistä ilmanpaineen vaihteluista (kuva 5.4). Talviajan (joulukuu-helmikuu) tuulissa näkyy yleensä voimakas matalapainetoiminta, joka aiheuttaa länsi-itä -tyyppiseen eli leveyspiirien suuntaisen kiertoliikkeen PohjoisEuroopassa ja tuulet ovat yleensä etelän ja lännen väliltä. Sen sijaan kylminä talvina pohjoisen puoleiset tuulet tuovat kylmää, arktista ilmaa pitkälle Etelä-Itämerelle asti. Talvella saavutetaan myös tuulennopeuden maksimi. Vuosina 19911999 talven keskituuli oli 8-10 m/s (Niros et al. 2003), joskin eri havaintoasemien väliset erot ovat suurimmillaan juuri talvella.

Keväällä (maaliskuu-toukokuu) tuulennopeudet ovat talvisia arvoja pienempiä, koska syklonitoiminta on heikohkoa ja ilmakehän rajakerros on stabiili, mikä pienentää pintatuulen nopeuksia. Keskituulennopeus on tällöin $6-8 \mathrm{~m} / \mathrm{s}$. Tuulten suuntajakaumaa hallitsevat edelleen etelän ja lännen väliset tuulet, mutta myös pohjoisen kylmän ilman purkauksiin ja keväisiin lämpimiin kaakkoistuuliin liittyviä tilanteita esiintyy. Kesällä (kesäkuu-elokuu) matalapainetoiminta on heikoimmillaan ja tuulennopeudet vastaavasti pienimillään: keskituulet ovat 6-7 m/s, ja tuulten suuntajakaumaa dominoivat lähinnä länsi- ja luoteistuulet. Silloin paikallis- 

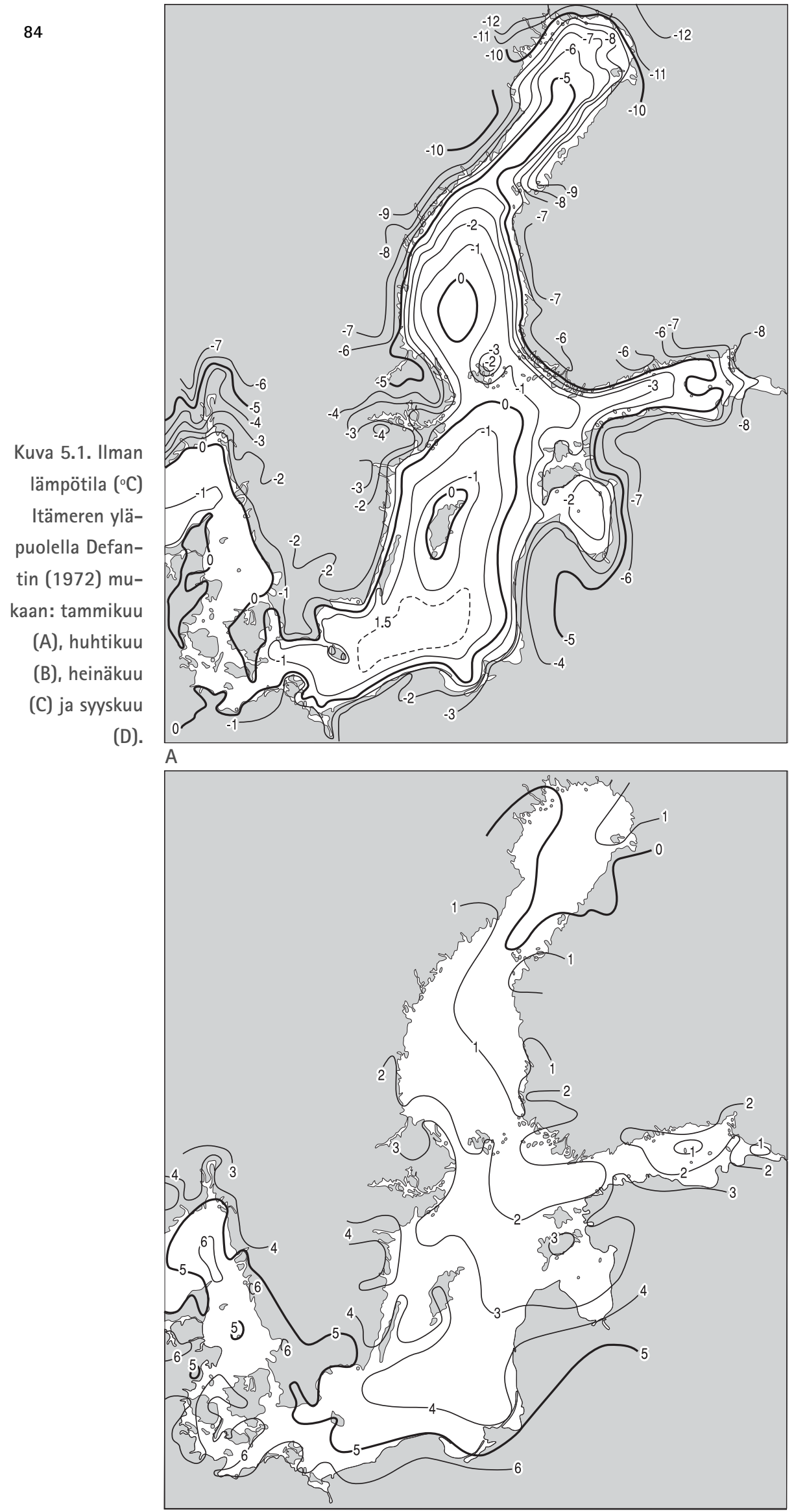


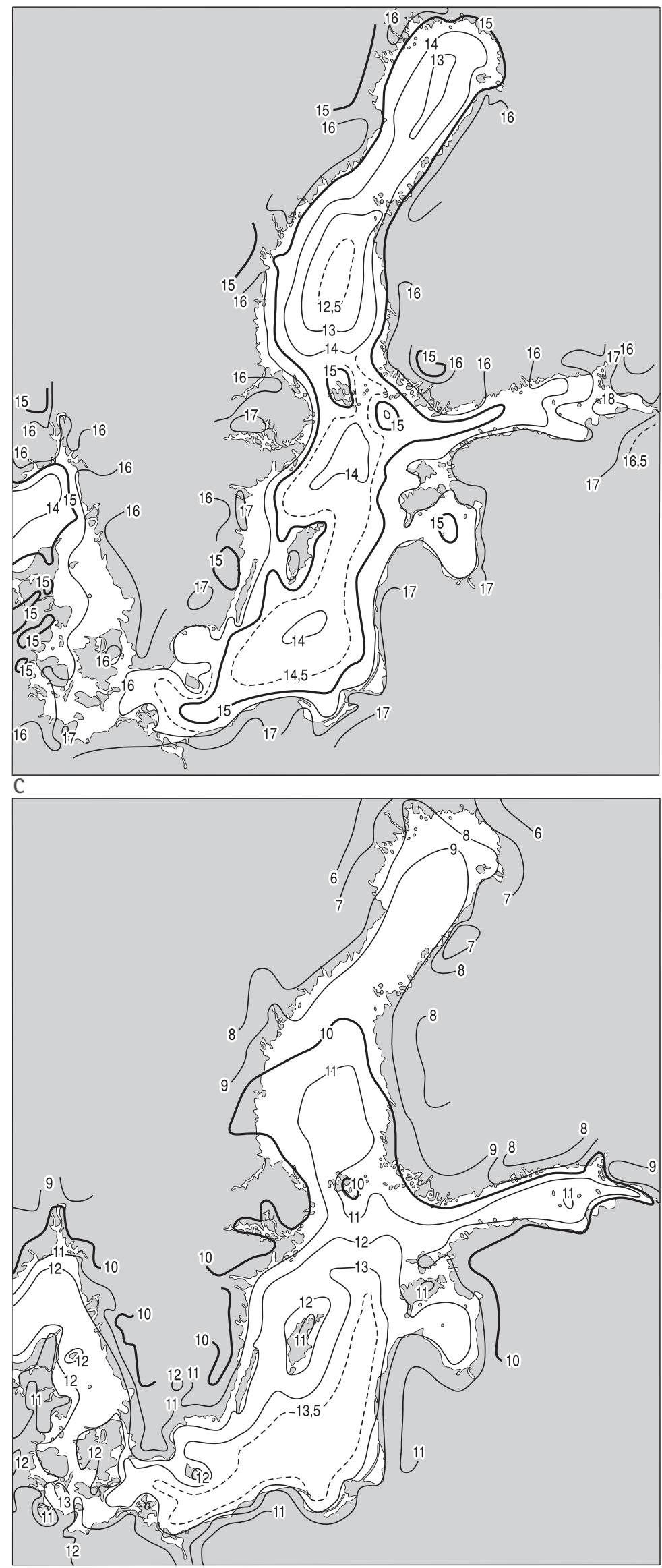




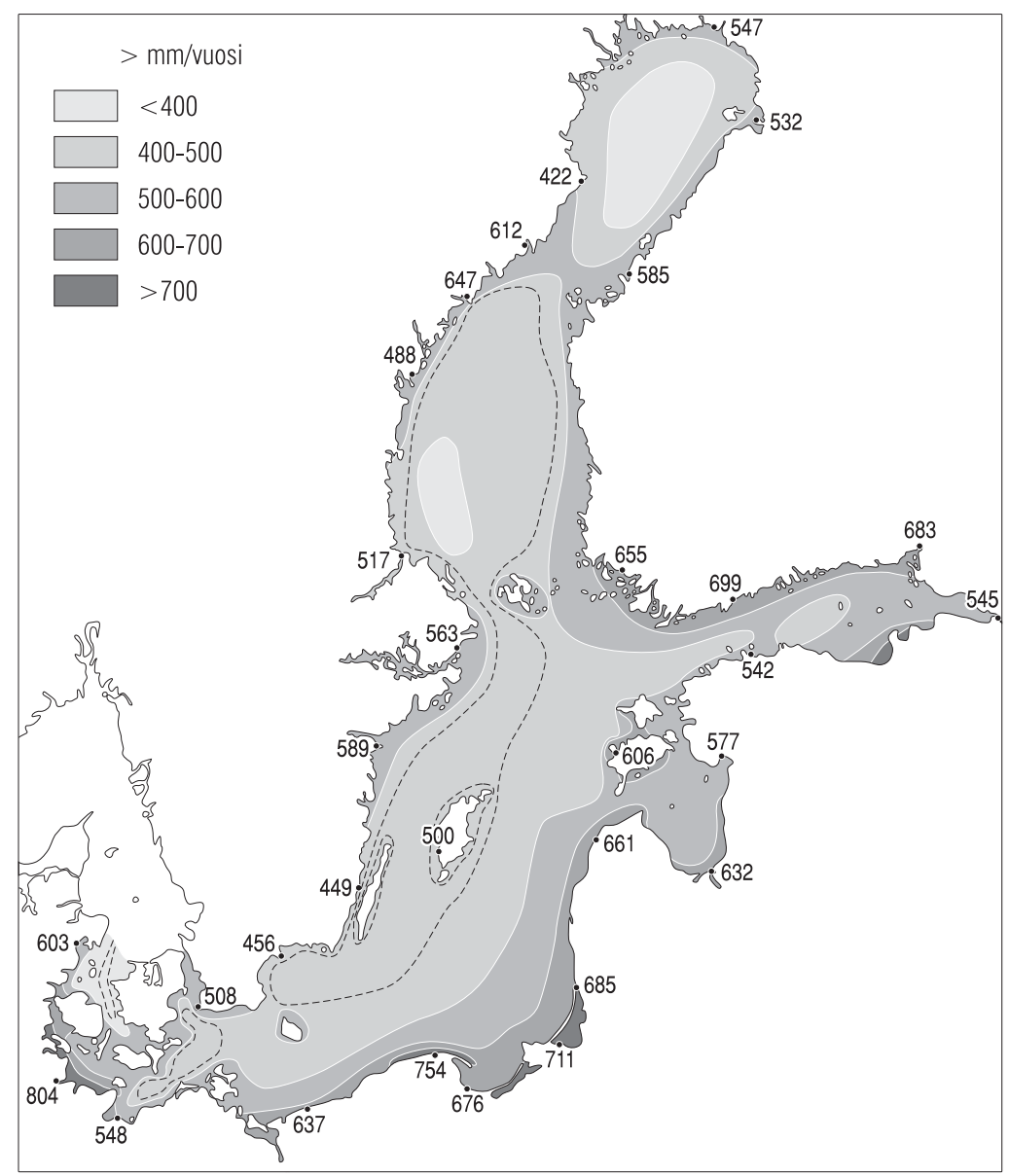

Kuva 5.2. Vuosisademäärän alueellinen jakauma Itämerellä. Katkoviiva kuvaa 450 $\mathrm{mm}: \mathrm{n}$ rajaa. (Piirretty Brogmusin [1952] mukaan.)

ten rannikonläheisten maa- ja merituulten osuus on merkittävä, minkä takia tuulennopeudella on huomattava vuorokauden sisäinen vaihtelu. Syksyllä (syyskuu-marraskuu) tuulennopeudet jälleen kasvavat matalapainetoiminnan voimistuessa talvisiin arvoihin, keskinopeus on $8-10 \mathrm{~m} / \mathrm{s}$ ja suunta yleensä etelän ja lännen väliltä.

Keskituuli antaa sinänsä yleiskuvan tuulten voimakkuudesta, muttei vielä kerro vaihtelusta. Suurimmat tuulennopeudet ovat yli $30 \mathrm{~m} / \mathrm{s}$ ja niitä on havaittu marras-tammikuussa avomerellä, jossa rannikoiden aiheuttaman kitkan vaikutus on vähäisin. Kuitenkin suurten tuulennopeuksien osuus kaikista tuulitilanteista on varsin pieni: yli $17 \mathrm{~m} / \mathrm{s}$ puhaltavien tuulten osuus on alle $5 \%$, ja välillä $11-17 \mathrm{~m} / \mathrm{s}$ olevia nopeuksia on $20-25 \%$. Yli $50 \%$ havainnoista osuu välille $5-9 \mathrm{~m} / \mathrm{s}$, ja heikkoja tuulia $(0-3 \mathrm{~m} / \mathrm{s})$ on noin $15 \%$. Verrattaessa merellisiä olosuhteita järviimme tuulen nopeuksissa on sangen huomattava ero.

\subsubsection{Pilvisyys ja auringonsäteily}

Pilvisyyden kuukausikeskiarvot ovat Itämeren alueella 4/8-6/8 (taulukko 5.1). Suurimmillaan pilvisyys on syksyllä ja talvella ja pienimmillään kesällä. Pohjoisessa kuukausikeskiarvojen vaihteluväli on pienempi (1/8) kuin muualla (2/8). 


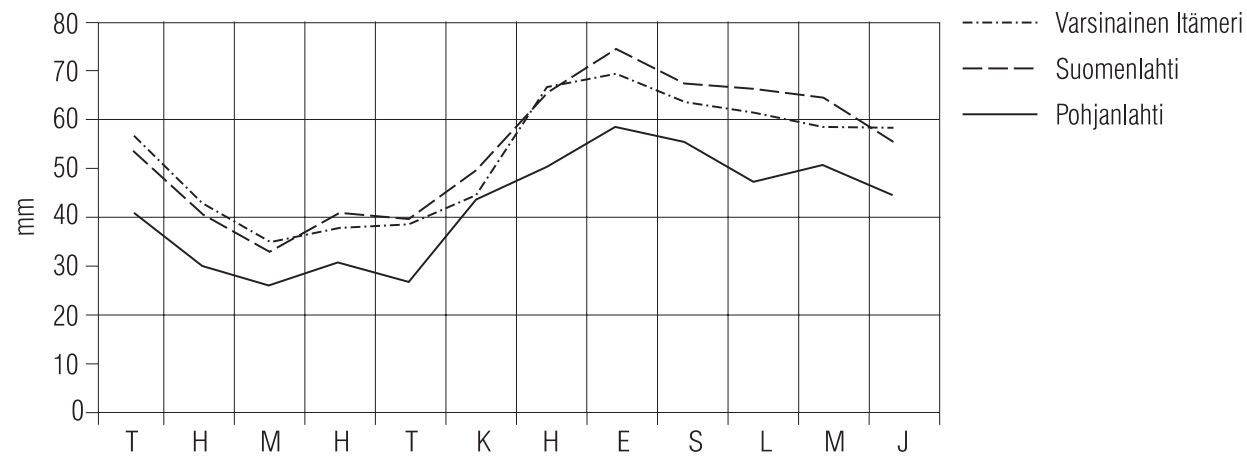

Kuva 5.3. Sateen vuodenaikaisvaihtelu eri merialueilla (piirretty Dahlströmin (1977) mukaan).

Joillakin säähavaintoasemilla tehdään suoria auringonsäteilyn mittauksia, mutta Itämeren merialueella ei kuitenkaan ole hyviä laatuvarmistettuja säteilyasemia. Suomessa lähimmät ovat Helsinki, jossa tosin on paikallisia ilmakehän sameusefektejä, sekä Jokioinen (taulukko 5.2). Tulevan säteilyn keskiarvo on pienimmillään joulukuussa $\left(6 \mathrm{~W} / \mathrm{m}^{2}\right)$ ja suurimmillaan kesäkuussa $\left(249 \mathrm{~W} / \mathrm{m}^{2}\right)$. Pilvisyyden kuukausikeskiarvo on Jokioisissa välillä 4,9-6,7, pienimmillään kesällä. Säteilystä tulee osa suorana säteilynä ja osa hajasäteilynä. Suoraa säteilyä tulee enemmän silloin, kun taivas on pilvetön ja auringon korkeuskulma suuri. Kesäkuussa suoran säteilyn osuus on keskimäärin 62 \% kokonaissäteilystä. Hajasäteilyn osuus on taas suhteellisesti suurin talvella (75 $\%)$. Kun taivas on paksun pilviverhon peitossa, säteilyä tulee karkeasti ottaen yhtä paljon kaikista suunnista.

Auringonsäteilyä voidaan arvioida laskennallisesti ajan, paikan ja sääolojen perusteella. Kaavat ovat muotoa

$Q_{\mathrm{s}}=T_{\mathrm{tr}}(\theta, e) \sin \theta F(N, \theta)\left(r_{\mathrm{o}} / r\right)^{2} Q_{\mathrm{sc}}$

missä $T_{\text {tr }}$ on kirkkaan ilmakehän läpäisykerroin, $\theta$ on auringon korkeuskulma, $e$ on ilman vesihöyrynpaine, $F$ kuvaa pilvisyyden $N$ vaikutusta, $r$ on aktuaalinen ja $r_{\mathrm{o}}$ keskimääräinen maapallon etäisyys auringosta, ja $Q_{\mathrm{sc}}=1,37 \mathrm{~kW} / \mathrm{m}^{2}$ on $a u$ -

Taulukko 5.2. Aurigonsäteilyn keskiarvo Jokioisten havaintoasemalla (6049'N 23³0'E) vuosina 1971-1980. (Ilmatieteen laitos 1982)

\begin{tabular}{|l|l|l|l|}
\hline \multirow{2}{*}{ Kuukausi } & Kokonaissäteily & Hajasäteily & Pilvisyys \\
\cline { 2 - 4 } & $\mathbf{W} / \mathrm{m}^{2}$ & $\%$ & $1 / 8$ \\
\hline Tammikuu & 10 & 74 & 6,4 \\
\hline Helmikuu & 36 & 63 & 6,0 \\
\hline Maaliskuu & 91 & 50 & 5,5 \\
\hline Huhtikuu & 150 & 46 & 5,6 \\
\hline Toukokuu & 218 & 39 & 5,1 \\
\hline Kesäkuu & 249 & 38 & 4,9 \\
\hline Heinäkuu & 212 & 44 & 5,3 \\
\hline Elokuu & 170 & 44 & 5,6 \\
\hline Syyskuu & 94 & 51 & 5,9 \\
\hline Lokakuu & 44 & 56 & 6,2 \\
\hline Marraskuu & 14 & 66 & 6,7 \\
\hline Joulukuu & 6 & 75 & 6,5 \\
\hline
\end{tabular}




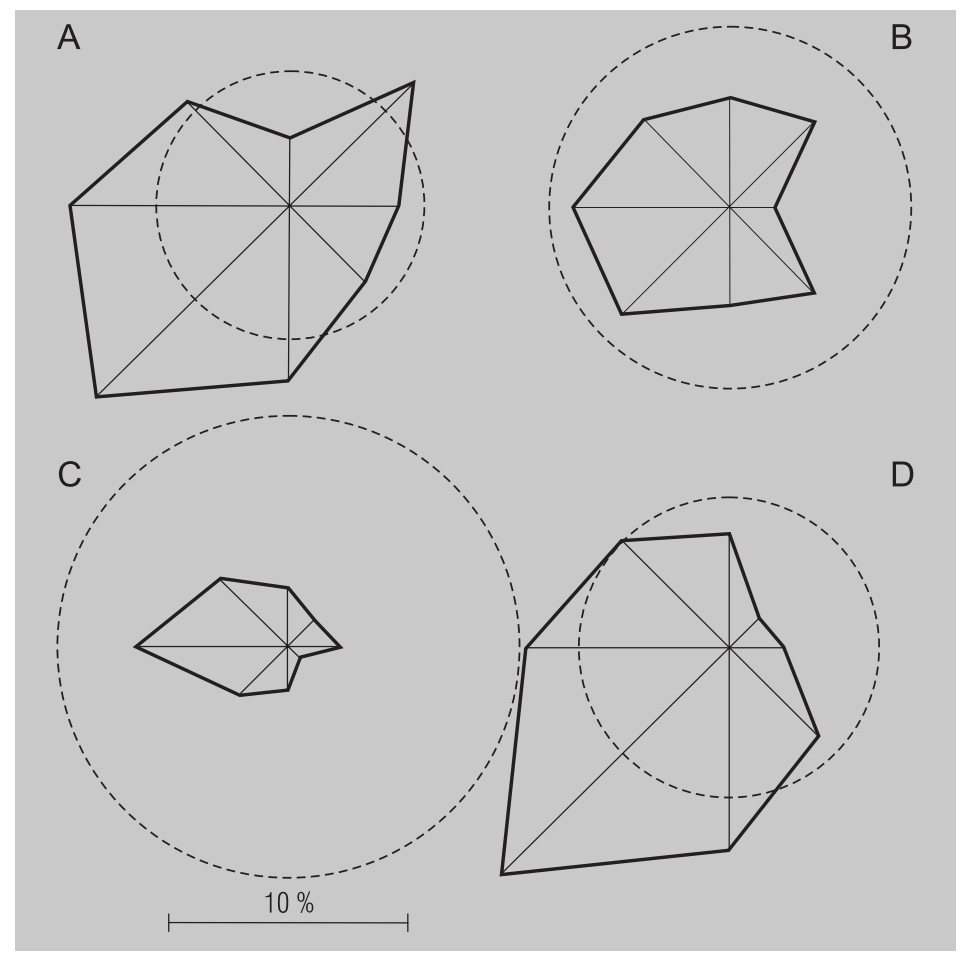

Kuva 5.4. Tuulen suuntajakauma prosentteina Gotlannin altaalla. Kuvassa on huomioitu vain yli $5 \mathrm{~m} / \mathrm{s}$ suuruiset tuulet. A) Talvi, B) Kevät, C) Kesä ja D) Syksy. (Mälkki ja Tamsalu 1985)

rinkovakio eli auringosta kohtisuoralle pinnalle tuleva säteily ilmakehän ulkopuolella kun $r=r_{0}$. Astronomiset kaavat on annettu tämän luvun lopussa. Kirkkaalla ilmalla $F-1$ ja täysin pilvisellä säällä on $F-0,1$.

Zillmanin (1972) kirkkaan ilman läpäisykerroin ja Reedin (1977) pilvisyyskorjaus ovat

$T_{t r}=\frac{\sin \theta}{1,085 \sin \theta+e(2,7+\sin \theta) \cdot 10^{-3}+0,01}$

$F=1-0,632 N+0,0019 \cdot \theta$

Alemmassa kaavassa korkeuskulma on otettava asteina. Näiden avulla voidaan myös konstruoida korjauskaavoja suorien mittauksien soveltamiseksi maa-asemilta läheisille merialueille; korjaukseen tarvitaan pilvisyys, ilman kosteus sekä auringon korkeuskulma merellä ja vertailuasemalla.

Auringonsäteilystä meren pinnasta takaisin lähtevää osuutta $Q_{\mathrm{r}}$ kuvataan albedolla $\alpha, Q_{\mathrm{r}}=$ $\alpha Q_{s}(0 \leq \alpha \leq 1)$. Tämä osuus sisältää pinnasta heijastuneen säteilyn sekä meren pintakerroksesta takaisin siroavan säteilyn. Perusarvona käytetään yleensä $\alpha=7 \%$ vesipinnalle, $50 \%$ kuivalle jäänpinnalle ja $85 \%$ kuivalle, puhtaalle lumipinnalle. Albedo on näennäinen optinen ominaisuus, joka kohteen lisäksi riippuu myös tulevan säteilyn suuntajakautumasta ja siis auringon korkeuskulmasta ja pilvisyydestä. Osa $(1-\alpha) Q_{s}$ tulevasta säteilystä jää mereen. Ainoastaan näkyvä valo tunkeutuu veteen metriä syvemmälle veteen, kun taas ultravioletti- ja infrapunasäteily imeytyvät hyvin lähellä pintaa. 


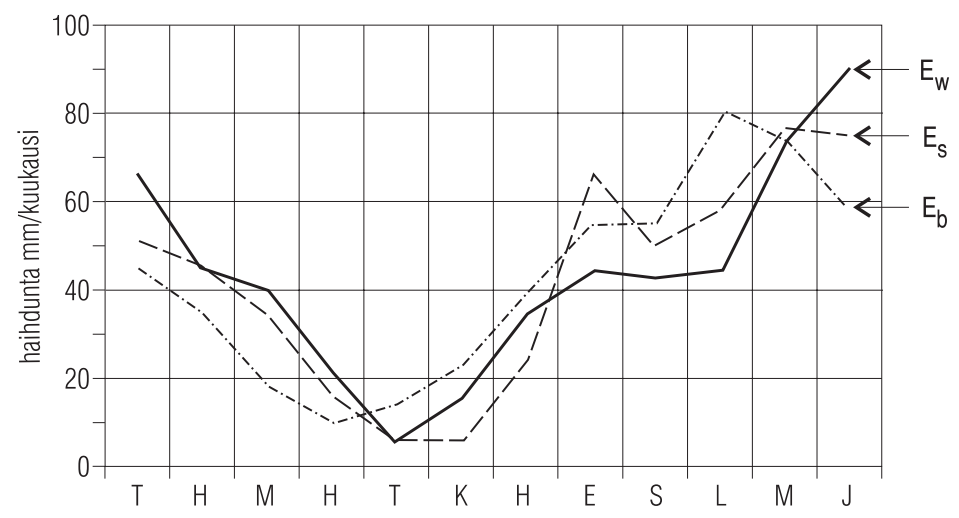

Kuva 5.5. Haihdunnan kuukausiarvot Gotlannin altaalla kolmen eri arvion mukaan (piirretty Ehlinin (1981) mukaan): $E_{w}$ - Palmén ja Söderman (1966), $E_{s}$ - Simojoki (1949), $E_{b}$ - Brogmus (1952).

\subsection{Meren ja ilmakehän välinen veden ja lämmön vaihto}

\subsection{Haihdunta}

Yleisimpien arvioiden mukaan haihdunta on Itämeren alueella vuositasolla $400-500 \mathrm{~mm}$, mikä on jossain määrin vähemmän kuin sademäärä. Kuukausiarvot vaihtelevat välillä 10-80 mm (kuva 5.5). Keskimäärin näyttää siltä, että haihdunnan minimi on keväällä, jolloin meri on kylmä ja tuulet heikkoja. Maksimi on loppusyksystä voimakkaiden tuulten aikana, jolloin turbulenttinen lämmön ja kosteuden vaihto on intensiivistä. Etelässä haihtuminen on suurempaa kuin pohjoisessa johtuen korkeammista meren pintalämpötiloista ja jääpeitteen lyhyemmästä kestoajasta. Talvella haihduntaa tapahtuu myös jään pinnalta, mutta kylmissä säissä ilman absoluuttinen kosteus on aina pieni ja siksi haihdunnankin määrä pysyy pienenä.

Haihdunnan suora mittaus on merioloissa hyvin hankalaa, ja siksi sen arvioimiseksi yleensä käytetään epäsuoria menetelmiä. Näitä ovat aerodynaaminen menetelmä, aerologinen menetelmä ja energiatasemenetelmä. Haihdunta $(E)$ ilmaistaan millimetreinä kuten sademäärä.
Aerodynaaminen menetelmä perustuu turbulenttisen rajakerroksen teoriaan. Niin sanottu bulkkikaava perustuu tuulen nopeuteen sekä ilman ja merenpinnan väliseen kosteuseroon

$\rho E=\rho_{\mathrm{a}} L_{\mathrm{E}} C_{\mathrm{E}}\left(q_{\mathrm{o}}-q_{\mathrm{a}}\right) U_{\mathrm{a}}$,

missä $\rho_{\mathrm{a}}$ on ilman tiheys, $L_{\mathrm{E}}$ on veden höyrystymislämpö, $C_{\mathrm{E}} \approx 1,3 \cdot 10^{-3}$ on kosteuden turbulenttinen vaihtokerroin, $q_{\mathrm{o}}$ ja $q_{\mathrm{a}}$ ovat ilman ominaiskosteudet veden pinnassa ja ilmassa (2 metrin korkeudella), ja $U_{\mathrm{a}}$ on tuulen nopeus (10 metrin korkeudella). Ilman tiheys saadaan tilayhtälöstä $\rho_{\mathrm{a}}=p_{\mathrm{a}} /\left(R_{\mathrm{a}} \underline{T}\right), p_{\mathrm{a}}$ on ilmanpaine, $R_{\mathrm{a}}$ on ilman kaasuvakio, ja $T$ on absoluuttinen lämpötila $^{1}$. Kun $\underline{T}=273,15 \mathrm{~K}\left(T=0^{\circ} \mathrm{C}\right)$, on ilman tiheys $\rho_{\mathrm{a}} \approx 1,3 \mathrm{~kg} / \mathrm{m}^{3}$.

Ominaiskosteus tarkoittaa ilmassa olevan vesihöyryn suhteellista massaa. Vesihöyryä voi olla korkeintaan kyllästyskosteuden $q_{\mathrm{s}}=q_{\mathrm{s}}(T)$ verran (katso kaavaliite tämän luvun lopussa). Kosteuden kuvaamiseen käytetään myös vesihöyrynpainetta $e, q=0,622 e / p$, joka kuvaa vesihöyryn osuutta ilmanpaineessa. Suhteellinen kosteus,

${ }^{1}$ Eräissä termodynaamisissa laskelmissa käytetään tässä esityksessä lämpötilan Kelvin-asteikkoa Celcius-asteikon asemasta. Tällöin lämpötilan symboli $T$ alleviivataan ( $(\underline{D})$. 
Taulukko 5.3. Lämpötaloustarkastelun vakiot ja vakioina pidettävät suureet.

\begin{tabular}{|l|l|l|}
\hline Suure & Symboli & Arvo \\
\hline Stefan-Boltzmannin vakio & $\sigma$ & $5,67 \cdot 10^{-8} \mathrm{~W} /\left(\mathrm{m}^{2} \mathrm{~K}\right)$ \\
\hline Aurinkovakio & $Q_{\mathrm{so}}$ & $1,37 \mathrm{~kW} / \mathrm{m}^{2}$ \\
\hline - optisen kaistan osuus & $\gamma$ & 0,50 \\
\hline Veden tiheys & $\varrho$ & $1.005 \mathrm{~kg} / \mathrm{m}^{3}$ \\
\hline Veden ominaislämpö & $c$ & $4,2 \mathrm{~kJ} /\left(\mathrm{kg}{ }^{\circ} \mathrm{C}\right)$ \\
\hline Veden/jään emissiviteetti & $\varepsilon$ & 0,97 \\
\hline Höyrystymislämpö & $L_{\mathrm{E}}$ & $2,5 \mathrm{MJ} / \mathrm{kg}$ \\
\hline Jäätymislämpö & $L$ & $335 \mathrm{~kJ} / \mathrm{kg}$ \\
\hline Jään tiheys & $\rho_{\mathrm{i}}$ & $910 \mathrm{~kg} / \mathrm{m}^{3}$ \\
\hline
\end{tabular}

joka yleensä ilmoitetaan säähavainnoissa, tarkoittaa puolestaan ilman kosteutta suhteessa kyllästyskosteuteen: $R=q / q_{\mathrm{s}}=e / e_{\mathrm{s}}$. Meren pinnassa voidaan olettaa suhteellisen kosteuden olevan $100 \%$ eli $q_{\mathrm{o}}=q_{\mathrm{s}}\left(T_{\mathrm{o}}\right)$, missä $T_{\mathrm{o}}$ on meren pintalämpötila. Kun tiedetään veden pintalämpötila, ilman kosteus ja tuulen nopeus, voidaan haihdunta laskennallisesti arvioida. Esimerkiksi jos $q_{\mathrm{o}}-q_{\mathrm{a}}=10^{-3}$ ja $U_{\mathrm{a}}=10 \mathrm{~m} / \mathrm{s}$, saadaan haihdunnan laskennalliseksi arvioksi $1,5 \mathrm{~mm}$ vuorokaudessa.

Energiatasemenetelmä perustuu haihdunnan arviointiin lämpötaseen jäännösterminä (residuaalina). Haihdunta kuluttaa energiaa määrän $Q_{\mathrm{e}}=\rho L_{\mathrm{E}} E$, missä $L_{\mathrm{E}}$ on veden haihtumislämpö, ja se on merkittävä osa meren lämpötaloutta. Tätä käsitellään kokonaisuudessaan seuraavassa alakohdassa. Aerologinen menetelmä tarkastelee tietyn suuren ilmatilavuuden vesihöyrytasetta, jolloin haihdunnan osuus tulee niinikään residuaalina mukaan.

\subsubsection{Meri-ilma -lämmönvaihto}

Merenpinnan lämpötaseeseen kuuluvat termit ovat tuleva ja lähtevä auringonsäteily $\left(Q_{s}\right.$ ja $\left.Q_{\mathrm{r}}\right)$, ilmakehän ja merenpinnan lämpösäteilyt $\left(Q_{\mathrm{La}}\right.$ ja $\left.Q_{\mathrm{Lo}}\right)$, aistittavan lämmön vaihto ilmakehän pintakerroksen kanssa $\left(Q_{c}\right)$, haihtumislämpö $\left(Q_{\mathrm{e}}\right)$ sekä sateen $(P)$ tuoma lämpö $\left(Q_{\mathrm{P}}\right)$. Se kirjoitetaan

$Q_{\mathrm{n}}=Q_{\mathrm{s}}-Q_{\mathrm{r}}+Q_{\mathrm{La}}-Q_{\mathrm{Lo}}+Q_{\mathrm{c}}+Q_{\mathrm{e}}+Q_{\mathrm{p}}$

missä $Q_{n}$ on netto lämpövuo. Summa $Q_{R}=Q_{\text {s }}$ $-Q_{\mathrm{r}}+Q_{\mathrm{La}}-Q_{\mathrm{Lo}}$ on pinnan säteilytase ja summa $Q_{c}+Q_{\mathrm{e}}$ on turbulenttinen lämmönvaihto. Auringonsäteilyä sanotaan myös lyhytaaltoiseksi säteilyksi ja ilmakehän sekä merenpinnan lämpösäteilyä pitkäaaltoiseksi säteilyksi, syystä että auringon lämpöenergia tulee pääosin spektrin kaistalta 0,3-3 $\mathrm{m}$, kun taas maapallon luonnonoloissa lämpösäteily tulee pääosin kaistalta 5-15 $\mu \mathrm{m}$. Lämpötaseen termejä voidaan suoraan mitata tai arvioida laskennallisilla kaavoilla. Tärkeällä sijalla ovat kaavat, jotka soveltuvat sääasemien rutiinihavaintoihin. Taulukossa 5.3 on lista lämpötalouslaskelmissa tarvittavista parametreista ja niiden sopivista arvoista. Näissä laskelmissa moni suure, kuten veden tiheys, voidaan ottaa vakiona.

Lämpötasetarkasteluissa auringon valo tulee energialähteeksi meren pintakerrokseen, kun 
taas muu osa säteilystä lisätään pinnan lämpötaseeseen. Valon osuutta kokonaissäteilystä merkitään tässä symbolilla $\gamma(\gamma \approx 50 \%)$, ja siis pintaan imeytyvä osuus on

$Q_{\mathrm{so}}=(1-\alpha)(1-\gamma) Q_{\mathrm{s}}$

Karkeammissa tarkasteluissa otetaan usein koko auringonsäteily pinnan lämpötaseeseen.

Merenpinnan lämpösäteily noudattaa harmaan kappaleen säteilylakia

$Q_{\mathrm{Lo}}=\varepsilon \sigma \underline{T}_{\mathrm{o}}^{4}$

missä $\varepsilon=0,96-0,98$ on emissiviteetti ja $\sigma=$ $5,67 \cdot 10^{-8} \mathrm{~W} /\left(\mathrm{m}^{2} \mathrm{~K}^{4}\right)$ on Stefan-Boltzmanin vakio. Ilmakehän lämpösäteilyn arviointi on vaikeata, sillä se tulee eri ilmakerroksista riippuen ilmakehän koostumuksesta. Käytännössä sovelletaan analogiapohjalta semi-empiiristä säteilylakia

$Q_{\mathrm{La}}=\varepsilon \varepsilon_{\mathrm{a}} \sigma \underline{T}_{\mathrm{a}}^{4}$

missä $\underline{T}_{\mathrm{a}}$ on ilman lämpötila ja $\varepsilon_{\mathrm{a}}$ on ilmakehän tehoisa emissiviteetti $\left(0 \leq \varepsilon_{a} \leq 1\right)$. Tämä riippuu ensi sijassa pilvisyydestä ja ilman kosteudesta; laajalti käytetty muoto on

$\varepsilon_{\mathrm{a}}=\varepsilon_{\mathrm{a}}(N, e)=\left(a+b e^{1 / 2}\right)\left(1+c N^{2}\right)$

missä sopivat empiiriset kertoimet ovat $a=0,68$, $b=0,036 \mathrm{mbar}^{-1 / 2}$ ja $c=0,18$.

Turbulenttiset lämmönvaihtotermit kirjoitetaan yleensä

$Q_{\mathrm{H}}=\rho_{\mathrm{a}} c_{\mathrm{p}} C_{\mathrm{H}}\left(T_{\mathrm{a}}-T_{\mathrm{o}}\right) U_{\mathrm{a}}$

$Q_{\mathrm{e}}=L_{\mathrm{E}} E=\rho_{\mathrm{a}} L_{\mathrm{E}} C_{\mathrm{E}}\left(q_{\mathrm{a}}-q_{\mathrm{o}}\right) U_{\mathrm{a}}$ missä $c_{\mathrm{p}}$ on ilman ominaislämpö vakiopaineessa ja $C_{\mathrm{H}} \approx C_{\mathrm{E}}$ on aistittavan lämmön vaihtokerroin.

Sateen mukana tuleva lämmitysteho on $Q_{\mathrm{P}}=$ $Q_{\mathrm{PS}}+Q_{\mathrm{PL}}$. Tässä ensimmäinen termi on aistittavan lämmön siirto $Q_{\mathrm{PS}}=\rho c P\left(T_{\mathrm{P}}-T_{\mathrm{o}}\right)$, missä $c$ on veden ominaislämpö, ja jälkimmäinen termi on olomuodon muutokseen liittyvä lämmönsiirto $Q_{\mathrm{PL}}= \pm \rho L P$. Esimerkiksi jos $P=10 \mathrm{~mm} / \mathrm{vrk}$ ja $T_{\mathrm{P}}-T_{\mathrm{o}}=5^{\circ} \mathrm{C}$, saadaan $Q_{\mathrm{PS}} \approx 2 \mathrm{~W} / \mathrm{m}^{2}$. Tämä ei ole paljon, mutta jos sade tulee eri olomuodossa kuin mitä pinta on, liittyy mahdollisiin olomuodon muutoksiin suuria lämpömääriä. Jos veteen sataisi lunta $10 \mathrm{~mm} / \mathrm{vrk}$, olomuodon muutos jäähdyttäisi vettä teholla $\rho L P=30 \mathrm{~W} / \mathrm{m}^{2}$.

Talvella, kun meri on jäässä, meren jää- tai lumipinnan lämpötase määräytyy samojen kaavojen ja auringonsäteilyä lukuunottamatta likimain samojen parametrien mukaisesti kuin avovesikaudella. Auringonsäteilyn kohdalla on huomioitava, että jään ja lumen albedot ovat paljon suurempia kuin avoveden ja lisäksi vielä voimakkaasti vaihtelevia. Ohjeellisina arvoina voidaan pitää seuraavia:

$\begin{array}{lcc}\text { Pinta } & \text { Albedo (\%) } & \text { Vaihteluväli } \\ \text { Avovesi } & 7 & 5-10 \\ \text { Märkä jää } & 30 & 20-40 \\ \text { Kuiva jää } & 50 & 30-60 \\ \text { Märkä lumi } & 60 & 40-70 \\ \text { Kuiva lumi } & 85 & 80-95\end{array}$

Avoveden 5-10 \% tasosta albedo alkaa kasvaa meren jäädyttyä ja jään paksuuntuessa. Ohuen $(10 \mathrm{~cm})$ ja paljaan jään albedo on vielä 20-30 $\%$, mutta yli $30 \mathrm{~cm}$ paksulla kuivalla jäällä se on noin $50 \%$. Lumen peittämän jään albedo on yleensä paljon korkeampi kuin $50 \%$, jopa $95 \%$ suuruisia arvoja on havaittu. Keväällä, kun lumi ja jää alkavat sulaa, albedo alkaa samalla hiljalleen laskea johtuen ennen kaikkea nestemäisen veden ilmaantumisesta lumeen ja jään pinnalle. 
Taulukko 5.4. Eri lähteisiin perustuvia arvioita Itämeren keskimääräisestä sadannasta ja haihdunnasta (mm/vuosi).

\begin{tabular}{|l|l|l|l|l|}
\hline Julkaisu & Aika & Sademäärä & Haihdunta & Erotus \\
\hline Simojoki (1949) & $1886-1935$ & 525 & 460 & 65 \\
\hline Brogmus (1952) & $(40-50$ vuotta) & 474 & 474 & 0 \\
\hline Dahlström (1977) & $1931-1960$ & 619 & - & - \\
\hline Henning (1979) & 1919 & - & 493 & - \\
\hline $\begin{array}{l}\text { Omstedt ja Axell } \\
(2003)\end{array}$ & $1980-1998$ & 600 & 470 & 130 \\
\hline
\end{tabular}

Lisäksi albedo riippuu hieman pilvisyydestä ja auringon korkeuskulmasta.

\subsection{Vesitase}

Itämeren vesitaseen muodostavat sadanta, haihdunta, jokivirtaama ja vedenvaihto Pohjanmeren kanssa Tanskan salmien kautta. Sadannan ja haihdunnan erotusta sanotaan ilmakehän nettovuoksi. Makean veden tase koostuu ilmakehän nettovuosta ja jokivirtaamasta.

\subsubsection{Sadanta ja haihdunta}

Meren vesitaseessa ilmakehän vaikutus tuntuu sadannan ja haihdunnan kautta. Edellistä voidaan pitää puhtaasti ulkoisena tekijänä, kun taas haihdunta seuraa meren ja ilmakehän välisestä vuorovaikutuksesta. Sadannan ja haihdunnan erotus $P-E$ kertoo onko meren vedenvaihto ilmakehän kanssa positiivinen vai negatiivinen. Edellisessä tapauksessa pintavesi makeutuu ja jälkimmäisessä väkevöityy.

Vuositasolla koko Itämeren alueen haihdunta on hieman pienempi kuin sadanta: keskimäärin vuotuinen sadanta on $500-600 \mathrm{~mm}$ ja haihdunta 450-500 mm, joten ilmakehästä tuleva nettovuo on siis noin $100 \mathrm{~mm}$ (taulukko 5.4). Tähän nettovuon arviointiin liittyy kylläkin melko suuria epävarmuustekijöitä. Itämeren poh- joisosissa sadanta ylittää haihdunnan 100-150 mm:n verran, kun taas etelässä tilanne on päinvastainen ja haihdunta on 50-100 mm sadantaa suurempi. Sadanta ja haihdunta ovat kumpikin itseisarvoltaan noin $50 \%$ jokivirtaamasta, mutta niiden nettovaikutus on tästä vain $10 \%$.

\subsubsection{Jokivirtaama}

Maa-alue, josta sadantaa kulkeutuu jokia pitkin Itämereen, on Itämeren valuma-alue (kuva 1.1). Se on pinta-alaltaan 4,3 kertaa Itämeren kokoinen, $1,7 \cdot 10^{6} \mathrm{~km}^{2}$. Valuma-alueeseen kuuluu Itämeren rantavaltioiden lisäksi pieniä osia Valko-Venäjästä, Ukrainasta, Slovakiasta, Tsekin tasavallasta ja Norjasta, mutta kuten nähdään, valuma-alueen rajat kulkevat hyvin lähellä valtakuntien rajoja. Luoteessa on Skandinavian vuoristoalue ja metsiä, pohjoisimpana Lappi, koillisessa ovat Suomen ja Karjalan järvi- ja metsäalueet, ja etelässä sekä idässä valuma-alue muodostuu tasaisesta maatalousalueesta. Valuma-alueella on pitkä ulottuvuus pohjois-eteläsuunnassa (49-69 $\left.{ }^{\circ} \mathrm{N}\right)$, joten ilmasto-olot vaihtelevat varsin paljon. Pohjoisessa on huomattavasti pidemmät ja lumisemmat talvet.

Itämereen tuleva vuotuinen jokivirtaama on Fonseliuksen ja Mikulskin mukaan noin 440 $\mathrm{km}^{3}$, mikäli Tanskan salmia ja Kattegatia ei huomioida (taulukko 5.5). Tämä vastaa $1.170 \mathrm{~mm}$ paksuista vesikerrosta koko Itämerelle levitettynä 
Taulukko 5.5. Itämereen keskimäärin tulevat vuotuiset jokivirtaamat $\left(\mathrm{km}^{3}\right)$ merialuettain Mikulskin $(1970,1972)$ ja Fonseliuksen (1996) mukaan ajalle 1950-1970.

\begin{tabular}{|l|r|r|}
\hline & Fonselius & Mikulski \\
\hline Perämeri & 98 & 100 \\
\hline Selkämeri & 91 & 83 \\
\hline Suomenlahti & 112 & 112 \\
\hline Riianlahti & 32 & 30 \\
\hline Varsinainen Itämeri & 114 & 111 \\
\hline Yhteensä & 447 & 436 \\
\hline $\begin{array}{l}\text { Tanskan salmet ja } \\
\text { Kattegat }\end{array}$ & 37 & - \\
\hline
\end{tabular}

eli vuosisademäärää kaksinkertaisena. Suurimman virtaaman saa Pohjanlahti, hiukan alle 200 $\mathrm{km}^{3}$, mikä osaksi selittää sen alhaisen suolapitoisuuden. Suomenlahteen tulee noin $110 \mathrm{~km}^{3}$ ja se saa Itämeren altaista pinta-alaansa kohti eniten makeaa vettä, saman verran kuin koko Varsinainen Itämeri yhteensä. Riianlahden osuus on alle $40 \mathrm{~km}^{3}$. Jokivirtaamissa on toki ajallisia vaihteluita, jotka johtuvat siitä, että sademäärät vaihtelevat vuosien ja vuosikymmenten aikana.

Maantieteelliset ja ilmastolliset erot aiheuttavat jokivirtaamiin suuria eroja. Pohjanlahteen laskee suuri joukko pienehköjä jokia Ruotsin ja Suomen vuoristoista sekä metsäalueilta lahden molemmin puolin. Sen sijaan Itämeren etelä- ja kaakkoisosiin laskee vain joitakin jokia, mutta useat niistä ovat suuria. Virtaamaltaan suurimmat Itämereen laskevat joet ovat $\left(\mathrm{km}^{3} /\right.$ vuosi): Neva (82), Vistula (31), Väinäjoki [Daugava] (22), Neman (21), Kemijoki (18), Tornionjoki (17) ja Luulajanjoki (16). Suomenlahteen Pietarissa laskeva Neva on siis ylivoimaisesti suurin näistä joista, ja sen virtaama on noin 20 \% Itämereen laskevasta jokivedestä.

Jokivirtaamissa on suuri vuodenaikaisvaihtelu (kuva 5.6), vaikka nykyään vesistöjen säännöstely tasoittaa suurimmat huiput pois. Maksimi saavutetaan keväällä lumen sulamisaikana. Huipun ajankohdassa on suuri ero etelän ja pohjoisen välillä johtuen ilmastollisista oloista. Lounaisella Itämerellä suurimmat vuotuiset jo- kivirtaamat saattavat ajoittua jo maaliskuuhun, keskiosissa tämä tilanne on vasta huhtikuussa, Suomenlahdella touko-kesäkuussa ja Perämerellä vasta heinäkuussa. Vastaavasti virtaaman minimi saavutetaan loppukesällä etelässä mutta vasta talvella pohjoisessa. Koska virtaamahuiput ja -minimit osuvat Itämeren eri osissa eri aikoihin, koko Itämeren saamassa jokivirtaamassa ei esiinny kovin suurta vuodenaikaisvaihtelua. Osasyynä tähän on myös se, että vesistöjen säännöstelyllä tasataan tulvahuippuja ja lisätään virtaamaa aikana, jolloin luonnollinen valunta on pientä. Ihmisen toiminta siis tasoittaa makean veden syöttöä Itämereen.

\subsubsection{Vedenvaihto Pohjanmeren kanssa}

Vesi vaihtuu Itämeren ja Pohjanmeren välillä Tanskan salmien kautta (kuva 5.7). Pohjanmeren vesi on tavanmukaista Atlantin vettä, jonka suolaisuus on noin $35 \%$ ja lämpötila vaihtelee 0 ja $20^{\circ} \mathrm{C}$ välillä.

Yleisesti arvioidaan, että vuotuinen sisäänvirtaus Itämereen Kattegatista on keskimäärin noin $1.200 \mathrm{~km}^{3}$. Suurimmat arviot antavat $1.500 \mathrm{~km}^{3}$ ja pienimmät $1.000 \mathrm{~km}^{3}$. Tämä on noin kolme kertaa jokivirtaaman suuruinen ja vastaa 3.200 $\mathrm{mm}$ paksuista vesikerrosta levitettynä tasaisesti koko Itämerelle. Yksittäiset suurimmat kuukausittaiset sisäänvirtaukset ovat $120 \mathrm{~km}^{3}$ marras- 


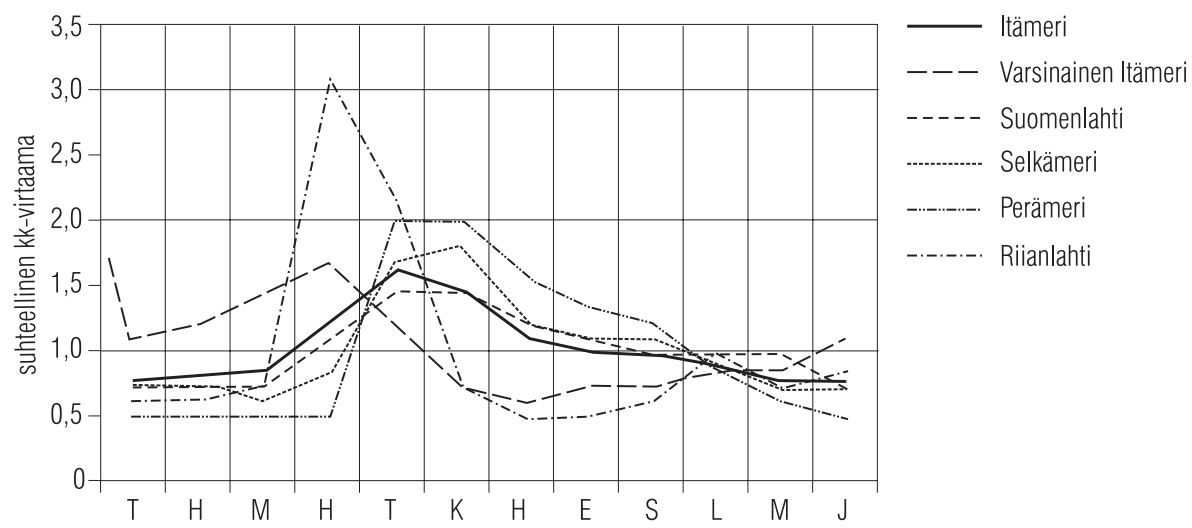

Kuva 5.6. Itämeren ja sen altaisiin tuleva jokivirtaama kuukausittain. Pystyakseli osoittaa suhteelliset osuudet vuotuisista keskivirtaamista. (Piirretty Mikulskin [1970] mukaan.)

kuun ja tammikuun välisenä aikana, kun taas pienin sisäänvirtaus on keskimäärin toukokuussa, $70 \mathrm{~km}^{3}$. Sisäänvirtaus on hyvin vaihtelevaa sekä vuodenaikojen että vuosien välillä. Se riippuu voimakkaasti säätilanteesta, tuulen ja ilmanpaineen jakaumista, sekä Itämeren ja Pohjanmeren välisestä vedenkorkeus- ja suolaisuuserosta. Erityisen voimakkaita sisäänvirtauksia, suolapulsseja, Itämereen tulee noin kerran 10 vuodessa.

Veden ulosvirtauksen Itämereltä määrää lähinnä tämän vedenkorkeus Pohjanmereen nähden. Keskimääräinen vuotuinen ulosvirtaus on noin $1.700 \mathrm{~km}^{3}$, mikä vastaa $4.530 \mathrm{~mm}$ vesipatjaa otettuna koko Itämeren alueelta. Ulosvirtauksen maksimitaso on $2.100 \mathrm{~km}^{3}$ ja minimi puolestaan $1.300 \mathrm{~km}^{3}$. Kuukausittainen maksimi on 150 $\mathrm{km}^{3}$ (joulukuu-maaliskuu) ja minimi $115 \mathrm{~km}^{3}$ (kesäkuu). Ulosvirtausta voimistavat itätuulet ja heikentävät länsituulet.

Lyhyellä aikavälillä vedenvaihto on paljolti veden edestakaista liikettä sääolojen ohjaamana. Itämeren ja Pohjanmeren veden raja-alue on tyynellä säällä Belttien pohjoissuulla, itätuulilla Skagerrakissa, ja Darssin kynnyksellä sekä Juutinraumassa länsituulilla. Itämeren aktiivinen varastokapasiteetti, keskimääräisen vedenkorkeuden kuukausimaksimin ja-minimin erotus, on $500 \mathrm{~km}^{3}$, eli $1.250 \mathrm{~mm}$ koko Itämeren alueelle levitettynä. Tämä on suunnilleen sama kuin vuotuinen jokivirtaama Itämereen. Belteistä ja Juutinraumasta Itämereen virtaavan veden suolaisuus on 15-20\%o. Tämä on huomattavasti Pohjanmeren suolaisuuden alapuolella, sillä matalassa Kattegatissa tapahtuu sisään tulevan Pohjanmeren veden ja Itämerestä ulos virtaavan veden voimakasta sekoittumista.

Knudsenin kaavat soveltuvat puolisuljettujen altaiden vedenvaihdon tarkasteluun. Ne perustuvat massan ja suolan säilymislakeihin. Olkoon makean veden nettovuo altaaseen $F$, ulosvirtauksen virtaama ja suolaisuus $\left(V_{\mathrm{o}}, S_{\mathrm{o}}\right)$ sekä sisäänvirtauksen virtaama ja suolaisuus $\left(V_{\mathrm{i}}, S_{\mathrm{i}}\right)$. Tällöin on

$V_{\mathrm{o}}=F+V_{\mathrm{i}}$ ja $S_{\mathrm{i}} V_{\mathrm{i}}=S_{\mathrm{o}} V_{\mathrm{o}}$

Tässä on viisi suuretta ja kaksi yhtälöä; kaksi niistä voidaan siis ratkaista, jos kolme muuta tunnetaan. Itämeren tarkasteluissa yleensä ratkaistaan virtaamat sisään ja ulos

$V_{o}=\frac{S_{i}}{S_{i}-S_{o}} F, V_{i}=\frac{S_{o}}{S_{i}-S_{o}} F$

Edelleen nähdään, että $V_{o} / V_{i}=S_{i} / S_{o}$. Jos käytetään edellä mainittuja virtaamakeskiarvoja, saadaan Itämeren suulle $V_{o} / V_{i}=1,4$ ja silloin olisi $S_{\mathrm{o}}=$ $24,7 \%$ o (jos $S_{\mathrm{i}}=35 \%$ ). Lähtösuureiden arvot 


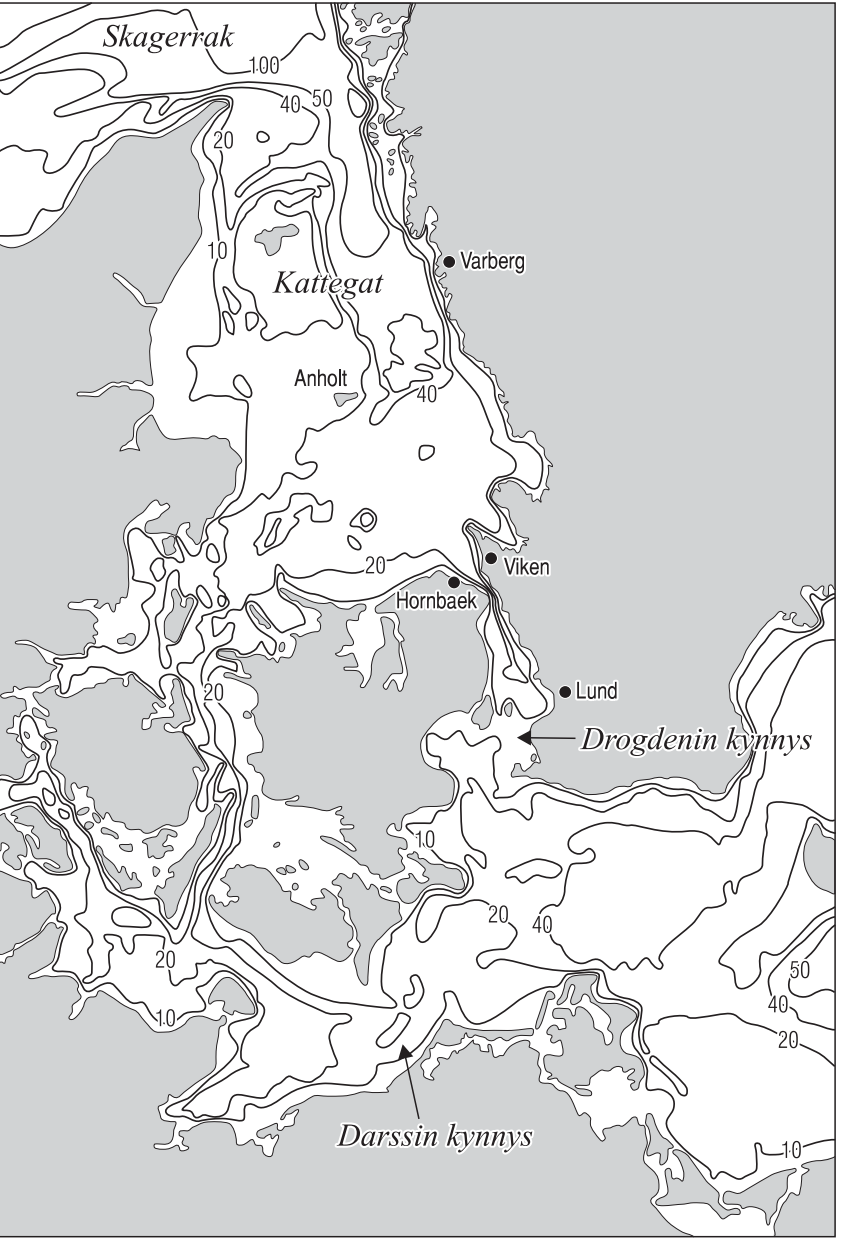

Kuva 5.7. Yksityiskohtainen topografiakuva (m) Itämeren suualueelta. (Piirretty Gustafssonin ja Anderssonin [2001] mukaan.)

vaihtelevat jossain määrin eri tutkimuksissa sen mukaan mihin kohtaan täsmälleen Knudsenin kaavoja sovelletaan. Tällainen budjettitarkastelu ei kuvaa dynaamista veden kiertoa Itämeren ja Pohjanmeren välillä, eli sitä, että vesi tulee sisään, "pyörähtää” ja menee takaisin. Samoin on havaittu Suomenlahden ja Gotlannin altaan vedenvaihtotarkasteluissa Knudsenin kaavojen antavan aivan liian pieniä arvoja (Andrejev ym. 2004).

Esimerkki (Brogmus 1952). Darssin kynnyksellä on mittausten mukaan $S_{\mathrm{o}}=8,7 \%$ ja $S_{\mathrm{i}}$ $=17,4 \%$. Kun Itämereen tuleva makean ve- den määrä on $F=472 \mathrm{~km}^{3} /$ vuosi, niin sisään- ja ulosvirtaamien täytyy olla $V_{\mathrm{i}}=472 \mathrm{~km}^{3} /$ vuosi ja $V_{\mathrm{o}}=944 \mathrm{~km}^{3} /$ vuosi. Nämä numerot ovat pienempiä kuin nykyisen käsityksen mukaiset, ja siis Brogmusin käyttämät suolaisuudet eivät ole kovin edustavia.

\subsubsection{Vesitasemallit}

Itämeren vesitasetta voidaan tarkastella keskimääräisen vedenkorkeuden yhtälön avulla

$A\left(\frac{d \xi}{d t}+\frac{H}{\bar{\rho}} \frac{d \bar{\rho}}{d t}\right)=$
$(P-E) A+V_{r}+V_{i}-V_{o}$

missä $A$ on Itämeren pinta-ala, $\xi$ on Itämeren pinnankorkeus, $\bar{\rho}$ on veden keskitiheys, $V_{\mathrm{r}}$ on jokivirtaama ja $V_{\mathrm{i}}$ sekä $V_{\mathrm{o}}$ ovat sisään- ja ulosvirtaamat Tanskan salmissa. Yhtälön oikealla puolella ovat vesitaseen ohjaustermit ja vasemmalla on Itämeren pinnankorkeuden muutos ja tiheyden muutosta vastaava veden tilavuuden muutos.

Veden tiheyden suhteellinen muutos voisi ääritapauksessa olla $10^{-3}$, mistä seuraava pinnankorkeuden muutos olisi $50 \mathrm{~mm}$. Oikean puolen termeissä virtaamat dominoivat, meri- ilmakehä vedenvaihdon nettotaso on kertaluokkaa pienempi. Pohjavesivalunnan, joka on hyvin pieni, voidaan ajatella sisältyvän jokivirtaamaan. Paikallinen jään muodostus ja sulaminen eivät vaikuta vedenpinnan korkeuteen, mutta Tanskan salmien vedenvaihdossa jää on laskettava virtaamiin mukaan.

Makean veden tase (kuva 5.8) on $F=(P-E) A+V_{\mathrm{r}}$. Itämerellä se on ympäri vuoden positiivinen eli meri saa makeaa vettä ilmakehästä ja joista enemmän kuin luovuttaa haihtumalla. Ylijäämä eli nettovuo on, kuten aiemmin jo todettiin, noin $500 \mathrm{~km}^{3}$ vuodessa. Tällaiseen mereen muodostuu suolaisuuden voimakas kerrostunei- 
suus, jossa makea vesi on kevyempänä pinnalla ja alempana on suolaisempi raskas vesi. Ylijäämä poistuu Itämerestä myöhemmin meriveteen sekoittuneena.

Kun makean veden tase on positiivinen, meriallas on huonosti tuulettuva, koska suolaisuuden kerrostuneisuus pyrkii vastustamaan veden pystysuuntaista kiertoa. Jos kerrostuneisuus on voimakas kuten Itämeren altaissa, syvä vesi uudistuu vain horisontaalisen kiertoliikkeen avulla ja saattaa seurata happikato. Tyyppiesimerkki huonosti tuulettuvasta altaasta on Itämeren lisäksi Musta meri. Sen sijaan esimerkiksi Välimeren makean veden tase on negatiivinen ja se tuulettuu talvisaikaan hyvin, kun kerrostuneisuus ei estä konvektion tunkeutumista syvälle. Suolainen, raskas Välimeren vesi poistuu Atlantille Gibraltarin salmen pohjakerroksessa, kun taas pinnalla virtaa sisään Atlantin vettä.

\subsection{Suolan säilymislaki}

Vesitaseen ohella makean veden tase ja vedenvaihto Pohjanmeren kanssa vaikuttavat Itämeren veden suolaisuuteen. Meriveden suolaisuus on niin sanottu konservatiivinen suure eli suolan kokonaismäärä voi muuttua vain reunoilta tapahtuvan syötön kautta, kun taas meren sisällä tapahtuu suolan kulkeutumista ja sekoittumista. Nettomuutoksia suolan määrään seuraa ainoastaan vedenvaihdosta Tanskan salmissa.

Mehukatti-malli. Itämeren vesi on sekoitus makeata vettä ja merivettä. Olkoon makean veden osuus $v$ ja meriveden osuus siten $1-v$. Itämeren keskisuolaisuus $S_{\mathrm{I}}$ on

$S_{\mathrm{I}}=(1-v) S_{\mathrm{V}}$

missä $S_{\mathrm{V}}=35 \%$ on valtameriveden suolaisuus. Kun Itämeren keskisuolaisuus on 7,4\%o, on $v$ $=0,80$. Itämeren vesi on siis laimennettua merivettä suhteessa 1:4; laimennus on epähomo-

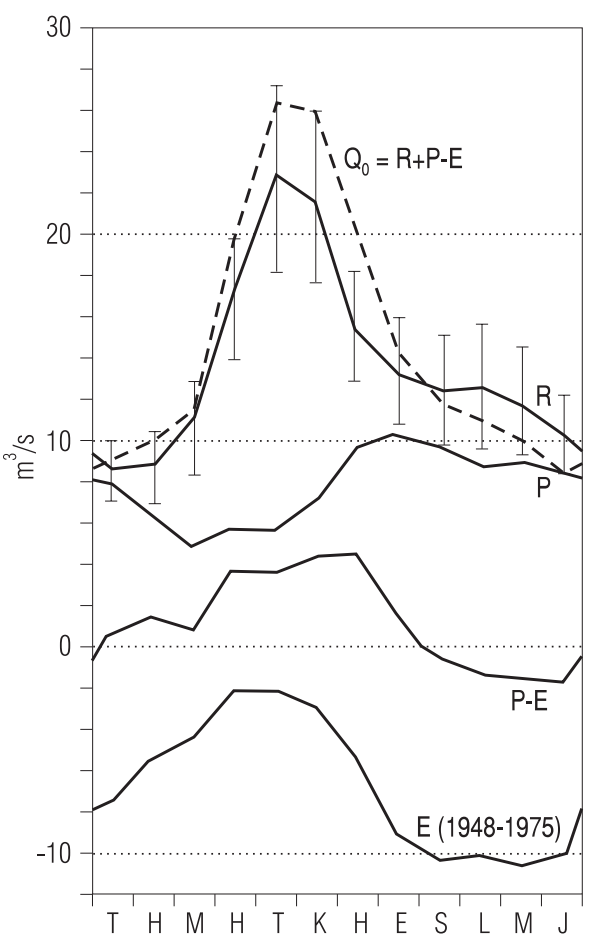

Kuva 5.8. Keskimääräinen makean veden tase $Q_{0}$ Itämerellä: sadanta $P$ ja jokivirtaama R (19311960) sekä haihdunta E (1948-1975). (Piirretty Jacobsenin [1980] mukaan.)

geeninen, sillä Perämerellä laimennus on 1:9 ja Arkonan altaassa 1:2. Itämeren tilavuus on $21.205 \mathrm{~km}^{3}$. Makean veden nettovuo on noin $500 \mathrm{~km}^{3} /$ vuosi, joten makean veden osan uudistaminen kestää noin 35 vuotta.

Meriveden viipymisaikaa Itämeressä on melko vaikeata arvioida, koska syvien vesien kiertoliike tunnetaan sangen huonosti. Kattegatin suulla sisäänvirtaus on suuri, keskimäärin $1.200 \mathrm{~km}^{3}$ / vuosi, mikä teoriassa vaihtaisi 3,4 vuodessa koko Itämeren meriveden. Mutta osa sisään virtaavasta vedestä kääntyy aina takaisin, ja meriveden uusiutumisaika tulee pidemmäksi altaan etäisyyden suuaukosta kasvaessa. Kun Darssin kynnyksellä vuotuinen sisäänvirtaus on $472 \mathrm{~km}^{3}$ ja sisäänvirtaavan veden suolaisuus 17,4\%o (Knudsenin kaavoihin liittyvä esimerkki edellä), meriveden vaihtoajaksi tulee sen kautta jo 17 vuotta. Edel- 


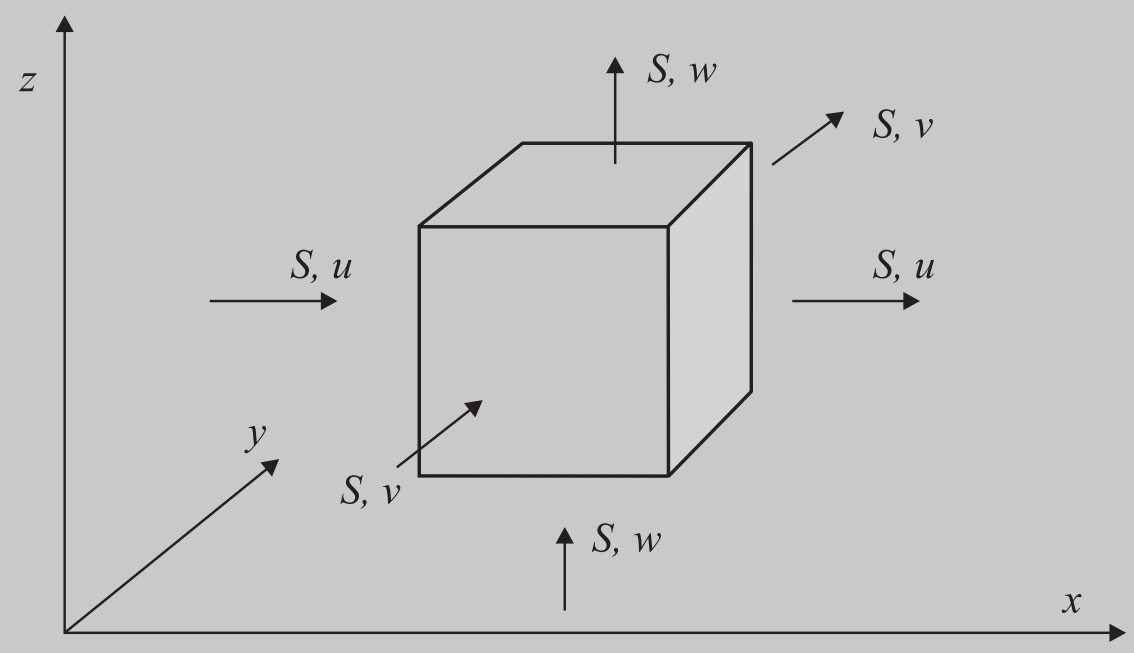

Kuva 5.9. Skemaattinen kuva suolan säilymislaista meren tilavuusalkiossa. Nuolet kuvaavat suolan kuljetusta eli advektiota. Sen lisäksi suolaisuutta sekoittuu diffuusion välityksellä alkion pintojen läpi.

leen voidaan jatkaa suuruusluokka-analyysi avulla seuraavasti. Jos nopeuden ja matkan arvoiksi valitaan $U \sim 1 \mathrm{~mm} / \mathrm{s}$ ja $L \sim 10^{3} \mathrm{~km}$, saadaan advektiiviseksi ajan suuruusluokaksi $T_{\mathrm{A}} \sim 10^{9} \mathrm{~s}$ $\sim 30$ vuotta. Puhtaassa satunnaiskulun mallissa sen sijaan ajan suuruusluokaksi tulee $T_{\mathrm{D}} \sim L^{2} / D$, missä $D$ on diffuusio- eli sekoittumiskerroin. Tämän arvo $D \sim 10 \mathrm{~km}^{2} / \mathrm{vrk}$ antaisi vaihtoajaksi 300 vuotta. Puhdas satunnaiskulku on ilmeisesti kaukana asiantilasta, joten karkeasti arvioiden tulisi meriveden vaihtoajaksi 30-100 vuotta.

Pääosa Itämeren vesimassasta on makeaa vettä ja veden keskimääräistä viipymää arvioitaessa sillä on suurempi paino (4:1). Edustavaksi viipymäajaksi voidaan arvioida noin 50 vuotta.

Koska suolaisuus vaikuttaa merkittävästi veden tiheyteen, sen kehitystä on tarkasteltava yksityiskohtaisesti. Pintaveden makeutuminen stabiloittaa vesirunkoa, kun taas pintaveden väkevöityminen voi johtaa epästabiiliin tilanteeseen ja laukaista veden vertikaalisen kiertoliikkeen. Itämerellä merkittävin ajankohta tässä suhteessa on kevätvalunnan huippu, jolloin pintavesi ma- keutuu huomattavasti ja lämpenevä pintakerros eristyy tehokkaasti alusvedestä. Haihdunnan tai jäätymisen aiheuttama pintaveden suolaisuuden kasvu ei näy selvästi Itämeren hydrografiassa.

Suolan säilymislaki on differentiaaliyhtälö, jossa suolaisuutta tarkastellaan meren pienissä tilavuusalkiossa (kuva 5.9). Suolaisuus muuttuu meren sisällä virtauksen aiheuttaman kulkeutumisen eli advektion ja diffuusion vaikutuksesta. Diffuusio on merissä käytännössä turbulenttista ja lisäksi vahvasti anisotrooppista: horisontaalinen sekoittuminen on paljon voimakkaampaa kuin vertikaalinen, minkä takia näissä suunnissa on käytettävä eri diffuusiokerrointa. Suolaisuuden säilymislaki on:

$\frac{\partial S}{\partial t}=-\boldsymbol{u} \cdot \nabla S+K_{H s} \nabla_{H}^{2} S+K_{V s} \frac{\partial^{2} S}{\partial z^{2}}$

Oikean puolen ensimmäinen termi kuvaa advektiota ja muut termit diffuusiota; $K_{\mathrm{HS}}$ ja $K_{V S}$ ovat suolaisuuden horisontaalinen ja vertikaalinen turbulenttinen diffuusiokerroin, ja $\nabla_{\mathrm{H}}=\mathbf{i} \partial / \partial x+$ $\mathbf{j} \partial / \partial y$ on horisontaalinen gradienttioperaattori. 
Suolaisuuden säilymislain pitää myös täyttää reunaehdot. Reunaehtoja on kolmea tyyppiä: Dirichlet-reunaehdossa annetaan suolaisuuden absoluuttinen arvo reunalla, Neumann-reunaehdossa annetaan suolaisuuden vuo reunalla, kun taas sekareunaehto koostuu niistä molemmista.

Sadanta ja haihdunta vaikuttavat veden suolaisuuteen merenpinnan reunaehtona. Ne muuttavat makean veden pitoisuutta $f$, ja diffuusion voimakkuus määrää sitten $f$ :n gradientin. Suolaisuus on taas $S=1-f$, ja näin ollen suolaisuusgradientin täytyy vastata makean veden pitoisuuden gradienttia. Pohja ei vaikuta suolaisuuteen (jos pohjavesivirtaamaa ei nyt huomioida), joten siihen voidaan soveltaa nollavuoehtoa. Siis

$z=0: K_{V s} \frac{\partial S}{\partial z}=-(P-E) ; z=-H: \frac{\partial S}{\partial z}=0(5-13)$

Kiinteillä rannoilla on niinikään nollavuoehto. Reunaehtoina jokisuihin annetaan joen virtausnopeus mereen olettaen veden suolaisuus nollaksi, kun taas Tanskan salmissa annetaan sisään- ja ulosvirtausten suolaisuudet ja voimakkuudet.

Suolaisuuden kuten monien meriveden ominaisuuksien vertikaalista sekoittumista tarkastellaan 1-dimensioisilla malleilla, toisin sanoen oletetaan tilanne horisontaalisesti homogeeniseksi, ja jätetään yhtälöstä (5-12) horisontaaligradientteja sisältävät termit pois. Tällöin on

$$
\frac{\partial S}{\partial t}=K_{v s} \frac{\partial^{2} S}{\partial z^{2}}
$$

ja reunaehtoina ovat (5-13). Vakaan tilan ratkaisu on $\mathrm{d}^{2} S / \mathrm{d} z^{2}=0$.

Kun $(P-E) \approx 100 \mathrm{~mm} /$ vuosi, vakaan tilan vuosikeskiarvossa pitäisi olla $\mathrm{d} S / \mathrm{d} z=-(P-E) / K_{\mathrm{vs}} \approx$ $0,032 \% \mathrm{~m}^{-1}$, jos otetaan koko syvyyttä edustava kerroin $K_{\mathrm{vs}}=1 \mathrm{~cm}^{2} / \mathrm{s}$. Toisin sanoen keskisyvyyden (54 metriä) alueella suolaisuusero olisi pinnan ja pohjan välillä $1,7 \%$. Luku ei sinänsä ole epärealistinen, mutta herkkä sille, millainen edustava diffuusiokerroin valitaan. Sekoittumisen lisäksi suolaisuusrakenteeseen vaikuttavat horisontaaliset virtaukset, jotka yleensä pyrkivät voimistamaan suolaisuuseroja, ja lineaarinen suolaisuusjakautuma modifioituu enemmän kaksikerroksiseksi rakenteeksi.

Jään muodostuminen vaikuttaa myös veden suolaisuuteen, sillä kasvaessaan jää hylkii meriveden suoloista osan pois. Tämä kasvattaa pintakerroksen suolaisuutta ja vähentää kerrostuneisuuden stabiliteettia. Vastaavasti keväällä jään sulaessa veden pintakerros makeutuu ja stabiloituu. Uuden jään suolaisuus on noin $1 / 3$ veden suolaisuudesta, jolloin jään kasvu paksuuteen $h$ vastaa meren suolaisuustaseen kannalta määrän $2 / 3 h$ verran haihduntaa. Uuden jään paksuuskasvu voi hyvin olla 10-20 mm/vrk, kun taas keskimääräinen sydäntalven kasvuvauhti on noin $5 \mathrm{~mm} / \mathrm{vrk}$. Keväällä jää on sulaessaan liki suolatonta ja jään sulaminen vastaa siis suolaisuustaseen kannalta sadantaa; sulamisnopeus on 10-30 mm/vrk. Jään kasvun ja sulamisen vaikutukset ovat merkittäviä verrattuna esimerkiksi keskimääräiseen sadannan ja haihdunnan arvoon (1,5-2 mm/vrk).

\subsection{Lämpötase}

Lämpötila voi muuttua reunojen kautta kuten suolaisuus, mutta lisäksi auringonsäteilyn tunkeutuminen veteen voi suoraan lämmittää merta myös sisältä. Näin ollen lämpötila ei tarkkaan ottaen ole konservatiivinen suure, sillä valon tunkeutuminen pintaveteen toimii lämpötilan lähdeterminä. Hydrografisissa tarkasteluissa valon tunkeutumisen vaikutus voidaan yleensä jättää pois. Meri-ilmakehä -vuorovaikutus ohjaa Itämeren lämpötasetta pinnan kautta, kun taas avoimilla reunoilla (jokisuut ja Tanskan salmet) lämpöä vaihtuu vedenvaihdon mukana. Avoimilla reunoilla ei ole lämpötilan kehityksen kannalta vastaavaa merkitystä kuin niillä on vesi- ja suolataseissa. 
Lämpötalouden tarkasteluissa tarvittavat meriveden lämpöopilliset perusominaisuudet on esitetty taulukossa 5.3. Lämmön sekoittumisessa on olennaisena tekijänä turbulenttinen diffuusio. Koska meren turbulenssi on vahvasti anisotrooppista, on käytettävä eri diffuusiokerrointa vertikaalisessa ja horisontaalisessa suunnassa.

Meriveden lämpöenergian nollareferenssi on tässä kätevä valita nestemäisen veden $0{ }^{\circ} \mathrm{C}$ lämpötilan mukaan, ja siten lämpöenergia on tilavuusyksikköä kohti $q=\rho c T$. Lämpökapasiteettia $\rho c$ voidaan tässä yhteydessä pitää vakiona, jolloin lämmön säilymislaki kirjoitetaan lämpötilayhtälönä muodossa

$\frac{\partial T}{\partial t}=-\boldsymbol{u} \cdot \nabla T+\underline{K}_{H T} \nabla_{H}^{2} T+$

$K_{V T} \frac{\partial^{2} T}{\partial z^{2}}+(1-\alpha) \gamma \frac{Q_{s}}{\rho c} \lambda \exp (\lambda z)$

missä $K_{\mathrm{HT}}$ ja $K_{\mathrm{VT}}$ ovat horisontaalinen ja vertikaalinen turbulenttinen lämmön diffuusiokerroin ja $\lambda$ on valon vaimenemiskerroin. Yhtälön oikea puoli kuvaa lämpötilan muutosta meressä advektion, diffuusion ja auringonsäteilyn vaikutuksesta. Itämeressä $\lambda \sim 0,2 \mathrm{~m}^{-1}$. Vastaavasti kuten suolaisuuden tapauksessa, reunaehtoina ovat pinnalla ja pohjalla vuoehdot

$z=0: K_{v T} \frac{\partial T}{\partial z}=Q_{n} ; z=-H:-K_{v T} \frac{\partial T}{\partial z}=Q_{\iota}(5-1$

missä $Q_{\mathrm{b}}$ on pohjasta tuleva lämpö. Tällä on merkitystä matalilla alueilla, joissa pohja lämpenee kesällä ja puolestaan lämmittää vettä syksyllä ja talvella.

Rannan ja veden välinen lämmönvaihto on yleensä niin vähäistä, ettei sitä tarvitse huomioida ja lämpövuo voidaan asettaa siellä nollaksi. Avoimella reunalla lämpötila voidaan kiinnittää tai lämpövuo nollata ja jokisuissa voidaan lämpövuo nollata. Itämeren lämpötaseen kannalta avoin reuna ja jokisuut eivät ole kovin kriittisiä, koska niistä ei saada merkittävää pysyvää lämmitystä.
Talvella lämpötaseessa on myös otettava huomioon jäätyminen ja sulaminen. Jäänmuodostus alkaa, kun veden pintalämpötila on jäätymispisteessä ja nettolämpövuo on negatiivinen. Jäätalven ajan veden lämpötila pysyy jäätymispisteessä jään alapinnalla, ja lämmönsiirto merestä ilmaan merkitsee aina jään kylmenemistä tai paksuuntumista. Keväällä jäät sulavat ja silloin veden pintalämpötila pysyy jäätymispisteessä niin kauan kuin jäätä riittää. Kun lämpömäärän nollareferenssi on meillä nestemäisen veden lämpötilassa $0{ }^{\circ} \mathrm{C}$, jään muodostus ilmenee "negatiivisena" lämpömääränä. Merijään lämpöenergia siis on

$q_{\mathrm{i}}=-\rho_{\mathrm{i}} h L+\rho_{\mathrm{i}} c_{\mathrm{i}} T_{\mathrm{i}}$

missä alaindeksi i viittaa jäähän; $\rho_{\mathrm{i}}=910 \mathrm{~kg} / \mathrm{m}^{3}$ on jään tiheys, $h$ on jään paksuus ja $c_{\mathrm{i}}=2,1 \mathrm{~kJ} /$ $\left(\mathrm{kg}{ }^{\circ} \mathrm{C}\right)$ on jään ominaislämpö. Olomuodon muutosenergia $L$ on huomattavan suuri. Esimerkiksi $-20{ }^{\circ} \mathrm{C}$ lämpötilassa jään lämpöenergia on $-342 \mathrm{MJ} / \mathrm{m}^{3}$, mistä $-304 \mathrm{MJ} / \mathrm{m}^{3}$ on olomuodon muutoksen osuus.

Jääpeitteen lämpömäärän osuus meren energiataseessa on pieni, koska jää on ohutta. Jään merkitys meren energiataloudessa on kuitenkin suuri, sillä se vaikuttaa ilmakehän ja meren välissä tehokkaana eristeenä ja pienentää meren saamaa auringonsäteilyä. Lisäksi kylmän jäätalven aikana ilmakehän kyllästyskosteus on alhainen ja sen myötä haihdunta jää vähäiseksi.

Lämpöenergian syöttö Itämereen tapahtuu pääasiassa merenpinnan kautta ja lämpö sekoittuu syvemmälle vertikaalisen diffuusion vaikutuksesta. Tämän takia suuri osa Itämeren lämpötaloustutkimuksista on kohdistunut merenpinnan lämpötaseeseen ja mallinnuksessa on sovellettu yksiulotteisia vertikaalimalleja. Tarkastellaan vesipatsasta, jonka syvyys on $H$ ja joka rajoittuu merenpintaan. Lämpöenergia on yksikköpinta-alaa kohti $\rho c<T>H$, missä $<T>$ on keskilämpötila syvyyden suhteen. Tämän kehitystä 
voidaan arvioida integroimalla lämmön säilymislaki syvyyden suhteen:

$\frac{\partial<T>}{\partial t}=Q_{A}+\frac{K_{H T}}{H} \nabla_{H}^{2}<T>$

$+\frac{Q_{n}+(1-\alpha) \gamma Q_{s}}{H \rho c}$

missä $Q_{\mathrm{A}}=-<(\boldsymbol{u} \cdot \nabla) T>$ on advektio. Lisäksi on oletettu vielä, että $\lambda H<<1$, eli auringonsäteily imeytyy kokonaisuudessaan vesirunkoon eikä mene pohjaan asti, ja että pohjasta tuleva lämpöenergia $K_{\mathrm{VT}} \partial T /\left.\partial z\right|_{z=-H}=0$.

Koska advektio on virtausnopeuden ja lämpötilan epälineaarinen funktio, sitä ei keskiarvoistettaessa voida yksinkertaistaa enempää. Advektiota arvioidaan esimerkiksi keskimääräisen virtauskentän avulla tai käyttäen matemaattista Itämerimallia. Horisontaalinen diffuusiotermi ainoastaan tasoittaa lämpötiloja altaiden sisällä.

Merenpinnan läpi menevä lämpövuo on suuruusluokkaa $Q_{\mathrm{n}} \sim 100 \mathrm{~W} / \mathrm{m}^{2}$, kesäaikana positiivinen ja talvisaikaan negatiivinen. Tämä vastaa 54 metrin paksun vesipatsaan lämmitystä tai jäähdytystä nopeudella $Q_{\mathrm{n}} /(\rho \mathrm{c}) \sim 0,037^{\circ} \mathrm{C} / \mathrm{vrk}$. Jos virtausnopeus on $U \sim 5 \mathrm{~cm} / \mathrm{s}$ ja lämpötila muuttuu $\Delta T \sim 1{ }^{\circ} \mathrm{C}$ matkaa $L \sim 10 \mathrm{~km}$ kohti, advektion aiheuttama muutos on $U \Delta T / L \sim 0,4^{\circ} \mathrm{C} / \mathrm{vrk}$; ja jos otetaan horisontaaliseksi diffuusiokertoimeksi $D$ $\sim 10^{6} \mathrm{~m}^{2} / \mathrm{s}$ ja lämpötilan horisontaalisen vaihtelun tasoksi sama kuin edellä, diffuusion lämpötilaa tasoittava vaikutus on $D \Delta T / L^{2} \sim 0,01^{\circ} \mathrm{C} /$ vrk.

Meren pintakerroksen (pinnasta termokliiniin) lämpövaraston vuotuista kulkua voidaan luonnehtia seuraavasti:

Talvi Meri jäässä, talvitermokliini halokliiniin kohdalla

Kevät Kevätkierto, maksimitiheyden lämpötila $1,5-3^{\circ} \mathrm{C}$

Alkukesä Termokliini kehittyy, syvyys $\sim 10 \mathrm{~m}$

Keskikesä Pintalämpötilan maksimi heinäkuun lopussa tai elokuun alussa

Loppukesä Termokliinin syveneminen
Syksy

Jäähtyminen, syyskierto, maksimitiheyden lämpötila $1,5-3{ }^{\circ} \mathrm{C}$

Pintakerros on välittömässä vuorovaikutuksessa sääolojen kanssa. Voimakkaan halokliinin takia pintakerros ja alusvesi eivät vaihda kovin intensiivisesti lämpöä keskenään. Alusveden lämpövarasto uusiutuukin lähinnä horisontaalisen advektion vaikutuksesta. Suolaisuuden aiheuttama kerrostuneisuus on niin voimakas, että lämpötilaerot eivät pysty murtamaan sitä. Lisäksi alusveden lämpötila voi olla suurempi kuin sen suolaisuutta vastaava maksimitiheyden lämpötila.

Itämeren lämpötaloudessa on suuri merkitys energian sisäänsyötöllä ilmakehästä. Tavanmukaisten säätietojen lisäksi pinnan lämpötaseen määrittäminen edellyttää veden pintalämpötilan tuntemista. Taulukossa 5.6 on esitettynä merenpinnan lämpötase yhden vuoden ajalta maaliskuusta 1961 helmikuuhun 1962 lounaiselta Selkämereltä. Kyseisenä aikana meri oli koko ajan jäätön. Auringonsäteilyn ohjaus näkyy selvästi. Suunnilleen kevätpäivän ja syyspäivän tasausten välisen ajan säteilytaso on yli $100 \mathrm{~W} / \mathrm{m}^{2}$, kun taas ilmakehän ja merenpinnan lämpösäteilytase on koko ajan negatiivinen ja itseisarvoltaan välillä 40-70 W/m². Säteilytase on negatiivinen marraskuusta helmikuuhun. Aistittavan lämmön vuo on samoin negatiivinen marraskuusta helmikuuhun, jolloin meri on yleensä ilmaa lämpimämpi. Haihtumislämpö on kuukausitasolla aina negatiivinen, mutta merkittävän suuri ainoastaan syksyllä ja talvella. Tarkasteluvuonna energiasyötön nettoarvo oli $25 \mathrm{~W} / \mathrm{m}^{2}$.

Taulukossa 5.7 on esitettynä Suomea reunustavien merialueiden lämpövarasto eri kuukausina. Lämpövarasto on suurimmillaan lokakuun alussa ja saavuttaa minimin maaliskuun aikana.

Perämerellä ja Suomenlahdella talviset luvut ovat negatiivisia, sillä jää sitoo olomuodon muutoslämpöä. 
Taulukko 5.6. Merenpinnan lämpötase Finngrundetilla, lounaiselle Selkämerellä ajalla maaliskuu 1961 - helmikuu 1962 (Hankimo 1964). Yksikkö W/m², positiivinen vuo merta kohti.

\begin{tabular}{|l|l|l|l|l|c|}
\hline & $\begin{array}{l}\text { Auringon } \\
\text { nettosäteily }\end{array}$ & $\begin{array}{l}\text { Maapallon } \\
\text { lämpösäteilytase }\end{array}$ & $\begin{array}{l}\text { Aistittavan } \\
\text { lämmön vuo }\end{array}$ & $\begin{array}{l}\text { Haihtumis- } \\
\text { lämpö }\end{array}$ & $\begin{array}{l}\text { Netto } \\
\text { lämpövuo }\end{array}$ \\
\hline Maaliskuu & 91 & -56 & 14 & -30 & 19 \\
\hline Huhtikuu & 175 & -67 & 12 & -13 & 107 \\
\hline Toukokuu & 230 & -50 & 17 & -1 & 196 \\
\hline Kesäkuu & 295 & -52 & 18 & -3 & 257 \\
\hline Heinäkuu & 259 & -47 & 5 & -17 & 200 \\
\hline Elokuu & 184 & -46 & 5 & -46 & 97 \\
\hline Syyskuu & 113 & -53 & 4 & -53 & 11 \\
\hline Lokakuu & 48 & -44 & 2 & -49 & -43 \\
\hline Marraskuu & 18 & -49 & -22 & -67 & -120 \\
\hline Joulukuu & 8 & -54 & -58 & -81 & -186 \\
\hline Tammikuu & 11 & -49 & -41 & -53 & -132 \\
\hline Helmikuu & 33 & -44 & -41 & -56 & -108 \\
\hline Keskiarvo & 122 & -51 & -7 & -39 & 25 \\
\hline
\end{tabular}

Taulukko 5.7. Itämeren pohjoisten altaiden lämpövarasto kunkin kuukauden 1. päivänä (Jurva 1937b). Nollareferenssinä on $0{ }^{\circ} \mathrm{C}$ veden lämpövarasto, yksikkönä $10^{18} \mathrm{~J}$.

\begin{tabular}{|l|l|l|l|l|l|}
\hline & Perämeri & Selkämeri & Ahvenanmeri & Saaristomeri & Suomenlahti \\
\hline Tammikuu & $-1,0$ & 29,7 & 3,3 & 1,3 & 7,9 \\
\hline Helmikuu & $-2,7$ & 11,5 & 1,7 & 0,4 & 1,7 \\
\hline Maaliskuu & $-4,9$ & 2,7 & 1,3 & 0,1 & $-2,6$ \\
\hline Huhtikuu & $-5,7$ & 7,6 & 0,8 & 0,2 & $-0,6$ \\
\hline Toukokuu & $-1,7$ & 24,5 & 1,7 & 1,7 & 7,3 \\
\hline Kesäku & 20,5 & 56,9 & 3,8 & 7,1 & 19,3 \\
\hline Heinäkuu & 31,8 & 80,8 & 6,3 & 9,2 & 30,1 \\
\hline Elokuu & 41,0 & 111,8 & 8,8 & 9,2 & 41,8 \\
\hline Syyskuu & 41,4 & 126,9 & 9,2 & 9,2 & 43,5 \\
\hline Lokakuu & 38,1 & 135,2 & 9,2 & 7,5 & 38,1 \\
\hline Marraskuu & 27,2 & 98,8 & 7,1 & 5,9 & 30,6 \\
\hline Joulukuu & 8,5 & 74,1 & 4,6 & 3,3 & 18,0 \\
\hline Max-min & 47,1 & 132,5 & 8,4 & 9,1 & 46,1 \\
\hline
\end{tabular}




\section{Kaavaliite: auringon sijainti ja kyllästyskosteus}

Maapallon radan elliptisyys:

$\left(r_{\mathrm{o}} / r\right)^{2}=1,000110+0,034221 \cos j+0,001280 \sin j+0,00719 \cos 2 j+0,000077 \sin 2 j$

missä $j=(J-1) 2 \pi / 365$ aika vuoden alusta ja $J$ on Juliaaninen päivänumero $(J=1,0$ tammikuun 1. päivänä klo 0.00$)$.

Auringon korkeuskulma:

$\sin \theta=\sin \phi \sin \delta+\cos \phi \cos \delta \cos \tau$

$\sin \delta=\sin \varepsilon \sin j, t_{\mathrm{GMT}}=-\Lambda / 15^{\circ}+\Delta t$

missä $\phi$ on leveysaste, $\delta$ on deklinaatio, $\tau$ on tuntikulma (aurinkoajan keskipäivällä $\tau=0$ ), $\varepsilon=$ $23^{\circ} 27^{\prime}$ on ekliptikan kaltevuus, $t_{\mathrm{GMT}}$ on paikallinen keskipäivä GMT ajassa, $\Lambda$ on pituusaste, ja $\Delta t$ on aikakorjaus $(|\Delta t|<30 \mathrm{~min}$ ja sille ei ole yksinkertaista laskukaavaa, löytyy taulukoituna tai vaikka Yliopiston almanakasta).

Ilman kyllästyskosteus vesipinnan yllä $\left(e_{\mathrm{w}}\right)$ ja jääpinnan yllä $\left(e_{\mathrm{i}}\right)$ vesihöyrynpaineena, lämpötilan yksikkönä Celciusaste ja vesihöyrynpaineen millibaari:

$\log _{10} e_{w}(T)=\frac{0,7859+0,03477 T}{1+0,00412 T}$

$\log _{10} e_{i}(T)=\log _{10} e_{w}(T)+0,00422$ 


\section{Veden litikkeet}

Tämä luku käsittelee aluksi Itämeren virtauksia havaintojen valossa, mikä on ollut matemaattisten mallien kehittämiseen asti ainoa tapa tutkia virtauskentän ominaisuuksia. Virtausdynamiikan perusyhtälöitä tarkastellaan Itämeren oloissa ja luodaan lyhyt katsaus tärkeisiin erikoistapauksiin, joissa virtauksia voidaan kuvata yksinkertaistettujen liikeyhtälöiden avulla. Tutustutaan inertialiikkeeseen, tuulen ajovirtaan eli Ekmanvirtaukseen ja geostrofiseen virtaukseen. Seuraavaksi paneudutaan syvemmin virtausten perusdynamiikkaan; erityisesti pintavirtausten ja pohjanläheisten virtausten syntyyn sekä vedenvaihtoprosesseihin. Samalla analysoidaan Itämeren virtaushavaintoja suhteessa virtausdynamiikan teoriaan. Luku sisältää aaltoteoriaa, erityisesti niin sanottujen matalan veden aaltojen fysiikkaa, erikoistapauksena altaiden ominaisheilahtelut eli seichet. Sen jälkeen tutkitaan topografisia aaltoja. Vaikka vuorovesi-ilmiö ei ole Itämerellä kovin tärkeä ilmiö, niin sen perusteet käydään läpi. Edelleen tarkastellaan tuulien ja veden virtausten aiheuttamia varsin suuria vedenkorkeuden vaihteluita. Lopuksi perehdytään pinta-aaltojen ja sisäisten aaltojen teoriaan ja ominaisuuksiin Itämerellä.

\subsection{Itämeren kiertoliike ja virtauskentän yleispiirteitä}

Itämeren veden kiertoliikkeen tutkimuksen peruslähtökohtana on ollut jo viime vuosisadan alusta asti lähinnä majakkalaivoilla kerätty virtamittausaineisto. Näiden varsin alkeellisten, mutta suuntaa-antavien mittausten tuloksien avulla voitiin jo varhain muodostaa kuva pintakerroksen virtauksista. Päätulokseksi mittausten analyysista on saatu, että Itämeren altaissa vallitsee keskimäärin vastapäiväinen kiertoliike (kuva 6.1A-C). Tästä seuraa moninaisia vaikutuksia Itämeren fysiikkaan. Vaikka keskimääräi- 
set virtausnopeudet ovat alhaisia, luokkaa $5 \mathrm{~cm} / \mathrm{s}$, systeemin pysyvyys on melko suuri. Itämeren pääaltaissa havaitaan vastapäiväisen kiertoliikkeen ilmentymänä suurimittaisia virtauspyörteitä. Itämeren keskusaltaassa on suuri vastapäiväinen pyörre, jossa pintavesi virtaa sisään Baltian rannikkoa pitkin, ja ulosvirtaus suuntautuu pääosin Ruotsin rannikolla etelään. Suomenlahdella (kuva 6.1C) vesi virtaa sisään Viron rannikkoa myötäillen ulosvirtauksen tapahtuessa Suomen rannikon ja Suomenlahden keskilinjan välisellä alueella. Pohjanlahdella on kaksi laajamittaista pyörrettä: eteläisempi on Selkämerellä, jossa vesi virtaa pohjoiseen Suomen rannikkoa pitkin ja vastaavasti ulos Ruotsin rannikon suuntaisesti. Merenkurkku toimii välivyöhykkeenä. Sen pohjoispuolella on Selkämeren pyörrettä vastaava sirkulaatio, jossa vesi virtaa pohjoiseen Suomen rannikolla ja etelään Ruotsin rannikon suuntaisesti.

Virtausten yleinen kiertosuunta tulee esille myös tarkasteltaessa mitattuja virtauksen suuntajakaumia eli virtausruusuja (kuva 6.2). Pohjanlahdella tehtyjen virtausmittausten mukaan Suomen rannikon lähellä virtaus suuntautuu yleisen kiertoliikkeen mukaisesti lähinnä pohjoiseen tai toiseen mahdolliseen suuntaan eli etelään. Avomerellä virtausruusujen suuntajakaumat ovat huomattavasti rannikkoalueita symmetrisempiä. Tämä perustuu siihen, että avomerellä rannikot eivät ohjaa virtauksien suuntaa, ja lisäksi keskimääräisvirtauksen pysyvyys on avomerellä rannikkoalueita pienempi, ja virtauskenttä sisältää paljon pyörteitä.

Huolimatta Itämeren pintavirtausten melko suuresta pysyvyydestä virtauskentässä esiintyy kuitenkin ajallisia ja paikallisia vaihteluita ja pienimittaista pyörteilyä, minkä vuoksi samaan aikaan mereen laitettujen poijujen reitit poikkeavat toisistaan (kuva 6.3). Tämä johtuu siitä, että pienikin sijaintiero meressä johtaa tilanteeseen, jossa jokaisen poijun sijaintipaikassa vallitsevat tuuli- ja virtausolot poikkeavat hiukan naapu-

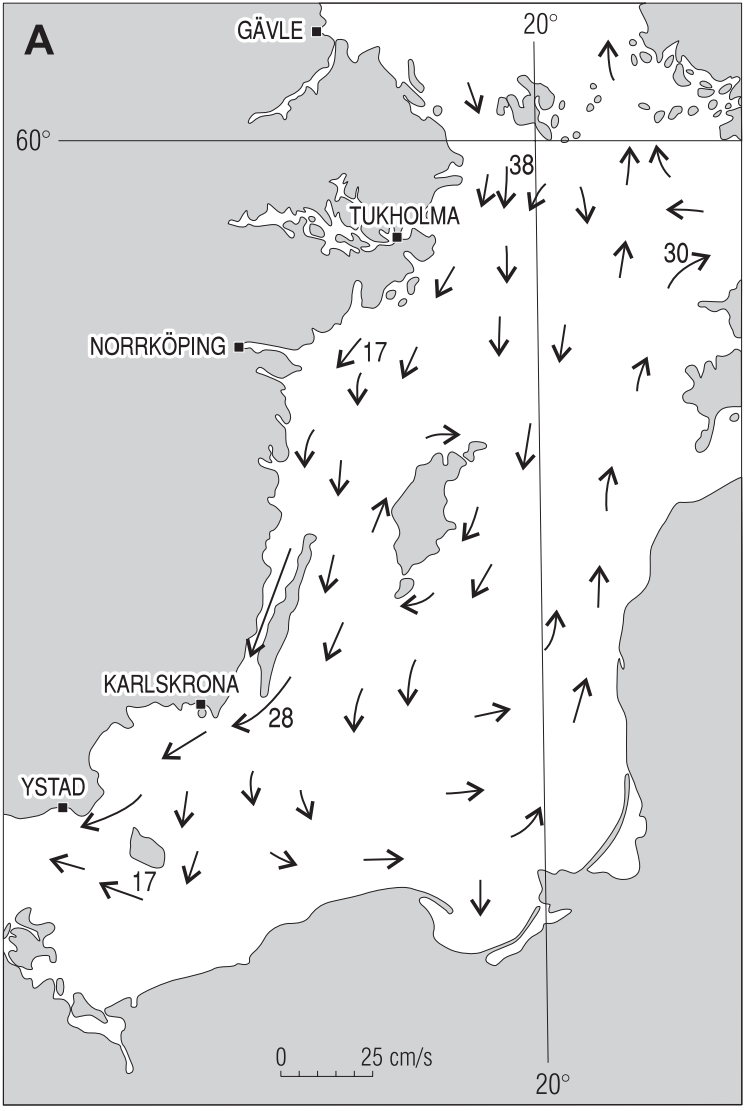

ripoijun vastaavista oloista. Näin ajan myötä poijut erkaantuvat toisistaan, jolloin niiden kokemat erot paikallisissa tuuli- ja virtausoloissa korostuvat entisestään.

Salmipaikkojen virtauksissa on omat erityispiirteensä, sillä salmissa virtaus on usein salmien suuntaista. Tarkastellaan virtauksia kapeassa Ahvenanraumassa (kuva 6.4). Nähdään, että virtaus salmen suuntaisesti on keskimäärin huomattavasti suurempi kuin salmen poikkisuuntainen virtaus. Salmen aiheuttama virtauksen "ohjaus" on ilmeistä. Ahvenanrauma on syvä, yli 100 metriä, ja sen virtauksella on tyypillinen kaksikerrosjakauma. Pinnassa vesi virtaa Pohjanlahdelta ulos edellä kuvatun veden syklonaalisen kierron takia (kuva 6.1), kun taasen 40 metrin alapuolella havaitaan sisäänvirtaus Pohjanlahdelle. Kyseiset virtaukset ovat esimerkkitapauksessa suuruudeltaan $10-25 \mathrm{~cm} / \mathrm{s}$, mikä on salmivirta- 
Kuva 6.1. Itämeren pintakerroksen keskimääräinen kiertoliike mittausten perusteella (A-B) ja mallilaskelmiin perustuen (C). Virtauksen pysyvyys on merkitty prosentteina. A) virtaukset Etelä-Itämerellä. Piirretty julkaisun (Sjöberg 1992) pohjalta. B) virtaukset Pohjois-Itämerellä (Palmén 1930), C) mallilaskelmaan perustuva skemaattinen kuva Suomenlahden keskimääräisestä pintavirtauksesta. (Andrejev ym. 2004)
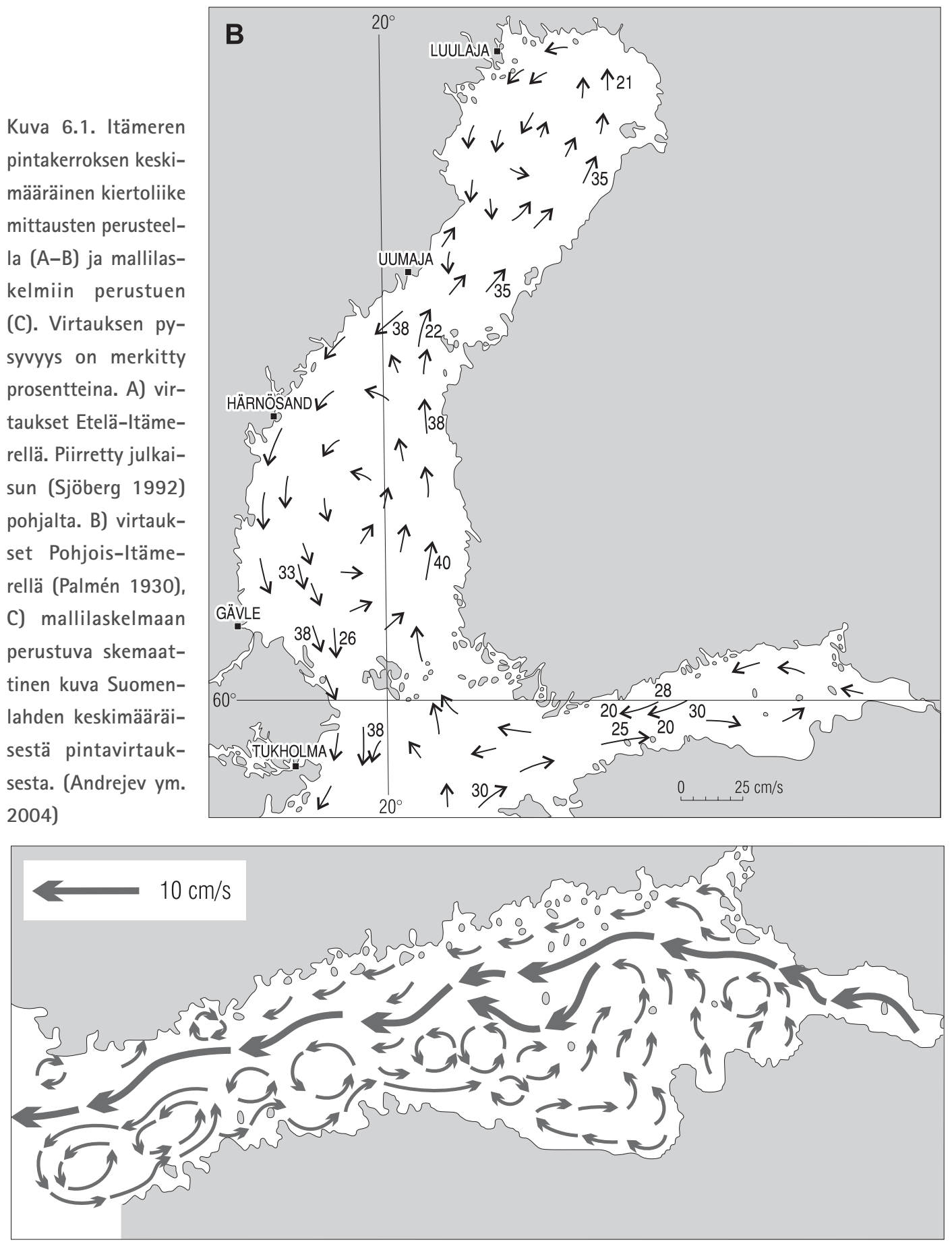

uksille tyypillistä. Salmen poikkisuuntaan tapahtuva virtaus on heikkoa (nopeudet $0-5 \mathrm{~cm} / \mathrm{s}$ ) ja virtauksen vertikaaliprofiili on vaihteleva.
Virtausten pystyjaukauma on Itämerellä yleensä joko yksi- tai kaksikerroksinen. Tällä on voimakas kytkentä yleiseen hydrografiaan. Kuvas- 

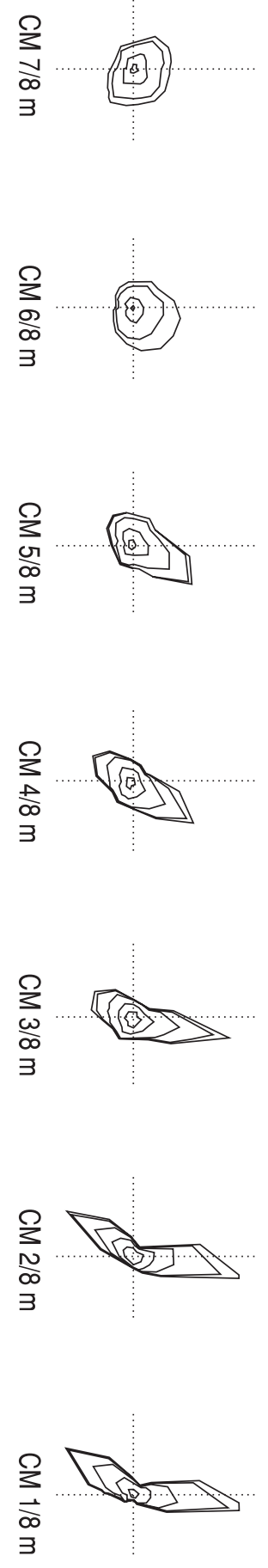

Kuva 6.2. Virtausruusuja perustuen mittauksiin Rauman edustalla vuonna 1991 (Murthy ym. 1993). Asema CM1 on lähinnä rannikkoa (10 kilometriä rannikosta), ja CM7 sijaitsee kauimpana (55 kilometriä) rannikosta, vaaka-akseli osoittaa oikealle pohjoiseen. Mittaussyvyys on 8 metriä.

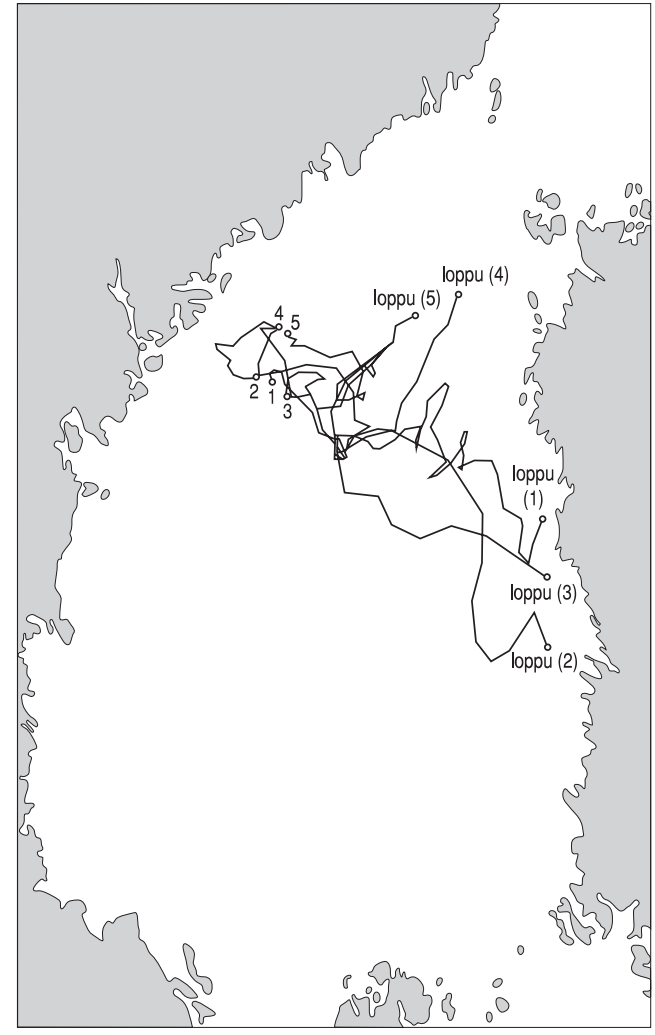

Kuva 6.3. Ajelehtivien poijujen liike Pohjanlahdella 7-18 heinäkuuta, 1991: poijujen 1-5 sijoittamispaikat, niiden polut ja loppusijainnit. (Piirretty Håkanssonin ym. [1994] kuvasta.)

sa 6.5 on virtausnopeuksien aikasarja Saaristomerellä (syvyys 41 metriä). Alueella on usein heikohko kaksikerroksinen suolaisuusjakauma. Nähdään, että pintavirtaukset, joiden syntyyn tuulella on keskeinen merkitys, vaihtelevat mittausjakson aikana 5 ja $15 \mathrm{~cm} / \mathrm{s}$ välillä. Virtaukset pohjan lähellä ovat selvästi pienempiä, 2-5 $\mathrm{cm} / \mathrm{s}$. Kuvasta 6.5 havaitaan yhteys virtausten, suolaisuuden, lämpötilan ja happitilanteen välillä. Pohjanläheinen suolaisuus ja lämpötila pysyivät alkusyksyn lähes vakioina, kun happitilanne vastaavasti huononi, koska vedenvaihtoa pohjan ja pinnan välillä ei ollut. Lokakuun lopussa oli voimakas virtaustilanne, jolloin kerrosrakenne rikkoutui. Pohjanläheinen lämpötila nousi, kun lämpimämpää vettä siirtyi pinnasta pohjaan. Vas- 
taavasti pohjan suolaisuus pieneni ja happitilanne parani hypähdyksellisesti, kun pinnasta pääsi hapekasta vettä pohjaan asti. Tilanteen jälkeen pohjan lämpötila laski hitaasti vesimassan yleisen jäähtymisen takia. Suolaisuus pysyi vakiona, kun kerrosrakenne oli hävinnyt. Happitilanne pysyi vakaana, koska hapenkulutus on talven aikana vähäistä ja kerrostuneisuutta ei ollut.

\subsection{Virtausdynamiikan perusteita - skaala-analyysi}

Merten virtaus on kolmiulotteista, mutta anisotrooppista horisontaalitason ja vertikaalisuunnan välillä. Tämä seuraa siitä, että vertikaalitasossa tilannetta hallitsee gravitaatio. Horisontaalinen virtaus on Itämerellä suuruusluokkaa $10 \mathrm{~cm} / \mathrm{s}$, kun taas pystynopeudet ovat alle $1 \mathrm{~mm} / \mathrm{s}$. Massan säilymislakiin käytetään meren dynamiikassa aina kokoonpuristumattoman nesteen mallia.

Merkitään horisontaalista ja vertikaalista virtausta symboleilla $\boldsymbol{U}=(u, v)$ ja $w$. Koordinaatisto suunnataan siten, että $x$-akseli osoittaa itään, $y$-akseli pohjoiseen ja $z$-akseli ylös. Horisontaalista nabla-operaattoria merkitään $\nabla_{\mathrm{H}}$. Dynamiikan perusyhtälöt eli liikemäärän säilymislain horisontaalinen komponentti, liikemäärän säilymislain hydrostatiikan perusyhtälöksi redukoitunut vertikaalinen komponentti, ja massan säilymislaki eli jatkuvuusyhtälö voidaan kirjoittaa muodossa:

$$
\begin{aligned}
& \frac{\partial \boldsymbol{U}}{\partial t}+\left(\boldsymbol{U} \cdot \nabla_{H}\right) \boldsymbol{U}+w \frac{\partial \boldsymbol{U}}{\partial z}+f \boldsymbol{k} \times \boldsymbol{U}= \\
& -\frac{1}{\rho} \nabla_{H} p+A_{H} \nabla_{H}^{2} \boldsymbol{U}+A_{v} \frac{\partial^{2} \boldsymbol{U}}{\partial z^{2}} \\
& \frac{\partial p}{\partial z}=-\rho g \\
& \frac{\partial w}{\partial z}+\nabla_{H} \cdot U=0
\end{aligned}
$$

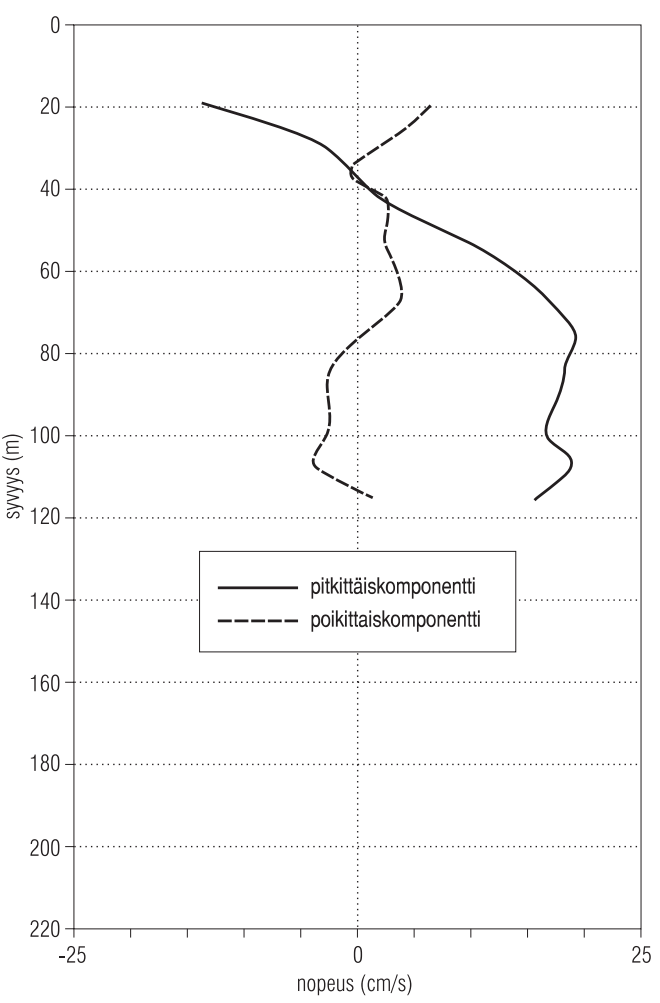

Kuva 6.4. Esimerkki hetkellisestä salmivirtauksesta Ahvenanmerellä (asema F33,60 $32^{\circ} \mathrm{N}, 18^{\circ} 57^{\prime} \mathrm{E}$ ). Plus-merkkiset suunnat tarkoittavat virtauksia pohjoiseen ja itään, miinus-merkkiset etelään ja länteen. (Riikka Hietala, henkilökohtainen tiedonanto)

missä $f=2 \Omega \sin \phi$ on Coriolis-parametri, $\Omega=$ $0,7292 \cdot 10^{-4} s^{-1}$ on maapallon kulmanopeus, $\phi$ on leveysaste, $\rho$ on tiheys, $p$ on paine ja $A_{H}$ sekä $A_{v}$ ovat horisontaalinen ja vertikaalinen turbulenttinen viskositeettikerroin.

Itämeren dynamiikassa tyypilliset mitat ovat: $U=10 \mathrm{~cm} / \mathrm{s}, T=5$ vuorokautta (synoptinen jakso), $L=50 \mathrm{~km}, H=25 \mathrm{~m}$. Niiden avulla arvioidaan horisontaalisen liikeyhtälön (6-1a) termien suuruudet oheisen kaavion mukaan (arvojen yksikkö on $10^{-6} \mathrm{~m} / \mathrm{s}^{2}$ ).

Jatkuvuusyhtälön perusteella $W U / H=U^{2} / L$, joten advektiotermit ovat samansuuruiset. Vedenkorkeushavaintojen perusteella pinnankaltevuus on tyypillisesti $10 \mathrm{~cm} / 100 \mathrm{~km}$, ja silloin 


\begin{tabular}{|l|ll|l|l|ll|}
\hline Inertia & \multicolumn{2}{|l|}{ Advektio } & Coriolis & Painegradientti & Kitka \\
\hline $\boldsymbol{U} / T$ & $\boldsymbol{U}^{2} / L$ & $W \boldsymbol{U} / H$ & $f \boldsymbol{U}$ & $\rho^{-1} \Delta_{\mathrm{H}} p / L$ & $A_{\mathrm{H}} \boldsymbol{U} / L^{2}$ & $A_{\mathrm{v}} \boldsymbol{U} / H^{2}$ \\
\hline 0.2 & 2 & 2 & 10 & 10 & 4 & 10 \\
\hline
\end{tabular}

pintakerroksen horisontaalinen painegradientti on $\nabla_{\mathrm{H}} p \approx \rho g \cdot 10^{-6}$.

Ylläolevassa jaotelmassa on esitetty suuruusluokka-arviot horisontaalisen liikeyhtälön termeistä. Dominoivat termit ovat Coriolis-kiihtyvyys, painegradientti ja vertikaalinen kitka, joka sisältää tuulienergian siirron mereen ja pohjakitkan aiheuttaman vaimennuksen. Noin kertalukua pienempiä termejä ovat advektio ja horisontaalinen kitka. Advektio tulee merkittäväksi, kun dynamiikka on intensiivistä ja $U$ kasvaa. Horisontaalinen kitka tulee merkittäväksi rannikon lähellä, kun $L$ pienenee. Inertia on merkittävä, kun aikaskaala $T$ on vain muutamien tuntien luokkaa.

Itämeren pienestä koosta ja maantieteellisestä sijainnista seuraa, että Coriolis-parametria voidaan pitää vakiona $\left(f=1,26 \cdot 10^{-4} \mathrm{~s}^{-1}\right.$, kun $\phi=$ $\left.60^{\circ} \mathrm{N}\right)$. Laskelmat voidaan käsitellä lokaalisessa tasoprojektiossa, joka pyörii vertikaaliakselin ympäri. Yhtälöt olisivat huomattavasti monimutkaisempia esitettyinä pallon pinnalla. Virtausongelman reunaehdot ovat Itämerellä suhteellisen yksinkertaiset. Lähes kaikkialla on kiinteä, passiivinen reuna, sisän tulevaa virtausta on jokisuissa ja sisään-ulos -virtausta Tanskan salmissa. Tanskan salmien tilanne vaikuttaa suoraan syvän veden kiertoon sekä välillisesti koko virtauskenttään hallitessaan Itämeren vedenpinnan yleistason muuttumista.

Itämeren virtaus on kombinaatio tuulen ajovirrasta, vesitaseen aiheuttamasta termohaliinisesta sirkulaatiosta ja geostrofisesta mukautumisesta ajovirran ja termohaliinin sirkulaation aiheuttamiin muutoksiin. Virtauskentissä voidaan erottaa kaksi perustapausta: barotrooppinen ja barokliininen virtaus. Barotrooppisessa tapauksessa veden tiheys riippuu vain syvyydestä, toisin sanoen tiheyden samanarvonkäyrät eli isopyknit ovat aina samansuuntaisia kuin isobaarit. Barokliinisessa tilanteessa isopyknien ja isobaarien välillä on kaltevuuskulma, joka myös yleensä muuttuu syvyyden suhteen. Tällöin painegradientti ja sen aiheuttama virtaus muuttuvat vertikaalisuunnassa.

Useissa virtausmittauksiin perustuvissa tutkimuksissa on ilmennyt, että Itämeren vaste on barotrooppinen yli 50 tuntia kestävissä tuulitilanteissa, ja 10-40 tuntia kestävissä tuulitilanteissa vaste on barokliininen. Alle 10 tuntia kestävissä tuulitilanteissa vaste häviää nopeasti. Energiaa barokliinisessa moodissa on kertaluokkaa enemmän kuin barotrooppisessa. Itämerta ei siis voida käsitellä homogeenisena vesialtaana. Meteorologiset olosuhteet säätelevät tarkoin virtauskentässä havaittuja vaihteluita, joten tuuli- ja virtausspektreissä on melko lailla samanlaisuutta. Varsinkin pinnan läheisessä kerroksessa virtauksen vaihtelut liittyvät selkeästi tuulen muutoksiin; inertiajakso on tosin merten sisäistä dynamiikkaa. Syvemmissä vesikerroksissa liike on enemmän kytketty tuulikentän divergenssiin ja pyörteisyyteen, kun taas vesirungon aaltoliikkeisiin ja vuoroveteen liittyvät vaihtelut ovat kertaluokkaa pienempiä.

Itämeren virtauksien energiaspektreissä tulee ilmi (kuva 6.6), että inertiajakso (13,2-14,5 tuntia Itämerellä) on voimakkain yksittäinen jakso. Vuorovesiaallon ja sisäisten aaltojen välisestä vuorovaikutuksesta löytyy viitteitä 10-12 tunnin periodeissa. Myös hyvin lyhytperiodisia piikkejä on nähtävissä kuvan 6.6 tapauksessa virtausnopeuden komponenteille (8, 7,5, 6, 5, 7 ja 4 tuntia). 


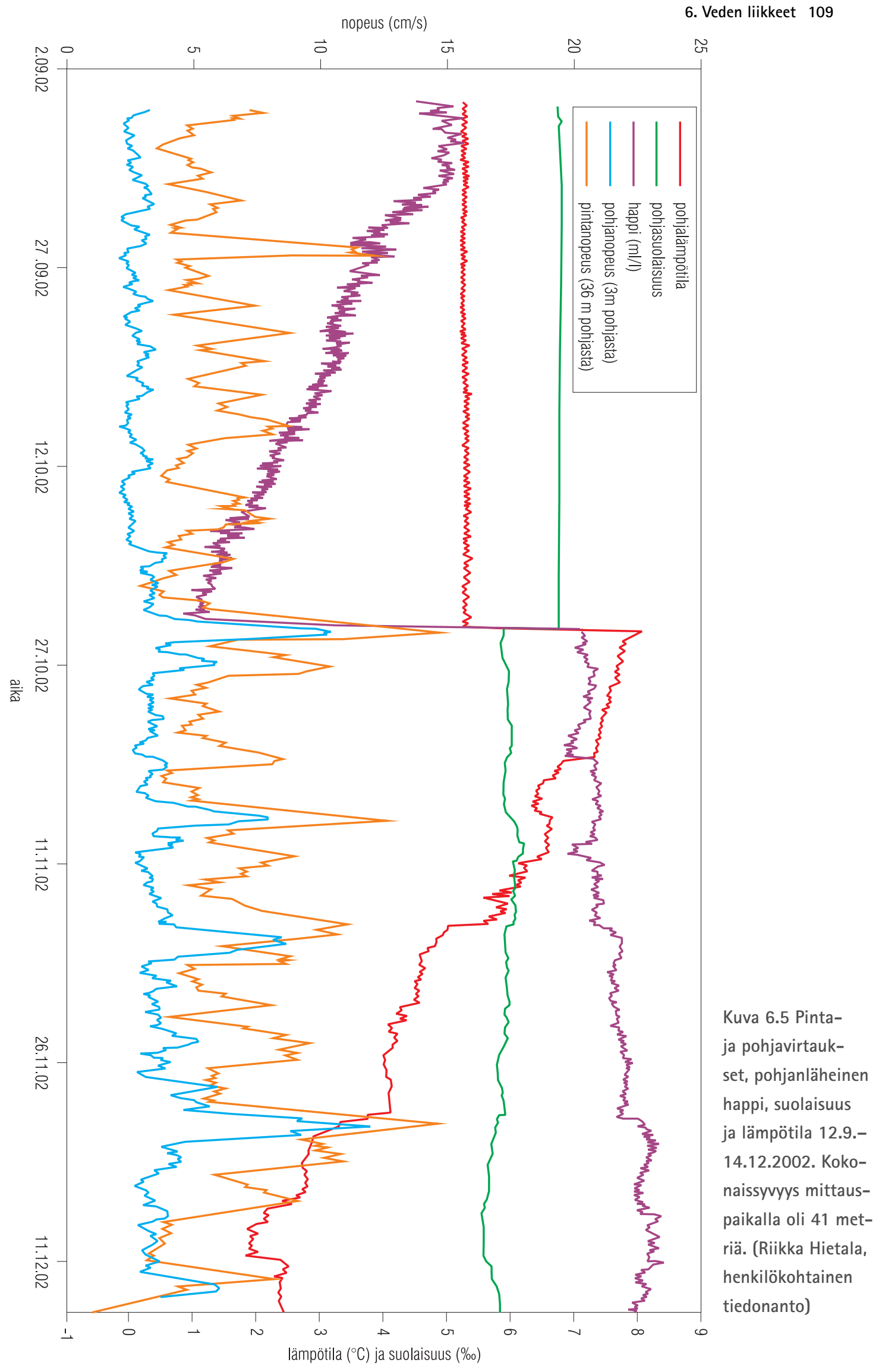




\subsection{Tärkeitä erikoistapauksia merten dynamiikassa}

\subsubsection{Inertialiike ja Itämeren vasteet}

Inertialiike tarkoittaa meritieteessä vesimassan ympyränmuotoista rataliikettä, jossa inertia eli hitausvoima ja Coriolis-kiihtyvyys ovat tasapainossa. Tällaisen liikkeen esiintymisen Itämerellä vahvistivat 1930-luvulla Gustafsson ja Kullenberg (1936). He analysoivat ankkuroiduista aluksista kesinä 1931-1933 tehtyjä virtausmittauksia. Kyseinen tutkimus oli myös ensimmäinen inertialiikkeen kartoitus koko maailmassa. Myöhemmin on selvinnyt, että inertialiike on Itämeren dynamiikan eräs hallitsevista piirteistä (kuva 6.7).

Inertialiike syntyy tilanteessa, jossa virtausta ylläpitänyt tuuli tyyntyy. Veden virtaus jatkuu massan hitauden vuoksi ja kääntyy pyörivällä alustalla ympyräksi. Inertialiikkeen perusyhtälö saadaan horisontaalisesta liikeyhtälöstä. Ulkoiset voimat ja kitka nollataan ja virtauskenttä oletetaan homogeeniseksi. Vesihiukkasen liikeyhtälöön jäävät vain inertia ja Coriolis-kiihtyvyys:

$$
\frac{d \boldsymbol{U}}{d t}=-f \boldsymbol{k} \times \boldsymbol{U}
$$

Operaatio $-\mathbf{k} \times \boldsymbol{U}$ kääntää nopeusvektorin $90^{\circ}$ oikealle ja osoittaen Coriolis-kiihtyvyyden suuntaan. Tämä yksinkertainen vektoriyhtälö ratkaistaan kirjoittamalla se ensin yhtälöpariksi ja käyttäen lineaaristen differentiaaliyhtälöiden ratkaisumenetelmiä. Saadaan ratkaisu:

$$
|\boldsymbol{U}|=\text { vakio, } \alpha=\alpha_{\mathrm{o}}-f t
$$

missä $\alpha$ on liikesuunta, ja $\alpha_{o}=\alpha(t=0)$.

Siis nopeuden itseisarvo on vakio, ja nopeuden suunta kiertyy kulmanopeudella $-f$, pohjoisella pallonpuoliskolla $(f>0)$ myötäpäivään. Yksi kierros kestää niin sanotun inertiaalijakson $T_{\mathrm{I}}$, jonka pituus on
$T_{I}=\frac{2 \pi}{f}$

Kiertoympyrän säde on $R_{\mathrm{I}}=U_{\mathrm{o}} \mid f$. Itämerellä inertiaalijakso on $13,2-14,5$ tuntia $\left(60^{\circ}\right.$ leveysasteella 13,8 tuntia). Jos oletetaan, että $U_{\mathrm{o}}=10$ $\mathrm{cm} / \mathrm{s}$, niin kiertoympyrän säde on noin $800 \mathrm{~m}$.

Todellisuudessa kiertoympyrä pienenee ajan myötä kitkan takia. Se voidaan mallittaa yksinkertaisella tavalla lisäämällä yhtälön oikealle puolelle vaimennustermi $-r U$, missä $r$ on kitkakerroin. Vaimennuskertoimen käänteisluku $1 / r$ on systeemin relaksaatioaika (edellä mainitussa Gustafssonin ja Kullenbergin havaintosarjassa on $1 / r \approx 1$ viikko). Inertialiike on eri vaiheessa termokliinin ylä- ja alapuolella ja rannikon läheisyydessä se vaimenee nopeasti kitkan takia.

\subsubsection{Ekman-virtaus}

Ruotsalainen merentutkija V.W. Ekman selitti teoreettisesti jo sata vuotta sitten tuulen ajovirran muodostuksen. Tuulen aiheuttama kitka merenpintaan toimii ulkoisena voimana, vertikaalinen kitka eli veden turbulenttinen viskositeetti siirtää tuulienergiaa alaspäin pintakerroksessa ja Coriolis pyrkii kääntämään virtaussuuntaa oikealle. Perusmallissa oletetaan vakaa, horisontaalisesti homogeeninen tilanne ja viskositeetti $\mathrm{A}_{\mathrm{v}}$ vakioksi.

Ekman-yhtälöt voidaan kirjoittaa muodossa:

$$
\begin{aligned}
& f v_{E}+A_{z} \frac{d^{2} u_{E}}{d z^{2}}=0,-f v_{E}+A_{z} \frac{d^{2} v_{E}}{d z^{2}}=0 \\
& z \rightarrow \infty: \boldsymbol{u}_{\mathrm{E}} \rightarrow 0 ; z=0: A_{\mathrm{z}} \mathrm{d} \boldsymbol{u}_{\mathrm{E}} / \mathrm{d} z=\tau_{\mathrm{a}} / \rho
\end{aligned}
$$

missä $u_{\mathrm{E}}, v_{\mathrm{E}}$ ovat Ekman-virtausnopeuden komponentit $x$ - ja $y$-suunnassa. Ekmanin probleeman ratkaisu on:

$\left|\boldsymbol{u}_{\mathrm{E}}(z)\right|=\exp (-\lambda z)\left|\boldsymbol{u}_{\mathrm{o}}\right|, \alpha=\alpha_{\mathrm{o}}-\lambda z$ 


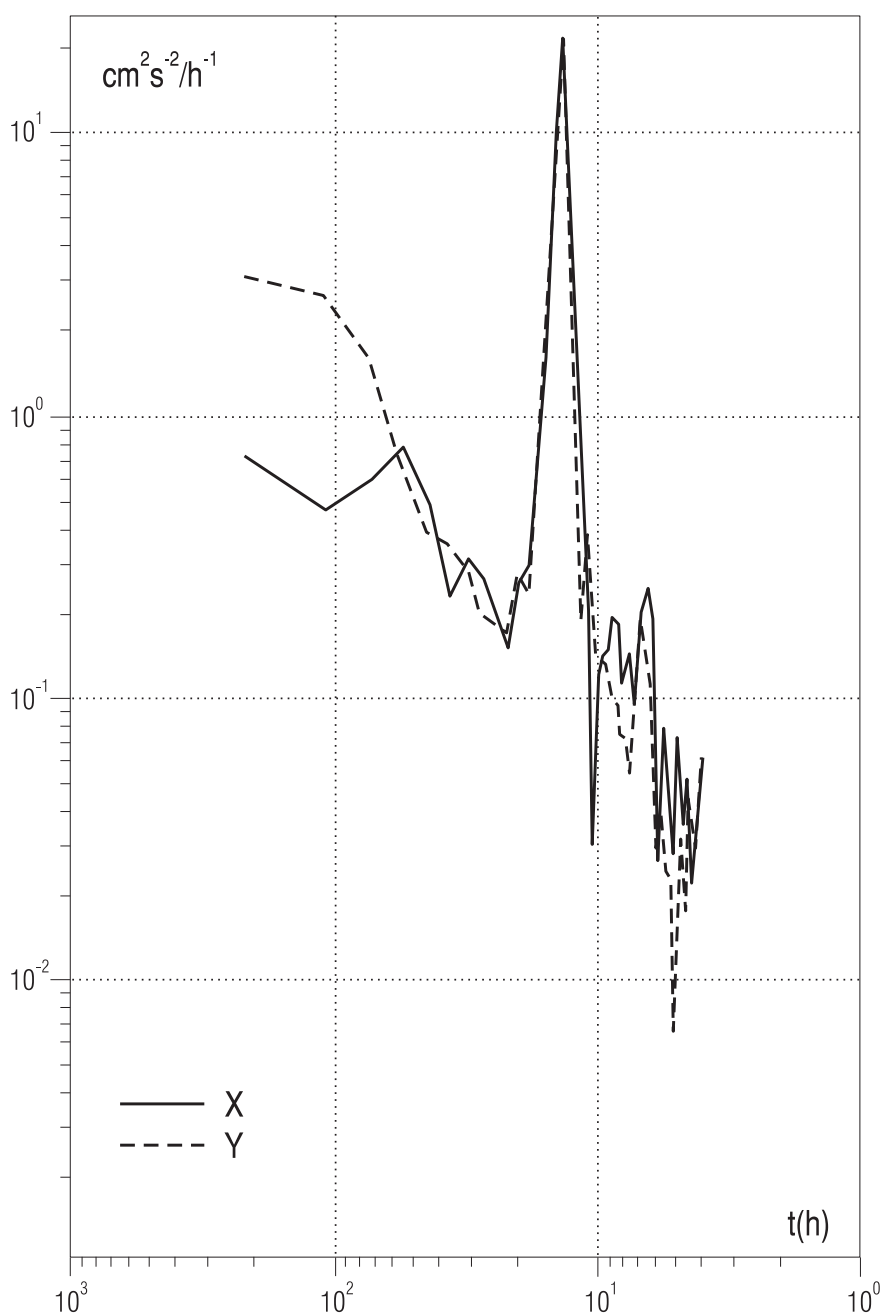

Kuva 6.6. Virtausten energiaspektri Selkämerellä 13 metrin syvyydellä (piirretty Aleniuksen [1980] kuvasta). Jatkuva viiva edustaa virtauksen $\mathrm{x}$-komponenttia rannikkoa vastaan kohtisuoraan, pisteviiva virtausnopeuden y-komponenttia rannikon suuntaan.

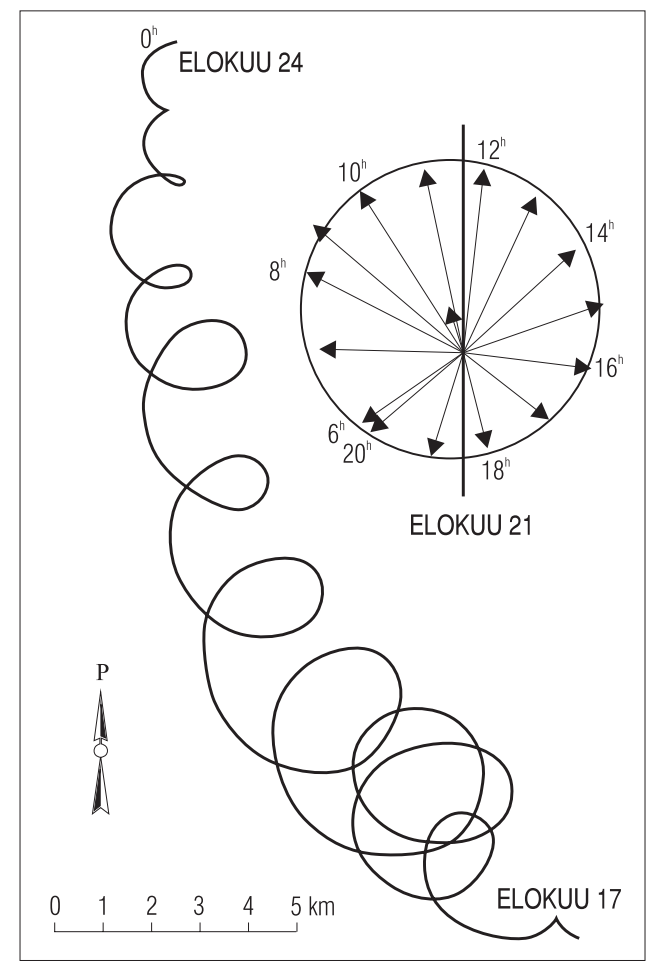

Kuva 6.7. Esimerkki inertialiikkeestä Itämerellä. (Gustafsson ja Kullenberg 1936) missä $\boldsymbol{u}_{\mathrm{o}}$ on pintavirtaus, $\lambda=\left(\mathrm{f} / 2 \mathrm{~A}_{\mathrm{v}}\right)^{1 / 2}$ ja $\alpha_{\mathrm{o}}$ on sen suunta, joka poikkeaa $45^{\circ}$ oikealle tuulen suunnasta. Virtausnopeus pienenee eksponentiaalisesti syvyyden mukana ja kiertyy samalla myötäpäivään. Tuloksena on spiraalimaisesti kiertyvä profiili, niin sanottu Ekman-spiraali (kuva 6.8). Tietyllä syvyydellä virtaus on pintavirtaukselle vastakkainen, jolloin virtausnopeus on mitätön verrattuna pintavirtaukseen.
Tätä syvyyttä kutsutaan Ekman-syvyydeksi (tai kitkakerroksen syvyydeksi) ja kerrosta pinnasta Ekman-syvyydelle kutsutaan Ekman-kerrokseksi. Ekman-syvyys $D_{\mathrm{E}}$ on

$D_{E}=\pi\left(2 A_{V} / f\right)^{1 / 2}$

Ekmanin spiraali pitää kvalitatiivisesti paikkansa. Virtausnopeus pienenee ja liikkeen suunta 


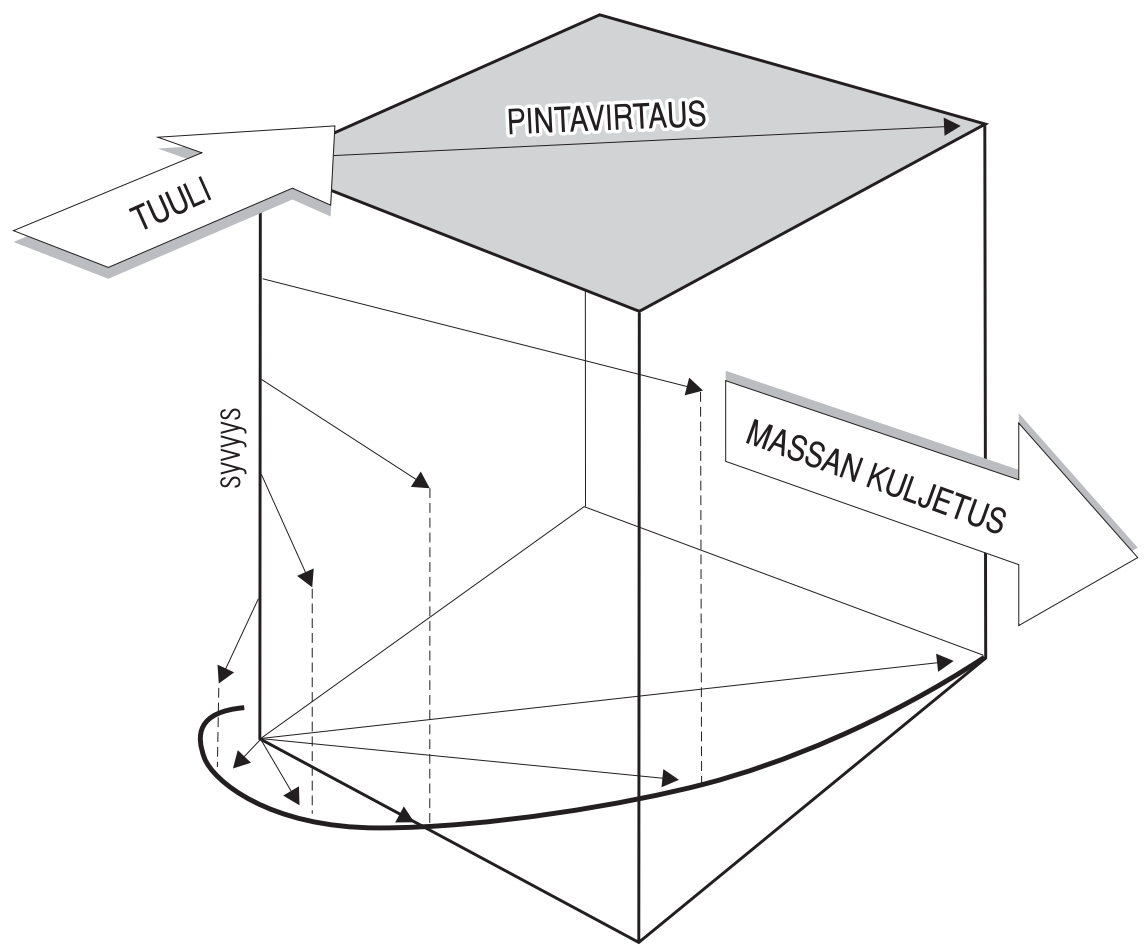

Kuva 6.8. Ekman-spiraali: virtaus kiertyy syvyyden mukana oikealle ja heikkenee. Massan kokonaiskuljetus suuntautuu pohjoisella pallonpuoliskolla kohtisuoraan oikealle tuulen suunnasta.

kiertyy syvempään mennessä; teorian olettama vakioviskositeetti ei ole kovin hyvä approksimaatio ja siksi yksityiskohdissaan spiraalia ei havaita luonnossa. Pintavirtaus kulkee avomerellä tuulen suunnasta oikealle nopeudella 2-3\% tuulen nopeudesta, mutta kiertokulma tuulen suhteen ei ole Ekman-teorian mukainen $45^{\circ}$ vaan $20-30^{\circ}$. Tätä yksinkertaista pintavirtausmallia käytetään monissa sovelluksissa, kuten vedessä kelluvien kappaleiden ajelehtimisen ennustamisessa. Kuvassa 6.9 on esitetty havaintoja vapaasti ajelehtivan jään ja pintakerroksen virtausnopeudesta. Jään liikesuunta on siinä $15^{\circ}$ tuulennopeudesta oikealle ja liikenopeus $2 \%$ tuulennopeudesta.

Veden kokonaiskuljetus voidaan integroida Ekman-spiraalista. Tätä kutsutaan Ekman-kuljetukseksi tai massan kuljetukseksi. Se on suuntautunut (pohjoisella pallonpuoliskolla) $90^{\circ}$ oikealle tuulen suunnasta. Ekman-kuljetus on riippumaton viskositeetista, mikä poistaa kuljetusvirtateoriasta spiraalin rajoittuneisuuden ja on siksi hyvin pätevä tulos.

Mallia voidaan soveltaa tuulen ajamaan kumpuamiseen. Jos tuulee rannikon suuntaan siten, että rannikko jää vasemmalla, Ekman-kuljetus suuntautuu suoraan ulospäin. Tällöin ulosvirtaava pintavesi korvautuu massan jatkuvuuden nojalla syvemmältä kumpuavalla vedellä. Kuvan 6.10 esimerkissä pohjoistuuli on aiheuttanut Selkämerellä kumpuamista.

\subsubsection{Geostrofinen virtaus}

Geostrofisella virtauksella, eli "maapallon virittämällä virtauksella”, tarkoitetaan vakaata, kitkatonta virtausta, jossa painegradienttivoima ja Coriolis-kiihtyvyys tasapainottavat toisensa. 


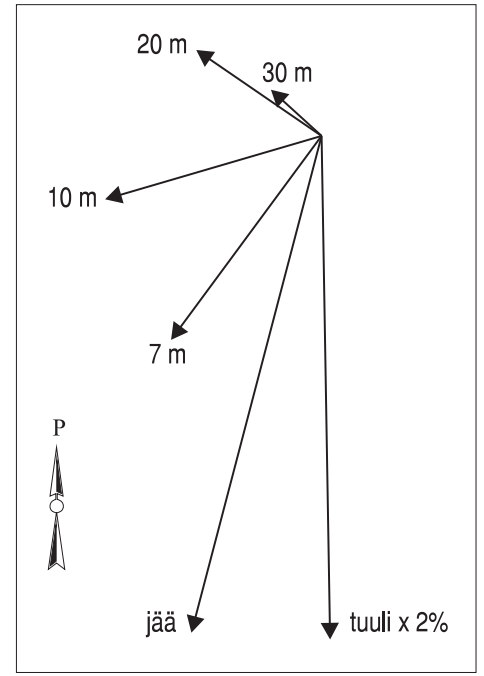

Kuva 6.9. Tuulen ajama jään liike ja Ekman-kerroksen virtaus Perämerellä huhtikuussa 1975 (Leppäranta 1990).

Geostrofinen tasapaino voidaan kirjoittaa muodossa:

$f \boldsymbol{k} \times \boldsymbol{U}=-\frac{1}{\rho} \nabla_{H} p, \frac{\partial p}{\partial z}=-\rho g(6-8)$

Tällöin virtaus on isobaarien suuntaista siten, että matalampi paine on pohjoisella pallonpuoliskolla virtaussuuntaan nähden vasemmalla. Barotrooppisessa tilanteessa geostrofinen virtaus ei riipu syvyydestä, barokliinisessa tapauksessa virtaus muuttuu syvyyden suhteen.

Geostrofinen pintakerroksen virtaus aiheutuu merenpinnan kaltevuudesta. Jos pinnan kaltevuus on itäsuuntaan $\beta$, on pohjoiseen suuntautuva virtausnopeus $v$ $=g \beta / f ;$ käytännössä $\beta \sim 10^{-6} \quad(=1$

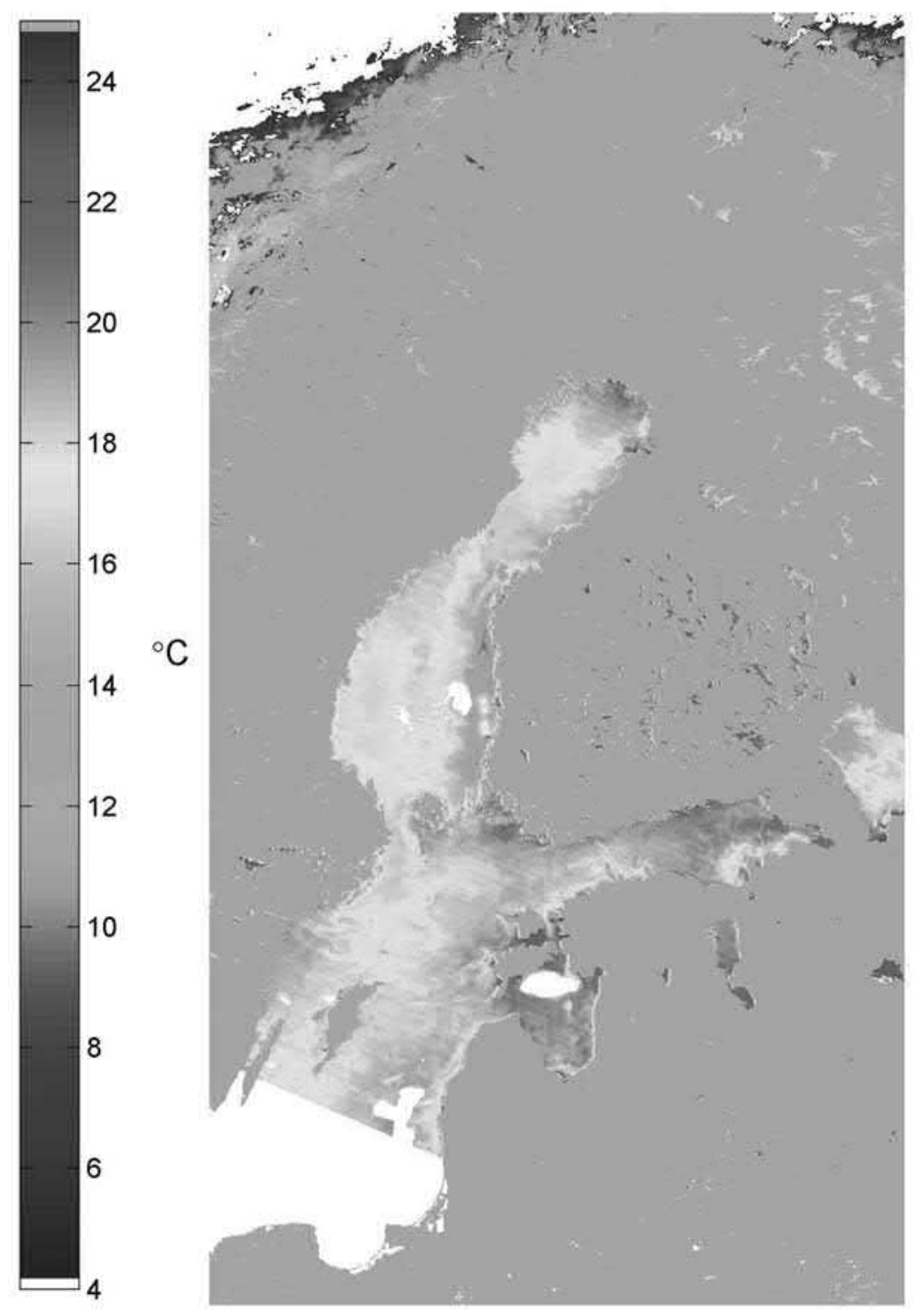

Kuva 6.10. Pintalämpötilakuva Itämereltä 15.7.2003. Selkämerellä on kumpuamistilanne, jossa kylmä vesi erottuu sinisenä. (Kuva on prosessoitu Suomen ympäristökeskuksessa Ilmatieteen laitoksen vastaanottamasta NOAA AVHRR satelliittidatasta.)

$\mathrm{cm} / 10 \mathrm{~km}$ ), jolloin $v \sim 10 \mathrm{~cm} / \mathrm{s}$. Kaksikerroksisessa systeemissä, jollainen Itämeri tyypillisesti on, saadaan pintakerroksen virtaus $v_{1}$ pinnankaltevuudesta, ja ero alakerrokseen saadaan pintakerroksen ja alakerroksen välisen tiheyseron avulla: 

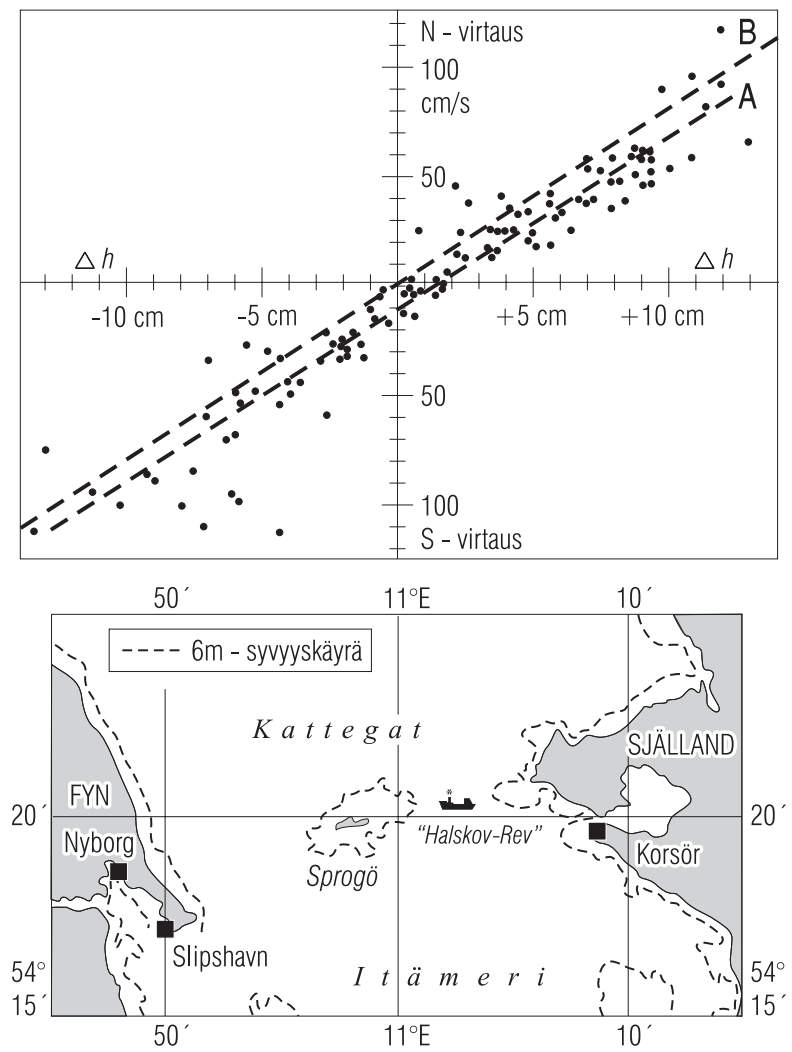

Kuva 6.11. Pinnankaltevuus Iso-Beltin poikki laskettuna Korsörin ja Slipshavnin vedenkorkeuseroista sekä kaltevuuden suhde pintavirtaukseen, joka on havaittu majakkalaivalta "Halskov Rev". (Piirretty kuvan Dietrich ym. [1957] pohjalta.)

$v_{1}-v_{2}=\frac{g}{f} \frac{\rho_{1}-\rho_{2}}{\rho_{2}} \frac{H_{B}-H_{A}}{L}$

missä $v_{1}$ ja $v_{2}$ ovat virtaukset pintakerroksessa ja alakerroksessa, $\rho_{1}$ ja $\rho_{2}$ ovat vastaavat tiheydet, $H_{A}$ ja $H_{B}$ ovat yläkerroksen paksuudet havaintoasemilla $\mathrm{A}$ ja $\mathrm{B}$, ja $L$ on havaintoasemien $\mathrm{A}$ ja B etäisyys.

Geostrofisen virtauksen määritystehtävä sisältää yhden dynaamisen oseanografian fundamentaalisista perusongelmista: vertailutason ongelman. Jollakin syvyystasolla on tunnettava geostrofinen virtaus tai paineen tasa-arvopinnan kaltevuus. Yleensä on oletettu, että merten yläkerroksen alla 1-2 kilometrin syvyydes- sä painepinnat ovat horisontaalisia, jolloin siis geostrofinen virtaus nolla. Itämerellä näin syviä vesiä ei ole.

Pinnan kaltevuuden tarkka määritys ratkaisisi vertailutason ongelman, mutta koska kaltevuudet ovat pieniä $\left(10^{-6}\right)$, niiden mittaaminen on hyvin vaikeata. Yksi ensimmäisiä todistuksia geostrofiselle virtaukselle olivat Iso-Beltin vedenkorkeusgradientin mittaukset ja niiden vertailu mitattuihin salmen läpivirtauksiin (kuva 6.11). Itämerellä on analysoitu syvien altaiden virtauksia myös geostrofisella mallilla. Liikkeettömän pinnan olettamus on melko huono, sillä pohjanläheinen kitkakerros tulee vastaan syvyyksillä, jossa geostrofinen virtaus on vielä merkittävä. 
Geostrofisen mallin antamat absoluuttiset virtaukset voivat olla harhaisia, mutta suhteelliset virtaukset vesirungon sisällä tulevat joka tapauksessa oikein.

\subsubsection{Tuulen ajovirran ja geostrofisen virtauksen yhdistäminen}

Horisontaaliliikkeen yhtälö on

$\frac{\partial \boldsymbol{U}}{\partial t}+\boldsymbol{U} \cdot \nabla \boldsymbol{U}+f \boldsymbol{k} \times \boldsymbol{U}=-\frac{1}{\rho} \nabla p$

$+A_{H} \nabla_{H}^{2} \boldsymbol{U}+A_{V} \frac{\partial^{2} \boldsymbol{U}}{\partial z^{2}}$

Tarkastellaan Ekmanin teorian yhdistämistä geostrofiseen teoriaan. Oletetaan stationäärinen tilanne ja jätetään advektio sekä horisontaalikitka pois. Virtaus jaetaan tuulen ajamaan ja geostrofiseen komponenttiin:

$\boldsymbol{U}=\boldsymbol{u}_{\mathrm{E}}+\boldsymbol{u}_{\mathrm{G}}$

Tällöin saadaan

$f \mathrm{k} \cdot\left(\boldsymbol{u}_{\mathrm{E}}+\boldsymbol{u}_{\mathrm{G}}\right)=-\rho^{-1} \nabla p+A_{\mathrm{V}} \partial^{2} \boldsymbol{U} / \partial \mathrm{z}^{2}(6-12)$

Jos lisäksi oletetaan, että $\left|\partial^{2} \boldsymbol{u}_{\mathrm{E}} / \partial z^{2}\right|>>\mid \partial^{2} \boldsymbol{u}_{\mathrm{G}}{ }^{\prime}$ $\partial z^{2}$, voidaan Ekman-virtaus ja geostrofinen virtaus laskea erikseen ja summata.

$f \mathrm{k} \cdot \boldsymbol{u}_{\mathrm{E}}=A_{\mathrm{V}} \partial^{2} \boldsymbol{u}_{\mathrm{E}} / \partial \mathrm{z}^{2}$,

$f \mathrm{k} \cdot \boldsymbol{u}_{\mathrm{G}}=-\rho^{-1} \nabla p$

Erityisesti barotrooppisessa tapauksessa on $\boldsymbol{U}_{\mathrm{G}}$ $=$ vakio ja siis $\partial^{2} \boldsymbol{U}_{\boldsymbol{G}} / \partial \mathrm{z}^{2}=0$ eli tällainen hajotelma soveltuu tilanteeseen hyvin.

\subsection{Itämeren virtausdynamiikan pääpiirteet ja vedenvaihto}

\subsubsection{Virtausten muodostuminen}

Itämeren virtausten syntymekanismit ovat termohaliininen horisontaalinen tiheysgradientti ja tuulen leikkausjännitys veden pintaan. Näin muodostuvia virtauksia ohjaavat Coriolis-kiihtyvyys ja pohjatopografia. Suurten jokien tuoma vesivolyymi voi myös aiheuttaa paikallisia vedenkorkeusmuutoksia ja sitä kautta virtauksia. Meren pienen koon takia pohja- ja reunakitkat vaimentavat merkitsevästi virtauksia.

Itämeren altaissa yleinen sirkulaatio on tyypillinen kerrostuneelle systeemille. Kuhunkin altaaseen tuleva vesimassa asettuu tiheyttään vastaavaan vesikerrokseen: makea vesi pintaan ja suolaisempi vesi syvemmälle. Itämeressä sekoittuminen on pystysuunnassa erityisesti rajoittunutta suolaisuuden voimakkaan kerrostuneisuuden takia.

Pisimmässä aikaskaalassa (kuukausista eteenpäin) on havaittavissa barokliininen perusvirtaus. Tämä on seurausta makean veden positiivisesta taseesta ja siihen liittyvästä suolaisuuden voimakkaasta horisontaalisesta gradientista. Systeemi toimii niin, että makea pintavesi poistuu Itämerestä pinnan läheisessä kerroksessa, kun taas suolaista vettä tulee sisään lähellä pohjaa. Tuulen ajovirta on hallitseva, kun virtausten aikajänne on 1-10 vuorokautta. Tuulen vaihteluiden vuoksi keskimääräinen virtaus on heikko, vaikka hetkelliset virtaukset voivat olla kertaluokkaa keskivirtausta suurempia.

Itämeren keskimääräinen, havaittu kiertoliike on yhdistelmä barokliinisesta perusvirtauksesta ja tuulen keskimääräisestä ajovirrasta. Havaittavissa on heikko, vastapäivään tapahtuva kiertoliike. Itämeressä ei ole voimakasta pysyvää virtausta kuten valtamerien Golf- tai Kuroshio-virran tyyppinen stabiili virtaus. 


\subsubsection{Pintavirtaus ja sen dynamiikka}

Virtauksia alettiin mitata Itämerellä 1900-luvun alkupuolella majakkalaivoilta. Tämän pohjalta Witting (1912) sekä Palmén (1930) laativat Pohjois-Itämeren virtauskartaston, johon edelleenkin pohjautuu peruskuvamme keskimääräisestä kiertoliikkeestä (kuva 6.1A-B). Merialtaissa kiertoliike on syklonaalista eli vastapäiväistä. Altaan kokoisia virtauspyörteitä esiintyy Gotlannin altaalla, Suomenlahdella, Selkämerellä ja Perämerellä. Tämä keskimääräinen kiertoliike kuljettaa vettä, lämpöä ja suoloja. Sen ansiosta altaiden itäpuolella vesi on lämpimämpää ja suolaisempaa kuin länsipuolella, ja kapealla Suomenlahdella vastaava ero näkyy etelä- ja pohjoispuolen välillä (katso kuvat 4.17 ja 4.18).

Keskimääräinen virtaus on suuruusluokkaa 5-10 cm/s. Kovien tuulten vallitessa ajovirran nopeus voi kasvaa tasolle $50 \mathrm{~cm} / \mathrm{s}$ ja salmivirroissa nopeus voi olla jopa $100 \mathrm{~cm} / \mathrm{s}$. Yleisesti ottaen voidaan arvioida pintavirtaukseksi 2-3 prosenttia tuulen nopeudesta.

Keskimääräinen kiertoliike on nimensä mukaisesti vain pitkän ajan keskiarvo, eikä kyseisenlainen virtausrakenne ole aina vallitseva tilanne. Palmén (1930) määritteli keskimääräisvirtauksen suunnan stabiliteetin eli suunnan pysyvyyden $R$ virtauksen vektori- ja skalaarinopeuksien suhteena:

$R=\frac{|\langle\boldsymbol{U}\rangle|}{\langle|\boldsymbol{U}|\rangle} \cdot 100 \%$,

Pysyvyys on virtauksen suunnan vaihtelun mittari, ja keskivirtaus itsessään kuvaa veden nettokuljetusta. Mikäli virtauksen suunta on tarkasteltavana aikajaksona vakio, virtauksen pysyvyys on 100 prosenttia, ja pysyvyyden saavuttaessa arvon 0 myös keskivirtaus ja veden nettokuljetus on nolla. Käytännössä pintavirtauksen pysyvyys on tyypillisesti 20-40 prosenttia, Suomenlahden ulosvirtauksessa jopa 50-80 prosenttia. Yleisesti virtausten pysyvyys on suurempi altaiden länsi- kuin itärannikolla johtuen Coriolis-efektin "lukitsevasta" vaikutuksesta yhdessä jokivirtaamien kanssa.

Virtausten melko suuresta pysyvyydestä johtuen eliölajien leviämisreitit noudattavat rannikoita. Niinpä Suomenlahteen etelästä levinneet lajit ovat asettuneet ensin Viron rannikolle ja Pietarin edustalle kotiutuneet vieraslajit leviävät länteen Suomen rannikkoa pitkin. Etelästä pohjoiseen suuntautuva pintavirtaus on tuonut meidänkin rannikollemme uusia lajeja, muiden muassa uuden Prorocentrum minimum -panssarilevän. Se saapui eteläiselle Itämerelle Pohjanmereltä vuonna 1982 ja eteni sitten noin 100 kilometriä vuosittain pohjoiseen päin saavuttaen Suomenlahden vuonna 1993. Lajin leviämistä on seurattu erityisen tarkkaan, sillä se on aiheuttanut myrkyllisiä leväkukintoja valtamerissä. Vastaavia virtausten mukana levinneitä lajeja on viime aikoina ollut muitakin, esimerkiksi Merenkurkkuun saakka levinnyt pohjalla elävä monisukamato, Marenzeria viridis, joka saapui ensin Pohjanmerelle Pohjois-Amerikasta.

\subsubsection{Syvän veden virtaukset ja sisäänvirtaus Itämereen}

Syvän veden kiertokulku Itämeressä etenee Tanskan salmista syvänteitä ja kynnyksiä pitkin itään ja pohjoiseen. Sisäänvirtauksen vastapainona makea vesi virtaa ulos pintakerroksessa. Vedenvaihto Pohjanmeren kanssa riippuu huomattavasti vallitsevista sääoloista ja niihin liittyvistä vedenkorkeusvaihteluista. Tärkeitä tekijöitä vedenvaihdossa ovat barotrooppiset virtaukset, jotka liittyvät Itämeren ja Kattegatin välisiin vedenkorkeuseroihin. Näistä aiheutuva veden edestakainen heilahtelu Itämeren suualueella on paljon suurempaa kuin makean veden ulosvirtaus. Barotrooppiset virtaukset ovat tärkeä elementti 
Itämeren pystysuuntaisessa sirkulaatiossa ja suolaisuusjakauman muodostumisessa.

Sisäänvirtaavat vesimassat syntyvät Kattegatissa makeasta Itämeren pintavedestä ja syvemmästä Pohjanmereltä tulevasta suolaisesta vedestä. Koska pintaveden kierto suualueella on varsin vaihtelevaa, Itämereen sisäänvirtaavan veden suolaisuus vaihtelee sangen suurissa rajoissa mutta se on joka tapauksessa huomattavasti suurempi kuin etäämpänä Itämeren sisäosissa.

Sisäänvirtaus Itämerelle saa aikaan sen, että altaiden syvänteisiin muodostuu suolainen alusvesi. Syvänteiden välillä vedenvaihto tapahtuu pohjanläheisten virtausten kautta kynnysten ylitse, missä veden liikkeen määräävänä tekijänä on gravitaatio ja kynnyssyvyys. Sisäänvirtaava suolainen vesi asettuu sellaiselle syvyydelle, jossa alkuperäisen veden tiheys on sama kuin sen. Suolainen alusvesi sekoittuu ympäröivien vesimassojen kanssa ajan mittaan, jolloin suolaisuus vähitellen pienenee. Pystysuuntainen sekoittuminen tiheyspintojen läpi syvänteissä kuljettaa suolaista vettä ylöspäin. Tässä prosessissa tuulipakote on ilmeisesti merkittävä tekijä.

Itämeren perusongelma on syvän veden uusiutumisen hitaus pohjanläheisessä kerroksessa. Se tapahtuu kvasi-horisontaalisia tiheyspintoja seuraavien virtausten avulla, missä vesimassat joutuvat ylittämään erilaisia kynnyksiä. Useat fysikaaliset tekijät vaikuttavat pohjanläheisten virtausten piirteisiin. Tärkeimpänä tekijänä on topografia, mutta myös pohjakitka, sekoittuminen ympäröivien vesimassojen kanssa, Corioliskiihtyvyys sekä tiheyserot sisäänvirtaavan veden ja sitä ympäröivien vesimassojen välillä vaikuttavat. Itämereen tulevia huomattavia suolapulsseja ja erilaisia intruusiota käsitellään erikseen luvussa 8.

Suolainen vesi virtaa Itämereen Kattegatista Drogdenin kynnyksen yli Juutinraumassa ja Darssin kynnyksen yli Belttien meressä (kuva 4.3, 6.12). Arkonan allas on ensimmäinen Itämeren allas, jonka kautta suolainen valtamerivesi kulkee Itämeren sisäosiin. Siinä sisäänvirtaava vesi muodostaa 5-15 metriä paksun pohjakerroksen, jossa suolaisuus voi nousta 24 promilleen. Veden suolaisuus pienenee sekoittumisen takia, ja koska Arkonan allas on varsin matala, kovat tuulet voivat aiheuttaa intensiivistä sekoittumista ja pohjan läheisen kerroksen vesimassojen selkeätä laimenemista.

Syvän veden virtaus etenee Bornholmin altaaseen Bornholmin kanavassa, jossa kynnys on Bornholmin Hammarenin ja Skånen Sandhammaren välissä (kynnyssyvyys 45 metriä). Sisäänvirtaavan veden suolaisuus vaihtelee 8 ja 18,5 promillen välillä. Bornholmin altaasta virtaus etenee kohti itää Stolpen kanavan kautta Itäiselle Gotlannin altaalle. Noin 90 metriä syvän Stolpen kanavan kynnyssyvyys on Bornholmin altaan suuntaan 60 metriä, ja Gotlannin altaan suuntaan 80 metriä (Fonselius 1996).

Itäisestä Gotlannin altaasta osa vedestä virtaa kaakkoon Gdanskin syvänteeseen; kynnyssyvyys 114 metriä syvään Gdanskin lahteen on 100 metriä. Suurin osa vedestä virtaa pohjoiseen kohti Gotlannin syvännettä (249 metriä). Sen jälkeen veden liike jatkuu yli 140 metriä syvän kynnyksen yli Fårön syvänteelle (205 metriä) ja edelleen yli 115 metrin kynnyksen Pohjoiselle Gotlannin altaalle. Pohjoisessa Gotlannin allas rajoittuu Ahvenanmereen, jonka kynnyssyvyys on 70 metriä. Sen vuoksi Gotlannin altaan alusvesi ei voi virrata pohjoiseen Selkämerelle, vaan se virtaa lounaaseen Läntiselle Gotlannin altaalle sekä itään hivenen sisään Suomenlahteen.

Erityisesti Gotlannin altaassa ja Suomenlahdessa syvän veden hitaasta uusiutumisesta johtuen sen sisältämä happi kuluu usein loppuun. Hapen kuluminen johtuu bakteerien toiminnasta näiden hajottaessa laskeutuvan eloperäisen aineksen. Kun hapesta on kulutettu noin puolet, suurin osa pohjan eläimistä alkaa kärsiä. Hapen loppuessa muodostuu usein rikkivetypitoista vettä, jossa kaikki korkeampi elämä on mahdotonta. Nykyisellä tuotantotasolla syvän 


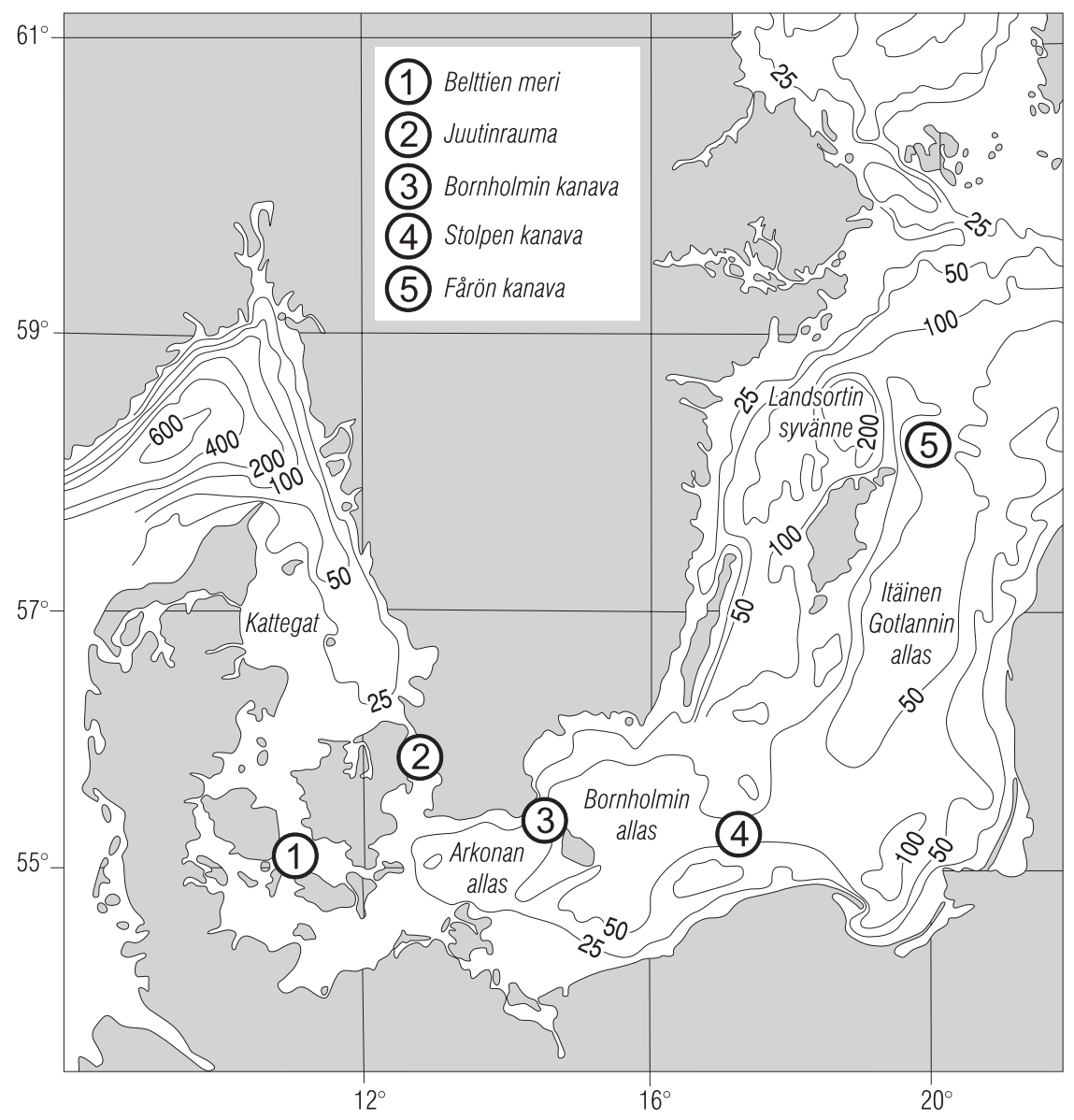

Kuva 6.12. Skemaattinen kuva syvän veden virtauksen kannalta keskeisistä altaista ja kynnyksistä lounaisella Itämerellä ja Gotlannin merellä. (Piirretty Kõutsin [1999] pohjalta.)

veden happivarastot riittävät vain kohtuullisen lyhyeksi ajaksi (muutamia vuosia). Hapettomilla pohja-alueilla sedimenttiin varastoitunutta fosforia vapautuu rautayhdisteistä. Tuloksena on valtava määrä liukoista fosforia, joka hapellisissa oloissa jäisi pohjaan. Ilmiötä kutsutaan sisäiseksi kuormitukseksi, joka esimerkiksi Suomenlahdella on jo suurempi fosforin lähde kuin ulkoinen kuormitus. Syvä vesi onkin merkittävä fosforivarasto, joka edistää levien kasvua pintaan joutuessaan, sillä liukoinen fosfori on suoraan käyttökelpoista leville.

Syvä vesi muodostuu Pohjanlahdella lähinnä siten, että Gotlannin meren pintavesi kylmenee talvella ja vajoaa Ahvenanmeren kynnyksen yli
Selkämerelle. Kynnyssyvyys on 70 metriä Söderarmin ja Lågskärin välillä. Ahvenanmeren pohjan läheiset kerrokset täyttyvät ensiksi suolaisella vedellä pohjoiselle kynnyssyvyydelle (100 metriä) asti. Vesi virtaa syvintä reittiä pitkin pohjoiseen ja itään Finngrundetin ohitse Ulvön syvänteelle asti. Merenkurkun maksimisyvyys on 65 metriä. Siinä on Holmöarnin etelä- ja pohjoispuolella kaksi kynnysaluetta, joiden molempien syvyys on 25 metriä. Perämeren syvä vesi muodostuu vastaavalla mekanismilla Selkämeren pintavedestä, joka virtaa sisään Merenkurkun keskellä sijaitsevan Nordvalenin matalikon molemmin puolin kohti koillista. Virtaukset tällä alueella ovat usein varsin voimakkaita. Pohjan- 


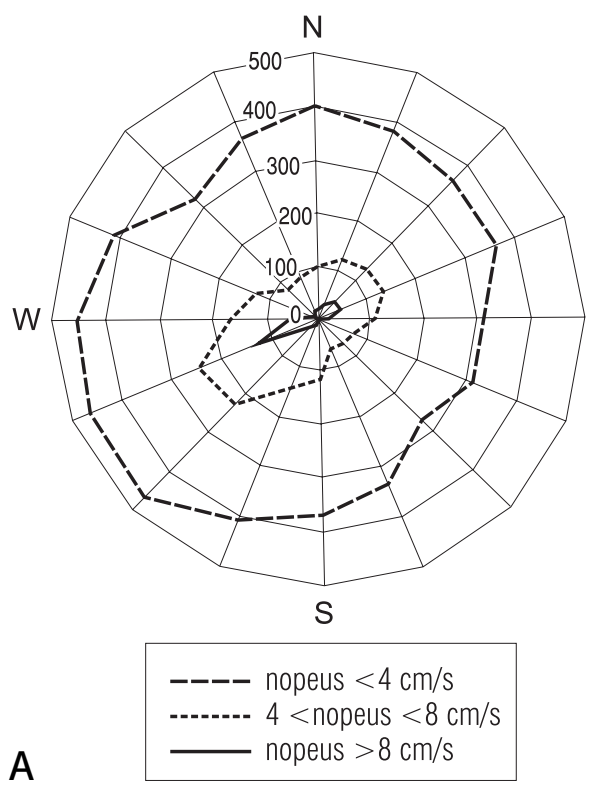

Kuva 6.13. A) Virtausruusu pohjanläheisistä virtauksista Utön eteläpuolella, B) vastaavan alueen pohjatopografia, syvyys metreinä. Virtausruusu edustaa tilannetta B-kuvan keskialueelta. (Riikka Hietala, henkilökohtainen tiedonanto)

lahden syvän veden tehokkaasta muodostumismekanismista johtuen siinä on aina runsaasti happea eikä ravinteita myöskään lähde liikkeelle pohjasta.

Esimerkkinä pohjanläheisten virtausten voimakkaasta topografisesta ohjauksesta on kuva 6.13, joka esittää tilannetta eräässä Saaristomeren syvänteessä. Nähdään, että virtaukset suuntautuvat sitä enemmän syvyyden samanarvonkäyrien suuntaisesti mitä suuremmasta nopeusluokasta on kyse. Suurimmilla nopeuksilla samanarvonkäyriin nähden poikkisuuntaisia virtauksia ei juuri esiinny. Pohjanläheiset virtaukset ovat siten riippuvia paikallisesta topografisesta ohjauksesta.

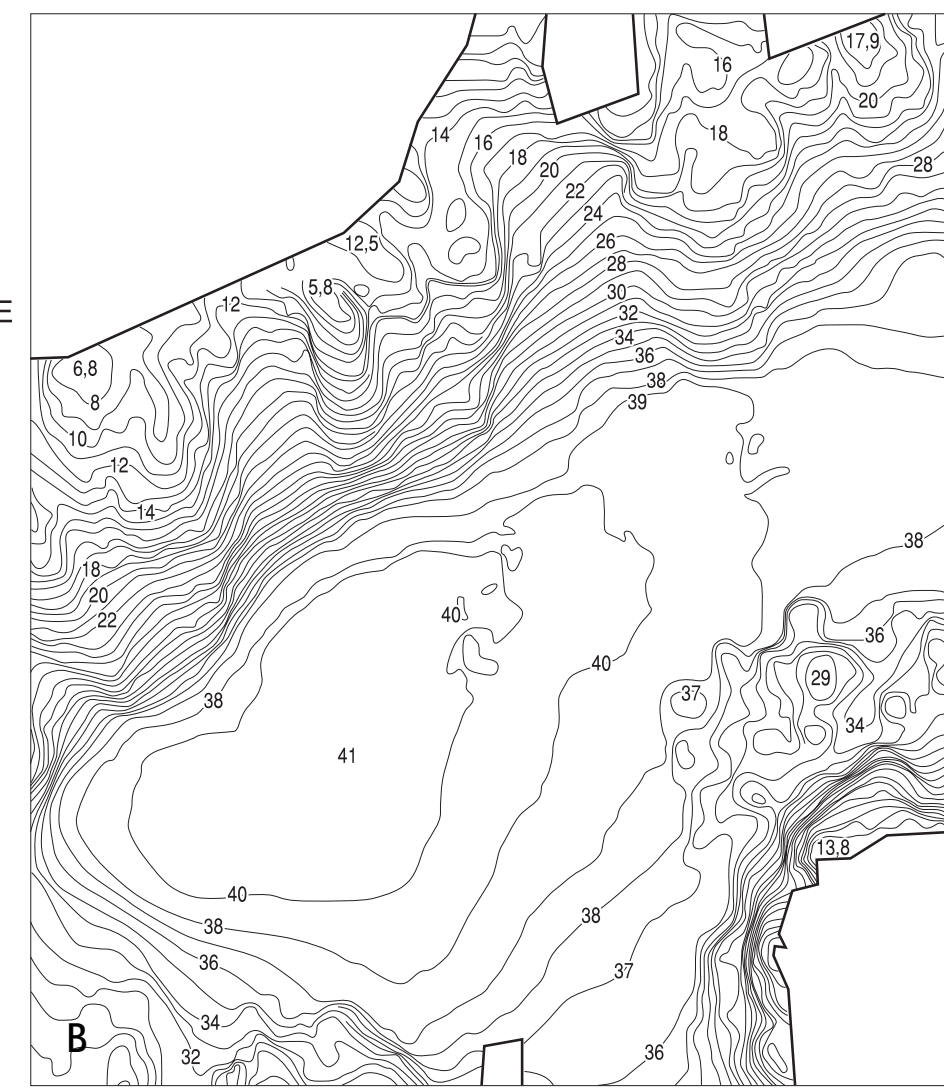

\subsubsection{Vedenvaihto altaiden välillä: salmivirtausmallit}

Itämeren keskeinen dynamiikan ilmiö on salmivirtaus (kuva 6.14). Suuria altaita yhdistävät salmet ja kanavat. Altaat saavat syvän vetensä yleensä Pohjanmeren suunnassa sijaitsevasta naapurialtaasta. Selkeä korrelaatio vallitseekin tietyn altaan alusveden suolaisuuden ja etelä- tai länsipuolella olevan naapurialtaan pintasuolaisuuden välillä. Tähän liittyvät suuret suolaisuuden hyppäykset salmikohdissa, kun taas altaiden sisällä suolaisuuden horisontaaliset gradientit ovat usein pieniä. Poikkeuksena on erityisesti Suomenlahti, jossa altaan sisällä on suuri ja jatkuva itä-länsisuuntainen suolaisuusgradientti.

Knudsenin (1900) yhtälöitä (katso luku 5) on käytetty arvioitaessa pitkän ajan keskimääräistä suolan ja veden vaihtoa tiettyjen salmien 


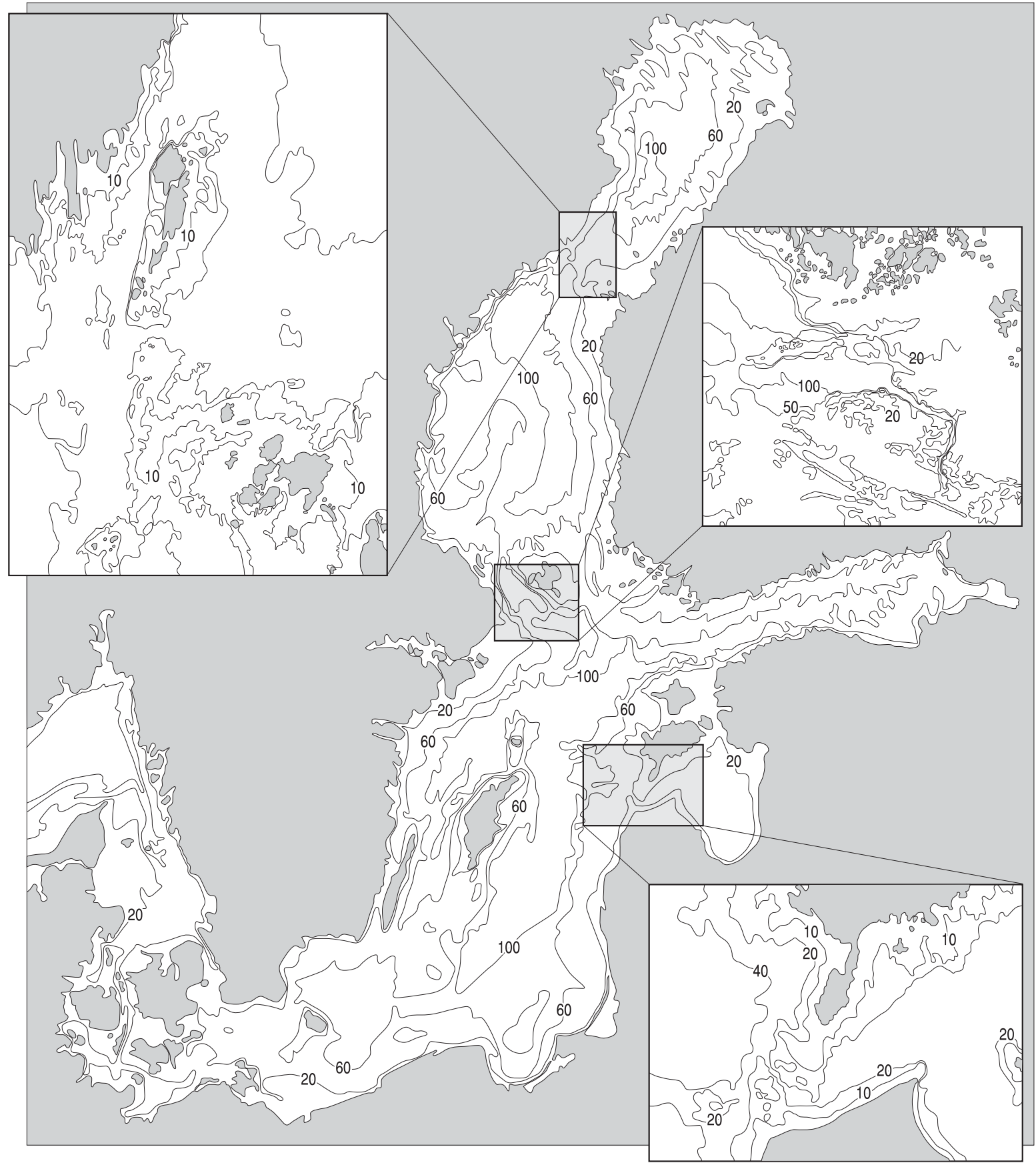

Kuva 6.14. Itämeren salmia (syvyys metreinä), joissa Stigebrandtin virtausmallia on sovellettu: Irben salmi, Ahvenanmeren-Gotlannin altaan kynnysalue ja Merenkurkku. (Piirretty Stigebrandtin [2001] kuvasta.) 
kautta. Tällaiset yksinkertaiset tarkastelut eivät kuitenkaan selitä varsinaisesti salmien dynamiikkaa: ajallis-paikallisia vaihteluita ja pystysuuntaista sirkulaatiota. Jotta ajasta riippuvainen vedenvaihto salmessa voidaan määrittää, tarvitaan malli, joka kuvaa alueen dynaamiset prosessit ja joka ottaa huomioon vallitsevat pakotetekijät ja reunaehdot.

Salmivirtauksissa voidaan erottaa dynaamisesti kaksi perustapausta: barokliininen ja barotrooppinen. Barotrooppisen moodin pakotteena on salmen päiden välinen vedenkorkeusero. Barokliinisen moodin pakotteena on salmen suunnassa vallitseva barokliininen (sisäinen) painegradientti, jonka aiheuttaa tiheysero salmen päissä olevien altaiden välillä. Barokliininen ja barotrooppinen salmivirtaus esiintyvät usein samanaikaisesti, ja barokliininen osa voi olla vähäinen, jos barotrooppiset virtausnopeudet ovat suuria. Virtausten amplitudeihin salmessa vaikuttavat kitkatekijät, Coriolis-kiihtyvyys ja topografinen ohjaus. Paikalliset tuuliolot vaikuttavat yleensä suoraan hyvin vähän salmen virtauksiin, mutta epäsuorasti ne näkyvät altaiden välisen barotrooppisen sekä barokliinisen painegradientin syntymisenä.

Stigebrandt (2001) on kehittänyt yksinkertaisen mallin, jossa Itämeren altaat on yhdistetty Kattegatiin kapeilla ja matalilla salmilla. Mallissa huomioidaan barotrooppinen virtaus ja kitkatekijät ja sen pakotteena on Kattegatissa havaittu vedenkorkeus. Sillä voidaan ennustaa hyvin Itämeren keskimääräinen vedenkorkeus sekä Belttien meren ja Juutinrauman virtaamat. Vedenkorkeuseron $\Delta h$ altaiden välillä aiheuttaa barotrooppinen virtaama $Q$ salmen läpi. Virtausta hidastaa pohjakitka ja suuren skaalan topografinen vastus, jonka aiheuttaa salmien päissä virtausten hidastuminen tai kiihtyminen. Näin saadaan Stigebrandtin kaava:

$Q^{2}=\frac{1}{\phi} \Delta h$ missä $\phi\left[\mathrm{s}^{2} \mathrm{~m}^{-5}\right]$ on salmelle ominainen kitkakerroin. Tämä on Bernoulli-tyyppinen kitkakorjattu yksinkertainen kaava.

Itämeren keskimääräinen vedenkorkeus $h_{B}$ voidaan laskea Kattegatin tunnetun vedenkorkeuden $h_{k}$ avulla $\left(\Delta h=h_{k}-h_{B}\right)$ yllä olevasta yhtälöstä (6-15), jossa $\phi:$ lle käytetään arvoa kytketyn kanavasysteemin suulla. Lisäksi tarvitaan Itämeren vesitilavuudelle muutosyhtälö:

$A \frac{d h_{B}}{d t}=Q+Q_{r}$

missä $A$ on Itämeren pinta-ala ja $Q_{F}$ on makean veden nettovuo Itämereen.

Mallitulosten mukaan alle kuukauden aikaskaalassa esiintyvät vedenkorkeuden oskillaatiot vaimenevat huomattavasti Tanskan salmien vaikutuksesta. Tätä pidemmässä aikaskaalassa esiintyvät oskillaatiot säilyttävät amplitudinsa. Itämeren voidaan katsoa olevan mallin mukaan alle kuukauden aikaskaalassa esiintyville, sisäiseen pakotteeseen perustuville vedenkorkeuksille suljettu systeemi.

Salmissa on periaatteessa kaksi erilaista pystysuuntaista sirkulaatiojärjestelmää. Ensinnäkin meren pintakerroksessa jokien tuomalla makealla vedellä on suuri merkitys sen sekoittuessa tuulen vaikutuksesta alla olevaan suolaisempaan veteen. Tätä kutsutaan usein estuaariseksi sirkulaatioksi. Toinen sirkulaatiosysteemi liittyy syvään veteen, joka sijaitsee salmessa kynnyssyvyyden alapuolella. Syvä vesi on siinä yleensä "lukittuna", mutta voi päästä salmesta ulos, mikäli sekoittuminen nostaa sen kynnyksen yli. Monissa salmissa nämä kaksi sirkulaatiojärjestelmää vallitsevat samanaikaisesti. Usein näiden järjestelmien vuorovaikutus on heikko, jolloin pinnalle tuleva vesimassa on peräisin kynnyksen yläpuolisesta välikerroksesta. Joissain kapeissa salmissa edellä mainitut järjestelmät voivat yhtyä (niin sanottu ylisekoittunut estuaari). 
Barokliiniselle kaksikerrosvirtaukselle voidaan esittää barokliiniseen hydrauliseen säätelyyn perustuva vakaan tilan yhtälö

$$
\frac{u_{1}^{2}}{g^{\prime} H_{1}}+\frac{u_{0}^{2}}{g^{\prime} H_{0}}=1
$$

missä $u_{1}, H_{1}$ ovat yläkerroksen virtausnopeus ja paksuus, $u_{0}$ ja $H_{0}$ ovat vastaavat suureet alakerroksessa,

$$
g^{\prime}=g \frac{\Delta \rho}{\rho_{0}}
$$

on niin sanottu redukoitu painovoima, $\Delta \rho$ on kerrosten välinen tiheysero ja $\rho_{0}$ on referenssitiheys.

Ajasta riippumattomassa tilanteessa tarvitaan lisäksi Knudsenin yhtälöiden tyyppiset tilavuuden ja suolaisuuden säilymisyhtälöt tutkittavassa salmessa.

Olettaen, että tiheys riippuu vain suolaisuudesta, päästään Stigebrandtin yhtälöön:

$$
P^{3}\left(1+\frac{\eta^{3}}{(1-\eta)^{3}}\right)-2 P^{2}+P=\frac{\eta^{3}}{F_{e}^{2}}
$$

missä $P=Q_{I} / Q_{P}$ on sekoittumisparametri, $\eta=H_{0} / H, H=H_{0}+H_{l}, W$ on salmen leveys,

$$
F_{e}^{2}=\frac{Q_{F}^{2}}{g \beta S_{0} H^{3} W^{2}}
$$

on Frouden luku (estuaarille ominainen Frouden luku on 1) ja $\beta$ on suolaisuuden muutoksiin liittyvä tiheyden muutoskerroin:

$\beta=\frac{1}{\rho} \frac{\partial \rho}{\partial S}$

Yhtälöllä (6-18) on kaksi reaalijuurta vain, jos $F_{e} \leq 1$. Barokliininen virtaus on maksimissaan, kun edellä mainitut kaksi juurta yhtyvät (kaksoisjuuri). Saavutetaanko kyseinen tilanne vai ei, riippuu sekoittumisesta altaassa ja salmen topografiasta. Jos maksimaalinen, barokliininen nopeus saavutetaan, estuaarin sanotaan olevan ylisekoittunut.

Kyseistä mallia on sovellettu Merenkurkkuun, jossa on kaksi syvää salmea Holmöarnin saaren molemmin puolin (kuva 6.14). Molemmissa kanavissa kynnyssyvyys on yli 20 metriä ja salmien leveys on alle kaksi kilometriä. Oletetaan, että $H=20$ metriä, Selkämeren suolaisuus $S_{0}=5,5$ promillea, makean veden tuotto $Q_{F}=3.425 \mathrm{~m}^{3} \mathrm{~s}^{-1}$ ja salmien leveys yhteensä $W=3.300 \mathrm{~m}$. Näillä oletuksilla saadaan: $F_{e}=0,055$ ja ehto ylisekoittumiselle (maksimaalinen barokliininen kuljetus) antaa $P=3,1$, mikä tarkoittaa, että $Q_{1}=10.600$ $\mathrm{m}^{3} \mathrm{~s}^{-1}$ ja $Q_{0}=7.125 \mathrm{~m}^{3} \mathrm{~s}^{-1}$ ja $S_{1}=3,7$ promillea. Malli antaa täten suolaisuuseron $S_{0}-S_{1}$ Perämeren ja Selkämeren välillä (2 promillea), mikä on lähellä havaittua arvoa.

Jos salmen leveys on suurempi kuin barokliininen Rossbyn säde $R_{l}=c / f$, jossa $c_{i}$ on sisäisten aaltojen etenemisnopeus, niin rotaation vaikutus voi estää kaksikerroksisen systeemin ulottumisen koko kanavan leveydelle. Tällainen tilanne vallitsee Irben salmessa, jossa salmen pohjoisosissa ulosmenevä makea vesi muodostaa kapean rannikkovirtauksen. Leveän salmen tapauksessa vedenvaihdon arvioimiseksi käytetään usein geostrofista menetelmää barokliinisessa kaksikerrossysteemissä. Itämeressä $R_{I}$ on tyypillisesti 3-10 kilometriä, joskus jopa alle kilometrin.

\subsection{Aaltoliike}

\subsubsection{Yleistä}

Aaltoliike on ajan ja/tai paikan suhteen jaksollinen, toistuva ilmiö. Sen matemaattinen perusmalli on siniaalto:

$\eta(x, t)=A \sin (\boldsymbol{k} \cdot \boldsymbol{x}-\omega t+\phi)$ 
Tässä $A$ on aallon amplitudi, $\boldsymbol{k}$ on aaltoluku, $\omega$ on taajuus ja $\phi$ on vaihe. Aaltoluku kuvaa paikan suhteen toistuvuutta ja se on vektori, sillä aallon suunnalla voi olla komponentteja jokaisen koordinaatin $x, y$ ja $z$ suuntaan. Aallon pituus on $\lambda=$ $2 \pi / k$ ja aallon periodi $T=2 \pi / \omega$. Aallon vaiheella kuvataan, missä pisteissä aalto leikkaa nollatason. Aallon korkeus eli harjan ja laaksonpohjan välinen pystysuora etäisyys on $2 A$.

Siniaalto saadaan lineaarisen aaltoteorian perusratkaisuna. Lineaarisessa teoriassa siniaaltoja voidaan laskea yhteen ja kuvata siten useampijaksoisia ilmiöitä; kääntäen, mikä tahansa jaksollinen ilmiö voidaan hajottaa harmonisella analyysillä sinimuotoisiin perusaaltoihin. Yksittäinen etenevä siniaalto on kuvattavissa siis kolmella parametrilla: amplitudi, pituus ja periodi.

Merentutkimuksessa aaltoilmiöt jaetaan kolmeen kategoriaan: matalan veden aallot eli pitkät aallot, syvän veden aallot eli lyhyet aallot ja vuorovesi. Matalan veden aalloissa $(\lambda>20 H)$ koko vesirunko on liikkeessä, kun taas syvän veden aalloissa $(\lambda<2 H)$ vain pintakerros; näiden välialueella $(2 H<\lambda<20 H)$ teoria on komplisoidumpaa. Vuorovesi on ulkoisen pakotteen ohjaamaa aaltoliikettä. Itämeren alueella sen merkitys on hyvin vähäinen.

\subsubsection{Matalan veden aallot}

Matalan veden lineaarisessa teoriassa tiheys oletetaan vakioksi ja advektiotermit jätetään pois. Jälkimmäinen ehto voidaan tulkita siten, että advektio on paljon painegradienttia pienempi: $U^{2} / L \ll g H / L$ eli $\mathrm{Fr}=U /[g H]^{1 / 2} \ll 1$, toisin sanoen Frouden luku on paljon pienempi kuin yksi. Lisäksi oletetaan, että pinnankorkeuden vaihtelut ovat pieniä syvyyteen verrattuna (niin sanottu pieniamplitudinen liike), jolloin $g(H+\xi)$ $\approx g H$. Tällöin saadaan perusyhtälöt:

$\frac{\partial u}{\partial t}-f v=-\frac{1}{\rho} \frac{\partial p}{\partial x}$ $\frac{\partial v}{\partial t}+f u=-\frac{1}{\rho} \frac{\partial p}{\partial y}$

$\frac{\partial p}{\partial z}=-g \rho$

$\frac{\partial w}{\partial z}=-\left(\frac{\partial u}{\partial x}+\frac{\partial v}{\partial y}\right)$

Koska tiheys on vakio, paine on $p(z)=p_{0}+\rho g(\xi$ $-z)$, missä $\xi$ on veden pinnankorkeus. Näin ollen painegradientti on syvyyden suhteen vakio, sillä

$\frac{\partial}{\partial z}\left(\frac{\partial p}{\partial x}\right)=\frac{\partial}{\partial x}\left(\frac{\partial p}{\partial z}\right)=$

$=\frac{\partial}{\partial x}(-\rho g)=0$

ja painegradientin suuruus tulee suoraan vedenpinnan kaltevuudesta, $\rho^{-1} \nabla p=g \nabla \xi$. Painetta ei siksi tarvitse laskea, vaan riittää tuntea pinnankorkeus.

Tasasyvyisyys yksinkertaistaa tarkasteluja. Koska horisontaaliliikettä ajavassa voimassa eikä pohjan topografiassa ole vertikaalirakennetta, sitä ei myöskään ole virtausnopeudessa eli $\partial u / \partial z$ $=\partial v / \partial z=0$. Pohjalla $w=0$, ja jatkuvuusyhtälöstä saadaan $w(\xi) \approx-H(\partial u / \partial x+\partial v / \partial y)$ eli

$\frac{\partial \xi}{\partial t}=-H\left(\frac{\partial u}{\partial x}+\frac{\partial v}{\partial y}\right)$

Yhtälöillä $(u, v, \xi)$ on aaltoratkaisuja, jotka saadaan selville sijoittamalla $u: n, v: n$ ja $\xi: n$ paikalle vakio $\cdot \exp \left[\mathrm{i}\left(k_{\mathrm{x}} x+k_{\mathrm{y}} y-\omega t\right)\right]$. Saadaan seuraava dispersiorelaatio:

$\omega\left(\omega^{2}-f-g H k^{2}\right)=0$

missä $k^{2}=\left(k_{\mathrm{x}}^{2}+k_{\mathrm{y}}^{2}\right)$. Ensimmäinen juuri $\omega=0$ antaa vakaan tilan, ja juuret $\omega= \pm\left[f+g h k^{2}\right]^{1 / 2}$ antavat niin sanotut Poincare-aallot.

Kun $f<<(g h)^{1 / 2} k$, saadaan $\omega / k=c=(g h)^{1 / 2}$, missä $c$ on aallon kulkunopeus, eli klassinen matalan veden aallon ratkaisu. Klassisessa teoriassa kahden vastakkaiseen suuntaan etenevän aallon summa on Seiche, altaan ominaisheilahtelu. 
Koko Itämeren mitassa Coriolis-kiihtyvyyden vaikutus on merkittävä, mutta sen osa-altaissa klassinen Seiche-ratkaisu on hyvä approksimaatio.

Pitkulaisen altaan seisova Seiche-aalto on erikoistapaus ("seiche" tulee sveitsinranskasta ja tarkoittaa edestakaista heilahtelua). Tämä ilmiö todennettiin ensimmäistä kertaa vuonna 1869 Genevejärvessä. Seichejä havaitaan järvissä, lahdissa ja satamissa eli erilaisissa suljetuissa tai puolisuljetuissa altaissa. Seiche voi myös esiintyä altaan poikittaissuunnassa. Jokaisessa vesialtaassa, jossa seichejä esiintyy, on ominainen vapaan heilahtelun periodi, joka riippuu altaan dimensioista sekä siitä, kuinka monta solmukohtaa seisovalla aallolla on. Aalto saavuttaa altaan vastakkaisen pään (altaan leveys $L$ ) ajassa $L(g H)^{-1 / 2}$. Heijastuttuaan altaan päässä aalto palaa lähtöpisteeseen samassa ajassa. Näin koko periodin pituudeksi $T_{1}$ saadaan

$$
T_{1}=\frac{2 L}{\sqrt{g H}}
$$

Tätä kaavaa kutsutaan myös Merianin kaavaksi keksijänsä J. R. Merianin mukaan. Kaava on tarkka suljetulle altaalle, jonka poikkileikkaus on suorakaiteen muotoinen ja jossa syvyys on vakio. Se edustaa teoreettisesti pisintä mahdollista vapaata heilahtelua. Tällä heilahtelulla on yksi solmupiste altaan keskellä. Solmupisteessä vedenkorkeus on vakio. Mikäli solmupisteitä on useampia (n), heilahdusjakso on $T_{\mathrm{n}}=T_{1} / \mathrm{n}$.

Jos allas on puolisuljettu, kuten merenlahti, solmupiste esiintyy aina altaan avoimessa päässä, koska lahden ulkopuoliset vesimassat osallistuvat myös oskillaatioon. Tästä on seurauksena, että yksisolmuisen vapaan heilahtelun periodi $T_{1 s}$ on puolisuljetussa altaassa aina kaksi kertaa pitempi kuin vastaavassa kokonaan suljetussa.

Itämeren ajallisesti muuttuvassa virtauskentässä seicheillä on tärkeä merkitys (taulukko 6.1). Vedenkorkeushavainnoissa esiintyy niiden aiheuttamia jatkuvia fluktuaatioita. Itämeren altaista löytyy usein ominaisheilahduksia, kun tuuli tyyntyy. Esimerkiksi itäisellä Suomenlahdella vedenpinta voi länsituulilla kohota jopa lähes kaksi metriä yli normaalitason (kuten ennätyksellisten vedenkorkeuksien yhteydessä 9.1.2005). Samanaikaisesti vastaavaa vedenpinnan aleneminen voidaan havaita eteläisellä Itämerellä. Kallistuksen aiheuttaneen sääilmiön ylitettyä Itämeren tuulen suunta kääntyy ja samoin virtaussuunta, ja vedenpinta alkaa palautua tasapainotilaan. Näin vedenkorkeuksiin syntyy havaittava seiche, jonka kitka vaimentaa vähitellen pois.

Itämeren tunnetuin seiche on Suomenlahden ja varsinaisen Itämeren yhteinen oskillaatio. Jo 1911 Rolf Witting sai tämän yksisolmuisen oskillaation periodiksi 28-31 tuntia (Merianin kaava antaisi noin 25 tuntia). Tulosta voidaan pitää hyvänä ottaen huomioon, että tutkimus sisälsi erilaisia yksinkertaistuksia mm. pohjatopografian huomioimisessa. Neumann (1941) käytti tutkimuksissaan vedenkorkeushavaintoja ja numeerisia laskelmia ja sai tulokseksi noin 27,5 tuntia. Myöhemmin mallittajat eivät laskeneet vain yksisolmuisen oskillaation periodia, vaan arvioivat myös monisolmuisten seichejen periodeja. Yksidimensioiset mallit antoivat perusmoodille periodin 27,7 tuntia. Kaksidimensionaaliset matalan veden mallit (Wübber ja Krauss, 1979) antoivat saman periodin toiselle moodille (taulukko 6.1), kun maapallon pyörimistä ei otettu huomioon. Pyöriminen mukaan otettuna periodi lyheni 26,4 tuntiin. Jälkimmäinen arvo on lähellä havaittuja. Myös 17-19 tunnin periodi havaittiin. Korkeammilla moodeilla on lähinnä paikallista merkitystä. Pohjanlahden liittäminen mukaan tuo vielä pidemmän heilahdusajan eli noin 39 tuntia. Merten dynamiikassa esiintyy myös muita aaltoja, kun Coriolis-kiihtyvyys tai syvyysvaihtelut otetaan mukaan tarkasteluun. Näistä tärkeimmät ovat Kelvin-aallot ja topografiset aallot. Kelvinaaltoja muodostuu kiinteän, suoran rantaviivan tuntumassa. Niitä on havaittu esimerkiksi Englannin kanaalissa. Kelvin-aallot etenevät pohjoisella pallonpuoliskolla niin, että ranta jää aallon kulkusuuntaan nähden oikealle. 
Taulukko 6.1. Eri merialtaille laskettuja Seiche-aaltojen periodeja (vakiosyvyysapproksimaatio) sekä koko Itämeren oskillaation moodit (Wübber ja Krauss 1979, alempi taulukko).

\begin{tabular}{|l|l|l|l|}
\hline & $\begin{array}{l}\text { pituus } \\
(\mathrm{km})\end{array}$ & $\begin{array}{l}\text { syvyys } \\
(\mathrm{m})\end{array}$ & $\begin{array}{l}\text { periodi } \\
(\mathrm{h})\end{array}$ \\
\hline $\begin{array}{l}\text { Suomenlahti } \\
\text { (pitkittäin) }\end{array}$ & 300 & 38 & 8,6 \\
\hline $\begin{array}{l}\text { Suomenlahti } \\
\text { (poikittain) }\end{array}$ & 80 & 38 & 2,3 \\
\hline Riianlahti & 100 & 28 & 3,4 \\
\hline $\begin{array}{l}\text { Gotlannin allas } \\
\text { (pitkittäin) }\end{array}$ & 600 & 64 & 13,3 \\
\hline $\begin{array}{l}\text { Koko Itämeri } \\
\text { (suulta Kemiin) }\end{array}$ & 1500 & 56 & 35,6 \\
\hline $\begin{array}{l}\text { Koko Itämeri } \\
\text { (suulta Pietariin) }\end{array}$ & 1000 & 56 & 23,7 \\
\hline
\end{tabular}

Koko Itämeri

\begin{tabular}{|l|l|l|}
\hline Moodi & Periodi $(\mathrm{h})$ & \\
\hline & $\mathrm{f}=0$ & $\mathrm{f} \neq 0$ \\
\hline 1 & 40,5 & 31,0 \\
\hline 2 & 27,7 & 26,4 \\
\hline 3 & 23,7 & 22,4 \\
\hline 4 & 21,4 & 19,8 \\
\hline 5 & 17,9 & 17,1 \\
\hline 6 & 13,0 & 13,0 \\
\hline 7 & 10,5 & 10,5 \\
\hline 8 & 8,7 & 8,7 \\
\hline
\end{tabular}

Itämeressä on havainnollistettu topografisten aaltojen olemassaolo sekä mittausten että mallitulosten avulla (Mälkki ja Tamsalu 1985). Nämä pyörteet syntyvät ja etenevät topografian määräämään suuntaan siten, että matalampi alue on pyörteen liikesuuntaan nähden oikealla. Itämeren lämpötila- ja suolaisuusjakaumien takia myötäpäivään liikkuvilla pyörteillä on kylmä keskus termokliinissä ja suolainen keskus halokliinissä. Vastapäivään liikkuvilla pyörteillä on lämmin keskus termokliinissä ja vähäsuolainen keskus halokliinissä. Tällaisten pohjaan lukkiutuneiden ("bottom-trapped") aaltojen mitta on tyypillisesti 30-40 kilometriä ja etenemisnopeus luokkaa $1,5 \mathrm{~cm} / \mathrm{s}$. Voimakkain periodinen vaihtelu esiintyy 6-8 päivän jaksoissa alueilla, joissa pohjan jyrkkyys on suurin.

Topografisten aaltojen dynamiikkaa tutkitaan pyörteisyysyhtälön avulla barotrooppiselle merelle:

$$
\frac{\partial \zeta}{\partial t}=\frac{f}{H} U \cdot \nabla H+\nabla \cdot \frac{\tau_{0}-\tau_{b}}{\rho H}+A_{H} \nabla^{2} \zeta
$$

missä $\zeta$ on virtauksen pyörteisyys maapallon pinnan suhteen. Pyörteisyyden synnyssä keskeinen osuus on $f$-termillä. Jos $f \neq 0$, niin pyörteisyyttä syntyy alueilla, joilla pohjan kaltevuus on jyrkin. Matalassa vedessä esiintyvät pyörteet, jotka ovat Ekman-tyyppisiä, häviävät nopeasti pakotteen loppuessa.

Eräs pyörteiden syntyalue on Stolpen kanaalin suualue Bornholmin altaan puolella. Avomerellä tuuli voi aiheuttaa erilaisia pyörteitä alueilla, joilla on vaihteleva pohjatopografia. Kun pohjanläheiset vesikerrokset ovat eristyksissä suorasta tuulen vaikutuksesta, topografisten aaltojen syntymekanismina voi olla barokliininen instabiliteetti.

Kuvassa 6.15 on esitetty virtausnopeuksien spektri Porin edustalla muutamissa kohdissa. Spektrissä dominoivana piirteenä on inertiaalioskillaatio, mutta muitakin periodeja on näkyvissä. Erityisen kiinnostava on 57-65 tunnin jakso, joka ilmeisesti liittyy barotrooppisiin topografisiin aaltoihin (aallonpituus noin 390 kilometriä). Rannikolle lukkiutuneiden [coastally trapped] aaltojen ja inertiaoskillaatioiden taajuuskaistoilla on paljon energiaa.

\subsubsection{Vuorovesi}

Auringon ja kuun vetovoiman aiheuttama pinnankorkeuden vaihtelu tunnetaan vuorovesi-ilmiönä. Vedenpinnan korkeinta vaihetta kutsutaan vuokseksi ja matalinta luoteeksi. Auringon ja kuun vetovoimien suuruus vaihtelee eri puolil- 
la maapallon pintaa. Kuun ja auringon puolella vesi pyrkii siirtymään niitä kohti ja vastakkaisella puolella niistä poispäin. Vetovoimat pyrkivät muovaamaan maapalloa ellipsoidiksi, jonka pääakseli on kuun ja auringon vetovoimaresultantin suuntainen. Kuun vuorovesivaikutus on suurempi kuin auringon, ero on noin seitsemän suhteessa kolmeen.

Kuun aiheuttama vuorovesiellipsoidi kiertää maapallon pinnalla maapallon pyörimisen ja kuun kiertoliikkeen vuoksi. Näin muodostuu vuorokauden aikana kaksi nousuvettä ja kaksi laskuvettä. Vastaava pätee myös auringon suhteen. Käytännössä vuorovedet vaihtelevat alueittain, sillä meret ovat eri syvyisiä, merenpohjan muodot vaihtelevat, rantaviiva sekä salmet, saaret ja muut tekijät aiheuttavat kitkaa meren ja maan välille. Valtamerellä merenpinta saattaa nousta vain metrin verran, mutta niiden kapeissa salmissa ja lahdissa nousuvesi voi olla jopa toistakymmentä metriä. Lähellä päiväntasaajaa vuorovesivaihtelu on voimakkaimmillaan, koska alueet ovat lähempänä kuuta.

Itämeressä vuorovesi-ilmiö on heikko, koska Tanskan salmet vaimentavat vuorovesi-aallot melko tarkkaan pois. Vuorovesien amplitudi on harvoin enemmän kuin $10 \mathrm{~cm}$, joskin Tanskan salmien läheisyydessä voi esiintyä suurempia arvoja. Myös itäisellä Suomenlahdella on havaittu yli $10 \mathrm{~cm}$ suuruisia amplitudeja. Yleensä Itämeressä esiintyvä vuorovesityyppi on sekoitus kokovuorokautisesta ja puolivuorokautisesta aallosta. Tyypillinen vuorovesiamplitudi on alle 3 $\mathrm{cm}$, mutta silti joillain rannikkoalueilla, kuten Strömman kanavassa Kemiössä, havaitaan vuorovesivirtauksia. Sekä vuorokautinen että puolivuorokautinen vuorovesikomponentti tulevat esille vedenkorkeuden spektrianalyysissä (kuva 6.16). Itämeren eliöstön kannalta vuorovedellä ei ole merkitystä eikä Itämeressä ole valtamerten kaltaisia vuorovesiekosysteemejä.

\subsubsection{Vedenpinnan korkeus}

Itämeren vedenkorkeuden taajuusspektristä voidaan nähdä jaksollisten aaltojen esiintyminen ja epäsäännöllisiä vaihteluita (kuva 6.16). Vedenkorkeuden mittausjärjestelmässä aallokko ei näy. 1-24 tunnin jaksonpituuksissa vedenkorkeusmuutokset liittyvät tuulen ajovirtaan, vuorovesiin ja seicheihin. Rannikkoalueen aallot ja virtaukset aiheuttavat noin $1 \mathrm{~cm}$ :n vedenkorkeusvaihteluita. Vuorovesien merkitys on vähäinen. Ajoittain Seiche-aaltojen amplitudit voivat olla suuria, mikä vaikuttaa muun muassa Pietarin suuriin vedenkorkeuksiin.

Tuuli ja ilmanpainevaihtelut aiheuttavat vedenkorkeusvaihteluita muutamien päivien jaksoista aina useisiin viikkoihin asti. Tuuli vaikuttaa vedenkorkeuteen kasaamalla vettä, mikä on erityisen selvää lahtien pohjukoissa, joissa suurimmat ääriarvot saavutetaan. Korkea ilmanpaine painaa vedenpintaa alaspäin. Yhden millibaarin paine-ero vastaa suunnilleen yhtä senttimetriä vedenkorkeudessa (barometri-ilmiö). Normaali ilmanpaineen vaihtelu voi aiheuttaa useiden kymmenien senttimetrien vedenkorkeusvaihtelun.

Vedenkorkeushavaintojen analyysissä tulevat esille sekä vuosi- että puolivuotisjaksot. Veden tiheyden vaihtelut aiheuttavat myös vedenkorkeusvaihteluita, mutta niiden osuus tulee esille vasta kuukausien aikaskaalassa. Itämeren pysyvä horisontaalinen suolaisuusgradientti aiheuttaa sen, että keskimääräinen vedenkorkeus on suurempi pohjoisessa kuin etelässä. Keskimäärin vedenkorkeus laskee Perämeren arvoista noin 35-40 cm Skagerrakiin päin mentäessä.

Itämeren keskimääräistä vedenkorkeutta edustaa Landsort, joka on yksisolmuisen seichen solmupiste. Itämeren kaltaisessa puolisuljetussa meressä tilavuuden vaihtelu on läheisesti kytköksissä vedenkorkeusvaihteluihin. Kuten edellisessä luvussa esitettiin, tilavuuden muutokset johtuvat vedenvaihdosta Tanskan salmien kautta, 

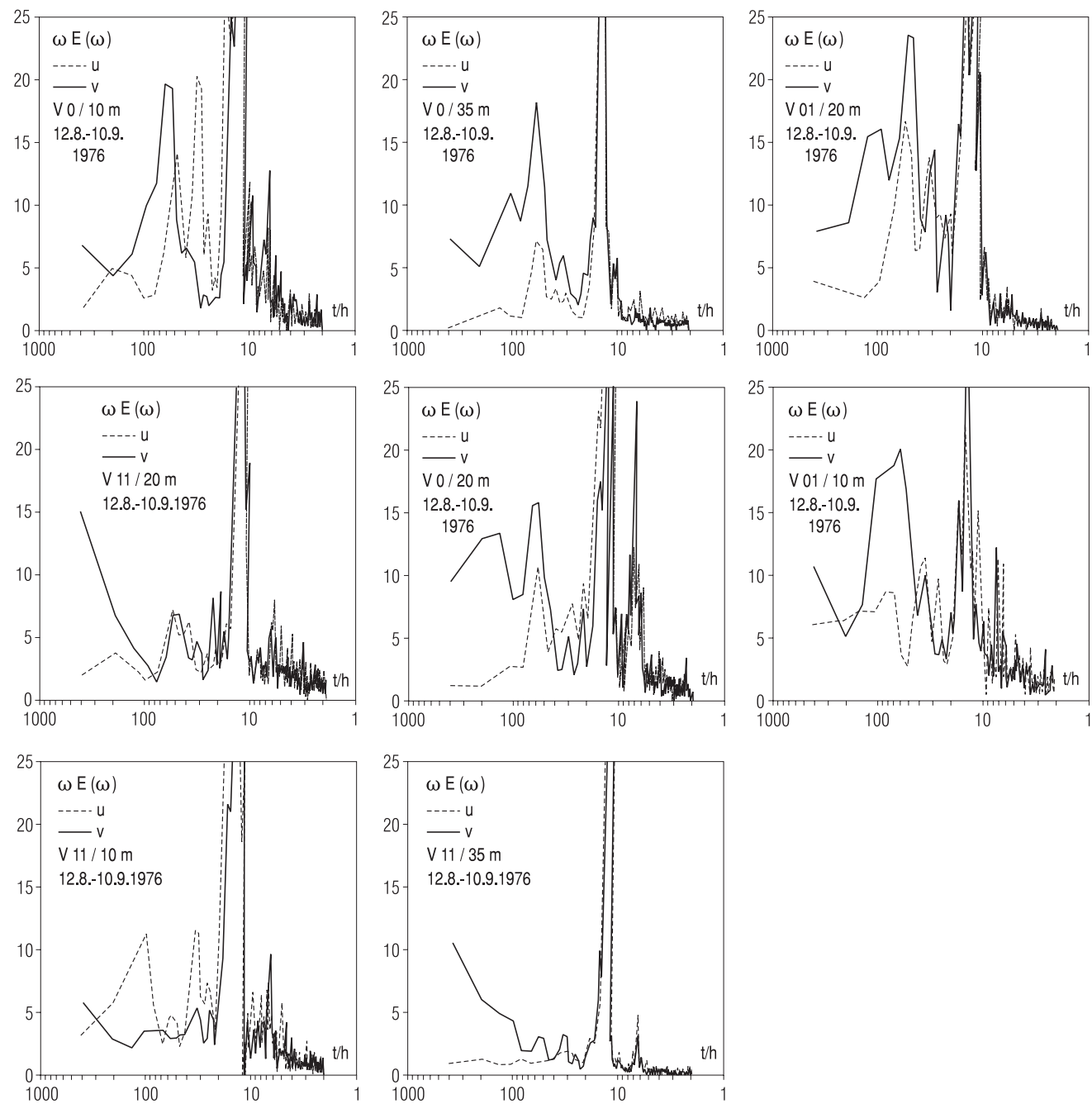

Kuva 6.15. Virtausmittauksiin perustuvia energiaspektrejä Porin edustalta elo-syyskuussa 1976, $\omega$ on taajuus ja $E(\omega)$ on tehospektri. (Piirretty Aleniuksen ja Mälkin [1978] kuvasta.)

makean veden tulosta ja lämpötilanvaihteluihin liittyvästä laajenemisesta tai supistumisesta, joista viimeksi mainitun vaikutus vedenpinnan muutoksiin on $2 \mathrm{~cm}$ :n luokkaa. Suurien sisäänja ulosvirtausten aikana Itämeren vedenkorkeus voi muuttua lähes metrin muutamassa viikossa. Vedenvaihto Tanskan salmien kautta on tärkein vedenkorkeuden muutoksen syy kuukausien aikaskaalassa.

Merentutkimuslaitoksella on otettu käyttöön teoreettinen keskivesi (MW), joka on käytännön tarpeita varten tehty ennuste vedenkorkeuden pitkäaikaisesta keskiarvosta. Siinä on otettu huomioon maan kohoaminen sekä vedenkorkeuden hidas nousu. Näiden muutosten vuoksi teoreettinen keskivesi ei ole vakio, vaan se muuttuu vuosittain. Esimerkiksi radiossa luetaan ja sanomalehdissä ilmoitetaan vedenkorkeudet suhteessa teoreettiseen keskiveteen.

Vedenkorkeuden ennustamisessa on käytetty sekä kaksi- että kolmidimensionaalisia malleja, joskin kaksidimensionaalinen barotrooppimalli linearisoidussa muodossa on todettu riittävän tarkaksi käytettäviksi ennustuksissa. Kyseiset ver- 


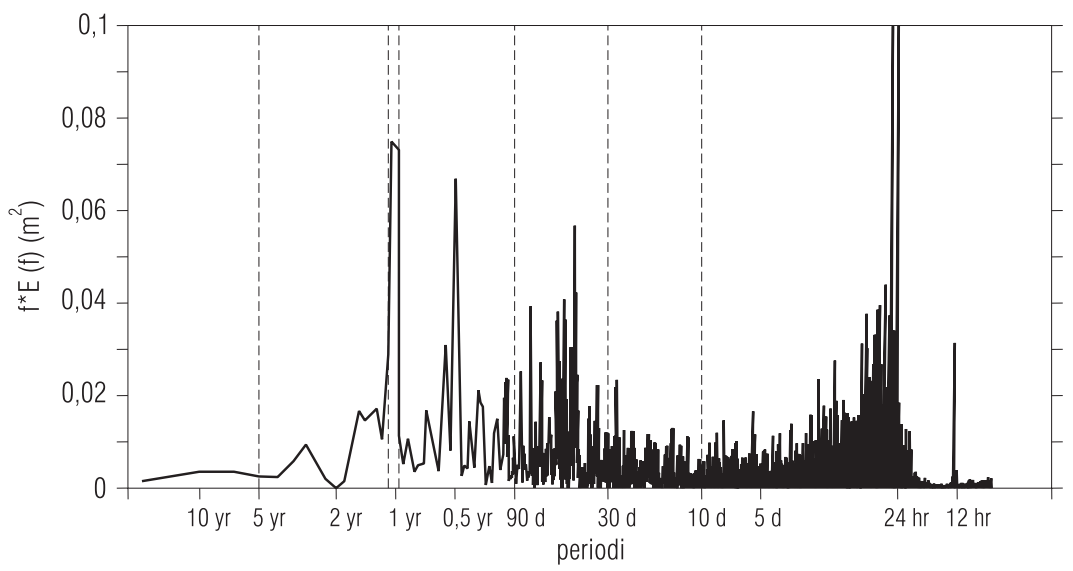

Kuva 6.16. Vedenkorkeuden energiaspektri $f E(f), f$ on taajuus ja $E$ on tehospektri Helsingin mareografilta jaksolta 1980-1999. (Piirretty Johanssonin ym. [2001] mukaan.) yr=vuosi, d=päivä ja hr=tunti.

tikaali-integroidut niin sanotut matalan veden yhtälöt voidaan esittää muodossa:

$$
\begin{aligned}
& \frac{\partial \bar{u}}{\partial t}=-f \bar{v}-g \frac{\partial \xi}{\partial x}+\frac{\tau^{x}}{\rho H}-r \frac{\sqrt{\bar{u}^{2}+\bar{v}^{2}}}{H} \\
& \frac{\partial \bar{v}}{\partial t}=f \bar{u}-g \frac{\partial \xi}{\partial y}+\frac{\tau^{y}}{\rho H}-r \frac{\sqrt{\bar{u}^{2}+\bar{v}^{2}}}{H} \\
& \frac{\partial \xi}{\partial t}=-\left[\frac{\partial H \bar{u}}{\partial x}+\frac{\partial H \bar{v}}{\partial y}\right]
\end{aligned}
$$

missä $\bar{u}$ ja $\bar{v}$ ovat pystysuunnassa integroidut horisontaaliset nopeuskomponentit, $\xi$ on vedenkorkeus, $H$ on veden syvyys, $\tau^{x}, \tau^{y}$ ovat tuulen leikkausjännityksen $x$ - ja $y$-komponentit ja $r$ on pohjakitkan kerroin.

Barotrooppinen kaksidimensionaalinen vedenkorkeusmalli antaa tarkkoja tuloksia melko karkealla horisontaalisella resoluutiolla. Tärkeää mallien toiminnassa on tarkka meteorologinen ennuste, jollainen saadaan esimerkiksi HIRLAM-mallista (HIRLAM=High Resolution Limited Area Model) tai ECMWF-mallista (European Centre for Medium Range Weather Forecasts) ainakin pariksi vuorokaudeksi eteenpäin.
Mallitettaessa jo tapahtuneita tilanteita [hindcasting] tämä ongelma on pieni, koska ennusteiden sijasta voidaan meteorologisten mallien tuottamia analyyseja käyttää pakotteena.

Vedenkorkeuden reunaehto Tanskan salmissa on keskeinen tekijä ennusteen onnistumiselle. Reunaehto voidaan ottaa vedenkorkeushavainnoista, mutta tällöin malli saa ennusteen kannalta "vanhaa" tietoa jo tapahtuneista vedenkorkeuden muutoksista. Eräs mahdollisuus on ottaa reunaehdoksi Pohjanmeren mallista saatava ennuste Tanskan salmissa tai laajentaa käytettävän mallin alueellisista ulottuvuutta myös Pohjanmeren käsittäväksi.

Muun muassa 9.1.2005 tapahtunut tulvatilanne Itämerellä pystyttiin hyvin ennustamaan sekä kaksi- että kolmidimensionaalisilla malleilla. Mallit kuvasivat veden sisääntulon Tanskan salmien kautta, tuulien ja ilmanpaine-erojen aiheuttaman vedenpinnan kallistumisen sekä Seiche-aaltojen aiheuttaman vedenkorkeuden pitkäperiodisen heilahtelun. Tekijöiden yhteisvaikutuksesta saatiin ennustettua ennätykselliset vedenkorkeudet Suomen ja Viron rannikolla hyvissä ajoin ja samalla voitiin antaa ennalta varoitus kansalaisille ja viranomaisille. 


\subsubsection{Pinta-aallot}

Tuulen leikkausjännitys yhdessä paineen fluktuaatioiden kanssa käynnistää aaltoliikkeen. Tuulen alkaessa puhaltaa tyynen vedenpinnan yllä se saa veden virtaamaan ja aiheuttaa vedessä pyörteisyyttä. Pyörteisyys puolestaan saa aikaan paine-eroja, jotka rikkovat sileän vedenpinnan. Pintaan syntyvä kohoutuma tai painuma pyrkii palautumaan, palautus menee yli tasapainotilan toiseen suuntaan, ja niin edelleen. Aivan alkuvaiheessa muodostuu pientä pintavärettä, jossa palauttavana voimana toimii pintajännitys. Näitä aaltoja sanotaan kapillaariaalloiksi, ja niiden aallonpituus alle $2 \mathrm{~cm}$ ja periodi alle 0,1 sekuntia.

Kun kapillaariväreily kasvaa, painovoimasta tulee palauttava voima. Pienet aallot ovat aluksi jyrkkiä, mutta alkavat kasvaa pituutta nopeammin kuin korkeutta. Aallokko kasvaa kooltaan tiettyyn kyllästystilaan asti, jossa tuulen syöttämä mekaaninen energia on tasapainossa aallokossa tapahtuvan energian kulutuksen kanssa. Kyllästystila riippuu meren syvyydestä, tuulen nopeudesta ja kestosta sekä tuulen pyyhkäisymatkasta, jolla tarkoitetaan etäisyyttä rannasta tuulen suuntaan.

Meren syvyydellä on myös kvalitatiivinen merkitys, sillä aallokon vaikutussyvyys on puolet aallonpituudesta. Aaltojen pituus vaihtelee kapillaarivireen senteistä noin 100 metriin asti. Kun meri on puolta aallonmittaa syvempi, pohja ei enää vaikuta aallokkoon. Tällöin puhutaan syvän veden aalloista. Matalissa vesissä syvyydellä on myös kvantitatiivinen vaikutus. Aallot jyrkkenevät veden madaltuessa ja murtuvat lopulta rannan mataloituessa.

Syvän veden aaltojen teoriaa sovellettaessa pinta-aaltoihin meren syvyydellä ei ole merkitystä $(\lambda<2 H)$. Aallon etenemisnopeus riippuu aallonpituudesta:

$c=\sqrt{\frac{g \lambda}{2 \pi}}$
Aallokko on dispersiivinen eli eripituiset aallot etenevät eri nopeuksin. Pitkät aallot etenevät nopeimmin; ne voivat edetä nopeammin kuin myrskyalue liikkuu.

Itämerellä pinta-aalloilla on omat erityispiirteensä valtameriin nähden. Itämeri on matala, eikä klassista syvän veden aaltojen teoriaa aina voida soveltaa. Erityisesti rantavyöhykkeet ovat matalan veden alueita. Lisäksi Itämeren altaat ovat pienikokoisia, joten pyyhkäisymatkat ovat lyhyitä; samoin tuulitilanteiden kestot ovat usein lyhyitä, joten molemmat edellä mainitut tekijät rajoittavat aallokon kasvua. Vesialtaiden muodot vaikuttavat jossain määrin aallokon muodostumiseen. Ilmakehän rajakerroksen stabiliteetti vaikuttaa tuulen leikkausjännitykseen ja sitä kautta aallokon kehitykseen, toisin sanoen epästabiilissa tilanteessa (vesi on ilmaa lämpimämpää) aallot kasvavat enemmän kuin stabiilissa tehokkaamman mekaanisen energian siirron takia. Syksyllä ja talvella ilman kerrostuneisuus on usein epästabiili, mutta ajanjakson korkeat aallokot johtuvat pääasiassa siitä, että kovia tuulia on useammin kuin kesäkautena.

Pyyhkäisymatkan rajoittaman aallokon tutkimisessa käytetään useimmiten Kitaigorodskiin (1962) mallilakia. Tämä on syvän veden malli ja tarkastelee tilannetta, kun tuuli alkaa puhaltaa rannalta tyynelle vesialueelle ja pysyy vakiona $(U)$ niin kauan, että aallokosta tulee pyyhkäisymatkan $X$ rajoittama. Palauttavana voimana on painovoima $(g)$. Tällöin kehittyneen aallokon karakteristiset suhteet voidaan yksinkertaisesti johtaa dimensioanalyysin perusteella (esim. Pettersson, 2004). Dimensioton pyyhkäisymatka ja energia ovat

$\widetilde{X}=g X / U^{2}, \widetilde{\varepsilon}=\varepsilon g^{2} / U^{4}$

missä $\varepsilon$ on aallokon kokonaisenergia (kuva $6.17 \mathrm{a}, \mathrm{b})$. Aallokon oletetaan koostuvan suuresta määrästä erikokoisia aaltoja, jolloin kokonais- 


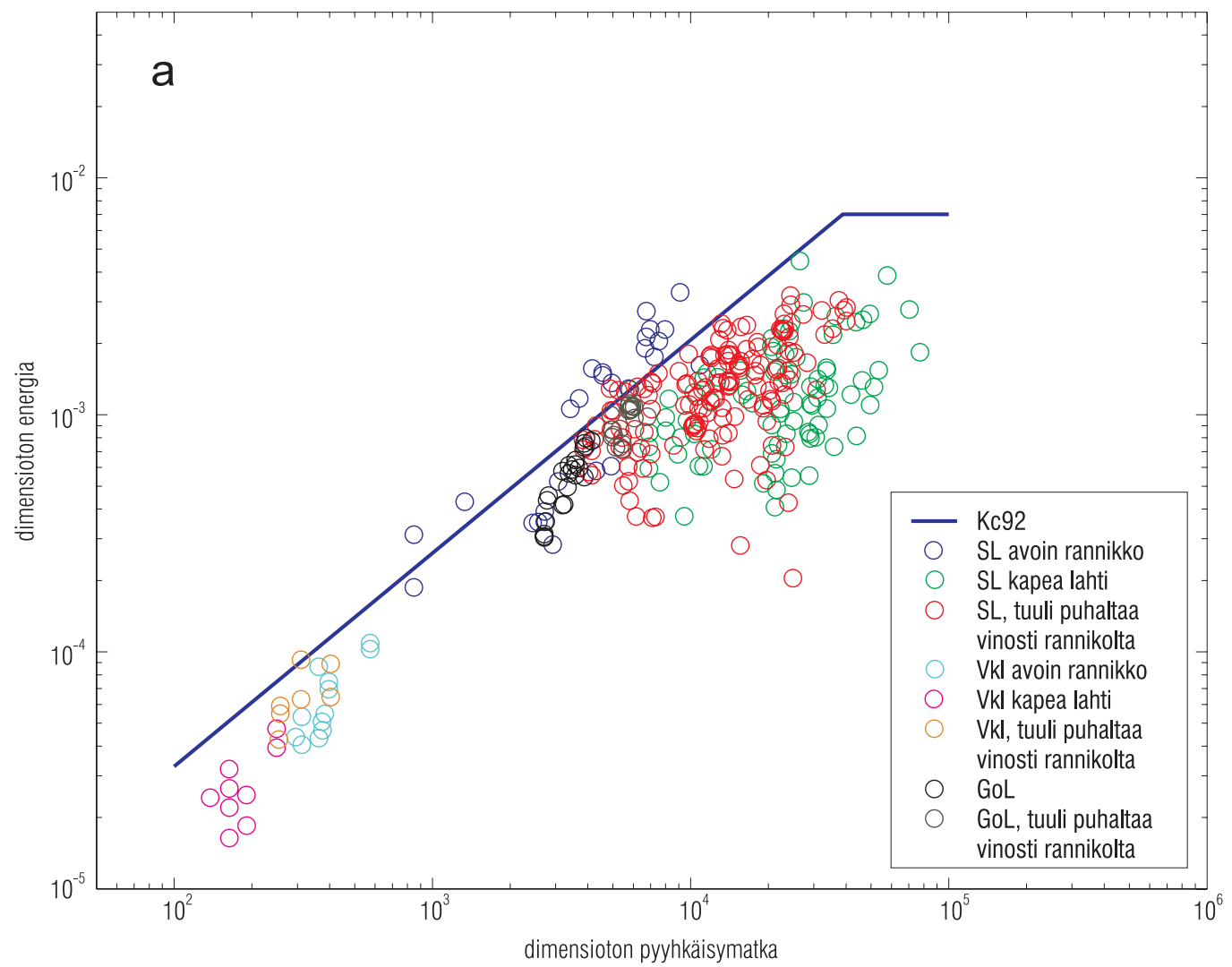

Kuva 6.17. Aallokon kasvu dimensiottomana esityksenä: A) energia pyyhkäisymatkan funktiona, B) huipun kulmataajuus pyyhkäisymatkan funktiona, C) energia huipun taajuuden funktiona. Yhtenäinen viiva on teorian mukainen (Kahma ja Calkoen, 1992), muut symbolit esittävät mittaustietoa Suomenlahdelta (SL), Vanhankaupunginlahdelta (VkI) ja Lyonin lahdelta (GoL). (Piirretty Petterssonin [2004] kuvasta.)

energia voidaan kirjoittaa spektritiheytenä $S(\omega)$, missä $\omega$ on aallon taajuus:

$$
\varepsilon=\int_{0}^{\infty} S(\omega) d \omega
$$

Tämän mallilain mukaan aallokon spektri on jatkuva ja sisältää yhden maksimin eli huipun, jonka taajuutta merkitään symbolilla $\omega_{p}$, dimensiottomana $\widetilde{\omega}_{p}=\omega_{p} U / g$. Tällä taajuudella aallokon sisältämä energia on suurin (kuva 6.17C).

Aallokon kehitys ja kyllästystila riippuvat myös veden ja ilman tiheydestä, mutta niitä voidaan tämän ongelman puitteissa pitää vakioina. Ylei- sessä tapauksessa tiheyksien suhde tulisi dimensiottomana suureena mukaan. Veden suolaisuus ja lämpötila vaikuttavat hieman veden tiheyteen ja viskositeettiin, mutta aallokon kehittymisessä niillä ei juuri ole merkitystä. Kun tuuli tyyntyy, pienet aallot vaimenevat ensin ja aallokko muuttuu mainingiksi.

Aallokko koostuu suuresta määrästä erikokoisia aaltoja, eikä karakteristisen aallonkorkeuden määrittäminen ole aivan selvä asia. Aaltopoijun tuottamasta vedenpinnan korkeuden havaintosarjasta voidaan konstruoida aallonkorkeuden havaintosarja. On osoittautunut, että aallonkorkeuden jakauman korkeimman kolmanneksen 

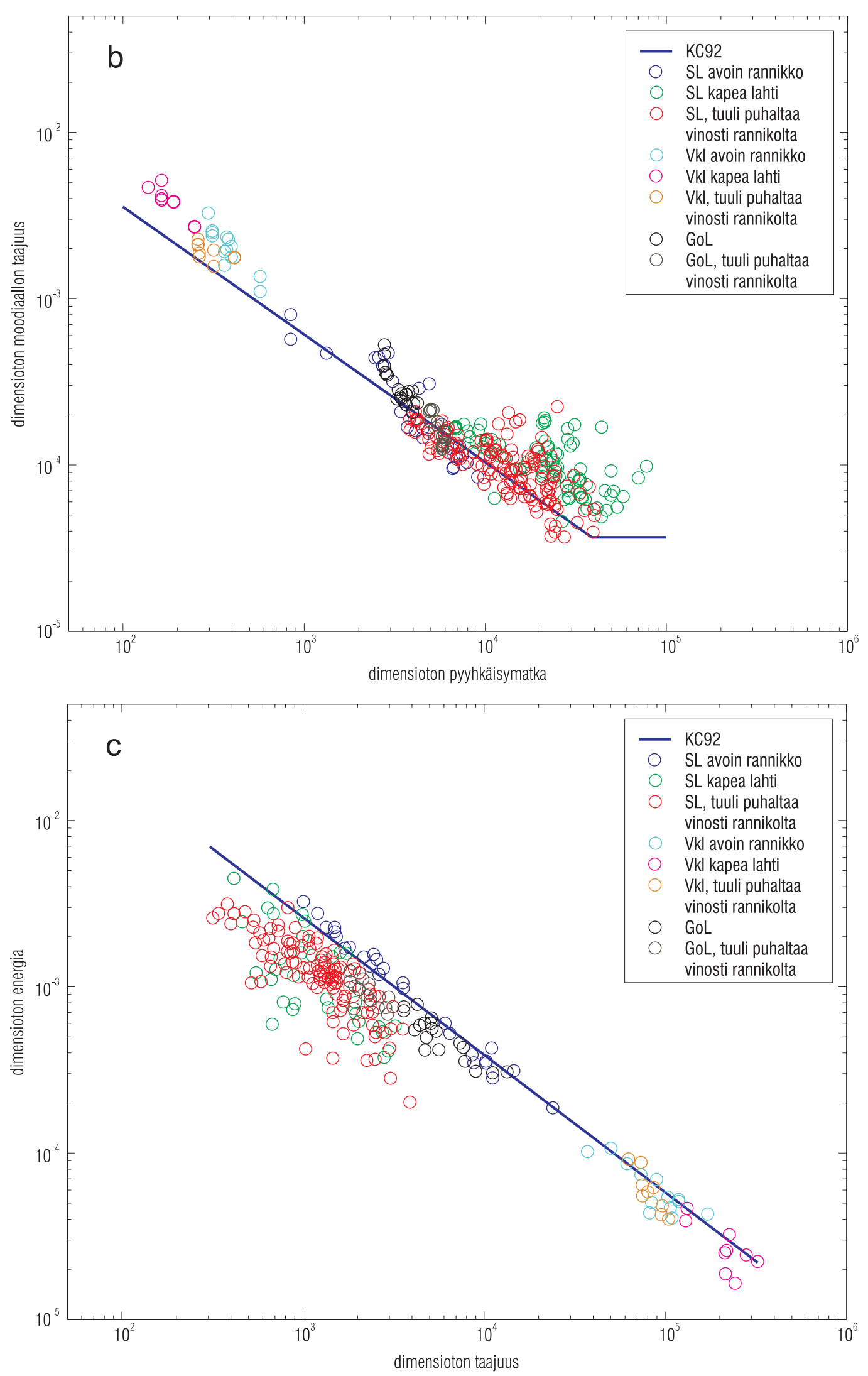

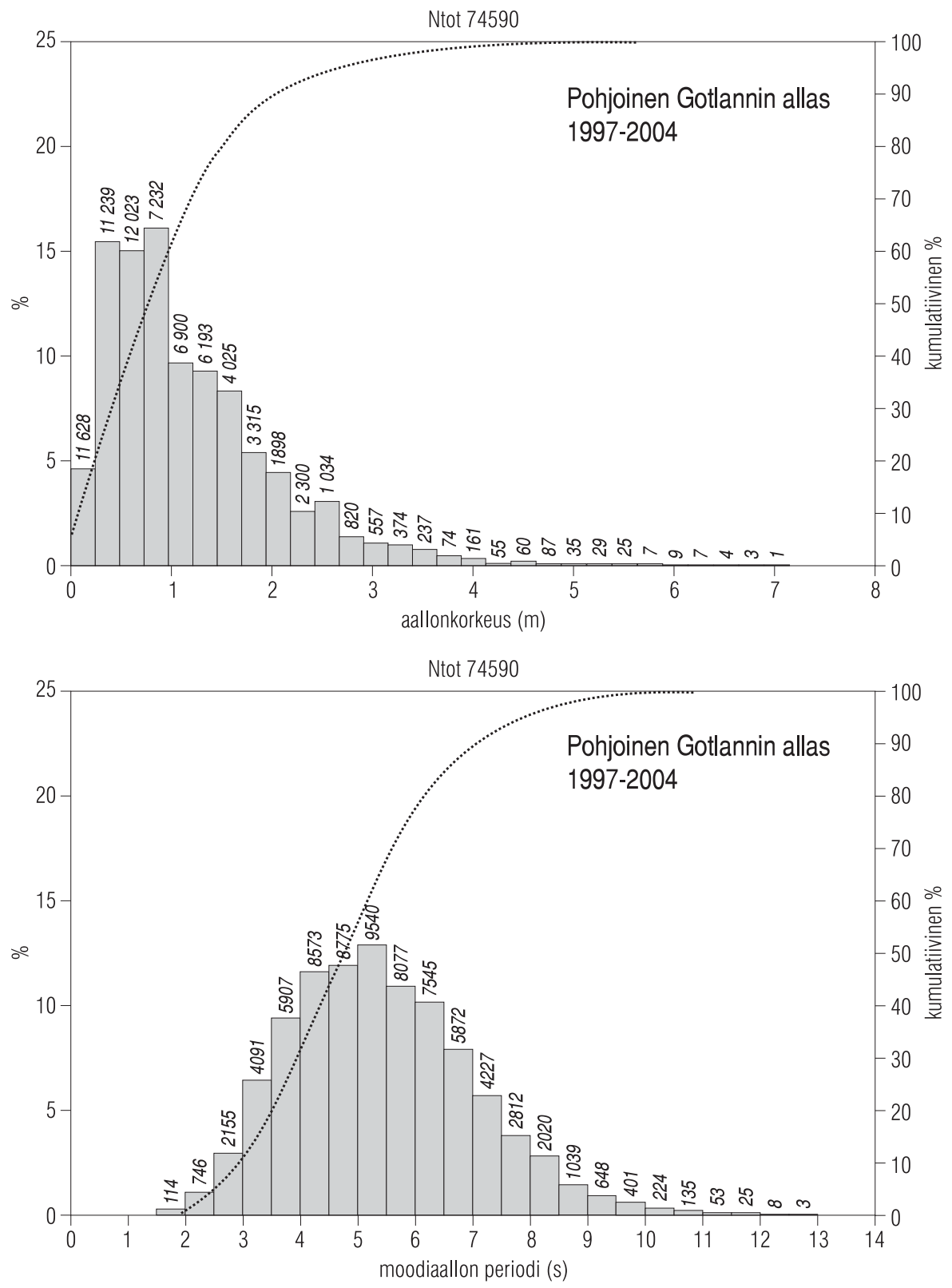

Kuva 6.18. Ylhäällä merkitsevän aallonkorkeuden ja alhaalla moodiaallon jaksonpituuden histogrammi Pohjoisen Gotlannin altaan aaltopoijun havaintojen mukaan 1997-2004. Vasemmalla oleva prosenttiosuus vastaa yksittäisten aallonkorkeuden moodiaallon periodien osuutta, oikealla oleva koko havaintoaineisto kumulatiivista prosenttiosuutta (pisteviiva), Ntot on havaintojen lukumäärä. (lähde: Merentutkimuslaitos)

keskiarvo vastaa hyvin kokeneiden merenkulkijoiden silmän arvioimaa aallonkorkeutta. Siksi tämä keskiarvo on otettu edustavaksi arvoksi ja sille käytetään nimitystä merkitsevä aallonkor- keus, $H_{s}$. Mittauksista merkitsevä aallonkorkeus saadaan arvioitua aallokon spektrin varianssin avulla. Aallokon korkein yksittäinen aalto on kaksinkertainen merkitsevään aallonkorkeuteen 


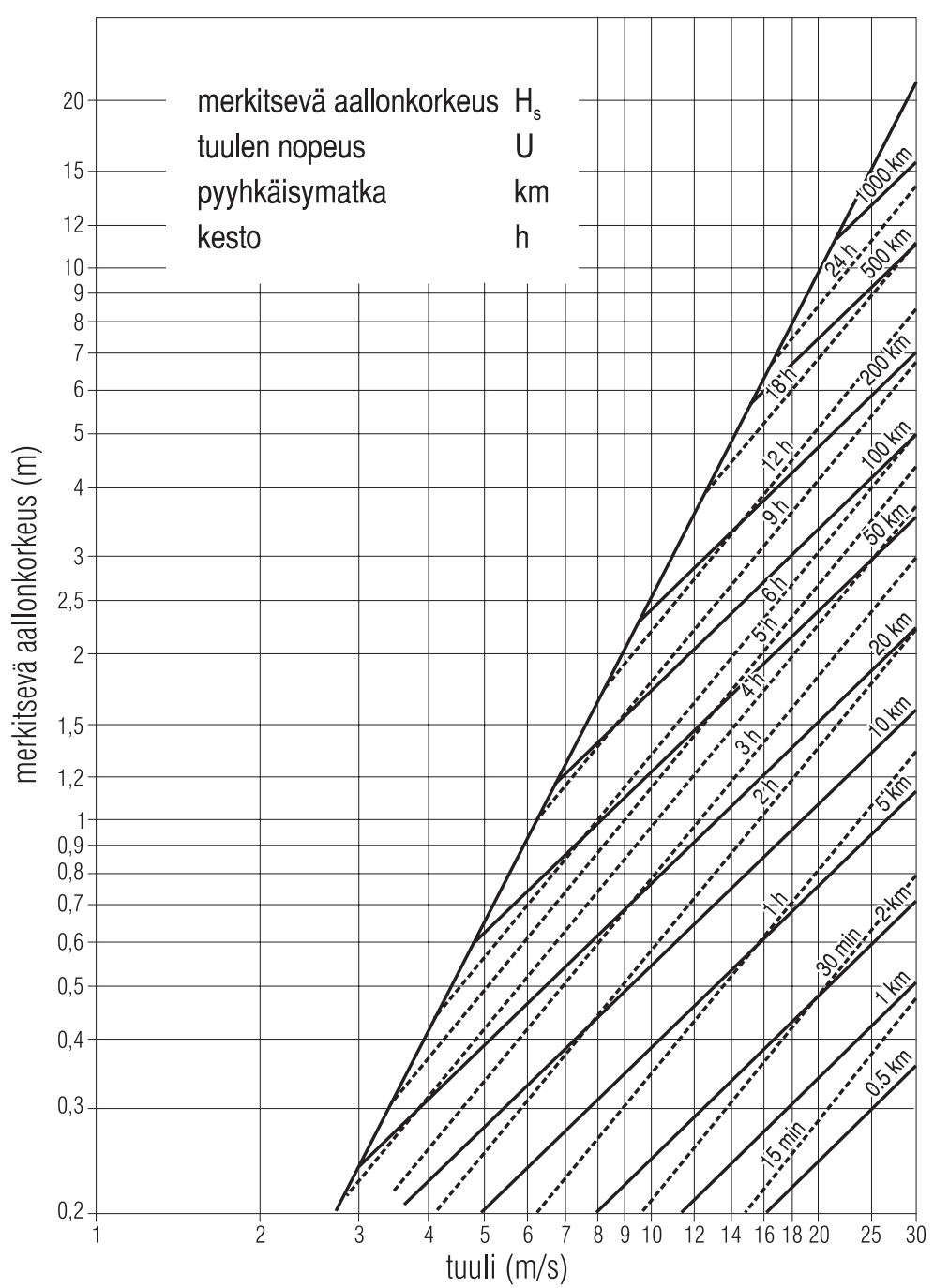

Kuva 6.19. Merkitsevä aallonkorkeus tuulen nopeuden, keston (pisteviiva) ja pyyhkäisymatkan (yhtenäinen viiva) funktiona. (Piirretty Kahman [1986] kuvasta.) nähden. Kuvasta (6.18) nähdään, että merkitsevä aallonkorkeus Pohjois-Itämeren aaltopoijulla on 90 prosentissa tapauksista alle 2 metriä, eli suuret aallonkorkeudet ovat melko harvinaisia.

Edellä esitetyn aaltoteorian pohjalta on Kahma (1986) kehittänyt aallokkonomogrammin (kuva 6.19). Sen avulla voidaan arvioida merkitsevän aallonkorkeuden kehitystä, kun tuulen nopeus, tuulen kesto ja pyyhkäisymatka tunnetaan. Vaakaakselilta haetaan tuulen nopeus, ja sitten edetään ylöspäin kunnes joko kestoaika tai pyyhkäisymatka tulee vastaan. Näin tulee automaattisesti samalla määritetyksi, onko tilanteessa rajoittavana tekijänä tuulen kestoaika vai pyyhkäisymatka.
Esimerkki. Tuulen nopeus $10 \mathrm{~m} / \mathrm{s}$ ja pyyhkäisymatka 100 kilometriä antavat merkitsevän aallonkorkeuden 1,8 metriä. Tähän tarvittava tuulen kestoaika on 9 tuntia. Kun tuuli kesto on ollut neljä tuntia, aallokko on vielä keston rajoittama ja merkitsevä aallonkorkeus on yhden metrin.

Tuulen ajamat aallot muuttuvat rannikon tuntumassa syvän veden aalloista matalan veden aalloiksi. Tällöin aaltojen nopeus hidastuu matalan veden aaltoteorian mukaan $c=(g H)^{1 / 2}$, ja tapahtuu erilaisia ilmiöitä samaan tapaan kuin optiikassa valon aalto-ominaisuuksien pohjalta:

(i) heijastuminen eli reflektio (tulokulma = lähtökulma), (ii) taittuminen eli refraktio (aalto 
taittuu matalaan suuntaan etenemisnopeuden syvyysriippuvuudesta johtuen) sekä (iii) diffraktio (aallot etenevät esteen taakse kapean raon kautta raon toimiessa uuden aaltoliikkeen keskuksena). Energian säilymisen takia matalaan tultaessa aallonkorkeus ensin hieman laskee ja alkaa sitten kasvaa lopulta murtuen, kun aallonkorkeus/-syvyyssuhde on suurempi kuin 0,78.

Pinta-aaltojen vaikutus näkyy erityisesti monivuotisissa levissä, meillä rakkolevässä. Rannikkomme rakkolevä ei pysty kasvamaan lainkaan niillä rannoilla, joilla on voimakkain aallokko, tai se jää hyvin pieneksi. Hyvinkin lähellä suojaisilla rannoilla rakkolevä voi sitten kasvaa kookkaaksi. Aaltojen vaikutus määrää myös pohjan laadun. Matalilla alueilla muta-, lieju- ja hiekkapohjia tavataan vain suojaisilla rannoilla. Näillä pohjilla kasvavat muun muassa erilaiset vidat sekä järviruoko.

Itämerelläkin syntyy varsin korkeita aaltoja. Pohjoinen Gotlannin allas on aallokko-oloiltaan Itämeren vaikeimpia. Joulukuun 22. päivänä vuonna 2004 tällä alueella merkitsevä aallonkorkeus kasvoi Rafael-myrskyn aikana 7,7 metriin (www.fimr.fi). Korkein yksittäinen aalto oli 14 metriä. Yhtä suuri merkitsevä aallonkorkeus on Itämerellä mitattu vain kerran aikaisemmin, tammikuussa 1984 Ruotsin rannikolla sijaitsevan Almagrundetin lähistöllä. Suomenlahdella, Helsingin edustalla, mitattiin 15.11.2001 merkitsevä aallonkorkeus 5,2 metriä, korkeimman yksittäisen aallon ollessa noin 9 metriä. Sekä itäettä länsituuli voivat Suomenlahdella kasvattaa näin korkeita aaltoja, mutta tätä korkeammaksi ne eivät juuri pääse kasvamaan altaan pitkulaisen muodon takia. Eteläisellä Selkämerellä 1970-luvulla mitattu 5,5 metrin merkitsevä aallonkorkeus pitää yhä ykköspaikkaa alueella. Korkein yksittäinen aalto oli tuolloin 10 metriä. Perämerellä korkein mitattu merkitsevä aallonkorkeus on 3,1 metriä ja korkein yksittäinen aalto 5,6 metriä.
Nykyiset niin sanotut kolmannen sukupolven aaltomallit perustuvat aallokon energiataseyhtälön ratkaisemiseen (katso esimerkiksi Pettersson 2004):

$\frac{\partial S(\omega, \theta)}{\partial t}+c_{g} \cdot \nabla S(\omega, \theta)=G=G_{i n}+G_{e l}+G_{d s}$

missä $S(\omega, \Theta)$ on kaksidimensionaalinen (taajuus-suunta) aaltospektri, $\omega$ on aaltokomponentin kulmataajuus ja $\Theta$ on aaltokomponentin suunta, $c_{g}$ on aaltojen ryhmänopeus ja $G$ on lähdetermi, joka koostuu aaltokomponenttien epälineaarisista vuorovaikutuksista $G_{\mathrm{el}}$, tuulen aiheuttamasta kasvusta $G_{i n}$ ja energian häviöstä (lähinnä aaltojen murtumisesta) $G_{d s}$. Näistä lähdetermeistä vain ensimmäinen on ratkaistavissa, muut ovat vähemmän tunnettuja. Energiataseyhtälö pätee syvässä vedessä, mutta matalassa vedessä, jossa pohjan vaikutus korostuu, yhtälö vaatisi modifiointia.

Aaltoennustusmenetelmiä käytetään Itämerellä niin merenkulussa kuin väylien ja satamien suunnittelussakin ja ne ovat aaltotutkimuksen eräs tärkeä sovellus. Itämerellä on monia erityistekijöitä, jotka asettavat malleille suuria vaatimuksia. Näitä ovat muun muassa Itämeren koko, muoto ja varsinkin Suomenlahden kapeus. Talvella myös jään ulottuvuus vaikuttaa aallokkoon. Malleilla lasketaan lisäksi aallokko-oloja esimerkiksi onnettomuustutkintaa varten tai aaltotilastoja väylä- ja satamasuunnittelua varten. Merentutkimuslaitoksella tehdään ennusteita operatiivisesti neljästi vuorokaudessa ja ne päivittyvät automaattisesti Itämeri Nyt verkkosivuille. Tarkimmat ennusteet pohjautuvat WAM-aaltomalliin (niin sanottu kolmannen sukupolven malli), joka saa meteorologisen pakotteen Ilmatieteen laitoksen HIRLAM-mallista. 

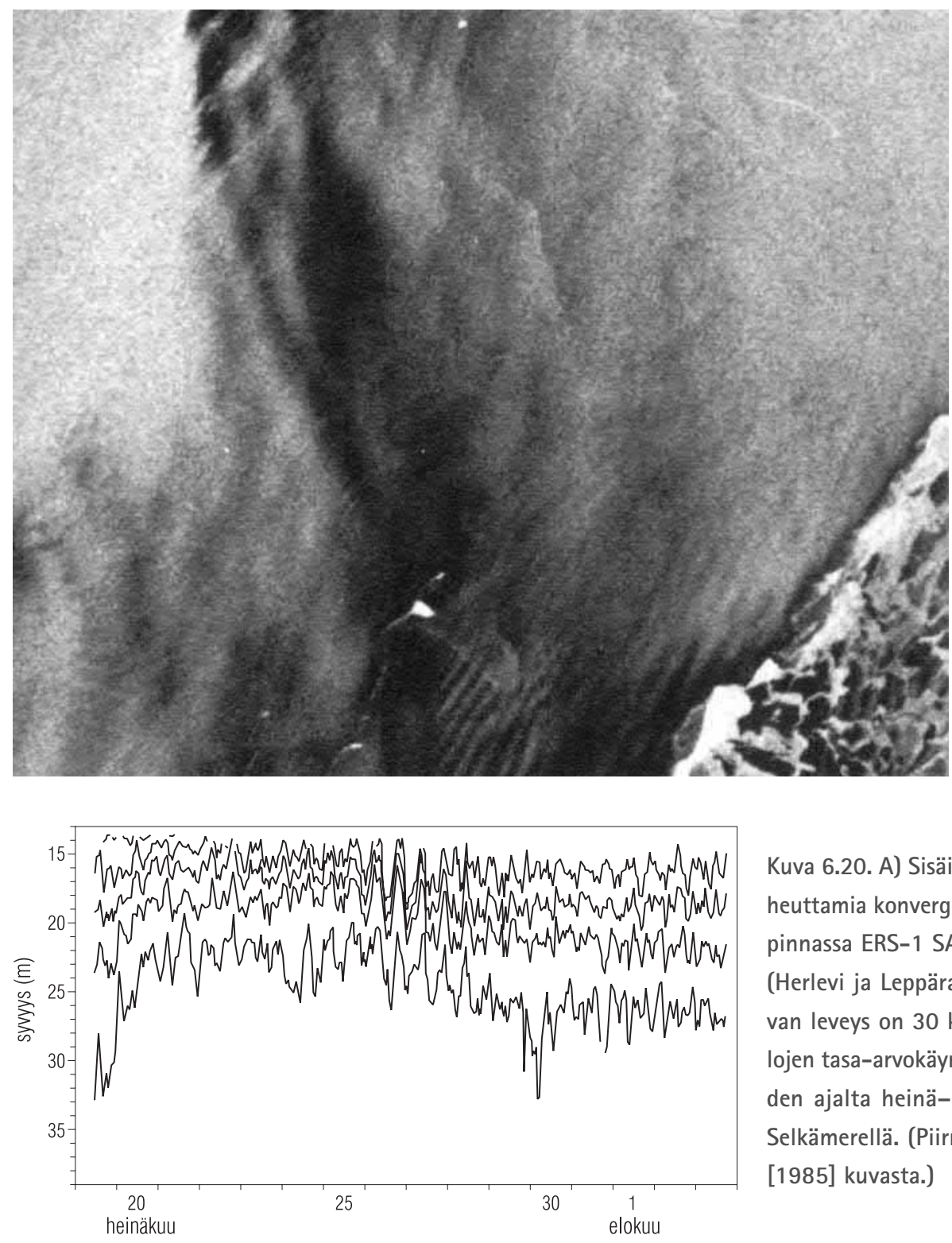

Kuva 6.20. A) Sisäisten aaltojen aiheuttamia konvergenssivöitä meren pinnassa ERS-1 SAR-tutkakuvassa (Herlevi ja Leppäranta 1994). Kuvan leveys on $30 \mathrm{~km}$. B) Lämpötilojen tasa-arvokäyriä 16 vuorokauden ajalta heinä-elokuussa 1978 Selkämerellä. (Piirretty Aleniuksen [1985] kuvasta.)

\subsubsection{Sisäiset aallot}

Kun vesipatsaassa on päällekkäin eri tiheyksiä omaavia kerroksia, saattaa kerrosten välipintoihin syntyä sisäisiä aaltoja. Palauttavana voimana on nettopainovoima eli painovoiman ja nosteen erotus. Vesirungon stabiliteetti eli tiheyskerrostuneisuus on keskeinen sisäisten aaltojen tausta- tekijä. Sisäiset aallot eivät vaadi suuria energioita, koska tiheyserot vesirungon sisällä ovat pieniä. Siten sisäisten aaltojen amplitudi voi olla kertaluokkaa suurempi kuin tuulen generoimassa pinta-aallokossa.

Sisäiset aallot eivät pinnassa tunnu vedenkorkeuden muutoksina. Sen sijaan aaltoihin liittyvä vesipartikkelien liike ulottuu pintaan, mikä luo 
sisäisten aaltojen harjojen kohdille konvergenssivöitä. Näitä vöitä voidaan havaita esim. materian kulkeutumisen takia pinnalla. On kuitenkin muistettava, etteivät kaikki tällaiset vyöt liity sisäisiin aaltoihin; havainnon varma tulkinta edellyttää tarkempaa analyysia (kuva 6.20A).

Vapaa sisäinen aalto on sellainen, jota ei jatkuvasti ylläpidä mikään ulkoinen voima. Kun nestepartikkelien tasapainotila tulee häirityksi ulkoisten voimien vaikutuksesta, kerrostuneessa nesteessä syntyy sisäisiä aaltoja (Mälkki ja Tamsalu 1985). Tällaisia voimia ovat ilmapainefluktuaatiot, tuuli, sateet, vuorovaikutukset pintaaaltojen ja toisten sisäisten aaltojen kanssa, sekoittuneen yläkerroksen epästabiilisuus, Ekmanvirtauksiin liittyvä konvergenssi tai divergenssi, vedenkorkeusvaihtelut sekä virtaukset epätasaisen pohjan yli. Myös merieläimet ja laivat voivat synnyttää sisäisiä aaltoja (Alenius 1985). Itämeressä kerrostuneisuus on stabiili, joten edellä mainitut mekanismit aiheuttavat sisäisiä aaltoja varsin yleisesti ja niitä voidaan havaita lähes kaikissa hydrodynaamisten suureiden mitatuissa vertikaaliprofiileissa. Sisäisissä aalloissa palauttavana voimana toimii painovoima, ja koska sisäiset tiheyserot ovat pieniä veden ja ilman tiheyseroon verrattuna, sisäisten aaltojen amplitudi voi helposti kasvaa (kuva 6.20B). Sisäisiä aaltoja vaimentavat veden viskositeetti, turbulenssi, tiheyskerrostuneisuuden hienorakenne, aaltojen murtuminen, aaltojen väliset vuorovaikutukset ja aaltojen absorboituminen pohjaan.

Sisäisten aaltojen taajuus on Coriolis-taajuuden $f$ ja Brunt-Väisälä-taajuuden $N=(-\mathrm{g} / \rho$ $\partial \rho / \partial z)^{1 / 2}$ välillä: $f<\omega<N$. Täten aaltojen periodit ulottuvat muutamasta minuutista aina puoleen vuorokauteen asti. Mittausten mukaan virtausnopeuksien fluktuaatioita sekä isotermien siirtymiä on havaittu näissä aikaskaaloissa. Tyypillisesti periodit ovat esim. Kielin lahdella 1-30 minuuttia, Suomenlahdella, Arkonan altaalla ja Darssin kynnyksellä on havaittu 5-6 tunnin jaksoja. Sisäisten aaltojen aiheuttamat suolaisuuden ja lämpötilan muutokset voivat olla huomattavia (Kuva 6.20B). Aleniuksen (1985) mukaan amplitudit näyttävät olevan metrin luokkaa aalloille, joiden periodi on yli 2 tuntia. Suurimmat muutokset havaitaan pyknokliinin tienoilla, jossa Väisälä-taajuus saavuttaa maksimiarvonsa. Kun etäisyys pyknokliinista kasvaa pohjaan tai pintaan päin mennessä, sisäisten aaltojen aiheuttamat muutokset hydrografiaan pienenevät. Mikäli kerrostuneisuudessa esiintyy sekä termokliini että halokliini havaitaan vastaavasti kaksi sisäisten aaltojen aiheuttamaa amplitudia.

Sisäisten aaltojen merkitystä voidaan toisaalta pohtia energian pystysuuntaisen siirron kannalta. Meren hyvin sekoittuneessa pintakerroksessa turbulenssi on jatkuvaa, koska kerros on jatkuvassa vuorovaikutuksessa ilmakehän kanssa. Sen sijaan pyknokliinin alapuolella turbulenssi on luonteeltaan ajoittaista. Kaikkein todennäköisimmin juuri sisäiset aallot ovat pyknokliinin alapuolisen turbulenssin selittävä tekijä. Sisäiset aallot aiheuttavatkin muutoksia lämpövoiden, suolaisuuden ja energian jakaumiin.

Itämeressä esiintyy varsin monenlaisia sisäisiä aaltoja, koska pakotetekijät ja pohjan muodot vaihtelevat. Ilmeisesti epälineaariset sisäiset aallot ovat fysikaalisesti tärkeimpiä, koska juuri ne aiheuttavat hydrodynaamisten suureiden jakaumissa muutoksia.

Epälineaaristen, dispersiivisten sisäisten aaltojen kuvauksessa käytetään usein Korteweg-de Vries -yhtälöä, joka perustuu perturbaatioteoriaan. Yhtälö pätee pitkille aalloille. Siinä oletetaan, että $H / \lambda<<1$ ja a/ $H<<1$, missä $H$ on veden syvyys, $\lambda$ on tyypillinen sisäisen aallon aallonpituus ja $a$ on tyypillinen aallon amplitudi. Kerrostuneen meren yhtälö voidaan kirjoittaa muodossa:

$$
\frac{\partial \eta}{\partial t}+c \frac{\partial \eta}{\partial x}+\alpha \eta \frac{\partial \eta}{\partial x}+\beta \frac{\partial^{3} \eta}{\partial x^{3}}=0
$$


missä $\eta(\mathrm{x}, \mathrm{t})$ on termokliinin syvyyden vaihtelu, $\alpha, \beta$ ja c ovat parametrit, jotka kuvaavat epälineaarisuutta, dispersioita ja pitkien sisäisten aaltojen vaihenopeutta. Näiden parametrien arvot määritetään tiheyden pystyjakauman perusteella käyttäen niin sanottua Boussinesq-oletusta.

Pitkien sisäisten aaltojen vaihenopeus $c$ ja pyknokliinin pystyjakauman muutokset saadaan seuraavan yhtälön avulla (perustuu reuna-arvoongelman ominaisarvon ratkaisuun)

$$
\frac{d^{2}}{d z^{2}} \phi+\frac{N^{2}(z)}{c^{2}} \phi=0, \phi(-H)=\varphi(0)=0
$$

Valtamerillä tehtyjen tutkimusten mukaan dispersion ja pitkien aaltojen vaihenopeutta kuvaavien lineaaristen parametrien $(\beta, c)$ muutoksiin vaikuttavat syvyyden muutokset, ja epälineaarisuutta kuvaavan parametrin $\alpha$ muutoksiin vaikuttaa eniten kerrostuneisuus.

Kuvassa 6.21 on esitetty Brunt-Väisälä-taajuuden pystyjakaumia perustuen lämpötila- ja suolaisuusprofiileihin. Suurimmat arvot 0,05 $\mathrm{s}^{-1}$ (jaksonpituus 2,1 min.) löytyvät pyknokliinin läheisyydestä, kun taas pintakerroksessa (60 metrin yläpuolella) taajuus on $0,004 \mathrm{~s}^{-1}$ (jaksonpituus 26,2 min.). Matalimmilla alueilla havaitaan minimiarvot 0,0012 $\mathrm{s}^{-1}$ (jaksonpituus 87,3 $\min$.).

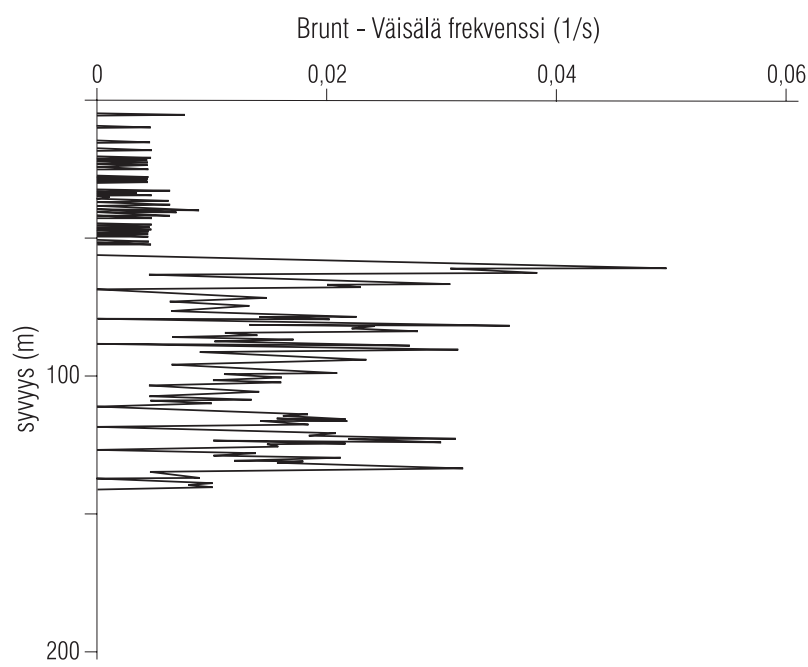

Kuva 6.21. Brunt-Väisälä-taajuuden N jakauma Gotlannin syvänteen lämpötila- ja suolaisuusprofiileihin perustuen. (Piirretty Kõutsin [1999] kuvasta.) 


\section{Itämeren jääolot}

\subsection{Itämeren jäätyminen}

Itämeri kuuluu pohjoisten jäätyvien merten reunavyöhykkeeseen, jossa ilmastolliset vaihtelut tuntuvat jääoloissa voimakkaasti. Jääpeite on yksi Itämeren keskeisistä fysikaalisista piirteistä ja sillä on merkitystä myös koko Pohjois-Euroopan ilmastosysteemissä. Jäätä muodostuu joka vuosi. Se puskuroi pintaveden lämpötilan jäätymispisteeseen ja sen vaikutus meren suolaisuuteen näkyy erityisesti keväällä sulamiskautena pintaveden makeutumisenaJää muuntaa meren ja ilmakehän välistä kytkentää eristäen merta kylmästä talvi-ilmasta, varastoiden sadannan ja ilmakehän laskeuman itseensä talven ajaksi sekä muokaten tuulienergian siirtymistä veteen. Itämerellä jääpeite on ollut myös merkittävä yhteiskunnallinen tekijä. 1800-luvun lopulle asti jään saarto eristi maamme muusta Euroopasta useaksi kuukaudeksi vuosittain.

Itämeren vesi jäähtyy syksyllä, kun auringon voima vähenee ja säteilytase kääntyy negatiiviseksi. Lisäksi kylmiä ilmamassoja ajautuu idästä ja pohjoisesta Itämeren ylle nopeuttaen meren jäähtymistä. Jäätalvi alkaa normaalivuosina lokakuun lopulla Kemin-Tornion edustalla. Jäätyminen etenee rannikkoa pitkin nopeasti etelään, kun taas altaiden keskialueet jäätyvät hitaasti niiden suuren lämpövaraston takia. Perämeri jäätyy kauttaaltaan keskimäärin tammikuussa ja Suomenlahti ja Selkämeri kuukautta myöhemmin. Perämerta lukuun ottamatta ulapat eivät leutoina talvina jäädy lainkaan. Normaalitalvina jään

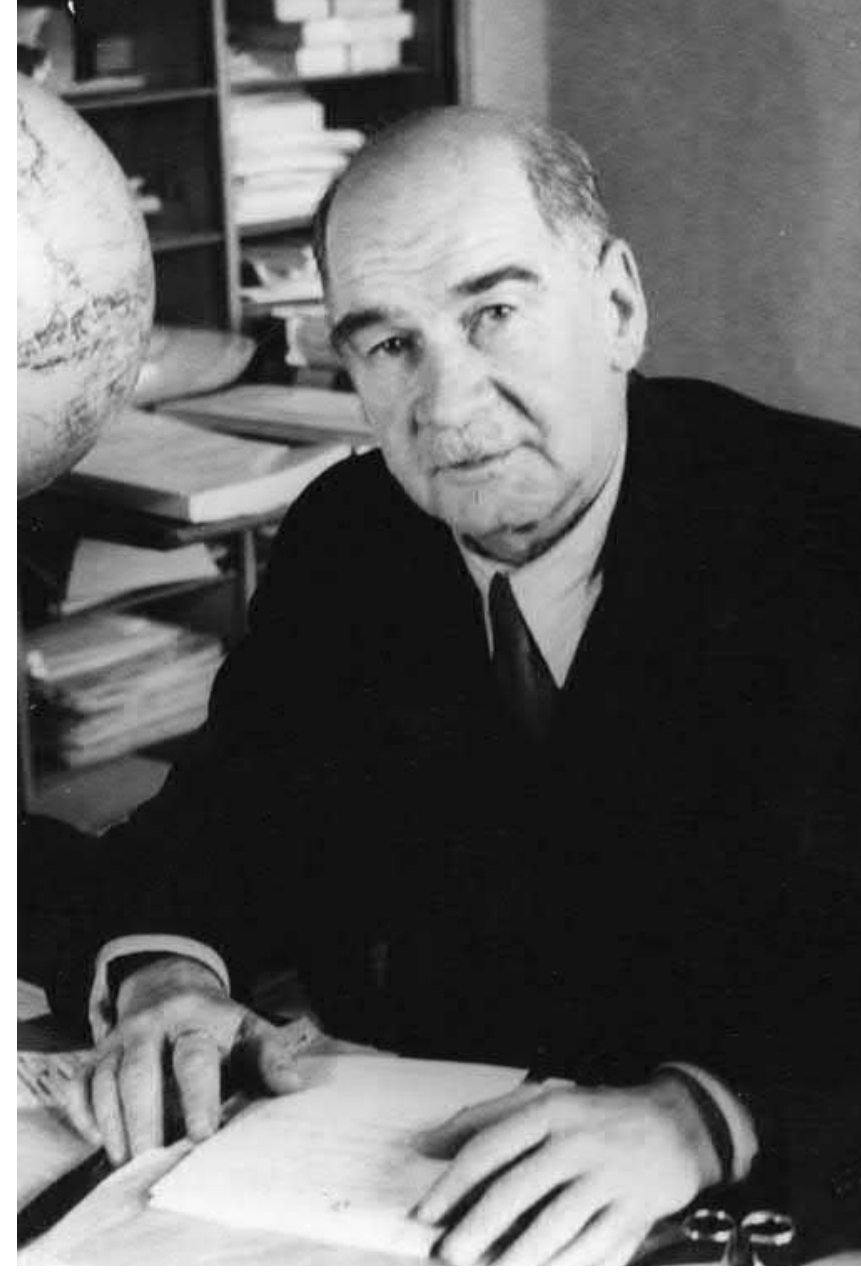

Kuva 7.0. Professori Risto Jurva (1888-1953) oli Itämeren jääntutkimuksen pioneeri. Hän oli mukana jääpalvelutoiminnan suunnittelussa ja käynnistyksessä sekä kehitti kartografisen menetelmän, jossa jäätalven kulkua kuvataan ajasta riippumattomien vaiheiden mukaan. Hän kirjoitti laajalti jääolojen pitkäaikaisista muutoksista ja konstruoi Itämeren jääpeitteen laajuudesta vuonna 1720 alkavan aikasarjan, joka kuuluu tunnetuimpiin Itämeren aikasarjoihin. (Merentutkimuslaitoksen kuva-arkisto)

raja kulkee ulkomerellä Tallinna-Tukholma linjalla, ja jäätilanne on laajimmillaan 15.2.-15.3. välisenä aikana. Sulaminen käynnistyy etelässä jo maaliskuun alussa, kun jäät vahvistuvat vielä pohjoisessa. Viimeiset jäälautat sulavat Perämereltä yleensä touko-kesäkuun vaihteessa.

Itämeren murtoveden jäätymispiste $T_{\mathrm{f}}$ on hieman nollan alapuolella ja maksimitiheyden lämpötila sitä paljon korkeampi vaikkakin alempi kuin $4{ }^{\circ} \mathrm{C}$ (katso luku 4). Yhden promillen lisäys 
suolaisuuteen alentaa jäätymispistettä $0,055^{\circ} \mathrm{C}$ ja maksimitiheyden lämpötilaa $\left(T_{\mathrm{D}}\right) 0,215^{\circ} \mathrm{C}$. Kun $S=6 \%$, on siis $T_{\mathrm{f}}=-0,33^{\circ} \mathrm{C}$ ja $T_{\mathrm{D}}=2,7^{\circ} \mathrm{C}$. Teoriassa suolaisuudeltaan homogeeninen murtovesiallas käyttäytyisi kuin makeavetinen järvi siinä suhteessa, että syyskierto jatkuu kunnes vesi on jäähtynyt tiheysmaksimin lämpötilaan, ja siitä edelleen jäähtyessään pintakerros stabiloituu. Tällaisessa tapauksessa suolaisuuden aiheuttama maksimitiheyden lämpötilan ja jäätymispisteen aleneminen viivästyttäisivät jäätymistä muutamia päiviä. Syksyllä vesi jäähtyy keskimäärin noin $5^{\circ} \mathrm{C} / \mathrm{kk}$. Jos suolaisuus on $6 \%$, makeaan veteen verrattuna jäätymispiste tulee vastaan 2 vuorokautta myöhemmin ja pintavesi on "jäätymiskypsä” eli jäähtymisessä stabiloituva 8 vuorokautta myöhemmin, mutta aika tästä jäätymiseen on lyhyempi kuin järvissä.

Itämeren vesirungossa syksyiseen jäähtymiseen liittyvä vertikaalikierto ulottuu vain halokliiniin asti. Usein esiintyvät voimakkaat tuulet sekoittavat pintavettä tehokkaasti, minkä takia ohutta stabiilia pintakerrosta ei muodostu kuten suojaisilla järvillä, ja veden jäätyessä yleensä lähes koko peitekerros on lähellä jäätymispistettä. Näin ollen tiheysmaksimin lämpötilan aleneminen ei suojaisia rannikko- ja saaristoalueita lukuun ottamatta vaikuta jäätymisen ajankohtaan. Itämeren jäätymisen syyt ovat peitekerroksen suhteellisen pieni tilavuus ja lämpövarasto, voimakas halokliini sekä vähäinen lämmönsyöttö Pohjanmereltä.

Jääpeitteen suurin vuotuinen laajuus on keskimäärin 45 \% Itämeren pinta-alasta, vaihteluväli on 10-100 \% (kuva 7.1). Jäätalven pituus on 5-7 kk Kemissä ja 0-4 kk Utössä. Jääpeite on rannikolla ja saaristossa kiintojäätä ja muualla ajojäätä (kuva 7.2). Kiintojää on ehyttä ja tasaista, ja se pysyy vakaana alku- ja lopputalvea lukuun ottamatta. Keskimäärin kiintojään reuna asettuu 10 metrin syvyyskäyrän tuntumaan. Jäätymisen, jään kasvun ja sulamisen klimatologia seuraavat ilman lämpötilan kulkua melko hyvin, ja kiintojää kasvaa ja sulaa samaan tapaan kuin järviemme jääpeite. Sen suurin vuotuinen paksuus on Kemissä ollut 50-110 cm, ja ennätys on mitattu vuonna 1985 Tornion edustalla, $122 \mathrm{~cm}$.

Kiintojään ulkopuolella on ajojäätä, joka ajelehtii tuulten ja virtausten vaikutuksesta. Liike johtaa jääpeitteen rikkoutumiseen ja siten avovesialueiden muodostumiseen sekä jään kasautumiseen ja erilaisten jäätyyppien muodostukseen. Tärkein näistä tyypeistä on ahtojää, jääteleistä rakentuvat röykkiöt, joissa parhaimmillaan jäätä on kasautunut 30 metrin paksuudelta. Kaiken kaikkiaan ajojääkentissä on ahtojäätä 10-50 \% kokonaistilavuudesta. Ajojään kulkeutuminen siirtää jäätä ja siihen varastoitunutta makeata vettä ja kylmää pitkiäkin matkoja. Myös jäähän varastoitunutta sedimenttiä siirtyy tällä tavalla tehokkaasti merialueilta toisille.

\subsection{Jään rakenne ja ominaisuudet}

\subsubsection{Jään kiderakenne}

Merijään kiteistä puhuttaessa tarkoitetaan makrokiteitä, jotka koostuvat erillisistä päällekkäin asettautuneista kidelevyelementistä. Ne ovat kooltaan kuin järvien jääkiteet, mutta hienorakenteellisia eroja on: merijään (makro)kiteiden pinnat ovat rosoisia, ja niiden sisällä levyelementtien välissä on suolaliuostaskuja (kuva 7.3). Merijään tärkeimmät epäpuhtaudet ovat suola ja kaasukuplat. Edellisen merkitys on suuri ja sitä käsitellään seuraavassa kohdassa. Kaasukuplien suhteellinen tilavuus on suuruusluokkaa $v_{a}-1$ $\%$. Puhtaan jään tiheys on $\rho_{\text {io }}=917 \mathrm{~kg} / \mathrm{m}^{3}$ lämpötilassa $0{ }^{\circ} \mathrm{C}$. Suolaisuus ja lämpötila vaikuttavat hieman merijään tiheyteen, mutta suurin vaikutus on kaasukuplilla, jotka pienentävät sitä:

$\rho_{\mathrm{i}} \approx\left(1-v_{\mathrm{a}}\right) \rho_{\mathrm{io}}$ 


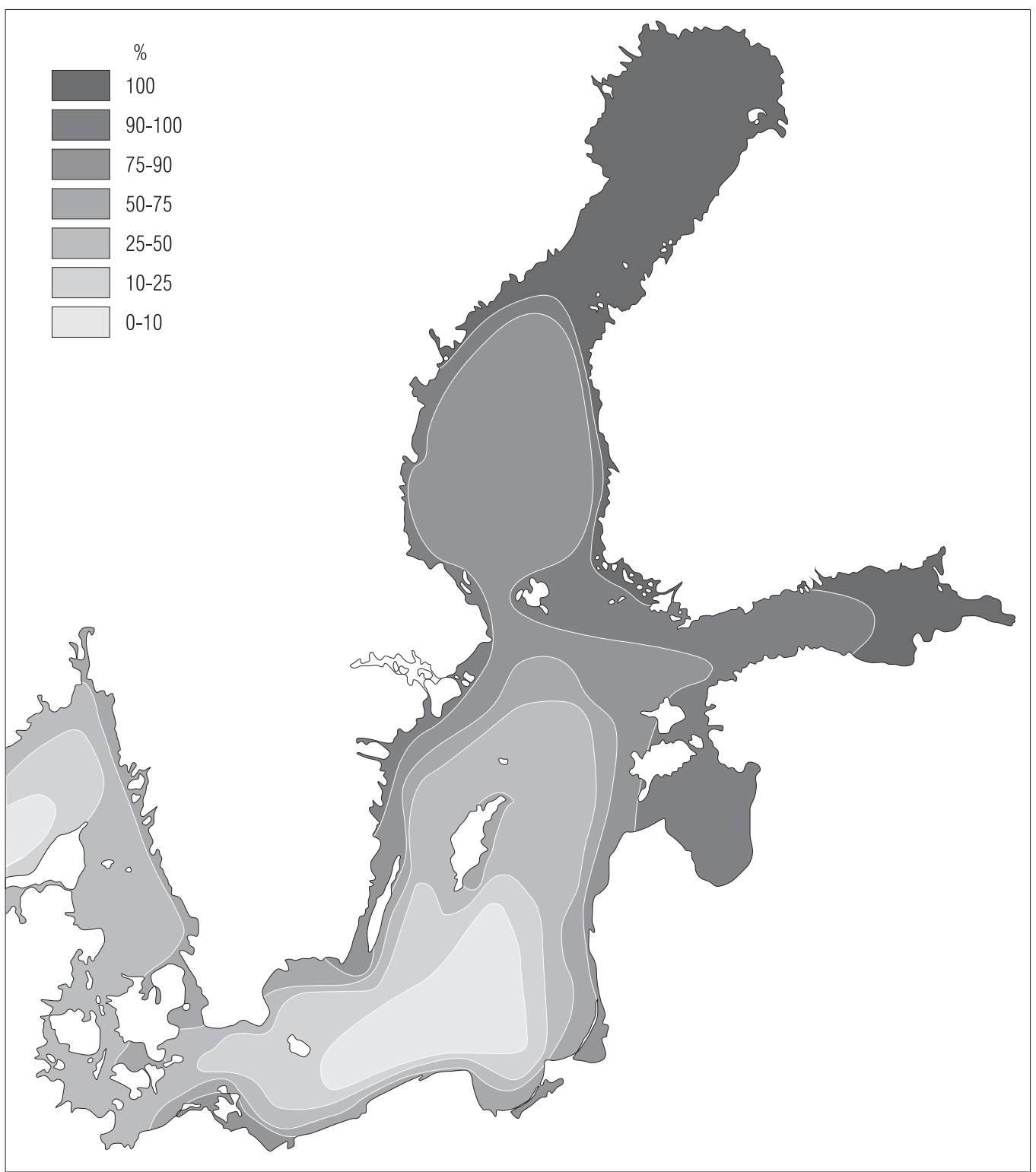

Kuva 7.1. Jäätymisen vuotuinen todennäköisyys Itämerellä. (SMHI ja Merentutkimuslaitos 1982)

Tiheysmittausten avulla voidaan siis arvioida kaasukuplien tilavuutta.

Jäätä syntyy Itämerellä kolmen eri mekanismin avulla. Tavallisesti muodostuu niin sanottua kongelaattijäätä jääkiteiden kasvaessa jään alapinnasta veteen. Nämä kiteet ovat rakenteeltaan pylväsmäisiä, halkaisijaltaan $0,5-5 \mathrm{~cm}$ ja pituudeltaan jopa 5-50 cm. Suppojäätä muodostuu avopaikoissa, erityisesti ulkomerellä. Suppojää- kiteet ovat pieniä (suuruusluokaltaan $1 \mathrm{~mm}$ ), ne kulkevat vapaasti virtausten mukana ja tarttuvat myöhemmin ehyen jääpeitteen alapintaan tai jäätyvät yhteen hyhmänä. Matalissa vesissä, kun halokliinia ei ole, suppoa kiinnittyy myös meren pohjaan ja kasvillisuuteen. Supon määrästä ei Itämereltä ole paljon havaintoihin perustuvaa tietoa, mutta sitä tiedetään esiintyvän. 


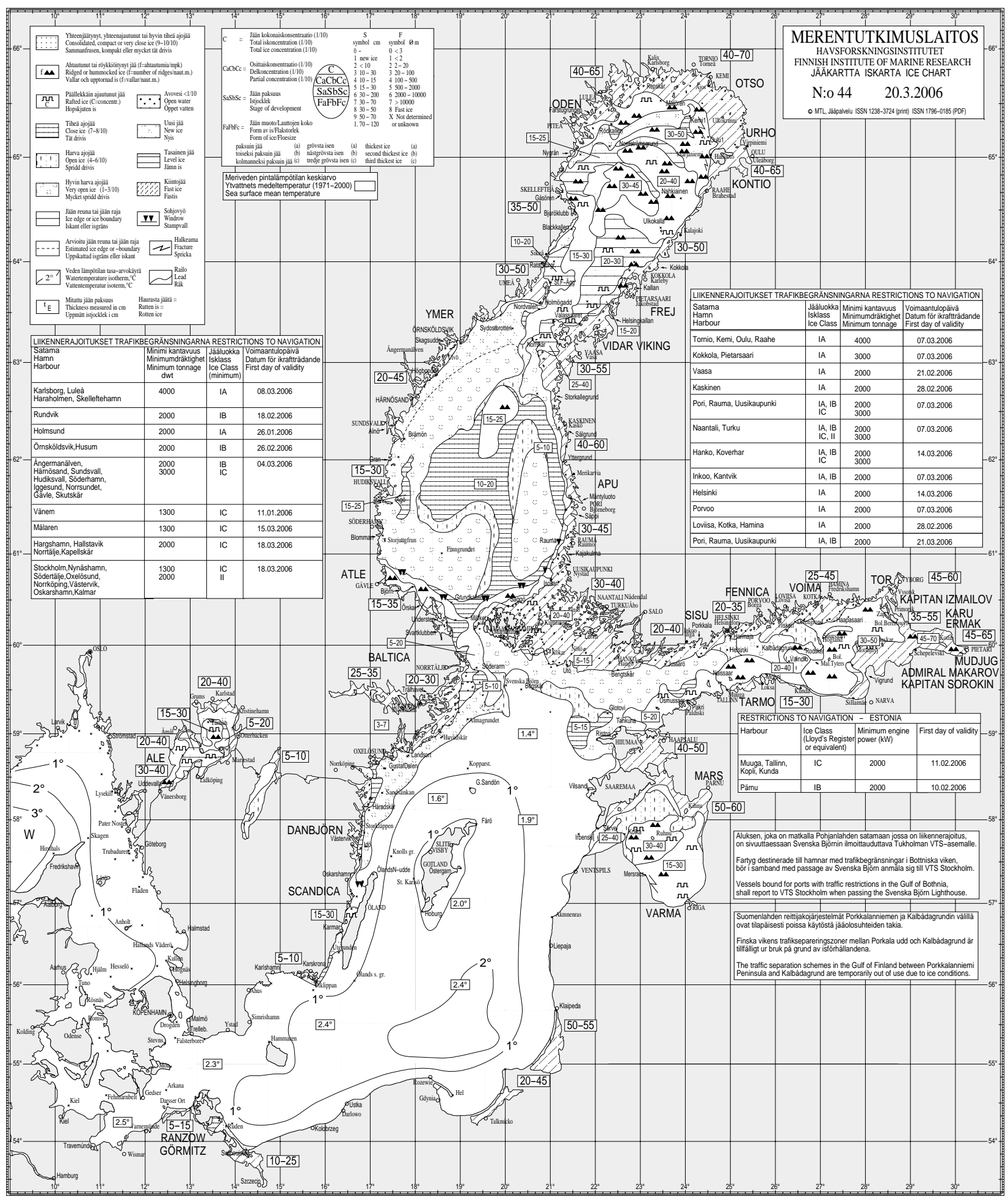

Kuva 7.2. Itämeren jääkartta 20.3.2006. (Merentutkimuslaitos) 

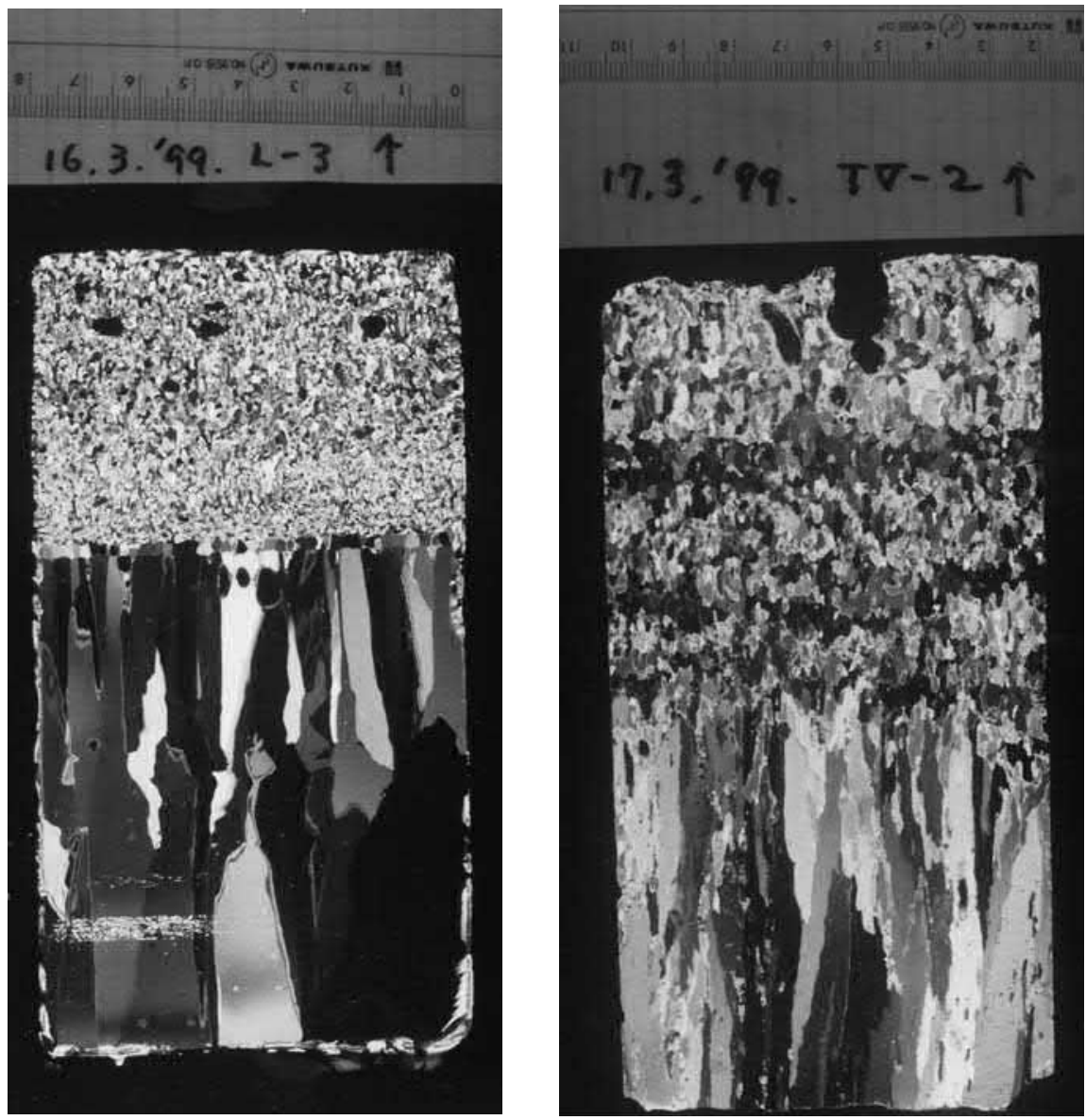

Kuva 7.3. Jääkiteitä Itämeren jäässä (vas.) ja makeavetisessä järvijäässä (oik.). Yläosassa on kohvajäätä ja alempana pylväskiteistä jäätä. YIhäällä cm-asteikko. (Toshiyuki Kawamura)

Kohvajäätä muodostuu jäällä olevasta sohjosta, jota on syntynyt lumesta ja jäälle nousseesta merivedestä, sadevedestä tai sulamisvedestä. Ensimmäinen tapaus on merkittävin; se voi toteutua, kun lumi on painanut jään kokonaan vedenpinnan alle, eli

$\frac{h_{s}}{h_{i}}>\frac{\rho-\rho_{i}}{\rho_{s}}$

missä $h_{s}$ ja $h_{\mathrm{i}}$ ovat lumen ja jään paksuudet sekä $\rho_{s}$ ja $\rho_{\mathrm{i}}$ ovat lumen ja jään tiheydet. Koska $(\rho-$ $\left.\rho_{\mathrm{i}}\right) / \rho_{\mathrm{s}} \approx 1 / 3$, lumen paksuuden täytyy olla vähintään kolmasosa jään paksuudesta, jotta jäälle voisi nousta merivettä. Kohvajäätä on Itämeren jääpeitteessä 10-50 \%. Kiteet ovat pieniä, yleen- sä kooltaan 1-5 mm (kuva 7.3). Kohvajään kasvua mitataan kohvatikulla, joka asetetaan jäähän pian jäätymisen jälkeen ja josta voidaan seurata ylöspäin suuntautuvaa kasvua (Palosuo 1965). Yleensä kohvajää näkyy jäänäytteessä sameana yläkerroksena johtuen valon sironnasta siinä olevista ilmakuplista.

Rannikon ja saariston kiintojääpeitteen jää on yleensä kaksikerroksista. Päällä on kohvajäätä ja alla kongelaattijäätä. Keskimääräinen jään paksuus kasvaa mentäessä pohjoiseen ja itään päin (taulukko 7.1), sillä talvi-ilmasto kylmenee näihin suuntiin. Jään paksuuden hajonta on suurinta etelässä, eikä jäätä esiinny siellä lainkaan lauhkeimpina talvina. 
Taulukko 7.1. Suurin vuotuinen jään paksuus $(\mathrm{cm})$ Suomen rannikolla 1961-1990. (Seinä ja Peltola 1991)

\begin{tabular}{|l|l|l|l|l|l|}
\hline & Min & $\begin{array}{l}\text { Kes- } \\
\text { kiar- } \\
\text { vo }\end{array}$ & Max & $\begin{array}{l}\text { Ha- } \\
\text { jonta }\end{array}$ & $\mathrm{n}$ \\
\hline Kemi & 58 & 76 & 111 & 11 & 30 \\
\hline Valassaaret & 18 & 51 & 80 & 16 & 25 \\
\hline Kumlinge & 0 & 37 & 75 & 19 & 17 \\
\hline Utö & 0 & 21 & 69 & 22 & 19 \\
\hline Kotka & 16 & 50 & 90 & 18 & 26 \\
\hline
\end{tabular}

\subsubsection{Jään suolaisuus}

Kun suolainen vesi jäätyy, jää kiteytyy vain vesimolekyyleistä, toisin sanoen jäätyminen erottaa veden siihen liuenneista aineista. Erottelu ei kuitenkaan ole täydellinen ja merijään sisään koteloituu suoloja. Itämeren murtovesi käyttäytyy tässä suhteessa kuten normaali merivesi. Jään sisään muodostuvat suolaliuostaskut tarjoavat myös kasvuympäristön jääleville.

Suolaisen veden jäätyessä jään ja veden rajapinta muodostuu solukkoiseksi. Kun jää siitä kasvaa, jääkidehilaan tulee vain vesimolekyylejä, mutta kide-elementtien väliin jää suolaliuosta. Näistä solukoista umpeutuu sitten jään kasvaessa suolaliuostaskuja. Kylmässä jäässä on lisäksi suolakiteitä, sillä eri suolat kiteytyvät omissa lämpötiloissaan eli niiden eutektisissa pisteissä. Tärkein suoloista on natriumkloridi, jonka eutektinen piste on $-22,9^{\circ} \mathrm{C}$; sitä ennen kiteytyy natriumsulfaatti $\left(-8,2^{\circ} \mathrm{C}\right)$. Itämerellä tehtyjen tutkimusten mukaan solukkoinen kasvu käynnistyy, jos veden suolaisuus on suurempi kuin noin $1,5 \%$. Suomen järvissä jään ja veden rajapinta on tasainen, ja vain vähän epäpuhtauksia siirtyy vedestä jäähän.

Itämerellä uuden jään suolaisuus on $S_{\mathrm{i}}=\kappa S$, $\approx 0,25-0,4$, toisin sanoen Itämeren uusi jää on suolaisuudeltaan 1-3\%o. Sydäntalven aikana jään suolaisuus hieman laskee, kun suolaliuosta valuu mereen, mutta kerroin $\kappa$ pysyy tasolla
0,2-0,3 sulamiskauden alkuun asti. Sulamisvaiheessa suolaonkalot huuhtoutuvat tehokkaasti ja jäästä tulee melkein suolatonta (suolaisuus on suuruusluokaltaan enää $0,1 \%$ ). Samalla jäässä eläneet levät ja muut eliöt joutuvat veteen. Tätä niin sanottua siemenvaikutusta on tutkittu jonkin verran Itämeressäkin. Näyttää siltä, että eräät jään levälajit voivat ryhtyä kasvamaan vedessä muodostaen osan kevätkukinnasta.

Merijäätä on siis tarkasteltava monikomponenttisena materiana, ja sen koostumus muuttuu lämpötilan mukana. Suola on jäässä pääasiassa liuoksena ja suolaliuos on aina termodynaamisessa tasapainossa ympäristönsä kanssa niin, että sen suolaisuus vastaa jäätymispisteen lämpötilaa $S_{\mathrm{b}}=S_{\mathrm{b}}(T)$. Jään jäähtyessä suolaliuos väkevöityy ja taskut pienenevät, jään lämmetessä muutos on päinvastainen. Suolaliuoksen suhteellinen tilavuus $v_{\mathrm{b}}$ on likimain

$v_{b}=\frac{\rho_{i} S_{i}}{\rho_{b} S_{b}}$

missä $\rho_{\mathrm{b}} \approx 1+0,8 \cdot S_{\mathrm{b}}$ on suolaliuoksen tiheys ja $S_{\mathrm{b}}$ sen suolaisuus. Jos jää on kylmempää kuin $22,9^{\circ} \mathrm{C}$, kaavaan tulee suolakiteiden aiheuttama korjaus. Suolaliuoksen suolaisuus ja suolakiteiden määrä lämpötilan funktiona on luettavissa merijään faasidiagrammista (kuva 7.4).

Suolaisuuden takia merijää poikkeaa ominaisuuksiltaan hieman makean veden jäästä. Merkittävintä ero on sähköisissä ominaisuuksissa ja jään lujuudessa. Sähköisillä ominaisuuksilla ei sinänsä ole suurta merkitystä, mutta niiden kautta saadaan epäsuorasti tietoa muista ominaisuuksista. Esimerkiksi mikroaaltojen sirontakerroin riippuu jään dielektrisyysvakiosta ja suolaisuuden vaikutus tuntuu sitä kautta jäästä tehdyissä tutkahavainnoissa. Suolataskut tekevät merijään huokoiseksi ja siksi Itämeren jään murtolujuus on heikompi kuin makean veden jään. Suolataskut vaikuttavat kuormituspintoihin eli kovaa, murrettavaa pintaa on suolataskujen takia vähemmän. 


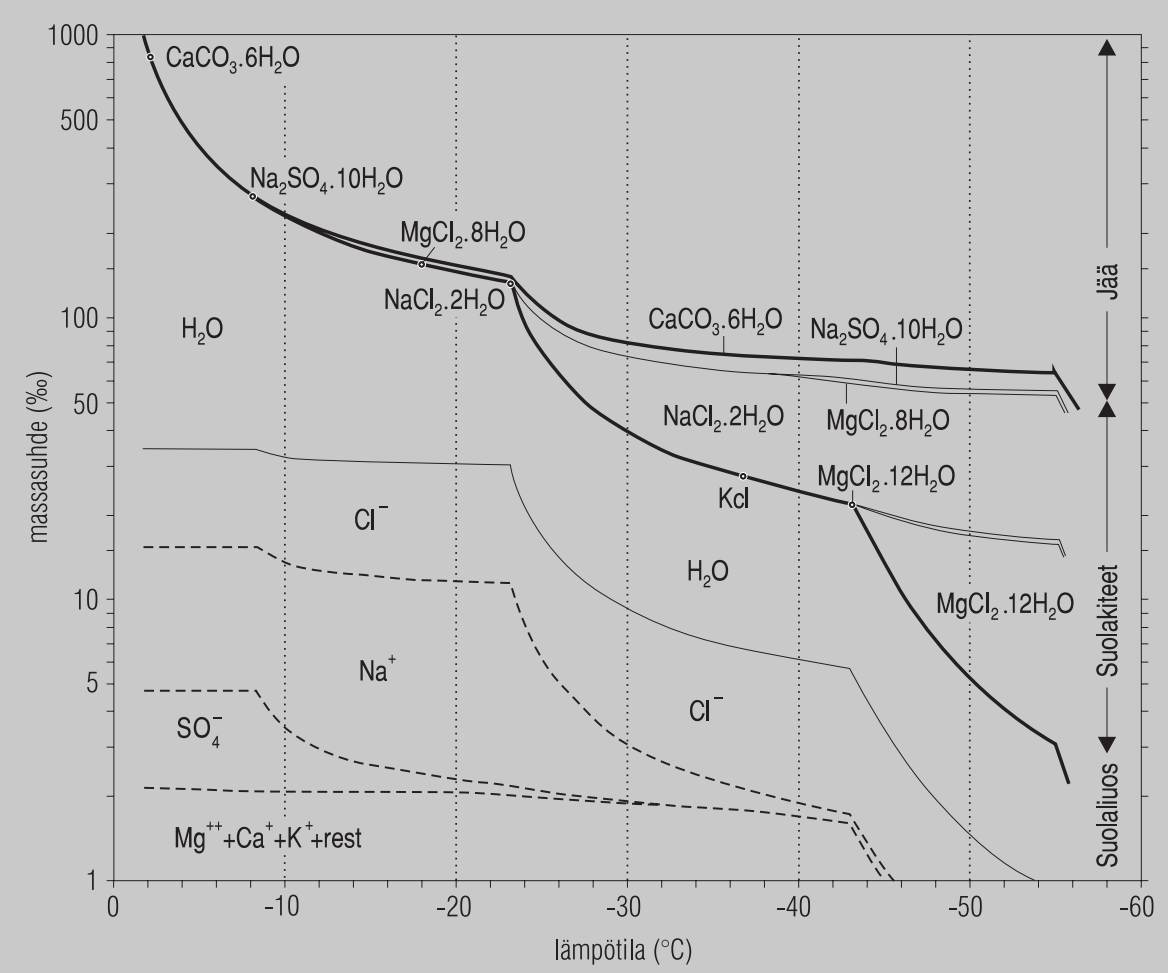

Kuvia 7.4. Merijään faasidiagrammi, joka kuvaa jään, suolakiteiden ja suolaliuoksen massaosuuksia lämpötilan funktiona. Kemialliset symbolit kuvaavat eri suolojen kiteytymisiä suolaliuoksesta. (Piirretty Assurin [1958] mukaan.)

Lämpötalouden osalta merijää eroaa kvalitatiivisesti makean veden jäästä. Jään lämpötilan muuttuessa suolataskujen suolaisuus muuttuu, ja sen takia myös suolataskujen tilavuus muuttuu. Näin suolataskujen dynamiikka kasvattaa merijään ominaislämpöä, erityisesti kun jään lämpötila on lähellä nollaa. Lisäksi lämpö siirtyy sekä jäätä että suolataskuja pitkin, joten merijään lämmönjohtavuus eroaa hieman makean veden jään lämmönjohtavuudesta. Tehtäessä laskelmia jään paksuuden kehityksestä voidaan lämpötaloudellisia ominaisuuksia pitää vakioina yksinkertaisissa malleissa.

Merijään muodostuminen ja sulaminen vaikuttavat suolataseeseen ja sitä kautta pintakerroksen stabiliteettiin. Kasvava jää hylkii suolaa pintaveteen, mikä nostaa veden tiheyttä ja heikentää pintakerroksen stabiliteettia. Intensiivi- nenkään jään tuotanto ei Itämerellä kasvata suolaisuutta niin paljon, että se käynnistäisi pohjaan asti ulottuvan vertikaalisen täyskierron.

Merijäässä tavattava elämä perustuu suolaliuostaskuihin. Jään muodostuessa suolaliuostaskuihin konsentroituu suolan lisäksi ravinteita ja muita liuenneita aineita. Tilanteissa, joissa valo tunkeutuu jäähän, suolaliuostaskuissa on edellytykset levien kasvulle. Merijään sisässä elävät levät ovat sopeutuneet hyvinkin alhaisiin lämpötiloihin ja korkeaan suolaisuuteen. Ne selviävät pitkistäkin valottomista jaksoista. Itämeren jäästä löydetyt levät ovat pitkälti samoja kuin napamerten merijäässä elävät levät. Ne lienevät kulkeutuneet Itämereen jääkausien aikana pohjoisesta.

Merijäässä elävät levät kykenevät kasvamaan jään sisäisissä suolaliuostaskuissa. Niiden ongel- 
ma on päästä suljettuihin kanaviin. Tämän täytyy tapahtua merijään muodostumisvaiheessa. Mekanismia ei tunneta tarkasti, mutta ilmeisesti muodostuvat jääkiteet keräävät vedessä kelluvia soluja tai ne joutuvat kehittyviin pieniin lautasjään lauttoihin veden huuhtoessa niitä. Kerääntymismekanismi on joka tapauksessa niin tehokas ja jäässä elämään pystyvien lajien soluja niin paljon, että Itämerenkin merijäässä on runsaasti aktiivisia leviä. Niiden kasvua rajoittaa lähinnä valon määrä, mutta aktiivisimman kasvun vaiheessa myös suolaliuostaskujen ravinteet kuluvat loppuun. Suolaliuostaskut ovat pieniä (halkaisija 0,1-1 mm, pituutta voi olla useita senttimetrejä), ja tämä rajoittaa jäähän kehittyvän biomassan määrää. Mikään tätä suurempi eläin ei pysty elämään jään sisällä. Suolavesitaskuihin muodostuukin yksinkertainen ravintoverkko, jossa levät tuottavat eloperäistä ainesta bakteereille ja alkueläimille.

Merijään aktiivisin kerros on jään alapinnalla. Sinne muodostuu hauras, huokoinen jääkidekerros [englanniksi skeletar layer], jonka levät saattavat värjätä ruskeanvihreäksi. Tämän kerroksen levät saavat ravinteita jään alapuolisesta vedestä, mutta niiden kasvua rajoittaa suurimman osan talvea valon puute. Jäätä peittävän lumikerroksen paksuudella onkin suuri merkitys jäässä syntyvän biomassan muodostumisessa.

Jään sulaminen tuo makeata vettä pintakerrokseen, mikä vahvistaa veden stabiliteettia. Toisaalta keväisessä pintakerroksessa, jossa jää on juuri sulanut, pintaveden lämpeneminen aiheuttaa vertikaalista kiertoa kunnes maksimitiheyden lämpötila on saavutettu. Keskisellä ja eteläisellä Itämerellä, missä jäätä ei joka vuosi ole, talvinen pintalämpötila voi pysyä maksimitiheyden lämpötilan yläpuolella ja siten termokliinin muodostuminen voi alkaa heti alkukeväästä, jolloin ravinteet jäävät todellakin aivan pinnan lähelle. Kevään stabiili pintakerros on biologisen tuotannon kannalta edullinen, sillä silloin kasviplankton voi pysytellä suhteellisen ohuessa pintakerroksessa, missä auringonvaloa on runsaasti saatavilla.

\subsection{Jään kasvu ja sulaminen}

\subsubsection{Jään paksuuskasvu}

Termodynaamisesti Itämeren jää kasvaa suolaisuuden vaikutusta lukuun ottamatta kuten järvija jokijää. Yksityiskohdissa on eroja kuten jään alapinnan rakenteessa, mutta jään paksuuden kehityksessä erot ovat pieniä. Kasvunopeus on alkuja keskitalvena suuruusluokaltaan $1 \mathrm{~cm} / \mathrm{vrk}$ (taulukko 7.2). Jää kasvaa alapinnasta, kun uutta jäätä kiteytyy suoraan kongelaattijääksi pylväskiteiseen muotoon tai suppojäätä kiinnittyy jään pohjaan. Jään yläpintaan voi sen sijaan kasvaa kohvajäätä.

Taulukko 7.2. Jään ja lumen paksuus (keskiarvo \pm hajonta) jaksolta 1961-1990 Kemissä (6541'N 2431'E) ja Utössä (59² $\left.47^{\prime} \mathrm{N} 21^{\circ} 22^{\prime} \mathrm{E}\right)$. Yksikkönä on cm. Mittausaineisto on Merentutkimuslaitokselta (1961, 1962, 1964, 1965, 1966, 1971, 1978, 1982), Kalliosaari ja Seinä (1987) ja Seinä ja Kalliosaari (1991). x = ei voida arvioida. Kun jäävuosia on 30 , jäätä on silloin ollut joka vuosi.

\begin{tabular}{|c|c|c|c|}
\hline Kemi & Jään paksuus & Lumi & $\begin{array}{l}\text { Jää- } \\
\text { vuosia }\end{array}$ \\
\hline 1.11. & $3,0 \pm x$ & $0,0 \pm x$ & 1 \\
\hline 11.11 & $9,0 \pm 6,3$ & $0,0 \pm 0,0$ & 5 \\
\hline 21.11 & $13,0 \pm 8,3$ & $1,3 \pm 3,4$ & 13 \\
\hline 1.12 & $17,0 \pm 8,9$ & $3,7 \pm 7,6$ & 23 \\
\hline 11.12 & $23,0 \pm 8,8$ & $4,2 \pm 7,5$ & 27 \\
\hline 21.12 & $30,6 \pm 8,8$ & $5,9 \pm 7,0$ & 30 \\
\hline 1.1. & $39,3 \pm 8,2$ & $8,7 \pm 8,0$ & 30 \\
\hline 11.1. & $45,8 \pm 9,2$ & $12,7 \pm 8,1$ & 30 \\
\hline 21.1. & $51,5 \pm 9,6$ & $16,1 \pm 9,2$ & 30 \\
\hline 1.2. & $57,0 \pm 10,6$ & $19,5 \pm 9,7$ & 30 \\
\hline 11.2 & $60,9 \pm 10,5$ & $21,9 \pm 10,1$ & 30 \\
\hline 21.2. & $64,0 \pm 10,5$ & $24,8 \pm 9,8$ & 30 \\
\hline 1.3. & $66,5 \pm 11,2$ & $25,9 \pm 10,5$ & 30 \\
\hline 11.3. & $68,3 \pm 11,0$ & $26,2 \pm 10,7$ & 30 \\
\hline 21.3. & $69,9 \pm 11,1$ & $26,2 \pm 11,7$ & 30 \\
\hline 1.4. & $71,5 \pm 10,1$ & $23,6 \pm 12,8$ & 30 \\
\hline 11.4. & $72,0 \pm 10,6$ & $16,3 \pm 10,4$ & 30 \\
\hline 21.4. & $69,4 \pm 13,1$ & $7,2 \pm 7,7$ & 30 \\
\hline 1.5. & $59,0 \pm 18,0$ & $4,4 \pm 10,4$ & 28 \\
\hline 11.5. & $51,4 \pm 13,1$ & $2,9 \pm 6,1$ & 14 \\
\hline 21.5. & $40,0 \pm x$ & $0,0 \pm x$ & 1 \\
\hline
\end{tabular}




\begin{tabular}{|l|c|l|c|}
\hline Utö & Jään paksuus & Lumi & $\begin{array}{l}\text { Jää- } \\
\text { vuosia }\end{array}$ \\
\hline 1.1. & $\mathrm{x} \pm \mathrm{x}$ & $\mathrm{x} \pm \mathrm{x}$ & 1 \\
\hline 11.11. & $11,5 \pm 9,2$ & $0,5 \pm 0,7$ & 4 \\
\hline 21.11. & $22,7 \pm 15,2$ & $2,3 \pm 1,5$ & 6 \\
\hline 1.2. & $22,4 \pm 12,4$ & $4,6 \pm 2,9$ & 8 \\
\hline 11.2. & $23,4 \pm 15,9$ & $2,4 \pm 2,6$ & 14 \\
\hline 21.2. & $30,1 \pm 15,6$ & $5,0 \pm 5,4$ & 15 \\
\hline 1.3. & $28,4 \pm 18,0$ & $4,1 \pm 4,9$ & 17 \\
\hline 11.3. & $30,4 \pm 17,9$ & $5,0 \pm 5,7$ & 18 \\
\hline 21.3. & $37,6 \pm 17,2$ & $6,4 \pm 4,7$ & 16 \\
\hline 1.4. & $34,8 \pm 16,4$ & $4,3 \pm 5,9$ & 15 \\
\hline 11.4. & $33,2 \pm 16,6$ & $2,2 \pm 2,3$ & 8 \\
\hline 21.4. & $31,2 \pm 12,7$ & $0,4 \pm 0,9$ & 5 \\
\hline 1.5. & $28,0 \pm \mathrm{x}$ & $0,0 \pm \mathrm{x}$ & 1 \\
\hline
\end{tabular}

Jään kiteytymisen päästyä käyntiin muodostuu ensijään kerros, varhaisin jääpeitteen kerros. Sen jähmettyessä yhtenäiseksi jääpeitteeksi alkupaksuus on tyynen veden tilanteessa suuruusluokkaa $1 \mathrm{~mm}$. Voimakkaan turbulenssin vallitessa jääkiteet muodostavat ensin höllyvää suppoa ja jähmettyessään ehyeksi jääkanneksi tämän paksuus on jo 5-10 cm. Jää kasvaa sitten alapinnastaan veteen ja yläpinnastaan lumisohjoon tai sadetai sulaveteen.

Jään termodynaaminen paksuuntuminen on klassinen geofysiikan ongelma, johon on olemassa likimääräisiä analyyttisiä ratkaisuja. Jäätymisessä vapautuva lämpö siirtyy johtumalla jään ja lumen läpi ilmakehään. Mitä paksumpaa jää on, sitä hitaampaa on johtuminen, eli kasvaessaan jää eristää itsensä. Sulamisvaiheessa jäähän siirtyy lämpöä auringosta, ilmasta tai vedestä. Ainoastaan auringonsäteily sulattaa jäätä sisältä. Ilman ja jään sekä veden ja jään välinen lämmönvaihto sulattaa jäätä vain ylä- ja alapinnalta.

Lämmönjohtuminen jään läpi noudattaa Fourierin lakia

$\frac{\partial}{\partial t}\left(\rho_{i} c_{i} T\right)=\frac{\partial}{\partial z}\left(\kappa_{i} \frac{\partial T}{\partial z}\right)-I$

missä $c_{\mathrm{i}}$ on jään ominaislämpö, $\kappa_{\mathrm{i}}$ on jään lämmönjohtokyky, ja $I$ on jäähän tunkeutuva auringonsäteily. Reunaehdot tulevat lämpövuon jatkuvuudesta ja reunojen paikanmuutoksista jään kasvaessa ja sulaessa:

Yläpinta: $\kappa_{i} \frac{\partial T}{\partial z}=Q_{n}+Q_{n}$

Pohja: $T=T_{f}, \rho_{i} L \frac{d h}{d t}=\kappa_{i} \frac{\partial T}{\partial z}-Q_{w}$

missä $Q_{n}$ on ylhäältä tuleva netto lämmönvuo, $Q_{\pi}$ on faasimuutoksiin liittyvä lämpöenergia jään yläpinnalla, $h$ on jään paksuus, $L$ on sulamislämpö ja $Q_{w}$ on vedestä tuleva lämpö. Jäästä tulevan lämmön täytyy yläpinnalla vastata jäästä ulos siirtyvää lämpöä, kun taas alapinnalla lämpötila on jäätymispisteessä ja lämmönsiirron ylös täytyy vastata vedestä tulevaa lämpöä ja jäätymisessä vapautuvaa lämpöä. Lämmönjohtumisyhtälö voidaan ratkaista numeerisesti, ja mikäli säätilan kehitys sekä vedestä tuleva lämpö ovat tiedossa, numeerinen ratkaisu on yleensä sangen lähellä oikeata (kuva 7.5).

Jään paksuuntumisen yksinkertainen analyyttinen ratkaisu on Zubovin (1945) malli, joka on parannettu versio klassisesta Stefanin laista. Zubovin lähtöoletukset ovat: (i) termistä hitautta ei huomioida, (ii) auringonsäteilyä ei huomioida, (iii) vedestä tulevaa lämpöä ei huomioida, ja (iv) ilman lämpötila on tunnettu, $T_{a}=T_{a}(t)$. Nämä olettamukset ovat kohtuullisen hyviä jään kasvukautena, mutta lumi aiheuttaa ongelmia. Lumen määrä ja laatu muuttuvat jatkuvasti ja lasketut jään paksuudet ovat jonkin verran liian suuria lumipeitteiseen jäähän sovellettuna.

Asettamalla jäätymisessä vapautuva lämpö, lämmönjohtuminen jään läpi ja jäästä ilmaan siirtyvä lämpö yhtä suuriksi, saadaan Zubovin mallin yhtälöpari

$\rho_{i} L \frac{d h}{d t}=\kappa_{i} \frac{T_{f}-T_{o}}{h}=K\left(T_{o}-T_{a}\right)$

missä $K$ on ilman ja jään välinen lämmönvaihtokerroin. 


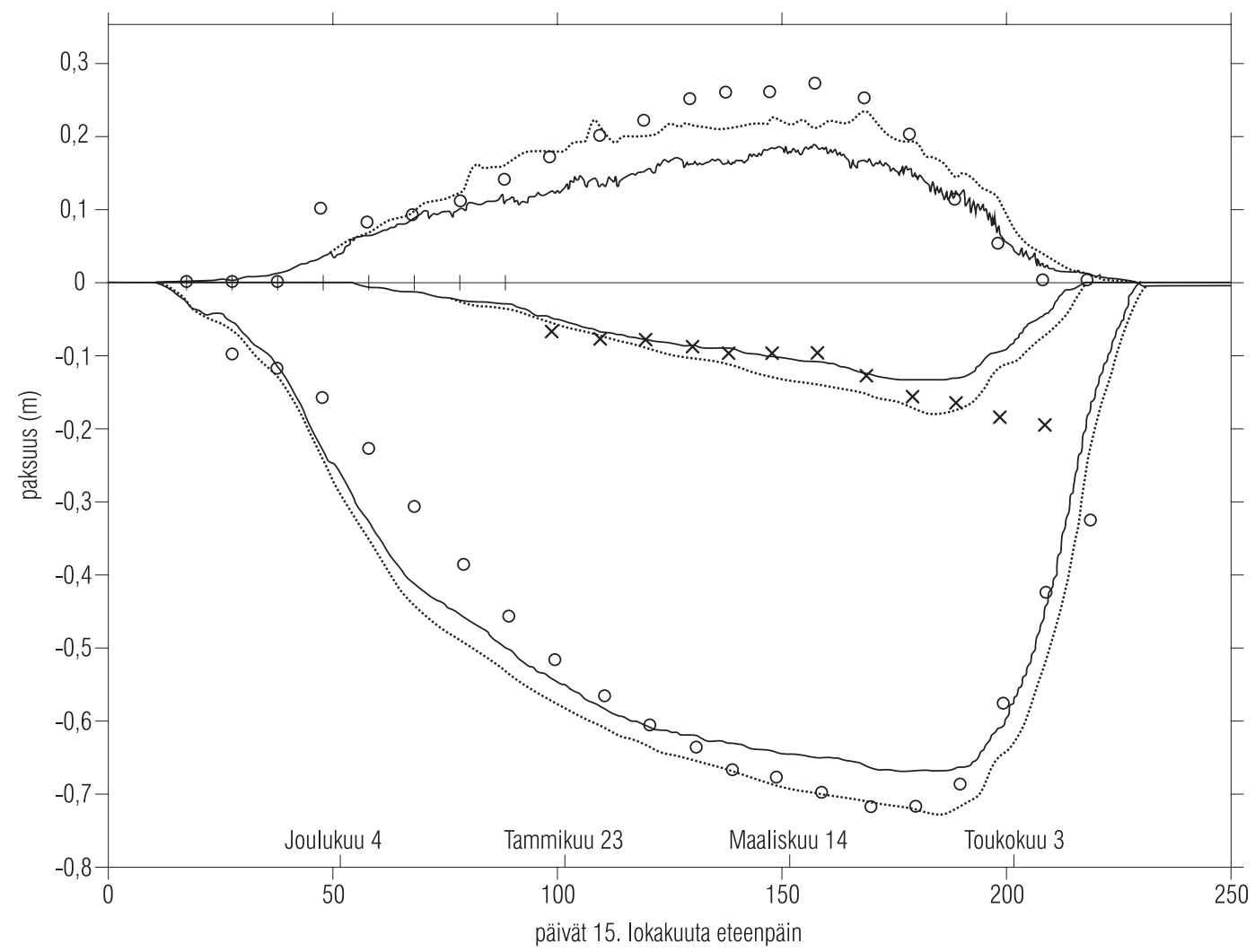

Kuva 7.5 Teräsjään, kohvajään ja lumen keskimääräinen paksuus Kemissä 1979-1990. Havaitut suureet on merkitty symbolein o (lumi ja jään kokonaispaksuus) sekä x (kohvajää), numeerisen mallin lasketut yhtenäisellä viivalla (SMHI:n hiladata) sekä pisteviivalla (Kemin lentosääaseman data). (Saloranta 2000)

Mallissa siis lämpö kulkee jään läpi, muttei varastoidu sen sisään. Ratkaisu on

$h=\sqrt{a^{2} S+d^{2}}-d$

missä $a=2 \kappa_{\mathrm{i}} / \mathrm{Q}_{\mathrm{i}} L \approx 3 \mathrm{~cm}\left({ }^{\circ} \mathrm{C} \cdot \mathrm{vrk}\right)^{-1 / 2}, S$ on pakkassumma (yksikkönä ${ }^{\circ} \mathrm{C} \cdot$ vrk) ja $d=\kappa_{\mathrm{i}} / K \approx 10$ $\mathrm{cm}$ on ilman pintakerroksen eritystehokkuus jään yllä (yksikkönä cm). Esimerkiksi 100 pakkaspäivää keskilämpötilalla $-10{ }^{\circ} \mathrm{C}$ antaa $S=$ $1.000{ }^{\circ} \mathrm{C} \cdot$ vrk. Neliöjuurimuotoinen riippuvuus lämpötilasta kuvaa hyvin, kuinka jää eristää itsensä paksuuntuessaan. Jään kasvattamiseen tarvitaan sitä suurempi määrä pakkasta, mitä suurempi jään paksuus on.

Suurin ongelma Zubovin mallissa on lumipeitteen puuttuminen. Lumipeite eristää jäätä ja ensi vaiheessa pienentää kasvunopeutta. $\mathrm{Zu}$ - bovin kaavaan verrattuna kasvunopeus voi jopa puolittua. Lumen eristävyyden huomioimiseksi mukaan otetaan lisäyhtälö lämmön johtumiseksi myös lumen läpi. Jos oletetaan että lumen pintalämpötila on jo lähellä ilman lämpötilaa, saadaan ehto

$\kappa_{i} \frac{T_{f}-T_{o}}{h}=\kappa_{s} \frac{T_{o}-T_{s}}{h_{s}}=K\left(T_{s}-T_{a}\right)$

missä $T_{s}$ on lumen pintalämpötila, $\kappa_{s}$ on lumen lämmönjohtokyky, ja $h_{s}$ on lumen paksuus. Koska lumen paksuus ja lämmönjohtavuus riippuvat ajasta, jään paksuutta ei voi ratkaista analyyttisesti. Usein käytetään kertoimen $a$ asemasta semi-empiiristä kerrointa $a^{*}<a$.

Pedagoginen esimerkki lumen vaikutuksesta saadaan olettamalla $h_{s}=\lambda h$ ja $\kappa_{s}=$ vakio. Tällöin ratkaisu saadaan, kun Zubovin kaavaan otetaan 
kerroin $a^{*}=a /\left(1+\lambda \kappa_{\mathrm{i}} / \kappa_{s}\right)^{1 / 2}$. Kohvajäätä ei pääse muodostumaan, jos $\lambda<\left(\rho_{\mathrm{w}}-\rho_{\mathrm{i}}\right) / \rho_{\mathrm{s}} \approx 0,3$, ja kun $\kappa_{\mathrm{s}} \approx \kappa_{\mathrm{i}} / 10$, pätee $0,5 a<a^{*}<a$.

Lumi voi myös muuttua ensin sohjoksi ja sitten jäätyä kohvajääksi. Sohjon muodostumiseen tarvittava vesi tulee sadevedestä, lumen sulamisvedestä tai jäälle tulvineesta merivedestä. Viimeksi mainittu on Itämerellä merkittävin kohvajään syntytapa. Lumipeitteinen jää kelluu Arkhimedeen lain mukaisesti eli

$\rho_{\mathrm{s}} h_{\mathrm{s}}+\rho_{\mathrm{i}} h=\rho h_{\mathrm{w}}$

missä $h_{\mathrm{w}}$ on vedenpinnan alapuolella olevan lumen ja jään osuus. Kun $h<h_{\text {w }}$, jään pinta on vedenpinnan alapuolella. Heti kun vain jäähän tulee halkeamia, vesi pääsee sekoittumaan lumeen ja kohvajäätä voi sitten muodostua. Jos $\rho_{\mathrm{s}} / \rho_{\mathrm{i}} \approx 0,3$, jää painuu vedenpinnan alle, kun $h_{s} \approx h / 3$. Tällöin $50 \mathrm{~cm}$ jää kantaa korkeintaan $15-20 \mathrm{~cm}$ lunta.

Kohvajää kasvaa heti lumen alla, ja lämpöä tarvitsee siirtää pääasiassa vain lumen läpi. Lisäksi kohvajään muodostuminen on helpompaa kuin teräsjään, koska lumisohjossa on jo jäätä. Äärimmäisessä tapauksessa lunta tulee koko ajan sopivasti niin, että kohvajää kasvaa jatkuvasti eikä teräsjäätä muodostu lainkaan. Tällöin on $h_{\mathrm{k}} / h_{\mathrm{s}}=\rho_{\mathrm{s}} /\left(\rho_{\mathrm{w}}-\rho_{\mathrm{i}}\right) \approx 3$ ja kohvajää kasvaa verrannollisena pakkassumman neliöjuureen kuten teräsjääkin, mutta pakkassumman kertoimena on $a^{*} \approx 0,7 a$.

\subsubsection{Jään sulaminen}

Jään sulamisen alkaessa jään lämpötila nousee kauttaaltaan tasolle $0^{\circ} \mathrm{C}$. Tällöin lämpöä ei johdu jään läpi, vaan jää sulaa ylä- ja alapinnoiltaan, kun vastaavat lämpötaseet ovat positiivisia, ja lisäksi auringonsäteily sulattaa jäätä sisältä. Säteilyn tunkeutumista lumeen ja jäähän voidaan kuvata Beerin lailla kuten säteilyn veteen tunkeutumistakin: $Q(z)=Q(0) \exp (-\lambda z)$, missä $Q$ on säteilytaso ja $\lambda$ säteilyn vaimenemiskerroin, joka on suuruusluokkaa $0,2 \mathrm{~cm}^{-1}$ lumen tapauksessa ja $0,02 \mathrm{~cm}^{-1}$ jään tapauksessa. Säteilyn vaimenemismatka on noin $3 \lambda^{-1}$ eli $15 \mathrm{~cm}$ lumessa ja $150 \mathrm{~cm}$ jäässä. Näin ollen $50 \mathrm{~cm}$ paksu jääpeite, jolla on $10 \mathrm{~cm}$ lunta, ei päästä valoa lävitseen veteen. Heti kun jää ja lumi alkavat ohentua, valoa riittää hyvin perustuotantoon jään alla.

Jään sulamista voidaan tutkia kaksiosaisena prosessina:

$\rho_{i} L \frac{d h}{d t}=-\left(Q_{n}+Q_{w}\right)<0$,

$\rho_{i} L \frac{d n}{d t}=(1-\alpha) \gamma \exp (-\lambda z) Q_{s}$

missä $n$ on sulanut sisäosa jääkannesta. Ensimmäinen yhtälö kuvaa jään paksuutta (= yläpinnan ja alapinnan välinen etäisyys) ja toinen jään sisäistä sulamista, jolloin jään nettotilavuudeksi tulee $h-n$. Kaavat koskevat vain sulamista ja siksi ensimmäisessä kaavassa oikean puolen on oltava negatiivinen (positiivisessa tapauksessa jää alkaisi jäähtyä ja kasvaa Zubovin lain pohjalta).

Yläpinnalta sulaa ensin lumi ja sitten jää. Lumipeite suojaa jäätä sulamiselta ja korkean albedonsa takia se sulaa hitaasti. Auringonsäteily ei paljonkaan tunkeudu lumeen, ja siksi jään sisäinen sulaminen käynnistyy kunnolla vasta, kun lumi on sulanut pois.

Pinnan energiataseen, erityisesti auringonsäteilyn, arviointi on käytännössä melko epätarkkaa. Siksi usein käytetään yksinkertaistettua menetelmää, lämpösummakaavaa

$\mathrm{d} h / \mathrm{d} t \approx A \max \left\{T_{\mathrm{a}}, 0\right\}$

missä $T_{\mathrm{a}}=T_{\mathrm{a}}(t)$ on ilman lämpötila, $A=A(t)$ on astepäiväkerroin, $A-0,1-1,0 \mathrm{~cm} /\left(\right.$ vrk $\left.\cdot{ }^{\circ} \mathrm{C}\right)$. Jäälle ja lumelle on haettavissa omat tarkemmat astepäiväkertoimensa. 


\subsection{Ajojäät}

Itämeren altaat ovat niin suuria, ettei jääkansi niissä pysy ehyenä. Rannikon ja saariston tuntumassa oleva jää on kiintojäätä, joka pysyy tasaisena ja ehyenä suurimman osan talvea. Sitä tukevat saaret, karit ja pohjaan ankkuroituneet ahtojäävallit. Kiintojäävyöhyke ulottuu 5-15 m syvyisiin vesiin. Laajoilla ulapoilla tuulen pyyhkäisymatka kasvaa, jolloin tuulen jäähän kohdistama kuormitus kasvaa suureksi ja kykenee rikkomaan jääpeitteen. Tuulen voima ajaa edelleen lautoiksi rikkoutuneen jääkentän liikkeeseen. Näin syntyy ajojäätä. Tilanne on vastaavanlainen kuin aallokon muodostuksessa: yhä suurempi pyyhkäisymatka tuottaa yhä suuremman aallokon. Myös virtaukset voivat kuljettaa jäätä, mutta Itämerellä tuulen vaikutus on yleensä merkittävin. Tuulet, virtaukset ja vedenkorkeuden sekä lämpötilan vaihtelut aiheuttavat jäähän halkeamia ja ylläpitävät tätä lautoiksi rikkoutunutta tilaa.

Ajojään muodostuminen riippuu tuulesta, ulapan laajuudesta ja jään paksuudesta. Tätä tietoa kuvataan epäyhtälöllä

$$
\tau_{\mathrm{a}} L>P^{*} b
$$

missä $\tau_{\mathrm{a}}$ on tuulen leikkausjännitys jään pintaan, $L$ on pyyhkäisymatka ja $P^{*} \approx 10-100 \mathrm{kPa}$ on ulapan jään edustava keskilujuus paksuusyksikköä kohti. Jos tuulen nopeus on $15 \mathrm{~m} / \mathrm{s}$, on $\tau_{\mathrm{a}} \approx 1 / 2 \mathrm{~Pa}$, ja tällöin $100 \mathrm{~km}$ laajuiselle ulapalla noin $50 \mathrm{~cm}$ paksu jää yleensä rikkoutuu. Suomen järvillä laajatkin ulapat ovat kooltaan vain noin $10 \mathrm{~km}$, eikä niissä muodostu ajojäätä. Sen sijaan esimerkiksi Vänern-järvellä ja Laatokalla esiintyy ajojäätä.

Ajojääkentät ajelehtivat tuulten ja virtausten vaikutuksesta. Yleensä jään liike käyttäytyy kuten pintavirtaus: nopeus on 1-3\% tuulen nopeudesta ja suunta poikkeaa $20-30^{\circ}$ tuulen suunnasta oikealle. Ahtaissa, kauttaaltaan jäässä olevissa altaissa jäät saattavat pysyä paikallaan kovallakin tuulella sisäisen kitkansa takia, kuten kylminä talvina tapahtuu etenkin Perämerellä. Jään liike on tärkeä kuljetusmekanismi, sillä jään mukana siirtyy makeata vettä, kylmyyttä (jään sulattamiseen tarvitaan paljon lämpöä) ja jäähän kiinnittyneitä vieraita aineita.

\subsubsection{Ajojään morfologia}

Merijää "maisema" on vaihteleva ja monipuolinen järvien jääpeitteeseen verrattuna (kuva 7.6). Siinä on railoja, tasaisia ehyen jään alueita ja erilaista rikkoutunutta jäätä kuten ahtojäätä, päällekkäin ajautunutta jäätä ja sohjovöitä. Kiintojään reunassa on usein tiivis ahtojäävyöhyke, leveydeltään 1-10 kilometriä. Verrattaessa maisemaa Pohjoisen Jäämeren jääpeitteeseen, näkymä on samankaltainen, mutta geometriset dimensiot ovat Jäämerellä noin viisi kertaa Itämeren mittoja suuremmat.

Ajojääkentät koostuvat $10^{1}-10^{4} \mathrm{~m}$ kokoisista jäälautoista, kun taas näissä olevat rikkoutuneet jäämuodostumat koostuvat teleistä (jääkappaleista, joiden halkaisija on 0,1-10 metriä). Jääkenttien morfologia on itsesimilaarinen: geometristen mittojen suhteet säilyvät, vaikka jään paksuus ja lauttojen keskikoko muuttuisivat. Niinpä valokuvissa on oltava jokin ulkopuolinen tieto (laiva, saari, ihminen) absoluuttisen mitan arvioimiseksi.

Ajojääkenttien ominaisuuksia kuvaavat seuraavat suureet (katso kuva 7.2):
Suure

Jään laatu

Jään peittävyys

Jään paksuus

Jäälauttojen koko

\section{Määrittely}

Tärkeimmät: tasainen jää, lautasjää, päällekkäin ajautunut jää, sohjovyöt, ahtojää, kiintojää Jään suhteellinen ala Etäisyys pinnasta pohjaan (kolot lasketaan mukaan) Keskiluku tai jakauma, yleensä "tyypillinen halkaisija" 


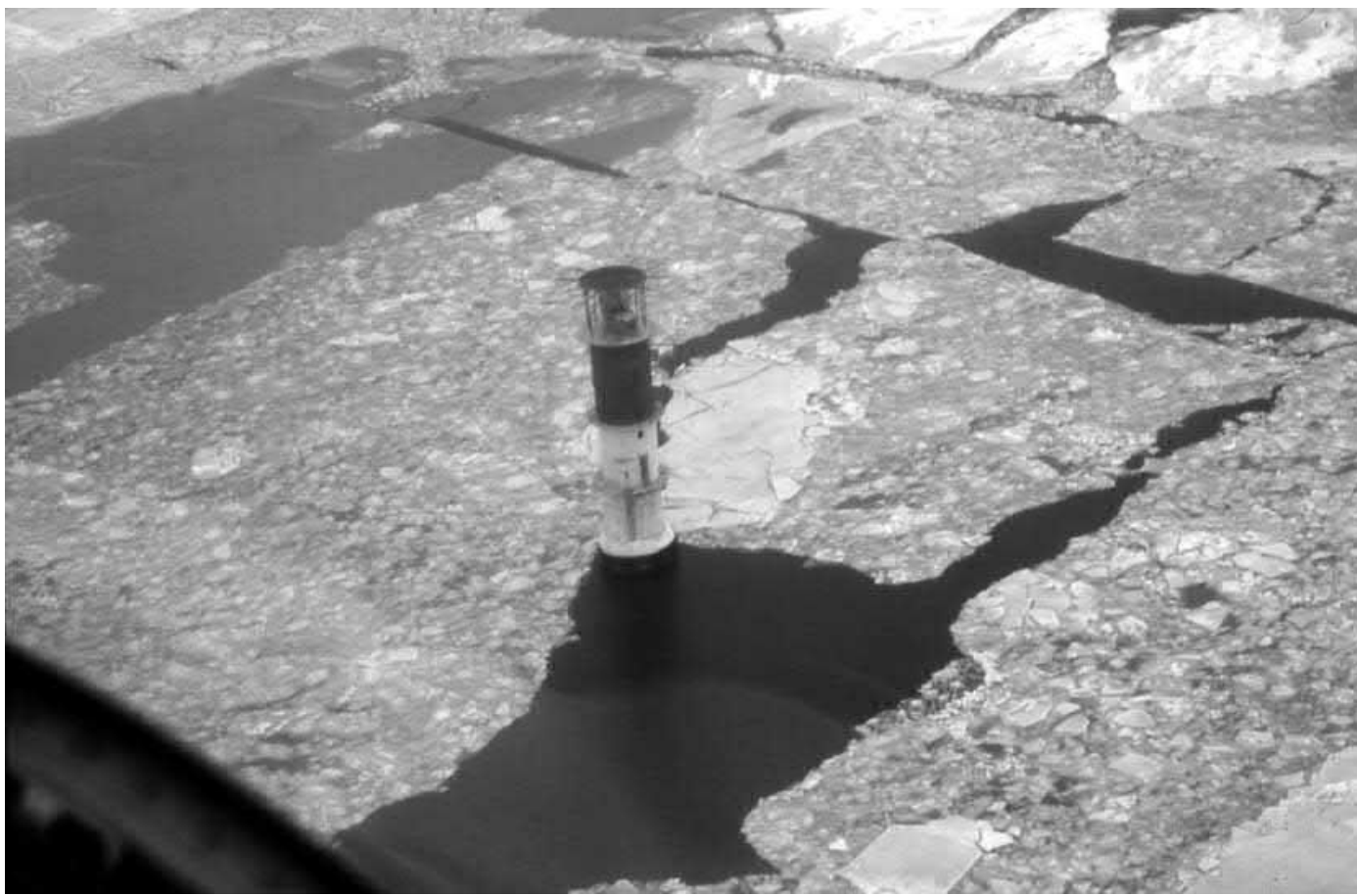

Kuva 7.6. Ajojäätä virtaa Nahkiaisen majakan ohi Perämerellä. (Matti Leppäranta)

Jään laadut perustuvat visuaalisiin havaintoihin, ja myös operatiivisissa jääkartoissa (kuva 7.2) annetaan tietoa niiden esiintymisestä. Kiintojää ja muukin tasainen jää kasvaa termodynaamisesti ylä- ja alapinnoiltaan kuten edellisessä kohdassa käsiteltiin. Muut jään laadut sen sijaan muodostuvat erilaisissa mekaanisissa deformaatioprosesseissa. Jään laaduista ahtojää on merkittävin. Ahtojäät ovat tuulen teliröykkiöiksi ajamia jääkasautumia (kuva 7.7), ja niitä muodostuu paljon kiintojään reunaan mutta myös keskisille jääalueille. Suurimmat ahtojääröykkiöt ovat jäävalleja.

Jään paksuus ja peittävyys eli konsentraatio ovat tärkeimmät ajojäiden dynamiikkaa ohjaavat jään ominaisuudet. Ne kertovat jääkentän vahvuudesta, kuinka paljon jääkentässä on sisäistä kitkaa ja kuinka paljon voimaa tarvitaan esimerkiksi ahtojäiden synnyttämiseen. Peittävyys luokitellaan seuraavasti:

\section{Peittävyysväli}

$0-30 \%$

$30-50 \%$

$50-70 \%$

$70-90 \%$

$90-100 \%$

\section{Verbaalinen kuvaus}

Hyvin harva ajojää

Harva ajojää

Tiheä ajojää

Hyvin tiheä ajojää

Kompakti ajojää
Jään peittävyys kertoo, paljonko alueella on avovettä. Siitä riippuu myös ilmakehän ja meren vesirungon lämmön, liike-energian ja materian vaihto. Peittävyys voidaan hyvin havaita kaukohavaintomenetelmin (katso kohta 3.3), sillä se on pinnan laatuun liittyvä suure.

Mekaniikan synnyttämiä avovesialueita sanotaan railoiksi, jotka määritelmän mukaan ovat "tuulten tai virtausten avaamia avovesialueita, joita pitkin voidaan laivalla kulkea". Pienempiä avautumia sanotaan halkeamiksi (järvia-lueellamme railoiksi sanotaan pieniä halkeamia). Itämeren ajojääkenttien railot ovat muodoltaan 


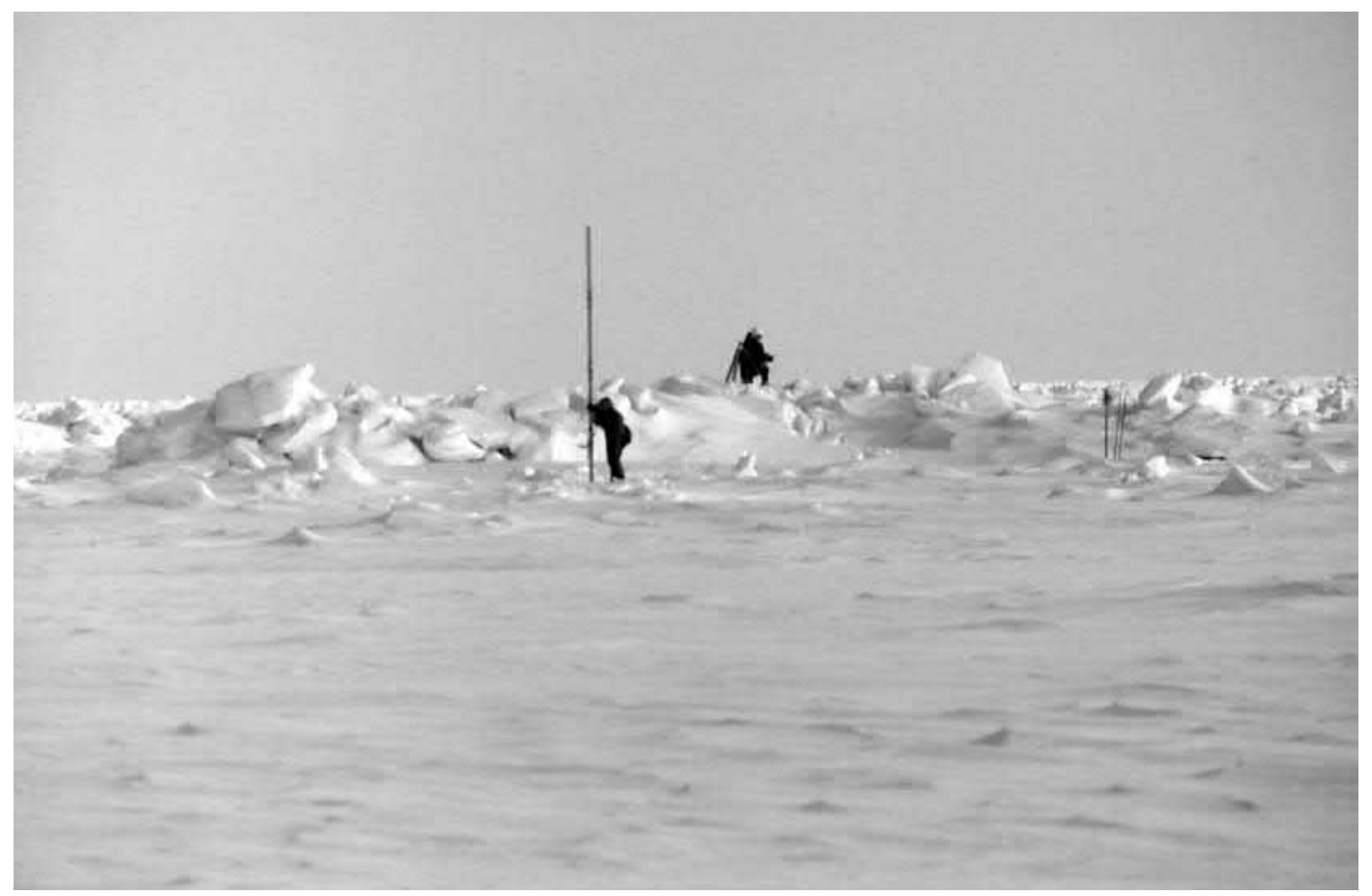

Kuva 7.7. Ahtojään topografiaa mitataan Perämerellä. (Leppäranta 2004)

lähinnä pitkulaisia, ja niitä avautuu usein kiintojään reunan tuntumaan. Mekaniikan ja termodynamiikan yhteisesti pysyvämmin avoimena pitämiä ajojääalueita, niin sanottuja polinjoita, ei ole Itämerellä.

Jään paksuus on ajojään fysiikassa jään tärkein ominaisuus. Jään lujuus on verrannollinen jään paksuuteen (katso kaava 7-11), ja jään tilavuus tai massa on samoin verrannollinen siihen.

Jään paksuus vaihtelee paljon: pienelläkin alueella voi olla muutaman sentin paksuista uutta jäätä ja toisaalta yli kymmenen metriä paksuja ahtojäävalleja. Käytännön ongelmana on se, että ei ole olemassa hyvää kaukohavaintomenetelmää, jonka avulla lentokoneesta tai satelliitista voitaisiin kartoittaa jään paksuutta. Rannikkoja saaristoalueella on kyllä havaintoasemia, jotka mittaavat kiintojään paksuuden, mutta ajojäiden paksuustilanteen seuraamiseksi ei ole vielä valmista omaa järjestelmää. Jään paksuuden määritysongelma on yhteinen kaikkien merien ajojäiden parissa työskenteleville. Viime vuosi- na merijään paksuuden havaintomenetelmiä on tutkittu laajalti.

Jäälauttojen koon ja muodon merkitys ajojään fysiikassa on sekundäärinen. Kun ajojääjääkenttä on harva ja lautat ovat pieniä, diffuusio on merkittävää. Tiiviissä jääkentässä sisäinen kitka tulee suureksi, lautat liittyvät yhteen ja diffuusio heikkenee. Jäälauttojen koko ja muoto ovat pinnan ominaisuuksia kuten peittävyyskin ja niitä on voitu tutkia pitkään ilmakuvausten ja satelliittien avulla. Sydäntalven aikana jäälauttojen koko on vaikeammin hahmotettavissa, sillä ne jäätyvät yhteen ja rajat jäävät helposti lumen alle. Myöhäistalven ja kevään aikana jäälautat hajoavat pienemmiksi ja niiden muoto pyöristyy talvisajan monikulmiorakenteista.

Jään paksuutta ja lauttakokoa kuvataan paikallisilla jakautumilla. Paikallisuus tarkoittaa tässä alueita muutamista kilometreistä aina altaiden kokoluokkaan asti. Jään paksuusjakautuma $\Pi$ $=\Pi(h)$ määritellään 


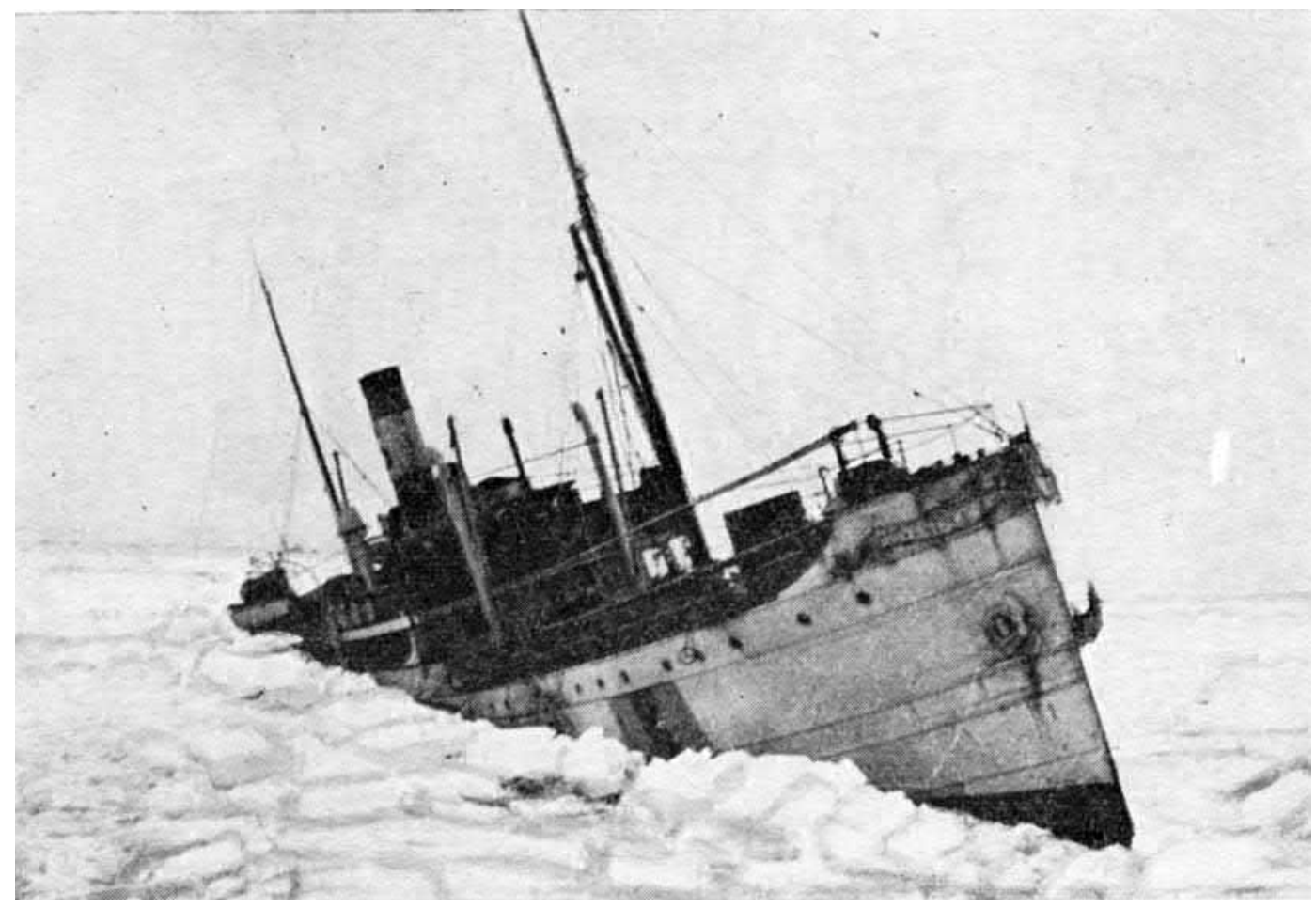

Kuva 7.8. Laiva jään puristuksessa. (Ramsay 1947)

$\Pi(h)=S(h) / S$,

missä $S$ on tarkasteltavan alueen pinta-ala ja $S(h)$ on sen osa-alueen pinta-ala, jossa jään paksuus on korkeintaan h. Paksuusjakautuma on analoginen todennäköisyyslaskennan kumulatiiviselle jakautumalle eli kertymäfunktiolle. Luku $\Pi(b)$ kertoo kuinka suurta osaa alueesta peittää jää, jonka paksuus on korkeintaan $h$, kun taas kertymäfunktio kertoisi, mikä on todennäköisyys että jään paksuus on korkeintaan $h$. Vastaavanlainen jakautuma voidaan samaan tapaan määritellä lauttakoolle. Tämän kokospektri on laaja, yksittäisistä metrisistä teleistä useampiin kilometreihin.

Jään paksuusjakauman yläpää kattaa ahtojäät. Massiivisimmat muodostumat ovat 5-15 metriä paksuja ahtojäävalleja, joiden yläosa eli harja on 0,5-2 metriä korkea ja alaosa eli köli on 3-15 metriä syvä. Suurin Itämerellä mitattu ahtojäävalli on ollut paksuudeltaan 31,5 metriä, josta harjan osuus oli 3,5 metriä. Vallit kelluvat Arkimedeen lain mukaan, mutta geometrian takia maksimisyvyyden ja -korkeuden suhde on 4-6. Vallien määrää kuvataan esiintymisfrekvenssillä pituusyksikköä kohti. Tämä on Itämerellä yleensä 1-10 vallia/km (siis esimerkiksi laiva kohtaa tämän määrän valleja jääkentässä kulkiessaan). Ahtojään kokonaismassa on yleensä 10-50 \% jään kokonaismassasta, mutta ääritapauksissa laaja jääkenttä voi kasautua pieneen alaan, jolloin keskipaksuus moninkertaistuu (pakkaantuminen voi olla $1 / 5$ alaan alkuperäisestä). Rannikolla, missä jääröykkiöt ulottuvat pohjaan, Arkhimedeen laki ei enää toimi ja pohjautuneet ahtojäät voivat kasvaa harjaltaan 10-15 metriä korkeaksi. Tällaisia korkeita jääkasoja nähdään vuosittain Perämeren rannikolla.

Yksittäisten havaintojen mukaan ahtojäävallien pinnoilla kasvaa runsaasti leviä. Tämä saattaakin olla talven tuotannon kannalta tärkeä elinympäristö, sillä erityisesti Perämeren jäästä on 

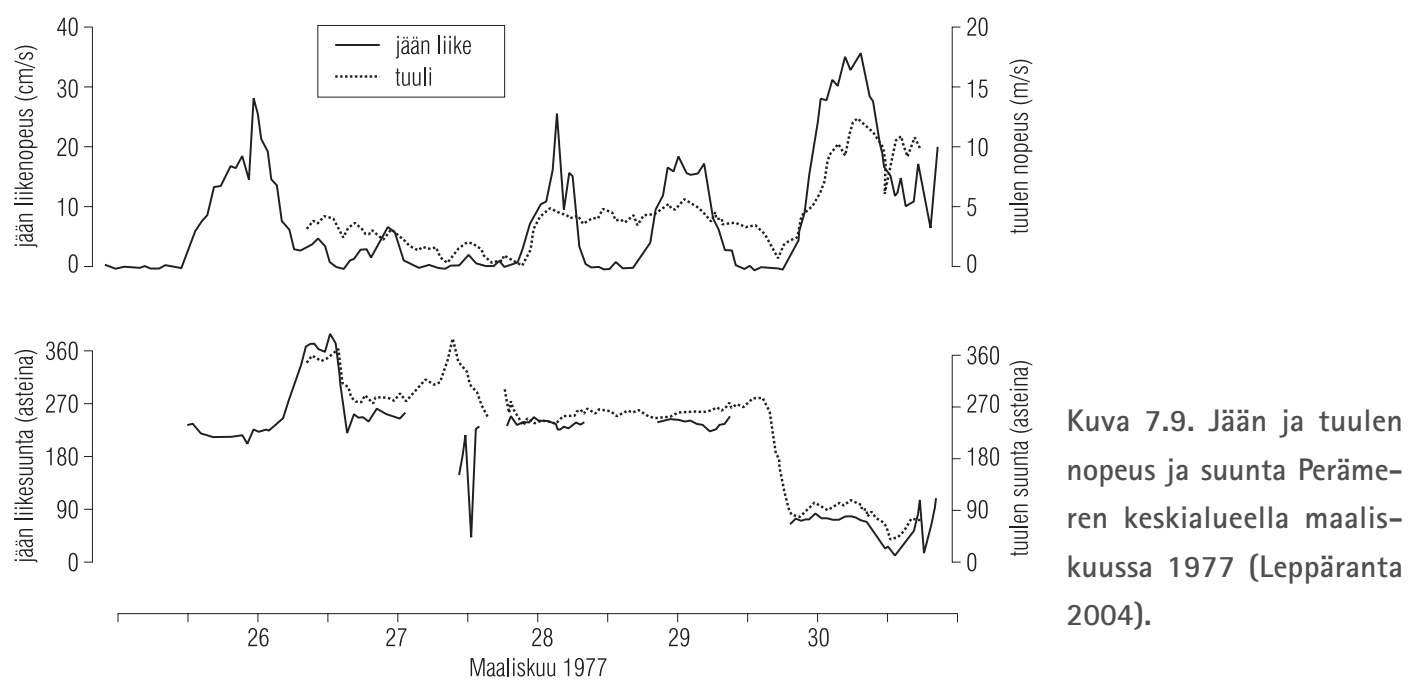

löydetty vain niukasti jään sisässä kasvavia leviä. Syy siihen saattaa olla jään alhainen suolaisuus, jolloin suolaliuostaskuja on niukasti.

Itämeren ajankohtaisesta jäätilanteesta saa tietoa jääkartoista (kuva 7.2), joita Suomessa laaditaan ja julkaistaan päivittäin Merentutkimuslaitoksen verkkosivuilla. Jääkartoissa esitetään jään laajuus, jääkentät ja jäälaadut. Jään liike voi muuttaa jääoloja paljon jo muutamassa päivässä, minkä takia jääkarttojen tiheä päivitys on mielekästä. Jääkartoissa olevat jäätiedot perustuvat satelliittikuviin (lähinnä NOAA, Terra Aqua ja Radarsat) sekä laivojen ja rannikkoasemien jääraportteihin.

\subsubsection{Ajojään dynamiikka}

Ajojäätä voidaan tarkastella kaksiulotteisena kokoonpuristuvana materiana, jonka peittävyys voi olla mitä vain nollan ja $100 \%$ välillä sekä muuttua helposti. Avoimissa $(A<70 \%)$ jääkentissä jäälautat ajelehtivat vapaasti, toisistaan riippumatta, kuten ajopoijutkin. Tiiviissä $(A>90 \%)$ jääkentissä on sen sijaan paljon sisäistä kitkaa ja ne voivat pysyä liikkumattomina kovallakin tuulella. Ajojään dynamiikkaan kuuluva jään puristus on aiheuttanut hankaluuksia talvimerenkululle (kuva 7.8).

Ajojään kinematiikkaa mitataan ajopoijuilla ja kaukokartoitusmenetelmillä. Ajopoijut ajelehtivat jään mukana, ja niiden sijainti paikannetaan satelliiteilla tai maanpäällisin geodeettisin menetelmin. Kaukokartoitusmenetelmät perustuvat jään piirteiden tunnistamiseen peräkkäisistä kuvista. Ajopoijuja rajoittaa alueellinen erotuskyky (kovin monta poijua ei voida käyttää kerrallaan) ja satelliittikuvauksia rajoittaa ajallinen erotuskyky (ylilentojen aikaväli on pitkä). Kuvassa 7.9 on esimerkki havaitusta jään liikenopeudesta.

Ajojäk̈kenttiä tarkastellaan jatkumona eli kontinuumina, jonka pituusmitta tai fysikaalinen erotuskyky on paljon suurempi kuin jäälauttojen koko. Ajojääkenttien dynamiikkaa voidaan analysoida samaan tapaan kuin virtauksia yleisessä virtausopissa. Jään tilaa kuvataan yleensä parilla $J=\{A, H\}$, missä $A$ on jään peittävyys, ja $H=$ $h A$ on jääkentän keskipaksuus. Suure $H$ kuvaa alueellista keskipaksuutta, kun avovesi on otettu mukaan nollan suuruisena, ja suure $h$ kuvaa fyysisten jäälauttojen paksuutta. Ajelehtimisen fysiikassa keskeinen merkitys on jään sisäisellä kitkalla, joka kertoo, kuinka voimakkaasti jääkenttä vastustaa muodonmuutoksia eli defor- 
maatiota ja joka riippuu ajojään tilasuureista ja deformaationopeudesta. Sisäisen kitkan $\boldsymbol{F}$ kvalitatiiviset ominaisuudet ovat:

$\boldsymbol{F} \approx 0$, kun $A<0.7$ (vähäiset jäälauttojen väliset kontaktit)

$\boldsymbol{F} \approx 0$, jääkenttä avautuu (jälautat eivät vastusta hajaantumista)

Leikkauksessa kitka on pienempi kuin puristuksessa

Myötölujuus $>0$, kun $A \approx 1$ (yhtenäinen jääkenttä voi olla staattisessa tilassa)

Ei muistia

Kompakti ajojää on plastista $(A>0,9)$, hyvin tiheä ajojää on viskoosia $(0,7<A<0,9)$ ja tiheä tai harva ajojää on kitkatonta $(A<0,7)$. Myötölujuus on plastisen materian ominaisuus ja se tarkoittaa vähimmäiskuormitusta, joka tarvitaan materian muovaamiseksi. Esimerkiksi jos Perämerellä on yhteenjäätynyt puolimetrinen jääkenttä, tarvitaan yli $15 \mathrm{~m} / \mathrm{s}$ puhaltava tuuli sen saamiseksi liikkeelle. Materiaesimerkkeinä plastisesta materiasta käy hyytelö ja viskoosista materiasta hillo.

Plastinen virtaus on jäykänluonteista niin, että laajoilla alueilla virtausnopeus vaihtelee vain vähän. Sen sijaan deformaatiovyöhykkeillä muutokset ovat intensiivisiä (kuva 7.10). Usein esimerkiksi kiintojään reunassa on kapea deformaatiovyöhyke, jossa muodostuu runsaasti ahtojäätä. Viskoosissa virtauksessa muutosvyöhykkeet ovat pehmeämpiä. Kitkattomalle liikkeelle voidaan käyttää niin sanottua vapaan ajelehtimisen mallia, jossa jäälautat liikkuvat toisistaan riippumatta.

Ajojään liikeyhtälö perustuu jatkumomekaniikan yleiseen liikeyhtälöön, jossa materian saama kiihtyvyys tietyssä pisteessä seuraa materian sisäisistä voimista ja ulkoisesta ohjauksesta. Sisäisenä voimana on plastinen sisäinen kitka, ja ulkoisina voimina ovat tuulen ja veden leikkausvoimat eli kitkavoimat jään ala- ja yläpintaan sekä painovoima. Materian kiihtyvyydessä on

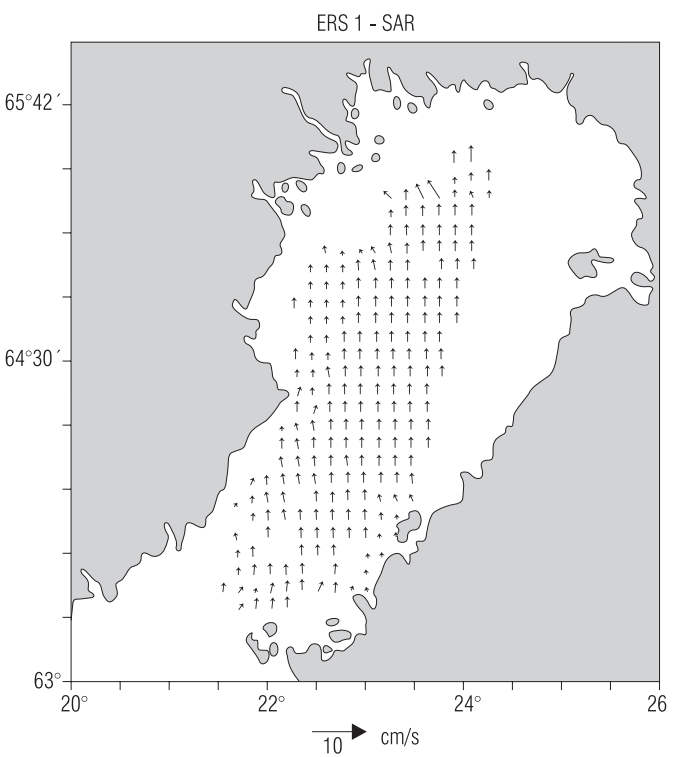

Kuva 7.10. Jään liike Perämerellä 5-8.3.1994 mitattuna ERS-1 tutkakuvista. (Leppäranta ym. 1998)

otettava huomioon Coriolis-ilmiö kuten mertenkin virtausopissa. Yleisessä muodossa ajojään liikeyhtälö kirjoitetaan

$\rho_{i} H\left(\frac{\partial \boldsymbol{q}}{\partial t}+\boldsymbol{q} \cdot \nabla \boldsymbol{q}+f \boldsymbol{k} \times \boldsymbol{q}\right)=$
$\boldsymbol{F}+\tau_{a}+\tau_{w}-\rho_{i} h g \nabla \xi$

missä $\boldsymbol{q}$ on jään nopeus, $\tau_{\mathrm{a}}$ on tuulen ja $\tau_{\mathrm{w}}$ veden leikkausvoima. Vasemmalla puolella ovat kiihtyvyystermit (lokaali kiihtyvyys, advektio ja Coriolis-kiihtyvyys) ja oikealla ovat jään sisäinen kitka ja ulkoiset tekijät eli tuuli, virtaus ja painovoima (vedenpinnan kaltevuudesta). Tämä yhtälö on samankaltainen kuin yksikerroksisen vedenkorkeusmallin liikeyhtälö (katso luku 6). Olennaisena erona on se, että ajojään sisäinen kitka on sangen komplisoitu liittyen plastisiin muodonmuutoksiin, kun taas veden virtauksissa sisäinen kitka aiheutuu turbulenttisesta viskositeetista $K$, ja sitä approksimoidaan termillä $K \nabla^{2} \boldsymbol{u}$.

Tuulen ja virtauksen leikkausvoimat jään ylä- ja alapintaan ovat tavanmukaisia neliöllisiä lakeja 
$\tau_{\mathrm{a}}=\rho_{\mathrm{a}} C_{\mathrm{a}} U_{\mathrm{a}}\left[\cos \theta_{\mathrm{a}} \boldsymbol{U}_{\mathrm{a}}+\sin \theta_{\mathrm{a}} \mathbf{k} \cdot \boldsymbol{U}_{\mathrm{a}}\right]$

$\tau_{\mathrm{w}}=\rho_{\mathrm{w}} C_{\mathrm{w}}|\boldsymbol{u}-\boldsymbol{q}|\left[\cos \theta_{\mathrm{w}}(\boldsymbol{u}-\boldsymbol{q})\right.$

$\left.+\sin \theta_{\mathrm{w}} \mathbf{k} \cdot(\boldsymbol{u}-\boldsymbol{q})\right]$

missä $\boldsymbol{U}_{\text {a }}$ on tuulen nopeus, $\boldsymbol{u}$ on veden virtausnopeus, $C_{\mathrm{a}}$ ja $C_{\mathrm{w}}$ ovat tuulen ja jään sekä jään ja veden vastuskertoimet sekä $\theta_{w}$ ja $\theta_{w}$ ovat rajakerroksen kiertokulmat ilmassa ja vedessä. Itämeren vedenkorkeusmallissa on vastaavanlainen tuulen leikkausvoima, ja jään alapintaan kohdistuvan kitkavoiman asemasta siinä on pohjakitka. Tuulikitkan vastuskerroin ja kiertokulma ovat hieman erilaiset ajojään ja vapaan veden rajapinnoilla. Pintatuulta käytettäessä, mikä on usein mahdollista Itämerellä, kiertokulma on nolla, sillä tuulen kitkavoima on pintatuulen suuntainen.

\begin{tabular}{|l|l|l|l|}
\hline Termi & Skaala & $\mathrm{N} / \mathrm{m}^{2}$ & Huomautuksia \\
\hline Inertia & $\rho_{\mathrm{i}} \mathrm{Hq} / \mathrm{T}$ & $10^{-3}$ & $\begin{array}{l}>10^{-2} \text { nopeissa } \\
\text { muutoksissa }\end{array}$ \\
\hline Advektio & $\rho_{\mathrm{i}} \mathrm{Hq}^{2} / \mathrm{L}$ & $10^{-4}$ & $\begin{array}{l}\text { Pitkäaikaisvaiku- } \\
\text { tus voi olla mer- } \\
\text { kitsevä }\end{array}$ \\
\hline Coriolis & $\rho_{\mathrm{i}} \mathrm{Hfq}$ & $10^{-2}$ & $\begin{array}{l}\text { Useimmiten }< \\
10^{-1}\end{array}$ \\
\hline $\begin{array}{l}\text { Sisäinen } \\
\text { kitka }\end{array}$ & $P^{*} \mathrm{H} / \mathrm{L}$ & $10^{-1}$ & $\begin{array}{l}\mathrm{A}>0,9 \text { (0, jos } \mathrm{A} \\
<0,7)\end{array}$ \\
\hline $\begin{array}{l}\text { Tuulen } \\
\text { voima }\end{array}$ & $\rho_{\mathrm{a}} \mathrm{C}_{\mathrm{a}} \mathrm{U}_{\mathrm{a}}^{2}$ & $10^{-1}$ & $\begin{array}{l}\text { Yleensä merkit- } \\
\text { tävä }\end{array}$ \\
\hline $\begin{array}{l}\text { Virtauksen } \\
\text { voima }\end{array}$ & $\rho_{\mathrm{w}} \mathrm{C}_{\mathrm{w}} q^{2}$ & $10^{-1}$ & $\begin{array}{l}\text { Yleensä merkit- } \\
\text { tävä }\end{array}$ \\
\hline $\begin{array}{l}\text { Painegra- } \\
\text { dientti }\end{array}$ & $\rho_{\mathrm{i}} \mathrm{HfU}_{\mathrm{g}}$ & $10^{-2}$ & $\begin{array}{l}\text { Enimmäkseen }< \\
10^{-2}\end{array}$ \\
\hline
\end{tabular}

Taulukko 7.3. Ajojään liikeyhtälön parametrit Itämerellä.

\begin{tabular}{|l|l|l|l|}
\hline Parametri & Merkintä & Arvo & Huomautuksia \\
\hline Jään tiheys & $\rho_{\mathrm{i}}$ & $910 \mathrm{~kg} / \mathrm{m}^{3}$ & \\
\hline Ilman vastuskerroin & $\mathrm{C}_{\mathrm{a}}$ & $1,8 \cdot 10^{-3}$ & Pintatuuli \\
\hline Ilman kiertokulma & $\theta_{\mathrm{a}}$ & $0^{\circ}$ & Pintatuuli \\
\hline Veden tiheys & $\rho_{\mathrm{w}}$ & $1.005 \mathrm{~kg} / \mathrm{m}^{3}$ & $\mathrm{~T}=0^{\circ} \mathrm{C}, \mathrm{S}=5 \% 0$ \\
\hline Veden vastuskerroin & $\mathrm{C}_{\mathrm{w}}$ & $3,5 \cdot 10^{-3}$ & Geostrofinen virtaus \\
\hline Veden kiertokulma & $\theta_{\mathrm{w}}$ & $20^{\circ}$ & Geostrofinen virtaus \\
\hline
\end{tabular}

Painovoiman vaikutus seuraa, jos merenpinta on kalteva kuten kaltevan tason tapauksessa. Merten virtausopista tiedetään (ks. luku 6), että merenpinnan kaltevuus vastaa pintakerroksen geostrofista virtausta:

$g \nabla \xi=-f \mathbf{k} \cdot \boldsymbol{u}_{\mathrm{g}}$

Nyt voidaan tarkastella liikeyhtälön termien suuruusluokkia. Oletetaan perusskaalat $H=50 \mathrm{~cm}$, $q=10 \mathrm{~cm} / \mathrm{s}, T=1 \mathrm{vrk}, L=100 \mathrm{~km}, P^{*}=10^{4}$ $\mathrm{N} / \mathrm{m}, U_{\mathrm{a}}=10 \mathrm{~m} / \mathrm{s}$, and $U_{\mathrm{g}}=5 \mathrm{~cm} / \mathrm{s}$. Siten saadaan seuraava jaotelma:
Ajojään liikkeessä jään täytyy säilyä kuten yleensäkin virtausopissa materian säilymislain tulee toteutua. Jään säilymislaissa on lisäksi termodynaaminen lähde/nielu-termi uuden jään muodostuksen sekä jään sulamisen huomioimiseksi. Kun ajojään tilamuuttujina ovat jään peittävyys ja keskipaksuus, näille molemmille tulee omat säilymislait. Nämä suureet muuttuvat kuljetuksen eli advektion, mekaanisen deformaation ja termodynamiikan ohjaamina:

$\frac{\partial A}{\partial t}=-\boldsymbol{q} \cdot \nabla A-A \nabla \cdot \boldsymbol{q}+\phi_{A}, 0 \leq A \leq 1$

$\frac{\partial H}{\partial t}=-\boldsymbol{q} \cdot \nabla H-H \nabla \cdot \boldsymbol{q}+\phi_{h}$ 
Mekaanisen deformaation termit ovat $-A \nabla \cdot \boldsymbol{q}$ ja $-H \nabla \cdot \boldsymbol{q}$. Jos jäät ajautuvat yhteen, nopeuskenttä on konvergenttinen $(\boldsymbol{\nabla} \cdot \boldsymbol{q}<0)$ ja peittävyys sekä jääkentän keskipaksuus kasvavat. Peittävyyden kasvaessa keskipaksuus kasvaa sen mukana. Se voi kasvaa vain tasolle $100 \%$, minkä jälkeen keskipaksuuden kasvu kuvastaa ahtojään muodostumista. Esimerkiksi jos $\nabla \cdot \boldsymbol{q}=-0,01 \mathrm{~h}^{-1}, A$ = 1 ja $H=30 \mathrm{~cm}$, keskipaksuus vahvistuu ahtojään muodostuksen takia $0,3 \mathrm{~cm}$ tunnissa. Lähestulkoon aina tapahtuu jäätymistä tai sulamista, mutta näiden aikaskaala on paljon pidempi kuin dynamiikan aikaskaala, joten usein lyhytaikaisia dynamiikan laskelmia tehtäessä termodynamiikan osuus voidaan jättää huomiotta.

Itämeren alueella on käytetty paljon kolmitasoisesta tilafunktiota $J=\left\{A, H_{\mathrm{u}}, H_{\mathrm{d}}\right\}$, jolloin peittävyys käsitellään kuten kaksitasoisessa tapauksessa. Jään paksuus hajotetaan kahteen osaan, $H=H_{\mathrm{u}}+H_{\mathrm{d}}$ : ehyt jää $H_{\mathrm{u}}$, joka kasvaa ja ohenee jäätymisen ja sulamisen takia, sekä ahtojään paksuus $H_{\mathrm{d}}$. Mekaaninen paksuuntuminen on mahdollista vain, kun $A=1$ ja liiketila on konvergenttinen $(\nabla \cdot \boldsymbol{q}<0)$. Sen sijaan ahtojää ohenee vain sulamalla, toisin sanoen ahtojäät eivät purkaudu paineen päätyttyä.

Vapa ajelehtiminen tarkoittaa tilannetta, jossa jään sisäinen kitka ei ole merkittävä. Näin on aina, kun peittävyys on alle $70 \%$. Ongelma on tällöin hyvin yksinkertainen ja redukoituu algebralliseksi yhtälöksi, jossa keskeiset tekijät ovat tuulen ja veden leikkausjännitykset jään ala- ja yläpintaan. Coriolis-kiihtyvyys ja painovoima otetaan vielä mukaan vapaan ajelehtimisen perusyhtälöön

$$
\rho_{\mathrm{i}} H f \mathbf{k} \cdot \boldsymbol{q}=\tau_{\mathrm{a}}+\tau_{\mathrm{w}}+\rho_{\mathrm{i}} H f \boldsymbol{u}_{\mathrm{g}}
$$

Painovoima ja Coriolis-kiihtyvyys voidaan yhdistää, ja jään ja veden välinen leikkausvoima voidaan lausua muodossa $\tau_{\mathrm{w}}=\tau_{\mathrm{w}}(\boldsymbol{u}-\boldsymbol{q})$. Sitten yhtälöstä (7.17) voidaan ratkaista suhteellinen jään liike $\boldsymbol{q}-\boldsymbol{u}_{\mathrm{g}}$ tuulen funktiona eli

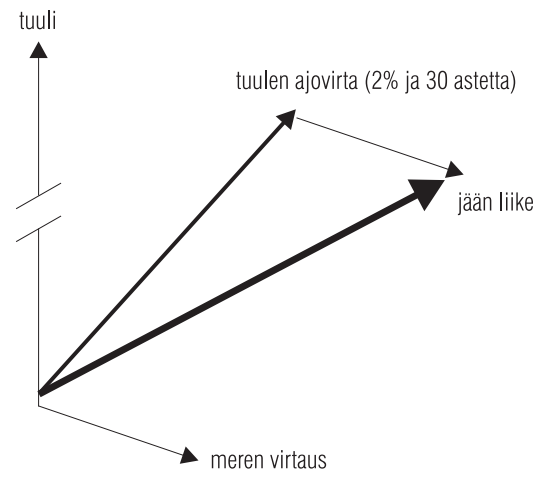

Kuva 7.11. Ajojään vapaan ajelehtimisen ratkaisu vektorilaskuna: jään nopeus $=$ tuulen ajama liike + merivirta.

$\boldsymbol{q}=\boldsymbol{q}_{\mathrm{a}}^{\prime}+\boldsymbol{u}_{\mathrm{g}}$

missä $\boldsymbol{q}_{\mathrm{a}}$ on puhdas tuulen ajovirta, jonka nopeus on $2,5 \%$ tuulen nopeudesta ja suunta $20^{\circ}$ oikealle tuulen suunnasta Itämeren olosuhteissa (kuva 7.11). Samalla kaavalla voidaan määrittää minkä tahansa kelluvan kappaleen liike ja itse pintavirtauskin. Eroja tulee vastuskertoimien kautta, sillä tuulen ajovirran liikenopeus suhteessa tuulen nopeuteen on ensi approksimaatiossa $q_{\mathrm{a}}^{\prime} / U_{\mathrm{a}}=\left[\rho_{\mathrm{a}} C_{\mathrm{a}} /\left(\rho_{\mathrm{w}} C_{\mathrm{w}}\right)\right]^{1 / 2}$ ja sen kiertokulma pintatuuleen nähden on $\theta_{\mathrm{w}}$.

Tiiviissä jääkentissä sisäisen kitkan merkitys on suuri ja se näkyy erityisesti Perämerellä, Suomenlahden pohjukassa ja Riianlahdella. Näissä altaissa geometria selvästi rajoittaa jäiden liikkeitä. Esimerkkeinä kuvissa 7.12 ja 7.13 on empiiristä tietoa: tuulikertoimen riippuvuus jään peittävyydestä sekä Perämeren pinnankaltevuus avovesi- sekä jääoloissa. Reologisen yhtälön liittäminen tekee ajojään liikeyhtälöstä vaikean epälineaarisen tapauksen. Analyyttisesti on mahdollista ratkaista eräitä kanava- ja vyöhyketilanteita, mutta yleinen tehtävä ratkeaa vain numeeristen mallien avulla.

Tiiviin jääkentän yksinkertaisin tapaus on lahtimalli (kuva 7.14). Tuuli ajaa jäätä kohti lahden pohjukkaa. Tiivis jää lähtee liikkeelle vain, jos tuuli on riittävän voimakas (katso kaava 7-11). 

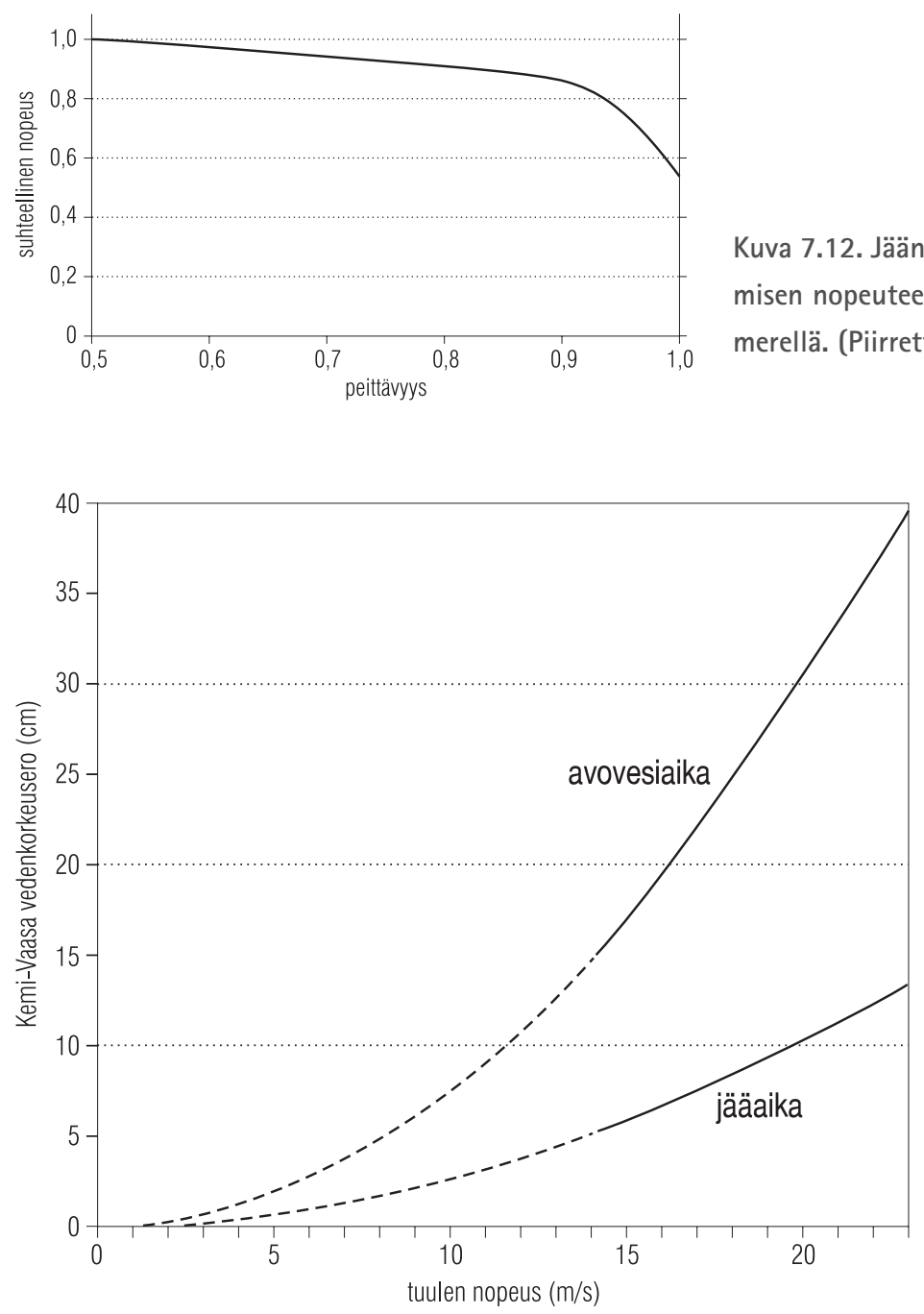

Kuva 7.12. Jään nopeus suhteessa vapaan ajelehtimisen nopeuteen jään peittävyyden funktiona Itämerellä. (Piirretty Shirokovin [1977] mukaan.)
Kuva 7.13. Kemin ja Vaasan välinen vedenkorkeusero avovesi- ja jääoloissa tuulen nopeuden funktiona. (Piirretty Lisitzinin [1957] mukaan.)

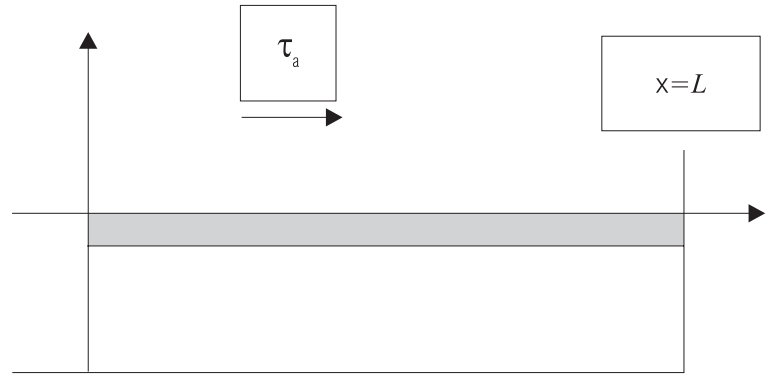

Kuva 7.14. Tiiviin ajojään dynamiikan lahtimalli. Tuuli $\tau_{\text {a }}$ työntää jäätä oikealle, kohdassa $x=L$ on ranta ja alussa vapaa reuna on kohdassa $x=0$ (vasemmassa laidassa). 
Tällöin jää alkaa ahtoutua lahden pohjukasta lähtien. Samalla paksuus kasvaa ja jääkentän pituus lyhenee ja ennen pitkää, ajanhetkellä $t_{s}$, ollaan tilanteessa $\tau_{a} L\left(t_{s}\right)=P^{*} h\left(t_{s}\right)$. Tällöin jään liike pysähtyy ja ahtoutunut jääkenttä jää staattiseen tilaan. Jään ajelehtimisnopeus on alussa korkeintaan vapaan ajelehtimisen tasolla (alkutilasta riippuen) ja sen jälkeen vähenee nollaan ahtoutumisen jatkuessa.

\subsection{Jäämallit}

Itämeren ajojään dynamiikan lyhyen aikavälin ( 1 tunti - 1 viikko) mallintaminen oli mallien käytön alkuvaiheessa 1970-luvulla keskeistä. Se liittyi jääennustusten laatimiseen talvimerenkulkua varten. Ennustustoiminta käynnistyi Suomessa vuonna 1976, jolloin kolmitasomallilla laadittiin 30 tunnin ennusteita. Ennustusjakson pituus on pidentynyt sittemmin 3 vuorokauteen sääennusteiden laadun parannuttua.

Ilmastomallit astuivat kuvaan 1990-luvulla, jolloin Itämerelle konstruoitiin koko jäätalven kehitystä kuvaava malli. Mallin pakotteena kehitystyössä oli säähavaintoaineisto ja vertailuaineistona julkaistut jääkartat. Näin saatiin kesästä lähtevä, jäätalven kulkua kuvaava malli melko hyvin toimivaksi ja sen jälkeen voitiin laatia jäätalvien tulevaisuuden skenaarioita olemassa olevien ilmastoskenaarioiden pohjalta.

Jäämallit koostuvat neljästä elementistä:

(i) ajojään tilan kuvaus

(ii) ajojään sisäisen kitkan malli

(iii) liikemäärän säilymislaki

(iv) jään säilymislaki

Jäämallia ohjaavat aurinko, ilmakehä ja alla oleva meri. Lämpötalous kasvattaa ja sulattaa jäätä, kun taas tuuli ja virtaukset ajavat jäätä liikkeeseen. Termodynamiikka ja dynamiikka ovat vuorovaikutuksessa, sillä jään paksuus vaikuttaa jään lujuuteen ja jään liike avaa jäähän avovesialueita, joissa alkaa kasvaa uutta jäätä. Ohut jää kasvaa paljon nopeammin kuin paksu jää, ja siksi jääkentän ajoittainen avautuminen lisää jään kokonaistuotantoa.

Termodynamiikka on mukana jään säilymislaissa, muut elementit liittyvät puhtaasti dynamiikkaan. Jään suolaisuus oletetaan tunnetuksi. Mallintajan on valittava tarkoitukseen sopiva ajojään tilan kuvaus ja sisäisen kitkan malli, ja sen jälkeen jääolojen evoluutiota on mahdollista integroida. Vapaan ajelehtimisen mallissa oletetaan sisäinen kitka nollaksi, mutta Itämeren oloissa sellaisen käytettävyys on hyvin rajallista. Nykyisin käytetään yleensä plastista kitkamallia, jolloin ajojään puristuslujuus tulee tärkeimmäksi säätöparametriksi. Vastaavanlaisia malleja on käytössä muillakin jäätyvillä subarktisilla merillä kuten St. Lawrence-lahdella, Bohain merellä ja Ohotan merellä.

Itämeren jääkenttä on tiiviissä vuorovaikutuksessa meren kanssa, ja siksi jäämallit ovat nykyisin kytkettyjä jää-meri-malleja. Tällöin jään ja veden välinen lämmön, suolan ja liike-energian vaihto on mallin sisäistä fysiikkaa, ja ilmakehä jää ulkoiseksi systeemiä ohjaavaksi tekijäksi. Mallin meriosa on luvussa 6 esitetyn mukainen kaksi- tai kolmiulotteinen malli, ja reunaehdot yksinkertaistuvat niin, että pintalämpötila on aina nolla, kun on jäätä. Jää-meri-systeemi on vuorovaikutuksessa ilmakehän kanssa, sillä ilmakehä tuntee pinnan karkeuden ja lämpötilan. Siksi kokonaisvaltaisia ilmakehä-jää-meri -malleja on ollut myös kehitteillä viime vuosina.

Itämeren jäätalvien ilmastomallin kalibrointi normaalitalvena on kuvassa 7.15. Mallin alkuhetki oli edellinen vappu, ja sään sekä veden kuljetuksen ohjaama lämpöenergian talous ohjasi veden lämpötilaa ja jäänmuodostusta. Kuvassa on esitettynä vertailu oikeaan jäätilanteeseen, kun jään laajuus oli maksimissaan. Mallituloksessa Gotlannin altaassa on liian korkea lämpötila todellisuuteen verrattuna ja Selkämerellä 

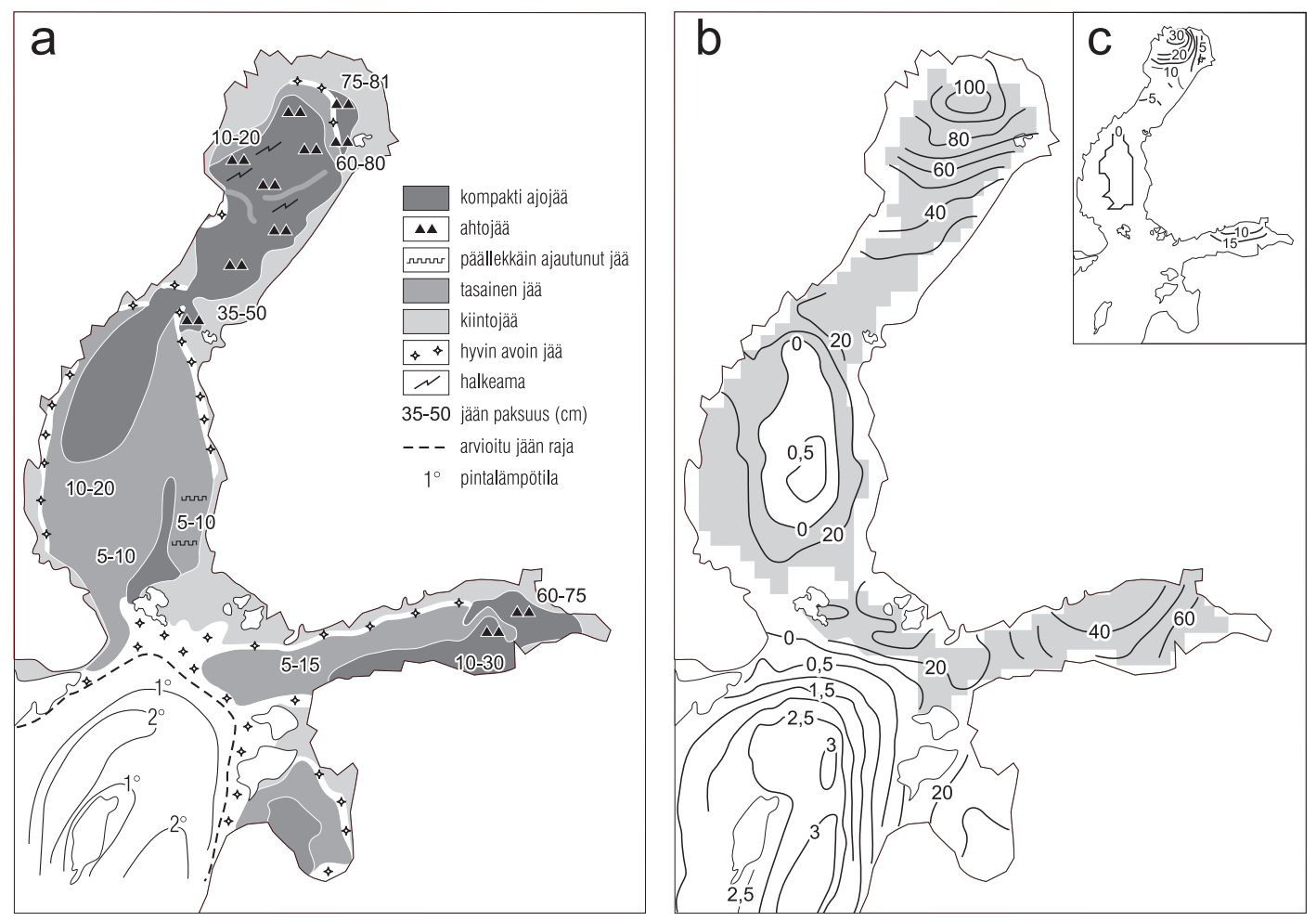

Kuva 7.15. Itämeren ilmastollisen jäämallin kalibrointi: A) havaittu jäätilanne jääkartan mukaan, B) mallin laskema jään paksuus $(\mathrm{cm})$ ja avoveden pintalämpötila $\left({ }^{\circ} \mathrm{C}\right)$ ja $\mathrm{C}$ ) ahtojään keskipaksuus $(\mathrm{cm})$. Mallin alkuaika 1.5.1983, vertailupäivä 22.3.1984. (Haapala ja Leppäranta 1996)

on mallissa avovesialue siellä, missä oikeasti oli ohutta jäätä. Muualla niin jään keskipaksuudet kuin ahtojäät ovat mallissa hyvin kuvattuina. Vastaavia vertailuja tehtiin myös leudon ja ankaran talven tapauksille ja yhteensopivuudet olivat samantapaisia.

\subsection{Jääpeitteen vaikutukset Itämereen}

\subsubsection{Luonnontieteellinen merkitys}

Itämerellä on jäätä 5-7 kuukautta vuosittain, joten jäällä on suuri merkitys Itämeren fysiikkaan, tilaan ja ekologiaan. Jääpeitteen suurin vuotuinen laajuus on 10-100 \% Itämeren pinta-alasta ja kiintojään suurin vuotuinen paksuus on 50 $120 \mathrm{~cm}$. Jääpeite on jäykkä, ohut kerros meren ja ilmakehän välissä. Se vaikuttaa suoraan meren ja ilmakehän väliseen liike-energian, lämpöenergian sekä kosteuden vaihtoon. Vapaasti ajelehtivat jääkentät voivat jopa lisätä liike-energian siirtoa avovesitilanteeseen verrattuna, sillä ajojään pinnankarkeus on yleensä hieman suurempi kuin vesipinnan. Tiiviissä jääkentissä liikemäärän siirto on talvella heikompi (kuva 7.13).

Jää ja sillä oleva lumi ovat hyviä eristeitä, ja siksi lämmönvaihto ilmakehän ja meren välillä heikkenee jääpeitteen vahvistuessa. Ne suojaavat vettä ja estävät sen jäätymistä kovin syvään. Jääpeiteaikana sadanta kerrostuu jäälle usean kuukauden ajan ja vapautuu veteen hyvin lyhyenä sulamisjaksona. Koska jään suolaisuus on alhai- 
nen, sulamisen aikana tulee pintaveteen runsaasti makeaa vettä, joka näkyy selvästi suolaisuuden vuotuisissa aikasarjoissa.

Sadannan lisäksi myös ilmakehän ainelaskeuma varastoituu jääpeitteeseen, ja edelleen jäässä on myös vedestä ja joskus myös meren pohjasta peräisin olevaa ainesta. Näitä vieraita aineksia sanotaan jään sedimenteiksi. Ne vapautuvat meriveteen sulamiskautena, ja silloin pintakerroksen ainesyöttöön tulee voimakas maksimi. Lisäksi ajojäiden liike kuljettaa jään sedimenttejä pitkiäkin matkoja ennen kuin ne vapautuvat mereen.

Jäällä on merkitystä Itämeren ekologialle sekä mekaanisena elementtinä että kasvualustana. Ensimmäinen vaikutus perustuu pienempään sekoittumiseen. Jokivedet virtaavat jääpeitteen alla hyvinkin pitkiä matkoja. Samalla jokivesien tuomat ravinteet leviävät. Ravinteiden leviämiskuvio onkin täysin erilainen jään alla kuin ilman jääpeitettä. Jään alle muodostuu myös voimakkaita leväkukintoja keskellä talvea. Ne ovat mahdollisia makeamman veden muodostaessa jään alle ohuen sekoittumattoman kerroksen, jossa levät voivat kasvaa käyttäen hyväkseen jään läpi tulevaa niukkaa valoa. Ilman veden suolaisuuskerrostuneisuutta levät eivät pysyisi valaistussa kerroksessa, vaikka jään alla onkin riittävästi ravinteita levien kasvuun. Jään ja lumen optiset paksuudet ovat noin $100 \mathrm{~cm}$ ja $10 \mathrm{~cm}$, joten erityisesti kun lumi on ohentunut, valoa pääsee hyvin jään läpi.

Jähän liittyvä levätuotanto on tärkeä eloperäisen aineksen tuottaja keskellä muuten vähätuottoisinta vuodenaikaa. Eräät eläinplanktonlajit käyttävät hyväkseen jään alapinnalla kasvavia leviä. Emme tunne vielä täydellisesti jään tuotannon merkitystä suurempien äyriäisten ja kalojen elämään. Alustavat havainnot antavat vinkkejä siitä, että jään alla saattaa pyöriä monimutkainenkin ravintoverkko. Jään sisällä tapahtuva tuotanto käyttää epäorgaanisia ravinteita hyväkseen ja tuottaa eloperäistä ainesta. Jäällä on siten merkitystä Itämeren ravinteiden kierrossa. Suurin vaikutus on ilmeisesti sulamisvaiheessa, jolloin jäähän kertynyt eloperäinen aines joutuu veteen. Suuri osa siitä vajonnee pohjaan, mutta osa jää veteenkin. Jään sulamisvaiheessa veteen joutuu myös runsas määrä niitä ravinteita, lähinnä epäorgaanista typpeä, joka on laskeutunut ilmakuormituksesta jään pinnalle.

Itämeren hylkeet ovat mukautuneet jääoloihin. Ne saavat poikasensa kevätjäällä, joka on turvallinen ympäristö poikasten varttua ensi viikkonsa. Hyvin leutoina talvina jäiden puute voi aiheuttaa ongelmia.

\subsubsection{Ihmisen toiminta}

Ihmisen toimintaan jääoloilla on ollut hyvin suuri merkitys. Ennen höyrylaivojen aikaa, kun matkustus ja kuljetus olivat voimakkaasti merestä riippuvia, jäät eristivät Suomen muusta maailmasta. Tällöin puhuttiin jäiden saarrosta. Konevoiman myötä talvimerenkulku alkoi laajentua, ja vuonna 1877 ensimmäisen kerran matkustajalaiva Express liikennöi Suomen ja Ruotsin välillä koko talven, Hangosta Tukholmaan. Lähes 100 vuotta sen jälkeen, vuonna 1970, merenkulku oli ympärivuotista kaikkiin tärkeimpiin Itämeren satamiin. Jäät vaikuttavat yhä merenkulkuun, sillä Suomen ja muidenkin on pidettävä yllä jäänmurtajalaivastoa.

Kun meriympäristöön rakennetaan, tulee jääkuormat ottaa huomioon. Muun muassa merenkulun turvalaitteiden on kestettävä vaihtelevat jääolot. Erityisesti ajojäiden rakenteisiin kohdistamat kuormat voivat olla suuria. Joitakin jäät ovat vaurioittaneet majakoita Itämerellä.

Meren jääpeitteestä on myös hyötyä liikenteelle saaristoon tehtyjen talviteiden ansiosta. Jään kantokyky on likimain $P=a b^{2}, a \approx 5 \mathrm{~kg} / \mathrm{cm}^{2}$, ja siis $25 \mathrm{~cm}$ paksu jää kantaa jo hyvin henkilöauton. Esimerkiksi Perämerellä tehdään melko pitkä jäätie joka talvi mantereelta Hailuotoon. 
Toisaalta kelirikkoajat ovat vaikeuttaneet saariston elämää, ja yhteydenpitoa varten on ollut kelirikkoaluksia. Hylkeenpyyntiä on harjoitettu paljon kevätjäiden aikaan, ja kalastusmenetelmiä on kehitetty talvioloihin soveltuviksi. Virkistystoiminnan merkityksen kasvaessa ovat talviset merijäät tulleet merkittävään asemaan ulkoilun, hiihdon ja luistelun merkeissä. 


\section{Krittiset prosessit ja ääritilanteet}

Luvuissa 1-7 on käyty läpi Itämeren fysiikan perusteet. Tässä luvussa tarkastelua syvennetään kriittisiin prosesseihin ja ääritilanteisiin, joilla on suuri merkitys Itämeren lyhyen ja pitkän aikavälin kehityksessä. Kriittiset prosessit liittyvät meren ja ilmakehän vuorovaikutukseen sekä meren dynamiikkaan, ääritilanteita puolestaan syntyy harvoin ja monien tekijöiden yhteisvaikutuksesta.

Tärkeä kriittinen prosessi on kumpuaminen, jossa meren pintakerroksiin tulee suuria määriä ravinteita alemmista vesikerroksista. Tämän seurauksena muun muassa leväkukinnot voivat kiihtyä, jos muut olosuhteet ovat otollisia. Suolapulssit tuovat Pohjanmereltä suuria määriä suolaista ja hapekasta vettä, joka pystyy uudistamaan Itämeren syvänteiden hapettomat pohjavedet ja ylläpitämään Itämeren suolaisuuskerrostuneisuutta. Kahden vesimassan vaakasuuntaista rajavyöhykettä, jossa hydrografiset ominaisuudet muuttuvat hypähdyksenomaisesti, kutsutaan rintamaksi ja siihen liittyy usein biologista aktiviteettia. Intruusiot ovat eriytyneitä pyörteitä, jotka tunkeutuvat homogeeniseen vesimassaan ja muuttavat tämän kerrostuneisuusolosuhteita. Niillä on merkittävä rooli vesirungon horisontaalisessa ja vertikaalisessa sekoittumisessa.

On myös tärkeää kartoittaa, millaisia ääritilanteita Itämeressä voi esiintyä, koska niillä on tieteellisen mielenkiinnon lisäksi vaikutusta myös yhteiskunnan toimintaan monilla aloilla kuten meriympäristön turvallisuuteen, satamien käyt-

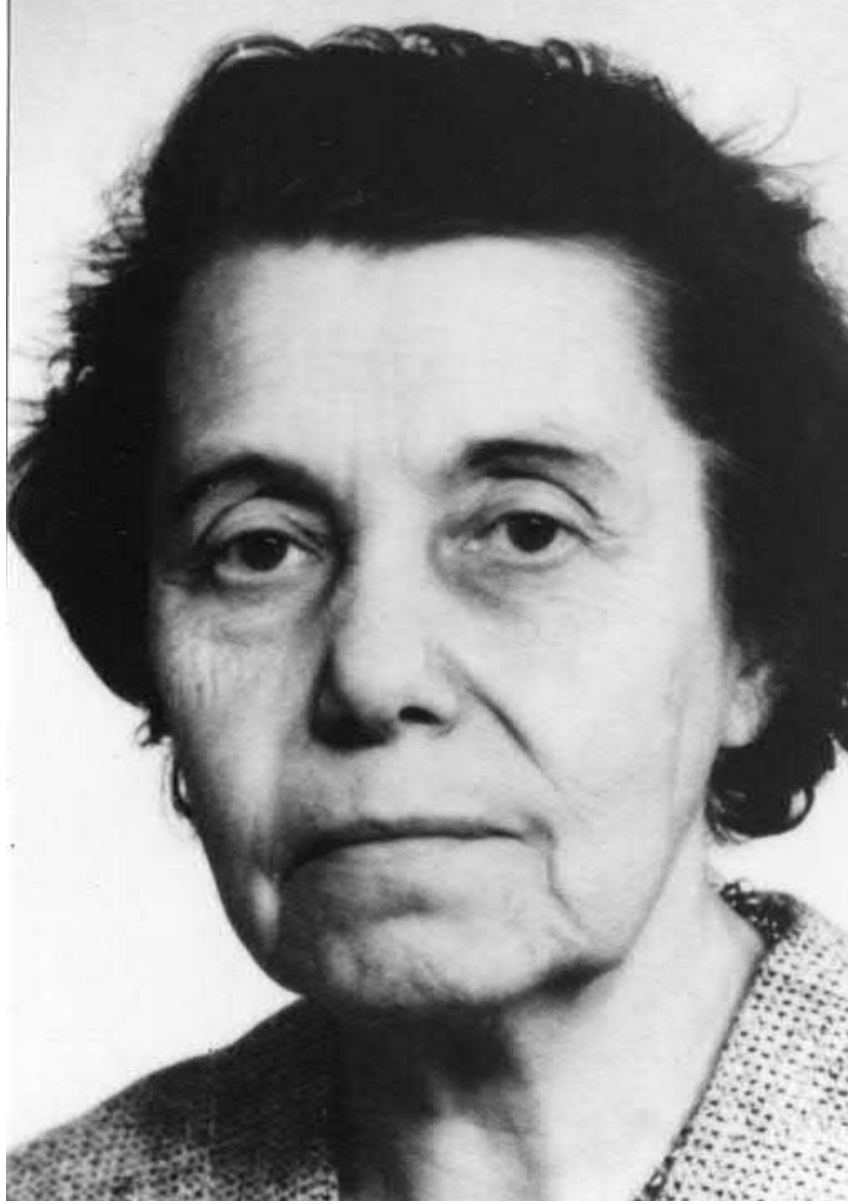

Kuva 8.0. Professori Eugenie Lisitzin (1905-1989) tuli tutkijana kansainvälisesti tunnetuksi vedenkorkeus- ja vuorovesitutkimuksiensa ansiosta. Hän toimi Merentutkimuslaitoksen vedenkorkeusosaston johtajana 1955-72 ja myös laitoksen vs. johtajana. Yhdeksää kieltä hallinnut kosmopoliitti Lisitzin oli todellinen "Ensimmäinen Nainen", sillä hänen aikanaan naista ei saatu nimittää Merentutkimuslaitoksen virkoihin (sääntö kumottiin 1961), kemiallista osastoa kuitenkin lukuun ottamatta. Näin Lisitzin joutui hakemaan erivapautta tullakseen nimitetyksi virkaan. Lisitzin oli ensimmäinen nainen, joka väitteli fysiikan tohtoriksi Suomessa (1938). Samoin hän ensimmäisenä naisena tuli valituksi Suomen Tiedeseuran matemaattis-luonnontieteellisen osaston jäseneksi. Hän sai professorin arvonimen 1965. (Merentutkimuslaitoksen kuva-arkisto)

töön ja suunnitteluun sekä meren virkistyskäyttöön. Äärimmäiset vedenkorkeudet ovat nopeita, yllättäviä tapahtumia, äärimmäiset jäätalvet puolestaan kehittyvät kuukausien kuluessa. 


\subsection{Meri-ilmakehä vuorovaikutus}

\subsubsection{NAO-indeksi}

Pohjois-Euroopan ilmasto on voimakkaasti kytköksissä Pohjois-Atlantilta tulevaan länsivirtaukseen, jonka voimakkuutta kuvaa NAO-indeksi (katso luku 5). Matalapaineet kuljettavat mukanaan merkittäviä lämpömääriä, jotka tasoittavat etelän ja pohjoisen lämpötilaeroja. Myös Golfvirran vaikutus korostuu, kun tuulet kuljettavat Pohjois-Atlantilla lämpöä itään päin. Niiden talvien lukumäärä, jolloin NAO-indeksi on positiivinen, on ollut kasvussa viime vuosikymmeninä ja tämän katsotaankin olevan eräs merkki ilmaston lämpenemisestä (katso luku 9.4). NAOindeksiä ei voida ennustaa, mutta sitä voidaan käyttää kuvaamaan menneiden vuosien ilmastollisia olosuhteita Itämeren alueella. Sillä onkin selvä yhteys esimerkiksi Itämeren vedenpinnan korkeuteen ja jäätalvien ankaruuteen. Itämeren ylle saapuva ilmamassa ja meri ovat vuorovaikutuksessa, jonka laatu riippuu suuresti ilman pintakerroksen ja merenpinnan lämpötilaerosta.

\subsubsection{Maa-merituuli}

Lämpimänä ja heikkotuulisena kesäpäivänä aurinko lämmittää meren lähellä olevaa maata. Tällöin lämmin ilma laajenee ja kohoaa keveytensä takia ylöspäin. Lämpimän maan ylle syntyy näin matalapaine, joka pyrkii täyttymään mereltä virtaavasta kylmästä ilmasta. Maanpinnan lähellä viriää mereltä virtaava viilentävä tuuli eli merituuli. Merellä vallitsee korkeapaine, josta merituuli lähtee ja jossa ilma laskeutuu alaspäin. Noin kilometrin korkeudessa virtaava ylävirtaus puhaltaa vastakkaiseen suuntaan eli maan yllä olevasta matalasta meren yllä olevaan korkeaan. Meren yllä oleva korkeapaine ja maan yllä oleva matalapaine ovat niin sanottuja termisiä matalaja korkeapaineita. Ilmiön syntymiseksi tarvitaan maan ja meren välillä vähintään 8 asteen lämpötilaero. Tuulen nopeus on tyypillisesti 3-9 m/s. Merituuli ulottuu 20-50 kilometriä sisämaahan päin. Myöhään iltapäivällä merituuli heikkenee maan ja meren lämpötilaeron pienetessä ja kesäyönä voi esiintyä päinvastainen ilmiö eli maatuuli, kun maa on merta kylmempää.

\subsubsection{Matalapainekehitys ja konvektiiviset sadenauhat}

Syksyllä ja alkutalvella, kun meri on ilmaa lämpimämpi, Itämerellä havaitaan usein niin sanottu terminen matalapaine. Tällainen pienimittainen matalapaine syvenee ilmanpaineen laskiessa, kun merestä vapautuu lämpöä ja kosteutta ilmaan. Otollinen olosuhde matalan voimistumiselle on kylmän ilman valuminen meren yläpuolelle, jolloin lämmön luovutus meren ja ilmakehän välillä on asymmetrinen: avomerellä ilmakehä saa merestä lämpöä, mantereella maa jäähdyttää ilmaa. On oleellista, että ilmakehä on meren yläpuolella epästabiili: merestä saatu lämpö ja kosteus labilisoivat tilannetta entisestään ja matalan voimistuminen voi olla intensiivistä. Tilanteeseen liittyy usein voimakkaita tuulia ja runsaita sateita. Terminen matala havaitaan usein esimerkiksi Perämerellä syksyisin, siellä sitä kutsutaankin Perämeren matalaksi. Myös eteläisellä Itämerellä on havaittu samankaltaisia ilmiöitä. Olosuhteista riippuen matala voi olla pitkä- tai lyhytkestoinen eli stationäärinen tai ei-stationäärinen.

Talvella kylmän itävirtauksen vallitessa Suomenlahdella ja Ruotsin itärannikolla havaitaan konvektiivisia sadenauhoja (kuva 8.1), joissa esiintyy sakeita lumikuuroja. Ilmiön synnyssä on keskeistä asymmetria lämmön ja kosteuden vaihdossa maa-ilma-rajapinnalla ja meri-ilmarajapinnalla, ja lisäksi rannikoiden geometria vaikuttaa siihen. Itätuulen puhaltaessa meren yllä tuulen alapuolelle syntyy paikallinen termi- 


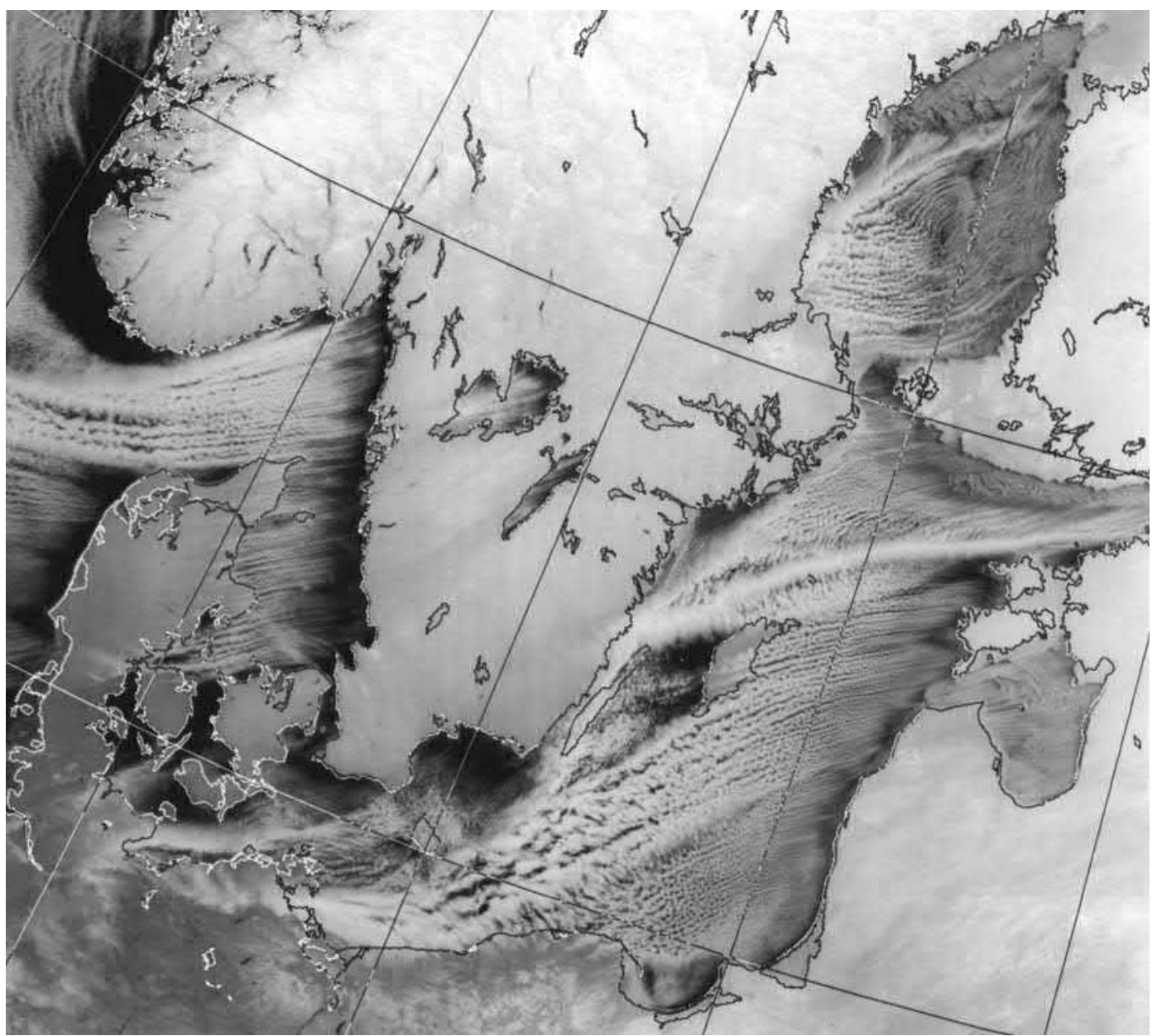

Kuva 8.1. Konvektiivisia sadenauhoja Itämeren yllä (Nils Gustafsson/SMHI).

nen tuuli, joka puhaltaa kylmältä maalta lämpimälle merelle. Tämä perustuu siihen, että maan yläpuolella oleva ilma on kylmänä tiheämpää kuin meren yllä oleva lämmin ilma. Näin tuuli suuntautuu merelle päin pyrkien tasoittamaan tiheyseroa (kesäinen maatuuli toimii samalla mekanismilla). Suomenlahden tapauksessa kummaltakin rannikolta suuntautuu tuuli avomerelle, jossa sitten syntyy konvektiota voimistava konvergenssi.

Sadenauhan saapuessa vastakkaiselle rannikolle saattaa jälleen syntyä paikallinen maalta merelle puhaltava tuuli (esimerkiksi Ruotsin itärannikolla), joka voimistaa konvektiota konvergenssin kautta puhaltaessaan itäisen perusvir- tauksen vastaisesti. Rannikon lähellä sadenauhat ovat voimakkaimmillaan, mutta sisämaahan kylmän pinnan ylle ajautuessaan ne häviävät nopeasti. Nämä konvektiiviset sateet voivat aiheuttaa rannikolle ajautuessaan haittaa liikenteelle, koska sademäärät saattavat olla erittäin suuria. Ilmiön ennustaminen on vaikeaa, ja niinpä sitä varten on tarpeen käyttää kytkettyjä meri-ilmakehämalleja, joissa meri ja ilmakehä vuorovaikuttavat jatkuvasti keskenään. Näin voidaan ennustaa ilmakehän rajakerroksen lämpötila, tuuli ja kosteusjakauma riittävällä tarkkuudella. Käytännön ennustustyössä säätutkien tarjoama havaintoaineisto on lyhtyaikaisissa ennusteissa tärkeä elementti. 


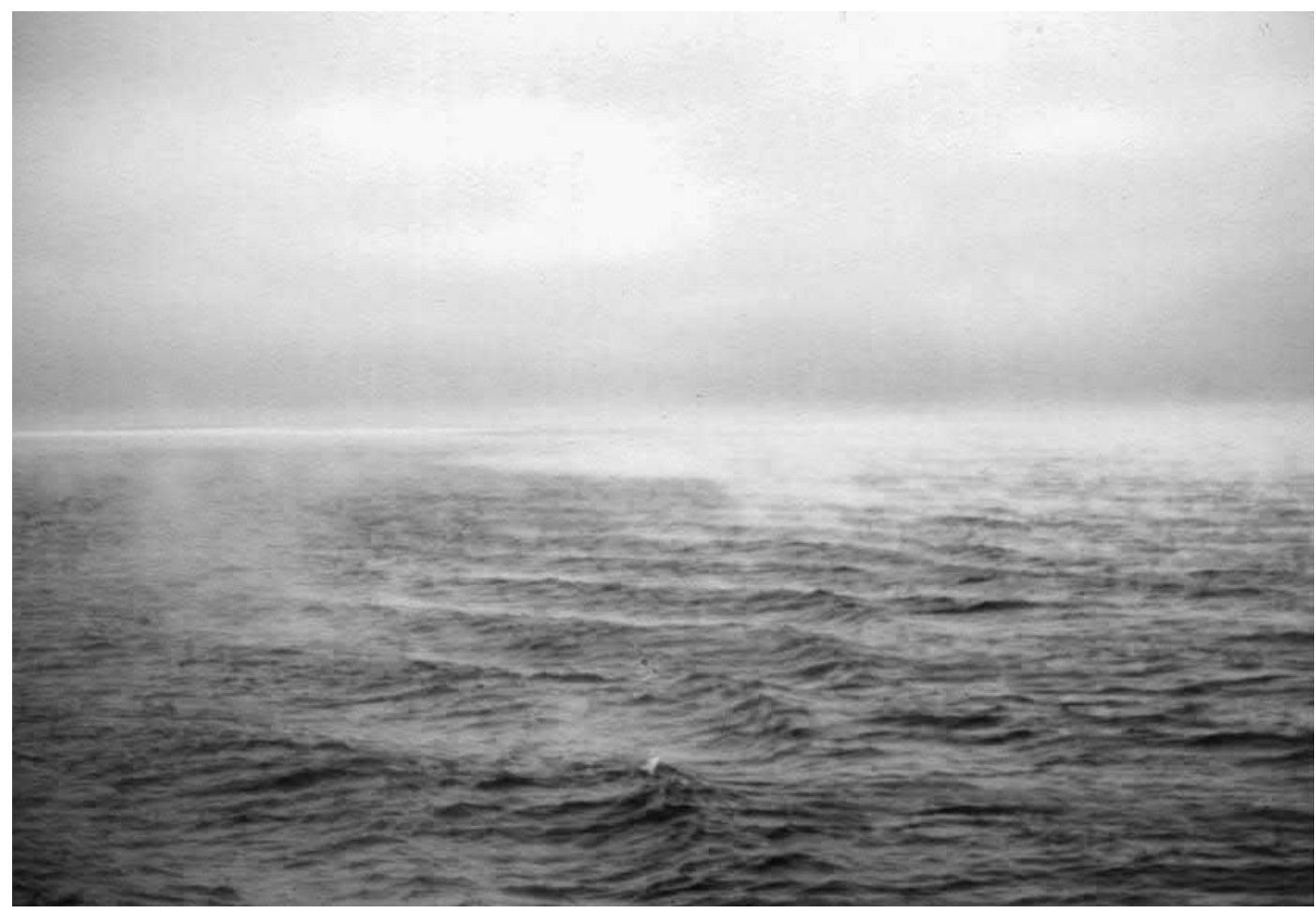

Kuva 8.2 Merisavua Selkämerellä tammikuussa 1978. (Matti Leppäranta)

\subsubsection{Sumu ja merisavu}

Erityisesti loppukesällä esiintyy rannikon lähellä vaikeasti ennustettavia sumuja. Tällainen ilmiö esiintyy tyypillisesti lämpimässä ja kosteassa ilmamassassa. Sumun laukaisevana tekijänä saattaa olla muun muassa rannikon läheinen kumpuaminen, johon liittyy meren pintalämpötilan äkillinen aleneminen. Alailmakehän lämpötila vastaavasti alenee nopeasti, ilman suhteellinen kosteus kasvaa ja ilma saavuttaa kastepisteen pinnan lähellä. Otolliset olosuhteet äkilliselle sumun muodostumiselle syntyvät yleensä heikkotuulisessa tilanteessa.

Sumun ennustaminen vaatii jälleen tarkkaa meren ja ilmakehän vuorovaikutuksen kuvausta eli meren pintalämpötilan ennusteen on oltava realistinen. Ilmiön ennustaminen on merkityksellistä, koska nopeasti kehittyvät sumut saattavat aiheuttaa meriliikenteelle riskitilanteita.
Merisavu on myöhäissyksyn ja talviajan ilmiö (kuva 8.2), jonka muodostuessa meri on paljon ilmaa lämpimämpi. Merenpinnasta haihtuu vesihöyryä, joka noustessaan ylös jäähtyy nopeasti, jolloin ilman kosteus saavuttaa kastepisteen. Mekanismi on sama kuin sumun muodostuksessa, mutta kosteuden tiivistyminen nousevissa ilmavirtauksissa saa aikaa savumaisen visuaalisen vaikutelman. Merisavua esiintyy usein pakkassäällä railoissa ja jääpeitteen reunan tuntumassa.

\subsubsection{Rakenteiden jäätäminen}

Kylmissä vesissä kiinteisiin rakenteisiin ja laivoihin voi kerääntyä jäätä. Alijäähtynyt vesihöyry muodostaa huurretta kohtaamiinsa pintoihin. Kun pintavesi on jäätymispisteessä, tai hieman 


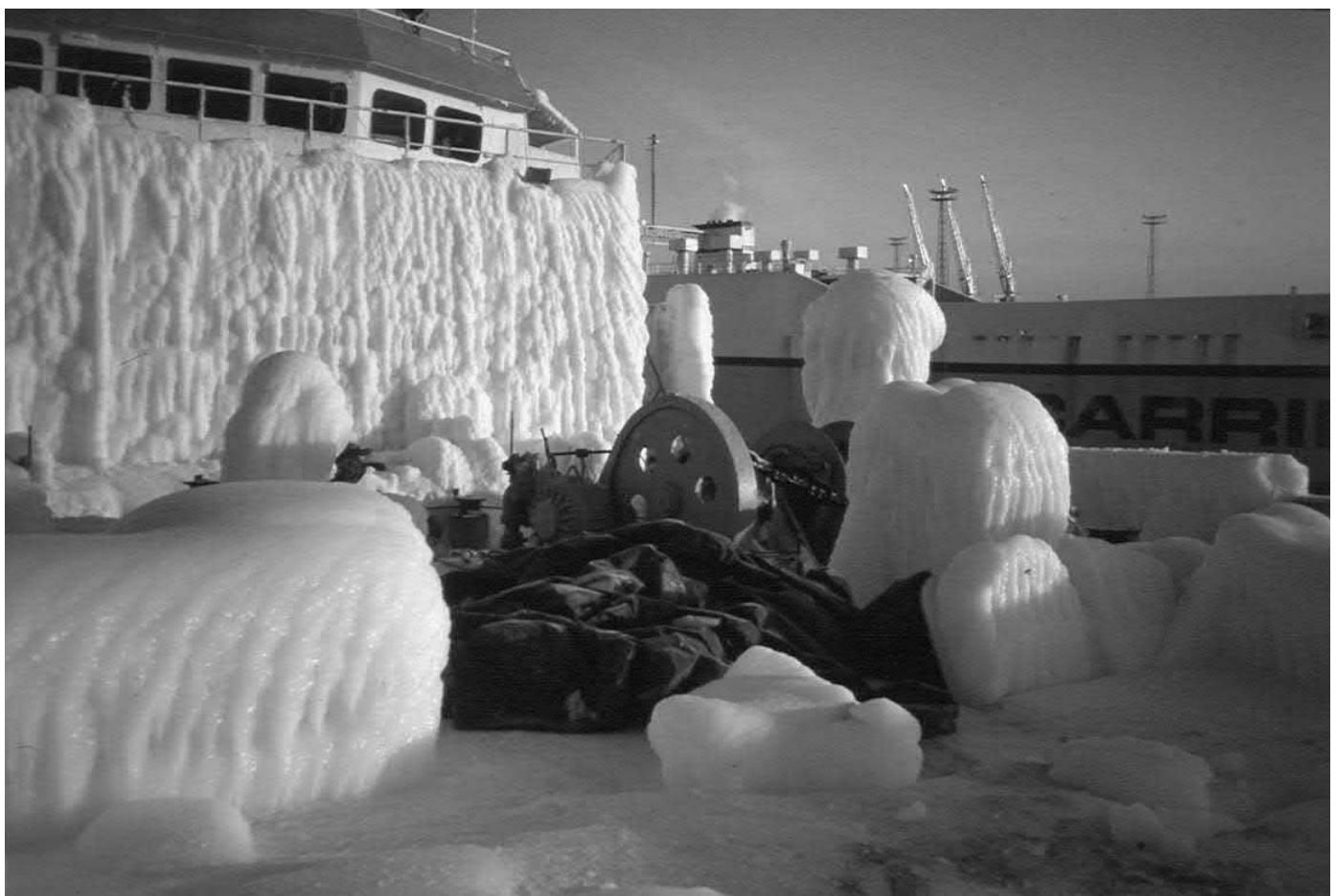

Kuva 8.3. Jäätä on keräytynyt alukseen Suomenlahdella, nyt alus on jo turvassa Helsingin länsisatamassa. (Lasse Makkonen)

alijäähtynyt, roiskeet jäätyvät helposti rakenteiden ja laivojen pintoihin (kuva 8.3). Roiskeita tulee voimakkaasta aallokosta tai laivan liikkeestä ja ne voivat johtaa vaaratilanteisiin, jos esimerkiksi laivan tasapaino muuttuu voimakkaan jäätämisen seurauksena. Niinpä sääennusteissa merenkulkijoille ilmoitetaan myös jään keräytymisriskistä.

\subsection{Kumpuaminen}

\subsubsection{Teoria}

Kumpuamisella [englanniksi upwelling] tarkoitetaan meren dynamiikan aiheuttamaa syvemmältä pintaa kohti suuntautuvaa veden liikettä (konvektio puolestaan tarkoittaa veden tiheysmuutoksen ajamaa pystysuoraa kiertoliikettä). Käytännössä pintaan kumpuava vesi ei ole peräi- sin kovinkaan syvältä; valtamerillä kumpuaminen rajoittuu parin sadan metrin kerrokseen, Itämerellä muutamaan kymmeneen metriin. Yleinen edellytys kumpuamisen synnylle on se, että horisontaalinen advektio kuljettaa vesimassoja pois kumpuamisalueelta eli pintakerroksessa on divergenttinen horisontaalinen virtaus.

Kumpuaminen on yleinen ilmiö niin valtamerillä kuin myös Itämerellä. Kumpuamista on tutkittu Itämerellä jonkin verran ja useita eri syntymekanismeja on löydetty. Tärkein kumpuamislaji on niin sanottu Ekman-kumpuaminen (kuva 8.4). Tuuli puhaltaa rannikon suuntaisesti siten, että rannikko on tuulen suuntaan katsottuna vasemmalla puolella, ja Ekman-teorian mukaan vesi kulkeutuu tuulen suunnasta oikealle eli avomerelle päin. Rannikolta poistuva vesi korvautuu syvemmän veden kumpuamisella pintaan. Jos taas rannikko on tuulen suuntaan nähden oikealla puolella, ulkomeren vesi ajautuu 


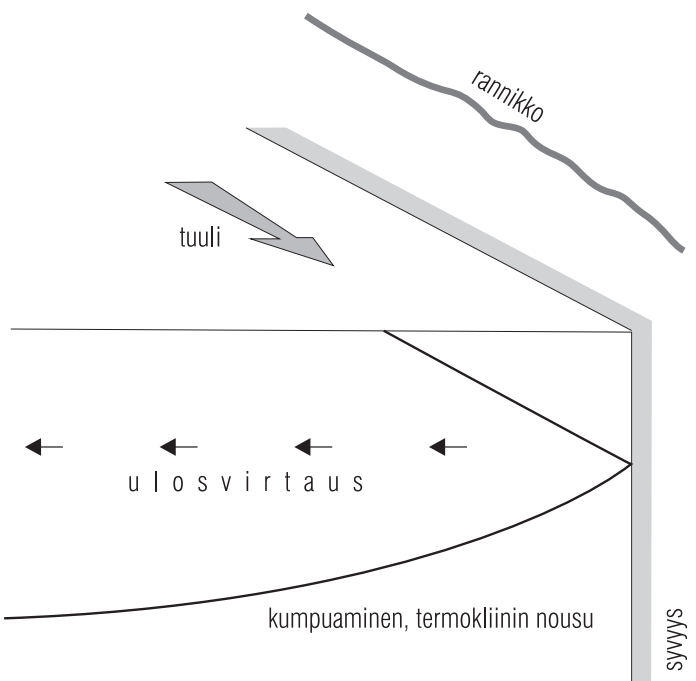

Kuva 8.4. Skemaattinen kuva kumpuamisesta (perustuen Ekman-teoriaan). Kuvassa näkyvät vallitseva tuulen suunta, termokliinin kallistuminen ja vallitsevat virtaukset. (Piirretty Gillin (1982) kuvasta.)

rantaan päin ja tapahtuu pintaveden painumista [englanniksi downwelling] syvempään.

Kumpuamista voi tapahtua myös ulkomerellä jos virtauskenttä on divergenttinen. Tärkeä erikoistapaus on Ekman-pumppaus. Jos tuulen leikkausjännityksen pyörteisyys on positiivinen, kuten vastapäivään kiertävissä pyörteissä, Ekman-kuljetus suuntautuu pyörteestä ulospäin ja pyörteen keskialueilla vesi kumpuaa. Myös rannikolta avomerelle suuntautuvat tuulet aiheuttavat kumpuamista virtauskentän kehittymisen aikana. Yksi mahdollinen kumpuamismekanismi liittyy vielä Kelvin-aallon dynamiikkaan (Myrberg ja Andrejev 2003).

Kesätilanteessa, kun termokliini on olemassa, kumpuamiseen liittyy usein voimakas pintalämpötilan aleneminen, sillä kumpuamisalueella termokliini saattaa kallistumisensa yhteydessä nousta pintaan. Vastaavasti ulkomeren puolella termokliini painuu alaspäin. Kumpuamisalueella kylmä vesi saattaa tuoda suuren määrän ravinteita pintaan, mikä voi ajan myötä kiihdyttää leväkukintoja.

\subsubsection{Karakteristiset piirteet}

Kumpuamistapahtumien kartoitusta on Itämeren alueella rajoittanut havaintojen saannin vaikeus. Kaukokartoitus on pitkälti ainoa menetelmä, jolla ilmiötä voidaan tarkastella kokonaisvaltaisesti (kuva 8.5). Numeerinen mallitus on myös tarjonnut apuvälineitä kumpuamisen tutkimuksissa.

Tyypillinen kumpuamistapahtuman kesto on Itämerellä 0,5-10 päivää. Yleensä lämpötilan horisontaalinen gradientti on pinnalla $0,5-1,0$ ${ }^{\circ} \mathrm{C} / \mathrm{km}$ ja lämpötilaero kumpuamisalueen ja avomeren välillä on $2-10^{\circ} \mathrm{C}$. Esimerkiksi Suomenlahdella (Haapala 1994) rannikon suuntaisen tuulen pitää kestää noin 60 tuntia, ennen kuin kumpuaminen kehittyy. Tämä johtuu meren suuren massan hitaudesta. Tuulen nopeuden pitää samassa yhdessä olla vähintään kohtalainen, eli noin $7-10 \mathrm{~m} / \mathrm{s}$. Virtauksen vertikaalinopeus on kumpuamisen yhteydessä huomattavasti normaalitilannetta suurempi, mutta silti ainakin kaksi kertaluokkaa pienempi kuin horisontaalinen virtausnopeus. Kumpuamisvyöhykkeen laajuus on tyypillisesti 5-20 kilometriä rannikosta ulospäin ja 30-150 kilometriä rannikon suunnassa.

Yksittäiset kumpuamistapaukset liittyvät kulloinkin vallitseviin tuuliolosuhteisiin. Numeeriset mallit tarjoavat mahdollisuuksia tarkastella kumpuamisen pitkän ajan statistiikkaa ja mahdollista systematiikkaa. Määritellään kumpuamisindeksi $Q_{k}$ vertikaalinopeuden $w$ avulla seuraavasti:

$Q_{k}=\frac{\sum_{n=1}^{N} w_{n}}{\sum_{n=1}^{N}\left|w_{n}\right|} \cdot 100 \%$ 


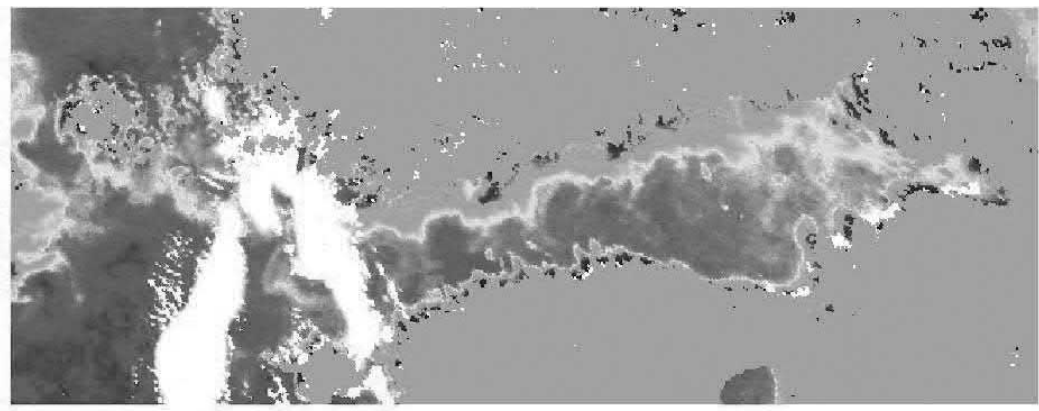

${ }^{\circ} \mathrm{C}$

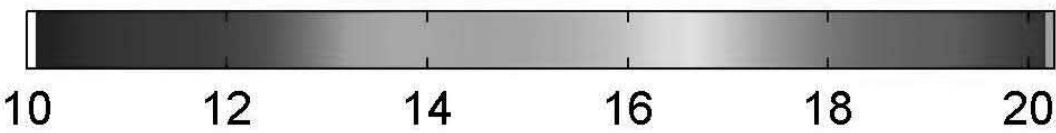

Kuva 8.5. Satelliittikuva kumpuamisesta Suomenlahdella 2.9.2002 (data on prosessoitu SYKE:ssä, ja Ilmatieteen laitos on vastaanottanut kyseisen NOAA AVHRR satelliitti-instrumentin datan).

missä summataan mallin aika-askelten suhteen. Indeksi edustaa mallilla laskettua veden vertikaalinopeuden stabiliteettia. Jos pystynopeus on suuntautunut ylöspäin koko laskentaperiodin ajan, saadaan $Q_{k}=100 \%$ eli tapahtuu jatkuvaa kumpuamista. Jos vertikaalinopeus on koko ajan suuntautunut alaspäin kumpuamisindeksi saa arvon $Q_{k}=-100 \%$, eli tapahtuu jatkuvaa vajoamista. Mitä suurempi on vertikaalinopeuden suunnan vaihtelu ajan funktiona, sitä lähempänä $Q_{k}:$ n arvo on nollaa.

Kuvassa 8.6 on esitetty Itämeren tärkeimmät kumpuamisalueet (ja vajoamisalueet) 10 vuoden mallilaskentaan perustuen. Mainittavimmat kumpuamisalueet sijaitsevat rannikon myötäisillä kapeilla vyöhykkeillä. Lisäksi kuvasta 8.6 nähdään kumpuamista tapahtuvan myös avomerellä, jossa pohjan muotojen pystyvirtauksia ohjaava liike ja tuulikentän epähomogeenisuus ovat merkittäviä tekijöitä. Aktiivisimmilla kumpuamisalueilla $Q_{k}$ on jopa $30-50 \%$. Aktiivisia kumpuamisalueita ovat Perämeri, Selkämeren keskiosa ja itärannikko, Suomenlahden pohjoisrannikko, Hiidenmaan ja Saarenmaan itäranni- kot, Gotlannin itärannikko, Ruotsin rannikko Gotlannin merellä sekä Puolan ja Saksan rannikot. Lisäksi Suomenlahden ja Gotlannin meren keskiosissa on kumpuamisalueita.

\subsubsection{Kumpuamisen seurausvaikutukset}

Kumpuamisen selkein seurausvaikutus on kesätilanteessa pintalämpötilan jyrkkä lasku (kuva 8.5). Kumpuamisen yhteydessä pintaveden lämpötila voi parissa päivässä laskea yli kymmenen astetta. Tämä kylmän veden alue näkyy hyvin satelliittikuvissa. Yleensä advektio tasoittaa melko pian lämpötilaerot, mutta tilanteen jäljet voivat näkyä parikin viikkoa.

Kesätilanteessa, kun lämpötilakerrostuneisuus on voimakas, kumpuamisella saattaa olla varsin merkittäviä seurausvaikutuksia. Biologinen toiminta on alkukesällä lämpimissä ja runsaasti valoa tarjoavissa olosuhteissa meren pintakerroksessa intensiivistä. Tällöin ravinteet kuluvat loppuun, eikä voimakkaasta lämpötilakerrostuneisuudesta johtuen ravinnepitoista vettä tule 


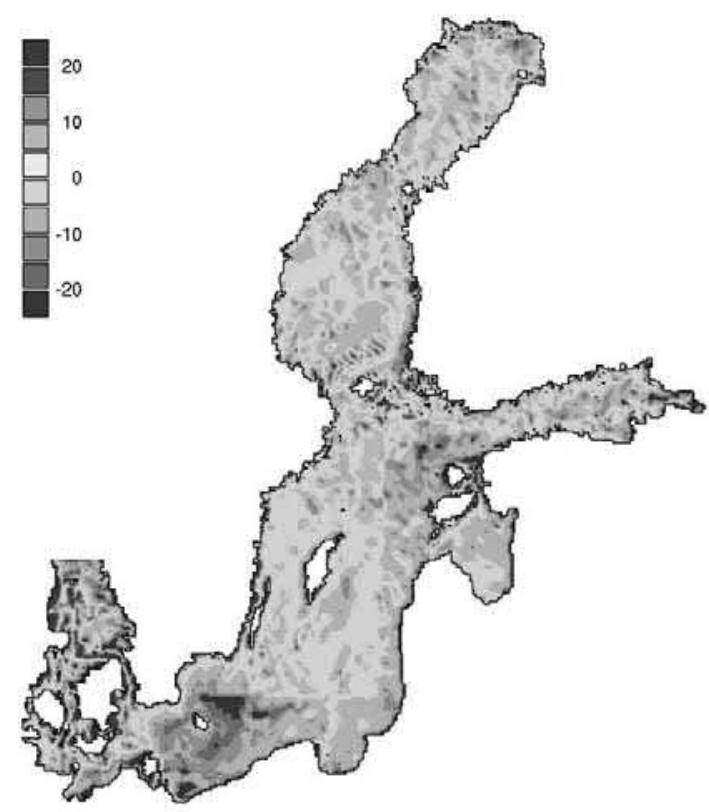

Kuva 8.6. Keskeiset kumpuamisalueet Itämerellä (prosentteina): positiivinen indeksi - kumpuaminen, negatiivinen indeksi - vajoaminen. (Piirretty Myrbergin ja Andrejevin [2003] kuvasta.)

syvältä tuottavaan pintakerrokseen. Näin leväkukinnat vähentyvät ja saattavat loppua, vaikka olosuhteet olisivat muuten niille otolliset. Kumpuaminen aiheuttaa muutoksen ravinnetilanteeseen, kun termokliinin noustessa pintaan syvistä vesikerroksista pääsee ravinteita tuottavaan kerrokseen. Pintavesi on tällöin vielä liian kylmää leväkukintojen synnylle, mutta seuraavan lämpimän ja tyynen jakson aikana pintaveden lämpötila nousee ja edellytykset voimakkaalle ja nopealle leväkukinnalle ovat olemassa. Tällaisia tilanteita havaitaan muun muassa Suomenlahdella useasti elokuussa, jolloin voimakkaan kerrostuneisuuden takia ravinteet ovat pintakerroksessa vähissä, ja toisaalta kumpuamisen edellytyksenä olevia kohtalaisia tuulennopeuksia (7-10 m/s) alkaa esiintyä keskikesän heikkojen tuulien jälkeen.

\subsection{Rintamat ja intruusiot}

\subsubsection{Rintamat}

Kahden tiheydeltään erilaisen vesimassan rajavyöhykkeelle voi muodostua rintama. Nämä vesimassat eivät voi olla tasapainossa vierekkäin, vaan suurempitiheyksinen vajoaa kevyemmän alle. Horisontaalinen tiheysero tietyllä alueella voi johtua myös klimatologisista syistä, jolloin syntyy jatkuvaa konvektiota. Tällöin syntyy vastaavasti myös horisontaalivirtauksia ja rintama muodostuu. Koska meriveden tiheys riippuu sekä suolaisuudesta että lämpötilasta, niin periaatteessa on mahdollista, että niiden aiheuttamat tiheyserot kompensoivat toisensa. Tämä ei kuitenkaan ole enää dynaamisessa mielessä rintama, vaan harvinainen erikoistapaus.

Rintamia voi esiintyä joka puolella Itämerta (kuva 8.7), sillä niiden syntyyn on olemassa useita erilaisia mekanismeja. Tällaisia ovat esimerkiksi rannikon läheinen kumpuaminen, topografiset tekijät, pyörteet, paikallisesti vaihteleva meri-ilmakehä-vuorovaikutus ja vedenvaihto altaiden väillä. Rintama voi olla varsin pysyvä, kuten on laita Suomenlahden suualueella, jossa rintama erottaa toisistaan Gotlannin meren suolaisen ja Suomenlahden makeamman vesimassan. Myös Tanskan salmissa on pysyvä, joskin ajallisesti liikkuva rintama, joka erottaa toisistaan Pohjanmeren ja Itämeren veden. Edelleen suurten jokien suilla, kuten Nevan edustalla, on suuria suolaisuusgradientteja. Suomenlahden ja Pohjanlahden Suomen puoleisilla rannikoilla on havaittu luonteeltaan melko pysyviä lämpötilarintamia, joiden synty johtuu paljolti kumpuamisten ja topografisten tekijöiden sekä muiden yllämainittujen tekijöiden yhteisvaikutuksesta. 


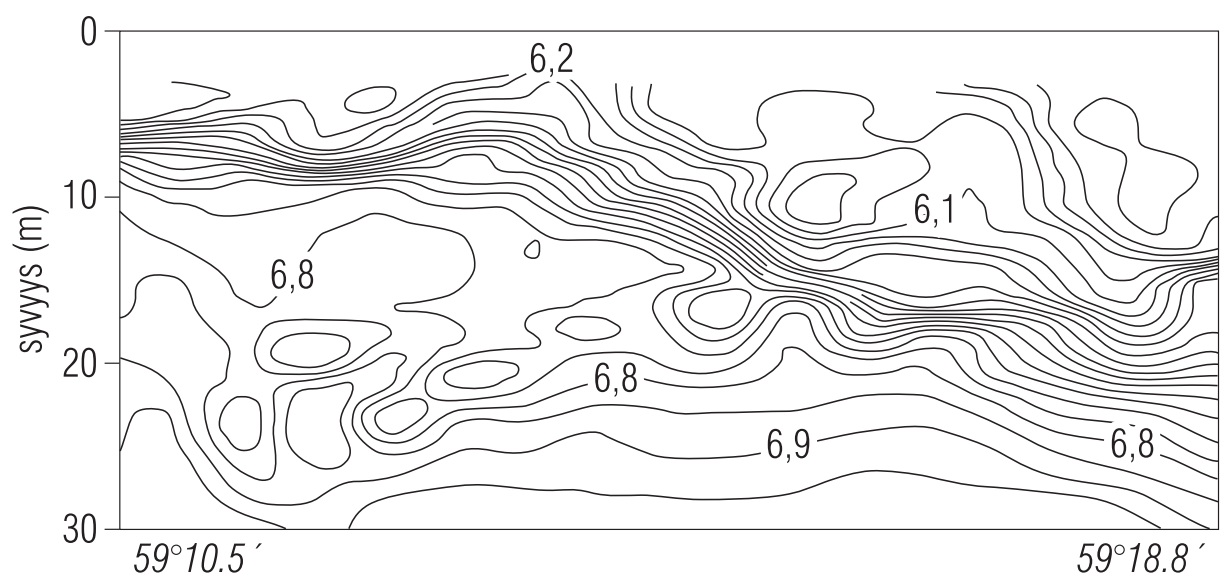

Kuva 8.7. Suolaisuuden poikkileikkaus etelä-pohjoissuunnassa Suomenlahden suulla heinäkuussa 1993. (Piirretty Konosen ym. [1996] kuvasta.)

\subsubsection{Intruusiot}

Intruusiolla tarkoitetaan sitä, että anomaalinen ja ympäröivistä vesimassoista eriytynyt, usein linssinmuotoinen pyörre tunkeutuu homogeeniseen vesimassaan (kuva 8.8). Suuret intruusiot tapahtuvat pitkäkestoisina pyörteinä geostrofisesta mukautumisesta johtuen. Pienissä intruusioissa esiintyy hienorakennetta ja erikokoisia pyörteitä. Intruusiopyörteet voivat kuljettaa ytimessään pitkiäkin matkoja vesimassaa, joka poikkeaa selvästi ympäröivistä vesimassoista. Linssimäisten pyörteiden koko on synoptista suuruusluokkaaa hiukan pienempi, eli niiden säde on 1-10 kilometriä.

Intrusiivisten alueiden esiintymissyvyys on tyypillisesti 100-150 metriä (muun muassa Gotlannin syvänteessä). Lämpötila- ja suolaisuusanomaliat ovat suuruusluokiltaan $0,5^{\circ} \mathrm{C}$ ja 0,5 $\%$. Pyörteet ovat antisyklonaalisia (myötäpäivään kiertäviä), ja niiden ydin on ympäröiviä vesimassoja kylmempi ja vähäsuolaisempi. Ilmiön vertikaalinen ulottuvuus on muutamia kymmeniä metrejä ja etenemisnopeus luokkaa $1 \mathrm{~cm} / \mathrm{s}$. Pyörteen elinaika voi olla useita viikkoja.

Intrusiivisten pyörteiden syntymekanismit ja niiden vaikutukset meren prosesseihin eivät ole vielä täysin tunnettuja. Joka tapauksessa niil- lä voi olla suurta merkitystä vesimassojen horisontaalisessa ja vertikaalisessa sekoittumisessa. Tällaisessa pyörteessä anomaalisen vesimassan syntyalue on kaltevalla pinnalla, jossa halokliini koskettaa meren pohjaa. Pyörre kuljettaa tätä kylmää ja vähäsuolaista vesimassaa lähialtaisiin, ja lopputuloksena on uudenlainen kerrostuneisuus, jossa intrusiivisiä pyörteitä ei ole. Ilmiö esiintyy tyypillisesti loppusyksystä, jolloin lämpötilajakauma on melko homogeeninen termokliinin hävittyä.

\subsection{Suolapulssit}

\subsubsection{Taustaa}

Itämeri ja Pohjanmeri ovat jatkuvassa vedenvaihdossa keskenään (luku 4), mutta niiden välinen "normaali" vedenvaihto ei ole riittävää, jotta hydrografiset olosuhteet Itämeren syvänteissä muuttuisivat oleellisesti. Tähän tarvitaan poikkeuksellisen voimakas sisäänvirtaus, jota kutsutaan suolapulssiksi [englanniksi Major Baltic inflow]. Suolapulssi tuo Itämereen riittävän tiheää (suolaista) vettä, joka uudistaa syvänteiden vesi- 


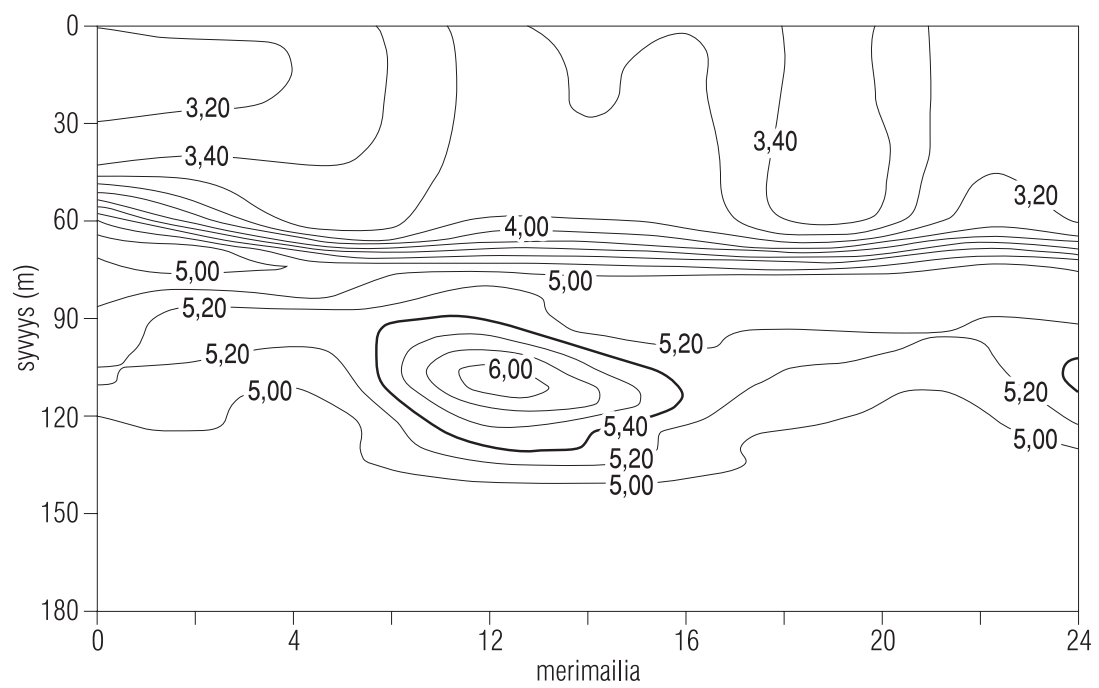

Kuva 8.8. Lämpötilaleikkauskuva Gotlannin altaalta. Kuvassa erottuu linssimäinen intruusivinen pyörre. (Piirretty Kõutsin [1999] kuvasta.)

massat. Samalla syvänteiden happitilanne paranee. Suolapulsseja saadaan Itämereen keskimääräin noin kerran kymmenessä vuodessa, mutta pulssien väliajat vaihtelevat suuresti.

Itämeren nykyisen suolaisuuden, kerrostuneisuuden ja happiolojen säilyttämiseksi suuret suolapulssit ovat välttämättömiä. Ilman niitä Itämeri alkaisi makeutua, mutta samalla syvänteiden happitilanne muuttuisi hyvin huonoksi, sillä suolaisuuskerrostuneisuus ei kuitenkaan katoaisi kovin nopeasti. Elämä häviäisi yhä laajemmilta alueilta Itämeren syvissä altaissa, ja tällä olisi huomattavia seurausvaikutuksia koko ekosysteemiin.

\subsubsection{Edellytykset suurelle suolapulssille}

Suurten suolapulssien esiintyminen on harvinaista, eikä suotuisia olosuhteita niiden syntymiseksi muodostu kovinkaan helposti. Suuren pulssin elinkaaressa on kolme vaihetta: ensimmäinen vaihe on esivaihe, sitten seuraa varsinainen sisäänvirtaus, ja lopuksi tulee jälkivaihe (kuva 8.9). Pulssin esivaiheessa vallitsee tyypillisesti itä- tuuli, jolloin Itämeren vedenkorkeus alenee huomattavasti eli Itämeri "tyhjenee”. Esivaihe päättyy, kun varsinainen pulssi alkaa suolaisen veden virratessa Darssin kynnyksen yli Itämerelle. Tällöin melko vähäsuolaista vettä $(S<17 \%$ ) virtaa Darssin kynnyksen yli Itämerelle, kun taas Drogdenin kynnyksen yli virtaa Tanskan salmissa jo huomattavasti suolaisempaa vettä ( $S$ $>25 \%$ ). On todettu, että esivaiheen viimeiset 15 päivää ennen varsinaisen pulssin alkua ja siihen liittyvät sääolosuhteet ovat pulssin synnyn kaikkein tärkein osa. Varsinaisen pulssin aikana vallitsevat voimakkaat länsituulet, ja Itämeren vedenkorkeus nousee (kuvat 8.10, 8.11). Darssin ja Drogdenin kynnysten yli Itämereen virtaa raskasta ja suolaista vettä, joka vajoaa pohjaan. Pulssin jälkivaiheen käynnistää veden voimakas ulosvirtaus Itämereltä, kun länsituulet heikkenevät ja normaalia korkeammalla oleva vedenpinta laskee. Osa suolaisesta vedestä virtaa tällöin takaisin Pohjanmerelle.

Olosuhteet, joissa Itämeren alueella vallitsee aluksi kohtalaisen voimakas itätuuli muutaman viikon ajan ja sen jälkeen tulevat voimakkaat länsituulet, eivät toteudu kovinkaan usein. Huo- 


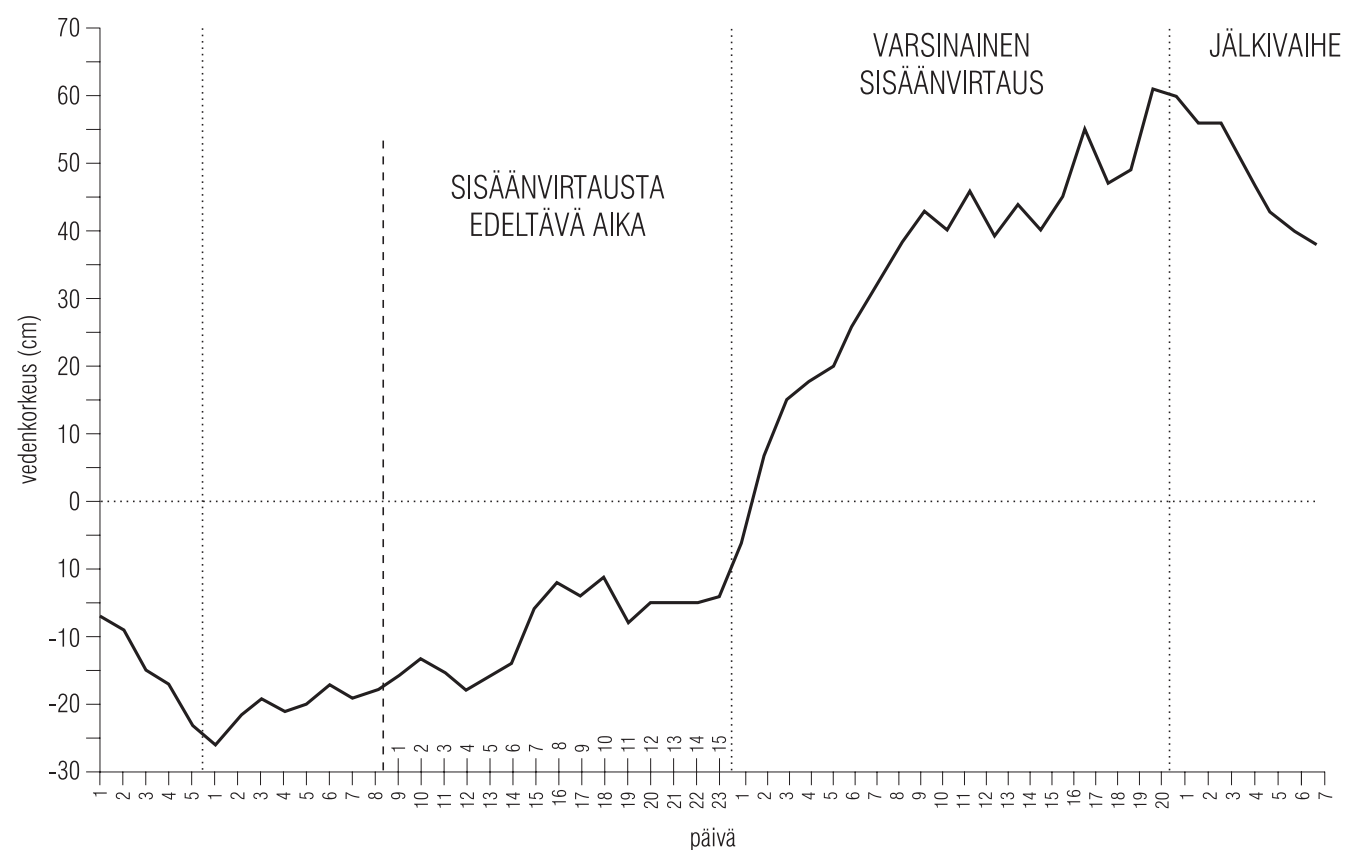

Kuva 8.9. Suuren suolapulssin eri vaiheet: esivaihe, varsinainen pulssi ja jälkivaihe (piirretty Matthäusin ja Schinken [1994] kuvasta). Varsinainen esivaihe (vasemmanpuoleisin pystyviiva) alkaa Itämeren vedenkorkeuden minimistä. Viimeisen 15 päivän aikana esivaiheessa (seuraava pystyviiva oikealla) alkaa jo hiukan päästä suolaista vettä Itämereen.

mattavia suolapulsseja ei ole havaittu tapahtuvaksi kesäaikaan, vaan otollisin aika on loka- ja huhtikuun välillä. Matalapaineiden keskusten kulkuradoilla on suolapulssille siis suuri merkitys. Pohjanmeren raskaamman veden täytyy virrata riittävän pitkälle Itämereen, ettei se pääse virtaamaan pulssin jälkivaiheen aikana takaisin Pohjanmereen. Länsimyrskyn on oltava riittävän pitkäkestoinen, jotta riittävän suuret vesimassat ehtivät virrata Itämereen.

\subsubsection{Suolapulssien karakteristiset piirteet, suuruus ja esiintymistiheys}

Pulssien intensiteettiä kuvataan indeksillä, joka perustuu sisäänvirtauksen kestoaikaan $k$ ja sisäänvirtaavan veden suolaisuuteen $S$. Se määritellään:

$Q=50\left(\frac{k-5}{25}+\frac{S-17}{7}\right)$ missä $k$ :n yksikkö on vuorokausi ja $S$ :n yksikkö on promille. Indeksin $Q$ arvo vaihtelee 0:n $(k=$ 5 vrk, $S=17 \%$ ja 100:n $(k=30$ vrk, $S=24$ $\%$ ) välillä.

Pulssit jaotellaan niiden intensiteetin perusteella heikkoihin $(Q<15)$, keskisuuriin $(15<Q$ $<45)$, suuriin $(30<Q<45)$ ja erittäin suuriin $(Q>45)$. Heikkojen pulssien osuus kaikista tapauksista on noin puolet. Niiden kesto ei ylitä 8 päivää eikä niissä keskimääräinen suolaisuus ylitä 18,6 \%o. Indeksin kaikkein korkeimmat arvot saavutetaan marraskuun ja tammikuun välisenä aikana.

Pulsseista on olemassa mittauksia jo 1800-luvun lopusta lähtien. Ainoastaan maailmansotien ajalta havaintosarjassa on katkoksia. Suuret pulssit esiintyvät tyypillisesti ryppäissä (17 tapausta), huomattavasti harvemmin erillään (6 tapausta). Useissa tapauksissa pulsseja on esiintynyt runsaasti 3-5 vuoden jaksoissa, joista huomatta- 

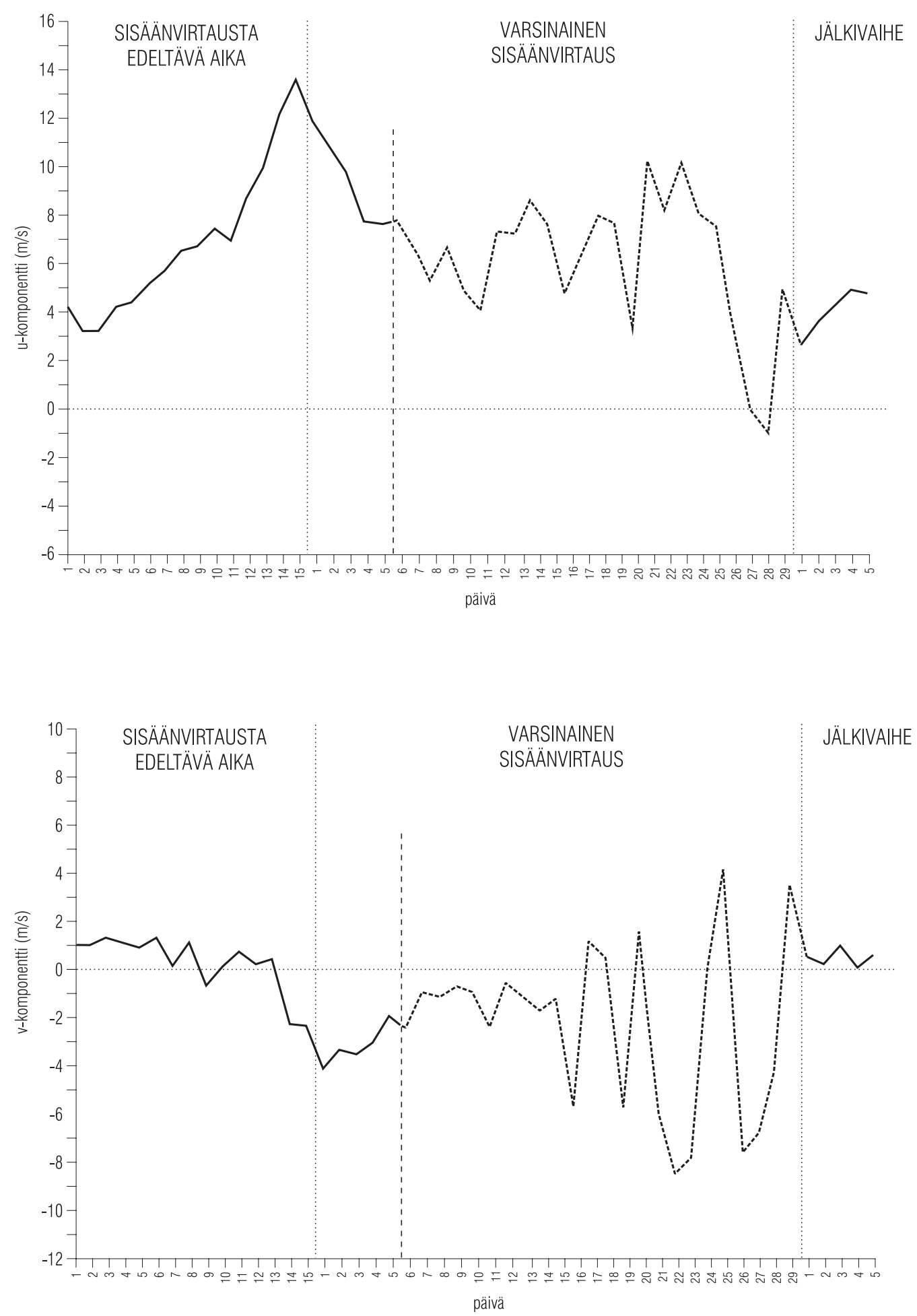

Kuva 8.10. Tuulen itä(u)- ja pohjois(v)-komponentit suolapulssin eri vaiheissa. Positiiviset arvot tarkoittavat itä- ja pohjoistuulia (katso muut selitykset kuvasta 8.9.). (Piirretty Matthäusin ja Schinken [1994] kuvasta.) 

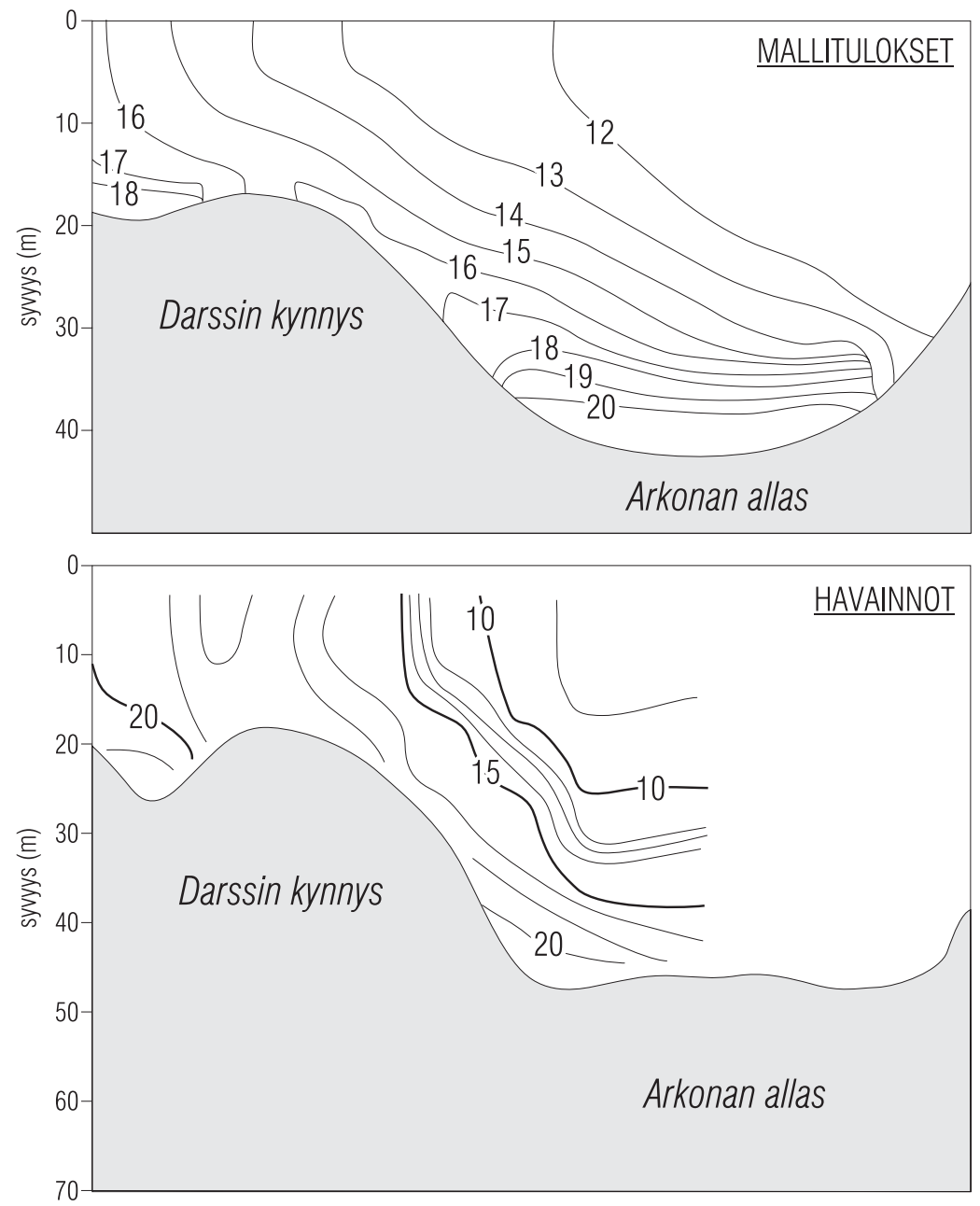

Kuva 8.11. Suolaisuuden poikkileikkaus Darssin kynnykseltä Arkonan altaaseen tammikuussa 1993. A) Mallitulosten mukaan (piirretty Andrejev ym. [2002] kuvasta). B) Mittausten mukaan (piirretty Matthäusin [1993] kuvasta). A-kuvassa on mallin käyttämä approksimaatio topografiasta.

vimpina voidaan mainita jaksot 1948-1952 (12 pulssia) ja 1968-1972 (10 pulssia). Pisin ajanjakso ilman minkäänlaista mainittavaa pulssia oli vuosien 1983-1992 välillä. Myöskään jaksoina 1927-1930 sekä 1956-1959 ei esiintynyt pulsseja (kuva 8.12).

Kuvassa 8.12 on esitetty suurimpien pulssien karakteristiset arvot. Kaikkein voimakkain pulssi oli vuonna $1951(Q=79,1)$. Sen jälkeisistä pulsseista voimakkain oli vuodenvaihteessa 1975-76 ( $Q=60)$. Suurten pulssien yhteydessä suolaisuuden vertikaalinen keskiarvo on $20 \%$ : $\mathrm{n}$ molemmin puolin. Lämpötiloissa on suurta vaihtelua, koska pulssien tapahtuma-aika on syyskuun ja huhtikuun välillä. Jos pulssi tulee syyskuun ja joulukuun välillä, niin Itämeren syvänteiden lämpötila nousee, kun taasen tammi-huhtikuussa tapahtuvat pulssit aiheuttavat lämpötilan laskun. Sisäänvirtaavan veden keskitiheys on $1.013-1.017 \mathrm{~kg} / \mathrm{m}^{3}$ ja happipitoisuus $7,5-8,5 \mathrm{ml} / \mathrm{l}$.

Pulssin aikana Itämeren pinnankorkeus vaihtelee $-60 \mathrm{~cm}: n$ ja $+70 \mathrm{~cm}: n$ välillä, eli sen eri vaiheiden aikana keskimääräinen vedenkorkeus muuttuu jopa yli metrin. Suurten pulssien aikana sisäänvirtaavan veden tilavuus on kokonaisuudessaan usein yli $200 \mathrm{~km}^{3}$, jopa yli $300 \mathrm{~km}^{3}(310$ $\mathrm{km}^{3}$ tammikuussa 1993). Sinänsä vesivolyymin suuruus ei välttämättä kuvaa pulssin vaikutusta Itämeren kerrostuneisuus- ja happioloihin, sillä 


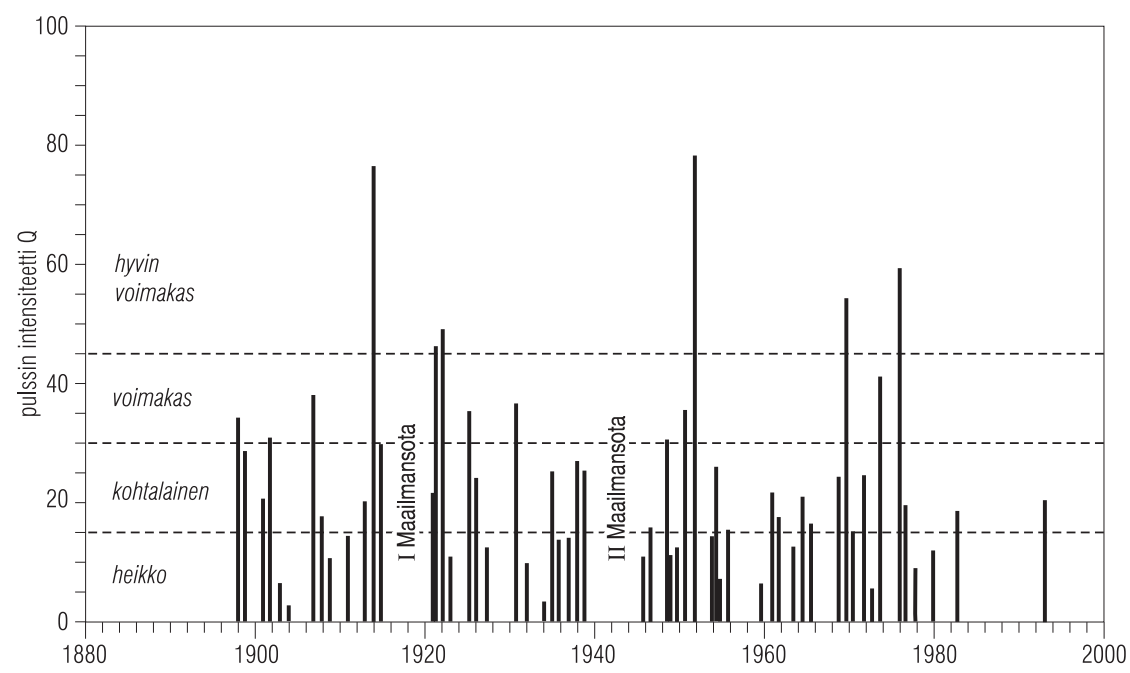

Kuva 8.12. Havaitut suolapulssit ja niiden intensiteetit $Q$ vuodesta 1880 eteenpäin. (Piirretty Matthäusin ja Schinken [1994] kuvasta.)

yhtälailla merkittävää on, että sisäänvirtaava vesi on riittävän suolaista.

Viime vuosikymmeninä pulsseja on esiintynyt keskimääräistä harvemmin. Tähän on esitetty useita syitä, mutta mitään selkeää yksittäistä syytä ei ole vielä löydetty. Pohjois-Atlantin keskusmatalan keskimääräisessä sijainnissa mahdollisesti tapahtuvat muutokset vaikuttavat tuulijakaumaan ja sitä kautta pulssien esiintymiseen. Sademäärien ja jokivirtaamien kasvu voi aiheuttaa Itämeren makean veden ylijäämän kasvun. Makea vesi poistuu Itämerestä pintakerroksessa, joten Kattegatissa ja Skagerrakissa vesi makeutuu, jolloin pulssin kannalta tarpeeksi suolaisen sisäänvirtaavan veden esiintymistodennäköisyys pienenee.

\subsubsection{Suolapulssin merkitys Itämeren kannalta}

Itämeren voimakas ja pysyvä halokliini estää koko vesipatsaan vertikaalisen sekoittumisen, eikä ilmasta pääse siirtymään hapekasta vettä alusveteen. Biologiset prosessit kuitenkin kuluttavat hapen usein loppuun pohjanläheisissä ker- roksissa, jolloin syvänteissä syntyy pahanhajuista rikkivetyä. Edelleen hapettomissa olosuhteissa Itämeren sedimentteihin varastoitunut fosfori liukenee veteen. Tämä kiihdyttää sinileväkukintoja, ja sinilevät sitovat ilmasta veteen liuennutta typpeä. Ravinteiden saatavuuden kasvaessa kaikki levät lisääntyvät, hajoavat ja kuluttavat happea. Syntyy noidankehä, jota on vaikea pysäyttää. Ainoa tekijä, joka auttaa asiaa pysyvästi on ravinnepäästöjen saaminen kuriin. Suuret, taajaan tapahtuvat suolapulssit parantavat happitilannetta pohjanläheisessä kerroksessa, mutta vaikutus ei ole pysyvä, vaan happi kuluu loppuun ja palataan edellä mainittuun noidankehään, jos pulsseja ei esiinny muutamiin vuosiin (kuva 8.13).

Pulssien vaikutus Itämeren tilaan ei välttämättä ole kaikilta osin myönteinen. On sinänsä selvä, että suurten syvänteiden happitilanne huononee jatkuvasti ja hapeton alue suurenee, jos pulsseja ei esiinny. Sen sijaan Suomenlahdella tilanne on usein päinvastainen. Mikäli pulsseja ei esiinny pitkään aikaan, suolaisuus Itämeressä alkaa luonnollisesti pienentyä. Suomenlahdessa halokliini alkaa heiketä ja saattaa ajan myötä kadota kokonaan. Tällöin ilman hapet- 


\section{ITÄMEREN HYDROGRAFIA; STAGNAATIO, "SEISOVA VESI"}
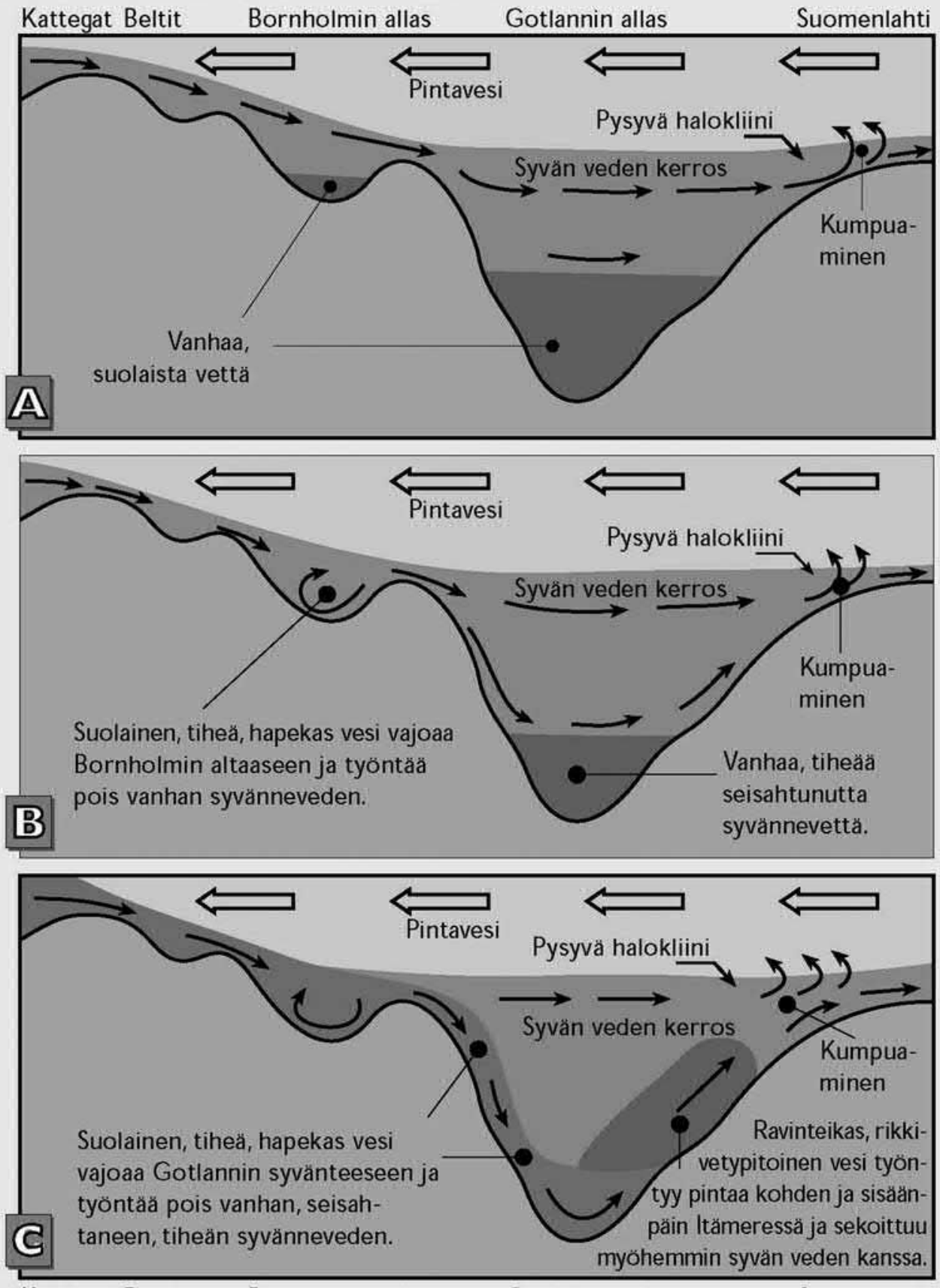

Kattegat Beltit Bornholmin allas Gotlannin allas Suomenlahti

Kuva 8.13. Skemaattinen kuva hapekkaan ja suolaisen veden kulusta Itämeren eri osiin, ja sen vaikutuksesta Itämeren pohjanläheiseen happitilanteeseen stagnaation jälkeen. (Piirretty Itämeri -ympäristö ja ekologia kalvosarjan kuvasta, laatijoina Furman ym. [www.ymparisto.fi].) 
tama pintavesi pääsee talvisen konvektion aikana sekoittumaan koko vesimassaan, ja pohjan läheinen happitilanne paranee. Tällaisen pitkän pulssittoman (stagnaatio) jakson katkaisee jossain vaiheessa pulssi, jolloin suurissa syvänteissä, kuten Gotlannin altaassa happitilanne paranee. Suolainen ja raskas Pohjanmeren vesi työntää edellään vanhaa ja hapetonta Gotlannin altaan pohjavettä, joka siirtyy pohjoiseen ja aiheuttaa Suomenlahdessa happitilanteen huononemisen (kuva 8.13). Jos kuitenkin pulsseja esiintyy riittävän usein, niiden vaikutus on toki koko Itämeren tilaa parantava.

\subsubsection{Lämmin kesäpulssi 2002 ja 2003}

Uutena ilmiönä Itämerellä havaittiin kesinä 2002 ja 2003 poikkeuksellinen lämpimän veden sisäänvirtaus, jolloin syvänteiden lämpötilat kohosivat selvästi. Pohjan lähellä sisäänvirranneen veden lämpötila oli jopa $14-16^{\circ} \mathrm{C}$. Tämänlaista voimakasta kesäpulssia ei oltu Itämerellä havaittu aiemmin ja sillä todettiin olevan kielteisiä ekologisia seurausvaikutuksia. Sen uskotaan liittyvän ilmastonmuutokseen. Ilmiön tutkiminen on kuitenkin vielä alkuvaiheessa, joten selkeää syytä sille ei ole vielä löydetty.

\subsection{Poikkeukselliset vedenkorkeudet}

\subsection{Itämeren vedenkorkeuden pitkäaikainen muuttuminen}

Itämeren pitkäaikaisen vedenkorkeusvaihtelun tutkimisessa on otettava huomioon monia seikkoja. Viime jääkauden jälkeinen maankohoaminen on nykyisin suurimmillaan Perämerellä, 8-9 $\mathrm{mm} /$ vuosi, kun taas eteläisellä Itämerellä kohoaminen on olematonta, ja jopa vajoamista tapahtuu. Maankohoamisnopeus on myös vaihdellut eri aikoina. Ekman (1988) on tutkinut Itämeren pisintä yhtäjaksoista vedenkorkeuden aikasarjaa (Tukholma, 1774-), josta ilmenee, että maankohoaminen on ollut keskimäärin $1 \mathrm{~mm} /$ vuosi, ja että se on ollut hitaampaa tarkastelujakson jälkiosassa. Maankohoaminen näkyy erityisesti etelärannikollamme esiintyvissä kuroutuvissa lahdissa (niin sanotut fladat) tai maankohoamarantoina Pohjanlahden rannikolla. Molemmissa maankohoamisen myötä syntyneissä ekosysteemeissä on oma erityinen kasvilajistonsa, joihin kuuluu harvinaisia lajeja. Fladat ovat lisäksi tärkeitä kalojen kutupaikkoja, ja niiden pohjaliejuun varastoituu lisäksi suuria määriä ravinteita.

Vedenkorkeuden pitkäaikaismuutoksiin vaikuttaa lisäksi globaalinen merenpinnan nousu (muutamia millejä vuodessa), joka johtuu meren lämpötilan noususta ja jäätiköiden sulamisesta. Lämpötilan noustessa merivedessä tapahtuu lämpölaajenemista ja toisaalta jäätiköiden sulaminen tuo meriin lisää vettä. Nousevan lämpötilan aiheuttamat kasvavat sademäärät voivat toisaalta lisätä Antarktiksen mannerjäätikön massaa. Todennäköisin nettovaikutus ilmaston lämpenemisestä olisi kuitenkin merenpinnan nousu. Tektonisten prosessien osuutta pidetään yleensä paikallisena. Niinpä 1900-luvulla havaittu ilmaston lämpeneminen on nostanut merenpintaa, ja sen vuoksi vedenkorkeuden havaittu muutosnopeus määriteltyyn nollatasoon nähden on Itämeren etelärannikolla ollut nouseva, mutta muualla selvästi laskeva, koska maankohoaminen on edelleen ollut globaalia pinnannousua voimakkaampaa.

Itämeren pohjoisosissa vedenkorkeudella oli laskeva lineaarinen trendi aina 1980-luvulle asti johtuen maankohoamisen vaikutuksesta. Kuitenkin kahden viime vuosikymmenen aikana (kuva 8.14) vedenkorkeus ei ole enää laskenutkaan yhtä nopeasti, vaan keskimääräinen vedenkorkeus esimerkiksi Suomen rannikolla on $5 \mathrm{~cm}$ korkeampi kuin historiallinen, lineaarinen trendi olisi antanut odottaa (Johansson ym. 2004). Ilmiö on havaittu myös muualla päin Itämerta. 
Kuva 8.14. Havaittu vedenkorkeuden muutos noin 100 vuoden ajalta valituilla Suomen mareografeilla sekä 15 vuoden liukuvat keskiarvot. Ajasta riippuva teoreettinen keskivesi on ennustettu perustuen pitkän aikavälin keskimääräisen vedenkorkeuden oletettuihin muutoksiin. (Piirretty kuvasta Johansson ym. 2004.)

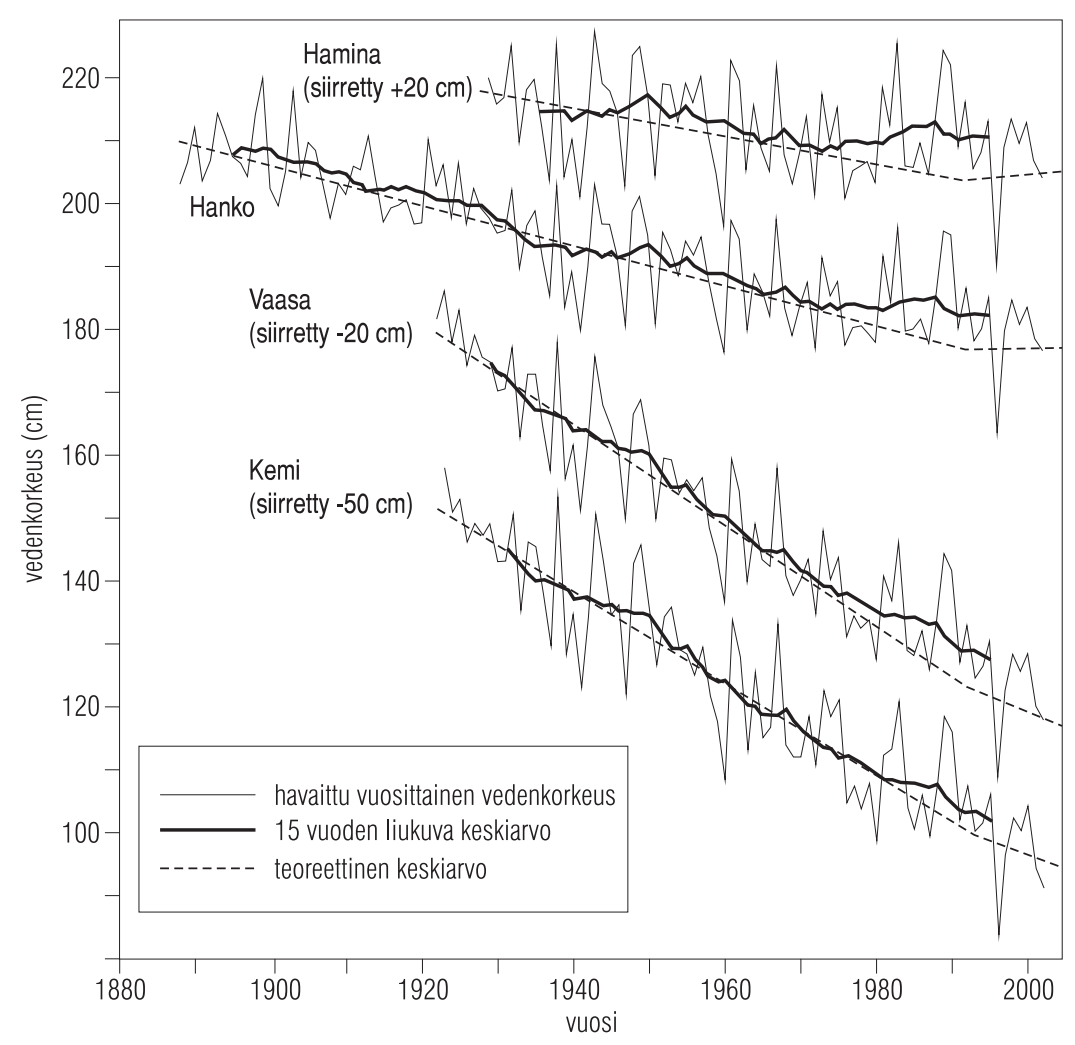

Esimerkiksi Dailidiene ym. (2006) ovat osoittaneet, että vedenkorkeus Liettuan rannikolla on noussut $13,5 \mathrm{~cm}$ sadassa vuodessa, mutta 1960 luvulta lähtien nousu on ollut $3 \mathrm{~mm} /$ vuosi. Näin suuret arvot ovat selitettävissä siten, että maankohoaminen on Itämeren eteläosissa vähäistä, jopa olematonta, eikä näin ole kompensoinut vedenpinnan nousua pitkään aikaan. Tämä yleinen nousu riippuu valtamerten pinnan nousun lisäksi myös vesitaseen muutoksista.

Kun vesibalanssin vaikutus vedenkorkeuteen on tiedossa, voidaan sitä käyttää hyväksi uusien, entistä tarkempien maankohoamislukujen laskemiseen. Kun vähennetään havaitusta vedenkorkeudesta vesibalanssin osuus, jäljelle jäävät maankohoamisen ja valtameren pinnannousun lineaariset vaikutukset. Ne puolestaan voidaan yhdistää niin sanotuksi suhteelliseksi maankohoamiseksi
On myös huomattava, että viime vuosina arvioidut suhteelliset maankohoamisarvot (www. fimr.fi) ovat pienempiä kuin aikaisemmin lasketut. Tämä selittyy sillä, että varhemmin lasketuissa maankohoamisarvioissa on ollut mukana vesibalanssin pitkäaikainen laskeva trendi, joka uusissa arvioissa on korjattu. Maankohoamisen $\left(u_{a i}\right)$ ja globaalisen pinnannousun $(G)$ erotuksena saadaan suhteellinen maankohoamisnopeus

$u_{r i}=u_{a i}-G$

Nykyisen käsityksen mukaan (Kimmo Kahma, henkilökohtainen tiedonanto) Suomen rannikolla Kemissä suhteellinen maankohoaminen on $7,20 \pm 0,27 \mathrm{~mm} /$ vuosi, kun taasen esimerkiksi etelämpänä sijaitsevassa Haminassa luvut ovat paljon pienemmät $(1,62 \pm 0,26 \mathrm{~mm} /$ vuosi).

Selkeitä trendejä on havaittu myös muissa vedenkorkeuteen liittyvissä analyyseissä. Muun 
muassa myös vuositasolla on havaittu nouseva epälineaarinen trendi vedenkorkeuksien vaihtelulle. Tällainen kehitys on havaittu yleisesti Itämeren alueella. 70 viime vuoden havaintojen mukaan maksimivedenkorkeudet ovat kasvaneet esimerkiksi noin $10 \mathrm{~cm}$ Suomen rannikolla. Myös todennäköisyys suurien vedenkorkeuksien esiintymiselle on kasvanut. Nämä ilmiöt liittynevät suuren mittakaavan meteorologisten ja hydrologisten olosuhteiden muutoksiin. Johanssonin (2001) mukaan vaihtelun maksimi Suomen rannikolla osui erityisesti 1960-1980 lukujen talville, jolloin keskihajonnat ja spektriamplitudit kasvoivat dramaattisesti. Tällöin talvimyrskyjen frekvenssi kasvoi. Samaan aikaan vedenkorkeuden alenevan, lineaarisen trendin luonne muuttui: aleneminen alkoi hidastua. Tällainen vaihtelu liittyy ilmaston muutoksiin kuten NAO:n voimistumiseen. Yleisesti ottaen spektrianalyysi osoittaa, että vuosittaisen spektripiikin amplitudi on myös kasvussa (Johansson 2001). Tämä on sopusoinnussa sen kanssa, että vedenkorkeuden vuosisyklin amplitudi on kasvussa. Myös vedenkorkeusmaksimien ja minimien ajankohdat eli vedenkorkeuden vuosisykli on muuttunut. Molempien ääripäiden ajankohta on siirtynyt entistä myöhemmäksi.

Lopuksi voidaan määritellä vuotuiselle keskivedenkorkeudelle $h_{i}(\mathrm{t})$ yhtälö (Johansson ym. 2004)

$h_{i}(t)=h_{g}(t)-u_{i t} t+k_{i} N(t)+l_{i} t+R_{i}+\varepsilon_{h}(t)$

missä $h_{g}(t)$ on globaali keskimääräinen vedenkorkeus, $k_{i} N(t)$ viittaa vesitaseeseen, jossa $N(t)$ on NAO-indeksi ja $k_{i}$ on regressiokerroin, mikä on saatu vedenkorkeuden ja NAO-indeksin välisestä lineaarisesta regressiosta, $l_{i} t$ edustaa muita mahdollisia lineaarisia trendejä kuten suolaisuusmuutoksia, $R_{i}$ on paikkakohtainen vaaitusvakio, joka riippuu vedenkorkeusarvojen suhteesta peruskallioon sidottuun referenssitasoon, ja $\varepsilon_{h i}(t)$ edustaa muita tekijöitä, jotka katoavat pitkän ajan keskiarvoissa.

\subsubsection{Itämeren vedenkorkeuden lyhytaikaiset muutokset}

Vedenkorkeuden lyhytaikaisilla vaihteluilla tarkoitetaan alle kuukauden aikaskaalassa tapahtuvia muutoksia. Lyhimmät vaihtelut (1-24 tuntia) liittyvät tuulen ajovirtaan, vuoroveteen ja altaiden ominaisheilahteluihin. Rannikkovyöhykkeen aallot ja virtaukset aiheuttavat noin $1 \mathrm{~cm}$ :n vedenkorkeusvaihteluita. Vuorovesien merkitys on vähäinen sekoittuen aallokon ja virtausten vaikutusten kanssa siten, että niiden aiheuttamia signaaleja on vaikea erottaa hälystä vedenkorkeusmittauksissa.

Tuuli ja ilmanpainevaihtelut aiheuttavat vedenkorkeusvaihteluita muutamien päivien jaksoista aina useisiin viikkoihin asti. Tuuli vaikuttaa vedenkorkeuteen kasaamalla vettä, mikä on erityisen selvää lahtien pohjukoissa ja tästä johtuvat näiden kohtien suuret ääriarvot. Tuulen vaikutus voi olla hyvin paikallista. Korkea ilmanpaine painaa vedenpintaa alaspäin. Yhden millibaarin paine-ero vastaa suunnilleen yhtä senttimetriä vedenkorkeudessa (barometri-efekti). Normaali ilmanpaineen vaihtelu voi siis aiheuttaa useiden kymmenien senttimetrien vedenkorkeusvaihtelun. Veden tiheys vaikuttaa myös vedenkorkeuteen, mutta sen osuus tulee esille vasta kuukausien keskiarvoissa. Itämerellä vallitseva pysyvä horisontaalinen suolaisuusgradientti aiheuttaa sen, että pohjoisessa vesi on makeampaa ja siis kevyempää kuin etelässä, joten vedenkorkeus on keskimääräinen suurempi pohjoisessa. Keskimäärin vedenkorkeus laskee Perämeren arvoista noin 35-40 cm Skagerrakiin mentäessä. Itämeren keskimääräistä vedenkorkeutta edustaa Tukholman edustalla oleva Landsort, joka on yksisolmuisen seichen solmupiste. 
Itämeren kaltaisessa puolisuljetussa meressä tilavuuden vaihtelu on läheisesti kytköksissä vedenkorkeusvaihteluihin. Kuten edellisessä luvussa esitettiin, niin tilavuuden muutokset johtuvat vedenvaihdosta Tanskan salmien kautta, makean veden tulosta ja lämpötilanvaihteluihin liittyvästä laajenemisesta tai supistumisesta, joista viimeksi mainitun vaikutus vedenpinnan muutoksiin on luokkaa $2 \mathrm{~cm}$. Vedenvaihto Tanskan salmien kautta on tärkein vedenkorkeuden muutoksen syy yli kuukauden aikaskaalassa.

\subsubsection{Mitattuja vedenkorkeuksia, minimi- ja maksimiarvoja}

Vedenkorkeuden ääriarvoista on esimerkkinä itäinen Suomenlahti ja erityisesti Pietari, jossa vedenkorkeusvaihteluilla on suuri käytännön merkitys. Siellä tulvaksi katsotaan tilanne, jossa vedenpinta nousee yli 1,6 metriä nollatason yläpuolelle. Näin on tapahtunut yli 280 kertaa vuoden 1703 jälkeen. Suurin vedenkorkeus Pietarissa, ja samalla koko Itämerellä, oli vuonna 1824 , jolloin pinta oli $412 \mathrm{~cm}$ yli nollatason. Tulva-aalto muodostuu länsimyrskyllä syvän matalapaineen pakottamana, progressiivisena aaltona. Itään mennessä aallot vahvistuvat, kun altaan poikkipinta-ala pienenee. Tällainen oskillaatio voi kasvaa muutamista kymmenistä senteistä Suomenlahden länsireunalla aina 3-4 metriin itäisellä Suomenlahdella (Alenius ym. 1998). 1970-luvulla aloitettiin Leningradin padon rakennus turvamaan kaupunkia tulvia vastaan.

Suomen rannikolla on mitattu suuria vedenkorkeusvaihteluita (taulukko 8.1). Suurin arvo on mitattu Perämeren pohjukassa, Kemissä (201 $\mathrm{cm})$. Suomenlahdella suurin mitattu arvo on idässä, Haminassa $(197 \mathrm{~cm})$. Vaikkei Hamina sijaitse kovin kaukana Pietarista, niin maksimien ero on varsin suuri. Haminan aikasarja on huomattavasti Pietarin aikasarjaa lyhyempi, mutta pääsyy on se, että Pietari sijaitsee altaan pääs- sä. Minimiarvojen poikkeamat nollatasosta ovat kaikilla mareografiasemilla vastaavia maksimeita pienempiä, koska minimiarvot aiheuttavat pohjoisenpuoleiset tuulet eivät ole yhtä voimakkaita ja pitkäkestoisia kuin maksimiarvot aiheuttavat länsi- ja lounaistuulet. Vedenkorkeusmittauksia (luku 3) on tehty myös muualla Itämeren alueella pitkään: pisin yhtenäinen havaintosarja on Tukholmasta vuodesta 1774 lähtien. Myös muissa Itämeren maissa havaintosarjojen pituus on tyypillisesti yli 100 vuotta ja havaitut maksimija minimiarvot ovat samankaltaisia Suomessa mitattujen arvojen kanssa.

Keskimääräiset vedenkorkeusvaihtelut ovat luonnollisesti huomattavasti ääritilanteita pienempiä. Johansson ym. (2001) ovat analysoineet Suomen vedenkorkeuksia ja laskeneet eri asemille pitkän ajan keskihajonnan keskiarvon. Kuten on oletettavaa, suurimmat vaihtelut tapahtuvat lahtien päissä. Kemissä hajonta on noin $28 \mathrm{~cm}$ ja Haminassa $25 \mathrm{~cm}$, kun taas minimi on Degerbyssä $(19 \mathrm{~cm})$ lähellä Itämeren solmupistettä. Tällainen vaihtelu on tyypillistä myös muualla Itämerellä.

Viime aikoina vedenkorkeuden ääritilanteita on toistunut aiempaa useammin ja myös uusia vedenkorkeuden paikallisia ääriarvoja on mitattu, kuten Suomen rannikolla 9.1.2005, jolloin Haminassa saavutettiin $197 \mathrm{~cm}$ vedenkorkeus ja Helsingissä $151 \mathrm{~cm}$. Pohdittaessa syitä tähän muutokseen havaitaan, että kyseessä on itse asiassa useiden tekijöiden yhteisvaikutus. Vedenkorkeuden ääriarvojen kannalta keskeinen tekijä on globaali merenpinnan nousu. Arvioiden mukaan keskimääräinen vedenkorkeus voisi nousta $10-90 \mathrm{~cm}$ vuoteen 2100 mennessä (luku 9). Näin suuri ilmaston lämpenemisen aiheuttama nousu luo perusedellytykset suurille vedenkorkeuksille. Itämeren vedenkorkeuden on todettu olevan selkeästi kytkennässä NAOindeksin kanssa varsinkin talvisin. Lisääntyvä myrskyisyys ja suuret NAO-indeksin arvot ovat omiaan kasvattamaan mahdollisuutta äärimmäi- 
Taulukko 8.1. Suomen mareografiasemilla mitatut vedenkorkeuksien ääriarvot teoreettisen keskiveden suhteen (lähde: Merentutkimuslaitos)

\begin{tabular}{|l|l|l|l|}
\hline Asema & Maksimi & Minimi & Aloitusvuosi \\
\hline Kemi & $+201 \mathrm{~cm}(22.9 .1982)$ & $-125 \mathrm{~cm}(21.11 .1923)$ & 1922 \\
\hline Oulu & $+183 \mathrm{~cm}(14.1 .1984)$ & $-131 \mathrm{~cm}(14.1 .1929)$ & 1922 \\
\hline Raahe & $+162 \mathrm{~cm}(14.1 .1984)$ & $-129 \mathrm{~cm}(4.10 .1936)$ & 1922 \\
\hline Pietarsaari & $+139 \mathrm{~cm}(14.1 .1984)$ & $-113 \mathrm{~cm}(4.10 .1936)$ & 1922 \\
\hline Vaasa & $+144 \mathrm{~cm}(14.1 .1984)$ & $-100 \mathrm{~cm}(14.1 .1929)$ & 1922 \\
\hline Kaskinen & $+148 \mathrm{~cm}(14.1 .1984)$ & $-91 \mathrm{~cm}(31.1 .1998)$ & 1926 \\
\hline Mäntyluoto & $+132 \mathrm{~cm}(14.1 .1984)$ & $-80 \mathrm{~cm}(10.4 .1934)$ & 1925 \\
\hline Rauma & $+121 \mathrm{~cm}(6.12 .1986)$ & $-77 \mathrm{~cm}(10.4 .1934)$ & 1933 \\
\hline Turku & $+130 \mathrm{~cm}(9.1 .2005)$ & $-74 \mathrm{~cm}(10.4 .1934)$ & 1922 \\
\hline Föglö & $+100 \mathrm{~cm}(18.1 .1983)$ & $-71 \mathrm{~cm}(10.4 .1934)$ & 1923 \\
\hline Hanko & $+132 \mathrm{~cm}(9.1 .2005)$ & $-78 \mathrm{~cm}(10.4 .1934)$ & 1887 \\
\hline Helsinki & $+151 \mathrm{~cm}(9.1 .2005)$ & $-92 \mathrm{~cm}(22.3 .1916)$ & 1904 \\
\hline Hamina & $+197 \mathrm{~cm}(9.1 .2005)$ & $-110 \mathrm{~cm}(20.11 .1975)$ & 1928 \\
\hline
\end{tabular}

siin vedenkorkeuksiin. Myös Itämeren vesitaseen muutokset vaikuttavat vedenkorkeutta kasvattavalla tavalla, koska sademäärät ja jokivirtaamat ovat ilmeisesti nousussa ilmaston yleisen lämpenemiseen liittyen. Kovat myrskyt ja korkeat aallot aiheuttavat rannikon eroosiota, joka altistaa rannikkoalueita suurten vedenkorkeuksien vaikutuksille. Jääpeitteen laajuuden ja keston väheneminen edesauttaa ääritilanteiden kehittymistä, sillä jääpeitteen vedenpinnan muutoksia vaimentava vaikutus vähenee. Yksittäisissä tilanteissa myös Itämeren ominaisheilahtelut eli seichet voivat vahvistaa hetkellisten vedenkorkeusmaksimeja. 


\section{Itämeren toiminta systeeminä}

\subsection{Taustaa}

Luvuissa 4-7 on käyty läpi Itämeren fysiikan pääpiirteet ja luvussa 8 on tarkasteltu kriittisiä prosesseja ja äritilanteita. Tässä luvussa analysoidaan Itämeren toimintaa systeeminä nyt ja tulevaisuudessa. Ensin tarkastellaan lyhyesti Itämeren erityispiirteitä ja kytkentöjä valtameriin ja ilmastoon, sitten Itämeren fysiikassa sadan viime vuoden aikana tapahtuneita muutoksia ja fysikaalisten tekijöiden muutosten heijastusvaikutuksia ekosysteemien toimintaan. Samassa yhteydessä luodaan myös katsaus ihmisen toiminnan vaikutuksista Itämereen sekä hyvin tärkeänä elementtinä pohditaan globaalisen ilmastonmuutoksen vaikutuksia Itämeren tulevaisuuteen. Lopuksi pohditaan mitä haasteita Itämeren fysiikan tutkimuksessa on edessä lähivuosikymmeninä.

\subsubsection{Itämeren murtovesialtaan erityispiirteet}

Itämeri on pieneksi välimereksi luokiteltu murtovesiallas, jonka kaltaisia maailmassa on vain muutamia. Itämeren pienuuden ja mataluuden lisäksi sen fysiikan kannalta on oleellista hyvin rajoitettu vedenvaihto Pohjanmeren kanssa. Tästä seuraa moninaisia vaikutuksia. Itämeren ja Pohjanmeren välistä vedenvaihtoa säätelevät kapeat ja matalat Tanskan salmet. Pohjanmereltä Itämereen pohjanläheisissä kerroksissa sisään virtaava raskas suolainen vesi joutuu ylittämään monia kynnyksiä matkalla pohjoiseen ja itään. Näin ollen suolainen vesi ei pääse vapaasti leviämään Itämeren ääriosiin asti ja suolaisuus pieneneekin huomattavasti, kun etäisyys Tanskan salmista kasvaa. Suolaisuuden mukana vähenee varsinaisen merilajiston märä ja monet merilajit pienenevät kooltaan siirryttäessä vähäsuolaisempaan veteen. Esimerkiksi Tanskan vesillä syötävän kokoiseksi kasvava sinisimpukka jää rannikollamme pieneksi. Toisaalta Itämerelle tulee runsaasti makeaa vettä jokivirtaamina sekä sateena. Itämeren vesitase onkin voimakkaasti positiivinen. Makea ja kevyt vesi virtaa ulos pintakerroksessa. Tyypillisesti noin 50-80 metrin syvyydellä sijaitseva halokliini erottaa nämä suolaisuudeltaan ja alkuperältään erilaiset vesimassat toisistaan. Tämä suolaisuuden rakenne on luonteeltaan pysyvä, eikä syksyinen konvektio eivätkä kovatkaan tuulet pysty sekoittamaan vesimassoja pohjaan asti niillä alueilla, joissa pysyvä halokliini esiintyy.

Itämeren syvänteissä vallitsee nykyään usein happikato, kun biologinen toiminta kuluttaa hapen loppuun, eikä pinnan kautta pohjanläheisten kerrosten happitilanne pääse kohenemaan halokliinin takia. Syvänteissä tilannetta 
voi parantaa vain Tanskan salmien kautta tuleva huomattava suolaisen ja hapekkaan veden sisäänvirtaus, jonka yhteydessä suolainen, raskas vesi pystyy syrjäyttämään pohjanläheisen hapettoman vesimassan. Näitä huomattavia suolapulsseja esiintyy kuitenkin hyvin epäsäännöllisesti, suurin piirtein kerran vuosikymmenessä, joten happikato on lähes pysyvä olotila syvännealueilla. Hidas vedenvaihto Pohjanmeren kanssa heijastuu niin, että Itämeren veden uudistumiseen kokonaisuutena menee noin 50 vuotta. Siispä Itämeren vesimassan muisti on pitkä.

Itämeren pohjien happitilannetta pitää kuitenkin tarkastella mahdollisimman pitkässä perspektiivissä, jotta opitaan ymmärtämään, mikä osuus nykyisin usein esiintyvästä happikadosta on ihmisen aikaansaamaa ja mikä taasen kuuluu luonnollisen vaihtelun piiriin. Pisimmälle taaksepäin happitilanteen kartoittamisessa päästään sedimenttitutkimusten avulla, joiden mukaan Itämereen on aina kuulunut syvien pohjien ajoittainen hapettomuus. Eräät hapettomuuskausista kertovat sedimenttiaineistot ulottuvat noin 7.500 vuoden päähän. Itämeren suojelu pitääkin asettaa raameihin, joihin kuuluvat eripituiset stagnaatiot ja pohjan ajoittainen hapen puute. Suurin muutos luontaiseen tilanteeseen on kuitenkin se, että Itämeren syvän veden hapen kulutus on lisääntynyt selvästi rehevöitymisen myötä. Se johtuu lisääntyneiden ravinteiden aiheuttamasta perustuotannon kasvusta, joka puolestaan aiheuttaa entistä suuremman laskeutuvan eloperäisen aineksen määrän. Nykyisin uusiutuneet happivarastotkin auttavat syvänteiden happitilannetta vain lyhyeksi ajaksi, mikä on ongelma muun muassa turskan eteläisillä lisääntymisalueilla Bornholmin altaassa. Samalla pohjan pintasedimentin sisältämä ravinnepitoisuus on noussut selvästi.

Joskus esitetty ajatusleikki Tanskan salmien ruoppaamisesta ja suolaisen veden pulssien lisäämisestä sitä kautta ei toimi, sillä Itämerta ei pystytä muuttamaan joka vuosi hapettuvaksi.
Nykyisin vuotta pidemmät stagnaatiokaudet johtavat nopeasti syvän veden hapettomuuteen. Teoreettisena ratkaisuna toimisi ehkä Varsinaisen Itämeren muuttaminen Pohjanlahden kaltaiseksi altaaksi, jossa ei ole pysyvää halokliinia, mutta käytännössä sekään ei ole mahdollista.

Itämeren pohjan hapettomuus on ilmeisesti aina vaikuttanut ravinteiden poistumiseen siten, että osa pohjaan laskeutuneesta fosforista on saavuttanut pinnan uudelleen ruokkien sinileväkukintoja. Sinilevät voivat sitoa ilmasta veteen liuennutta typpeä, joten kaikista muista leväryhmistä poiketen ne ovat vain fosforirajoitteisia. Sinileväkukinnoista on myös todisteita koko Itämeren tunnetun historian ajalta. Sinilevien yhteyttämispigmenttejä, joita muilla leväryhmillä ei ole, on löytynyt useita tuhansia vuosia vanhoista sedimenteistä. Itämeren suojelussa pitää muistaa, että kesän sinileväkukinnat ovat luontainen osa ekosysteemiä. Ihmisen toiminta on vaikuttanut Itämeren ravinnetaseeseen siten, että erilaiset leväkukinnat ovat voimistuneet, pohjan hapen kulutus on kasvanut ja koko ekosysteemi kärsii rehevöitymisestä. Selvin osoitus veden kerrostuneisuuden vaikutuksesta sinileväkukintoihin on varsinaisen Itämeren ja Pohjanlahden vertailu. Pohjanlahdella sinileväkukinnat ovat vähäisiä johtuen siitä, että lähinnä jokivesien tuoma ulkoinen fosforikuormitus on vähäistä ja pohjan happitilanne on hyvä, jolloin sisäistä kuormitusta ei synny. Varsinaisella Itämerellä pelkästään nykyisen tasoinen sisäinen kuormitus voi pitää yllä huomattavaa sinilevien kasvua ja ulkoinenkin kuormitus on huomattavaa. Sisäinen kuormitus hidastaa Itämeren toipumista liiasta ravinnemäärästä, mutta laskelmien mukaan ulkoisen fosforikuormituksen alentaminen vaikuttaa sinileväkukintoihin ja se onkin ainoa tie pysyvään ratkaisuun. Nykyisen fosforitason tehokas alentaminen vaatii kuitenkin myös pohjan hapen kulutuksen tehokasta vähentämistä. 
Pohjan hapen kulutukseen vaikuttaa laskeutuvan aineksen määrä ja sen laatu. Bakteeritoiminta hajottaa tuoretta levämateriaalia nopeasti, ja seurauksena on hapen kuluminen. Itämeri on niin matala, että levät laskeutuvat nopeasti pysyvän halokliinin alapuolelle. Laskeutuminen kestää kevätkukinnan raskailla lajeilla vain muutaman päivän. Levämassan hajoamista tapahtuu laskeutumisen aikanakin, mutta hyvin vähän verrattuna valtameriin, joissa ainoastaan murtoosa happea kuluttavasta eloperäisestä aineksesta saavuttaa syvän veden. Itämeren sedimentin pinnalla onkin muutaman millin tuore laskeutunut kerros, kun taas valtamerien pohjille samanlaisen kerroksen laskeutuminen voi viedä vuosikymmeniä. Laskeutuvan eloperäisen aineksen määrään voi vaikuttaa vain alentamalla leville käyttökelpoisten ravinteiden määrää. Nykyisen tiedon mukaan suurin osa laskeutuneesta eloperäisestä aineksesta on peräisin levien kevätkukinnasta, sillä sinilevät kelluvat ja hajoavat lähinnä pintakerroksessa. Sinileväkukinnasta poiketen Itämeren kevätkukinta on lähinnä typpiravinteen rajoittama, joten laskeutuvan aineksen tehokkain rajoittaminen vaatii Itämeren typen tason vähentämistä. Siten typen kuormituksen rajoittaminen vaikuttaa koko ekosysteemiin mukaan lukien kesän sinileväkukinnat. Itämeren tehokas suojelu vaatiikin niiden keinojen löytämistä, joilla pystytään rajoittamaan kummankin pääravinteen, sekä typen että fosforin, määrää.

Itämeren pohjoisen sijainnin vuoksi auringonsäteilyn vuodensisäinen vaihtelu on suuri. Tämä näkyy ilman lämpötilan ja sitä kautta meren lämpötilan suurena vuoden sisäisenä vaihteluna. Kesäaikaan Itämerellä syntyy lämmin, sekoittunut pintakerros, jonka alarajalla on lämpötilan harppauskerros eli termokliini. Syksyisin ilman jäähtymisen sekä voimakkaiden tuulten vuoksi syntyy konvektiota, jolloin lämpötilan kerrosrakenne vähitellen katoaa. Konvektiivisen sekoittumisen alarajana on halokiini. Niillä alueilla, joissa halokliinia ei esiinny, vesimassat sekoittuvat pohjaan asti. Itämerellä meren ja ilman välinen vuorovaikutus on siis voimakkaasti vuodenajasta riippuva. Keväällä ja alkukesällä meri on ilmaa kylmempi, jolloin ilma luovuttaa lämpöä mereen, kun syksyllä ja talvella tilanne on päinvastainen. Tämä johtuu siitä, että meren suuri vesimassa seuraa viiveellä ilman lämpötilan muutoksia.

Itämeren alueella myös vuosien väliset ilmastolliset vaihtelut ovat suuria. Hyvänä esimerkkinä ovat Itämerestä talviseen aikaan jäätyvän osan suuret vaihtelut. Joinakin vuosina Itämeri voi jäätyä kokonaan, kun taas lauhana talvena vain noin 10 \% pinta-alasta jäätyy. Talviajan ilman keskilämpötilan hyvänä mittarina voidaankin käyttää jääpeitteen maksimaalista laajuutta. Samat vuosien väliset erot määräävät osittain kesän sinilevien kasvua. Samanlaisissakin ravinneoloissa voidaan - kesän lämpötilasta riippuen - päätyä lähes täysin sinilevättömään kesään tai vaikeaan sinilevävuoteen. Sen vuoksi keväisin annettavat sinileväennusteet ovat luonteeltaan hyvin epävarmoja ja ne kuvaavat lähinnä sinilevien kasvun kannalta parasta ja siis meren tilan kannalta huonointa mahdollista tilannetta eli sitä, että Itämeren alueella on kaunis ja lämmin kesä.

\subsubsection{Itämeren ilmastolliset kytkennät}

Itämeren alueen ilmastolliset vaihtelut ovat vuosien välillä siis varsin suuria. Leutoina talvina Itämeren ilmastoa karakterisoivat lämpimät länsituulet ja transienttien syklonien mukanaan siirtämät suuret lämpömäärät, ja tätä kautta Pohjois-Atlantin merivirran (Golf-virran) merkitys korostuu. Ajoittain Itämeren alue kuuluu taas kylmän talvikorkeapaineen piiriin, jolloin varsin kylmät ilmamassat voivat olla vallitsevina useiden kuukausien ajan. Esimerkkinä tästä ilmaston suuresta vaihtelevuudesta on Helsingin tammikuun keskilämpötila, joka vaihteli vuosina 1900-2000-16,5 ja +1,4 asteen välillä. Kesäai- 

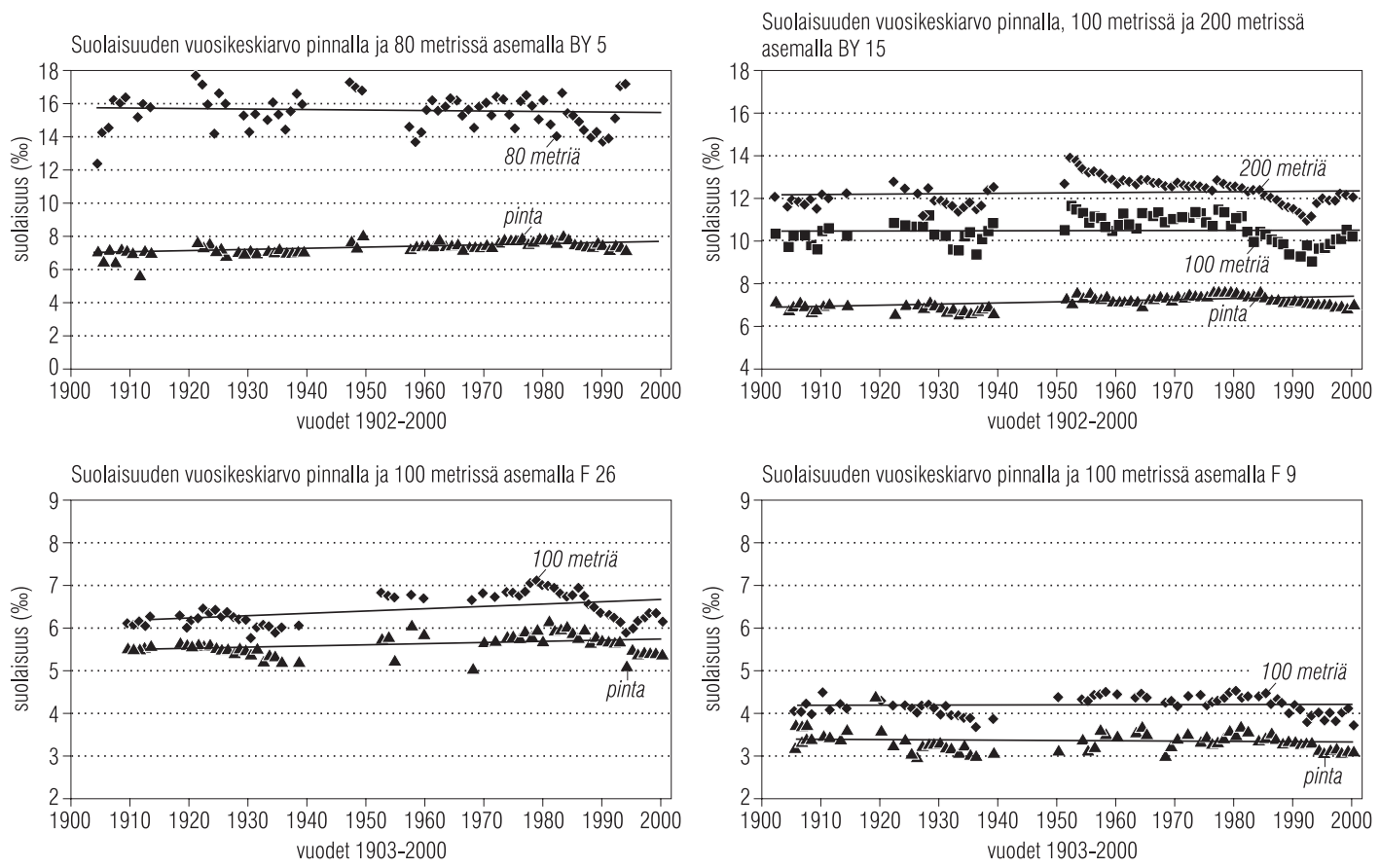

Kuva 9.1. Suolaisuuden pitkäaikaismuutos eri syvyyksillä: Bornholmin allas (BY5), Itäinen Gotlannin allas (BY15), Selkämeri (F26) ja Perämeri (F9). (Piirretty Fonseliuksen ja Valderraman [2003] mukaan.)

kana auringonsäteily on voimakasta ja erot vuosien välillä ovat talviaikaa selvästi pienempiä.

NAO:n merkitys Pohjois-Euroopan ilmastoon on suurimmillaan talviaikaan, kun auringonsäteilyn osuus lämpötaloudessa on pienemmillään. $\mathrm{NAO}$ on positiivinen, kun etelässä on korkeapaine ja pohjoisessa matalapaine, mikä merkitsee leveyspiirien suuntaista kiertoliikettä, meidän leveyspiireillämme lauhoja länsituulia. Tällöin matalapainetoiminta on merkittävää kuljettaen mukanaan suuria lämpömääriä, jotka tasoittavat etelän ja pohjoisen lämpötilaeroja. On todettu, että NAO-indeksin ja lauhojen jäätalvien sekä suurten vedenkorkeuksien korrelaatio on Itämerellä selkeä. Myös Pohjanmeren veden sisäänvirtaus Itämerelle on tällöin voimakasta. Kylmiin talviin liittyvät negatiiviset NAO-indeksin arvot. Tällöin pohjoisessa on korkeapaine ja etelässä matala, jolloin meillä vallitsevat idän ja pohjoisen väliset tuulet, ja talvikuukausien keskilämpötilat ovat sangen alhaisia. Niiden talvien lukumäärä, jolloin NAO-indeksi on positiivinen, on ollut kasvussa viime vuosikymmeninä ja tämän katsotaankin olevan eräs merkki Itämeren alueen ilmaston lämpenemisestä. Myös jokivirtaamien ja NAO:n välillä on havaittu riippuvuus.

Jos NAO-indeksi kyettäisiin ennustamaan, sen avulla voitaisiin ennakoida lämpötilojen, sateisuuden ja jäätalvien muutoksia sekä niiden tulevaa kehitystä. Tälläistä ei kuitenkaan ole näkyvissä. Jotkut ekologian piirteet on voitu yhdistää NAO-indeksiin. Selkeimmät merkit yhteydestä on saatu eläinplanktonin lajiston ja määrien vaihteluista. Havaitut muutokset liittyvät lähinnä suolaisuuden kehitykseen.

\subsection{Havaitut muutokset}

Suolaisuuden muutokset vuosikymmenten pituisissa jaksoissa riippuvat vesitasekomponenttien muutoksista eli jokivirtaamista, vedenvaihdosta Pohjanmeren kanssa, sadannasta ja haihdunnasta (kuva 9.1). Lisäksi lämpöolojen ja vesimassojen 

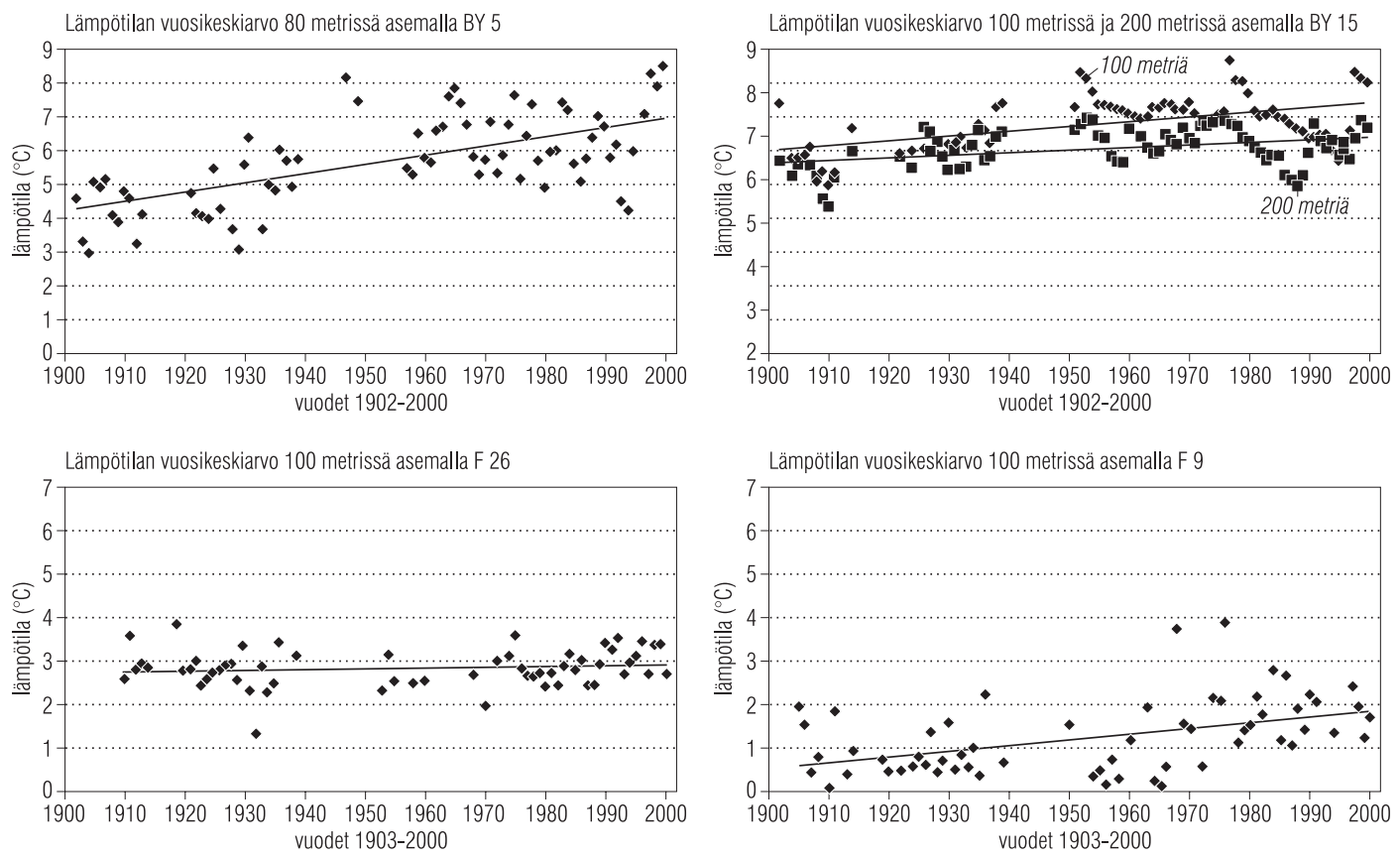

Kuva 9.2. Pohjalämpötilan pitkäaikaismuutos eri syvyyksillä: Bornholmin allas (BY5), Itäinen Gotlannin allas (BY15), Selkämeri (F26) ja Perämeri (F9). (Piirretty Fonseliuksen ja Valderraman [2003] mukaan.)

sekoittumiseen liittyvät vaihtelut vaikuttavat asiaan. On syytä huomata, että suolaisuuden vaihtelut eivät ole olleet viime vuosisadalla kovin suuria, mutta selviä trendejä on kuitenkin nähtävissä. Keskisellä Itämerellä suolaisuus laski 1930luvun alussa, mutta on noussut toisen maailmansodan jälkeen Itämeren eri osissa $(0,5-0,9$ $\%$ ). Suolaisuuden huippu saavutettiin 1950-luvun alussa liittyen silloiseen Itämereen tulleeseen suureen suolapulssiin. 1960-luvun alussa oli pieni minimi, jonka jälkeen suolaisuus pysyi melko lailla vakiona vuoteen 1978 asti. Tämän jälkeen suolaisuus pieneni vuoteen 1993 asti, jolloin 17 vuoden stagnaation jälkeen tuli jälleen suuri suolapulssi. Pintavesi ja alusvesi ovat käyttäytyneet melko lailla samalla tavoin. Vaikka halokliinin paikka on vaihdellut noin 20 metriä, stabiliteetti on pysynyt vahvana. Pohjan suolaisuuden vaihteluvälin suuruus on 3-4 kertaa suurempi kuin pintasuolaisuuden. Suolaisuuden vaihtelua suhteessa jokivirtaamien muutoksiin on myös tutkittu. Launiaisen (1982) mukaan pienenty- vät jokivirtaamat näkyvät pienen viiveen jälkeen kasvavina suolaisuuksina ja kääntäen.

Vaihtelut Itämeren suolaisuusoloissa liittyvät Pohjois-Euroopan ilmasto-olojen vaihteluihin. Erityisesti tuuli- ja painekentän vaihtelut vaikuttavat suolapulssien esiintymiseen ja sademäärät jokivirtaamiin. On myös esitetty teorioita, joiden mukaan kasvavat sademäärät suurentavat makean veden ulosvirtausta Itämerestä. Tällöin Kattegatin vedet muuttuisivat nykyistä vähäsuolaisemmiksi, uusien suolapulssien synty vaikeutuisi, ja Itämeren pitkäaikainen suolapitoisuus alenisi.

Itämeren pintalämpötila on monien tutkimusten mukaan noussut viimeisen sadan vuoden aikana noin 0,5 astetta. Syyt lämpötilan nousuun eivät ole vielä täysin selviä. Pohjan läheisten vesikerrosten lämpötilamuutokset liittyvät usein suolapulssien yhteydessä tapahtuviin nopeisiin heilahduksiin, eikä varsinaista trendiä niiden lämpötilakehityksestä ole helppo löytää (kuva 9.2). Jonkinlaista nousua on kuitenkin ollut ha- 


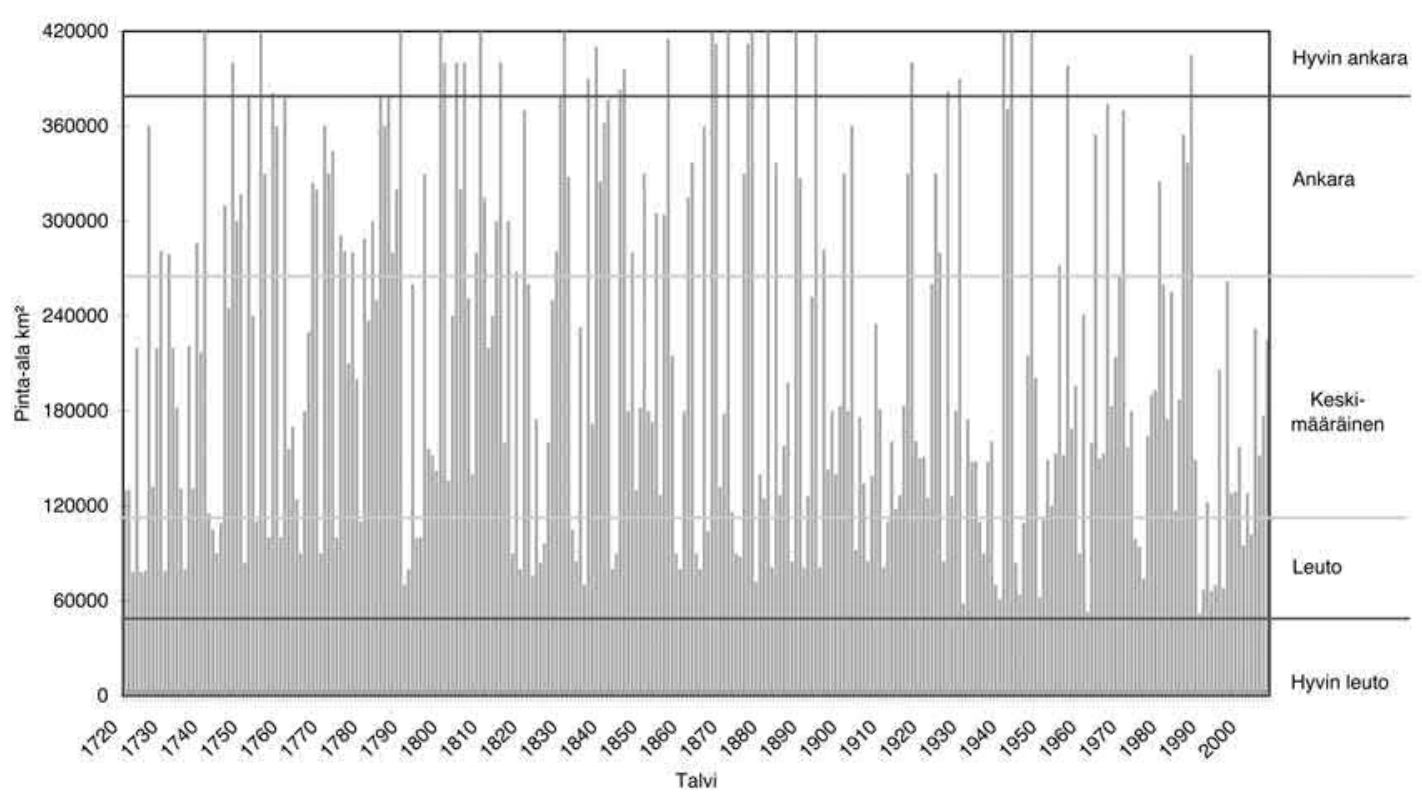

Kuva 9.3. Itämeren ja Kattegatin yhteinen jääpeitteen vuotuinen pinta-ala vuodesta 1720 lähtien. (Seinä ja Palosuo 1993)

vaittavissa. Viime vuosina on myös esiintynyt kesällä tapahtuneita pulsseja, jolloin Itämereen on virrannut pohjanläheisessä kerroksessa hyvin lämmintä vettä, mikä selittää hyvin suuret alusveden lämpötilamuutokset.

Itämeren jääpeitteen vuotuinen vaihtelu on hyvin suurta, sillä tämä meri sijaitsee globaalisen merijäävyöhykkeen reunalla. Ankarina talvina koko Itämeri jäätyy, kun taas leutoina talvina vain $10 \%$ sen alasta, Perämeri ja Suomenlahden pohjukka, saavat jääpeitteen. Keskimääräinen vuotuinen jään laajuus on 45 \% Itämeren pinta-alasta. Koska Itämeren lämpötaloudellinen muisti on vain 2-3 kuukautta, jään vuotuista laajuutta ei pitkälti etukäteen voida ennakoida. Jään määrä on kriittinen tulevan kevään fysikaalisia ja ekologisia olosuhteita arvioitaessa.

Itämeren jääoloista on pitkiä havaintosarjoja, jotka kuvaavat jääoloja rannikolla. Pisin on Risto Jurvan aikasarja (1720-) suurimmasta vuotui- sesta jään laajuudesta (kuva 9.3). Sitä hallitsee voimakas satunnaiselta näyttävä vaihtelu ilman muuta ajallista rakennetta. Itämeri on ollut kauttaaltaan jäässä keskimäärin kerran 30 vuodessa. Viimeksi näin on tapahtunut vuonna 1947, tosin vuonna 1987 jään pinta-ala oli suurimmillaan 96 \% Itämeren alasta. Hyvin leutoja talvia oli puolestaan 1980- ja 1990-lukujen taitteessa, erityisesti vuonna 1992 Perämeri oli vain muutaman viikon kauttaaltaan jäässä.

Itämeren jäätalvien pitkäaikainen kehitys on läheisessä suhteessa vallitseviin sääoloihin. Koska ilman lämpötila Itämeren alueella on vahvasti sidoksissa NAO-indeksiin, tämä korreloi hyvin jäästatistiikan kanssa. Länsivirtausten dominoidessa (korkea NAO-indeksi) ne tuovat lauhaa Atlantin ilmaa ja sen myötä leutoja jäätalvia, kun taas matalan indeksin aikana mantereinen ilmasto kylmine talvineen vallitsee Itämeren alueella. 


\subsection{Ihmisen vaikutus Itämereen}

Ihmisen vaikutus Itämeren ekosysteemiin on ollut havaittavissa jo 1800 -luvulla. Silloin vaikutukset ulottuivat kuitenkin vain hyvin rajoitetuille alueille kaupunkiasutuksen yhteyteen. Suomessa sisälahdet olivat jo 1900-luvun alussa niin rehevöityneitä, että esimerkiksi Töölönlahden sinivihreästä vedestä eli sinileväkukinnoista kirjoitettiin aikoinaan pääkaupungin lehdissä. Sedimenttitutkimukset ovat paljastaneet Suomen kaupunkien lähivesien rehevöitymisen alkaneen paikoin jo 1850-luvulla. Silloin syynä oli - kuten nykyisinkin - ravinteiden pääsy mereen. Kaupunkien lähivesien tila oli huonoimmillaan 1960- ja 1970-luvuilla. Erilaisten vesiensuojelutoimenpiteiden, muun muassa hyvin toimivien keskuspuhdistamojen rakentamisen sekä tehokkaan fosforin- ja typenpoiston ansiosta tilanne on parantunut huomattavasti entiseen verrattuna. Ongelmina ovat kuitenkin edelleen vanhat päästöt matalien alueiden pohjissa. Sedimentissä on monin paikoin runsaasti ravinteita, jotka hidastavat meren puhdistumista. Toisena ongelmana ovat pitkäikäiset myrkyt kuten dioksiinit ja TBT (tributyltiini), jotka pääsevät ravintoverkkoon, vaikka niiden käyttöä on rajoitettu tai kokonaan kielletty jo vuosia sitten. Tunnetut esimerkit Itämeren ympäristömyrkyistä (DDT ja raskasmetallit) kertovat ekosysteemiin päässeiden pitkäikäisten yhdisteiden erittäin hitaasta poistumisesta. Ongelmana eivät enää välttämättä olekaan nykyiset vaan vanhat päästöt, jotka ovat varastoituneet pohjasedimentteihin.

Suomen rannikkoa kuormittavat kaupunkien päästöjen lisäksi muun muassa maatalouden, teollisuuden ja haja-asutuksen ravinnepäästöt. Teollisuuslaitosten päästöt on rajattu nykyisin tehokkaasti, mutta maatalous on edelleen suuri ongelma erityisesti Etelä-Suomessa. Sedimenttitutkimusten mukaan maatalousvaltaisilla valuma-alueilla rehevöityminen alkoi Toisen Maailmansodan jälkeen ja se on lisääntynyt edelleen.
Näillä valuma-alueilla ei ole havaittu myönteistä kehitystä. Syitä tähän voi olla useita, mutta ilmeisesti, huolimatta kaikesta yrityksestä, valuma-alueilta tulee edelleen liikaa ravinteita rannikolle. Maatalousvaltaisten valuma-alueiden rehevöittämillä rannikkoalueilla on yleensä kuitenkin hyvät toipumismahdollisuudet, sillä niiden pohjalle on usein kertynyt vähän eloperäistä ainesta. Ongelman ratkaisu olisikin saada valumien sisältämät ravinnemäärät kuriin. Kalankasvatus on edelleen paikallisesti voimakas kuormittaja. Suomella on voimassa kansallinen Itämeriohjelma, minkä lisäksi Suomessa on suunniteltu vuoteen 2015 ulottuvia vesiensuojelun suuntaviivoja.

Koko Suomenlahden perustuotanto on muuta Itämerta korkeammalla tasolla. Osasyynä tähän saattaa olla luontainen rehevyys, sillä Suomenlahden valuma-alue on hyvin laaja lahden pinta-alaan nähden, mutta kaikki viittaa ihmisen vaikuttaneen huomattavasti koko Suomenlahteen. Muutoksen suuruuden arviota vaikeuttaa se seikka, ettei meillä ole kunnon vertailuaineistoa 1970-lukua edeltävältä ajalta. Sedimenttien sisältämä eloperäinen aines lisääntyi kuitenkin voimakkaasti jo ennen sitä. Suomenlahden perustuotanto on kasvanut 1970-luvulta nykypäivään ainakin kaksinkertaiseksi. Kaikki viittaa siihen, että Suomenlahteen tuleva ravinnekuormitus on aivan liian suuri. Syynä on ollut kaikkien rannikkovaltioiden toiminta, mutta tällä hetkellä suurin yksittäinen Suomenlahden kuormittaja on Pietarin alue. Muualla vesiensuojelutoimet ovat vaikuttaneet kuormituksen kehitykseen myönteisesti jo jonkin aikaa, mutta Pietarin kaupungin jäteveden puhdistus on vasta nyt modernisoitumassa.

Avomerialueen rehevöitymistä hidastaa ravinteiden hautautuminen pohjaan ja rannikkovyöhykkeen niin sanottu suodatusvaikutus. Viimeksi mainittu tarkoittaa ravinteiden jäämistä lähelle rannikkoa. Tämä näkyy parhaiten Pietarin edustalla, jossa suuri osa valtaisasta ravinnekuormituksesta jää lähelle kuormituslähdettä biologisen 


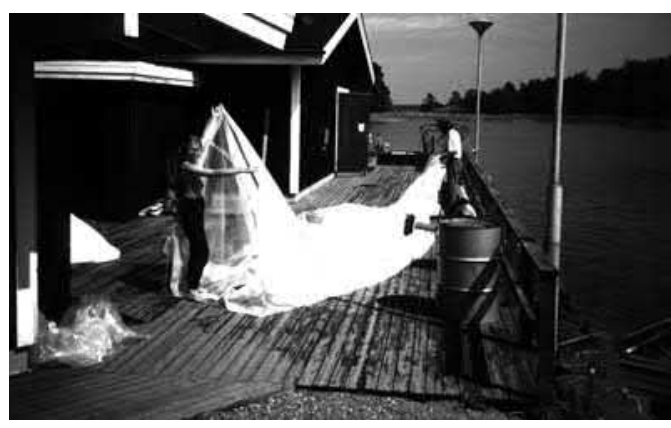

Kuva 9.4. Suuri osa Itämeren ekosysteemin toiminnan tutkimuksesta tehdään kokeellisesti. Kuvassa valmistetaan Tvärminnessä ravinnelisäyskokeita varten säkkejä, joiden syvyys on 8 metriä. Kokeet saattavat kestää useita viikkoja. (Tvärminnen eläintieteellinen asema/Antti Nevalainen)

toiminnan sitoessa ravinteita tehokkaasti. 'Puskurivyöhykkeet' eivät kuitenkaan riitä nykytilanteessa rajoittamaan kaikkea avomerelle tulevaa ravinnekuormitusta. Lisäksi ravinnekuormituksesta typen kohdalla osa tulee ilman kautta suoraan avomerelle laskeumana. Ilmakuormituksen osuus koko Itämeren typpikuormituksesta on noin kolmannes. Pohjanlahdellakin on merkkejä rannikon rehevöitymisestä suurimpien jokien suualueilla, mutta Pohjanlahden avomerialueen rehevöityminen on toistaiseksi vähäistä.

Itämeren ravinnetasojen on arvioitu kohonneen 4-8-kertaisiksi sadan viime vuoden kuluessa. Tämä näkyy ennen kaikkea pohjien happitilanteen huononemisena. Vaikka pohjien hapettomuus onkin osa Itämeren ekosysteemiä, nykyisin uusiutuneetkin happivarastot kuluvat entistä nopeammin. Samalla syvän veden ravinnetasot erityisesti fosforin osalta ovat kohonneet. Tämä kertoo lisääntyneestä eloperäisen aineksen laskeutumisesta. Samasta kertovat myös yhä voimakkaammat ja laajemmat sinileväkukinnat. Lisääntynyt perustuotanto on saattanut hyödyttää kalastusta, sillä osa lisätuotannosta lienee lisännyt ulapan kalatuotantoa. Lisääntyneen perustuotannon kaikista vaikutuksista - muun muassa myrkyllisistä leväkukinnoista - ei kuitenkaan tie- detä vielä riittävästi, jotta sen kaikkia vaikutuksia Itämeren ekologiaan voitaisiin arvioida (kuva 9.4). Nykykäsityksen mukaan rehevöityminen on kuitenkin liian suurta ja kansainvälinen tavoite onkin pienentää Itämeren ravinteiden määriä noin puoleen nykyisestä. Tavoitteeseen pääsy on kaikesta päätellen hidasta, mutta joillain alueilla, esimerkiksi Suomenlahdella, on havaittu merkkejä muutoksesta parempaan. Kevään leväkukinnan on 10 viime vuoden aikana havaittu pienentyneen noin kolmanneksen.

Meriliikenne on vaikuttanut hyvin pitkään Itämereen. Sen ensimmäinen vaikutus on ollut tulokaslajien saapuminen Itämereen. Jo viikinkiajoista lähtien rannoille on levinnyt maakasveja, jotka ovat levinneet painolastin mukana Itämerelle. Samalla Itämereen on levinnyt painolastihiekan mukana ainakin hietasimpukka, Mya arenaria. Se on vakiintunut hiekkapohjille kaikkialle Itämereen. Toinen kaikille tuttu vanha tulokaslaji on merirokko, Balanus improvisus. Se lienee saapunut Itämereen 1860-luvulla kiinnittyneenä Pohjois-Amerikasta saapuneen laivan runkoon. Nykyisin merirokko kuuluu Itämeren peruslajistoon. Tulokaslajien saapumismahdollisuudet ovat lisääntyneet meriliikenteen kasvaessa. Uusia lajeja tavataan vuosittain ja osa niistä jää pysyvästi Itämeren ekosysteemiin. Pysyvä leviäminen murtoveteen on kuitenkin hyvin vaativaa, sillä ainoastaan pieni osa tulokkaista sopeutuu Itämeren vaikeisiin oloihin. Itämeren tulokaslajeista on olemassa hyvä tietokanta (www. ku.lt/nemo/).

Nykyaikaisella meriliikenteellä on muitakin seuraamuksia Itämerelle, sillä meriliikenteen typpipäästöt ovat huomattavia. Ilman kautta tulevista typpipäästöistä laivaliikenteen osuus on noin $10 \%$. Lisäksi öljyonnettomuuden vaara on yhä kasvussa ja sen mahdolliset seuraukset vaihtelevat suuresti riippuen onnettomuuden paikasta ja ajankohdasta. Osa öljystä haihtuu nopeasti ilmaan, mutta osa jää pitkäksi aikaa vesiekosysteemiin. Öljy kulkeutuu nopeasti ran- 


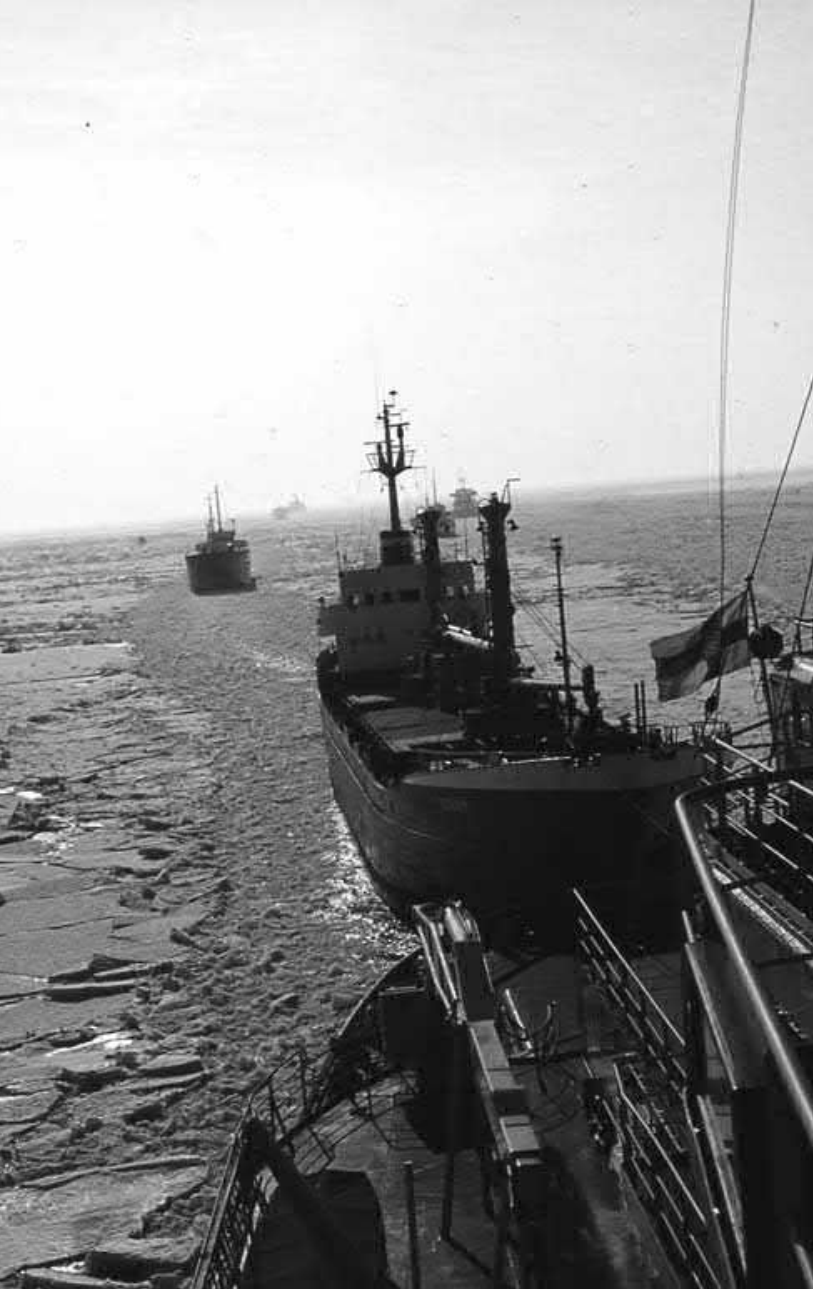

Kuva 9.5. Talvimerenkulku sujuu Itämerellä jäänmurtajien avustuksella. Ilmastonmuutoksella on vaikutuksia merenkulun olosuhteisiin Itämeren talvessa. (Matti Leppäranta)

nikolle saattaen aiheuttaa korvaamattomia haittoja lintukolonioille. Öljy sisältää myös suuren joukon myrkyllisiä yhdisteitä. Öljyä voi myös painua pohjaan bitumimaisena massana, jolloin se tuhoaa pohjan ekosysteemiä.

Jokien säännöstely on muuttanut pintaveden kulkua Itämereen. Säännöstellyissä vesistöissä virtaamat ovat muuttuneet siten, että yhä suurempi osa piistä jää järvialtaisiin. Itämeren piipitoisuus on laskenut jo pitkään, sillä pii sitoutuu lähinnä piilevien kuoriin, jotka hajoavat pohjas- sa hyvin hitaasti. Niinpä vesimassan piivarastot ovat lähinnä maalta tulevan piin varassa. Pii on yksi niistä ravinteista, jotka eivät varsinaisesti vaikuta perustuotannon määrään vaan lajistoon. Pii- ja tarttumalevät tarvitsevat rakenteisiinsa piitä. Nykyisin liukoinen pii loppuu vesimassasta jo ennen kevätkukinnan loppua. Kevätkukintojen lajisto onkin muuttumassa piilevien vallitsemasta normaalista kevätkukinnasta kylmän veden panssarilevien vallitsemaan kukintaan. Käytännössä kyseessä saattaa olla suuri ero, sillä piilevät eivät pysty uimaan, vaan ne laskeutuvat pohjaan kevätkukinnan päättyessä. Panssarilevät ovat uimakykyisiä, joten ne jäävät vesimassaan lisäten kesän ravinnepitoisuutta vedessä. Samalla muuttuu osa muistakin kevätkukinnan ominaisuuksista, joista meillä ei vielä ole kunnolla tietoa.

\subsection{Globaalimuutoksen vaikutus Itämereen}

\subsubsection{IImastonmuutos nyt}

Ilmasto kuvaa säätilan pitkän ajan keskiarvoa. Tyypillisesti ilmastosta puhuttaessa tarkoitetaan tiettyä normaalijaksoa, kuten 1961-1990, johon kulloinkin vallitsevaa ilmastoa verrataan. Maapallon ilmasto muuttuu koko ajan, ja muutokset voivat olla hyvinkin suuria pitkällä aikavälillä, mistä ovat esimerkkeinä jääkaudet ja niiden väliset lämpimät kaudet. Muutokset ovat tällöin kuitenkin varsin hitaita. Sen sijaan nykyisen, otaksutun ilmastonmuutoksen on arvioitu olevan huomattavasti nopeampaa kuin koskaan aikaisemmin. Tämän otaksunnan mukaan ihmisen toiminta olisi voimistamassa kasvihuoneilmiötä. Eräät ilmakehän kaasut toimivat samaan tapaan kuin lasi kasvihuoneessa: ne päästävät auringon valon maan pinnalle, mutta estävät maanpinnasta emittoitunutta pitkäaaltosäteilyä karkaamasta takaisin avaruuteen. Näiden kasvihuonekaasujen, kuten hiilidioksidin, aiheuttama 
kasvihuoneilmiö pitää planeettamme elämälle suotuisana: ilman sitä keskilämpötila maapallolla olisi huomattavasti nykyistä alempi. Ihmisen toiminta tuottaa huomattavia määriä kasvihuonekaasuja, jotka ilmeisesti voimistavat luonnollista kasvihuoneilmiötä. Sen seurauksena ilmasto muuttuu ja on jo muuttunut, sillä maapallon keskilämpötilan on arvioitu olevan yli puoli astetta korkeampi kuin 1850-luvulla, vaikka arvio keskilämpötilasta 1800-luvulla onkin vähäisten mittausasemien vuoksi varsin epätarkka. Suomessa keskilämpötilan on arvioitu nousseen aikavälillä 1901-2000 noin 0,7 astetta.

\subsubsection{IImastonmuutosskenaariot}

On syytä mainita, että ilmastonmuutoksen liittyvä keskustelu on tällä hetkellä varsin värikästä, ja eräät tutkijat katsovat, että kyse ei ole varsinaisesta ilmaston lämpenemisestä, vaan paremminkin hyvin pitkällä aikavälillä tapahtuvasta ilmaston luonnollisesta vaihtelusta. Lähivuosikymmenet näyttävät meille mitä todella tapahtuu. Debatti tutkijoiden välillä on asiaan kuuluvaa keskustelua, ja sen olemassaolo osoittaa, että olemme tekemisissä todellakin perimmäisten kysymysten kanssa - mitä ilmastossa tapahtuu ja miten ihmisten käy?

IPCC (Intergovernmental Panel on Climate Change) määrittelee raporteissaan kulloinkin käytettävissä olevan tiedon mukaan ilmastonmuutosskenaarioita tuleville vuosikymmenille. Näissä skenaarioissa, jotka perustuvat globaalisten, kytkettyjen meri-ilmakehämallien käyttöön, on keskeistä se, miten kasvihuonekaasujen päästöjen kehitys jatkuu: pienenevätkö päästöt, pysyvätkö ne ennallaan, vai kasvavatko ne entisestään. Useiden vuosikymmenten aikavälillä päästöjen määrästä riippuen maapallon ilmaston kehityksen suunnassa voidaan IPCC:n ennusteiden perusteella nähdä suuriakin eroja, vaikka raportit kirjoittaneet tutkijat katsovat, että lämpeneminen on ilmeisesti väistämätöntä joka tapauksessa. FINSKEN (Developing consistent global change scenarios for Finland) -projektissa (Jylhä ym. 2004) on käytetty edellä mainittujen globaalimallien simulointituloksia ja arvioitu erityisesti ilmastonmuutoksen kehittymistä Suomen alueella.

FINSKENin arvioiden mukaan ilman keskilämpötila sekä sademäärät ovat nousussa seuraavina vuosikymmeninä. Muutoksen voimakkuus riippuu paljolti päästörajoitusten tehokkuudesta. Keskilämpötilan arvioidaan nousevan Suomessa normaalikauteen 1961-1990 verrattuna 1-3 astetta vuoteen 2020 mennessä, kun sademäärien vastaava nousu on $0-15 \%$. Vuoteen 2050 mennessä keskilämpötilan arvioidaan nousevan normaalikauteen verrattuna $2-5^{\circ} \mathrm{C}$ ja sademäärän 0-30\%. Vuoteen 2080 mennessä arvioidut muutokset ovat $2-7^{\circ} \mathrm{C}$ ja $5-40 \%$. On selvää, että kyseiset trendit keskilämpötilassa ovat huomattavasti suurempia kuin viime vuosisadalla mitatut. Suuret vaihteluvälit skenaarioissa johtuvat malleihin liittyvistä epävarmuustekijöistä, erilaisista emissioskenaarioista ja myös ilmaston sisäisestä vaihtelusta. Toisaalta kesäaikaan ennustettu lievä lämpeneminen on tilastollisesti yhtä merkittävää kuin talviaikainen suurempi lämpeneminen, sillä kesäaikojen lämpötiloihin liittyy vähemmän vaihtelua kuin talviaikaisiin. Sademäärien kasvu on tilastollisesti merkittävintä talviaikaan ja vähiten merkittävää kesällä. On huomattava, että mallisimulointien tulokset eivät tue käsitystä Pohjois-Atlantin lämpimän merivirran (Golf-virran) heikkenemisestä. Tämä heikentäisi Suomessa ilmaston lämpenemistä, vaikkakin meidän leveysasteillamme syklonien mukanaan kuljettamat lämpö on merivirtojen tuoman lämmityksen lisäksi tärkeää.

Klimatologisten tuulijakaumien muutoksista Pohjois-Euroopassa ei voida tehdä yhtä selkeitä johtopäätöksiä kuin lämpötilan noususta. On osoitettu, että voimakkaat ilmanpainegradientit ja niihin liittyvät myrskyt heikkenivät viime 
vuosisadan aikana aina 1950-1970 luvuille asti, mutta nykyään myrskyjen taajuus on taasen samaa luokkaa kuin 100 vuotta sitten. Erityisesti Pohjois-Atlantilla myrskyjen esiintymistiheys on kasvussa, mutta Itämeren alueella kehitys ei ole näin voimakasta, vaikkakin länsituulten nopeus ja esiintymistaajuus ovat ehkä kasvussa. Myrskyjen esiintymisellä on talviaikaan korrelaatio positiivisen NAO-indeksin kanssa, kun taas kesäaikaan kytkentä on heikko.

\subsubsection{Ennustetut muutokset Itämeren fysiikassa}

Useat ilmastomallit ovat ennustaneet, että sademäärät nousevat lähivuosikymmeninä selvästi, minkä seurauksena jokivirtaamat kasvavat. Meier ja Kauker (2003) ovat laskeneet kytketyllä kolmidimensionaalisella jää-meri-mallilla, että tämänhetkinen Itämeren keskisuolaisuus on 7,4 promillea sekä makean veden nettovuo Itämereen on $16.000 \mathrm{~m}^{3} \mathrm{~s}^{-1}$. Herää kysymys, voisiko Itämeri muuttua käytännössä lähes makean veden altaaksi, jossa ei enää esiinny suolaisuuskerrostuneisuutta, ja jonka fysiikka olisi varsin toinen kuin nykyinen. Ilmastonmuutosskenaarioiden mukaan jokivirtaamat pienenevät kesällä, mutta talviaikaiset virtaamat kasvaisivat nykyisestä jopa $50 \%$ vuoteen 2100 mennessä.

Useimmat skenaariot, joissa makean veden nettoa oli kasvatettu tai pienennetty, osoittivat, että kerrostuneisuus on vakaassa tilassa 100 vuoden simuloinnin jälkeen, vaikkakin sekä pinta- että pohjakerroksissa suolaisuus pienenee. Vaikka makean veden tuottoa lisättäisiin 100 $\%$, Itämeri ei muutu makeaksi. Halokliini erottaa siis edelleen pinnan makeamman ja pohjanläheisen kerroksen suolaisemman veden toisistaan, jolloin tuulen sekoitusvaikutus rajoittuu vain yläkerrokseen. Jos makean veden tuoton muutos on rajoissa $\pm 30 \%$, halokliinin sijainti ei muutu oleellisesti nykyisestä, eli se sijaitsee 60 ja
100 metrin välillä. Sen sijaan kasvava jokivesien määrä laimentaa pintavesien suolaisuutta ja suolaisuusero pinnan ja pohjan välillä saattaa jopa kasvaa, jolloin veden pystysuora sekoittuminen heikkenee entisestään ja huonontaa hapen kulkeutumista pohjan läheisiin vesikerroksiin.

Mikäli Itämereen tulevan makean veden määrä pienenee huomattavasti (esimerkiksi $70 \%$ nykyiseen verrattuna), suolaisuus kasvaa ja pinnan ja pohjan välinen suolaisuusero pienenee. Tämä johtaisi siihen, että Gotlannin meren syvänteissä tapahtuisi nykyistä helpommin pohjaan asti ulottuvaa sekoittumista ja konvektiota, jolloin Itämeren happitilanne kohenisi. On kuitenkin epätodennäköistä, että makean veden tuotto pienenisi jatkossa.

Itämeressä tasapainottelevat sekä makean että suolaisen veden lajit ääriolosuhteissa. Promillenkin suolaisuuden muutoksen on havaittu vaikuttavan lajiston tasapainotilaan. Viime vuosien makeampi vaihe on vähentänyt muun muassa suuren suolaisen veden eläinplanktonin määrää. Nämä lajit ovat korvautuneet pienemmillä makean veden lajeilla, jotka ovat heikompaa ravintoa silakalle. Lisäksi voimakas makeutuminen uhkaa eräiden merikalojen kuten turskan lisääntymistä. Sen mätimunat tarvitsevat noin 10 promillen suolaisuuden.

Itämeren ja Pohjanmeren välinen vedenvaihto saattaa myös muuttua lisääntyvän makean veden tuoton vuoksi. Kun pinnalla virtaa kasvava määrä makeaa vettä ulos Itämereltä, veden suolaisuus pienenee myös Itämeren suualueella, jolloin suurten suolapulssien todennäköisyys pienenee. Samansuuntainen kehitys saattaa tapahtua, jos nykyinen tuuliklimatologia muuttuu jatkossa epäsuotuisammaksi pulsseille.

Ilman keskilämpötilan nousu, jota globaaliset meri-ilmakehämallit ennustavat, vaikuttaa myös Itämeren pinnan energiataseeseen. Koska lämmön advektio Itämeren ja Pohjanmeren välillä ei yleensä ole merkittävää, meren ilmasta saama lisälämpö ei siirry pois Itämereltä, vaan 
meren lämpötila nousee. Tätä näkemystä tukee Meierin (2002) tulos, minkä mukaan 1,5-kertainen hiilidioksidipitoisuus esiteolliseen aikaan nähden nostaisi 100 vuodessa Itämeren keskilämpötilaa $2,3^{\circ} \mathrm{C}$. Arviot lämpötilan noususta ovat vielä varsin alustavia, mutta joka tapauksessa Itämeren keskilämpötilan nousu usealla asteella johtaisi moniin muutoksiin meren fysiikassa. Nyrkkisääntönä voidaan pitää sitä, että ilman keskilämpötilan nousu yhdellä asteella pienentää merijään pinta-alaa noin $45.000 \mathrm{~km}^{2}$. Vaikka jäätalvien pituus, jään paksuus ja jääpeitteen laajuus pienenevätkin, niin esimerkiksi Haapalan ym. (2001) mukaan jäätä esiintyy vielä joka talvi Perämeren pohjoisosassa ja Suomenlahden itäisimmässä osassa. On ennustettu, että jääpeite pienenisi nykyisestä 50-80 \% vuoteen 2100 mennessä. Entistä lyhyempi jäätalvi pienentää meren pinnan keskimääräistä albedoa ja lisää meren hyödyksi koituvaa lämpöä. Samoin jääpeitteen sulattamiseen kuluu entistä vähemmän energiaa. Jääpeitteen pienenemisellä on myös kytkentä vedenkorkeuksien kasvuun lyhyellä aikavälillä, sillä tuulen energian syöttö meren pintaan kasvaa. Tätä vaikutusta edelleen kasvattaa tuulten mahdollinen voimistuminen. Samalla myös aallokko voimistuisi ja merijäät liikkuisivat entistä enemmän. Tämä johtaa niiden entistä helpompaan ahtautumiseen, millä olisi haitallinen vaikutus talvimerenkululle. (kuva 9.5).

Veden keskilämpötilan nousu aiheuttanee muutoksia koko ekosysteemiin, sillä useat prosessit ovat lämpötilasta riippuvia. Pintaveden lämpeneminen johtaa myös pohjan läheisen veden lämpenemiseen. Tämä aiheuttaa entistä nopeampaa ja voimakkaampaa hapen kulutusta ja vähähappisuutta, mikä johtaa eliöstön köyhtymiseen ja ääritapauksissa fosforin liukenemiseen pohjan sedimenteistä. Lämpötilakerrostuneen kauden piteneminen saattaa johtaa vuosittaisiin happikatoihin matalilla alueilla, joilla on korkea perustuotanto. Näillä alueilla termokliini on tärkein happivarastojen uusiutumista estävä tekijä.
Kesän lämpötilalla lienee myös suuri merkitys Itämeren lajistoon. Monet ulappalajit esiintyvät nykyisinkin runsaimmillaan lämpiminä kesinä. Myrkyllisiä sinileväkukintoja muodostava Nodularia spumigena kasvaa sitä nopeammin mitä lämpimämpää vesi on, kun taas veden ollessa viileätä sinileväkukinnat jäävät vähäisiksi. Sinilevien esiintymiseen vaikuttaa monimutkainen vuorovaikutusten ketju, johon liittyy muun muassa ravinnetasot ja kesän kumpuamisaktiivisuus, joten lämpötilojen nousu ei välttämättä yksin aiheuta sinileväkukintojen lisääntymistä. Lämpötila vaikuttaa myös muiden levien kasvuun. Lämpimässä pintavedessä on myös oma eläinplanktonyhteisönsä, johon kuuluvat lajit eivät ole yhtä hyvää ravintoa ulapan kaloille kuin merelliset kylmempään veteen sopeutuneet lajit. Yksi haitallinen eläinplanktonlaji, joka hyötyisi selvästi kesien lämpenemisestä, on petovesikirppu. Se pystyy lisääntymään tehokkaasti vain yli $+15^{\circ} \mathrm{C}$ :n lämpötilassa. Niinä vuosina, joina veden lämpötila on pitkään yli edellä mainitun rajan, petovesikirppu on jo nyt kalastajien riesana lähes koko rannikkoalueellamme. Suuret petovesikirppumassat tukkivat pyydyksiä tehokkaasti. Petovesikirppu on Kaspian mereltä saapunut tulokaslaji, joka havaittiin ensimmäisen kerran vuonna 1992. Lämpötilan nousu saattaa edistää myös muiden tulokaslajien leviämistä Itämereen (www.ku.lt/nemo/).

Jääpeitteen vähenemisen vaikutuksia Itämeren eliöstölle on vaikea arvioida. Jää on biologisesti aktiivinen elinympäristö, sillä siitä on mitattu varsin korkeata bakteeriaktiivisuutta sekä löydetty suuria määriä planktonleviä. Arktisella alueella vuosittain sulava jää toimii kylmän veden levien kasvupaikkana, josta ne siirtyvät veteen jään sulaessa. Sama mekanismi toiminee myös Itämeressä, jolloin jääpeitteisen alueen pieneneminen aiheuttaa lajistomuutoksia kevään leväkukinnassa. Monet piilevälajit menettäisivät talvisen kasvupaikkansa. Jääpeite vaikuttaa myös mekaanisesti jokivesien leviämiseen. Jäättömässä 
ympäristössä jokivesien vaikutusalue jää paljon pienemmäksi kuin jääpeitteisinä talvina. Lisäksi jää heikentää turbulenssia, jolloin eräät liikkuvat levälajit pystyvät muodostamaan massaesiintymiä jo talvella. Jää muokkaa myös rantaekosysteemejä ja puhdistaa kalliorantoja vuosittain. Lisäksi jää muodostaa suojaavan kannen rantavyöhykkeelle. Emme kuitenkaan tiedä tarpeeksi rantaekosysteemien herkkyydestä jääpeitteen muutoksille, jotta voisimme ennustaa mitä muutoksia voi seurata jäätalvien muuttumisesta.

Keskivedenkorkeuteen vaikuttavien kolmen tekijän - valtameren pinnan nousun, maankohoamisen ja vesitaseen - avulla voidaan laskea skenaarioita tulevaisuuden keskivedenkorkeudelle. Maankohoaminen etenee lineaarisesti tarkasteltavalla aikaskaalalla. Valtameren pinnan nousulle ja NAO-indeksille on saatavilla skenaarioita perustuen IPCC:n analyyseihin. Näiden skenaarioiden mukaan valtameren pinnan korkeus nousee noin $10-90 \mathrm{~cm}$ vuoteen 2100 mennessä. IPCC esittää raportissaan erilaisia emissioskenaarioita, jotka johtavat myös erilaisiin vedenkorkeusmuutoksiin (www.fimr.fi).

NAO-indeksille saadaan skenaarioita ilmastomalleilla. Mallit eivät ennusta luotettavasti NAO-indeksin vaihtelua vuosikymmenestä toiseen. Karkea arvio tulevaisuuden trendistä niiden perusteella voidaan silti tehdä. Vedenkorkeusskenaarioiden kannalta tällä ei ole suurta merkitystä, sillä NAO-indeksin vaihteluiden pysyessä kohtuullisissa rajoissa niiden vaikutus Suomen rannikon vedenkorkeuteen on pieni verrattuna valtameren pinnan nousuun, jonka epävarmuusrajat kasvavat hyvin suuriksi ajan myötä.

Suomenlahdella keskivedenkorkeuden pitkäaikainen lasku ei välttämättä jatku enää tulevaisuudessa. Kiihtyvä valtameren pinnan nousu tasapainottaa maankohoamisen vaikutusta, ja vedenkorkeus saattaa tasaantua vakiotasolle tai lähteä nousemaan. Sen sijaan Pohjanlahdella maankohoaminen on voimakkaampaa. Siellä vedenkorkeus jatkaa tulevaisuudessakin laskuaan.
Äärimmäisten skenaarioiden mukaan vedenkorkeus lähtee Pohjanlahdellakin nousemaan tämän vuosisadan puolivälin jälkeen (www.fimr.fi). Tanskalaistutkijat ovat tulleet siihen johtopäätökseen, että $50 \mathrm{~cm}: n$ globaalinen pinnannousu vuosien 1990 ja 2080 välillä johtaisi siellä 33-46 $\mathrm{cm}$ :n suuruiseen vedenkorkeuden nousuun.

Suomenlahden rannikolla keskivedenkorkeuden laskun hidastuminen vaikuttaa ainutlaatuisten rantaekosysteemien kehittymiseen. Pohjanlahdella syntyy niin sanottuja maankohoamisrantoja, joissa elää monimuotoinen kasvillisuus. Suomen etelärannikolla keskivedenkorkeuden lasku luo ainutlaatuisia hitaasti sulkeutuvia ja lopulta umpeen kasvavia lahtia, eli syntyy fladoja. Ne ovat matalia, pinta-alaltaan suuriakin lahtia, jotka kuroutuvat hitaasti merestä muuttuen lopulta rantaniityiksi. Fladat ovat eräiden harvinaisten levien ja kasvien elinpaikkoja, minkä lisäksi ne toimivat kalojen lisääntymisalueena sekä eloperäisen aineksen laskeutumispaikkoina. On hyvin vaikea arvioida mitä tapahtuu jo varastoituneelle ainekselle ja ravinteille, mikäli pitkälle kehittyneet fladasysteemit kohtaavat nousevan vedenkorkeuden.

Ilmastonmuutoksella on vaikutuksensa myös merisäähän. Kosteus ja sateet lisäävät sumunmuodostusta sekä huonontavat merinäkyvyyttä ja lisäävät alusten rakenteiden jäätymisriskiä. Yhtenäisten merijääkenttien vähetessä merellisten ja rannikkosäiden vaihtelevuus lisääntyy. Myrskyjen mahdollinen kasvava esiintymistiheys aikaansaa nykyistä korkeampaa aallokkoa ja sitä kautta tilanteita, jossa näkyvyys on huono.

\subsection{Tutkimuksen haasteita}

Itämeren fysiikan tutkimuksessa on edessä vielä paljon haasteita. Tulevaisuuden tutkimusten yleisenä haasteena on integroida mallitus ja mittaustoiminta, sekä integroida fysiikan ja ekologian tutkimus entistä paremmin yhteen. 


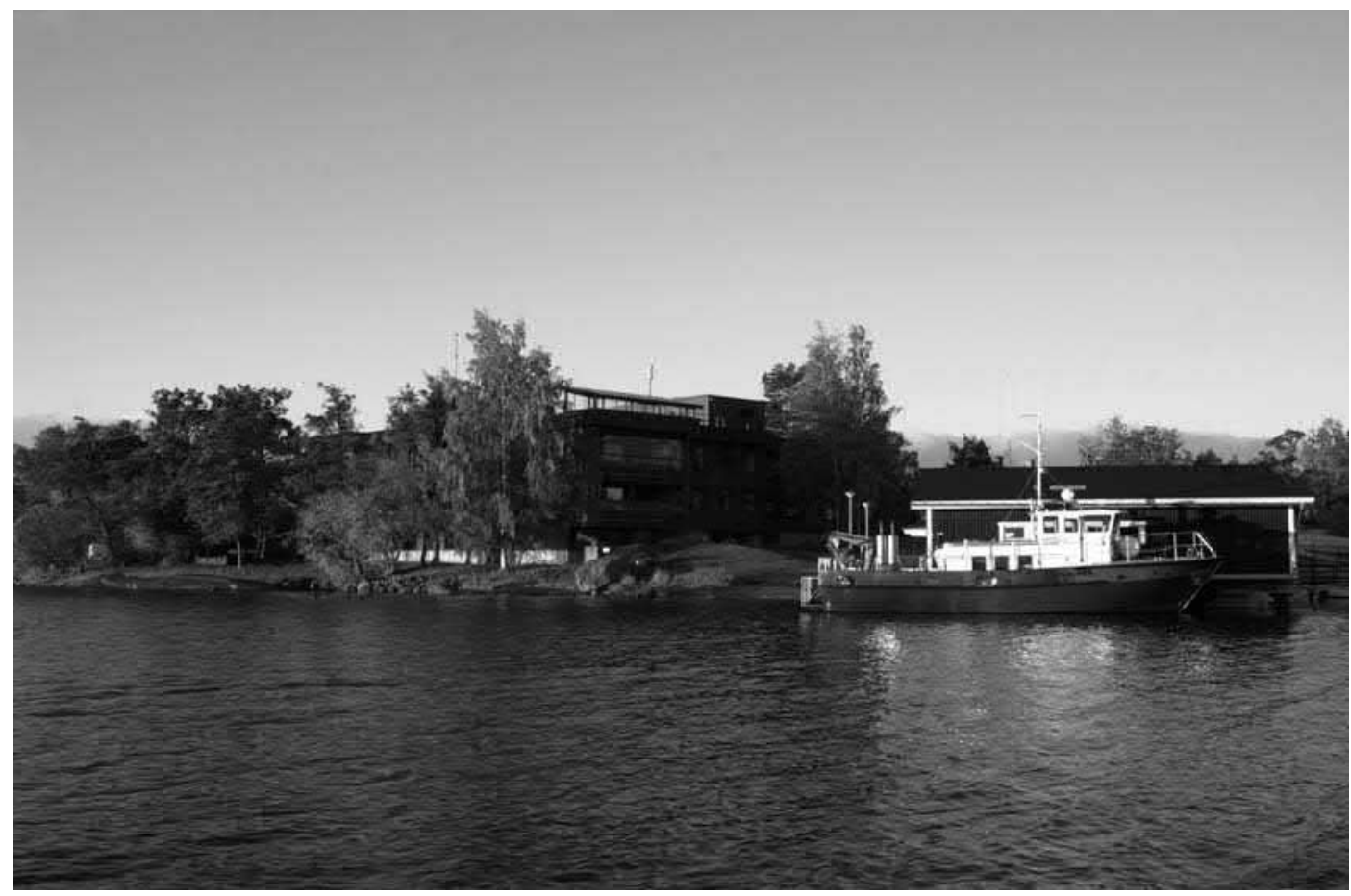

Kuva 9.6. Helsingin yliopiston Tvärminnen eläintieteellinen asema mereltä nähtynä. Asema on perustettu vuonna 1902 ja se on yksi Itämeren tutkimuksen tärkeimmistä kenttäasemista. (Riku Lumiaro/Merentutkimuslaitos)

Itämeren syvän veden kiertoliike tunnetaan vielä huonosti. Eräänä tärkeänä sovelluskohteena on suurten suolapulssien vielä osittain tuntemattoman dynamiikan selvittäminen. Toinen Itämeren fysiikan tärkeä, mutta melko heikosti tunnettu osa-alue on vertikaalinen sekoittuminen. Tämän prosessin tutkimuksen keskeisenä osana on mittaustoiminta modernin instrumentaation avulla. Mittaustuloksia voidaan hyödyntää numeeristen mallien parametrisoinneissa ja täten tarkentaa niissä ekosysteemiprosessienkin kannalta keskeistä sekoittumisen kuvausta.

Monien käytännön sovellutusten ja ympäristönsuojelun kannalta on kehitettävä menetelmiä, joiden avulla voidaan arvioida rannikon ja avomeren välistä vedenvaihtoa. Tämä pitää sisällään myös kiinto- ja ajojään rajavyöhykkeen tutkimuksen. Samoin eri merialtaiden välisen vedenvaihdon arvioimisessa tarvitaan panostusta tulevaisuudessa, jotta opitaan ymmärtämään sekä aikaskaaloja että mekanismeja, joiden raa- meissa tietyn altaan vesi uudistuu. Ympäristöonnettomuuksien, kuten öljypäästöjen, vaikutusten ennustamiseksi on kehitettävä edelleen matemaattisia malleja.

Itämeren ekosysteemitutkimuksen suurimpia haasteita on selvittää eri tekijöiden osuus ekosysteemin nykyisen tilan synnyssä ja siitä toipumisesta (kuva 9.6). Tiedämme aivan liian vähän fysikaalisten tekijöiden vaikutuksesta ravinne- ja tuotantodynamiikkaan, mukaan luettuna erityisesti laskeutuvan aineksen määriin. Sisäisen kuormituksen merkityksen arviointi on myös kesken.

Tulevaisuudessa tarvitaan entistä enemmän yhdistettyjä fysikaalis-kemiallis-biologisia tutkimusohjelmia, joissa voidaan saada uutta tietoa eri prosesseista ja niiden välisistä vuorovaikutussuhteista. Tämän toteuttamiseksi tarvitaan entistä laajempaa ja integroitua kansallista ja kansainvälistä yhteistyötä. 
Itämeren fysiikan tunteminen auttaa ymmärtämään Itämeren tilaa, ja meillä on ennen kaikkea yhteinen, konkreettinen huoli Itämeren tulevaisuudesta. Kyseessä on haaste tutkijoille ja päättäjille tehdä yhdessä työtä Itämeren, meidän meremme hyväksi, jotta tulevat sukupolvet voivat nauttia sen tarjoamasta ainutlaatuisesta ja myös puhtaasta meriympäristöstä. 


\section{Lähdeluettelo}

\subsection{Päälähteet}

Brogmus, W. 1952. Eine Revision des Wasseraushaltes. Kieler Meeresforschung 9(1), 15-42.

Dera, J. 1992. Marine Physics. Amsterdam-OxfordNew York-Tokyo: Elsevier, 526 s.

Ehlin, U. 1981. Hydrology of the Baltic Sea. Teoksessa: Voipio, A. (1981), s. 123-134.

Fonselius, S. 1996. Västerhavets och Östersjöns oceanografi. Norrköping: SMHI, $200 \mathrm{~s}$.

Leppäranta, M. 2004. The drift of sea ice. Heidelberg: Springer-Praxis, $290 \mathrm{~s}$.

Magaard, L. ja Rheinheimer, G. (toim.) 1974. Meereskunde der Ostsee. New York: SpringerVerlag.

Mikulski, Z. 1970. Inflow of river water to the Baltic Sea in the period 1951-1960. Nordic Hydrology 4, 216-227.

Mälkki, P. ja Tamsalu, R. 1985. Physical features of the Baltic Sea. Helsinki, Merentutkimuslaitos: Finnish Marine Research, 252, 110 s.

Rodhe, J. 1999. The Baltic and North Seas. A process-oriented review of the physical oceanography. Teoksessa: Robinson, A. \& Brink, K. (toim.), The Sea, Vol. 11. John Wiley\& Sons Inc.

SMHI ja Merentutkimuslaitos 1982. Itämeren, Kattegatin, Skagerrakin ja Vänern-järven jääkartasto. Norrköping, Sjöfartsverket.
Stigebrandt, A. 2001. Physical oceanography of the Baltic Sea. Teoksessa: F. Wulff ym. (toim.), $A$ system analysis of the Baltic Sea. Ecological studies, Vol. 148, s. 19-74. Berlin - Heidelberg: Springer-Verlag.

Voipio, A. (toim.) 1981. The Baltic Sea. Amsterdam, Elsevier, $418 \mathrm{s.}$

Voipio, A. ja Leinonen, M. (toim.) 1984. Itämeri. Helsinki, Kirjayhtymä, 179 s.

\subsection{Muut}

Alenius, P. 1978. On the use of CTD-profiling system on R.V. Aranda. Teoksessa: Proceedings of the XI Conference of the Baltic Oceanographers, Rostock, 24-27 April 1978, 600607.

Alenius, P. 1980. On currents, inertial and inertial waves in a coastal zone of the Bothnian Sea. Lisensiaattityö, Helsingin yliopisto, geofysiikan laitos, $126 \mathrm{~s}$.

Alenius, P. 1985. Itämeren sisäiset aallot. XII Geofysiikan päivät Helsingissä 14.-15.5.1985, 25-30.

Alenius, P. ja Mälkki, P. 1978. Some results of the current measurement projects of the Pori - Rauma region. Finnish Marine Research 244, 52-63. 
Andrejev, O., Myrberg, K., Mälkki, P. ja Perttilä, M. 2002. Three-dimensional modelling of the Baltic main inflow in 1993. Environmental and chemical physics 24(3), 121-26.

Andrejev, O., Myrberg, K., Alenius, P. ja Lundberg, P. A. 2004. Mean circulation and water exchange in the Gulf of Finland - a study based on three-dimensional modelling. Boreal Environment Research 9, 9-16.

Assur, A. 1958. Composition of sea ice and its tensile strength. Teoksessa: Thurston, W. (toim.), Arctic Sea Ice, s. 106-138. U.S. National Academy of Science/National Research Council: Publ. No 598.

Bock, K.H. 1971. Monatskarten des Salzgehalten der Ostsee, dargestellt für verschiedene Tiefenhorisonte. Deutsche Hydrographisces Zeitschrift, Ergänzungshäft Reihe B (4), 12, 1-147.

Dahlström, B. 1977. Estimation of precipitation for the Baltic Sea - preliminary result. Ad Hoc Meeting of the Pilot Study Group of Experts, Norrköping (moniste).

Dailidienė I., Tilickis, B., Davulienė, L., Stankevičius, A. ja Myrberg, K. 2006. Sea level variability at the Lithuanian coast of the Baltic Sea. Boreal Environment Research 11, 109-121.

Defant, F. 1972. Klima und Wetter der Ostsee. Kieler Meeresforschng 28(1), 1-30.

Dietrich, G., Kalle, K., Krauss, W. ja Siedler, G. (toim.). 1957. Allgemeine Meereskunde. Eine Einführung in die Ozeanographie. Bonträger, Berlin, $492 \mathrm{~s}$.

Ekman, M. 1998. Secular change of the seasonal sea level variation in the Baltic Sea and secular change of the winter climate. Geophysica 34, 131-140.

Fonselius, S. ja Valderrama, J. 2003. One hundred years of hydrographic measurements in the Baltic Sea. Journal of Sea Research, 49, 229-241.
Gill, A. 1982. Atmosphere-Ocean dynamics. Academic Press, Lontoo, $662 \mathrm{~s}$.

Granqvist, G. 1938. Zur Kenntnis der Temperatur und des Salzgehaltes des Baltischen Meeres and den Küsten Finnlands. Merentutkimuslaitoksen julkaisu / Havsforskningsinstitutets skrift, 122, 166 s. + liitteet.

Gustafsson, B.G. ja Andersson H.C., 2001. Modeling the exchange of the Baltic Sea from the meridional atmospheric pressure difference across the North Sea. Journal of Geophysical Research, 106, C9, 19,731-19,744.

Gustafsson, T. ja Kullenberg, B. 1936. Untersuchungen von Trägheitströmungen in der Ostsee. Sv. Hydr.-Biol. Kommn. Skr., Ny ser. Hydr., 13, 1-28.

Haapala, J. 1994. Upwelling and its influence on nutrient concentration in the coastal area of the Hanko Peninsula at the entrance of the Gulf of Finland. Estuarine, Coastal and Shelf Science 38, 507-521.

Haapala, J. ja Alenius, P. 1994. Temperature and salinity statistics for the Northern Baltic Sea 1961-1990. Finnish Marine Research 262, 51-121.

Haapala, J. ja Leppäranta, M. 1996. Simulating Baltic sea ice season with a coupled ice-ocean model. Tellus 48A(5), 622-643.

Haapala, J., Meier, H.E.M. ja Rinne, J. 2001. Numerical investigations of future ice conditions in the Baltic Sea. Ambio 30, No. 4-5, 237-244.

Hankimo, J. 1964. Some computations of the energy exchange between the sea and the atmosphere in the Baltic area. Ilmatieteellisen keskuslaitoksen toimituksia 57, 1-26.

Hela, I. 1944. Über die Schwankungen des Wasserstandes in der Ostsee mit besonderer Berücksichtigung des Wasseraustausches durch die dänischen Gewässer. Annales Academiae Scientiarum Fennicae. Ser. A I, Mathematicaphysica, 28, 108 s., liitelehti. 
Henning, D. 1979. Baltic Sea evaporation. Pilot study year. Summary of interim results. Sixth Meeting of Experts on the Water Balance of the Baltic Sea, Hanasaari Cultural Centre, Paper 10.

Herlevi, A. ja Leppäranta, M. 1994. ERS-1 SAR over open water in the Baltic Sea. EARSeL Advances in Remote Sensing 3(2), 64-70.

Holton, J.R. 1979. An Introduction to Dynamic Meteorology, Academic Press, Second Edition, International Geophysics Series 23, New York, $391 \mathrm{~s}$.

Håkansson, B., Alenius, P. ja Brydsten, L.1994. Fysisk miljö i Bottniska Viken. Vatten 50(3), 187-200.

Ilmatieteen laitos, 1982. Auringonsäteilyhavainnot 1971-1980. Suomen meteorologinen vuosikirja 71-80, Osa 4:1, Helsinki.

Ilmatieteen laitos, 1991. Tilastoja Suomen ilmastosta 1961-1990. Ilmatieteen laitos, Helsinki, $125 \mathrm{~s}$.

Jacobsen, T. 1980. Mixing, exchange and transport processes. Teoksessa: Melvasalo, T. ym. (toim.), Assessment of the effects of pollution on natural resources of the Baltic Sea. 1980. Baltic Sea Environment Proceedings, 5B, 114-128.

Johansson, M., Boman, H., Kahma, K. K. ja Launiainen, J. 2001. Trends in sea level variability in the Baltic Sea. Boreal Environment Research 6, 159-179.

Johansson, M., Kahma, K. K., Boman, H. ja Launiainen, J. 2004. Scenarios for sea level on the Finnish coast. Boreal Environment Research 9(2), 153-166.

Jurva, R. 1937a. Über die Eisverhältnisse des Baltischen Meeres an den Küsten Finnlands nebst einem Atlas, 248 s. Diss. Universität Helsinki, Matematisch-Naturwissenchaftliche Sektion der Philosophischen Fakultät, Helsinki.

Jurva, R. 1937b. Laskelmia meriemme lämpövarastosta. Suomi merellä 12, 162-191.
Jylhä, K., Tuomenvirta, H. ja Ruosteenoja, K. 2004. Climate Change projections to Finland during the 21st century. Boreal Environment Research 9, 127-152.

Kahma, K.K. 1986. On prediction of the fetch-limited wave spectrum in a steady wind. Finnish Marine Research 253, 52-78.

Kahma, K.K. ja Calkoen, C. 1992. Reconciling discrepancies in the observed growth of windgenerated waves. Journal of Physical Oceanography, 22(12), 1389-1405.

Kalliosaari, S. ja Seinä, A. 1987. Ice winters 19811985 along the Finnish coast. Finnish Marine Research 254, 5-63.

Kitaigorodskii, S.A. 1962. Applications of the theory of similarity to the analysis of windgenerated wave motion as a stochastic process. Izv. Akad.Nauk SSSR, Geophys. Ser. 1, 105-117.

Knudsen M. 1900. Ein Hydrographischer Lehrsatz. Annalen Maritimen Metorology 28, 316-320.

Kononen, K., Kuparinen, J., Mäkelä, K., Laanemets, J., Pavelson, J. ja Nómmann, S.1996. Initiation of cyanobacterial blooms in a frontal region at the entrance to the Gulf of Finland, Baltic Sea. Limnology and Oceanography 41(1), 98-112.

Kóuts, T. 1999. Processes of deep water renewal in the Baltic Sea. Dissertationes Geophysicales Universitatis Tartuensis, 50 s. +7 artkkelia (väitöskirja).

Kwiecien, K. 1987. Warunki klimatyczne. Teoksessa: B. Augustowski (toim.), Baltyk Poludniowy, s. 219-287. Gdanskie Towarzystwo Naukowe, Ossolineum, Wroclaw.

Launiainen, J. 1982. Variation of salinity at Finnish fixed hydrographic stations in the Gulf of Finland and river runoff the Baltic Sea. Suomenlahden itäosan vesiensuojelua koskeva seminaari, Leningrad 16-20.8 1982, $12 \mathrm{~s}$ (mimeogr.). 
Lenz, W. 1971. Monatskarte der Temperatur der Ostsee dargestellt für verschiedene Tiefenhorisonte. Deutsche Hydrographisces Zeitschrift, Ergänzungshäft Reihe B, 11, 1-148.

Leppäranta, M. 1990. Observations of free ice drift and currents in the Bay of Bothnia.. Acta Regiae Societatis Scientiarum et Litterarum Gothoburgensis, Geophysica 3, 84-98.

Leppäranta, M., Sun, Y. ja Haapala, J. 1998. Comparisons of sea-ice velocity fields from ERS-1 SAR and a dynamic model. Journal of Glaciology, 44(147), 248-262.

Lisitzin, E. 1938. Über die Ionisierungsspannungen der Elemente in verschiedenen Ionisierungszuständen. Väitöskirja: Universität Helsingfors, 121 s., Helsinki.

Lisitzin, E., 1957. On the reducing influence of sea ice on the piling-up of water due to wind stress. Comm. Physico-Math. Soc. Sci. Fenn. 20(7), 1-12.

Matthäus, W. 1993. Major Baltic inflows of highly saline water into the Baltic Sea - a review. ICES Statutory Meeting Dublin, Paper C.M.1993/C:52.

Matthäus, W. ja Schinke, H. 1994. Mean atmospheric circulation patterns associated with major Baltic inflows. Deutsche Hydrographische Zeitschrift 46(4), 321-339.

Meier, H.E.M. 2002. Regional ocean climate simulations with a $3 \mathrm{D}$ ice-ocean model for the Baltic Sea. Part I: model experiments and results for salinity and temperature. Climate Dynamics 19, 255-256.

Meier, H.E.M. ja Kauker, F. 2003. Sensitivity of the Baltic Sea salinity fro the fresh water supply. Climate Research 24, 231-242.

Mellor, G. 1996. Introduction to Physical Oceanography. Springer-Verlag, $260 \mathrm{~s}$.

Mietus, M. ja Owczarek, M. 1994. Charakterystyka warunkow meteorologicznych. Teoksessa: Warunki srodowiskowe polskiej strefy poludniowego Baltyku w 1993 roku, 9-26. Gdynia. Materiale Oddzialu Morskiego, IMGW.
Mikulski, Z., 1972. The inflow of the river waters to the Baltic Sea in 1961-1970. Proc. 8th Conf. Baltic Oceanogr., Copenhagen, October 1972.

Murthy, R., Håkansson, B. ja Alenius, P. 1993. The Gulf of Bothnia year 1991. Physical transport experiments. SMHI reports, Oceanography RO 15, 127 s. Norrköping, SMHI.

Myrberg, K. ja Andrejev, O. 2003. Main upwelling regions in the Baltic Sea: a statistical analysis based on three-dimensional modelling. Boreal Environment Research 8, 97-112.

Mälkki, P., 2001. Oceanography in Finland 19182000. Geophysica 37, Nos. 1-2, 225-259.

Neumann, G. 1941. Eigenschwingungen der Ostsee. Arch. Dtsch. Seewarte Marineobserv., 61(4), 1-59.

Niros, A., Vihma, T. ja Launiainen, J. 2003. Marine meteorological conditions and air-sea exchange processes over the northern Baltic Sea in 1990s. Geophysica 38 (1-2), 59-87.

Omstedt, A. ja Axell, L. 2003. Modeling the variations of salinity and temperature in the large Gulfs of the Baltic Sea. Continental Shelf Research 23, 265-294.

Palmén, E 1930. Untersuchungen über die Strömungen in den Finnland umgebenden Meeren. Commentationes physico-mathematicae / Societas Scientarium Fennica, 12, 93 s.

Palmén, E. ja Söderman, D. 1966. Computation of the evaporation for the Baltic Sea from the heat flux of water vapour in the atmosphere. Geophysica 8(4), 261-280.

Palosuo, E. 1953. A treatise on severe ice conditions in the Central Baltic. Merentutkimuslaitoksen julkaisu / Havsforskningsinstitutets skrift 156, 130 s., Helsinki.

Palosuo, E., 1965. Frozen slush on lake ice. Geophysica 9(2), 131-147.

Pettersson, H. 2004. Wave growth in a narrow bay. Contributions of the Finnish Institute of Marine Research (9), University of Helsinki, Faculty of Science. 33 s. +4 artikkelia, Helsinki. Merentutkimuslaitos (väitöskirja). 
Pickard, G. ja Emery, W. 1990. Descriptive Physical Oceanography. Butterworth-Heinemann, New York, 5. painos, $320 \mathrm{~s}$.

Ramsay, H. 1947. I kamp med Östersjöns isar -en bok om Finlands vintersjöfart. Holger Schildts Förlag, Helsingfors.

Reed, R. 1977. On estimating insolation over the Ocean. Journal of Physical Oceanography 7 , 482-485.

Saloranta, T. 2000. Modeling the evolution of snow, snow ice and ice in the Baltic Sea. Tellus 52A, 93-108.

Seinä, A. ja Kalliosaari, S. 1991. Ice winters 19861990 along the Finnish coast. Finnish Marine Research 259, 3-61.

Seinä, A. ja Palosuo, E. 1993. The classification of the maximum annual extent of ice cover in the Baltic Sea 1720-1992. Meri 20, 5-20.

Seinä, A. ja Peltola, J. 1991. Duration of the ice season and statistics of fast ice thickness along the Finnish coast 1961-1990. Finnish Marine Research 258, 46 s.

Shirokov, K.P. 1977. Vliyanie splochennosti na vetrovoj dreif l'dov. Sb. Rab. Leningr. GMO 9, 46-53 (venäjänkielinen).

Simojoki, H. 1949. Niederschlag und Verdunstung auf dem Baltischen Meer. Fennia, 71(1), 125.
Simojoki, H. 1978. The History of Geophysics in Finland 1828-1918. Societas Scientiarum Fennica, Helsinki.

Sjöberg, B. 1992. Atlas of Sweden. Sea and Coast. National Atlas of Sweden. SWA Publishing, SMHI, Norrköping.

UNESCO, 1981. The Practical Salinity Scale 1978 and the International Equation of State of Seawater 1980. Techn. Pap. Mar. Sci, 36.

Witting, R. 1911. Tidvatten i Östersjön och Finska viken. Fennia 29(2), $84 \mathrm{s.}$

Witting, R.1912. Zusammenfassende Übersicht der Hydrographie des Bottnischen und Finnischen Meerbusens und der nördlichen Ostsee nach den Untersuchungen bis Ende 1910. Finnländische hydrographisch-biologische Untersuchungen No. 7, $82 \mathrm{~s}$.

Wübber, C. ja Krauss, W. 1979. The two-dimensional seiches of the Baltic Sea. Oceanologica Acta 2(4), 435-446.

Zillman, J.W. 1972. Study of Some Aspects of the Radiation and Heat Budgets of the Southern Hemisphere Oceans. Canberra: Bur. of Meteorol., Dep. of Inter., Meteorol. Stud. Rep. 26.

Zubov, N.N. 1945. L'dy Arktiki [Arctic Ice]. Izdatel'stvo Glavsermorputi, Moscow (venäjänkielinen). 


\section{Kirjoittajat}

FT, dosentti Kai Myrberg on toiminut Merentutkimuslaitoksessa tutkijana vuodesta 1988 eritysalueenaan Itämeren fysikaalisten prosessien tutkimus matemaattisten mallien avulla. Hän on toiminut vuodesta 2002 Helsingin yliopiston geofysiikan dosenttina luennoiden kurssia "Itämeren Oseanografia". Hän ollut vierailevana tutkijana Virossa ja Saksassa sekä stipendiaattina ja post.doc -tutkijana Ruotsissa.

Professori Matti Leppäranta on Helsingin Yliopiston professori opetusalanaan maapallon vesivaipan fysiikka sekä Oulun yliopiston meritieteen dosentti. Hänen erikoisalanaan on jäätyvien merten meritiede. Hän on työskennellyt Merentutkimuslaitoksessa 1974-1992 sekä ollut vierailevana tutkijana Englannissa, Japanissa, Kanadassa ja Yhdysvalloissa.

Professori Harri Kuosa on työskennellyt Tvärminnen eläintieteellisellä asemalla ja Merentutkimuslaitoksella noin 20 vuotta. Tällä hetkellä hän on Itämeren tutkimuksen professori Tvärminnessä. Hänen erikoisalaansa on Itämeren ekosysteemi ja sen muutokset. 